DBROWN

STUDIES

\title{
The Idea of Atonement in the \\ Philosophy of Hermann Cohen
}

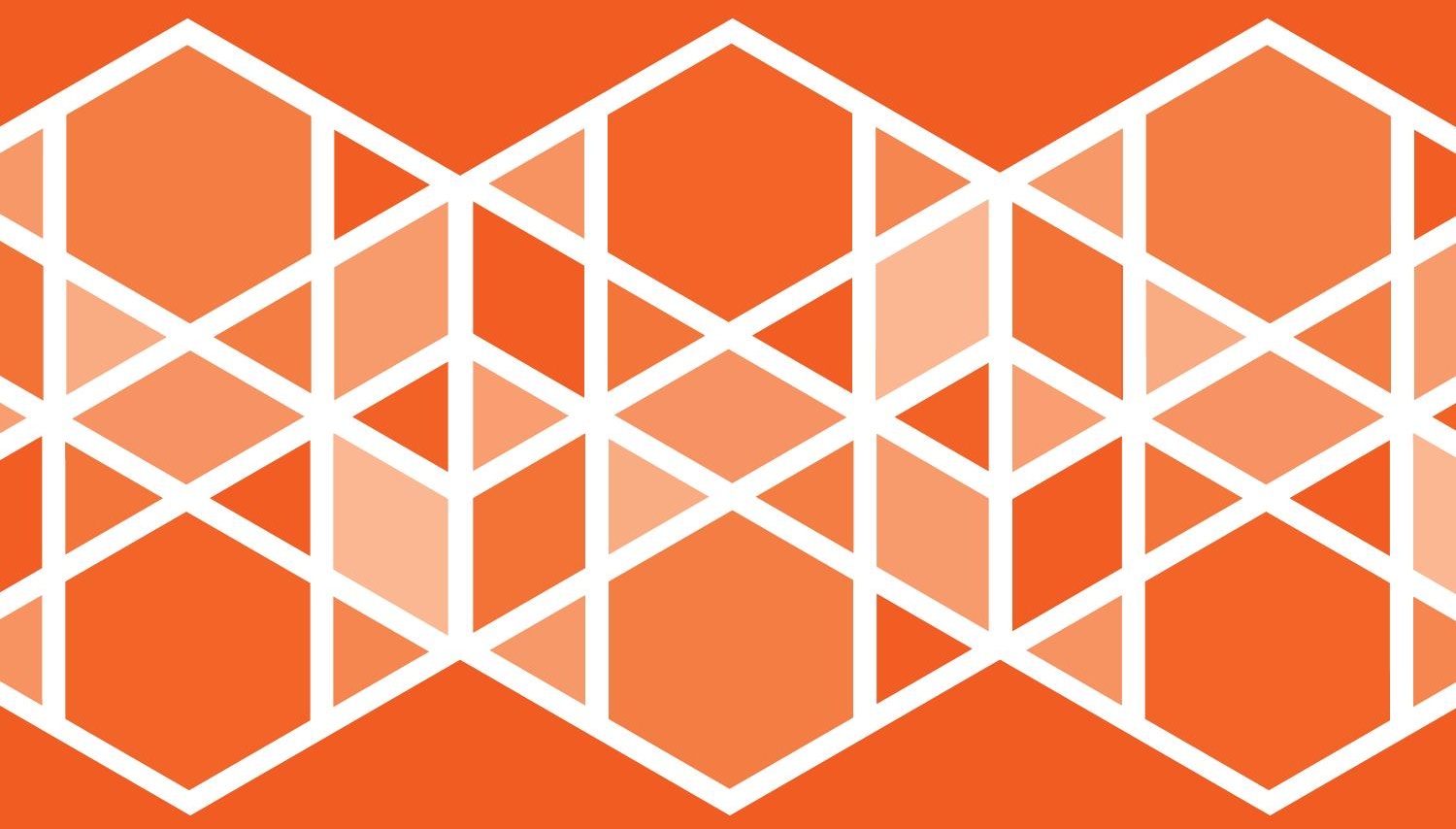

MICHAEL ZANK 


\section{THE IDEA OF ATONEMENT IN THE PHILOSOPHY OF HERMANN COHEN}


Program in Judaic Studies

Brown University

Box 1826

Providence, RI 02912

BROWN JUDAIC STUDIES

Edited by

Shaye J. D. Cohen

Number 324

\title{
THE IDEA OF ATONEMENT \\ IN THE PHILOSOPHY OF HERMANN COHEN
}

\author{
by \\ Michael Zank
}




\title{
THE IDEA OF ATONEMENT IN THE PHILOSOPHY OF HERMANN COHEN
}

\author{
With an Appendix of Manuscripts from \\ the National and University Library, Givat Ram, \\ Jerusalem and Nachlaß Natorp Ms. 831 \\ (Hessisches Staatsarchiv, Marburg)
}

\author{
by \\ Michael Zank
}

Brown Judaic Studies

Providence, Rhode Island 


\section{THE IDEA OF ATONEMENT IN THE PHILOSOPHY OF HERMANN COHEN \\ by Michael Zank}

Copyright (C 2020 by Brown University

Library of Congress Control Number: 2019953796

Open access edition funded by the National Endowment for the Humanities/ Andrew W. Mellon Foundation Humanities Open Book Program.

The text of this book is licensed under a Creative Commons AttributionNonCommercial-NoDerivatives 4.0 International License: https://creativecommons.org/licenses/by-nc-nd/4.0/. To use this book, or parts of this book, in any way not covered by the license, please contact Brown Judaic Studies, Brown University, Box 1826, Providence, RI 02912. 


$$
\text { M., B., \& B., }
$$
in Liebe zugeeignet. 



\section{Table of Contents}

Acknowledgments .................................................................

Preface by Wendell Dietrich..................................................iii

Introduction: Between Judaism and Philosophy...................................1

1. Hermann Cohen and Marburg Neo-Kantianism .....................

2. Hermann Cohen and the Philosophy of Judaism....................8

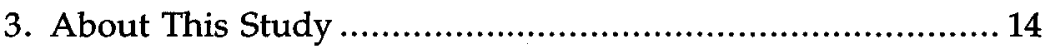

4. The Idea of Versöhnung (Atonement) .............................. 19

5. Identifying the Proper Narrative......................................... 33

Part I: Atonement in Hermann Cohen's Project of Renewing Jewish Philosophy of Religion and Ethics............................. 45

1. Biographical Background............................................. 48

2. Early Writings on the Religion of Israel and

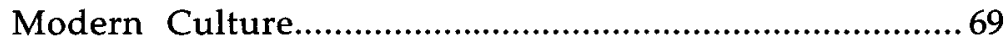

3. Turning Point: "Die Versöhnungsidee" .............................107

4. Renewing Jewish Philosophy of Religion .......................151

Part II: No Self Without Other. Substance, Self-Consciousness, and Concrete Subjectivity in Cohen's Logic, Ethics, and Philosophy of Religion.................................................207

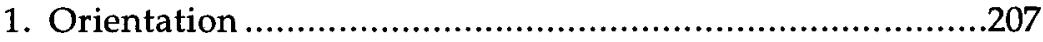

2. Early Writings on Religion............................................218

3. Substance, Self-Consciousness, and the Realization of the Good .......................................................................230

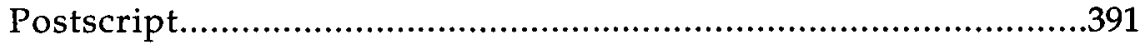

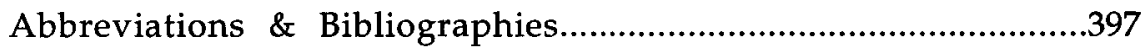

Appendix: Manuscripts by Hermann Cohen ................................457

A. Letters from the National and University

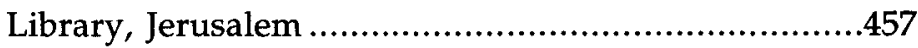

B. Manuscripts on Versöhnung..........................................

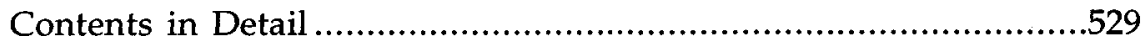





\section{Publishers' Preface}

Brown Judaic Studies has been publishing scholarly books in all areas of Judaic studies for forty years. Our books, many of which contain groundbreaking scholarship, were typically printed in small runs and are not easily accessible outside of major research libraries. We are delighted that with the support of a grant from the National Endowment for the Humanities/Andrew W. Mellon Foundation Humanities Open Book Program, we are now able to make available, in digital, open-access, format, fifty titles from our backlist.

In The Idea of Atonement in the Philosophy of Hermann Cohen (2000), Michael Zank argues that the idea of atonement serves as a key for understanding the larger philosophy of the German-Jewish philosopher Hermann Cohen (1842-1918). Zank situates his sensitive and wide-ranging philosophical evaluation of Cohen within the intellectual and social milieu within which Cohen wrote.

This edition has a new preface and contains corrections from the original text

Michael L. Satlow Managing Editor January, 2020 



\section{Preface to the Digital Edition}

The book you are accessing virtually is the second, corrected e-book version of first published by Brown Judaic Studies in 2000. ${ }^{1}$ That book was based on a PhD dissertation I defended in January 1994 at the Brandeis University Department of Near Eastern and Judaic Studies before Professors Marvin Fox, William A. Johnson, and Wendell Dietrich (Brown University). It was the latter who recommended the inclusion of the book in the Brown Judaic Studies series and he contributed a perceptive preface that he wrote on behalf of Professor Fox, who passed away in 1996.

Professor Fox - an orthodox rabbi of Ukrainian Jewish descent and a former military chaplain who had taught Aristotelian philosophy at Ohio State University before assuming the position of Philip W. Lown Professor of Jewish Philosophy at Brandeis - routinely discouraged his graduate students from writing dissertations on Hermann Cohen (1842-1918); not because he didn't like the subject but because he feared students were ill prepared. Fox was initially skeptical also in the case of this German-born and -trained former theologian, with two years of study at the Hebrew University in Jerusalem and on a quest to recover his Jewish roots. After the defense, Fox stepped out of the role of supervisor and asked whether it was true that Cohen had been a towering prophetic figure in his time. This book provides an answer to that question. I remain deeply grateful to Professor Fox for his support and mentorship.

The dissertation bore the title Reconciling Judaism and "Cultural Consciousness:" The Idea of Versöhnung in Hermann Cohen's Philosophy of Religion. In it I focused on Cohen's effort to reconcile disparate historical, philosophical, and religious discourses, an effort with significant political implications. In Cohen's thought, "atonement" not only deals with the

${ }^{1}$ My thanks to Michael Satlow, Managing Editor of Brown Judaic Studies, for encouraging me to ready this volume for a second, digital edition, and Laura Foster, Project Manager, for her tireless technical support. 
constitution of ethical and moral selves, but it also unifies Jewish and systematic philosophical spheres. The book title, The Idea of Atonement in the Philosophy of Hermann Cohen, said much the same, just shorter, but it also created the misleading impression that the book narrowly focuses on a particular theologoumenon. I assure the reader that it does more. Both parts of the title are relevant. It suggests, and the book demonstrates, that the thought-figure (Denkfigur) of atonement provides a helpful key not just to Cohen's Jewish thought but also to his systematic philosophy.

The structure of this book is as follows. Part I introduces the reader to Cohen's program of Jewish philosophy and ethics, its emergence and maturation. The procedure is genetic. Following a biographical introduction, I identify a turning point in Cohen's Jewish thought in the 1890s that leads to the formation of the basic conceptual orientation of Cohen's mature Jewish philosophy, and I demonstrate how this orientation shapes the posthumous Religion der Vernunft aus den Quellen des Judentums (1919). In my reading, the key term in this development, and the conceptual nucleus around which Cohen builds his Jewish philosophy and ethics, is "the idea of atonement" (Versöhnungsidee), which was the subject of an essay composed in the 1890s that remained unpublished until 1924. The focus on atonement might indicate a bending, on Cohen's part, of Jewish philosophy and ethics in the direction of a Christian doctrine. I show that it actually constitutes something more complex. Cohen's attention to the Jewish atonement-tradition represents a deliberate declaration of independence of modern Judaism from the mediation of Protestant theology. On the other hand, Cohen articulates his Jewish philosophy in a particular modern horizon, namely in the horizon of a German culture dominated by Protestant social and political values. It is this complex cultural embeddedness and the conscious embrace of philosophy's cultural historical particularities that render Cohen difficult to translate and require for a careful exposition that considers not just concepts but language and methodological justification. I remain convinced that it is worthwhile to follow the movement of Cohen's thought closely.

Between Cohen's early Jewish writings and his mature Jewish philosophy stands the publication of a three-part system of philosophy, not to speak of many other major and minor philosophical, political, and Jewish writings. Part II shows how Cohen's Jewish philosophical orientation informs his systematic philosophy. Specifically, I show how the Jewish philosophical conceptions of God and human being surface in his logic, ethics, and in the 1915 treatise on the concept of religion. ${ }^{2}$ Cohen saw the task of philosophy as systematic, which means that the parts of

\footnotetext{
${ }^{2}$ In a friendly review, Marc de Launay regrets that no separate chapter is devoted to Cohen's aesthetic philosophy. Attention to Cohen's aesthetics still surfaces in various places across the entire study. Se Marc De Launay, Revue de métaphysique et de morale, no. 4, 2001, pp. 150-151.
} 
the system communicate with one another and answer to the rules of a logic of cognition (Erkenntnislogik) that anticipates and makes room for ethics, aesthetics, and a psychology that was to articulate the unity of the "cultural consciousness." While Part I of this book culminates in a study of Religion der Vernunft aus den Quellen des Judentums (1919), Part II culminates in a close reading of Begriff der Religion im System der Philosophie (1915). Overall, this book remains the most comprehensive and in-depth study in any language devoted to both Cohen's Jewish philosophy and his philosophical concept of religion. ${ }^{3}$ The main body of the book is preceded by a substantive introduction and followed by a comprehensive bibliography of Cohen's writings and of secondary works consulted. In place of an index I give a detailed table of contents.

The appendix of letters and manuscripts by Cohen provides an intimate view of Cohen's social network as well as of his historical philological readings on the subject of "atonement." The letters and postcards here included were probably known to the editors of the 1935 edition of Cohen's letters but excluded for reasons of censorship. Cohen speaks here more freely than one would have felt comfortable revealing in the defensive situation of the 1930s. The notes on "atonement" show Cohen's approach to the study of religious concept formation and the symbolic practices of sacrifice and prayer. Here we can observe the thorough historical-philological work and engagement with classical sources and contemporary Jewish and Protestant scholarship that informed Cohen's philosophical thinking on religion. Of particular interest are his notes on Julius Wellhausen, August Gfrörer, and David Einhorn (vide infra, pp. 480505). It is in these notes that we find the raw material for Cohen's organic, rather than dialectic, account of the development of Jewish monotheism from its biblical prophetic and sacerdotal origins to rabbinic literature and Jewish liturgical practice.

I came to Cohen from a background of Jewish-Christian dialogue. I assumed that Cohen was an important resource for such a dialogue because of his exchange with the Protestant theologian Wilhelm Herrmann. I was under the impression that Cohen developed his late philosophy of religion, especially the 1915 treatise on the concept of religion, in the attempt to build a bridge between Jewish philosophy and Marburg Protestant theology, and I worked out in detail how Cohen's ethics was received by Wilhelm Herrmann, as reflected in the meticulous changes

\footnotetext{
${ }^{3}$ Students interested in reading more about Cohen's early neo-Kantian writings should turn to Frederick Beiser's recent Hermann Cohen. An Intellectual Biography (2018). The best English language introduction to Cohen's philosophy of critical idealism is Andrea Poma, The Critical Philosophy of Hermann Cohen. Albany: SUNY Press, 1997.
} 
Herrmann made in his writings over time. ${ }^{4}$ Cohen prominently refers to W. Herrmann in Religion of Reason, but he does so in exasperation. ${ }^{5}$ The dialogue, if that's what it was, did not end in agreement. As I made my way through Cohen's writings and learned from European and Israeli Cohen scholars I discovered a different and surprisingly unfamiliar narrative. There was another story to be told about Cohen's intellectual path. This book tells that story.

No one reading Cohen can escape the question of the connection between Cohen's critical philosophy and his constructive Jewish thought. How are the two connected? Was Cohen an example of the "old Jewish premise that being a Jew and being a philosopher are two incompatible things"? ${ }^{6}$ Was Cohen therefore first a Jew, then a philosopher, and then - again - a Jew? How does one introduce readers to the stereoscopic range of Cohen's writings? What is the relationship between the posthumous Religion der Vernunft aus den Quellen des Judentums and Cohen's systematic works? ${ }^{7}$ The Berlin Akademie für die Wissenschaft des Judentums published Cohen's Jewish Writings (1924, three volumes) and his Schriften zur Politik und Zeitgeschichte (1928, two volumes) in separate editions. Ever since then, the question remained, what has Cohen's Judaism to do with his philosophy. Are there two Cohens, one for Jews, the other for philosophers? Were these two strands reconciled in Cohen's mind or did he live parallel lives? Can we take him at his word when he says, Im Zusammenhang meiner wissenschaftlichen Einsichten steht mein Judentum ("my Judaism is connected with my scientific insights")?

${ }^{4}$ I published some of the results of this research in "Between Dialogue and Disputation: Wilhelm Herrmann and Hermann Cohen on Ethics, Religion, and the Self" in Gesche Linde, Richard Purkarthofer, Heiko Schulz, Peter Steinacker (ed.), Theologie zwischen Pragmatismus und Existenzdenken. FS für Hermann Deuser zum 60. Geburtstag, Marburg: N. G. Elwert Verlag, 2006, pp. 131-148.

${ }^{5}$ See Religion of Reason (1995), p. 159.

${ }^{6}$ Leo Strauss, "How to Begin to Study the Guide of the Perplexed," in Moses Maimonides, The Guide of the Perplexed, Vol. I, Chicago: University of Chicago Press, 1963, p. xiv.

${ }^{7}$ Cf. Helmut Holzhey, Gabriel Motzkin, Hartwig Wiedebach (ed.) "Religion of Reason Out of the Sources of Judaism." Tradition and the Concept of Origin in Hermann Cohen's Later Work (Hildesheim: Olms, 2000).

${ }^{8}$ The Olms Verlag Hermann Cohen Werke edition overcomes the division between Jewish and non-Jewish writings by organizing the content in several volumes of Kleinere Schriften on purely chronological grounds. Frederick Beiser (2018) posits a constant preoccupation of Cohen with both subjects. In contrast to the present volume, however, Beiser does not 
What provided me with a clue by which to answer these questions were manuscripts on Versöhnung preserved among the papers of Cohen's Marburg colleague, Paul Natorp. These notes provide a rare record of Cohen's thought process. ${ }^{9}$ They also support dating Cohen's essay on the idea of atonement to the 1890s. This allows us to reconstruct an important moment in Cohen's Denkweg, the path by which he rethought the place of Judaism in western culture and philosophical ethics, and of the place of religion in the context of the system of philosophy.

Cohen began his education as a Jewish seminarian before he went on to study the classics at the University of Breslau. From early on, he was eager to defend Judaism within modern culture. In a conciliatory response to anti-Jewish articles published by the eminent German historian Heinrich v. Treitschke in his Preussische Jahrbücher, Cohen described Jewish participation in modern culture as mediated by the Christian doctrine of incarnation. A decade later we find him making discoveries that lead him to a different theory of religion and ethics. His desire to defend Judaism proved philosophically productive. In subsequent writings he aimed to counter a threat to Jewish survival that, in his view, emanated from a pervasive Protestant intellectual supersessionism. That real-world problem forced Cohen to think more creatively about Jewish solutions to the problems of philosophical ethics and religion. Cohen forged a conception of ethics that overcame Kant's all-too-obviously Protestant prejudice against the law without relinquishing the Kantian commitment to critical idealism. Historical, existential and philosophical justifications flow together in this defense of a modern conception of ethics as a philosophy of law that has its center of gravity not in the transcendental subject of a good will, but in the cultural fact that law and its assumptions of agency and justice presuppose the responsibility of a legal person. The emphasis on individual responsibility presupposed by the law gives the philosophical problem of freedom, and hence of individuality and personhood, a new direction. What is significant about these philosophical moves is not just that they forge a direct path from Jewish tradition to a modern theory of the relation between logic, ethics, aesthetics, and religion. If this were all Cohen achieved, his philosophy would still be of interest as giving voice and relevance to a subaltern, colonized tradition in the midst of a dominant and colonizing one. But the greater value of Cohen's thought rests on his creative contribution

offer any indication of how Cohen might have integrated his two pursuits. For a critical appraisal see my review of Beiser and others in "New Work on Hermann Cohen" in Modern Judaism: A Journal of Jewish Ideas and Experience Volume 39 Issue 3 (2019), 370-394.

${ }^{9}$ Cohen's papers and manuscripts are considered lost since Martha Cohen was deported to Theresienstadt. 
to problems of logic, ethics, aesthetics, and the philosophy of religion in their systematic unity. Cohen moves from a Kantian idealism whose potential for a unified principle rests on a transcendental, or postulated, unification in a (lawful/lawgiving) subjectivity (as in Descartes' ego cogito) to a critical idealism that coordinates the problems of logic and ethics, nature and history, being and the ought, in a system unified by reflection on the validity of noëmatic ${ }^{10}$ judgments. This is not a philosophy of mind, but a philosophical critique of the criteria by which we deem things true, right, beautiful, and real. The unrealized goal of this philosophy was to describe the "unity of the cultural consciousness" of the "we" implied in the preceding sentence. This collective subjectivity was to come at the end, not at the beginning, of the philosophical enterprise, as conceived by Cohen.

Cohen also remains important as a Jewish thinker. In his rightly famous introduction to the 1924 edition of Hermann Cohen's Jewish Writings, Franz Rosenzweig reports on a spontaneous remark by the septuagenarian philosopher at a dinner held in his honor in 1914, during his "memorable journey to Russia" (merkwürdige Russlandreise). When a speaker pointed out that Cohen was turning to advocacy for his fellow Jews, Cohen interrupted: Ich bin ja ein Baal t'schuwoh schon vierunddreißig Jahr! ("I have been a ba'al t'shuvah for the past thirty-four years!") ${ }^{11}$ The obvious meaning was that it was not a new thing for Cohen to be engaged on behalf of his fellow Jews. The first essay he published under his own name in defense of Jews and Judaism was the above mentioned Bekenntniß in der Judenfrage.

This is not the place to interrogate the authenticity of anecdotes reported by Rosenzweig, nor challenge his interpretation. Steven S. Schwarzschild, who was the greatest disciple of Cohen in the United States, weighed in on the question of authenticity. ${ }^{12}$ I write on Rosenzweig's selfinterest in his portrayals of Cohen elsewhere. ${ }^{13}$ Here I am interested in

\footnotetext{
${ }^{10}$ Philosophy can be defined as noësis noëseos, or the knowledge of knowledge. All knowledge involves a knower (subject), a known (object), and a knowing (predicate). Idealism in the Cartesian tradition proceeds from the knowing subject. Cohen's "idealism without subject" (Henry Allison) proceeds from the known (object), and reflects on the formal conditions of valid judgments. This is the meaning of what Cohen calls "logic of origin."

${ }^{11} \mathrm{JS}$ I, Einleitung von Franz Rosenzweig, p. XXI.

${ }^{12}$ See Steven S. Schwarzschild, “Franz Rosenzweig's Anecdotes about Hermann Cohen" in The Tragedy of Optimism: Writings on Hermann Cohen, ed. George Y. Kohler. Albany: SUNY Press, 2018, chapter 5.
}

${ }^{13}$ See "Rosenzweig und Cohen. Beobachtungen zu einer Schüler-Lehrer-Beziehung" in Wolfdietrich Schmied-Kowarzik (ed.), Franz Rosenzweig's "Neues Denken."Internationaler Kongress Kassel 2004, vol. I: Selbst- 
the statement itself, which literally translates, "I have been a master of repentance for thirty-four years." This book explains what Cohen meant when he referred to himself as a "master of repentance" by tracing the development of Cohen's Jewish thought from early to late writings and identifying the most important turning points, attested in published writings and in manuscripts from the Marburg archives included in this book. I argue that Cohen entrusted the biblical and rabbinic concept of repentance, and with it the Jewish idea of atonement, with the ability "to carry the whole edifice of Judaism." (Vide infra, p. 137)

In my view, Cohen's interjection reminded his audience that, what seemed to them a recent turn to Jewish causes, had been his preoccupation for more than three decades, the same decades during which he attained prominence as a systematic philosopher and founder of a widely noted school of critical idealism. The expression he used, ba'al t'shuvah or "master of repentance" hinted at the realization that found its first expression in an essay that laid the ground not just for Cohen's mature philosophy of religion but for his understanding of the relationship between ethics and religion, philosophy and Judaism. The essay on the idea of atonement is the center of gravity around which this work revolves. I believe it contains the key to understanding Cohen, his philosophy, and his Judaism.

Cohen's discovery of the Jewish idea of atonement marks a departure from a view he expressed in earlier writings, most visibly in Bekenntni $\beta$ (1880), where he made modern Jews into "minority Protestants," to use a term recently proposed by Paul Nahme. ${ }^{14}$ The critical reaction of contemporary Jewish readers is entirely understandable. With the concept of atonement, Cohen launches his new approach. He uses the Christian context of modern Jewish philosophy to rebuild a Jewish philosophy of religion that meets the Christian challenge at the source shared by Christians and Jews, i.e. the Bible. Cohen reverses the traditional narrative of Judaism as a religion of stern justice and Christianity as a religion of love (vide infra, p. 148). With a clear path from biblical and rabbinic to a modern ethical consciousness, Cohen also finds an Archimedean point from which to evaluate and measure the cultural perils of the Christian doctrine of incarnation, the very idea that, in 1880, he saw as the precondition of the

begrenzendes Denken - in philosophos (Freiburg and Munich: Verlag Karl Alber, 2006) pp. 156-178, revised as "Rosenzweig und Cohen" in Zank, Jüdische Religionsphilosophie als Apologie des Mosaismus. [Religion in Philosophy and Theology, ed. Ingo Dalferth, vol. 88]. Tübingen: Mohr Siebeck, 2016, 139-161.

\section{${ }^{14}$ See Paul E. Nahme, Hermann Cohen and the Crisis of Liberalism. The} Enchantment of the Public Sphere. Series: New Jewish Philosophy and Thought, ed. Zachary Braiterman. Bloomington Indiana: Indiana University Press, 2019. 
modern concept of moral autonomy and hence one principally shared by modern Jews as well. The "world historic value of Judaism" henceforth required no more Christian detour. Christian incarnation, in turn, appeared entangled with a pantheism that obscured the ethical power of divine transcendence rather than translating it into a modern philosophical idiom. Cohen's ethics and his philosophy of religion thus co-evolved from his earlier, more conventionally Kantian position to the conception he elaborated in Ethik des reinen Willens (1904, second edition 1907) and later writings. In Begriff der Religion im System der Philosophie (1915), Cohen's mature philosophy of religion, which I describe closely on pp 314-389 of this book, Cohen goes as far as to suggest a gradual transformation of the Protestant understanding of Christ into a representation of the "ideal of the human being, namely not of humanity in its historical universality but of the individual in the awareness of its isolation, its neediness, its frailty; at the same time, however, also in its worthiness of redemption." (BR 67, here p. 376; my transl.) In other words, the Protestant Christ of faith, as conceived by Martin Kähler, Wilhelm Herrmann, and others influenced by the great systematic theologian Albrecht Ritschl, approximates a conception of humanity that arises out of the sources of Judaism. Notably, this convergence concerns a humanized Christ of faith, not the historical Jesus, "whose moral significance evaporates in the attempt to determine his empirical historicity" (p. 375).

The dissertation on which this book is based foregrounded the reconciliation between Judaism and "cultural consciousness." The unity of cultural consciousness was the task Cohen set for the capstone volume of his system of philosophy, a volume he never completed and for which we lack all manuscript evidence. Cohen sought, so my thesis, to show how Judaism was to be reconciled with a cultural consciousness that unfolds in philosophical logic, ethics, and aesthetics. As the young Leo Strauss put it, Cohen was building a bridge between Judaism and modern reason that only someone who had him/herself built such a bridge could examine for safe load. ${ }^{15}$ For Cohen, this unity, and hence the tenability of his system, was the subject of a philosophical psychology. The heart and soul of culture was to be distinguished by a logic, ethics, and aesthetics of reconciliation, a tendency toward the resolution of tensions and toward unity. His psychological project resonates with the idea of the purity of a pure conscience (reines Gewissen). The work, had it been written, might have shown in what sense one could be both Jew and philosopher with $a$ pure conscience and without mental reservation.

In the book (in contrast to my doctoral thesis), I shift the emphasis from the unity of the cultural consciousness to the problem of reconciliation

\footnotetext{
${ }^{15}$ See Thomas Meyer and Michael Zank, "More Early Writings by Leo Strauss from the Jüdische Wochenzeitung für Cassel, Hessen und Waldeck (1925-1928)" in Interpretation 39/11, Spring-Summer 2012, 109-137.
} 
or atonement itself. I show how, why, and when it appeared in Cohen's thought and writing, and I argue that it remained central to him, as attested by the structure of his posthumous Religion of Reason. The most striking discovery, one discussed in the book (pp. 156f, 274, 306ff, 332), but perhaps not sufficiently emphasized, is the return, in Cohen's thought, of the idea of God. Helmut Holzhey was perhaps the first to draw attention to the significance of this fact. ${ }^{16}$ It would be wrong to dismiss Cohen's insistence on God as an expression of Jewish apologetics. Following the discovery of the idea of atonement, Cohen produced an ever-accelerating series of essays on Jewish philosophy of religion, a philosophy of religion that he grounds in the classical doctrine of divine attributes, especially the attributes of love and justice. ${ }^{17}$ At the same time Cohen also writes his Ethics of Pure Will where the idea of God is justified in the context of a general philosophical ethics. (See Part II.) Without sympathy for this concept of God, a concept derived from Jewish philosophical sources but justified within general ethics, one may cherish some of Cohen's philosophical contributions, but one cannot fully appreciate his philosophical system.

My approach to Cohen is historical-philological in the sense described by Joachim Wach in regard to August Boeckh (vide infra, p. 224). I owe my attention to the influence of Boeckh and Steinthal ${ }^{18}$ on Hermann Cohen to the late Dieter Adelmann, whose untimely death has deprived the community of Cohen scholars of an inspired mentor. ${ }^{19}$ The Cohen that emerges in this study is a bold thinker. Among his peers, the one most similar in stature, originality, and boldness was perhaps Friedrich Nietzsche whose intellectual influence thoroughly eclipsed Cohen's. ${ }^{20}$ It would be worth a doctoral dissertation to compare and contrast the two. Their beginnings are similar, their ends opposite. While Cohen's socialist philosophy culminates in a concept of God that urges love of

${ }^{16}$ See WW 5/II p. $21^{*}$, cited infra p. 157, Fn. 329.

${ }^{17}$ See the monograph by Dana Hollander on this subject, forthcoming with University of Toronto Press.

${ }^{18}$ On Steinthal cf. Hartwig Wiedebach and Annette Winkelmann, Chajim H. Steinthal, Sprachwissenschaftler und Philosoph im 19. Jahrhundert (Leiden: Brill, 2002).

${ }^{19}$ See Dieter Adelmann, "Reinige dein Denken": Über den jüdischen Hintergrund der Philosophie von Hermann Cohen. Edited by Görge K. Hasselhoff (Würzburg: Königshausen \& Neumann, 2010), and idem, Vorbereitende Untersuchung für eine historisch-verifizierende Konfrontation der Fundamentalontologie Martin Heideggers mit Hermann Cohens "System der Philosophie." Ed. Görge Hasselhoff (Potsdam: Universitätsverlag Potsdam, 2012).

${ }^{20}$ Vide infra, p. 391. 
the poor, Nietzsche disparages Judeo-Socratic ethics and urges a return to aristocratic and Dionysian values. Nietzsche collapses at a moment of commiseration with a beast of burden, while one of Cohen's last reported utterings protested Christian Judeophobia. From Cohen's perspective, Nietzsche might have been the peak of Spinozistic pantheism. To Nietzsche, Cohen might have unwittingly embodied Jewish vitality. Aside from Nietzsche, Cohen's unacknowledged proximity to Hegel should be further investigated. ${ }^{21}$ The relationship between Cohen and Spinoza also remains an important subject. ${ }^{22}$ The subject of morality (thought) and legality (action) in post-Kantian ethics should be further explored. Jewish studies dissertations should be written on Cohen's place in early $20^{\text {th }}$-century Wissenschaft des Judentums, on the role of the Bible in the formation of modern Jewish thought from Mendelssohn to Cohen, Buber, and Rosenzweig, 23 and on the influence of Solomon Munk's Maimonides translation and commentary on Cohen's philosophical thought.24 The important topic of Jewish ethics and philosophy of religion after Cohen is the subject of the work of Robert Gibbs.25 Reinier Munk has foregrounded Cohen's attention to "alterity," and hence Cohen's place in the emergence of post-modern theories of subjectivity. 26

This study assumes that it is possible to know again what an author knew, and to gain a sense of the development of a thinker's trajectory, a trajectory that cannot be derived from the sequence of publications alone. I believe that my study brings into relief some of the thinking of Cohen that manifests in his writings but can be seen for what it is only if one looks beneath the surface and pulls on a thread that he weaves step by step without always foregrounding it. It is manifest only if one gets a hold

\footnotetext{
${ }^{21}$ See Myriam Bienenstock, Cohen und Rosenzweig. Ihre Auseinandersetzung mit dem deutschen Idealismus (Freiburg and Munich: Karl Alber Verlag, 2018).

${ }^{22} \mathrm{Cf}$. Kaplowitz, "The gravest obstacle and thus a great misfortune": Hermann Cohen's Interpretation of Spinoza. (PhD Dissertation, New York University, 2010).
}

${ }^{23}$ Note Alexandra Zirkle's forthcoming work on the role of biblical exegesis in the formation of modern Jewish thought. Cf. Zirkle, "Heinrich Graetz and the Exegetical Contours of Modern Jewish History." Jewish Quarterly Review, 109, 3 (2019), 360-383.

${ }^{24} \mathrm{Cf}$. Hermann Cohen, Ethics of Maimonides. Translated and edited by Almut Sh. Bruckstein. (Madison, Wis: University of Wisconsin Press, 2004).

${ }^{25}$ See Robert Gibbs, Correlations in Rosenzweig and Levinas (Princeton, N.J : Princeton University Press, 1994).

${ }^{26}$ See Reinier Munk, Hermann Cohen's Critical Idealism (Dordrecht: Springer, 2005). 
of it and follows where it leads. If my work on Cohen is methodical, its method is simply that I pay close attention to what he says, trusting that he means what he says. The Cohen who emerges here is both familiar and unfamiliar. He is more Jewish and at the same time more philosophical and both in surprising ways. I hope readers have the patience to read through the whole and allow for a complex picture to emerge, one that is not easily summarized. The best-case scenario for me would be if others picked up where I left off and completed and corrected my readings of Cohen. ${ }^{27}$ That Cohen's concept of atonement emerges in the decade before the publication of his Logik der reinen Erkenntnis, as established in this work, has been widely accepted..$^{28}$ Cohen's attention to the psychological force of Jewish liturgical prayer, as evidenced in the manuscripts on atonement included in this book, has been further developed by Steven Kepnes in what he aptly describes as "liturgical reasoning." 29 Dana Hollander has taken Cohen's attention to divine attributes further and made it the basis for her research on the concept of love of neighbor. ${ }^{30}$ Robert Erlewine and Paul Nahme have taken inspiration from Cohen for their respective work in contemporary Jewish thought and I am pleased that their critical appreciations look kindly at some of my insights. ${ }^{31}$

There remain flaws in this study that I am more fully aware of now that I read it from a distance of twenty years. Treating the development from early Jewish writings to late Jewish philosophy of religion and ethics, as I do in Part I, leaves the discussion of the system for later and deprives the reader of important background to Religion of Reason. Part I presupposes Part II, and vice versa. The close reading of Begriff der Religion at the end of the book calls for further analysis of the changes in Cohen's concept of religion compared to earlier writings, including the notes given in the appendix. It would have been useful to offer a conclusion that weaves the two strands of the book together and provides an overview of its findings. The introduction does only some of this work. I was overly confident that I said everything important somewhere in this book and that attentive

${ }^{27}$ See C. Bultmann in Journal for the Study of the Old Testament. Vol. 27 Issue 5, (2003), p. 20.

${ }^{28}$ See Hartwig Wiedebach in Journal of Jewish Thought \& Philosophy (Routledge), Vol. 11, Issue 1, May 2002, p. 72.

${ }^{29}$ Steven Kepnes, Jewish Liturgical Reasoning (New York: Oxford University Press, 2007).

${ }^{30} \mathrm{~A}$ volume on this subject is forthcoming with Toronto University Press.

${ }^{31}$ See Robert Erlewine, Monotheism and Tolerance: Recovering a Religion of Reason (Bloomington, Ind.: Indiana University Press, 2010), and Paul E. Nahme, Hermann Cohen and the Crisis of Liberalism: The Enchantment of the Public Sphere (Bloomington, Indiana: Indiana University Press, 2019). 
readers would piece things together on their own. Most regrettably, the book lacks an index, a fact that a searchable e-book alleviates only partially, as an index is also a way for an author to communicate important key terms.

Why is Cohen not better known today? 1929, the year Cohen's Religion der Vernunft appeared in a second, corrected edition, also saw Heidegger and Cassirer facing off at the Davos Hochschultage, an event that cemented the demise of neo-Kantianism in German-speaking academic philosophy. ${ }^{32}$ Later on, a Wall Street crash ushered in the Great Depression, which boosted the rise of fascism. Nearly forty years later, in 1968, Dieter Adelmann recounted the story how Heidegger had verdrängt (pushed aside), rather than overcome, Cohen's philosophy, leaving the task of "a point by point accounting" (J. Ebbinghaus) unfinished. Soon after, a new wave of neoKantian and Cohen-studies led to new appraisals of the philosophical characteristics and achievements of the Marburg school. That wave was partially driven by an affinity for the academic socialism of many of the neo-Kantians. But this revival was also driven by the indefatigable work of Professor Helmut Holzhey who, at the ETH Zurich, established a Hermann-Cohen-Archive and launched the new Hermann Cohen Werke edition. Most of the scholars of that generation took Cohen's Jewishness for granted. To them it no longer constituted an obstacle, but it still posed somewhat of an afterthought and a distraction. In a milieu where it was still somewhat embarrassing and occasionally odious to be reminded of Jews and Judaism, it simply occurred to no one to explore seriously the Jewish dimensions of Cohen's systematic philosophy. Cohen's Jewish philosophy was treated either as a Jugendsünde, a youthful transgression, or as part of his "late" philosophy of religion, and thus as a departure from his more rigorous philosophical thought. The Jewish reception of Cohen, with the exception of Steven Schwarzschild and William Kluback, was not much more enthusiastic. Just as Heidegger muscled out Cassirer as the belated representative of Wilhelminian bourgeois philosophy, so Rosenzweig (who died in 1929) posthumously replaced Hermann Cohen as the star of Jewish philosophy, not least because he was associated with a "return" to Judaism, while Cohen was associated with the selfdefeating excesses of German Jewish assimilation. Cohen's Jewishness was a negligible personal matter to the European philosophers who tried to retrieve him and an untenable distortion to the Jewish thinkers who dismissed him. Too much Judaism. Too little Jewishness.

The reception of this book has shown that there are now new ways of reading Cohen as both Jewishly and philosophically informed and curiously relevant. What remains to be rediscovered, and I hope that the new edition of this book will help to stimulate such a rediscovery, is the

\footnotetext{
${ }^{32}$ Cf. Peter E. Gordon, Continental Divide: Heidegger, Cassirer, Davos (Cambridge, Mass: Harvard University Press, 2010).
} 
extent to, and the manner in, which Judaism and philosophy are really intertwined for Cohen. While this may sound a little too postmodern for the taste of readers who wish to keep Cohen safely in the camp of late Enlightenment thinkers or consider him the last great rationalist, ${ }^{33}$ the fact is that his writings suggest a more complex picture. Cohen had things to say about the staying power of religions, about the moral virtue of loyalty to one's particular community, about the need for the emotions in the economy of ethical practice, about the need to take not just religion but religions seriously. He was a critical rationalist, not a dogmatic one. This book introduces readers to this complexity and intertwining of Jewish and philosophical reason, a complexity that arises from a movement of thought that tasks philosophy with attention to any and all forms of cultural production and an intertwining that is controlled by careful methodical reflections on the share of religion in reason and of reason in religion.

In the postscript to the book I point to a question that, to my mind, remains central today. Do we need to hate in order to love? Cohen insists that hatred, especially ethnic hatred, is always sin'at hinam, empty, ungrounded and ungrounding. We can and ought to love our own community without hating others, even those who hate us. This is not a Christian insight alone, but also a Jewish one. It should be the property of all humanity. Cohen's thought has guided me in many ways since I wrote this book. I have since published several essays where I expand on what I articulate here. An essay I wrote for a Cohen conference held in Rome in 2003 that I was unable to attend provided the title for a collection of these and other essays published under the title Jüdische Religionsphilosophie als Apologies des Mosaismus. ${ }^{34}$ A substantive study of "justice" in Jewish thought that the editors of the Cambridge History of Jewish Philosophy: The Modern Era solicited and kindly included in their distinguished volume ${ }^{35}$ culminates in a few paragraphs on the abiding significance of Hermann Cohen's political theory. The work on Leo Strauss, Martin Buber, and themes of political theology that I undertook after the first publication of this work have only confirmed my belief that we can still learn from Cohen. I can therefore only underscore what I wrote in the postscript to the first edition.

\footnotetext{
${ }^{33}$ So Beiser (2018).

${ }^{34}$ Jüdische Religionsphilosophie als Apologies des Mosaismus (Tübingen: Siebeck Mohr, 2016).

35"Justice" in The Cambridge History of Jewish Philosophy: The Modern Era, edited by Martin Kavka, Zachary Braiterman, and David Novak (Cambridge: Cambridge University Press, 2012), pp. 704-738.
} 


\section{Corrigenda to the Digital Edition}

P. 11 Line 10: strike "relative and"

P. 29 Line 12 from below: "ever"

P. 30 Second paragraph, line 10: "provides"

P. 38 Line 11: "to prevent his feelings from overcoming his"

P. 39 Third paragraph, line 12: "philosophical"

P. 46 Fifth paragraph, line 3: "began"

P. 47 Second paragraph, line 3: "responded to"

P. 47 Fifth paragraph, line 7: "for which he was"

P. 51 Third paragraph, line 1-2: “H. Steinthal (1823-1899), Cohen's teacher and mentor (...) in Berlin,"

P. 51, Fn 16, line 2: "AZdJ was edited"

P. 52 Third paragraph, line 7: "subsistence for"

P. 62 Second paragraph, line 4: "unable to reconcile"

P. 62 Fourth paragraph, line 3: "does not indicate (...) but brings"

P. 65 Second paragraph, line 6: "that he"

P. 67 Line 11: "Antisemitismusstreit"

P. 91 Line 15: „common"

P. 92 Line 13: "acceptance by"

P. 92 Line 18: "sources"

P. 99 Third paragraph, line 14: "Cohen felt he was"

P. 111 Fn 191, line 8: "particularly curious"

P. 119 Fourth line from the bottom: "doctrine of incarnation"

P. 123 Third paragraph, line 13: "simile (mashal)"

P. 138 Line 5 from the bottom: "Versöhnung is"

P. 140 Third paragraph, line 1: "tradition equally values"

P. 143 Line 7 from the bottom: "that traditional"

P. 143 Line 5 from the bottom: "prayer and"

P. 146 Third paragraph, line 5 from bottom: "purity"

P. 160 Second paragraph, line 3 from bottom: "demonstrate"

P. 161 Second paragraph, line 3: "to state publicly since 1898"

P. 161 Second paragraph, line 5: "being,"

P. 161 Second paragraph, line 6: "RV," 
P. 167 Second paragraph, line 7: "alike,"

P. 167 Third paragraph, line 5: "rhetoric"

P. 177 Second paragraph, line 9: "I show Cohen's"

P. 178 Second paragraph, line 2 from bottom: "exposition, which"

P. 178 Third paragraph, line 5: "table of contents a confusing, seemingly incongruous,"

P. 188 Fn 392, line 3: "self-assurance"

P. 193 Line 11: "specifically Judaism"

P. 193 Second paragraph, line 7: "on messianism"

P. 216 Line 9: "historical description"

P. 216 Line 7 from the bottom: "Kantian reason"

P. 218 First paragraph, line 9: "metaphors"

P. 218 Second paragraph, line 10: "hermeneutic"

P. 223 Second paragraph, line 1: "In the 1920's,"

P. 226 Third paragraph, lines 12-14: "In Cohen's system, "pure feeling" (reines Gefühl) is implied and operative in both, artistic production and the perception or appreciation of the arts."

P. 230 Second paragraph, line 2: "(Cultur-Factum) by which to"

P. 230 Second paragraph, line 6: "as later,"

P. 230 Second paragraph, line 8: "and that immediately"

P. 231 Line 1: "Cohen wrote"

P. 231 Line 2: "when he also began"

P. 232 Lines 11-12: "relation to, and a stronger reliance on,"

P. 235 Lines 2-3: "especially if"

P. 238 Second paragraph, line 12: "to the transcendental"

P. 258 Second paragraph, line 4: "in which energy"

P. 268 Last line: "agreement"

P. 270 Second paragraph, line 10: "for such a hybrid"

P. 271 Line 2: "a theory of temporality"

P. 272 Line 9: "handmaiden for"

P. 272 Second paragraph, line 10: "beyond the realm of necessity."

P. 272 Second paragraph, line 16: "terms of necessity."

P. 272 Second paragraph, second to last line: "Its effort aims at reconciliation and at-one-ment."

P. 273 Line 8: "most significant representation"

P. 273 Second paragraph, line 6: "precursor to"

P. 275 Second paragraph, line 9 from bottom: "philosophically"

P. 280 Line 9: "(one of a plurality)"

P. 282 Second paragraph, line 12 from bottom: "emancipation"

P. 290 Second paragraph, line 7: "a cultural"

P. 294 First line: "arises"

P. 300 First paragraph, line 8 from bottom: "Second Temple"

P. 301 Lines 6-7 from the bottom: "self and all"

P. 305 Second paragraph, line 5: "As poets, the prophets"

P. 314 Second paragraph, line 1: "validity of" 
P. 317 Third paragraph, second line: "it is homologous with"

P. 317 Fn 115: "Myth can be understood"

P. 319 Line 10 from the bottom: "program of "including" religion into ethics"

P. 319 Second to last line: "by a German"

P. 320 Second line: "times of war"

P. 321 Second paragraph, line 1: "aimed at"

P. 321 Second paragraph, line 5: "with one another"

P. 328 Second paragraph, line 3: "with Greek"

P. 328 Second paragraph, line 13: "was the prevailing"

P. 333 Line 6 from bottom: "Is not itself, or only negatively, grounded in ethics."

P. 334 Lines 12-13: "and each necessary in its own right."

P. 335 Third paragraph, line 7: "We posit (ansetzen)"

P. 337 Line 3: "insists on a congruity"

P. 341 Second paragraph, line 4: "is whether - if"

P. 341 Second paragraph, line 6: "Good - can it"

P. 341 Second paragraph, 7: "idea of God?"

P. 346 Second paragraph, line 5 from bottom: "referred to, namely Judaism"

P. 347 Second paragraph, line 7: "philosophical problems."

P. 354 Third paragraph, second to last line: "with the human spirit (...) so with"

P. 358 Line 7 from the bottom: "as well as"

P. 359 Second to last line: "perspective, though from"

P. 364 Line 7: "need for redemption"

P. 366 First paragraph, line 3 from bottom: "homogeneous with"

P. 366 First paragraph, line 2 from bottom: "was the beacon"

P. 373 Line 3: "atonement, describing"

P. 376 Line 4: "worthiness of redemption"

P. 378 Last line: "perspective - and"

P. 379 First line: "consciousness - is"

P. 379 Line 5: "The question raised"

P. 380 First and second line: "before the messianic age,"

P. 380 Last line: "historical particularity and"

P. 381 Line 5 from the bottom: "allows"

P. 393 Fn 1: "See the introduction to Leo Strauss, The Early Writings (19211932). SUNY Series in the Jewish Thought of Leo Strauss, ed. Kenneth H. Green, Albany: SUNY Press, 2002."

P. 459 Line 7 from bottom: " 56 , danke für"

P. 472 First line: "allow us"

P. 472 Line 6: "wherever a"

P. 473 Second paragraph, line 2: "strikethrough correction"

P. 473 Textbox and Translation: "216" is in the original (not footnote marker)

P. 475 Last paragraph: not blockquote

P. 476 First two paragraphs: not blockquote 
P. 487 Textbox, at page ref. "345", in parenthesis: ביתוסים (cf. p. 493, last paragraph)

P. 493 Second paragraph, line 6: "klar"

P. 496 Line 4 from bottom: "that support the"

P. 497 Fourth paragraph, line 3: "rules"

P. 497 Last line: "mercy"

P. 498 Line 3: "from Tractate"

P. 520 First textbox, line $1:$ פחדך

P. 524 First line: "The moral laws"

P. 524 Second paragraph, second to last line: "project might have" 


\section{Acknowledgments}

This book is the fruit of labor which has occupied me since 1989 when I was a student at the Department of Near Eastern and Judaic Studies at Brandeis University. I acknowledge the support of this fine institution which provided me with access to an outstanding faculty as well as with generous financial support. In my research I was greatly aided by the Boston Library Consortium as well as by an Interlibrary Loan system of which I made ample use. I found myself especially often at the $\mathrm{O}^{\prime}$ Neill Library at Boston College, Widener and the Andover Library of Harvard Divinity School, Mugar and School of Theology Libraries at Boston University, and at the library of Hebrew College in Brookline. My gratitude goes to the staff at all of these institutions, especially to Charles Cutter and Jim Rosenbloom at Brandeis University. Thanks also to the staff of the Leo -Baeck-Institute in New York as well as of the New York Public Library Main Branch in Manhattan.

Special thanks to Dr. Uwe Bredehorn, director of the archives at Philipps Universität in Marburg, for allowing me access to the collection of manuscripts by Hermann Cohen as well as for the permission, in agreement with Dr. Hartwig Wiedebach, to include a selection of these important and hitherto unpublished papers first in my dissertation and now in this publication. Thanks also to the staff at the archives of the National and University Library, Givat Ram, Jerusalem, for providing me with further manuscripts by Cohen that are likewise included here. I am finally grateful to Professor Helmut Holzhey for the permission to peruse the Hermann-Cohen-Archiv at Philosophisches Seminar der Universität Zürich. This magnificent collection of Coheniana, as well as the private archives of Dr. Wiedebach in Göppingen provided much of the documentary evidence that I rely on in the biographical and historical parts of this book.

The support of the Humanities Foundation at Boston University and its director Katherine T. O'Connor allowed me to take time off to 
immerse myself in this material again which made it possible for me to produce a book that is more than the cosmetic revision of a dissertation.

To recognize everyone who has helped me shape my ability to handle the sources, concepts, and methods that went into the making of this work is impossible. I feel privileged at this opportunity to mention first and foremost my mentor at Brandeis University, the late Professor Marvin Fox, whose guidance and good council were invaluable to me. He knew when to encourage and when to throw obstacles in one's path. $\mathrm{He}$ tested my resolve to dedicate the utmost to the work of what he considered a towering prophetic figure in modern Judaism. Among his colleagues at Brandeis University, Professors Marc Brettler, Michael Fishbane, Alfred Ivry, William A. Johnson, Jehuda Reinharz, and Krister Stendahl all had their share in rounding out my education. Michael Fishbane was the one who first brought me to Brandeis University. $\mathrm{He}$ provided a setting for myself and a splendid group of fellow-students to hone our skills in the reading of rabbinic midrash. Marc Brettler initiated me to biblical studies in the United States. Alfred Ivry guided my first steps in the study of Hermann Cohen and encouraged me not "to spread myself too thinly." With Bill Johnson I first explored the connection between Cohen and Wilhelm Herrmann. Jehuda Reinharz sharpened my perception of modern Jewish history, and Krister Stendahl offered himself more than once as a sounding board. I am deeply grateful to all of them.

Yet I did not arrive at these shores as an academic tabula rasa. I am indebted to Christian and Jewish scholars, theologians, and philosophers who were my teachers in Göttingen (Albeck, Berner, Geyer, Perlitt, Schwarzweller, Zimmerli), Kiel (Becker, Birkner, Donner, Ebach, Gelles, Luck, Maron, Metzger, Waack), Heidelberg (Berger, R. and E. Blum, Burchard, Eisinger, Gadamer, Gloy, Kienzle, Kronauer, Kulenkampff, Kwasmann, N. P. Levinson and P. Navé-Levinson, Peters, Pilot, Ringer, Ritter, Rupprecht, Schütt, Seebass, Talmon, Theißen, Tödt, Wiehl, Wieland), and Jerusalem (E. Fackenheim, D. Flusser, M. Krupp, Y. Leibowitz, P. Mendes-Flohr, Ch. and Sh. Safrai, A. Samuel, A. Shin'an).

The predecessor to this work, the doctoral dissertation I submitted to the Department of Near. Eastern and Judaic Studies at Brandeis University in 1994, received constructively critical responses which were on my mind as I prepared this book for publication. Aside from the anonymous reviewer for Brown Judaic Studies, I should like to acknowledge Professors Kenneth Seeskin, Norbert Samuelson, and Wendell Dietrich who contributed encouragement and incisive criticism of my first attempt to make sense of an enormously complex thinker. My friend Hinrich Witzel provided crucial help on several occasions when my thinking had reached an impasse. Adam Seligman forced me, from 
day one of his arrival at Boston University, to pay attention to some of the more radical notions in Cohen's ethics. Robert Gibbs, Peter Ochs, Steven Kepnes, Jacob Meskin, and others who are part of an ongoing discussion network to which I belong, have taught me what Jewish philosophy may be at this day and age. Finally, I would like to mention the circle assembled by Professors Helmut Holzhey and Gabriel Motzkin during two remarkable conferences on Hermann Cohen's philosophy of religion, in Jerusalem (1996) and Zürich (1998), as well as those gathered in Marburg in 1992. I have learned from all. Among them, but in a league of their own, are Dieter Adelmann and Hartwig Wiedebach. Their careful studies have set the benchmark that I tried to reach in my own effort to contribute to our understanding of Cohen's thought. Their sustained, kind, and generous collegiality as well as the exact and exacting knowledge they shared with me on many occasions over the course of the past seven years is hereby gratefully acknowledged.

Many of my linguistic shortcomings were graciously mended in a first round by Abe Shenitzer, meticulous translator and caring father-inlaw, and in a second round by my assistant, Ms. Lesleigh Cushing. I am deeply indebted to both for their selfless efforts at making my English comprehensible and idiomatic.

The dissertation was dedicated to my maternal grandparents, Heinrich and Frieda Koch, née Frank, and to my mother's twin brother Josef, who perished during the Holocaust. Today, however, I am more concerned with the present and the future than with the past. To take Cohen seriously must mean more than building memorials to an extinct German Jewry. We carry their memory, to the best of our abilities, but we hear their demand to turn around and care for the next generation. Hence a new dedication is in place. This book is my humble gift to the one who accompanied me on this ten-year voyage as a faithful companion, a well-spring of good council, and a caring friend: Miriam Shenitzer, and to our two most precious possessions, Benjamin Aaron Henry and Rachel Josephine.

Boston, Massachusetts March 1999 



\section{Preface by Wendell Dietrich}

It is a bitter-sweet honor to introduce Michael Zank's book to the scholarly public. Far better that it be done by Professor Zank's mentor at Brandeis, the late and deeply revered Professor Marvin Fox. But that was not to be.

It was Professor Fox who asked me to be a second reader for the Brandeis doctoral dissertation the research for which forms the basis for the present book. It was an invitation that I have always been glad that I accepted.

As to the present significance and pertinence of the book's topic, I can certify that, in my judgment as a historian of Judaic thought, Hermann Cohen's Religion of Reason Out of the Sources of Judaism is the single most consequential work of Judaic thought in the period of the nineteenth and twentieth centuries. There has been a very considerable revival of interest in Cohen in German-writing philosophical circles in the last twenty years or so. And Cohen's achievement is gaining increasingly wide recognition in English-writing Judaic thought and moral philosophy circles.

Michael Zank's book makes an important contribution to the reappraisal of Cohen's achievement and indicates features of Cohen's thought highly suitable for current retrieval.

Zank boldly aligns Cohen with the tasks of Jewish philosophy first taken up in the period of Jewish-Muslim philosophical symbiosis. That is, Cohen's Jewish philosophy takes the Torah as the central Jewish religious theme and Jewish philosophy thus in some broad sense provides "reasons for the Torah." Of course, Cohen executes that task, according to Zank, in a distinctively modern way. Cohen's treatment of Jewish philosophy in Religion of Reason is part of a Marburg neo-Kantian project of establishing the validity of judgments of truth in various fields of human activity (the logical, ethical, and the esthetic) and of establishing the unity of cultural consciousness. Further, Cohen is concerned to vindicate the truth claims of Judaism in a setting in late 
nineteenth century Germany where the common ethos of the volk is dominated by (for Cohen principally Protestant) Christianity. That common ethos also displays elements of revived anti-Semitism and Cohen's enterprise has a certain apologetic edge.

Characterizing Cohen's Jewish philosophy as Zank does requires him to make his way through a number of controversial mine-fields in twentieth century Cohen interpretation. The first is Franz Rosenzweig's influential and notorious presentation of the Cohen of Religion of Reason in Rosenzweig's "Introduction" to Cohen's "Jewish Writings." Rosenzweig's portrait of the Cohen of Religion of Reason is that of a late reversioner to Judaism and a philosopher who breaks through the "magic circle" of critical idealism in the direction of a more existentialist point of view. (Zank courteously but firmly dismisses Rosenzweig's views on both counts.) A second mine-field is the dispute between Julius Guttmann and Leo Strauss about the alleged permanent supersession of the medieval Jewish philosophical problematik. (Zank finds with Strauss on the matter of continuing contemporary validity of the medieval problematik and lines Cohen up as a continuator of that project. This puts Zank at odds with Guttmann's Philosophies of Judaism.) In recent times the late Steven Schwarzschild argued that Cohen's philosophy was simply philosophy as such properly construed, that is as an ethical critical idealism. (Zank side-steps what he takes to be Schwarzschild's overly ambitious claim.)

Zank appraises as justified the extensive revival of interest in the late nineteenth century neo-Kantians among contemporary German historians of philosophy and constructive philosophical practitioners. The curt dismissal of the neo-Kantians in favor of Husserl and Heidegger was ill considered it is now argued. Zank has mastered this German literature which is quite unknown in the Anglo-American philosophical world; his thoughtful critical reports will be instructive especially for the Anglo-American and the Israeli reader. And Zank pertinently observes that the latest German literature on Cohen as a philosopher is entirely innocent of a notion of Cohen producing a Jewish philosophy. Zank's interpretation of Cohen takes into account the new German literature while pressing an agenda which is comparable to more recent American construals of Cohen as a Judaic thinker. That is one of the distinctive excellences of Zank's interpretation.

So here is a new generation of Cohen interpreters and a fresh voice. I invite the reader to grapple seriously with Michael Zank's interpretation of Hermann Cohen.

Wendell S. Dietrich

Professor of Religious and Judaic Studies Brown University - March 1999 


\section{Introduction}

\section{Between Judaism and Philosophy}

\section{Hermann Cohen and Marburg Neo-Kantianism}

In 1857, fifteen-year old Hermann Jecheskel Cohen entered the newly founded Jewish Theological Seminary in Breslau intending to become a rabbi. After four years of study under the luminaries of modernist "historical-positive Judaism" he abruptly left the seminary and took up the study of Classics and Philosophy instead. In 1865, he graduated with a doctorate from the University of Halle. For the next six years he lived in Berlin working as a private tutor and freelance writer in the new field of "ethnic psychology," a predecessor to social psychology and linguistics. ${ }^{1}$ In 1871 he contributed a widely noted essay to a then-raging debate between his former teacher, the Berlin philosopher Adolf Trendelenburg, ${ }^{2}$ and the Heidelberg historian of philosophy Kuno

${ }^{1} \mathrm{Cf}$. "Die platonische Ideenlehre, psychologisch entwickelt" in: ZVPS 4/1866, 403464 (=S1,30-87), "Mythologische Vorstellungen von Gott und Seele, psychologisch entwickelt" in: ZVPS 5/1868, 396-434, and 6/1869, 113-131 (= S1,88-140), "Die dichterische Phantasie und der Mechanismus des Bewußtsein" in: ZVPS 6/1869, 173-263 (=S1,141-228). The major influence on Cohen at this early time is his mentor H. Steinthal. His theory of Völkerpsychologie und Sprachwissenschaft is discernibly present also in the method of Cohen's dissertation, Philosophorum de antinomia necessitatis et contingentiæ doctrinæ. Halæ 1865 (= S1,1-29).

${ }^{2}$ Friedrich Adolf Trendelenburg (1802-1872), important philosophical educator at Berlin University. In his Logische Untersuchungen (1840, 3rd ed. 1870) T. seeks to mediate between reality and thought through the common element of "movement," a philosophical motif that seems to have had great influence on Cohen. In T.'s critical adaptation of Hegel's association of logic and metaphysics we may also find the source for the often-noted proximity between Cohen and Hegel. Cf. G. Patzig, s.v. "Trendelenburg" in RGG vol. 6, 1011. 
Fischer ${ }^{3}$ on matters of interpreting Kant's transcendental esthetics. ${ }^{4}$ Invited by Friedrich Albert Lange, the author of an immensely popular philosophical History of Materialism, ${ }^{5}$ Cohen received a non-tenured appointment at the Prussian provincial university in Marburg/Hesse. In 1876, in a fortuitous moment of administrative liberalism during Prussia's Kulturkampf, Cohen succeeded Lange to the chair in philosophy, a highly conspicuous appointment for an unconverted Jew, which he held until his retirement in 1912. The decorated Prussian Geheimrat became mostly known for his works on Kant. Supported by his younger colleague, the Plato scholar and social philosopher Paul Natorp ${ }^{6}$ he developed a distinctive version of critical philosophy that is generally referred to as Marburg neo-Kantianism.

\footnotetext{
${ }^{3}$ Kuno Fischer (1824-1907), historian of modern philosophy. On his views on Kant see Kant's Leben und die Grundlagen seiner Lehre. Drei Vorträge. 2. ed. Heidelberg: C. Winter, 1906.

4"Zur Controverse zwischen Trendelenburg und Kuno Fischer" in: ZVPs 7/1871, 249-296 (= S1,229-275).

${ }^{5}$ Friedrich Albert Lange (1828-1875), socialist educator and philosopher. His Geschichte des Materialismus und Kritik seiner Bedeutung in der Gegenwart (first edition: Iserlohn, J. Baedeker, 1866) saw many editions and translations, e.g., into English: The history of materialism and criticism of its present importance. Authorized translation by Ernest Chester Thomas. London: Trubner \& Co., 1877-1881; third edition 1925, reprinted 1950, enlarged by a preface by Bertrand Russell; Hebrew (including Hermann Cohen's "biographical introduction with critical postscript"): Toldot ha-materialismus u-vikoret erko bi-zemanenu (...) mavo (...) meet Herman Kohen, transl. by Bar Tuvyah. New York/Warsaw: A.Y.Shtibl 1921, Yiddish: Geshikhte fun materyalizm. (fun Daytsh: Z. Blat.) [2te oyflage] Varshe: Y. A. Tsuker, 1929. On Lange and Cohen cf. the letters published in Lange, Über Politik und Philosophie. Briefe und Leitartikel 1862 bis 1875. Ed. Georg Eckert. (Duisburger Forschungen, 10. Beiheft) Duisburg, W. Braun, 1968. After Lange's death Cohen became his literary executor.

${ }^{6}$ Paul Gerhard Natorp (1854-1924), twelve years younger than Cohen and from a pious Protestant home, was encouraged by Cohen to use his knowledge of ancient philosophy towards research in the history of the "problem of knowledge" (cf. Natorp, Forschungen zur Geschichte des Erkenntnisproblems im Altertum: Protagoras, Demokrit, Epikur und die Skepsis. Berlin: W. Hertz, 1884). Natorp is still well-known as a Plato scholar (see his Platos Ideenlehre: Eine Einfuihrung in den Idealismus (Leipzig : Dürr, 1903, second edition: Meiner, 1961, third ed. 1994), but he also contributed important and innovative works to the fields of philosophical psychology (Allgemeine Psychologie in Leitsätzen zu akademischen Vorlesungen. 2. ed. Marburg : N.G. Elwert, 1910) and popular education (see, e.g., Sozialpadagogik. Theorie der Willenserziehung auf der Grundlage der Gemeinschaft. 2. ed., F. Frommann (E. Hauff) 1904). Natorp was also the more popular spokesman of the Marburg school, much more irenic than the easily-hurt and suspicious Cohen and a more accessible literary representative of the school's method. See, e.g., Philosophie, ihr Problem und ihre Probleme. Einführung in den kritischen Idealismus. (Wege zur Philosophie. Ergänzungsreibe: Einführungen in die Philosophie der Gegenwart, nr. 1): Göttingen, Vandenhoeck \& Ruprecht,
} 
The philosophy of critical idealism as it was taught in Marburg attracted a number of students from places as far away as St. Petersburg, Riga, and Madrid, and while not all of them were converted to the life of philosophy or went on to perpetuate their masters' ideas, it was a school of distinction nevertheless. Among the names that are still well known even beyond the narrow community of specialists are those of Ernst Cassirer, Hans-Georg Gadamer, Nicolai Hartmann, Heinz Heimsoeth, Boris Pasternak, and Jose Ortega y Gasset.$^{7}$ The Marburg of Cohen and Natorp ranked among the most widely recognized philosophical centers on the Continent. ${ }^{8}$

His first more widely read works ${ }^{9}$ paid homage to the ongoing Kant revival. ${ }^{10}$ But Cohen was rather an original thinker who brought to his study of philosophy a much wider blend of cultural and intellectual influences than initially visible. Trained in rabbinics, humanistic philology, as well as ancient and modern philosophy and hermeneutics, his writings reflect a wide range of interests. Equally well read in mathematics, physics, classical Greek literature, Roman law, classical Western and traditional Jewish music, the fine arts, and religion, he developed an interest in the general phenomenon of cultural creativity. His first attempts to articulate the underlying "mechanism" of creativity

1911, and his defense of Marburg before the Kant-Society in Berlin, Kant und die Marburger Schule, Berlin: Reuther und Reichard, 1912.

${ }^{7}$ One could also name those theologians who, encouraged by Wilhelm Herrmann, heard Cohen's lectures. For Karl Barth in Marburg see, for example, Dietrich Korsch, Dialektische Theologie nach Karl Barth. Tübingen: Mohr, 1996.

${ }^{8} \mathrm{Cf}$. the beautiful vignettes of academic life in Marburg described by Boris Pasternak in Safe Conduct. An Early Autobiography and Other Works, (transl. by Alec Brown), London: Elek Books, 1959. For a study of Marburg neo-Kantianism from the perspective of institutional history see Sieg, Aufstieg und Niedergang.

${ }^{9}$ See especially Kants Theorie der Erfahrung, Berlin: Dümmler, $1871\left(\mathrm{KTE}^{1}\right)$ second edition 1885, Die systematischen Begriffe in Kants vorkritischen Schriften nach ihrem Verhältnis zum kritischen Idealismus, Berlin: Dümmler, 1873 (= S1,276-335), Kants Begrïndung der Ethik, Berlin: Dümmler, $1877\left(\mathrm{KBE}^{1}\right)$, and Kants Begrïndung der Ästhetik, Berlin: Dümmler, 1889.

${ }^{10} \mathrm{On}$ the rise of neo-Kantianism in general see Köhnke, Klaus Christian, Entstehung und Aufstieg des Neukantianismus. Die deutsche Universitätsphilosophie zwischen Idealismus und Positivismus, Frankfurt am Main: Suhrkamp, 1986 [English edition: The Rise of Neokantianism. German Academic Philosophy between Idealism and Positivism, (transl. by R.J. Hollingdale) Cambridge/New York: Cambridge University Press, 1991]. Köhnke examines both Geistesgeschichte and institutional history for factors in the rise of neo-Kantianism. His description of the materialism debate of the mid-19th century is excellent and he contributes important information on the influence of the Berlin philosopher Adolf Trendelenburg on Cohen's generation. 
utilized H. Steinthal's ${ }^{11}$ method of "ethnic psychology and linguistics," in which cultural (linguistic) diversity is examined in terms of an underlying psychological mechanism from which cultural creativity can be explained. Turning against the mechanistic and psychological school of interpreting phenomena of consciousness, however, Cohen soon joined the revival of the transcendental philosophy of Kant, realizing, as did others, the pessimistic and nihilistic implications of the materialist presupposition of the psychologism of his time. What remained, however, was Cohen's conviction that a theory could be found (and was already in existence) that not only accounted for the unity underlying the diverse energies of human creativity but that secured human freedom its pride of place as the source and origin (Ursprung) of culture. Cohen became a disciple of the critical idealist tradition of Plato ${ }^{12}$ and Kant.

This philosophical agenda reached beyond the bookish world of the academy and deeply into the arena of public debates on politics and religion. His essays on the political questions of the day and his private correspondence demonstrate Cohen's participation in the struggle to advance the political fortune of the Socialist Party (SPD). Revisionist Socialism aimed to make the party a dominant force in Bismarck's Germany. For this purpose, socialism was to abandon the doctrines of class-struggle and revolutionary action and embrace an agenda of gradual reform instead. Cohen's Ethics was written to provide the theoretical underpinnings for such a revision. Among the Socialdemocratic leaders who were influenced by Cohen are Eduard Bernstein, ${ }^{13}$ Kurt Eisner, ${ }^{14}$ and Victor Adler. ${ }^{15}$ The moderate stance embraced by these and other socialist politicians eventually compelled the radical wing of the SPD to branch off, creating its own faction under the heading of an "Independent SPD" (USPD). This allowed the SPD as the party of social democracy to become a decisive mainstream force. This political side of Marburg is representative of the movement "back to

${ }^{11} \mathrm{On}$ H. Steinthal see Dieter Adelmann, "H. Steinthal und Hermann Cohen" in: Hermann Cohen's Philosophy of Religion. ed. Stéphane Moses and Hartwig Wiedebach, Hildeheim/Zürich/New York: Georg Olms, 1997, pp. 1-34.

${ }^{12}$ Cohen's preoccupation with Plato goes back to his days as a student of philosophy and classics in Breslau. Aside from his (Latin) dissertation and essay of 1866 (see notes above), see esp. Platos Ideenlehre und die Mathematik, Marburg: Elwertsche Verlagsbuchhandlung, 1879 (=S1,336-366).

${ }^{13}$ Eduard Bernstein (1850-1932), cf. Peter Gay, The Dilemma of Democratic Socialism; Eduard Bernstein's Challenge to Marx. New York: Collier Books, 1962.

${ }^{14}$ Kurt Eisner (1867-1919), cf. Allan Mitchell, Revolution in Bavaria, 1918-1919; the Eisner regime and the Soviet Republic. Princeton, N.J.: Princeton University Press, 1965 , and see the letter to Eisner, here in the appendix.

${ }^{15}$ Victor Adler (1852-1918), cf. William J. McGrath, Dionysian Art and Populist Politics in Austria. New Haven: Yale University Press, 1974. 
Kant" in general. ${ }^{16}$ In addition to its interests in retrieving the value of transcendental philosophy this movement was characterized by its strongly ethical, political, and pedagogical underpinnings. This indicates that academic philosophers who identified with it were often not only engaged in theoretical work but also in casting themselves as part of a liberal political opposition within the authoritarian state.

Taking the political and social mandate of philosophy seriously, Cohen drafted his ethics and philosophy of religion as contributions to the struggle for social progress and communal peace within the nation state. His Ethics of Pure Will (Ethik des reinen Willens; abbr. ErW) ${ }^{17}$ is a philosophy of law in which states, communities, and individuals are cast in light of their potential of self-transformation towards the ethical ideal. As a theory of political reform and a philosophy of law, this Ethics breaks away from the Kantian focus on morality and derives its concepts of will, action, and self-consciousness instead from the legal constitution of social interaction. ErW is openly indebted to the messianism and monotheism of the Hebrew prophets and it thus absorbed major Jewish religious ideas. From early on, and due to some of Cohen's own programmatic statements, it seemed as if religion was to receive no validation in his thought other than what ethics seemed to provide. Many readers felt that this was philosophically problematic and religiously dissatisfying. However, this judgment must not be accepted without examination. Cohen did not initially think it necessary or possible to distinguish a general concept of religion within the context of a philosophical system, and when he nevertheless published a philosophical treatise on religion ${ }^{18}$ it seemed like a departure in a new direction. However, the matter is not so simple, and it is the task of the present study to show just how intricate the relation of ethics and religion is in Cohen's thought.

Cohen's blueprint of a theoretical culture with practical implications gained wide attention. Yet his direct influence was short-lived. ${ }^{19}$ The rise

\footnotetext{
${ }^{16} \mathrm{Cf}$. Thomas E. Willey, Back to Kant. The Revival of Kantianism in German Social and Historical Thought, 1860-1914. Detroit: Wayne State University Press, 1978.

${ }^{17}$ System der Philosophie. Zweiter Teil: Ethik des reinen Willens, Berlin: Bruno Cassirer, 1904 (xvii and 641pp); 2. revised ed. 1907, 3. ed. 1921, 4. ed. 1923, Werke vol. 7, 1981.

${ }^{18}$ Der Begriff der Religion im System der Philosophie (Philosophische Arbeiten, ed. Hermann Cohen and Paul Natorp, X/1], Gießen: Töpelmann, 1915.

${ }^{19}$ I say this with hesitation. There is a whole slew of titles published in the 1920's and $30^{\prime}$ s that show that Cohen's philosophy continued to be studied and understood in its originality. Once the verdict of Heidegger and the fashion of the times, however, had agreed on a certain narrative of the history of philosophy, Cohen was no longer deemed fashionable by students and the then published histories of philosophy.
} 
and decline of neo-Kantianism more or less coincides with the duration of the Second German Reich (1871-1918). The war disrupted the uneasy peace among the social forces on the Continent and drowned many of the moderate and conciliatory voices in its maelstrom. After the war and the brief period of unrest and revolution that followed it, different stars appeared on the philosophical horizon and drew the young intelligentsia into their orbit. In 1929, Martin Heidegger, who had briefly taught in Marburg where he easily won over many of the students of an aging Paul Natorp, condemned neo-Kantianism as the quintessential expression of Wilhelminian bourgeois society and dramatically declared its end. ${ }^{20}$ Only over the course of the last two or three decades has interest in neo-Kantianism in general and in Cohen in particular again been on the rise. ${ }^{21}$ This retrieval is partly rooted in the realization that the

${ }^{20} \mathrm{Cf}$. Dieter Adelmann, Einheit des Bewusstseins als Grundproblem der Philosophie Hermann Cohens, Heidelberg: 1968, pp. 6-19: "Kurze Rekapitulation des Hergangs, in dem die Marburger Philosophie zwar verdrängt aber nicht 'überwunden' wurde." Also cf. William Kluback, "Hermann Cohen und Martin Heidegger: Meinungsverschiedenheit oder Entstellung" in: Zeitschrift für philosophische Forschung 40/1986, 283-287.

${ }^{21}$ Helmut Holzhey, Professor of Philosophy at Philosophisches Seminar der Universität Zürich and, not insignificantly, a German and former Protestant theologian, has generated the two single most important tools for the ongoing Cohen renaissance. In the 1960's he created the Hermann-Cohen-Archiv in Zürich where he has since assembled what little documents survived the destruction of the family archives following the deportation to Theresianstadt in 1941 of Hermann Cohen's widow Martha Cohen, neé Lewandowski. Since 1977 he has been editing the ongoing comprehensive edition of Hermann Cohen's works, published by Georg Olms Verlag. For the particular volumes of the Werke edition see here in the bibliography. Also cf. Werner Flach, "Eine Renaissance in der Philosophie? Zur Neuausgabe der Werke Hermann Cohens" in: Neue Zürcher Zeitung Nr. 243, Sa/So 18./19. Okt. 1980 p. 70.

While in the 1960's studies on Cohen were few and far between (the notable exceptions are Manfred Brelage, Studien zur Transzendentalphilosophie, Berlin: Walter de Gruyter, 1965 and Dieter Adelmann, Einheit des Bewusstseins (1968); see note above), the trickle of publications (mostly based on dissertations) has meanwhile steadily increased. The following list of examplary titles are in thematic and chronological order and limited to monographs.

On the Marburg school of neo-Kantianism: Helmut Holzhey, Cohen und Natorp, vol.1 "Ursprung und Einheit. Die Geschichte der "Marburger Schule" als Auseinandersetzung um die Logik des Denkens", vol. 2 "Der Marburger Neukantianismus in Quellen. Zeugnisse kritischer Lektüre. Briefe der Marburger. Dokumente zur Philosophiepolitik der Schule", Basel/Stuttgart: Schwabe \& Co, 1986, Alexis Philonenko, L' Ecole de Marbourg: Cohen, Natorp, Cassirer. Paris: Vrin, 1989, Ulrich Sieg, Aufstieg und Niedergang des Marburger Neukantianismus. Die Geschichte einer philosophischen Schulgemeinschaft, Würzburg: Königshausen und Neumann, 1994 (reviewed by this author in Journal of Jewish Studies vol. xlvii, No. 1, Spring 1996, pp. 185-189). 
On Cohen's logic and the foundations of the system of philosophy: Wolfgang Marx, Transzendentale Logik als Wissenschaftstheorie. Systematischkritische Untersuchungen zur philosophischen Grundlgungsproblematik in Cohens 'Logik der reinen Erkenntnis' [Studien zur Philosophie und Literatur des neunzehnten Jahrhunderts Band 32] Frankfurt/Main: Vittorio Klostermann, 1977, Werner Flach and Helmut Holzhey (ed.), Erkenntnistheorie und Logik im Neukantianismus [Seminar-Textbücher I, Fach: Philosophie], Hildesheim: Gerstenberg, 1980, Gerd Gerhardt, Wider die unbelehrbaren Empiriker: Die Argumentation gegen empirische Versionen der Transzendentalphilosophie bei H. Cohen und A. Riehl (Epistemata / Reihe Philosophie ; 11) Würzburg: Königshausen + Neumann, 1983, Geert Edel, Von der Vernunftkritik zur Erkenntnislogik. Die Entwicklung der theoretischen Philosophie Hermann Cohens, Freiburg i.Br.: Alber, 1988, Hans-Dieter Häußer, Transzendentale Reflexion und Erkenntnisgegenstand. Zur transzendentalphilosophischen Erkenntnisbegrïndung unter besonderer Berïcksichtigung objektivistischer Transformationen des Kritizismus. Ein Beitrag zur systematischen und historischen Genese des Neukantianismus [= Mainzer Philosophische Forschungen Nr. 35] Bonn: Bouvier, 1989, Gianna Gigliotti "Avventure e disavventure del trascendentale" Studio su Cohen e Natorp, Napoli: Guida Ed, 1989, Djeong-Uk Seo, Logik und Metaphysik der Erkenntnis: kritischer Vergleich von Hermann Cohens und Nicolai Hartmanns philosophischen Grundpositionen. Frankfurt am Main: Haag + Herchen, 1993, Jürgen Stolzenberg, Ursprung und System: Probleme der Begründung systematischer Philosophie im Werk Hermann Cohens, Paul Natorps und beim frühen Martin Heidegger. (Neue Studien zur Philosophie ; 9) Göttingen: Vandenhoeck \& Ruprecht, 1995.

On ethics: Eggert Winter, Ethik und Rechtswissenschaft. Eine historischsystematische Untersuchung zur Ethik-Konzeption des Marburger Neukantianismus im Werke Hermann Cohens [Schriften zur Rechtstheorie Heft 9] Berlin: Duncker \& Humblot, 1980, Manfred Pascher, Hermann Cohens Ethik als Gegenentwurf zur Rechtsphilosophie Hegels. (Innsbrucker Beiträge zur Kulturwissenschaft / Sonderheft 83) Innsbruck: Inst. für Sprachwiss, 1992, Peter A. Schmid, Ethik als Hermeneutik: systematische Untersuchungen zu Hermann Cohens Rechts- und Tugendlehre. (Studien und Materialien zum Neukantianismus ; 5) Würzburg: Königshausen \& Neumann, 1995.

On religion: Hans-Ludwig Ollig S.J., Religion und Freiheitsglaube. Zur Problematik von Hermann Cohens später Religionsphilosophie [Monographien zur philosophischen Forschung Band 179] Königstein/Ts.: Forum Academicum, 1979, Sylvain Zac, La Philosophie Religieuse de Hermann Cohen. Avant-propos de Paul Ricour, Paris: Librairie Philosophique J. Vrin, 1984, Mechthild Dreyer, Die Idee Gottes im Werk Hermann Cohens [Monographien zur philosophischen Forschung, Band 230] Königstein/Ts.: Hain, 1985, Irene Kajon, Ebraismo e sistema di filosofia in Hermann Cohen (Archivio di filosofia / Biblioteca ; 3) Padova : CEDAM, 1989.

On politics: Bernard Tucker, Ereignis. Wege durch die politische Philosophie des Marburger Neukantianismus [European University Studies Series XX, Philosophy, vol. 140], Frankfurt/Bern/New York: Peter Lang, 1984.

On psychology: Winrich de Schmidt, Psychologie und Transzendentalphilosophie. Zur Psychologie-Rezeption bei Hermann Cohen und Paul Natorp [Abh. zur Philosophie, Psychologie und Pädagogik, Band 105] Bonn: Bouvier, 1976.

In my view the best comprehensive introduction is Andrea Poma, La Filosofia Critica di Hermann Cohen, Milano: Mursia, 1988 (English: The Critical Philosophy of 
earlier decline of the neo-Kantian philosophical tradition had much to do with political changes affecting the academy and little with a departure internal to philosophical reasoning. ${ }^{22} \mathrm{~A}$ point by point accounting of the merits and limits of neo-Kantian philosophies has therefore only just begun. ${ }^{23}$

\section{Hermann Cohen and the Philosophy of Judaism}

Long before the 1915 essay on The Concept of Religion in the System of Philosophy, and alongside his philosophical and political work, Cohen had begun to engage in efforts that aimed to reform the Jewish tradition of study as well as establish it at the university level. Around the turn of the century, following two decades when anti-Semitism had begun to threaten Judaism from the outside and Zionism was rattling it from the inside, Cohen became a major champion of the idea that Jewish studies should be established on a par with the university-based faculties of Protestant Theology.24 In Marburg, Cohen inaugurated a home for Jewish students and apprentices. ${ }^{25}$ He called for the inclusion of ethics

Hermann Cohen (SUNY Press Albany, 1997) reviewed by this author in: The Journal of Religion vol. 78 No. 3 (July 1998): 464-465.

Building on the groundwork provided over the past two decades, the most recent studies have focused on more detailed questions. See, for example, Pierfrancesco Fiorato, Geschichtliche Ewigkeit: Ursprung und Zeitlichkeit in der Philosophie Hermann Cohens. Würzburg : Königshausen und Neumann, 1993 and Hartwig Wiedebach, Die Bedeutung der Nationalität fïr Hermann Cohen (Europaea Memoria Reihe I: Studien, Band 6) Hildesheim/Zürich/New York: Georg Olms Verlag, 1997.

22Brelage, Studien (1965) shows that fundamental ontology along with Husserlian phenomenology and other approaches to philosophy that sprung up in the first two decades of this century do not necessarily pose fundamental departures from Kantian transcendentalism but can be construed as completing the range of possible transcendental inquiries. Brelage's synoptic interpretation which covers Nicolai Hartmann, Eduard Husserl, Martin Heidegger, and Richard Hönigswald is inspired by the work of Hans Wagner, Philosophie und Reflexion, (München/Basel: Ernst Reinhardt Verlag, 1958). Cf. Wolfgang Cramer, Review of Hans Wagner, Philosophie und Reflexion, in: Philosophische Rundschau (11/1963) pp. 68-90.

${ }^{23}$ The demand to do so was first voiced by Julius Ebbinghaus, who held the same chair as Lange and Cohen had before him, in "Hermann Cohen als Philosoph und Publizist" in: APh 6 (1956) 109-122.

${ }^{24} \mathrm{Cf}$. "Zwei Vorschläge zur Sicherung unseres Fortbestandes" in: Bericht der Großloge, Festausgabe, Nr.2, March 07, 9-12 (= J2,133-141).

${ }^{25} \mathrm{Cf}$. "Die Sprüche im Israelitischen Schüler- und Lehrlingsheim zu Marburg a.L." in: $A Z d J$ 65. Jg., May 31, 1901. 
and philosophy of religion into the curriculum of Jewish seminaries, ${ }^{26}$ and he became a curator and instructor at the Lehranstalt für die Wissenschaft des Judentums, the first non-denominational institute of its kind and a model for the university-based department of Judaic Studies. Ismar Elbogen, Ephraim Urbach, Leo Baeck, and Franz Rosenzweig were among the many outstanding students of this institution who went on to forge important links between Leopold Zunz's and Abraham Geiger's science of Judaism and the culture of non-denominational Jewish learning that flourishes today in Israel, the United States, and elsewhere.

Cohen also helped to launch the ambitious literary project of a Grundriss der Gesamtwissenschaft des Judentums, a comprehensive systematic introduction into all fields of Jewish knowledge from a modern methodological perspective. Since 1904 he was officially contracted and widely advertised as one of the authors of this series for which he was to provide a volume on "Jewish philosophy of religion and ethics." It took until after his retirement from Marburg, when Cohen returned to Berlin where he now taught full-time at the Lehranstalt, and even until after his death in 1918 before the crowning volume of his career was published. In this religious magnum opus, a work of a kind he had intended to write since his first Berlin years, Cohen provided an exposition of Judaism based on his philosophical method which was, itself, an original synthesis of Western and Jewish ideas. ${ }^{27}$ Through his writings on Judaism and religion he had already become one of the most widely recognized Jewish religious thinkers of his age. His affirmation of Judaism was relatively unapologetic in style while engaging contemporary liberal Protestant scholarship in critical discussions. Both of these traits, and certainly their combination, were exceptional at a time when anti-Semitism was rampant and when, what little exposure non-

26“Die Errichtung von Lehrstühlen für Ethik und Religionsphilosophie an den jüdisch-theologischen Lehranstalten" Vortrag gehalten 6. January 1904, in: MGWJ $48 / 1904,2-21$.

${ }^{27}$ The young Leo Strauss was one of the few readers who fully comprehended the deep wit and ironies of Cohen's philosophy. Cf. Strauss, "Das Heilige" in Der Jude 7 (1923) p. 241, where he cites Cohen as "the most venerable example" of "an ideologue of Judaism" who "himself participated creatively in the shaping of the German intellectual world in such a way that through him Jewish forces entered the German world as formative elements, so that his introduction of German viewpoints into Jewish matters was preceded by the assimilation of the spirituality of both peoples in his work." For Strauss, Cohen seems, therefore, to be on a different plane than many other "ideologues" because "(o)nly he who himself has built the bridges can assess the quality of the banks, the width and depth of the abyss, and the difficulty of bridging it; one who has merely used the bridge can not." (My translation. Cf. the forthcoming volume of translations of early Jewish writings by Strauss with SUNY Press.) 
Jews did have to Judaism, was often tainted by contempt. Yet it was only through his fully matured "philosophy of Judaism and ethics," Religion of Reason Out of the Sources of Judaism (Religion der Vernunft aus den Quellen des Judentums, first edition 1919), that his hope of contributing to the renewal of the Jewish philosophy of religion was fulfilled. The historian of liturgy and chronist of German Jewish history, Ismar Elbogen, eloquently summarized Cohen's significance in the revitalization of Jewish studies early this century.

Among the founders of the Wissenschaft des Judentums there was no systematic thinker, the period was non-philosophical, their systematic attempts were soon forgotten. It is the merit of Hermann Cohen (1842-1918) to have demanded-with the full weight of both his personality and his scientific authority-'the institution of faculties for ethics and philosophy of religion.' In his posthumously published work ... he gave a systematic exposition of Judaism and one of the most remarkable attempts to conciliate between Judaism and the contemporary consciousness (Zeitbewusstsein) which was the first of its kind for centuries. ${ }^{28}$

Julius Guttmann, philosopher of religion and son of Cohen's fellow Breslau seminarian Jacob Guttmann, similarly credited Hermann Cohen with the "renewal of Jewish religious philosophy." 29 This label gave expression to a project Cohen himself had fully intended to earn. It is even plausible that Cohen's earliest and most lasting desire was to show the world something about the beauty and depth of Judaism even though this dream may have been dormant for a while and its full realization postponed until the end of his life. Like the messianic dream of young Herzl in Budapest which reached fruition only after a period of assimilation and integration into Western culture, ${ }^{30}$ Hermann Cohen's desire to restore to Judaism its intellectual dignity was rooted in his early youth. The moral and religious value of Judaism was a matter of course to Cohen. The son of the cantor and teacher of the Jewish community at Coswig in the principality of Anhalt was steeped in a tradition which he

\footnotetext{
${ }^{28}$ Ismar Elbogen, "Ein Jahrhundert Wissenschaft des Judentums" in: FS (1922) p. 116. Elbogen refers to Cohen's lecture before the constitutive assembly of the Gesellschaft zur Förderung der Wissenschaft des Judentums, "Die Errichtung von Lehrstühlen für Ethik und Religionsphilosophie an den jüdisch-theologischen Lehranstalten" (1904); cf. J 2, 108-125; and see below.

${ }^{29}$ Philosophies of Judaism. The History of Jewish Philosophy from Biblical Times to Franz Rosenzweig, New York: Schocken Books, 1973, p. 400.

${ }^{30}$ On Herzl cf. Reinharz Jehuda/Reinharz Shulamit, "Leadership and Charisma: The Case of Theodor Herzl" in: Mystics, Philosophers, and Politicians. Essays in Jewish Intellectual History in Honor of Alexander Altmann. Edited by Jehuda Reinharz and Daniel Swetschinski, with the collaboration of Kalman P. Bland. Durham, N.C.: Duke University Press, 1982, pp. 275-314.
} 
cherished and loved in filial piety. His "Teacher and Master" 31 introduced him to Munk's French translation of the Judeo-Arabic original of Maimonides's Guide for the Perplexed and prepared him for an early entry to the newly founded Jewish Theological Seminary in Breslau. Yet the road to a broadly acceptable new philosophy of Judaism would take Cohen a lifetime. The ideal for Cohen's pursuits was shaped by the model of some of the prominent Jews of Anhalt, a community with a long and distinguished history which had produced a number of outstanding personalities. From Moses Mendelssohn and his distinguished predecessors to Cohen's relative and mentor, $\mathrm{H}$. Steinthal, one of the most colorful and inspiring intellectuals of his time, Anhalt had provided a benevolent environment which nourished its own brand of Jewish culture. If Cohen's life-long pursuit can best be described as seeking to reconcile Judaism and "cultural consciousness," a synthesis of reform Jewish religion and humanistic German Bildung, then the Jewish community of Anhalt can be seen as the historical matrix in which this ideal was shaped. If in fact my contention is true that Cohen distinguished between Jewish and general philosophical concerns with religion, then we may find more than a faint echo of Moses Mendelssohn in Cohen's work. As in the cases of Mendelssohn and Steinthal, Cohen's most stimulating intellectual community was situated in Berlin, at a university which was itself quietly shaped by the spirit of Dessau. There is a continuity of scholarly influence which reaches from Mendelssohn to Wilhelm von Humboldt and Schleiermacher, from Humboldt and Schleiermacher to August Boeckh, 32 from Boeckh to Steinthal, and from Steinthal to Cohen. The intense and unique concern for philology, hermeneutics, esthetics, and the theory of language which permeates this school is evident in Cohen's life-long combination of philological and philosophical methods. Grounded in "positive-historical" Jewish rabbinic studies and in what one may call the Berlin school of hermeneutics, Cohen was immune to totalizing concepts of philosophy at the expense of sensitivity to the particularities of language.

To Cohen, a reconciliation of Judaism and "cultural consciousness" means the preservation and advancement of both. Yet such reconciliation demands a point of meeting. There is good evidence to suggest that Cohen searched for such a point of meeting for quite a while before he was able to identify the grounds he believed could support a bridge on

${ }^{31}$ Cf. Appendix A, Letter to Philippson.

${ }^{32}$ On August Boeckh see below and cf. Arnaldo Momigliano, "A Hundred Years After Ranke" in: Diogenes 7 (1054), 52-8, reprinted in: Studies in Historiography (London: Weidenfeld and Nicholson, 1966), pp. 105-111. 
which to cross safely back and forth. ${ }^{33}$ In some of the earliest essays we discern a series of groping attempts to make out the basis for a grand defense of Judaism. In an essay on Heinrich Heine, Cohen believes that Spinozist monotheism describes the core Jewish belief that is also at the heart of modern Western philosophy. ${ }^{34}$ In another essay, on the Sabbath, ${ }^{35}$ he sees social justice as the great Jewish concern. At the important turning point in his life when, in 1879/80, he recognized that anti-Semitism was a force to be reckoned with, Cohen understood belief in the profoundly awe-inspiring presence of God as the ever important contribution of the Hebrew prophets to religious culture. At the same time, Cohen felt that modern Jews were culturally indebted to Christianity for the discovery of the notion of the freedom and responsibility of the subject, the core idea of modernity. In the decade following the formulation of this contention, i.e., after the 1880 response to Treitschke ${ }^{36}$ and after the defense of the Talmud in a court case in $1888,{ }^{37}$ Cohen forges a Jewish path to the idea of subjectivity, to the notion of freedom and responsibility, and hence to a construction of Jewish philosophy that could relate to Christianity and modernity without depending on them. Out of the "sources of Judaism" Cohen began to reconstruct the idea of atonement (die Versöhnungsidee). Atonement (Versöhnung), messianism, the correlative ideas of God and human being, and the love of God and neighbor become the great themes in several essays written at the very period when he also wrote and published the first two volumes of his system of philosophy. At the age of fifty, at the height of his philosophical career, recognized internationally as a leading philosopher and sought out by students from near and far, Cohen began to produce, first a trickle, then a stream of essays on religion and Jewish themes, all of which coagulated into the magnum opus posthumum, Religion of Reason Out of the Sources of Judaism. A dream come true.

When Cohen engages in the pursuit of Jewish philosophy of religion he is mindful of his predecessors, medieval and modern. Moreover, his understanding of the task of Jewish philosophy is grounded in historical thinking about the nature of religious thought. Religion of Reason appears

\footnotetext{
${ }^{33} \mathrm{Cf}$. note 27 above.

34"Heine und das Judentum" anonymous in: Die Gegenwart. Berliner Wochenschrift fïr juidische Angelegenheiten 1. Jg., 1867 (= J 2,2-44).

35"Der Sabbath in seiner culturgeschichtlichen Bedeutung. Vortrag gehalten zu Berlin im Januar 1869 nebst einem Nachwort" in: Der Zeitgeist, ed. Adolf Moses (Milwaukee/Wisconsin, 1881) (= J2,45-72).

${ }^{36}$ Ein Bekenntniß in der Judenfrage, Berlin: Dümmler, $1880(=\mathrm{J} 2,73-94)$.

${ }^{37}$ Die Nächstenliebe im Talmud. Ein Gutachten dem Königl Landgerichte zu Marburg erstattet, Marburg: Elwert, 1888 (= J1,145-174).
} 
exactly a century after the founding of the Society for the Culture and Science of the Jews in $1819^{38}$ and it is undoubtedly the most mature and lasting expression of the ideology of the movement called Wissenschaft des Judentums. Cohen's philosophy responds to and is conceived within the context of the contemporary situation of Jews and Judaism in Central Europe in the age of the Second Reich, an age of great economic and cultural progress for many Jews and non-Jews alike but also an age of social and political conflict that erupts in the World War. As Hartwig Wiedebach recently established, ${ }^{39}$ there is a great deal of political thinking at the foundations of Cohen's Jewish thought. Indeed, it is more than plausible to interpret Cohen's Jewish thought as the attempt to provide an alternative to Zionism. Similarly, his philosophy of religion can be seen as aiming to resolve the historic theoretical conflict between religion and the modern state.

There is also a decidedly pedagogical side to Cohen's Jewish philosophy. Whereas his early essays (on Heine, on the Sabbath, and Bekenntnis) are of a defensive nature and thus fit the category of apologetic thinking - a category Franz Rosenzweig later saw exemplified in the works of Baeck and Brod which he claimed to be typical for all Jewish philosophy ${ }^{40}$-Cohen's mature Jewish thought rather seems to answer to a pedagogical concern. Even if the 1915 treatise on religion could be classified as apologetic, Religion der Vernunft is written to educate modern Jews towards a greater appreciation of their own heritage, an appreciation which is at the same time philosophically refined and religiously committed..$^{41}$

This is the background for the above mentioned concern with the future of Jewish learning as the key to the continuity of the Jewish religion. From the fate of Jewish education for school-age children to the future of Jewish studies at the university level, nothing could be taken for granted. Cohen saw Jewish education as the battleground for the future of Judaism. Cohen's Jewish thought was to give "the Jew in

${ }^{38}$ Cf. Paul R. Mendes-Flohr and Jehuda Reinharz (ed.), The Jew in the Modern World (First edition: Oxford University Press, 1980), p. 189, note 1.

${ }^{39}$ Hartwig Wiedebach, Die Bedeutung der Nationalität für Hermann Cohen (Europaea Memoria Reihe I: Studien, Band 6) Hildesheim/Zürich/New York: Georg Olms Verlag, 1997.

"See "Apologetisches Denken" in Franz Rosenzweig, Zweistromland. Kleinere Schriften $z u$ Glauben und Denken. Ed. Reinhold und Annemarie Mayer. Dordrecht/Boston/Lancaster: Martinus Nijhoff Publishers, 1984, pp. 677-686.

${ }^{41}$ It was part of the editorial program of the Grundriss series in which it appeared for its authors to desist from apologetics. This was explained and documented by Dieter Adelmann in his opening lecture to the conference on Hermann Cohen's Religion der Vernunft in Zürich, September 1998. See the forthcoming volume of proceedings, edited by Helmut Holzhey and Gabriel Motzkin. 
Protestant culture" an intellectual and spiritual anchor, a well reasoned argument to refrain from conversion, and a means for the modern Jew to participate intelligently and responsibly in the maintenance of Jewish religious life.

\section{About This Study}

In this work I present the result of nine years of studies on Hermann Cohen. The first part sketches the emergence and realization of Cohen's program to renew the discipline of "Jewish philosophy and ethics." The second part concerns his system of philosophy, the use in it of ideas associated with the Jewish tradition, and the problem of a general concept of religion. The order, Jewish thought first, philosophy second, needs some justification for it contradicts the standard procedure in virtually all expository writing on Cohen. In the past, Cohen's religious thought was considered an appendix to his philosophical work. Taking the real Cohen as the quintessential modernist who "resolved" (auflösen) religion into ethics, one was forced to regard his late philosophy of religion as a mixture of apologetics and a pious softening of the mind induced by aging. The postmodern shift to a recognition of the situatedness of rationality allows us to see the matter differently. It now appears quite plausible that the sometimes tortured attempts on Cohen's part to reconcile Judaism and "cultural consciousness" aimed to break new ground for the relation between a particular religious culture and the tasks of reason. Cohen is interesting to us not despite the fact that Judaism has a certain primacy in his parsing of the cultural enterprise but because of it.

Confusion arises when one fails to differentiate in Cohen between Judaism and religion. Judaism is the paradigm for religion but it is not the only religion. Similarly, physics is the paradigm of a science but it is not the only science. Just as physics in its relation to mathematics determines that general concept of knowledge, so Judaism in its relation to ethics determines the concept of religion. The idealizing philosophical analysis of transcendental grounds always begins with cultural facts whose character as such cultural facts, however, is a "judgment of origin" (Ursprungsurteil). Critical idealism à la Cohen has also been labeled "crypto-positivist" because of its correlation of the transcendental grounds or origins it determines in thought (logic), will (ethics), or feeling (esthetics) with cultural "facts." Those facts (e.g., the knowledge contained in science books, as Cohen poignantly formulates in distinction to Kant's "stars above me;" Sternenzelt über mir) are examined as to their origin in "pure" thought, will, and feeling. The facta of culture are to be determined as to the ideal suppositions in which their 
validity is grounded. In this kind of "objective" idealism, which has also been described as an idealism "without subject" or as "noëmatic reflection," 42 it is not the thinking I that provides the point of departure and whose certainty is beyond doubt. Rather, scientific knowledge and its constitution in thought (instantiated in the relation between mathematics and physics) provides the paradigm of certainty that is transferred to other aspects of culture as well. On the other hand, and in distinction from a positivist view widespread among many 19 th-century and even 20th-century scientists, philosophy is not made redundant by the sciences. Idealism gives account of a structure of thought that is implied in the making of a scientific fact. ${ }^{43}$ Moreover, it examines whether the same or an analogous structure can be identified as prevailing in other domains of human creativity and thus provide a guide to the ideal of a cultural consciousness that is no longer divided within itself; a consciousness and a culture in which the seemingly antithetical forces of necessity and freedom, knowledge and feeling, but also religious particularity and ethical universalism can be reconciled.

The striking confidence in the human ability to generate coherent progress on all levels and in all domains of culture could be taken as an indication that academic philosophers in Wilhelminian Germany had taken leave of their critical judgment and embraced a naive ideology of progress. Indeed, there is no doubt that the majority of people then felt more certain that things were changing for the better than people have been feeling since after the Second World War (or even since after the First). It was one of those universally accepted conventions turned selfevident truths that the felicity of human beings depended only on smart and responsible social engineering, a faith not to a small degree supported by the irrefutable testimony of feats of large scale mechanical engineering and other technological breakthroughs. ${ }^{44}$ Compared to such naive trust in cultural progress, however, critical idealism is radically pessimistic. In its view, philosophy does not produce new aspects of culture but determines what may rank as "culture" and by what

\footnotetext{
${ }^{42} \mathrm{Cf}$. Wagner, Philosophie und Reflexion, where noematic reflection is distinguished from noetic reflection.

${ }^{43}$ In contrast to the psychological interpretation of Kant's apriori that preceded and initially influenced Cohen's retrieval of transcendentalism (as well as in contrast to our contemporary research into "complex systems"), this structure is not identified with the function of the brain or the mechanism of consciousness. ${ }^{44}$ For example, it is well known that Theodore Herzl's dreams of a technologically progressive Altneuland were inspired by the recent completion of the Suez Canal. The large scale transformation of governments into institutions for the maximization of the life force of their populations has been described by Michel Foucault in History of Sexuality, vol. 1, and elsewhere.
} 
justification. In other words, it is a critique of culture and of pretenses to it. In a telling passage in Ethics Cohen speaks of contemporary civilization as "this remnant of savagery." The positive value of culture in this sense is a critical directive for development, not a judgment of fact. Just as scientific knowledge, cultural literacy is always in the making, always ready to correct itself.

Religion poses a particular challenge to such philosophical judgment. The question of its relation to the enterprise of cultural reconciliation is a vital one for the development of a viable pluralistic society and of no lesser concern today than it was to a Jewish philosopher at the turn of the century. But Cohen does not begin with a general definition of religion. Such a general concept would presuppose a universal cultural purpose for religion. But the possibility of such a purpose as present in one of many particular religions is, of course, the very question indicated in the problem of religion. The answer to it cannot be left for historians of religions, anthropologists, or religious believers to decide. On the other hand it is quite obvious that religions did in fact exert important roles in the history of logical, ethical, and esthetic concept formation. The history of the formation of concepts-in Cohen's parlance: Problemgeschichte-represents the movement of culture in the making and its study is guided by the search for the underlying problem of this history. It is in such problem-historical examinations of the contribution of religious concepts to problems of philosophy that religion or religions exert their contribution to culture. But this does not exhaust the function of religion(s). Religions are not mainly theoretical institutions but practical ones. Therefore, the function of religion(s) stretches the theoretical concerns of philosophy towards the field of practical culture. For Cohen, the decisive and at the same time most neglected contribution of religion to theoretical as well as practical concerns of philosophy is historically and concretely present in the biblical monotheistic tradition, i.e., in Judaism. When Cohen turns to the task of determining a comprehensive systematic concept of religion it is therefore not surprising that he elevates Judaism to the rank of the paradigmatic religion of reason. Judaism is the empirical anchor for the legitimacy of the concept of religion in the system of philosophy. However idealized and tentative the concept of Judaism may be here (Cohen tries to be as historical-critical as possible; in this echoing 
Protestant theology à la Martin Kähler ${ }^{45}$ and Wilhelm Herrmann ${ }^{46}$ ), it serves as the factual historical existent whose validity is grounded in the examination of the principle on which its development and its ongoing functions are founded. This principle, the correlation of unique God and human being, exerts its cultural function through its ethical direction and content. Furthermore, the monotheistic idea of God is not only the capstone of Ethics but a ground of the logic of being: if God alone is, all else merely becomes. Critical idealism and biblical monotheism are thus determined as distinct and equally vital sources of the cultural consciousness in its search for truth and unity.

On the surface, Cohen kept his major pursuits apart. His system of philosophy is a self-contained, if incomplete, whole ${ }^{47}$ and a separate philosophy of religion was not projected until the treatise of 1915 where, somewhat grudgingly and not without cunning, Cohen nevertheless induces the concept of religion into the system. His magnum opus on Judaism was planned at the same time as his systematic works but the latter were not to include it. It was to be part of a different series, published by a different publisher, and intended for a different audience. The separation between Jewish philosophy of religion and systematic philosophy, however, was not intended to encourage readers to interpret one body of text without regard to the other. Philosophical readers of Cohen's system, however, were not always in a position to judge the degree to which Jewish tradition played a constitutive part in the making of Cohen's philosophical reasoning. The author himself did not conceal that his philosophy aimed at a synthesis of Jewish and philosophical interests. In response to a group of Jewish readers sympathetic to his project he readily acknowledges the mutually constitutive interdependence between his Jewish and philosophical reasoning: "my Judaism stands in the context of my scientific insights" ("im Zusammenhang meiner wissenschaftlichen Einsichten steht mein Judentum").

You are quite right when you point out that it was the duty of truthfulness which demanded the recognition of Judaism in my

\footnotetext{
${ }^{45}$ Martin Kähler (1835-1912), The so-called historical Jesus and the historic, Biblical Christ. Translated, edited, and with an introd. by Carl E. Braaten. Foreword by Paul J. Tillich. Philadelphia: Fortress Press, 1964.

${ }^{46}$ Wilhelm Hermann (1846-1922), systematic theologian in Marburg, most prominent as the head of an anti-metaphysical school of theology inaugurated by Albrecht Ritschl. Cf. Mahlmann Theodor, s.v. "Herrmann, Wilhelm (1846-1922)" in: Theologische Realenzyclopädie Berlin/New York: Walter de Gruyter, 1977-1988.

${ }^{47}$ In addition to the published volumes on logic, ethics, and esthetics, Cohen projected follow-up volumes to logic and ethics, as well as a fifth part to the system, on psychology.
} 
systematic ethics. My enthusiasm for Judaism is rooted in the conviction that our idea of God is of ethical value; in the context of my scientific insights stands my Judaism. For this reason I consider myself fortunate to have been able to demonstrate its significance in the context of a philosophical system before publishing more extensive works on the idea of Judaism. (J 1, p. 333, emphasis added $)^{48}$

I deal with Cohen's Jewish thought first although its broad and mature formulation appears only late in his life and even posthumously. Most readers understood Begriff der Religion and Religion der Vernunft, if not as an intended departure from critical idealism, as a de facto transition to a prius of existence over essence. Many of the ideas present in the late philosophy of religion, especially that of a correlative self constituted in the speech acts of the liturgy of atonement, sounded too novel and pointed in the direction of the very type of thought that was to oust neo-Kantianism. Dealing with his Jewish thought first allows me to establish a new perspective on Cohen's work that contributes to the clarification of the dating and the programmatic character of Cohen's Jewish thought in relation to the system of philosophy as well as that of the system in relation to religion. Contrary to the common assumption of Cohen's late return to Judaism, it can be demonstrated that Cohen developed and pursued a program for the renewal of Jewish philosophy contemporaneously with his systematic work. This program manifests itself, among others, in two essays that were only published in the 1924 edition of his Jewish writings. These essays (on messianism and atonement, respectively) are augmented by a number of manuscripts that were preserved in the archive of Paul Natorp that are housed at the library of the university at Marburg. The very fact of the survival of these manuscripts is exceptional since most of Cohen's private papers were lost when his widow, Martha, was deported to Theresienstadt. The texts are also unique in that they provide us with a rare glance into Cohen's intellectual shop. Although their existence was known to the scholarly community for some time, no one examined them as to their significance for the chronology of Cohen's program of Jewish thought. I establish the relative date of the essays and manuscripts by comparing them with earlier and later writings. Such reading allows us to trace the development of the program of Jewish philosophy up to its full realization in Religion der Vernunft. (Part I)

${ }^{48}$ From "Antwort auf ein Glückwunschschreiben der Frankfurtloge," dated Dec. 11, 1904, published in Bericht der Großloge fiur Deutschland U.O.B.B.Febr. 1905, Nr. 2 , reprinted in the notes to Franz Rosenzweig's introduction to Hermann Cohen's Jewish Writings (1924). 
The core concept of Cohen's Jewish philosophy of religion is the atonement of the individual before God that has as its effects the individuation of guilt as well as the transformation of the self into a moral agent. Cohen calls this cluster of notions "the idea of Versöhnung." The "discovery of the individual" is credited to the Hebrew prophets, especially to Ezekiel. Using Ezekiel 18 as a prooftext Cohen describes the origination of an individualized concept of guilt that is at the root of individuality as understood in Western culture. Cohen's interest in the concept of atonement is awakened in a search for an immediate Jewish origin for the core notion of Western ethics: the autonomous self. However, this notion itself receives a critical philosophical examination in Cohen's Ethics where self-consciousness is determined in opposition to all substantive concepts of the self. Cohen's logic provides the foundation for this critical concept. In Part II, I therefore examine Cohen's logic, ethics, and philosophy of religion for the question of the constitution of self and individuality in light of Cohen's concept of Versöhnung. ${ }^{49}$

\section{The Idea of Versöhnung (Atonement)}

The idea of Versöhnung that, for the sake of convenience, we translate as 'atonement' plays an important role in Cohen's mind. It serves as a link between Judaism and culture, religion and reason, Jewish thought and the philosophy of religion, as well as between religion and ethics. Were one to look for a term that generated connectivity without aiming at identity, atonement would suggest itself prominently since it combines the advantages of a genuine concept of religion that ranks prominently in Jewish and Christian ritual and doctrine with the modern philosophical pedigree of a core term of Hegelian dialectic. As a fundamental religious term in Christian dogmatics, atonement refers to the doctrine of reconciliation of God and human being through the atoning death of Christ. For this reason alone, its function within a modern Jewish philosophy is highly remarkable. Even if it is not chosen for polemical reasons, it sets up a remarkable tension between its inherent ideal of unification and the attempt to authenticate it as a Jewish idea within a philosophy that operates in a predominantly Christian culture.

What Cohen calls the Versöhnungsidee refers to the reconciliation of the human being with God, with fellow-human being, and with him/herself as enacted in the concrete language and tradition of Jewish liturgy which grows from the biblical institution of the atoning sacrifice. In philosophical terms, this notion of atonement is interpreted as

${ }^{49}$ Literally "atonement," or "reconciliation." But see below. 
combining two distinct cultural achievements: the constitution of concrete subjectivity through religious practice and the limitation and guidance of such individuality by its ethical direction. The "discovery of the individual" is expressed in Ezekiel's term of a "soul that sinneth." By tying individuality to sin, the idea of atonement provides a condition for the realization of the Good in form of a transformation of the sinner. Individuality is thus always tied to the moral problem of realizing the Good. Atonement thus not only addresses the ritual acts of repentance $\left(t^{\prime}\right.$ shuvah) and purification (taharah) but can be interpreted as the perennial origin of the self as demanded by ethics. The term therefore indicates a point of meeting between a particular religion and the rational demands of ethics without collapsing religion and philosophical ethics into one. It thus carries the much wider connotations of a method of thought that Cohen explores and applies in contexts other than the philosophy of religion.

Cohen uses Versöhnung in a number of different contexts but, wherever he does so, he establishes correspondences between different areas of culture so that their division, in light of such connectivity, is revealed to be the result of intellectual effort rather than a matter of course. This is particularly significant in a philosophy that takes such great pains to establish distinctions between "independent" (selbständig) directions of culture. With its connotation of uniting the separate without obliterating their difference, atonement indicates possibilities of linkage between realms and concerns of reason whose separation must, therefore, not be taken as absolute. One only needs to juxtapose this characteristic of atonement with Cohen's definition of thought ("the unification of separation and unification") in order to sense that atonement represents no less than a metaphor for the activity of systematic philosophy in general. It thus provides us with a particularly promising key to Cohen's thought in that it allows us to see the above mentioned intention at work to connect Judaism and philosophy historically and systematically. A brief examination of its history indicates further reasons why Cohen, like Hegel before him, attributes such fertile conceptual power to the term.

The German term Versöhnung is a hybrid. By way of its assonances with Sühne on the one hand and Sohn (son) on the other, the term unites the concepts of propitiation and expiation with those of atonement and reconciliation. It thus represents classical Christian soteriology in a nutshell. The Hebrew term at the root of its conceptual history is the verb kipper whose etymology is mired in dispute. Theories vacillate between Arabic and Akkadian cognates, rendering it either as "covering up" or 
"wiping away."50 The abstract noun kapparah is a rabbinic coinage. The English word "atonement" first appears in Elizabethan English where it means "unification" (at-one-ment).

In the Hebrew Bible (e.g., Leviticus 16), kipper refers to a ritual of smearing or sprinkling of blood on objects or persons. In accordance with the meanings suggested by its cognates, the term denotes the act of either wiping away or of covering up ritual impurity or moral defilement. The result of this action is the restoration of purity, kipper being the precondition for the restoration of a state of purity of people and sacrificial institution. While this cultic action might be taken for an $e x$ opere operato priestly activity, later Jewish tradition emphasizes the efficacy of prayer and deeds of loving kindness. In this radical reinterpretation of the cultic tradition the inward and outward manifestations of the purity formerly achieved through ritual atonement are taken as efficacious replacements of the ritual itself. ${ }^{51}$ The "substance" of atonement is here replaced by the manifestation of its "accidents." At the same time, the problem of ritual defilement and its impact on the workings of the Temple took on the character of learning and debate on hypothetical matters that find little if any immediate practical application. In addition to the commonly available human means for restoration of purity, the rabbis emphasize the divine prerogative in the cluster of activities that make up kapparah, subordinating it to divine forgiveness (s'lihah). With this in mind it becomes clear why the philosopher of "pure" cognition, will, and feeling was fond of the saying attributed to the second century sage, Rabbi Akiva:

Blessed are you, Israel, for who purifies you and before whom do you purify yourselves? It is your Father in Heaven. ${ }^{52}$

To Cohen it was not a detriment to the concept, and its utility was not diminished for him by the fact, that atonement usually refers to the core doctrine of Christianity. One would underestimate his sense of humor were one to overlook this point. The posture of a "Jew in a

${ }^{50} \mathrm{On}$ the contentious etymology of kipper see Bernd Janowski, Sïhne als Heilsgeschehen. Studien zur Sühnetheologie der Priesterschrift und zur Wurzel KPR im Alten Orient und im Alten Testament, Neukirchen-Vluyn: Neukirchener Verlag, 1982 [=Wissenschaftliche Monographien zum Alten und Neuen Testament; Vol. 55] and Baruch Levine, In the Presence of the Lord. A study of cult and some cultic terms in ancient Israel, Leiden: Brill, 1974 [Studies in Late Antiquity ed. J. Neusner, vol. Five].

${ }^{51}$ This trend is found in rabbinic dicta reflecting on the effects of the destruction of the Second Temple on the possibility of atonement.

52Mishnah Yoma 8:9 given in Cohen's typically reversed order of the first two clauses. And see further below. 
Christian culture" is one of the most striking characteristics of Cohen's life and work and it is interestingly prefigured in an event that involves his father, whom he deeply admired. On the occasion of a publicly ordained church service during the Franco-Prussian war of 1869/70, Gerson Cohen decided to put aside his halakhic reservations and enter the Protestant church of Coswig to join the community in prayer for the sake of the Fatherland. Steeped in traditional halakhic practice, Cohen knew exactly how radical a step it was for his father to enter a church. Yet this event is significant for the son's overall understanding of the possibility of a rapprochement between Jews and Christians within the modern state. The level on which such meeting was not only the Jew's liberty but her duty was the level of national political cooperation towards the well-being and prosperity of the state in which the religious groups found their common home. The father's action prefigures Cohen's own thought and behavior. Hence for example his otherwise strange reply to the question why he, of all people, was attending the fourhundreth anniversary of Luther's birthday: "Who should attend if not I?" As Hartwig Wiedebach recently presented in the context of his study on Cohen's concept of nationalism, Luther and Protestantism counted for the Jewish philosopher as the inaugurators of the possibility of the emergence of the modern state as a secular entity. Thus Cohen judges the various aspects and historical movements of Christianity according to their contribution to the making of the cultural consciousness. Protestantism is thus a potential factor in the process of integrating philosophy and religion through an agenda of ethically reflected politics. The precondition for such transformation of the Christian community and its doctrine and practice is its ability to overcome those aspects of its atonement tradition that emphasize the passivity and receptivity of the human agent: Cohen as Pelagius.

Over the centuries, the Christian doctrine of atonement has been interpreted in a variety of ways, reflecting different views on the nature of $\sin$ and redemption. According to the typological classification of Aulén, 53 the "classical model" of the atonement refers to Christ's sinless death as the means to liberate humans from an objective enslavement to the forces of sin, death, and devil. In contrast, the medieval Augustinian interpretation subjectivized the experience of atonement and correspondingly stimulated the development of an inner experience that became one of the sources of the romantic notion of the self. One might say that the soul as we know it is a result of religious and moral soul searching cultivated in the subjectivized concept of atonement. Sin was determined as error and expressed in deviant actions and opinions rather

${ }^{53}$ Gustaf Aulèn, Christus Victor, New York: Macmillan, 1974, first published 1931. 
than as enslavement to objective powers of evil. While Luther briefly restored the classical model, Protestant pietism once again focused on the communicability of an inner experience of atonement and thus provided the psychological evidence to the modern concept of the freedom of the individual.

Just as the subjectivized religious view on the atonement influenced philosophical conceptions of the self, so, in turn, philosophical conceptions of the self influenced subsequent attempts to conceptualize the religious doctrine of the atonement. The irreconcilable opposition between the Hegel of the Phenomenology ${ }^{54}$ and the Schleiermacher of the On Religion ${ }^{55}$ may be grounded in the fact that the former's Swabian Lutheranism retained enough of the assumption of an objective side to the religious experience to feel repelled by the subjectivism of the Zögling of Herrnhut.

After the demise of Hegel and Hegelianism, the 19th century saw various philosophically inclined interpretations of Christian doctrine built upon the subjective model of atonement. So, for example, in The Christian Doctrine of Justification and Reconciliation, Albrecht Ritschl, ${ }^{56}$ who contributed prominently to the revival of Schleiermacher's early work on religion, construes atonement as a transformation within the individual who recognizes as erroneous the assumption of an angry God demanding propitiation. Liberation from this error is salvific and leads to a reconciled attitude towards the world. This transformation manifests itself in the Christian affirmation of one's worldly vocation (Berufsethik). The latter orientation towards practical morality is not only in keeping with Luther but offsets the otherwise Gnostic character of the theory. Cohen was greatly fond of Ritschl's work and read, excerpted, and quoted it approvingly.

One of the motifs of Cohen's doctrine of the atonement, the biblical motif of $\sin$ as "error" (sh'gagah), seems to have been inspired by Ritschl. However, there are patent differences that result from the completely different functions sin is assigned in Judaism and Christianity. Both

\footnotetext{
${ }^{54}$ Georg Wilhelm Friedrich Hegel (1770-1831), Phänomenologie des Geistes. English. The phenomenology of mind. Translated, with an introd. and notes, by J. B. Baillie. Introd. to the Torchbook ed. by George Lichtheim. New York: Harper \& Row, 1967.

${ }^{55}$ Friedrich Schleiermacher (1768-1834), On religion: speeches to its cultured despisers. Translated by John Oman. With an introd. by Rudolf Otto. New York, Harper, 1958.

${ }^{56}$ Albrecht Benjamin Ritschl (1822-1889), Die christliche Lehre von der Rechtfertigung und Versöhnung. Second, improved edition, Bonn: Adolph Marcus, 1883, 3. ed. 1889. Title of the English edition: A Critical History of the Christian Doctrine of Justification and Reconciliation (Translated, with the author's sanction, by John S. Black. Vol. 1, Edinburgh: Edmonston and Douglas, 1872).
} 
authors are too keenly interested in a philologically truthful conceptualization of their traditions for them to converge too closely. In Ritschl, sin concerns an erroneous assumption about God for which, given the appearance of the Gospel, we have no excuse. This corresponds to the Pauline gospel of grace as presented in Romans. The relation (objective in Paul, subjective in Ritschl) between human and God must be changed before good can come about. Grace must intervene to set our minds right about God before we can act as we should. Atonement aims at the constitution of a state of mind, if not a state of being.

In Cohen's Ethics of Pure Will, on the other hand, human beings are not so much in need of enlightenment about the beneficent nature of God than in an empirical situation of failing the ethical imperative. Thus the question arises whether the evil we do is to be grounded transcendentally in the direction of the will. Schopenhauer, against whom Cohen argues consistently, interprets Kant's notion of an intelligible character after the fashion of what Kant calls the common definition of a priori but which, in Schopenhauer's prize essay on the foundation of morals, ${ }^{57}$ is turned into a transcendentally grounded fact. The one who acts morally reprehensible is morally reprehensible. Thus the colloquial habit of labeling someone who steals a thief, or someone who murders a murderer. Cohen's Ethics with its task of defining human being, action, and self-consciousness denies the legitimacy of the concept of an intelligible character in order to prevent the extension of the status of identity to a being that, as the source of self-transformation (the Hebrew t'shuvah), must be kept open towards future change. Sin as an indication of evil is neither a noumenon (they must be evil for they act evil), nor a phenomenon (I experience them as evil) but simply an error (they may be guilty, they may deserve punishment, they are in need of forgiveness but, essentially, they made a mistake). ${ }^{58}$ Here atonement refers neither to a state of being nor to one of mind but to a constant practice of self-transformation. What unites Ritschl and Cohen, however, is the conscious embrace of optimism that permeates the structure of their thought.

The Ritschlian school took a turn further away from Ritschl and Cohen in Wilhelm Herrmann who, at the time, was widely recognized as the main representative of Ritschl's school. In his works, Herrmann

\footnotetext{
${ }^{57}$ Arthur Schopenhauer (1788-1860), Preisschrift ïber die Grundlage der Moral. (=Die beiden Grundprobleme der Ethik. vol. 2) Hamburg : Meiner, 1978. First published 1841. English: On the basis of morality. Translated by E. F. J. Payne. With an introd. by Richard Taylor. Indianapolis: Bobbs-Merrill, 1965.

58 This view has immediate implications for the reform of the penal system that existed at the time and of which Cohen had close, albeit indirect, personal knowledge through his friend, Kurt Eisner, who was incarcerated as a Socialist.
} 
frequently pays homage to both Ritschl and Cohen, yet it is probably more accurate to say that he develops a variant in the subjective interpretation of atonement that, from the very beginning, is all his own. To the mature Herrmann, religion is an experience of grace that restores wholeness to a self fragmented by the experience of its freedom in moral duty and the failure to comply with it. Without this religious experience the self has not fully realized itself. What is more, it has not even been fully discovered. It begins to exist fully only when it comes upon this realization. The reality of the self in its "communication with God"59 is associated with an appreciation of the person of Christ as he emerges from the Gospels and that transcends the problems raised by Higher Criticism. ${ }^{60}$ In this meeting of the self with Christ the immediacy of the experience transforms the consciousness involved in philosophical and moral self-examination into a new, real, live individual. This experience is one of totality, of otherness, of authenticity, and of uniqueness. One easily recognizes Herrmann as teacher and inspiration to both Karl Barth and Rudolf Bultmann. ${ }^{61}$ His deeply pietistic and almost Kierkegaardian departure from the ethical rigorism of Ritschl and Cohen may have caused Cohen to feel that, between himself and Herrmann, the Ritschlian legacy was more truthfully administered by the Jewish philosopher. Herrmann's solution to the problem of the self seemed to revive the notion of the absoluteness of God and soul, metaphysical constructs

${ }^{59} \mathrm{Cf}$. W. Herrmann, Der Verkehr des Christen mit Gott im Anschluss an Luther dargestellt, Stuttgart/Berlin: J.C.Cottasche, 1886 (5. and 6., improved edition 1908. 7th ed. 1921).

${ }^{60} \mathrm{Cf}$. W. Herrmann, Die Wirklichkeit Gottes [= Die christliche Religion unserer Zeit, vol.1], Tübingen: Mohr (Siebeck), 1914.

${ }^{61}$ Cf. Daniel L. Deegan: "Wilhelm Herrmann is important in present theological debates, particularly those between Bultmann and Barth, two of his most distinguished pupils. Barth's own break with liberal theology was in part a break with his teacher Herrmann, a rejection of revelation as constituted essentially by its mode of appropriation within the religious subject, and a rejection of the psychological pragmatism which determines the soteriological significance of Jesus in terms of the moral need of the individual. Barth sees Bultmann as setting forth in existentialist categories the transformation of the inner life of the believer and reminds us of all that Bultmann learned from Herrmann long before he had heard of Heidegger." (in: "The Theology of Wilhelm Herrmann: A Reassessment" in: The Journal of Religion vol.XLV, April 1965, Nr.2, p. 87). Similarly, more recently, Theodor Mahlmann: "Barth, for whom 'Herrmann was the teacher of [his] youth'..., takes from him the Christologization of theology while, at the same time, he eliminated the existentialization of faith. Bultmann ... called Herrmann 'my truly revered teacher' ... The transition [in Bultmann's theology] to Heidegger's existential analysis ... (and to personalism in general) is true to the essence of Herrmann's theology which is present even in the wording." See Mahlmann, op.cit., p. 171. 
Cohen intended to deconstruct. The focus of the debate between Cohen and Herrmann therefore involves characterizing the players in the drama of the atonement which implies also a decision on the stage where this drama is played out. Are God, Human Being, World ultimately transphilosophical, trans-foundational, albeit discovered as such only if and when their philosophical constructedness is presupposed and parsed to the very limit? Not by accident, this description of Herrmann's view resembles the argumentative structure of Rosenzweig's Star of Redemption, which like Herrmann's later works, takes Cohen's system as its point of departure. What further unites Herrmann with Rosenzweig against Ritschl and Cohen is their pessimism with respect to the selfsufficiency of reason. As Cohen puts it (with Plato): tes asphales tes hupotheseos. Neither to Herrmann nor to Rosenzweig, "culture" (as in Troeltsch's Kulturprotestantismus) is enough, and religion is misjudged, sold out to a deficient rationalism, if it fails to account for the individual soi même.

In contrast to Herrmann, Cohen speaks of the self in terms of a correlation between the "idea of God" and the self-consciousness of pure will as constituted in the individual through the speech acts of a liturgy. Whatever else religion is and does, as the religion of reason it is beholden to the virtue of truthfulness that anchors it within the cultural consciousness. Of course, from Herrmann's (and Natorp's) ${ }^{62}$ perspective, the religion of reason was in violation of truthfulness as long as it failed to account for an experience grounded in religion, namely the experience of totality (à la Schleiermacher) as correlated to a wholeness of the self. The respective religious groundings of these alternatives could hardly be more obvious. Their difference is perhaps not so much one between Christianity and Judaism rather than between apocalyptic and millenarian eschatology. Where Herrmann advocates rupture for the sake of life and authenticity, Cohen the quintessential bourgeois advocates development and continuity. One follows the Zoroastrian/Dionysian model, the other the Roman/Hellenistic/ Appollonian. The Jew as the advocate of European, the Christian as that of Oriental culture.

The more the human individual who experiences the atonement is made a reality, either by default or as a result of the process of atonement, the more the concept approximates the classical doctrine of an objective act of God that leads to the removal of an objective obstacle to an unfettered communication between a substantive soul and the really existing God. The ambivalence between objective and subjective

${ }^{62}$ On Natorp's philosophy of religion cf. Judy D. Saltzman, Paul Natorp's Philosophy of Religion, Hildesheim/New York: Olms, 1981. 
atonement is already present in the very terms by which this religious idea is expressed. The Judahite priestly ritual and its Christian descendants (e.g., the term apolutrosis, Rom 3:24) concern the objective side of the matter: one wipes away or covers something that blocks an ideally unhindered communication and communion between deity and human community. In the New Testament, especially in the Letter to the Hebrews, such unfettered communion is once and for all (ephapax) achieved by the perfect sacrifice of Christ that is sufficient to overcome the objective enslavement of all humans to the powers reigning the world at this age. In contrast, the subjective aspect of the concept concerns the establishment or restoration of a state of harmony between God and the human being. The objective side of atonement seems parallel to the notion of expiation although they are not identical. Sin, transgression, ritual defilement, violation of taboo, etc. must be made up for by the appropriate means of correction, including direct restitution of debt and paying of penalties as well as sacrifices to the gods, with death of the innocent (e.g., child sacrifice) or the self-sacrifice of a prince as ultimate penance. The objective character of expiation puts it on a continuum with the notion of propitiation, the placation of divine wrath. The subjective side of atonement, however, obviates the idea of propitiation. Monotheistic sacrifices are only rarely aimed at pleasing God (cf., among possible exceptions, Noah's sacrifice after the flood although he, coming as he does before Abraham, may not really qualify as a monotheist), and the idea of pleasing God through sacrifices can even be explicitly rejected in favor of the virtue of justice (e.g., Micah 6:68). Similarly, in a cultural context determined by Greco-Roman religious practice, early Christianity rejects the notion that it is possible to please God by means of human sacrifices. The radicalization of sinfulness developed in Paul's letters (e.g., Romans 1-3) aims to make the practice and meaning of propitiation obsolete. Once the idea of atonement is severed from the magical connotations of removing, or covering up, material impurities as well as from the notions of expiation and propitiation as primary purposes of sacrifices, it can become a symbol for reconciliation: between human being and human being, human being and God, and human being and him/herself.

Religious practices, including rites of expiation, are of a symbolic nature and are therefore not only open to interpretation but they themselves are interpretations and representations of reality. Due to their symbolic character, religious practices divide quite naturally into an objective, or "outer," side and a subjective, or "inner," side: the sign and the signified. The medieval Jewish philosophical tradition of "giving account for the reasons for the commandments" (ta'amey hamitsvot) quite evidently presupposes an awareness of this symbolic character of 
ceremonial laws. While, by the Middle Ages, this reflective practice is shaped and enhanced by the Greek philosophical tradition (after Plato's logon didonai), it has its origin already in the Bible where certain ritual commandments, whose justification is not self evident, are explicitly justified (cf., e.g., the two versions of the commandment of Sabbath in Ex 20 and Dtn 5). To label as reconciliation an interpretation that aims to resolve cognitive dissonances is a modern usage. The Jewish exegetical tradition of midrash, however, is to a large degree the cultivation of the art of creating dissonances in a text that are subsequently resolved. This activity of separation and unification, the classic mode of rabbinic thought, is the essence of Talmud Torah, a kind of love-making with the text (the garment of the LORD), and thus sacred "work" (avodah) par excellence. Medieval Jewish philosophy is often criticized for supplanting this self-perpetuating holy activity by making Aristotelian philosophy the hermeneutical key to Torah and reducing its "seventy faces" to but a single one. Even if this were accurate, such reduction is not the case in the modern philosophical situation. Kant is not Aristotle. Cohen's system of judgments is open ended, following the paradigm of the sciences. Cohen finds himself in a fundamentally different situation from Moses Mendelssohn, who was forced to take recourse to the perpetuity of the pursuit of esthetic perfection as the cultural analogue to the study of Torah. But it is the same sensitivity to the characteristic of openness of drash as a pursuit and a way of life that made Mendelssohn refrain from making too close an association between the thin doctrine of natural theology and the Mosaic legislation. In contrast, Cohen, who like Mendelssohn took his first philosophical education from the Guide for the Perplexed, can look to science and first philosophy, the logic of cognition, as a manifestation of the very principle of thought in action that is the essence of Jewish monotheism. The very metaphor Mendelssohn uses in response to his reading of The Critique of Pure Reason, referring to Kant as one who "destroys everything," points in the direction taken by Cohen. For there exists a figure in Jewish lore who is regarded as the destroyer, namely the young Abraham in Ur of the Chaldeans who smashes the idols in his father's workshop only to discover the one, the unique God. ${ }^{63}$ In the wake of Kant, the critique of metaphysics and Jewish monotheism could be seen as mutually constitutive.

The rabbinic tradition distinguishes between the sphere of action as primary and the sphere of meaning as secondary. Thus the rendering of Exodus 24:7 as "We will do and we will hear." Action comes first, but it

${ }^{63}$ Similarly, in God of Abraham (New York: Oxford University Press, 1996), Lenn E. Goodman makes Abraham the one who discovers monotheism as a "self-righting principle." 
is, of course, no blind action. Yet doing is mentioned first in order to distinguish obedience as a conditio sine qua non and as purely heteronomously determined from reflection on doing. The latter must not weaken commitment to obedience but elevate it by using it towards a cultivation of reason and knowledge. In a culture close to that of the Gilgamesh epic, $d a^{\prime} a t$ is "deep" knowledge, acquired through sustained practice that can be symbolized in the imagery of love. Not per chance is the Song of Songs regarded as composed in the inner sanctum of the intimate relation between Moses and God. Hearing as the privileged sensual perception (cf. Dtn 6:4), detracts from the world of appearance and points to the realm of hidden meaning. Commitment to the covenant is reaffirmed in the call to "hearken." Don't look, listen! The daily recitation of Dtn 6:4-5 signifies the voluntary act of taking upon oneself the "yoke of the kingdom of heaven." It is a shortsighted misperception, then, to think that, in Judaism, action is guided by commandments only, without recourse to meaning. After what we said above about the symbolic nature of ritual, no cultic activity of any sophistication should be taken at face value. The fact of practical halakhah and its primacy are not a matter of debate, at least in classical rabbinic culture. Determining the rules of conduct, however, is a matter of legal argument that involves discussions on practical matters as well as on the meaning and legitimacy of the specific rules that are, after all, text, and thus subject to "searching." The same basic attitude thus enters into halakhic and aggadic discourse. It is significant here that the boundaries of legal and non-legal discussions are not set by dogmatic limits. The only limits that exist at all are the honor of God and the need to rule individual cases. Since they are individual, they become precedents, not universal laws. Thus the legal tradition retains its "orality" despite all writing, i.e., its malleability and ability to adapt to any and all circumstances. Instead of substance (legal or dogmatic) we find continuity that provides a changing community with an every renewed source of identity. In this perspective, Torah is truly teaching of life (torat hayyim) rather than "law" as in the Christian understanding of the word. Torah is the manifestation of grace and the token of divine providence. Cohen has in mind this view of Torah when he sets out to make jurisprudence the source of the ethics of pure will. For Judaism provides him with a living historical model of a successful integration of the universal demands of morality with the need of the individual for a perpetual active renewal of her moral energy, involving mental energy as well. In this and in the idea of messianism as the goal of history and in the grounding of it all in the idea of the unique God, Judaism provides a model for the religion of reason. 
When medieval Jewish philosophers were challenged to articulate Jewish doctrine in situations of competing claims to truth they took refuge to the best available general means of articulation (Kalam in the case of Saadiah, neo-Aristotelianism in the case of Maimonides, and neoPlatonism in the case of Jehuda Halevi). But their work is also based on the conviction that Judaism, Torah, and God are inherently related to reason. The situation of contradictory claims to truth called upon the philosophers to exert the power of reason in order to achieve a reconciliation between reason(s) and revelation(s). ${ }^{64}$ Their philosophy, like all philosophy before or after, responded to tensions that called for resolution. In this way, the medieval philosophers no less than their modern successors responded to what they perceived as a fundamental philosophical task that was demanded no less from the side of philosophy than from the side of their religion. Monotheism was perceived as inherently reasonable, and philosophy as a condition for the knowledge of God was recognized as the chief among the commandments.

The religious character of Cohen's philosophy is manifest in the attempt to reconcile a concrete religious tradition (Judaism) with the general philosophical consciousness of the age, hardly an unusual attempt either in the history of philosophy or in that of Judaism. The philosophical rigor of this attempt may be seen as manifest in the degree to which the conceptualization of religion is entrusted to the critical guidance of idealist presuppositions and methodology. The originality of Cohen's religious thought, however, is only revealed once one realizes that Judaism-or better: the sources of Judaism that are subjected to philosophical examination-provide the historical and, as it were, empirical origin for a critical concept of reason, namely the very concept of religion. This seems to indicate an unresolved conflict between the religious basis and its theoretical conceptualization. How can there be a perfect mutuality and coordination between religion and reason, especially if the ideal of reason is the quintessentially modern ideal of autonomy and the religion at stake is the quintessentially heteronomous tradition of Judaism? Is Judaism transformed beyond recognition and made the historical inaugurator and liturgical generator of an autonomous subject? Cohen rejected this solution as inappropriate in his review of Moritz Lazarus's philosophical exposition of Jewish ethics which, in Cohen's view, had made this its core idea. Lazarus's Ethik des Judentums (vol. 1, 1899) credited the tannaitic rabbis not only with an impeccable sense of morality but with having introduced principles of

${ }^{64} \mathrm{Cf}$. John Clayton's forthcoming monograph on Religions, Reasons and Gods (Cambridge University Press). 
ethics equivalent to the Kantian categorical imperative. To Cohen such a characterization implied an obfuscation of the boundaries between philosophy and religion. Morality is essential to religion but it is philosophical ethics which determines concepts and principles of morality. How, then, are religion and philosophy nevertheless brought into agreement and mutual fertilization? Cohen's answer is simple. "Religion" is not the name for the manifold phenomena of cultic activity and mythological imagination. Rather, it refers to a rational transformation of myth into that phenomenon that we call religion and which is instantiated in the monotheistic tradition inaugurated by the Hebrew prophets. Thus religion already participates in the cultural process of self-transformation and critique. We still live with that cultural achievement that we associate with the Hebrew prophets, with their opposition to idolatry, and with the imagelessness of their monotheism in its implicit and explicit moral radicalism. From Greek culture we inherit conceptual thought which leads to the development of science and philosophy. In this narrative we recognize the classic story of Athens and Jerusalem. Add to this mix the Stoic and Christian ingredient and you arrive at the canon which provides us with the sources from which we craft our conceptual, moral, esthetic, and religious experience. Philosophy in its ability to harmonize and conceptualize is the superior tool yet it is dependent on the cultural and linguistic substrata that is its task to reflect on, purify, and, where possible, use to enrich and enhance the edifice of the cultural consciousness. From the outset, then, the harmonization or reconciliation between reason and revelation is not an unresolvable difficulty that demands violating the integrity of one for the sake of promoting the other. As in the case described above, where Cohen took the rational position against religious irrationalism, he defends, at least to his own mind, not philosophy at the expense of religion but both at the same time. Where logic and ethics suffer, religion, at least in Cohen's sense, cannot thrive. The reconciliation between religion and reason is, thus, a reconciliation between two that belong together and that cannot be pitted against each other without detriment to both.

In sum: Cohen's philosophy aims at a reconciliation between Judaism and the "cultural consciousness." This project of reconciliation manifests itself most explicitly in the idea of Versöhnung. The presuppositions associated with this program of reconciliation are the following.

i. Cohen attributes originative equivalence (Gleichursprünglichkeit) to religion and philosophy. I.e., he determines religion and philosophical reason as equally original impulses without having to declare them to be of the same origin. Both originate in needs for reconciliation. Where 
reason is concerned with judgments about being, religion is concerned with the tensions between ethical norms and the concrete potential for their realization. By virtue of the "basic law of truth," i.e., the postulate of an agreement between is and ought, logic and ethics, knowledge and moral imperative, ethics needs religion to mediate between its ideals concerning human affairs and the confines of empirical reality. Just as the idea of God is introduced in Cohen's ethics in order to bridge the gap between the real and the ideal, the "discovery of the individual in sin" (i.e., the idea of atonement) represents the bridge between the universalism of ethics and concrete subjectivity as a condition for the possibility of moral progress.

ii. Thus Cohen avoids subordination as well as coordination of philosophy and religion. Subordination would mean a subordination of religion to reason, whereby reason would empty religion of its concreteness. Or it would mean a subordination of reason to religion whereby the structure of a specific religion would be generalized to stand for all religions and, where this structure extends to thought, religion would be allowed to determine the idea of a totality of all conditions. Coordination, on the other hand, would mean for religion to gain distinction as its own direction of culture casting doubt on the sufficiency of reason as normative even for religion. The latter view could be expressed in the notion of a "religious a priori." In contrast, Cohen seeks to maintain religion while associating it with an ethics in need of such augmentation. The separation of religion from such an association with ethics would mean for Cohen to concede to a certain Christian paradigm of religion, one which he found detrimental to the hoped-for construction of a common culture.

iii. He further makes a fundamental statement about the way in which a particular religious tradition may champion the ideal of humanity/humanism (Menschheit) within the concrete limitations of its historical origins, its interests of self-preservation, and its specific liturgical system of symbols. Thus his philosophy of religion with its concept of atonement makes a major contribution to the most classical of all modern debates, namely that on a reconciliation between the competing claims of religion/religions and the secular state.

iv. Versöhnung establishes a link between philosophical thought and religious practice. Several general characteristics of thought, which, in Cohen's philosophy, is the origin of all contents and, thus, of being, can be seen in the religious tradition of Versöhnung as well, without reducing the religious symbolic practice and its meaning to an example of thought. Rather, Versöhnung and religious symbolism in general (as based on observations on Versöhnung as the paradigm of religious experience) remain concrete and particular religious practice while providing an 
analogy to the reflective processes of thought. So, for example, thought is an activity that, on principle, cannot achieve rest in an absolute synthesis but is in perpetual motion (cf. LrE p. 60ff). Philosophy and religion thus augment each other.

With this directive of a correspondence, mutual augmentation, or correlation between logic (thought as the "origin" of being in the sense of reflection on the transcendental grounds of the generation of objects for the sciences) and religion, Cohen continues the medieval Jewish tradition of philosophy which maintains that monotheism contains epistemologically significant implications. In this sense Cohen removes religion and religious philosophy from the realm of apologetics and argues for a philosophical relevance of Jewish monotheistic thinking, a relevance which, however, is disclosed as the Jewish texts and practices are subjected to historical criticism and philosophical analysis from the perspective of the possibility of a religion of reason.

\section{Identifying the Proper Narrative}

The common story of the development of Hermann Cohen's philosophy of religion is embedded in the narrative of the rise and decline of neo-Kantianism. Accordingly, the merit and character of his philosophy of religion is usually judged by its relation to this philosophical movement. To most readers, the seemingly "late" philosophy of religion constituted a departure from the neo-Kantian program. Whether one hailed this departure, as did Franz Rosenzweig, 65 or whether one deplored it, as did many of the non-Jewish neo-Kantians, depended on one's regard for Marburg critical idealism or, in some cases, also on one's understanding of the motivation for Cohen's embrace of Judaism. ${ }^{66}$ On the other hand, there were those readers who emphasized the patent continuities between Cohen's system and his works on religion. ${ }^{67}$ They, too, were divided into two camps. Here the judgment depended on whether one felt that Cohen was not going far enough in giving religion its due (as in the case of Wilhelm Herrmann and his school) or whether one thought that the Ethics had already provided a striking exposition of Jewish thought whose conceptual

\footnotetext{
${ }^{65}$ See his exceedingly influential and, at the same time, quite ambiguous "Einleitung" (J 1, xiii-xliv).

${ }^{66}$ See, e.g., Heimsoeth's letter to Hartmann, Nov. 14, 1915, Nicolai Hartmann und Heinz Heimsoeth im Briefwechsel, (Frida Hartmann/Renate Heimsoeth ed.), Bonn: Bouvier, 1978, p. 205.

${ }^{67} \mathrm{Cf}$. especially, and from a neutral historiographical perspective, the important essay of Alexander Altmann, "Hermann Cohens Begriff der Korrelation" in: Tramer Hans (ed.), Zwei Welten: Siegfried Moses zum Fünfundsiebzigsten Geburtstag, Tel Aviv, 1962, pp. 366-399.
} 
contents were merely reiterated in the philosophy of religion, as argued by Steven S. Schwarzschild. ${ }^{6}$

It made sense to Cohen's contemporaries to see his development in light of his contributions to the revival of academic philosophy associated with the name of Kant. If one followed the course of his publications and of the statements of purpose they contained, and similarly if today one reads only the major philosophical works in chronological order, a certain view of the development of his thought urges itself upon the reader. Given the modifications in formulations of his philosophical program pertaining to the relation between ethics and religion and given the focus on religion during his last period it seemed plausible that Cohen altered his attitude towards religion, perhaps even radically. This assumption has remained persuasive to many, particularly to those who, like Rosenzweig, interpreted Cohen's development as an experience of conversion from secularization to traditional religiosity. Such return to tradition has become widely spread over the course of the twentieth century. It indicates an intellectual and emotional disenchantment with modernity and has given the traditional term lakh'zor bit'shuvah ("to return in repentance") its current connotation. Rosenzweig presupposed this modern sense of the phrase when he referred to Cohen as a baal t'shuvah, alluding to an anecdote from Cohen's 1914 voyage to Russia. In response to a speech in which his hosts applauded him for turning his attention to his persecuted brothers, Cohen replied, "But I have already been a ba'al t'shuvah for thirty-four years. ${ }^{\prime 69}$ Cohen thereby seemed to acknowledge that he too had returned from assimilation to an existential affirmation of Judaism. Rosenzweig correctly dates this conversion to the year 1880, the year Cohen first took a public stance in defense of Judaism. The occasion for doing so was Heinrich von Treitschke's infamous defense of anti-Semitism. In Cohen's own mind, therefore, the Berlin Antisemitismusstreit was a turning point. But evidence of Cohen's "return to Judaism" did not rise to the surface of his philosophical works until much later, so that his claim seemed a projection in hindsight, the pious wish of a retired academic caught between loyalties who saw the light only dimly and late, an Elijah figure to the messianism of the Jewish renaissance movement of the 1920's.

\footnotetext{
${ }^{68}$ See Schwarzschild, "Introduction" to the Werke edition of Ethik des reinen Willens (WW 7, 1981, vii* - $\mathbf{x x x v}^{*}$ and again in his introduction to the new American edition of Religion of Reason.

69 "Ich bin ja ein Baal t'schuwoh schon vierundreißig Jahr!" Quoted in Rosenzweig, "Einleitung" p. xxi. It was recently announced that the Ukrainian national library is in possession of voice recordings from before the First World War. Among those recordings is one of Hermann Cohen, presumably made on the occasion of his 1914 trip to Russia.
} 
Because of the strongly interested reading of Rosenzweig and his generation, such an explanation of Cohen's intellectual development must be distrusted or, at least, other possible interpretations should be examined. The evidence amassed in this study sheds new light on the complex significance of t'shuvah in Cohen's life and thought. T'shuvah (literally: "turning around") is part of Cohen's idea of atonement, the idea that links ethics and religion, Judaism and "cultural consciousness," without obliterating their difference. Thus we may understand his reference to himself as a baal t'shuvah somewhat differently without completely rejecting the legitimacy of Rosenzweig's understanding. The expression can be translated as referring to a "mastery in the movement of turning around." Cohen speaks of himself as a baal $t$ 'shuvah not because he returned to the religious practices of Judaism, which he had never abandoned, but because of his mastery of the philosophical problem of repentance. This newly found philosophical consciousness is stirred by the conviction of the dignity of the Jewish monotheistic heritage, and it is this conviction which motivates Cohen's increasing engagement for the preservation and development of Jewish institutions of community and learning.

In the 1920's, most younger philosophers took neo-Kantianism as a negative point of departure for their own thought. Neo-Kantianism was as passé as Hegel once was and therefore one felt beyond the effort of giving a point by point account of what this philosophical movement had been all about. Cohen was reduced to a caricature, a rationalist paper tiger easily vanquished by a somber Heidegger (and a facetious Levinas) in Davos in 1929. In the context of Jewish philosophical thought, on the other hand, Cohen was not as easily dismissed. Jewish existentialists held on to Cohen by means of the narrative introduced by Rosenzweig of Cohen's gradual return, almost despite his philosophical judgment, to Judaism. Thus he could still serve as a precursor and the prophet of their own "overcoming" of idealism whose turn to language and liturgy prefigured their own understanding of Judaism as a dialogic rather than a conceptual religion. Cohen became a John the Baptist to the Jewish renaissance movement of the 1920's: the greatest among the representatives of the old (Wissenschaft-des-Judentums-) paradigm, but the smallest among those who returned to Jewish authenticity and national self-determination. Moving away from the 19th-century Reform idea of ethical monotheism as a universal value, Buber, Scholem, Agnon, Bialik, and others infused Romantic notions of national particularity with the spirit of Hebrew literature, and thus pursued the vocation of cultural 
continuity in a new key. Instead of a "mission to the Gentiles,"70 cultural Zionism focused on the restoration of a Jewish national identity. Instead of cerebral concepts of ethics and religion more immediate expressions of life were sought to activate political engagement and emotional intensity. This renaissance was certainly part of a more general phenomenon, but it received a particularly strong momentum among the members of the Jewish intelligentsia who felt that the pursuit of assimilation and integration was no longer a valid option. The assertion of cultural difference as an intellectual stance displaced all rhetoric of reconciliation. If Cohen's evidently ardent Jewish religiosity was to be passed on and preserved by the younger generation, it was to be reinterpreted to match the parameters of their own experience. Especially his German nationalism-which was eventually perceived as an embarrassing feature-needed reinterpretation. His infatuation with Deutschtum was clearly a delusion not atypical for his generation. On the other hand, his increasing recognition of Judaism as the religion of reason (so the title of the 1919 edition) was a return to sanity, affirming Jewish existence as the core and origin of Jewish cultural dignity. Thus Cohen was reinvented in the image of his readers. The motivation for Cohen's return to Judaism seemed self-evident. Clearly, Cohen had rejected idealism as illusory and turned to the ultimate grounding of all thought and culture in the particular roots of his origins. Even where Cohen himself had failed to acknowledge his own move fully and explicitly, the "unwritten" Cohen, as witnessed in anecdotes circulated by young intellectuals who came to visit this rare exemplar of Western Jewish distinction, seemed to confirm this interpretation beyond any doubt.

Against the grain of this well established reductionist reading, Alexander Altmann raised the caveat of the letter of the written Cohen and Steven Schwarzschild argued for the very opposite of the consensus: there is nothing in the philosophy of religion that is not already in Cohen's systematic ethics. Altmann and Schwarzschild certainly pointed in the right direction. There is a deep agreement between Cohen's "late" philosophy of religion and his system. But we also need to consider that his philosophy of religion may shed an entirely different light on the character of his systematic philosophy. It may not have been immediately discernible to his readers, but the tensions between philosophy and religion as well as between Judaism and culture may have been driving forces in Cohen's philosophical thought from early on. His attempts to resolve these tensions may have taken a long time to

\footnotetext{
${ }^{70}$ On the motif of a "mission to the Gentiles" and other expressions of Reform Jewish ideology see Michael A. Meyer, Response to Modernity. A History of the Reform Movement in Judaism, New York/Oxford: Oxford University Press, 1988.
} 
surface but this does not mean that the problems were not on his mind. We must entertain the possibility that ideas took shape in the mind of this philosopher over a long period of time and that such ideas did not always manifest themselves in the most evident and chronologically unambiguous record of publication. Therefore it is worthwhile to read in the margins and note the appearance of ideas mentioned in asides, in short and difficult to place essays, as well as in manuscripts. Such hints allow us to recognize the deeper structures and hidden foundations that the architect hides under the facade of a clean surface. Thus while Judaism and religion emerge in larger edifices of their own only after the system is mostly complete this does not mean that the relation between them has not been considered before. In particular, once one differentiates between an integration of Jewish concepts into the system on the one hand and the concept of religion as a general philosophical problem on the other, it becomes clearer how both can coexist in one œuvre. While Rosenzweig's statement about a peculiarly improvised architectonic of Cohen's works seems accurate with respect to the concept of religion, Cohen had nevertheless carefully measured the grounds with respect to a place for Judaism in the edifice of the "cultural consciousness" before he proceeded with the construction of his system. Where Cohen did in fact modify some of his formulations with respect to the relation between the system and a general concept of religion we shall need to explain the meaning and intention of such clarifications from this new perspective of synchronicity.

Cohen's "late" philosophy of religion is manifest in two works of different scope and disposition, Begriff der Religion and Religion der Vernunft, that were published in short sequence. The significance of this dual presentation of religion and Judaism is not immediately evident and it generates some of the difficulties in the interpretation of Cohen's religious thought. There is no conceptual tension between the two books, so that one could determine Begriff to be a last attempt to salvage critical idealism in the face of a religious awakening which comes fully to the fore only in Religion. What then is the distribution of labor underlying the division? Why two works instead of one, if Cohen wished to make a case for religion? The duality can be resolved if one distinguishes the books by genre. Begriff is a contribution to the philosophy of religion from the perspective of critical idealism. Since the system was not originally envisaged to include a special treatise on religion it appears, as Rosenzweig puts it, as a kind of appendage or afterthought. Religion is attributed a certain Eigenart (peculiarity) while being denied philosophical independence (Selbständigkeit). Cohen uses the term Eigenart before the treatise on the concept of religion but without the same methodological emphasis. It strikes one as an unfortunate choice of 
words, as too imprecise to indicate the status of religion within the system. It will become clear, however, that religion cannot receive the precise treatment of independent areas of transcendental analysis. For religion mediates between the theoretical demands of ethics and its trajectory of realization in concrete individuals as members of particular communities. As such the concept of religion belongs into the realm not of founding but of application. This is no different in Begriff than in the Ethics. The separate treatment of religion in Begriff, however, felt to some readers as if Cohen were giving in to the "extra-philosophical" urge to defend Judaism ${ }^{71}$ while to others it seemed as if he were making a lastditch attempt to prevent his religious feelings to overcome his philosophical judgment. ${ }^{72}$

Der Begriff der Religion im System der Philosophie is dedicated to the Marburg school. Accordingly, this treatise has always been associated with discussions involving Cohen's close Marburg interlocutors of many years, the philosopher Paul Natorp and the Protestant theologian Wilhelm Herrmann. This conversation had previously surfaced in various works of the three authors who recognized each other while begging to differ on a number of points. All along, on the matter of religion there had been agreement between Herrmann and Natorp against Cohen whose disagreement with the others ran much deeper than the published works revealed. Now it seemed as if Cohen's turn to religion as the frame for the problem of constituting concrete subjectivity marked a breaking of new ground for the Jewish philosopher who sought to bridge the gap between himself and his Protestant colleagues.

Here was an opportunity for the celebrated neo-Kantian to make a bold statement on a question which moved all of his readers, Jews and non-Jews, philosophers and theologians, friends and critics, politicians and artists, believers and atheists. While not his first publication on the topic, ${ }^{73}$ Begriff was expected to contain the definitive clarification as to Cohen's views on religion and knowledge, religion and ethics, religion and esthetics, as well as religion and psychology. Moreover, a year into the World War, with former students fighting and dying in the trenches and the initial enthusiasm, the spirit of 1914, having evaporated, the time was ripe for a profound reevaluation. When it was finally published, Begriff fell short of many of the expectations it had stimulated. The

${ }^{71}$ Cf. Mechthild Dreyer, Die Idee Gottes im Werk Hermann Cohens (Königstein/Ts.: Hain, 1985).

${ }^{72}$ So in the reviews coming out of Wilhelm Herrmann's school, esp. Hinrich Knittermeyer.

${ }^{73} \mathrm{Cf}$. especially the essay "Religion und Sittlichkeit. Eine Betrachtung zur Grundlegung der Religionsphilosophie" first published in JJGL 10/1907, 98-171; enlarged separate edition Berlin: Poppelauer, 1907 (= J2,98-168). 
Christian theologians among its readers were disappointed to find more of the usual idealism instead of a clear statement of the personal fideistic underpinnings of Cohen's religiosity. Wilhelm Hermann felt that Cohen had failed to give the reality and revelation of God their due. The younger generation was divided in their response. Nicolai Hartmann, for example, picked up on the novel emphases made in this work and appreciated that Cohen was convincingly speaking of a subject that was dear to him. His friend and fellow Marburg student of philosophy Heinz Heimsoeth, however, regarded the book as blatantly apologetic.

The crux of this debate lies in the disagreement over the term religion. While the theologians were ready to accept Cohen's superiority in philosophical knowledge and ingenuity, they felt themselves to be experts in religion. What he called religion was to them an unmodern, medieval, scholastically rationalist reduction and a chimera rather than a philosophically-reflected account of a living experience such as they were aiming for. Cohen appeared to be stubbornly subjecting the reality of religious life, of which, by all accounts, he seemed to have considerable knowledge, to the censorship of an ill-conceived idealist purism that disallowed recognition of religious experience beyond ethics. It is quite evident, on the other hand, that his interlocutors were taking their own religion as a model and developed a philosophical project that complied with it. They could not accept a concept of religion as sufficient that did not correspond to the experience of their religion. Nor could they recognize as a religion a tradition that emphasizes law over doctrine, as well as communal well-being over individual redemption.

While it disappointed his readers, the treatise may still have introduced modifications to the system of philosophy, as Cohen explicitly stated. What are the kind and degree of such change and how does it affect his system? Is it unhinged by the introduction of a new problem into its purview or is it on principle open to modification? As it happens, the systematicity of Cohen's philosophical project is conceived so as to be able to accommodate growth and augmentation of the kind proposed in Begriff so that, all impressions to the contrary notwithstanding, the introduction of the concept of religion to the system of philosophy does not pose a threat to the systematic coherence of Cohen's thought. This being the case, readers who expect to find a radical philosophically departure in Cohen's late work on religion may approach the book from a flawed understanding of Cohen's philosophical program.

If one agrees that Begriff is in a fundamental sense consistent with the system of philosophy and if one is averse to the very project of systematic philosophy, one may still try to find a way of affirming 
Cohen's move beyond his own critical idealism. It is not evident why someone should formulate concepts and ideas just so that the systematic unity of what he calls "cultural consciousness" should be maintained. Was Cohen not at all touched by the aphoristic postmodernism of a Nietzsche and the anti-systematic posture of a Kierkegaard? Cohen's student Franz Rosenzweig, whose influence on 20th century Jewish philosophy has been increasing over time, ${ }^{74}$ advocated the idea of "breaking through the veil of idealism" and of discovering the primordial power of revelation both of which are ways of pointing to an "unpreconceivable" (unvordenklich) grounding of all thought in experience. Coming from such a perspective one may be inclined to position Cohen at the threshold of idealism and existentialism. And so, distinguishing his philosophy of religion from his Jewish thought, one might arrive at the conclusion that it is primarily in the manifestation of the latter, i.e., in Religion der Vernunft, that one finally encounters the radical departure one saw coming all along. Instead of dealing with a repressed Victorian philosopher who, until the end, tried to be a good German nationalist while castrating his Jewish identity, one might see the duality of the late philosophy of religion as a last and truest statement, a death bed confession reaffirming the religion of one's youth without regard to the follies of most of one's life. The carefully maintained balance between Judaism and Germanism, between religion and philosophico-metaphysical matrix in the culture of Luther, Leibniz, Kant, and Mozart finally explodes in a vigorous defense of Jewish piety that, until then, had been kept under the lid of philosophical subtleties.

As plausible as this scenario may seem from a psychological perspective, it represents a classical case of seeking a biographical explanation where a literary and philosophical one might suffice. What rings true as a biographical and historical story might nevertheless be inaccurate. Our interest in Cohen grows exponentially if we can ascertain that he himself took into consideration any number of possible resolutions of the tension between Judaism and modern culture and that his solutions are chosen to extract from it directives that may be applied more universally.

\footnotetext{
${ }^{74}$ Aside from Rosenzweig's towering presence in all accounts of 20th-century Jewish thought (beginning with the Hebrew and English editions of Julius Guttmann's Philosophies of Judaism whose original German manuscript had ended with Hermann Cohen), note the position of Rosenzweig in Norbert Samuelson's study on Judaism and the Doctrine of Creation, as well as (somewhat more to the point) the recent titles by Robert Gibbs and Richard Cohen where Rosenzweig and Levinas are correlated/elevated as the most significant inspirations to contemporary Jewish philosophy.
} 
We shall see that Cohen's mature philosophy of religion and his Jewish thought are mutually constitutive and their mutual constitution will guide us to the level of reflection at which Cohen sought to resolve problems that arise if religion is released from the task of playing a constructive role within the whole of culture. It seems to me that Cohen seeks to avoid the Enlightenment mistake of privatizing religion as well as to avoid the pitfalls of the neo-Romantic trend of his time (the time of a Schleiermacher revival) which hoped to make religion the last resort for an affirmation of the ineffability of the individual.

While the treatise on religion, then, takes on the discussion of a topic that was raised to challenge critical idealism, Cohen continues to believe that the reality of the subject was not a fact to be ascertained scientifically, i.e., not a matter of knowledge, but a presupposition of action, determined by its ethical direction and thus functionally located in the system, not beyond or before it. The concrete subject experiences transformation as prefigured in liturgical language and thus constitutes itself before God as the precondition of the realization of ethics.

Apparently this was not what Cohen's readers had expected to find. It did not elude them that the book contained hardly anything new, a fact which makes the question all the more puzzling why the book was written at all. While Cohen was praised for not shying away from a difficult philosophical task, his solution seemed less than satisfactory. It is unlikely that the war played into his decision to address the problem of concrete subjectivity, at least not as a source for his awareness of the problem. He had already addressed it from the perspectives of the logic of cognition as well as of the Ethics of Pure Will where he points out explicitly that the "discovery of the individual" was the merit of the Hebrew prophets. In no substantive sense, then, does the treatise on religion represent a departure from the system. Cohen's own assertion that Begriff was to modify the system to make room for religion is, therefore, somewhat misleading and possibly politically motivated. Having raised the stakes while failing to deliver a major revision of his philosophical concept of religion, Cohen nevertheless feels disappointed by its mostly critical reception, again presumably for political reasons. At the time of a strained Burgfrieden, his bona fide efforts at establishing a workable compromise between the religious factions ought not to have been called into question by his liberal Christian colleagues. In conceptual terms, the self as the concrete subject that is presented in Begriff and again in Religion der Vernunft is not the absolute, real, natural, and immediately evident "given" of common experience, nor the gift of grace, that others wanted it to be. To the degree that religion contributes to the constitution of the cultural consciousness it serves the purpose of an actualization of ethics. As such, the religious concept of the self 
remains a task whose realization is facilitated for the individual through religion. However much the self's transformation through sin and atonement may be fueled by the affect of love towards God, community, fellow-human being, and self, it is functionally integrated into, and by, the task of moral self-constitution. The self itself is no-thing, no substance. Instead, like all erstwhile substances, it is a problem for cognition and a task for action that begins with the realization of the self as confronted by an other. There are no absolute substances. There is no isolated self. The denial of the concrete subject as given, against the grain of common experience, is perhaps the most radical feature of Cohen's philosophy, one which reaches far beyond the pale of a mere reiteration of Kant. The correlativity of the subject is consistently developed in Cohen's systematic works and continues to be maintained in his philosophy of religion as well as in his Jewish thought.

When Cohen's exposition of Jewish philosophy, Religion of Reason Out of the Sources of Judaism, appeared posthumously in 1919, it was examined for an indication of the same post-idealist departure that the earlier treatise on religion seemed to have promised but failed to deliver. Religion der Vernunft seemed to have broken away completely from an accommodation to Marburg. Perhaps here the author could speak more frankly, more personally, without philosophical constrictions. Indeed, $\mathrm{RV}$ is a book on Judaism, written with Jewish readers in mind, and published in a prestigious and groundbreaking series of Jewish scholarship which Cohen himself had helped to inaugurate (Grundriss der Gesamtwissenschaft des Judentums). It represents Jewish philosophy of religion and ethics comprehensively, historically and systematically, and thus realizes one of Cohen's oldest projects of publication, a major public defense of the values and ideas of Judaism. RV is not part of the system of philosophy. It was not intended as such. But this does not mean that it was meant to replace or abandon it. In 1917, in an essay of "admonitions of the old to young," Cohen recommends for Jews to read his Logic. ${ }^{75}$ Jewish philosophy was to Cohen a time-honored yet recently much neglected pursuit in its own right. From essays composed between the 1890 's and the early 1900 's it emerges that Cohen regarded philosophy as an integral part of any successful renewal of Judaism as a culture of learning. In his view, Judaism was fighting a war of survival against forces aiming at no less than its annihilation. From the outside, Judaism was challenged by a pervasive "Anti." ${ }^{76}$ On the inside of Jewish communal politics and the orientation of the young generation Jews

\footnotetext{
${ }^{75}$ See "Mahnung des Alters an die Jugend," J2,175-192.

${ }^{76}$ Cohen used this abbreviation in his letters. See Holzhey, Cohen und Natorp, vol. 2, passim.
} 
underwent an attrition of its religious existence caused by the multiple assaults of complacency, ignorance, obscurantism, and Zionism. Echoing Fichte's speeches to the German nation, ${ }^{77}$ Cohen saw the healing balm for Judaism in its Wissenschaft. There is a distinct correlation, then, also between Cohen's hope for a renewal of an idealistically grounded universal culture and his effort in Jewish thought. The temporal coincidence of the zenith of his philosophical enterprise with his first major essays on Jewish philosophy cannot be accidental. In Ethik des reinen Willens the Jewish philosophical agenda is clearly discernible, to the point of Hebrew roots of his German terminology. Neither the systematic work by itself, however, nor certainly Begriff der Religion, nor even Religion der Vernunft as an independent work made good on the promise of contributing to the renewal of Jewish philosophy and ethics. For there to be a Jewish philosophy and ethics there had to be philosophy and ethics. But it had to be a philosophy and ethics that, in its very foundations, was of a different caliber than the common Western thought. Jewish monotheism was to be taken seriously and evaluated as a source and origin of concepts and ideas fundamental to the unity of the cultural consciousness. It is this correlativity of Judaism and philosophy which Cohen is after all along.

More narrowly, Jewish thought (Religion der Vernunft) is distinguished from philosophy of religion (Begriff der Religion) in genre, audience, and pedagogical intention. The two disciplines are, however, related in that they are based on a theory of the historical and systematic relation between religion and philosophy that is consistent in Cohen's work at least since the 1890 's. For this reason alone, the rise of neoKantianism is insufficient as the all-encompassing matrix by which to account for Hermann Cohen's Jewish thought and philosophy of religion. Some of his contemporaries recognized all along the harmonization of Judaism and Platonic/Kantian idealism as Cohen's underlying agenda. While Kuno Fischer regarded this as a detriment to the philosophical and literary quality of Cohen's works ("mehr Judentum als Philosophie"), and Troeltsch's labeling of Cohen as Philo modernus might have been intended as a back-handed compliment, many Jewish contemporaries hailed the elevation of Judaism in Cohen's ethics, praise in which he took pride. Judaism was "an integral part" of his "scientific insights." We are beginning to understand what this may have meant. Neither were the realms to be mixed nor was one to be obliterated for the sake of the other. Rather, as indicated in the separation

${ }^{77}$ Johann Gottlieb Fichte, Addresses to the German nation, translated by R. F. Jones and G. H. Turnbull. Chicago and London: The Open Court Publishing Company, 1922. 
of tasks between BR and RV, Cohen sought to do philosophical justice to religion (a task in keeping with his understanding of the philosophical tradition and hence part of the narrative of neo-Kantianism) while providing a philosophically reasoned foundation for the modern Jewish consciousness (a task in keeping with the history of 19th-century Jewish reform and the project of a Gesamtwissenschaft des Judentums).

The emergence of Cohen's Jewish thought and of his philosophy of religion can therefore be narrated as two distinct tales within a larger story. One tale deals with the effort of retrieving the philosophical depth of Judaism and of restoring it to the curriculum of Jewish learning and self-development. The other one deals with the presence of this philosophical depth in Western culture. Judaism has been made to play a subaltern role in philosophy despite the fact that its most fundamental achievement, the idea of God, has been central to Western metaphysics. The second tale to be told is then about the attempt of restoring and making fertile the Jewish contribution to philosophy. In this work I am confident to have given much of the first and at least a useful first version of the second tale. Both contribute to the larger story of the meeting and cross-fertilization of Judaism and Western culture or, more accurately, of the contribution of Judaism to and within the ongoing project of a unity of the cultural consciousness. 


\section{Part I}

\section{Atonement in Hermann Cohen's Project of Renewing Jewish Philosophy of Religion and Ethics}

In the first part of this study I examine the emergence and realization of Hermann Cohen's program of "Jewish philosophy and ethics." The search for the roots of Cohen's Jewish thought takes us into his childhood and youth whence his ideas gradually evolved and matured into a magnum opus, the posthumously published Religion of Reason Out of the Sources of Judaism. Following this course of growth biographically allows me to place the development of the ideas of the author in the context of the Jewish environments that shaped his life and molded his thought. Cohen's knowledge of Jewish sources and his interpretation of Jewish history, literature, and ethical values are grounded in a specific Jewish society. Against this backdrop we see Hermann Cohen in a truer light than that provided by the widely spread myth about Cohen's late return to Judaism. In contrast to some of the outstanding figures of the Jewish renaissance of the 1920's (e.g., Gerhard G. Scholem, Franz Rosenzweig), Cohen lived not at the margins of religious tradition but in close association with two of its modern centers, the community of scholars, rabbis, and cantors associated with the Breslau Jewish Theological Seminary and the scholars sustaining the Lehranstalt für die Wissenschaft des Judentums in Berlin.

The biographical and historical material I present in this part serves to contextualize certain writings that mark important turning points in Cohen's pursuit of a philosophically reasoned exposition of Judaism. Two essays in particular are significant in this respect, namely Cohen's defense of Judaism against Treitschke (1880) and an essay on the idea of atonement (from the early 1890's) that remained unpublished until 1924. A contextualized and close reading of these texts allows us to recognize 
the major philosophical, cultural-historical, and political problems Cohen's Jewish philosophy of religion and ethics were meant to address.

Briefly, the development I sketch in detail below comprises the following stages:

1. Cohen's childhood and youth, his Jewish education and the decision to leave the Jewish Theological seminary. The purpose of this chapter is quite self-evident. Thorough grounding in a Jewish culture and religious education are the condition for Cohen to take on the task of renewing Jewish philosophy.

2. As a young man in Breslau and Berlin, Cohen faces the then typical challenges of a society that exerts economic pressure on an ambitious Jew to convert. Cohen's private and anonymous musings on his situation invoke such borderline Jewish thinkers as Spinoza and Heine. Attached to his family-based religious heritage with "filial piety" he also seeks somewhat romantically to vindicate the notions of Judaism that are perennially valid even outside the particular religious framework. The profound otherness of God and the social messianic ethics of the Sabbath are to inspire the modern contemporary regardless of her religious persuasion and nationality. Cohen intends to defend these ideas of Judaism publicly and thus generate due esteem for the profundity of this religious heritage in its cultural value. The methodological instrument that was to allow him to make such particular cultural contributions plausible in their perennial cultural value was $H$. Steinthal's method of "ethno-psychology and linguistics" (Völkerpsychologie und Sprachwissenschaft).

Around 1870, Cohen's philosophical and methodological path is profoundly rerouted when he begins to write on Kantian philosophy. He received a call to Philipps Universität in Marburg and begins a career that was highly unusual for an unconverted Jew and must have seemed a confirmation of his conviction that it was possible to stay true towards one's particular community while pursuing the good of society at large. The Prussian government had accepted him as a philosopher and a Jew.

The confidence that this appointment generated was, however, marred in $1879 / 80$ when it suddenly became evident that anti-Jewish sentiments were again becoming acceptable even among liberal scholars. Cohen had the position and inclination to answer Treitschke's charges of a foreignness between Jewish and Christian religion. He even believed he had the answer that could put all religious strife to rest.

The position he took in this debate was to argue that, in the German sphere of culture, Jews and Christians, especially Protestants, had mutually influenced each other to such a degree that, in cultural terms, one could no longer speak of distinct groups. The Kantian idea of moral autonomy was deeply informed by Christian motifs, and by virtue of 
their Kantian morality all modern Jews were therefore Christians. Conversely, by virtue of their realization of the otherness of God and in their pursuit of social justice, all modern Christians were Israelites.

Cohen's Bekenntnis in der Judenfrage was acceptable neither to Treitschke nor to his Jewish friends who shunned Cohen for criticizing some of the major Jewish scholars who had likewise answered to Treitschke's attacks. This led to an enforced moratorium on Cohen's part. Only after the death of his former mentor $H$. Steinthal, who had now turned against him, was he able to assume a position of responsibility in the institution that was to become one of his major platforms: the Lehranstalt für die Wissenschaft des Judentums.

A second opportunity for Cohen to exonerate himself as an authentic and reliable defender of Judaism arises in 1888 when he is called as an expert witness for the prosecution in a libel suit against an anti-Semitic propagandist who had slandered the ethics of the Talmud.

3. In a profound reorientation Cohen seeks to unearth a direct cultural and religious link between the idea of moral autonomy and the sources of Judaism. In an essay on the idea of atonement, a declaration of independence from Christian cultural mediation, Cohen establishes the foundation of his future Jewish philosophy and ethics.

4. Around the turn of the century, Cohen's reinvigorated confidence in the cultural independence and philosophical value of Judaism finds expression in various writings as well as in his taking on the institutional responsibilities of curator and lecturer at the Lehranstalt für die Wissenschaft des Judentums. He also helps to launch the Grundriss für die Gesamtwissenschaft des Judentums, a project of encyclopedic dimensions for which he is to contribute a volume on "Jewish philosophy of religion and ethics."

This plan is eventually realized in the posthumously published work, Die Religion der Vernunft aus den Quellen des Judentums. 


\section{Biographical Background}

\subsection{Childhood in Anhalt: Coswig and Dessau (1842-1856)}

...only when we experience religion can our life be religion.

N. A. Nobel to Hermann Cohen

(4. July, 1912) ${ }^{1}$

Hermann Jecheskel Cohen ${ }^{2}$ was born on July $4,1842^{3}$ in Coswig, a small town in the German principality of Anhalt.

The history of Anhalt began in 1218, when it split from Saxony under Henry, grandson of Albert the Bear, margrave of Brandenburg. Subsequently, Henry was the founder of the line of Aschersleben, Bernburg and Zerbst. Between 1603, when the duchy was sundered, and 1871, Anhalt consisted of a larger eastern part (Anhalt-Dessau-Cöthen)

${ }^{1}$ On the occasion of Hermann Cohen's 70th birthday, Rabbi N. A. Nobel wrote a letter which was published first in the Mitteilungen der Grossloge für Deutschland U.O.B.B. and later again in Gabe Herrn Rabbiner Dr. Nobel zum 50. Geburtstag dargebracht, Martin Buber (ed., et.al.), Frankfurt: J. Kauffmann, 1921, pp. 12-14. The sentence I quote is in the context of Nobel's thoughts about Cohen's traditional religious upbringing which Nobel sees as the source of Cohen's lifelong religiosity.

${ }^{2}$ Biographical information can be found, among others, in S. H. Bergmann, s.v. "Cohen, Hermann" in EJ 5: 673-676, Toni Cassirer, Mein Leben mit Ernst Cassirer, (Hildesheim, 1981), esp. 89-95, Julius Ebbinghaus, "Cohen, Hermann" in: EPh 2:125-128, idem, "Cohen, Hermann, Philosoph" in: NDB 3: 310-313, idem, "Hermann Cohen als Philosoph und Publizist" in: APh 6 (1956) 109-122, idem, "Zur Berufung Cohens auf den Marburger Lehrstuhl" in: ibid. 9/1959, 90-92, R. A. Fritzsche, Hermann Cohen aus persönlicher Erinnerung, Berlin: B.Cassirer, 1922 (which Rosenzweig called "the pearl of Cohen literature"), Hinrich Knittermeyer, "Hermann Cohen (1842-1918)/Philosoph" in: Lebensbilder aus Kurhessen und Waldeck 1830-1930 vol.5, (Marburg, 1955), 13-32, Jehuda Melber, Hermann Cohen's Philosophy of Judaism (New York: 1968) p. 92f, Franz Rosenzweig, "Einleitung" in J 1 (1924) pp. XIII-LXIV. Aside from these I was able to use documents from the Hermann-Cohen-Archiv in Zürich, as well as documentary and historical information provided by Franz Orlik, who researched Cohen's life for an exhibition he curated in Marburg and Coswig on the occasion of Cohen's 150th birthday. The catalogue for this exhibition, Hermann Cohen (1842-1918). Kantinterpret-Begründer der "Marburger Schule"-Jüdischer Religionsphilosoph was published in Marburg 1992 as Number 63 of the Schriften der Universitätsbibliothek Marburg. Furthermore, I utilized the archives of the LeoBaeck-Institute in New York as well as the department of manuscripts of the National and University Libraries, Givat Ram, Jerusalem.

"For no apparent reason, Cohen gave his date of birth as "XXIV. m. Julii" in a vita he wrote in Latin in 1865 when he submitted an essay to the university of Halle as a basis for his application for a doctoral degree. The Latin quotes in the headlines are from this vita. Cf. S 1 (1928) p. $28 f$ and Orlik p. $30 f$. 
and the western part of Anhalt-Bernburg. Anhalt-Dessau-Cöthen is "low-lying, and occupies a section of sandy plains of the valley of the Elbe which crosses it from the east to the west, and portions of the tributary valleys of Mulde and Saale flowing northwards. There is fertile loess land east of the Saale, but the State contains much pine forest and bog land, interspersed with rich pasture." 4

Rich in natural resources, industrial products and excellent conditions for transportation, Anhalt was able to retain its independence until its integration into the German state in 1871, and even regained it in 1919 when, after the collapse of the Empire, it constituted itself as a Free State. ${ }^{5}$ In the 19 th century, the predominant line of Anhalt was that of Anhalt-Dessau which, under Leopold IV of Anhalt-Dessau (1817-1871), reunited the various principalities into the duchy of Anhalt in 1863.

The city of Dessau, the largest city of the principality, ${ }^{6}$ was also the cultural center of Anhalt. One of the first humanistic schools, the Philanthropin, was founded in Dessau in 1774 by Johann Bernhard Basedow (1724-1790). During the 19th century, the opera house and the theaters were famous for their progressiveness. In the 20th century, Dessau was also one of the centers of the Bauhaus movement of architecture and design. Here Walter Gropius (1883-1969) built the original Bauhaus, which originally functioned as a school of design.?

Coswig has a small castle which, in the early 19th century, was occupied by the last princesses of the Zerbst line. According to the reminiscences collected by Hermann Steinthal in 1918, the relations between the nobility and the Jews in Coswig, as in all of Anhalt, were genuinely friendly. ${ }^{8}$ The earliest records mentioning Jews in Bernburg, Aschersleben and Cöthen date from the 14th century. In the 15th century,

\footnotetext{
${ }^{4} E B$ 14, 1:957-8.

${ }^{5} \mathrm{Ibid}$. Today, after the reorganization of the territories of the former GDR, Anhalt is part of the Bundesland Sachsen-Anhalt.

${ }^{6}$ Ibid. In 1925, the total population was 351,471 of whom 70,241 lived in Dessau, 34,178 in Bernburg, 26,588 in Cöthen, 19,229 in Zerbst and 12,306 in Rosslau. Most of the inhabitants were Protestants who were organized by the consistory in Dessau.

${ }^{7}$ Cf. Rat der Stadt Dessau (ed.), Dessau 775 Jahre 1213-1988, Dessau, 1988.

${ }^{8}$ The most comprehensive source on the history of Coswig including its Jewish community is Ernst Werner, Geschichte der Stadt Coswig-Anhalt, 3. ed. Coswig: Mehnert, 1929 (212pp). Jews had been admitted to Coswig in 1777. In 1800, when a synagogue was built, only 10 Jewish families were living there. Emancipation began in the principality of Anhalt on January 1, 1810 (Werner pp. 92f quoted in Orlik p. 12f). Census data from 1830 indicate the number of Jews living in Anhalt as 3,000. The sympathetic relation between the local nobility and the Jews is described by H. Steinthal in $A Z d J 82$ (1918), Nr. 19 (10. Mai 1918) pp. 222f, quoted in Orlik, op.cit., p. 14.
} 
Isaac Eilenburg, mentioned in the responsa of Israel Isserlein, was the rabbi of Aschersleben. ${ }^{9}$

No source mentions Jews during the period from the late 15th until the early 17th century. Typically for German Jewish history, it was only with the rise of enlightened absolutism that Jews were admitted to, and encouraged to settle in, the realm of German states, albeit in limited numbers and depending on their wealth and economic utility. Nevertheless, as in the case of other enlightened monarchies, the progressiveness of the nobility in matters of culture and education encouraged the Jewish establishment to pursue their own cultural development. Hence, the early 17th century sees the beginning of a long and productive history of Jewish printing presses and educational institutions. The first Hebrew presses were established in Cöthen in 1621. In 1695, the court Jew Moses Benjamin Wolff established a press in Dessau which was reopened by his son Elijah in 1742. The most outstanding works printed in this period were Maimonides' Mishneh Torah and his Moreh Nevukhim with commentaries, as well as the tannaitic midrash Sifra and the order Mo'ed of the Palestinian Talmud. ${ }^{10}$

During the early period of Hebrew enlightenment (Haskalah) Moses Philippson (1775-1814) also established a Hebrew press in Dessau. The last issues of the Haskalah journal $\mathrm{Ha}-\mathrm{Me}$ 'assef, edited by Shalom Cohen, a moderate Enlightenment poet, ${ }^{11}$ were printed here as well as Sulamith, the first Jewish monthly in the German language (1806-1833). ${ }^{12}$

The Anhalt spirit of educational reform also inspired the institution of a Jewish school pioneering the combination of Jewish and secular studies, namely the Franzschule which became a model for Samuel Meier Ehrenberg's reform of the Samson'sche Freischule in Wolfenbüttel. ${ }^{13}$ Anhalt Jews became a major force in the movement towards the modernization of Judaism.

In the 18th and 19th centuries, a number of eminent Jewish scholars and reformers emerged from the Jewish community of Anhalt. The most famous of them was the philosopher Moses Mendelssohn ("Moshe miDessau"), the paradigm of the modern German Jew. ${ }^{14}$ Also from Anhalt

${ }^{9}$ Cf. EJ 3:1, s.v. "Anhalt."

${ }^{10}$ See ibid.

${ }^{11}$ Cf. op.cit. 11:1161.

${ }^{12}$ Cf. op.cit. 15:502f.

${ }^{13} \mathrm{Cf}$. Monika Richarz, Jüdisches Leben in Deutschland. Selbstzeugnisse zur Sozialgeschichte 1780-1871 New York: Leo-Baeck-Institute, 1976, p. 344f.

${ }^{14} \mathrm{Cf}$. A. Altmann, Moses Mendelssohn, Alabama, 1973. Martha Cohen pointed out the symbolism of the equidistant location of Coswig between Dessau (Mendelssohn) in the West and Wittenberg (Luther) in the East. Cf. preface to Religion der Vernunft aus den Quellen des Judentums, 2. ed. 1929. In the 20th century, 
were the pioneering Jewish historiographer, Isaac Marcus Jost (1793$1860),{ }^{15}$ and his colleague, the moderate reform-theologian Ludwig Philippson (1811-1889), the son of the above mentioned Moses. Ludwig Philippson was an early proponent of the movement for the Wissenschaft des Judentums. He founded and, until his death, edited the Allgemeine Zeitung des Judentums in which Hermann Cohen later published many of his essays on Judaism and current Jewish events. ${ }^{16}$ Cohen attests to his early admiration for his fellow Anhaltinian Philippson in the essay "Über die Bedeutung einer philosophischen Jugendschrift Ludwig Philippsons," written on the occasion of Philippson's centenary.

In addition to general considerations of grateful piety towards a teacher of Judaism of historic proportions I was also moved (viz. to write the essay) by the thought of the great Anhaltinian compatriot and the lively memory of the veneration which I felt since my earliest youth for this universal advocate of Judaism. (J 2, 441)

H. Steinthal (1823-1899), a distant relative of Hermann Cohen and his teacher and mentor during his early years in Berlin was born in Gröbzig (a few miles SSW of Cöthen and SSE of Bernburg). ${ }^{18}$ Cohen's relation to

the composer Kurt Weill (1900-1950) lived in the Jewish community center of Dessau during his youth. Cf. Wolfgang Paul, Rundgang. Bau- und Kunstdenkmale der Innenstadt Dessau, Dessau: IWG Dessau, s.a., p. 11. Also cf. Salomon Steinthal "Aus Cohens Heimat" in: Jüdisches Gemeindeblatt fïr Anhalt und Umgegend 3. Jg, Nr. 4, 4. Nov. 1927.

${ }^{15}$ Cf. EJ 10:299.

${ }^{16}$ Founded by L. Philippson in 1837 as a "unparteiisches Organ für alles jüdische Interesse", was edited from 1890 until 1909 by the historian of literature Gustav Karpeles and from 1910 until 1919 by Ludwig Geiger. Incidentally, the latter wrote a very personal eulogy on the occasion of Cohen's death in 1918. See $A Z d J$ 82. Jg., Nr. 15, 12. April 1918. Between 1890 and 1917, Cohen published 13 articles in the $A Z d J$. "Der Religionswechsel in der neuen Ära des Antisemitismus" (1890) (=J2,342-345), "Dem fünfzigjährigen Doctor medicinæ Herrn Sanitätsrath Dr. Salomon Neumann ein Festgruß" (1892), "Zum Prioritätsstreit über das Gebot der Nächstenliebe" (1894) (=J1,175-181), “Unsere Ehrenpflicht gegen Dreyfus (1899) (=J2,346-351), "Der 80. Geburtstag der Herrn Sanitätsrat Dr. Salomon Neumann" (1899), "Die Sprüche im Israelitischen Schüler- und Lehrlingsheim zu Marburg a.L." (1901) (=J2,102-107), "Über die literarische Behandlung unserer Gegner" (1902) (=J2,360-368), "Immanuel Kant. Zu seinem 100jährigen Todestage (12. Febr. 1904)", "Der geschichtliche Sinn des Abschlusses der Dreyfus-Affäre" (1906) (=J2,352-359), "Salomon Neumann" (1908) (=J2,425-438), "Die Eigenart der Alttestamentlichen Religion" (1913) (=J2,410-415), "Der Nächste. Bibelexegese und Literaturgeschichte" (1914) (=J1,182-195), "Der ethische Monotheismus der Propheten und seine soziologische Würdigung" (1917).

${ }^{17}$ Also see the letter to Philippson here in the appendix.

${ }^{18}$ For H. (Chaiim, Heymann, Heinemann, or Heinrich) Steinthal's biography see Ingrid Belke, "Einleitung" in: Moritz Lazarus und Heymann Steinthal. Die Begründer der Völkerpsychologie in ihren Briefen, Tübingen: Mohr, 1971, pp.LXXXI-CIII. On. 
his immediate Heimat is not untypical for the local-patriotic attachment cultivated by the Jews of that period. After Kurt Eisner, the later Prime Minister of Bavaria, had sent him a photograph or sketch of Coswig which Mrs. Eisner had made for the philosopher as a present for his sixtieth birthday, Cohen describes his sentiments towards his "kleine Vaterstadt" which he called a "living root" of his life:

Sometimes I think that only a small town can be home (Heimat) because only there one attends a Volksschule, grows up with the children of the middle and lower estates, and the landscape unites with the city (die Landschaft mit der Stadt zsammenfließt). But I know that you too have your Berlin local patriotism. ${ }^{19}$

Hermann Cohen's parents were Gerson Cohen, cantor and Jewish primary school teacher, and Friederike Salomon. ${ }^{20}$ The mother's father, Heinemann Salomon, had been a salesman in Oranienbaum, a small town south of Coswig. ${ }^{21}$ It was probably Friederike who financed her son's studies by running a store selling ladies' hats and accessories in her apartment, at Domstrasse 6 . This kind of petty commerce was not untypical as a means of subsistence of German Jews throughout the early modern and modern periods until emancipation made it possible for them to climb the social ladder.

Cohen and $H$. Steinthal see the essay by Dieter Adelmann, "H. Steinthal und Hermann Cohen" in Moses/Wiedebach [1997], pp. 1-33.

${ }^{19}$ Letter from August 14, 1902 (Schwadron Collection, File II; for the full text see the Appendix). It is partly quoted by Jacob Toury in Die politischen Orientierungen der Juden in Deutschland. Von Jena bis Weimar, Tübingen: J.C.B. Mohr (Siebeck), 1966 p. 274f. Toury regards this passage as an example for what he calls "Lokalpatriotismus als Zuflucht des Zugehörigkeitsgefühls." However, I believe that he underestimates the pervasiveness of local patriotic sentiments among Germans in general. After all, Germany was a late-comer among European nation states not least because German nationalism had to unite the large number of often minute principalities which commanded the primary allegiance of their natives. Cf. Theodor Mommsen, "Auch ein Wort über unser Judenthum" (Berlin, 1880) in: Walter Boehlich, Der Berliner Antisemitismusstreit, Frankfurt: Insel, 1965, p. 212.

${ }^{20}$ The Personenstandsregister of the Jewish community of Coswig, administered by the Protestant minister, registers as its second entry the marriage of the parents in 1831: "Herr Gerson Cohn (sic), Vorsänger und Lehrer der hiesigen israelitischen Gemeinde, ehelicher zweiter Sohn des Hesekiel Cohn in Fraustadt im Herzogthum Posen, und Jungfer Friederike Salomon, eheliche dritte Tochter des verstorbenen israelitischen Handelsmanns Heinemann Salomon in Oranienbaum, sind am vierzehnten Juni 1831 in Oranienbaum copuliert." A few pages further, the birth of their only child, Hermann Cohn (sic), is also registered. ${ }^{21}$ Oranienbaum means "orange tree." The provincial residence lying in the plains of Wörlitz was famous for the beauty of its landscape. 
Gerson Cohen was born on April 15, 1797 in the Salesian town Fraustadt in the dukedom Posen, which had been Polish until the second partition in 1793 and which then became part of Southern Prussia. ${ }^{22}$ Trained in a traditional talmudic academy (yeshiva), Gerson Cohen became the cantor at the synagogue in Coswig, which had been built in 1800 and served a relatively small community. He was also the only teacher ever to serve the small Jewish primary school which existed around 1860 where he taught Hebrew and religion. General education was provided by the public schools, which Jewish children had been obliged to attend since emancipation in 1810 .

The essential factor in Hermann Cohen's early life was his family. From them he received more than his initiation into Hebrew and a basic education in the Jewish tradition. He was surrounded by a deep love for the religion of Israel which laid the foundation for the emotional attachment to Judaism which never failed to guide and influence him throughout his life. ${ }^{23}$ From Gerson, who was an autodidact in secular subjects and foreign languages, the younger Cohen also received two other essential impulses, namely his insatiable interest in universal and life-long learning and his belief in the inseparable connection of religion and social ethics, the foundation of Cohen's socialism. Both of these aspects are confirmed by the recollections of Gerson's former student, Hermann Steinthal, who recorded his memories of the elder and the younger Cohen and the role they played in the benign life of the Jews of Coswig.

The father had attended a yeshiva and had studied secular subjects on his own. These studies, however, he had done so thoroughly that he could teach French as well as Hebrew and German, that he read le guide des égarés as easily as the more nevukhim. (...) Gerson Cohen, the father of the great philosopher, however not only taught diligently but 'learned' even more. ${ }^{24}$

When one did not find him buried in a folio (of the Talmud) he was busy with a classical German author or with a scientific treatise. In political orientation he was a Democrat. (...) But he was also a

\footnotetext{
${ }^{22}$ Gerson Cohen's date of birth is in Fritzsche, Hermann Cohen, p. 41.

${ }^{23} \mathrm{Ibid}$. p. 7 and similar in other accounts of Cohen's biography. E.g., N.A. Nobel writes about the mature Cohen: "Seine Liebe zum Geiste der Bibel ist so gross, dass die Sprache der Bibel ihn bis zu Tränen rühren kann. Man merkt, dass Cohen bei seinem Vater, einem tief religiösen Mann alten Schlages, die Religion des Judentums so erlebte, dass das Leben seiner frühen Jugend Religion war." Op.cit., p. 3.

${ }^{24}$ Steinthal puts the German word 'lernte' in inverted commas to evoke the Yiddish connotations of the word where it is associated with the highest cultural value of traditional Jewish culture, the perpetual 'learning' of Talmud, talmud torah.
} 
Socialist. The servant was required to have her meals with the family at their table. Finally he was a patriot. In 1870, the beginning of the war, a day of prayer was held at the Protestant Church which he attended despite his great piety seeing that it was not worthwhile holding a service at the synagogue for the few remaining Jewish families. ${ }^{25}$

During his advanced years Gerson Cohen found support for the cantorial task in his son, who supported him as a shaliah tsibbur (cantor) during the high holiday services:

First he took over only the mussaf prayer, towards the end also the neilah prayer. (...) Hermann Cohen was not only endowed with a beautiful voice and musical sensitivity which he refined in the house of his parents-in-law, but also with deep religiosity. (...) As a tenured professor he exerted this holy office only once. ${ }^{26}$

The son loved his parents. He was grateful for their unwavering support of his philosophical studies and took pride in his traditional Jewish home. In 1876, three years after Friederike's death and one year into Hermann's tenure in Marburg, Gerson Cohen left Coswig and moved in with his son. With an emotional note published in the local press, he took leave from his congregation, which he greeted as their "old teacher of religion." 27 On July 25, 1879, Gerson Cohen died at the age of 82 in Marburg. ${ }^{28}$

During his youth as throughout his life, Hermann Cohen was also exposed to and involved in the world of the surrounding Protestant culture. He attended the Stadtschule in Coswig, headed by Julius Hoffmann, a German author of "mildly Christian and moralizing"29 books for young people, and, beginning in 1853, the Herzogliches Gymnasium in Dessau (about 6 miles west of Coswig). This school was frequented by the children of the upper class of the bourgeoisie. This layer of society seems to have been characterized by a Protestant spirit. Seven out of the 12 students of the Herzogliches Gymnasium who passed the exit exam (Abitur) in 1856 went on to study Protestant theology. ${ }^{30}$

Gerson Cohen took great care that his son should not neglect his Jewish religious studies. Throughout the years Hermann went to the

${ }^{25}$ Hermann Steinthal in AZdJ82/1918, Nr. 19 (10. Mai 1918), p. 223.

26Ibid. $223 \mathrm{f}$.

${ }^{27}$ Elbe=Zeitung. Organ für die Stadt und das Amt Coswig Nr. 104, 3.Okt. 1876, 3. Jg., p. 4. For another example of Gerson Cohen's style see the text of a birthday greeting he composed, here in the appendix.

${ }^{28} \mathrm{Cf}$. ibid. Nr. 86, 28. Juli 1879,6 . Jg., p. 4. A Hebrew epitaph, written by his son, is translated in Fritzsche, op.cit., p. 42.

${ }^{29}$ Ibid. p. 7 with more details about Cohen's early education.

${ }^{30}$ About the Herzogliches Gymnasium see the documents quoted by Orlik, op.cit., pp. 17f. 
Gymnasium in Dessau they studied Talmud together every Sunday. Hermann Cohen was to become a rabbi.

\subsection{Rabbinical Studies: Breslau (1857-1861)}

... that we call ourselves proudly the students of Frankel

from: "Verwahrung" (1861) 31

In 1857, after having completed the secunda at age 14, Hermann Cohen left the Gymnasium and moved to Breslau ${ }^{32}$ to become a rabbinical student.

In the 19th century, Breslau was one of Germany's largest cities and had the third largest Jewish community after Berlin and Frankfurt on the Main. In the wake of a general trend of urbanization, the Jewish population of Breslau increased from 4,409 in 1816 to 7,384 in 1850 and 13,000 in 1871.33

The Jewish community of Breslau played an important role in the history of the reform movement. The reform wing of the Jewish Einheitsgemeinde (a united community comprising an orthodox and a moderate reform wing) in Breslau was then headed by the famous scholar and reform rabbi Abraham Geiger (between 1840 and 1863). ${ }^{34}$ Geiger (1810-1874) was followed in this office by the rabbis cum scholars Manuel Joël and Jacob Guttmann, the latter one of the first graduates of the Breslau seminary and father of Cohen's later student Julius Guttmann. Geiger was also one of the founders of the theological seminary in Breslau-yet considered too radical to become its founding director-and later taught briefly at the Hochschule für die Wissenschaft des Judentums in Berlin. ${ }^{35}$

Breslau was the home of the Jüdisch Theologisches Seminar Fraenckelsche Stiftung, a pioneer institution of Jewish learning headed by the moderate reformer Zacharias Frankel. ${ }^{36}$ The seminary was founded

31 "Verwahrung" signed by a number of seminarians in defense of Zacharias Frankel against the attacks launched in S. R. Hirsch's Jeschurun. Published as a "Beilage" in $A Z d J$ 25. Jg., Nr. 5, Leipzig, 25. Januar 1861.

${ }^{32}$ City on the Oder in the former Habsburgian dukedom Salesia which belonged to the Prussian kingdom from 1742 until the end of the Second World War when it was given to Poland in exchange for the areas in the East annexed by the USSR. ${ }^{33}$ Richarz, op.cit. table p. 31. Cf. Bernhard Brilling, s.v. "Breslau" in: EI 4:1353-6.

${ }^{34} \mathrm{Cf}$. Brilling, op.cit. 1355.

${ }^{35} \mathrm{Cf}$. Jacob S. Levinger, s.v. “Geiger, Abraham" in EJ 7:357ff and Michael A. Meyer, Response to Modernity. A History of the Reform Movement in Judaism, (New York, 1988) p. 89 who sees Geiger as the "founding father of the Reform movement."

${ }^{36} \mathrm{Cf}$. Joseph Elijah Heller, s.v. "Frankel, Zacharias (1801-1875)" in EJ 7:79-82 and Brann (1904), pp. 28-40. In addition to the role Frankel played in the reform 
August 10, 1854. The historian Ismar Elbogen later wrote about this event: "The foundation of the Jewish-theological seminary in Breslau can be said to have made an epoch in the organization of the Wissenschaft des Judentums ...". 37

Aside from Frankel, the faculty included the historian Heinrich Graetz, ${ }^{38}$ the classical philologist Jacob Bernays, ${ }^{39}$ and the philosopher Manuel Joël. ${ }^{40}$ The seminary was the first of its kind. It deviated from the

movement he was also important within the new Jewish scholarship (Wissenschaft des Judentums). In 1851 he founded the Monatsschrift für die Geschichte und Wissenschaft des Judentums. See Michael A. Meyer, op.cit. pp. 84ff, who calls Frankel "the ideological father of present-day Conservative Judaism" (op.cit. p. 84). On the Jewish Theological Seminary see ibid. p. 141 and p. 191. Meyer (p. 414 n. 92): Frankel defined the objective of learning at the seminary as furthering "Glauben und Glaubenswissenschaft."

37"Ein Jahrhundert Wissenschaft des Judentums" in: FS (1922) 125ff, the quote is on p. 127. On Breslau and the Seminary see further J. Kaftan, "Breslauer Erinnerungen" in JJGL 26/1925, 53ff, and Das jüdisch-theologische Seminar Fraenckelsche Stiftung zu Breslau. Am Tage seines fünfundzwanzigjährigen Bestehens, den 10. August 1879, herausgegeben im Auftrage des Curatoriums der Commerzienrath Fraenckelschen Stiftungen, Breslau: Grass, Barth \& Co., 1879 (the copy owned by the Brandeis University libraries has handwritten additions presumably by a contemporary augmenting the lists of donors with dates, names, and sums), Guido Kisch (ed.), The Breslau Seminary. The Jewish Theological Seminary (Fraenckel Foundation) of Breslau 1854-1938, Memorial Volume, Tübingen: J.C.B.Mohr (Paul Siebeck), 1963, Marcus Brann, Geschichte des jüdisch-theologischen Seminars (Fraenckel'sche Stiftung) in Breslau. Festschrift zum fünfzigjährigen Jubiläum der Anstalt, Breslau: Schatzky, 1904 (the copy at Brandeis belonged to Julius Zimels, himself a graduate of the seminary, who corrected the biographical information about himself on p. 203).

${ }^{38}$ Heinrich Graetz (1817-1891) studied briefly at Breslau university but-in 1842he still needed special permission to do so and could not obtain a Ph.D. there. In 1869 (the year when Prussia confirmed its emancipation laws from 1812), however, he was appointed honorary professor at the same university. Cf. Shmuel Ettinger, s.v. "Graetz, Heinrich" in EJ 7:846 and Brann (1904) pp. 42-48 and bibl. pp. 116-124. Cf. also the passage on Graetz at the seminary in Philipp Bloch, "Heinrich Graetz. Ein Lebensbild" in MGWJ 48. Jg. (Neue Folge 12. Jg.), Breslau: Koebner, 1904, 306-309. The adversarial personal relationship and the deep disagreement between the precocious Cohen and his teacher Heinrich Graetz are well known but are not yet evaluated for the question of Cohen's intellectual development; see J 2, 418ff, $449 \mathrm{f}$ and $86 \mathrm{f}$ and cf. J 1, $224 \mathrm{f}$.

${ }^{39}$ On Jacob Bernays (1824-1881), son of the illustrious Hamburg haham Isaac Bernays, see Brann (1904), 53-58 and bibl. 124-126, and cf. Yehoshua Horowitz, s.v. "Bernays, family" in EJ 4:673. On Bernays's historiographical methodology see Arnaldo Momigliano, "Jacob Bernays" in: Essyas on Ancient and Modern Judaism. (Ed. Silvia Berti) Chicago and London: University of Chicago Press, 1994, pp. 148-170.

${ }^{40}$ On Manuel Joël (1826-1890) see Brann (1904) pp. 86-89 and bibl. 126f. Karl Joël (1864-1934) was his nephew; cf. EJ 10:134. See Karl Joël's eulogy, "Zur Erinnerung an Hermann Cohen" in NJM 2 /1917-1918, Nr. 15/16, pp. 374-376. 
classical yeshiva by including secular subjects. More significantly, it applied historical methods to the study of Jewish sources, an innovation which gave rise to the objections of the neo-orthodox movement. The seminary aimed to educate rabbis and teachers in the spirit of the Jewish enlightenment and to enable them to guide their communities-usually including both moderately reformed and strictly traditional Jews-in an age characterized by the prospects of emancipation and the dangers of assimilation. ${ }^{41}$ The Breslau seminary's influence on the religious life of Jews in Germany and Austro-Hungary as well as on Jewish studies and religious education in general can hardly be overestimated. ${ }^{42}$

When Cohen entered the seminary, the first class had not yet graduated. The complete course of studies was supposed to take seven years, a very long time by any standard..$^{43}$ In 1857, a total of 33 rabbinical students and eight teacher candidates were studying there. ${ }^{44}$ At this early stage it was not unusual for students like young Cohen to enroll before they finished their high school education. The seminary provided

${ }^{41}$ The list of former faculty and students and their publications compiled by Brann (1904) (pp. 140-207) and completed by Alfred Jospe (in: Kisch (ed.), Das Breslauer Seminar, $381 \mathrm{ff}$ ) is truly impressive, a "Who's Who" of German conservative Judaism and of Jewish studies. To name just the most illustrious graduates: Wilhelm Bacher (1868-76), Adolf Brüll (1867), Adolf Büchler (1889-90), I. Elbogen (1893-99), Moses Gaster (1873-81), Moritz Güdemann (1854-62, same as H. Cohen), Julius Guttmann (1898-1904), David Kaufmann (1867-77), J. N. Theodor (1868-78), M. S. Zuckermandel (1856-64). Leo Baeck (1873-1956), too, was a student at Breslau seminary (1891-94) and also later at the Hochschule für die Wissenschaft des Judentums (cf. Brann p. 143 and Meyer, op.cit., p. 207). Of the later faculty and students many became leading scholars and rabbis in Israel, the United States, and elsewhere (e.g. Ephraim E. Urbach, I. Heinemann, Chanoch Albeck, to name just a few) testifying to the influence the Breslau seminary continued to have on modern Judaism long after its gates had been brutally closed in 1938.

${ }^{42} \mathrm{Cf}$. the memorial volume Guido Kisch (ed.), Das Breslauer Seminar (1963). The essays collected here, however, still do not cover all relevant aspects for an overall assessment of the seminary's influence; in particular, a study of the community rabbis among the former students is missing. See Kisch's "Zur Einführung," pp. 15ff.

${ }^{43}$ Cf. Moritz Güdemann in: Richarz, op.cit., p. 371: "Für das Studium im Seminar waren sieben Jahre festgesetzt, eine lange Zeit, wenn man sie vor sich hat. Als mich bald nach meiner Ankunft der Professor der Geologie, Römer, der aus Hildesheim stammte und an den ich empfohlen war, nach der Länge der Studienzeit fragte und ich sie angab, so rief er erstaunt aus: Sieben Jahre! und schlug die Hände über dem Kopf zusammen." Güdemann was among the ten or twelve students of the first class of the seminary.

${ }^{44}$ Statistics in Brann (1904), pp. 134ff. There were usually ten new students and ten graduates every year. The first rabbinical students graduated only in 1861 . About the miserable living conditions of the first students see Güdemann's memoir quoted in Richarz, op.cit., pp. 369-372. 
not only a solid exegetical and theological curriculum ${ }^{45}$ but also prepared the students for the university. ${ }^{46}$ Those students who first had to complete their high school curriculum combined "classical studies and realia" equivalent to those at the Secunda and Prima of the Gymnasium with their theological courses. Students on the higher level pursued their general studies of history and philology at the university of Breslau while continuing their theological studies, which were structured roughly to correspond to those of the theological faculty at the university. The theological disciplines included study of the Bible in combination with exegesis and Aramaic Targums, Hebrew and Aramaic, geography of Palestine, historical and methodological introduction to Mishnah and Talmud, Babylonian and Palestinian Talmud, classical languages and "realia," Jewish history and history of Jewish literature, Midrash, philosophy of religion and ethics from Jewish sources, ritual practice, the spirit of the Mosaic-Talmudic criminal and civil law, pedagogy and catechetics, and homiletics. ${ }^{47}$

Hermann Cohen did not complete his rabbinical studies. Instead, in October of 1861 he registered as a student of philology and philosophy at the university of Breslau, abandoning the study of theology. Forty-three years and a distinguished career later the philosopher reveals some of the motives which led to this major decision in his life. ${ }^{48}$ What gave rise to Cohen's decision was the debate between Samson Raphael Hirsch and Zacharias Frankel. ${ }^{49}$

The occasion for this dispute was provided by Frankel's Darkhey haMishnah, in which he characterized the process of codification of the Oral Law through the men of the great assembly as a rational process. The actual wording of the passage in question does not constitute a denial of revelation or of the reliability of the oral tradition, but, like Frankel's style in general, it is ambiguous. Far from innocuous, the debate over the issue of whether it is appropriate to apply critical historical scholarship to the study of Torah marks a distinct watershed in the intellectual

\footnotetext{
${ }^{45}$ Cf. Brann (1904), pp. $67 \mathrm{f}$.

${ }^{46}$ Ibid. $65 \mathrm{ff}$.

${ }^{47} \mathrm{Cf}$. Das jüdisch-theologische Seminar p. $8 \mathrm{f}$ and Orlik p. $19 \mathrm{f}$.

${ }^{48} \mathrm{Cf}$. "Ein Gruß der Pietät an das Breslauer Seminar" (1904) in: J 2, 418-424, esp. p. 422f; also cf. Lothar Rothschild, "Die Geschichte des Seminars von 1904 bis 1938" in G. Kisch (ed.), Das Breslauer Seminar, pp. $123 \mathrm{f}$.

${ }^{49} \mathrm{Cf}$. Rosenzweig, "Einleitung" in J 1, p. XXI and see below. Hirsch had attacked the whole enterprise of the Jewish Theological Seminary before, and tried to prevent it from opening by sending circular letters to any number of Jewish communities where they sometimes achieved quite the contrary effect, namely spreading the news about the project more quickly and thus promoting rather than preventing it. See, e.g., Moritz Güdemann in Richarz, op.cit., p. 368f. The object of Hirsch's wrath at that time was Graetz, not Frankel.
} 
history of Judaism. While Hirsch's attack was just one instance in the process of modernization, it revolves around a key issue.

The students of the seminary played a particular role in the debate. Hirsch had expressed pity for the students who were seduced and led astray by their teacher. Their parents had entrusted them to the seminary to be educated as "teachers of the law in Israel," but instead they turned into heretics and blasphemers.

I pity you, Sons of my People, pity your parents and friends! One sends you to this institution trusting that you will there be educated to become teachers of the law in Israel, and you return to your parents full of heresies and apikorssim-principles, only because you were faithful students of your teacher Frankel who leads you astray. 50

These were just the editorial comments added to the translation of a Hebrew Sendschreiben in which Frankel was attacked in even harsher language. ${ }^{51}$ It was clear to everyone, however, that Hirsch was the true adversary in a fight which was perceived by the partisans of Frankel as directed against the survival of "intelligence and science in Judaism." 52

The 43 signers-among whom we also find " $\mathrm{H}$. Cohen from AnhaltBernburg"53 - react with unanimous and unambiguous outrage to what

\footnotetext{
${ }^{50}$ Hirsch as quoted in "Verwahrung" [="Beilage", AZd] 25. Jg., Nr. 5, Leipzig, 25. Januar 1861]. Following the publication of "Verwahrung" in the $A Z d J$ many more reactions, opinions, analyses etc. were published here, responding either to Hirsch's attacks or to the students' declaration of solidarity with Frankel. Some authors criticize Frankel for not being open enough about his essentially liberal approach, others defend Hirsch's impeccable character, etc. See AZdJ 25. Jg., Nr.8 (Febr. 19, 1861) 103-105, "Beilage" Nr. 8 and editorial in Nr. 9 (Febr. 26) and ibid., pp. 127f, p. 151f ("Polemica") and Nr. 20 (May 14) "Offene Erklärung" (signed by members of the committee for the reconstitution of the communities of Mähren in support of their erstwhile rabbi S. R. Hirsch).

${ }^{51}$ The author of the Sendschreiben was someone from Stuhlweissenburg, who described Frankel's book as "carrying lie and fraud in its bosom and leading the minds of our time away from Torah and into the void of madness and error." Frankel was labelled as "equal to an idolator and public offender of the Sabbath." 52"Aufruf" by Dr. B. Beer, calling Hirsch an "idiotische(r) Frömmler" and claiming "es geht um den Bestand der Intelligenz und Wissenschaft im Judenthum" (AZdJ "Beilage" Nr. 6, Jan. 25, 1861).

${ }^{53}$ Anhalt-Bernburg refers to the Regierungsbezirk of Anhalt, including Coswig. Among the other signers are B. Badt (Grand-Duchy of Posen), Dr. Isaac Bamberger (Hessen-Darmstadt), Philipp Bloch, J. Freudenthal (cand. phil. Hannover), Dr. Moritz Güdemann (Hannover), Jacob Guttmann (Salesia), stud. phil. Jacob Horowitz (Vienna), Joseph Heinemann (Gothenburg), G. Horowitz (Vienna), Dr. Joseph Perles (Hungary), M. S. Zuckermandel (stud. phil. Mähren). Cohen continued to remain close to several of his fellow-seminarians. The above names reappear prominently as participants in some of the prestigious projects of the Verein zur Förderung der Wissenschaft des Judentums which Cohen helped to
} 
they feel are unwarranted and tasteless attacks on the genuineness of Frankel's leadership and qualification as a teacher of the holy scriptures of Israel.

After attacking Hirsch for taking on the censoring posture of a pope (the allusion to the Protestant reformation is transparent), the students give expression to their regard for Frankel.

\begin{abstract}
To the contrary, we are pleased about this opportunity to declare in public that it is with pride that we call ourselves the students of Frankel, and that, with heart and hand, we are devoted to this our revered teacher like children to their father. We aspire to emulate him who planted in our chests the zeal for Israel's faith, who caused us to take a lively interest in the study of our sacred doctrine, the written and oral law, who guided us to the path of religious and scholarly research and, as far from fanaticism as from sheer destructiveness, uncovered for us with the proper earnest the trace of the divine spirit in the writings of our sages. To become like him shall be our pride.
\end{abstract}

The impressive list of signers demonstrates that these words were more than empty rhetoric. Today it is clear that the development initiated by Frankel and continued by his students could not be stopped by invoking an anathema against the forces of liberty and freedom of scholarship. Frankel and his students initiated the modern study of rabbinic literature and their contributions to this field are in many respects still unsurpassed. ${ }^{54}$

In his reminiscences dedicated to the Jewish Theological Seminary, one of his few even remotely autobiographical texts (aside from letters), Hermann Cohen expresses his personal admiration for Frankel. ${ }^{55} \mathrm{He}$ testifies to the deep impression Zacharias Frankel had made on him with his pursuit of the right balance between faith and science. Here he also describes the impact on himself of the debate between Hirsch and Frankel. Cohen's participation went beyond signing the collective declaration of solidarity with Frankel. He wrote a letter to Hirsch which the latter quoted in a Briefkastennotiz. ${ }^{56}$ At the time Cohen was nineteen, and this was his first, indirect, publication.

inaugurate (see below), as well as among the contributors to Festschrift Judaica (1912).

${ }^{54}$ See Chanoch Albeck, "Die Entwicklung der talmudischen Wissenschaft seit Zacharias Frankel" (Vortrag, 1925), published in Guido Kisch (1963), pp. 167-174 and Ephraim E. Urbach, "Zacharia Frankel, Israel Levi, Shaul Horovitz" (Hebrew), ibid., pp. 175-177.

55 "Ein Gruß der Pietät an das Breslauer Seminar" (1904) originally published in Ost und West, Illustrierte Monatsschrift fïr modernes Judentum, IV, Berlin 1904, pp. 747-756; reprinted in: J 2, 418-424 and also in Kisch (1963), pp. 303-308.

${ }^{56} \mathrm{Cf}$. Rosenzweig "Einleitung" p. xxi and note p. 331. 
To Mr. H.C. in B. The sentiments expressed in your letter are most honorable for you as for the teacher whom you revere so that I do not hesitate to answer it here in public.

Indeed it would be terrible if attacks on the scholarly principles of your teacher such as published in this and the previous issue of this journal had not saddened his students and friends. I fully recognize your sense of duty which compelled you to assure me that your revered teacher lives in the ancient orthodox way, how, 'with the tallis over his head he stands in synagogue, sings with you zemiroth Friday nights, and also, on occasion, eagerly remarks during shiur, 'here a yere shamayim [one who fears God] must be makhmir [halakhically strict rather than lenient]! 57

We owe it to an otherwise insignificant case of unfriendly gossip among the Jews of Coswig in 1865 that Cohen described the whole affair four years after the event, in a letter to Eduard Steinthal. ${ }^{58}$

A full analysis of the whole discussion and its impact on Cohen's further development-which cannot be given here-would have to take into consideration the following aspects:

1. Quite obviously, Hirsch's critique is not just a consequence of primitive anti-intellectualism. As the Briefkastennotiz shows, Hirsch is aware of arguing against a set of scholarly principles, i.e., what he sees as being at stake is the authenticity and hence the life of Jewish faith based on revelation. Similar to parallel phenomena in the history of Protestant theology in the 18th and 19th centuries, the fundamental concern is the truth and certainty of divine revelation contained in historical texts. Frankel must have been aware of the fine line he was trying to walk, and Hirsch simply denied the viability of a compromise between Judaism and the modern secular consciousness if this meant relinquishing the fundamental principle of the supernatural nature of the revelation of the Torah. Thus the fight involved ultimate metaphysical matters rather than philological trifles.

2. Frankel and his unwavering commitment to a creative synthesis of faith and science had a tremendous influence on Cohen. It may be possible to demonstrate the continuity between Frankel's basic program (as analyzed by Urbach in: Kisch (1963) pp. 175ff), that combined philological study with the genetic method of history, and

${ }^{57}$ Jeschurun 5621 (1861), 7. Jg., Nr. V, p. 297 f. quoted in J 1, p. 331.

${ }^{58}$ Briefe, pp. 11-17. Eduard Steinthal (1825-1899), merchant and father of the later director of the Deutsche Bank, Max Steinthal (1850-1940) was a cousin of H. Steinthal. See "Stammbaum von Heymann (Chajim) Steinthal" in Ingrid Belke (ed.), Moritz Lazarus und Heymann Steinthal, vol. II/2 (Tübingen: Mohr, 1986) pp. $796 f$. 
Cohen's quick absorption of the methods of Steinthal and his Völkerpsychologie.

3. Hirsch's attacks brought it home to Cohen that in a typical community he would have to bring a sacrificium intellectus. The community for which Frankel educated his students did not yet exist. Cohen was unable to compromise his sense of truthfulness with the "literal external view about the source of great divine ideas which contradicts the spirit of history." This kind of fundamentalism Cohen "always found (...) repulsive" ( 2 , 423). Hence he abandoned his plans for a rabbinic career.

The Jewish knowledge Cohen had acquired as a child and as a youth was undoubtedly above average and thorough enough to enable him to become the leading Jewish philosopher of his time. Although he neither graduated from the seminary nor continued the academic study of related subjects as far as they were available (e.g. Semitic languages such as Syriac and Arabic; see the memoirs of Moritz Güdemann), Cohen had nevertheless received a fundamental education in the classical Jewish curriculum, beginning with the groundwork laid by his yeshiva trained father ${ }^{59}$ and completed by three years of intensive course work with the elite of German Jewish learning and in close comradeship with members of the scholarly vanguard of the next generation. ${ }^{60}$

There are two reasons which lead me to believe that Cohen's exchanging classical philology and philosophy for his rabbinical studies indicates not a breach with his past but rather bring to the fore what had been present in his youth. One reason is that there seemed to be no crisis in his relationship with his parents which would most certainly have ensued if Cohen's leaving the seminary had been the expression of a rebellion of any sort. The second reason is that when he began to articulate his philosophy of Judaism (around the turn of the century) he was already connected to his fellow Breslau alumni with whom he felt the closest spiritual kinship. The questions to be answered are what was Cohen's relation to Judaism in the intermediate years (between 1861 and

\footnotetext{
${ }^{59}$ In a letter to Ludwig Philippson of Dec. 1879 Cohen calls his father a tsaddik and his מורי ורבי, and indicates that he owes his "religious understanding" to him. See here in the appendix.

${ }^{60}$ Cohen continued to emphasize his connection with "the Breslau school" (see letter to Philippson in the appendix). As a professor in Marburg, when the Jewish community was looking for a new rabbi, Cohen (unsuccessfully) opposed the orthodox candidate Munk (a graduate of the Esriel Hildesheimer seminary) and lobbied for a candidate from Breslau. Many of his later publications on Judaism were published in the Breslau journal $M G W J$, then edited by Brann, a former fellow-student of Cohen's. Some of their correspondence (from the National Archives in Jerusalem, Ms. Var 308/240) is given below, in the Appendix.
} 
1900 ) and what role did the rise of anti-Semitism play in bringing about Cohen's "return in repentance."

\subsection{From Filial Piety to Reaffirmation: Berlin and Marburg (1861-1904)}

On two occasions, Hermann Cohen became directly and publicly involved with anti-Semitism. The first was the Berlin Antisemitismusstreit of $1879 / 80$. The second one occurred eight years later and involved the first anti-Semitic delegate ever to be elected to the Reichstag, a librarian at Philipps University in Marburg, who was sued for libel of the Jewish religion. On these occasions the German Jewish neo-Kantian professor spoke out for the first time on behalf of Jews and Judaism. ${ }^{61}$ Ein Bekenntnis in der Judenfrage (1880) is the first essay on Judaism Cohen published under his name. His expert testimony to the court on "Love Thy Neighbor" in the Talmud (1888) is his first effort to articulate the principles of the Jewish religion out of its literary sources. However, the question of how to relate Judaism to the modern consciousness preoccupied Cohen continuously once he had left the theological seminary. If the conflict between Judaism and modern culture had caused him to leave the seminary in the first place, it was not in order to escape this tension. Rather, his academic pursuits were to provide him with the tools to address and resolve it.

The vindication of certain cultural merits of Judaism, and the perpetuation of Judaism as "a nationality," remained important to Cohen even when his initiatives seem at first to have been motivated mainly by a sense of justice and filial piety towards a religion despised by the nonJewish majority and abandoned by dissidents and converts who saw it as an obstacle to full integration.

Cohen did not relinquish interest in Judaism when he left the Theological Seminary, or we would be at a loss to explain why he felt compelled to answer Treitschke's attacks on Germany's Jews in 1879/80. However, Cohen's efforts to launch an academic career and to gain the position of a professor of philosophy overshadows all other pursuits in the period between 1861 and 1876, and, once an ordentlicher Professor, Cohen was preoccupied, apart from teaching, with consolidating his systematic renewal of Kantian philosophy.

Still, both in his private life with family, friends, and kindred spirits as well as in his writing, Judaism continues to play a significant role. While just four years after leaving the seminary he declares himself to be

${ }^{61} \mathrm{Cf}$. Ulrich Sieg, "'Der Wissenschaft und dem Leben tut dasselbe not: Ehrfurcht vor der Wahrheit.' Hermann Cohens Gutachten im Marburger Antisemitismusprozeß 1888" in: Brandt pp. 222-249. 
"standing on a totally different foundation" 62 than when he was fromm, 63 he continues spending the High Holidays with his family and, on such occasions supports his father in his cantorial duties. He has his taliss with him in Berlin ${ }^{64}$ and he studies Salomon Munk's first modern translation from the Arabic manuscripts of Le Guide des Egarés with his father. ${ }^{65}$ Typical of the Jewish society of his age, and perhaps of any minority community, his association is mainly with other Jewish individuals, preferably with extended family or friends who share a landsmannschaftlich sentiment. ${ }^{66}$ Jewishness is one of his "two nationalities." 67 As in the case of other Jewish individuals of the 19th century from Heine to Herzl, Cohen is moved and disturbed by encounters with the remnants of past Jewish ghettoization and by symbols of ongoing Christian triumphalism. ${ }^{68}$

Most importantly, however, Cohen states publicly that "the moral content which the prophets put into their concept of God has by no means been absorbed by culture" and that he intends to express this idea "more often and more publicly." 69 This implies that the form can and

\footnotetext{
${ }^{62}$ Briefe, p. 17.

${ }^{63} \mathrm{Cf}$. letter to Louis and Helene Lewandowsky, Sept. 22, 1871: "Wenn ich mich in die Gefühle meiner frommen Tage zurückversetze ..." op.cit., p. 33.

${ }^{64}$ See op.cit., p. 19.

${ }^{65}$ At least he asks Hermann Lewandowsky to sent it to him for that purpose, in a letter of August 2, 1870; op.cit., p. 24.

${ }^{66}$ Cohen found a friend and "brother" in Hermann Lewandowsky who was a teacher's son from Halle. Apparently they met in Breslau in 1861. (See Briefe, p. 5 and passim.) Through Hermann Lewandowsky, Cohen was introduced to the synagogue composer Louis Lewandowsky, and his wife Helene, whose daughter Martha he taught during his first year in Berlin (1864-65) and whom he married in 1878. H. Steinthal-Cohen's intellectual and spiritual mentor between 1865 and 1873 -was from Anhalt.

${ }^{67}$ Cf. Briefe, p. 23, letter to Dr. Moritz Kirschstein (August 28, 1867): "Mit einem Manne bin ich besonders recht bekannt geworden, obwohl demselben meine beiden Nationalitäten fehlen: er ist Däne und kein Jude und hat auch nur homöopathische Dosen von der Nationalität Christentum mich kosten lassen."

${ }^{68}$ In a letter to Louis and Helene Lewandowski of August 19, 1871, in which he describes a trip along the Rhine he writes "Eine Judengasse rührt mich freilich mehr als eine andere Ruine ..." and also expresses the disturbing impression the dome in Cologne made on him: "Mir gab das Alles Vielerlei zu denken und wenig Tröstliches. Ich lerne immer mehr die tiefe Weisheit des talmudischen Satzes verstehen: 'Auf Dir liegt die Arbeit nicht, daß Du sie vollendest; aber Du bist nicht frei, Dich ihrer zu entledigen.'" etc. See Briefe, p. 32.

${ }^{69}$ Letter to L. and H. Lewandowsky, Sept. 22, 1871 (Briefe, p. 33): "Ich habe es, wie Sie sich vielleicht erinnern, öffentlich ausgesprochen, und ich werde es wahrscheinlich noch öfter und noch öffentlicher thun, daß der sittliche Gehalt, den die Propheten in ihren Gottesgedanken legten, keineswegs von der Cultur aufgesogen ist." It was possibly the proximity of the High Holidays that put Cohen in the mood of making such a pious vow.
} 
perhaps should be severed from its content, i.e., the prophetic concept of God may not be the appropriate form for a contemporary appropriation of the content of Jewish socialism. In fact, Cohen spells out these consequences himself: "This is not to say that we shall continue needing the prophetic form for the exploitation of this thought; but this justifies our attachment to the forebears."70

Aside from his regard for the valid moral content of Judaism, Cohen associates his continued attachment to his religious upbringing with the sentimental perception that familiar rituals convey "a certain indescribable kind of elevation which lies in the things we grew up with."71 Cohen is also aware, however, that the younger generation of Jews hardly experiences the unbroken unity and continuity of Jewish religious and civil life which he and his friend Hermann Lewandowsky had experienced in their youth. ${ }^{72}$

Friendship and filial sentiments are the predominant feelings Cohen associates with Judaism. So, for example, while the Jewish New Year is to him full of " deep humanity and genuine poetry" this makes it "the most dignified occasion" for the renewal of friendship. ${ }^{73}$ The universal legacy of the teachings of Judaism, namely the socialist morality of the prophets, may have to forgo its association with the prophetic concept of God in order to be absorbed by the culture-at-large.

From 1861 to 1864 Cohen studied philology and philosophy in Breslau. ${ }^{74}$ There he was first encouraged to follow the academic path when, in 1863, an essay of his won a prize. ${ }^{75}$ In 1864 he moved to the Friedrich Wilhelms Universität in Berlin where he was registered from

70"Damit ist nicht gesagt, daß wir die prophetische Form für die Ausbeutung jenes Gedankens noch ferner brauchen sollen; aber die Anhänglichkeit, die Unsereins an die Alten hat, ist damit begründet" (Briefe, p. 34).

${ }^{71}$ The reference is to the rites of the Passover festival. Letter to Hermann Lewandowsky, April 5, 1871, op.cit., p. 30.

${ }^{72}$ Op.cit., p. 30 (April 5, 71). H. Steinthal expresses similar sentiments when he describes scenes from the religious life in his own home town in Anhalt. Cf. "Aus den Jugenderinnerungen Steinthals. Mit einer Vorbemerkung von Leo Baeck" in : Ingrid Belke, op.cit., vol. 1, 371-393.

73 Briefe, p. 33.

${ }^{74} \mathrm{He}$ was registered at Breslau University from October 29, 1861 until October 10, 1864. See Orlik, p. 25.

${ }^{75}$ The Breslau prize essay of 1863 compared the psychological teachings of Plato and Aristotle. The topic was: "Platons Lehre von dem Wesen und der Natur der menschlichen Seele aus den Dialogen Phädon, Philebos, Politeia und Timäos entwickelt, und die Psychologie des Aristoteles, wie sie in den Büchern von der Seele dargelegt und durch Stellen der Nikomachischen Ethik und des Buches Lambda der Metaphysik ergänzt wird, sollen einander gegenübergestellt, in Bezug auf Übereinstimmung und Abweichung verglichen und hinsichtlich ihres wissenschaftlichen Wertes beurtheilt werden." Quoted in Orlik, p. 25. 
October 18, 1864 until September 14, 1865. ${ }^{76}$ Answering a Preisaufgabe announced by the faculty of philosophy in 1864, Cohen composed an essay which gained an appreciative mention by Trendelenburg and which he subsequently submitted as a doctoral dissertation to the university of Halle-Wittenberg where he defended it successfully on October 27, 1865.77 The prize essay-cum-dissertation deals with the problem of necessity and contingency in the history of philosophy ${ }^{78}$ and became Cohen's first publication, Philosophorum de antinomia necessitatis et contingentix doctrinx (Halle: 1865).

The written reports of the professors participating in Cohen's doctoral examination (Rigorosum) confirm that the field in which he excelled was classical philosophy, ${ }^{79}$ and so it is not surprising that he would choose Plato's theory of forms as the subject of his first independent study. ${ }^{80}$ When he returned to Berlin, Cohen was a private scholar, a 23-year-old doctor of philosophy who still had to prove his worth and to find his place in the academic world. His mentor in these early years was $\mathrm{H}$. Steinthal (1823-1899). ${ }^{81}$

The association with Steinthal-and to a lesser degree also with Steinthal's brother-in-law, Moritz Lazarus ${ }^{82}$-was important for Cohen in two important respects. First, Steinthal's theory of culture, his ethnic psychology, provided the theoretical framework for Cohen's studies during this period, before Kant and F. A. Lange's neo-Kantianism

\footnotetext{
${ }^{76}$ See op. cit., 26ff. Since he had not graduated from the Seminary he needed a Reifezeugnis in order to advance to the university in Berlin. Therefore he took such an examination at the St.-Matthias-Gymnasium in Breslau on August 5, 1864. See op. cit., p. 24.

${ }^{77}$ Cf. op. cit., p. 33.

${ }^{78}$ See op.cit., p. 27. "Casum et continens quomodo philosophi definiverint et expediverint, doceatur, comparetur, examinetur." The historical positions to be discussed were Aristotle's Physics (Book II), Epicurus, Spinoza (Metaphysics ch. 3; Ethics Part I Prop. 29, Part II Prop. 31 and 44) and the relevant passages from Kant's first critique.

${ }^{79} \mathrm{Cf}$. op.cit., $32 \mathrm{f}$.

${ }^{80}$ Die platonische Ideenlehre, psychologisch entwickelt (1866).

${ }^{81}$ On Steinthal see Ingrid Belke (ed.), Moritz Lazarus und Heymann Steinthal. Die Begrïnder der Völkerpsychologie in ihren Briefen, Tübingen: J.C.B.Mohr (Paul Siebeck), 1971, "2. Heymann Steinthal" pp. LXXXI-CXLII and more recently Dieter Adelmann, "H. Steinthal und Hermann Cohen" in: Stéphane Moses and Hartwig Wiedebach (ed.), Hermann Cohen's Philosophy of Religion. International Conference in Jerusalem 1996 (Hildesheim, Zürich, New York: Georg Olms Verlag, 1997), pp. 1-34.

${ }^{82}$ During Cohen's early years in Berlin (1864-66), Moritz Lazarus was not in Berlin but in Bern/Switzerland where he taught psychology and ethnic psychology with great public success and recognition-a period which Lazarus deemed the "Lichtpunkt" of his life. Cf. Belke, op.cit., pp. xxvi-xxxii.
} 
became for him more powerful sources of inspiration. Second, Lazarus and Steinthal, both leading personalities of German Jewry, were among the organizers and spiritual fathers of the Hochschule für die Wissenschaft des Judentums (founded December 26, 1869, opened May 6, 1872, its name downgraded to Lehranstalt) in which Cohen was to become involved later. Although Lazarus and Steinthal were of great help to and influence on Cohen, his increasingly obvious theoretical shift from Steinthal's psychology to Kantian criticism caused a certain estrangement between the elder and the younger scholar. This turned into open enmity when Cohen dared to take Treitschke's side against Lazarus during the Berlin Antisemtitismusstreit.

Lazarus and Steinthal severed their personal relations with Cohen as a reaction to his Bekenntnis in der Judenfrage (1880). They even avoided serving on the same committee ${ }^{83}$ with a man who they thought had betrayed their confidence. Two of Lazarus' publications became objects of Cohen's public criticism, namely his response to Treitschke's antiSemitic articles ${ }^{84}$ and the publication of the first volume of his Ethik des Judentums (1898). ${ }^{85}$ In response to the critical review of the latter ${ }^{86}$ which Cohen had written for the Monatsschrift für die Geschichte und Wissenschaft des Judentums - the scholarly journal affiliated with the Jewish Theological Seminary in Breslau-Lazarus described his feelings about Cohen in unambiguous language in a letter to Sigmund Maybaum (December 19, 1899): ${ }^{87}$

Dear Herr Doktor! Even if, with God's help, I am doing well it may take a while before I shall be able to write you again in as much detail as I wish. Today only this much. I regard two facts as the source of the criticism of this man, Cohen. One of them everyone

${ }^{83}$ See, e.g., Steinthal's letter to his friend Gustav Glogau (Berlin, 29. November 1892) on the occasion of the foundation of a German association for ethical culture, which included, among others, Hermann Cohen and Ferdinand Tönnies. Steinthal wrote: "Du hast doch von der Gründung der deutschen Gesellschaft für ethische Kultur gehört, an deren Spitze der Astronom Förster [sic] steht, ein ganz vortrefflicher Mann. Doch konnte ich ihm den Gefallen nicht tun, Mitglied der Gesellschaft zu werden. Cohen in Marburg ist beigetreten..." Belke, op.cit., vol. II/ 1 (1983), p. 337. But see below.

${ }^{84}$ Was heißt national? Ein Vortrag, gehalten am 2. Dezember 1879 (1. and 2. ed.) Berlin, 1880.

${ }^{85}$ Die Ethik des Judentums, Band 1, Frankfurt a. Main, 1898; English by Henrietta Szold (Philadelphia/PA: JPS, 1900/01 and England: Jewish Historical Society, 1901). Russian translation: 1903.

86"Das Problem der jüdischen Sittenlehre" (= J 3, 1-35). Cf. letter to Brann, August 21,1899 , here in the appendix.

${ }^{87}$ Sigmund Maybaum (1844-1919), rabbi, since 1881 in Berlin, since 1888 teacher of homiletics at the Hochschule für die Wissenschaft des Judentums. Cf. Ingrid Belke, op.cit. vol. I (1971) p. 211n 
knows who experienced the beginning of Berlin anti-Semitism. Treitschke had written his unfortunate article. I had appeared against it with "What Does 'National' Mean?," then a brochure on the Jewish question was published by this person in which he stabbed me, his co-worker, in the back with an unbelievable criticism and a defense of Treitschke. Fortunately the whole matter attracted little attention. The Jews were smart and the Christians decent enough to keep silent over such mad demeanor. Only Herr von Treitschke naturally was pleased to accept the support.

I should mention that I never did anything to hurt this person; only a few favors (after all, he had been introduced to me by Steinthal) but not to such a degree that a debt of gratitude could have irked him. But no one could get up and claim to have ever heard a derogatory word from me about this person, either spoken or in writing.

Lazarus goes on to describe the far more aggravating fact that Cohen succeeded in destroying his much deeper relationship with Steinthal and that it was only due to his (Lazarus') intervention that Steinthal did not destroy Cohen's reputation.

The second fact is even more important, one which, aside from my sisters Nette and Emestine, only he and I know. Immediately after his brochure was published, Steinthal who, if I am not mistaken, is a distant relative of his and who was, at least, his teacher for several semesters and for many years his fatherly friend,--Steinthal immediately wrote him a letter of rejection in that passionate style which emanated from Steinthal's pure and fiery soul as soon as his moral anger was kindled. Steinthal showed him his indignation and disciplined him morally.-I admit that I would rather have suffered the lesser and greater ban of excommunication than to have been morally disciplined by Steinthal in such a manner.

The first inklings remain inexplicable as they were not qualifyable; but it may explain the continuation at this time. (Belke [1971], p. 230)

The extraordinary bitterness Lazarus expresses in this letter was caused by Steinthal's death seven months earlier. However, Lazarus testifies here to what amounted to a herem (a religious ban) which effectively prevented Cohen from associating with the Lehranstalt fiur die Wissenschaft des Judentums as long as either Steinthal or Lazarus were alive.

Nevertheless, shortly before Lazarus' death in 1903, Cohen and Lazarus at least put both of their signatures under the founding documents of the Gesellschaft zur Förderung der Wissenschaft des Judentums. ${ }^{88}$ In addition, after Steinthal and Lazarus had both passed

${ }^{88}$ See below. 
away, Cohen became a member of the board of the Lehranstalt (beginning in 1903), ${ }^{89}$ which had been Lazarus's position, and also filled the lectureship in philosophy of religion and the Bible (beginning in 1904) which had been Steinthal's between 1872 and 1899.90

The death of his erstwhile mentors, however, is not a sufficient reason for Cohen to rise to such prominence among the representatives of the Wissenschaft des Judentums. First he needed to acquire the intellectual position that was to generate the enthusiasm for Jewish philosophy of religion and ethics that speaks loudly and clearly out of his institutional engagement and his cuvre beginning at the turn of the century. The following chapters will trace this development in Cohen's thought from its early stages in the 1860's through the periods of defense against anti-Semitism, and finally show the reorientation in Cohen's thinking that was to propel him from the margins to the center of the turn-of-the-century efforts to reinvigorate modern Jewish religious scholarship.

\section{Early Writings on the Religion of Israel and Modern Culture}

\section{1 "Monotheistic Pantheism" and Social Justice}

In the decade between 1861 and 1871 Cohen began to develop a scholarly direction. Between 1865 and 1871, he published three major articles in the Zeitschrift für Völkerpsychologie und Sprachwissenschaft edited by Steinthal and Lazarus. The first subject to which he turned was, once

${ }^{89}$ See obituary of the Kuratorium for Cohen in $A Z d J 82$ Jg. Nr. 15, 12. April, 1918. ${ }^{90} \mathrm{Cf}$. Belke op. cit., vol. I, p. xcix and see I. Elbogen, Lehranstalt für die Wissenschaft des Judentums. Festschrift zur Einweihung des eigenen Heims, Berlin (22. Oktober) 1907, pp. 86f: After Steinthal's death and his successor's-Martin Schreiner'sillness, i.e., since April 1, 1903 (cf. op.cit., p. 84), the position in Bible and philosophy had been vacant: " $\mathrm{Da}$ zusammenhängende systematische Kurse über Philosophie in der Zwischenzeit nicht ganz entbehrt werden mußten, verdankt die Anstalt der Opferwilligkeit eines ihrer Kuratoren. Hermann Cohen in Marburg, der Führer der neukantischen Schule, hat sich seit 1904 in dankenswerter Weise bereit finden lassen, während der Ferien Vorlesungen und Übungen aus verschiedenen Gebieten der Philosophie zu halten. Der gefeierte Name des berühmten Philosophen hat es vermocht, eine stattliche Anzahl von Hörern zu den Vorträgen anzuziehen" (op.cit., p. 87 and cf. p. 89) Cohen was also curator of the Lehranstalt beginning in 1903 (cf. ibid., p. 93n). Note that Cohen was a member of the Gesellschaft zur Förderung der Wissenschaft des Judentums from the day it was founded (November 2,1902) and was in charge of writing a volume on ethics and the philosophy of religion for the "Grundriss" series. This is the volume which appeared posthumously, namely Die Religion der Vernunft aus den Quellen des Judentums (1919). See Ost und West (ed. Leo Winz), Heft 11 Nov. 1912 XII Jg., 993-1008 (esp. p. 999) and cf. AZdJ 82 Jg. Nr. 15, April 12, 1918 (obituary). Also see below, Pt. I, ch. 4.2. 
again, Plato's theory of forms. ${ }^{91}$ Both, his dissertation and this essay on Plato are significant for a genetic understanding of Cohen's philosophy. As Peter Schulthess has pointed out, they contain the first elements a) of a critique of contemporary interpretations of Plato and b) of Cohen's own reappropriation of the Platonic idea as the true origin of the $a$ priori. Plato becomes and remains an orienting figure in Cohen's thought before and beyond his discovery of Kant. ${ }^{92}$ In 1868/9 he applied Steinthal's psychological method to "mythological ideas of god and soul" and to the "literary imagination and the mechanism of the consciousness." 93 The subjects he chooses - the history of philosophy, religious mythology, and literature-will continue to occupy him. These essays are more significant, however, as evidence for Cohen's interest in a genetic method which unifies such diverse cultural productions as philosophy, religion, and art. ${ }^{94}$

Aside from these studies, Cohen anonymously published two essays, dealing with Judaism and the strain of being Jewish in 19th-century Germany ("Heine und das Judentum" 1867 and "Virchow und die Juden" 1868). ${ }^{95}$ The general world view expressed in these essays was what he calls the "position of scientific materialism and ethical idealism," 96 a world view the educated Jew shares with his educated Christian compatriots. The condition of this common world view is that one "has left behind the dogmatic aspects of one's religion and elevated oneself to the ethic of humanism" (ibid. 461). Nevertheless, while the Christian suggests that the Jew "have his certificate of birth rectified where and when the circumstances impede his activity in the viable culture" (ibid.) the Jew cannot do so, and, if he does, he suffers as a result of the violation not of his religious conscience but of his personal integrity, for he is denying and denigrating what he has received by

\footnotetext{
${ }^{91}$ Die platonische Ideenlehre, psychologisch entwickelt (1866), reprinted in S 1,1-29.

${ }^{92} \mathrm{Cf}$. Peter Schulthess, "Platon: Geburtsstätte des Cohenschen Apriori?" in Brandt pp. 55-75; similarly already Hans-Ludwig Ollig S.J., "Hermann Cohen und das Problem der Selbsterhaltung" in: ThPh 56 (1981) pp. 514-517.

93"Mythologische Vorstellungen von Gott und Seele, psychologisch entwickelt" (1868/9) in S 1, 88-140; "Die dichterische Phantasie und der Mechanismus des Bewußtseins" (1869), in S 1, 141-228.

${ }^{94}$ Aside from Steinthal, Trendelenburg's formulations of the task of philosophy had perhaps the strongest influence on Cohen during his years in Berlin. See Schulthess, op.cit., pp. 59-61.

${ }^{95}$ For the latter cf. Bruno Strauß "Vorwort", J 1, vi.

96"Virchow und die Juden" (1868), published anonymously in Die Zukunft. Demokratische Zeitung ed. Guido Weiß, August 14, 1868, also in J 2, 457-462. One of two articles (the second was not published and is lost) defending the famous surgeon and democratic politician against charges of having turned down Jewish applicants to positions in his hospital while accepting a baptized Jew. Cf. J 2, $482 \mathrm{f}$.
} 
birth, education, and the experience of suffering. While the Christian insinuates that Judaism may be shed as a worn garment, Cohen insists that one can and should hold on to Judaism without considering it a "religion."

Not so the Jew. To him the conception (Vorstellung) of Judaism is no longer religion; this he has eliminated. What remains alive in him of the Judaism which is his by birth, education, and suffering is a conception, a series of conceptions of a wholly different kind. (ibid.)

This "conception of Judaism" (Vorstellung Judentum) is made up of a sense of "personal honor" as well as of "time-honored images from the time of one's first youthful enthusiasm for something which one then called truth" (ibid.). In some cases (i.e., in his own case) this conception is augmented by "the historical recognition of the relative significance of Judaism for the development of human kind." (ibid.)

Like any other Jew aspiring to a foothold in Prussian society at that time, Cohen was confronted not only with the de facto discrimination which remained in place until the revolution of $1918 / 19$ but-until 1869-with a de iure exclusion of Jews from holding state offices, including tenured university appointments. It is therefore not surprising that in these first, exploratory literary products Cohen considered precedents and problems directly related to the issue of Jewish identity within the fabric of a society which exerted "economic pressure forcing the Jew to a false confession." 97 The historical precedents in the light of whose lives and ideas Cohen meditates his own position are those of the first modern Jewish dissident-Baruch de Spinoza ${ }^{98}$-and of the paradigmatic German Jew who converted for the sake of convenience but who was inconvenienced ever after-Heinrich Heine. ${ }^{99}$ Cohen tries to demonstrate that Heine shared Spinoza's pantheism, which is characterized by the idea of "an equal dignity of matter" and spirit ("Ebenwürdigkeit der Materie", op.cit. p. 24), to which Heine adds belief in "the progress of humanity" and in "the equal right of all humans to partake of all earthly pleasures" (ibid.). In this way, Heine creates his own type of world view which is, in essence, "Jewish-pantheistic, i.e. monotheistic-pantheistic" rather than "Hellenistic-pantheistic" (ibid. p. 23). For the young Cohen, Heine's Judaism is distinguished by his resistance to the Goethean "Hellenic-pantheistic" understanding of art as

\footnotetext{
${ }^{97}$ Sentence eliminated by the editor from the manuscript of "Virchow und die Juden" (1868); cf. J 2, 482f.

${ }_{98}$ Baruch de Spinoza (1632-1677).

${ }^{99}$ Heinrich Heine (1797-1856). The essay I am referring to is "Heine und das Judentum" (1867), published anonymously by a friend of Cohen's, Carl Hirsch (pseudonym Ben Jechiel). See note J 2, 469 and text ibid., pp. 2-44.
} 
the apotheosis of natural beauty and harmony (ibid. p. 22f). What we can sense here is the attempt to circumscribe the "entirely different" and not really "religious" notions which the modern Jew (Cohen) associates with Judaism as a world view. The older world view (monotheism) is not transformed but "related" to the newer one (pantheism), they are "forms of thought which, as kinds of perception (Anschauungsweisen), are related to each other" (p. 30). Heine's world view seems to be projected as a model because it manages to combine a kind of perception which is (supposedly) both modern and related to traditional monotheism (mediated through Spinoza's pantheism) with another aspect of Judaism in its modern version, namely ethical idealism. In this way, Cohen seems to try to associate a particular cultural heritage with a modern consciousness in a combination of scientific materialism and ethical idealism.

One may wonder whether any other aspects-beside the feeling of dignity and honor which are violated if a Jew abandons his heritagecontribute to the notion that old and new are to be combined. Through education and socialization-Cohen continues-religious ideas become so much part of the "mechanism" of an individual's consciousness that it should not surprise us if this individual not only scrutinizes his religious heritage for its inherent humanist content but also reads the achievements of later centuries into the religious terms of the past. What he justifies here is a kind of psychologically inevitable process of creative reappropriation of religious traditions even under secular conditions, a type of non-religious exegesis of religious literature.

\begin{abstract}
One should not be surprised that we dare say that an ancient religion should influence so significantly the world-view of a modern person. Well, if the religious ideas were not in so many ways intertwined with all our notions! Through his personal predicament, the impressions he received during his youth, and a love for the literature of his religion imbued in him since earliest childhood, the modern person [viz., Cohen himself!] is so naturally forced to evaluate its cultural substance [Kulturgehalt]. How easily one is here inclined to read with tenderly devoted appreciation the achievements of later centuries into the sentences of an earlier literature, so meaningful and full of allusions. One is inclined to do so all the more as philosophy has often provided mediation between the religious concepts and the newly won results of thought. (Ibid. p. 30f)
\end{abstract}

For a Jew, this tendency is particularly strong since his defense of the religious heritage in the forum of universal culture is also a matter of honor and, if successful, provides a cathartic experience. I.e., it is psychologically necessary and beneficial, while a dissociation from Judaism would not only be dishonorable but it would deprive the 
individual of the very material which not only comes most natural as a means of expressing his hopes and aspirations but which is intricately related to its cultural identity.

Hence the striving of the Jew to legitimize his religion before the cultural world, if successful, will also be an accomplishment of selfpurification, of self-liberation from the false and unpleasant elements which constitute the conception of "Judaism" for the majority of our contemporaries, namely that of an "accursedness," of a "slavery under the law," of "wrath," or of the "faith of the chosen people" which has been overcome by the "religion of mankind." (lbid. p. 131)

While legal conditions had changed for the better, the social conditions had not improved a great deal between 1825-when Heine complained about the necessity of being baptized in order to escape poverty (ibid. p. 40)-and 1868, when Cohen wrote the sentence about "the economic pressure forcing Jews to make a false confession."

In accordance with the intentions expressed in the essay on Heine as well as in the letter from September 22, 1871 (about "the moral content which the prophets had put into their concept of God" and which "has by no means been absorbed by culture"), ${ }^{100}$ Cohen's early essays on Jews and Judaism argue against the presumption of the Protestant majority that a modern cultivated Jew must profess Christianity in order to become part of a modern humanist society.

This defense is conducted on several levels. One is the presentation of the ethical content of certain Jewish traditions which have yet to be absorbed by the culture at large, such as the social message of the Sabbath as a symbol of universal human equality. ${ }^{101}$ In a later reminiscence Cohen described the lecture which contained this idea as having presented an opportunity "to pronounce the quintessence of prophetic socialism in the Sabbath and thereby to combine my deepest Jewish feelings with my ethico-political conviction." 102

${ }^{100}$ Letter to L. and H. Lewandowsky, Sept. 22, 1871 (Briefe, p. 33)

101 "Der Sabbat in seiner culturgeschichtlichen Bedeutung" (1869); lecture, Berlin , January 19, 1869, published with a postscript in Der Zeitgeist (Milwaukee, Wisconsin: 1881). Cohen gave this lecture in the context of a series of public talks on behalf of the Zunz-Foundation. Steinthal had spoken before Cohen. This series was the predecessor of the Montagsvorlesungen, public fundraising events at the Hochschule für die Wissenschaft des Judentums. In the audience were Berthold Auerbach (1812-1882), a widely acclaimed author of romantic novellas, who shared Cohen's mild Spinozism and, for most of his life, advocated Jewish emancipation combined with assimilation into the German nation, and Johann Jacoby (1805-1877), liberal (later social) democratic Prussian politician. Cf. J 2, 469 and 175.

102 "Mahnung des Alters an die Jugend" (1917) in: J 2, 175. 
The presence of men such as Berthold Auerbach and Johann Jacoby in the audience of Cohen's speech on the "significance of the Sabbath in cultural history" highlights the political orientation underlying Cohen's defense of Jewish ideas. The difference between the heyday of liberalism, when Jacoby had published his revolutionary pamphlet "Vier Fragen, beantwortet von einem Ostpreußen" (1841), ${ }^{103}$ and the late 1860s was that while the emancipation of the German bourgeoisie, Jewish and nonJewish, was well under way, the working class, the industrial proletariat, had been left out and threatened with violent disruptions the peaceful progress towards social justice and political stability. Cohen's speech aimed to overcome the ostensible opposition between the educated moralist opinion and the religious sentiments regarding the Sabbath. By looking at the history of this institution-so his contention-the original connection between the social and religious impulse can be uncovered and thus reintroduced into general knowledge:

If it were possible to introduce into general awareness the connection between the socio-economic aspect of the celebration of the Sunday, recognized by every practician of morality, with the religious institution of Sabbath, the contradiction would be revealed that limits the believers to the degree that they fail to promote the principled economic development of this their religious commandment with all the fire of a religious enthusiasm which time has not yet extinguished. $(\mathrm{J} 2,46)$

The inquiry takes for granted that any recourse to divine revelation is an excuse for ignorance ("The belief that something comes from God or from the gods is just an expression of scientific perplexity ..."). ${ }^{104}$ Instead, one should assume that the Sabbath, "just like any cultural phenomenon, originated in and must be explained according to the general conditions of the human spirit which generates all culture" (ibid. p. 48). Therefore, in order to explain the origins of the Sabbath one must understand the conditions from which it emerged.

[These conditions] are the natural climatic circumstances, the quality of the soil and of its produce, according to these further the economic condition of the people and its particular estates, its way of life, its morals, its skills, and finally, as the expression of the totality of cultural conditions, its political constitution. [Ibid.]

This naturalistic and psychological interpretation of the genesis of ideas from the life of a people as a whole are a good example of Steinthal's method of ethnic psychology, here applied to the history of a biblical institution which, when understood historically, may again yield

${ }^{103} \mathrm{Cf}$. Monika Richarz, Jüdisches Leben in Deutschland, p. 61.

104"Der Sabbat in seiner kulturgeschichtlichen Bedeutung" (1869), J 2, 48. 
significance and meaning for the present. What Cohen seeks is a justifiable continuity between religion and socialism. Thus, while he states that his intention is to vindicate the cultural achievements of the "old-Israelite spirit" (ibid. p. 62), he really aims to validate his claim of a continuity between traditional Jewish beliefs and the modern ethical world view.

Yet he goes even further in his assessment of the value of Israelite religion when he represents the biblical paradigm of associating religious and moral impulses as a model for modern societies faced with the challenge of workers' rights. Cohen's emphasis on the Jewish religious heritage and its exemplary function for the moral education of modern societies shows him to seek an alternative to several typical positions taken by Jewish intellectuals at the time.

On one side we find personalities such as Lazarus and Steinthal who-basing themselves on a modern scholarly theory of collective cultural identities-advocated the preservation of a coherent Jewish Volksgemeinschaft. This construction of a modern Jewish identity was essentially internationalist and perpetuated an aspect inherent in traditional Judaism which had been commonplace until the emancipation. For them, the Jewish collectivity was not to be split into separate national entities that identified exclusively with the various majorities among whom the Jews lived and that regarded Judaism merely as a set of personal beliefs. ${ }^{105}$ In this respect, Steinthal's and Lazarus' position resembles contemporary notions of multi-ethnicism.

Another option, shared by intellectuals who were more disenfranchised from the Jewish fray, was to participate in the struggle against the dominant bourgeoisie, which meant to turn against the very class into which the majority of Jews tried to integrate themselves and whose worst traits it seemed to emulate in the process. ${ }^{106}$ This perspective of a socialist Jewish "self-hatred" (Theodor Lessing) could be found, among others, in Ferdinand Lasalle (1825-1864) and, to a lesser degree, also in Eduard Bernstein (1850-1932), who engaged in the

\footnotetext{
${ }^{105} \mathrm{Cf}$. Jacob Katz, "Profile of Emancipated Jewry" in: Out of the Ghetto. The Social Background of Jewish Emancipation, 1770-1870 (New York: Schocken, 1978), p. 213. ${ }^{106}$ In the 1860 s and 70 s, i.e., before the Marxist doctrine took hold in the Socialist movement (this happened only in the 1880s), the various Arbeitervereine were a mixtum compositum of employees and industrial workers united in their opposition to the liberal bourgeoisie (in which class the Jews were counted). Cf. Robert S. Wistrich, Socialism and the Jews. The Dilemmas of Assimilation in Germany and Austria-Hungary (London/Toronto: Assoc. Univ. Presses, 1982), pp. 44-48.
} 
emancipation of the lower classes and yet allowed for some antiSemitism in the socialist movement. ${ }^{107}$

Nor did Cohen represent the type of "marginal, assimilated Jews such as Theodor Herzl, Max Nordau and Bernard Lazare" who, like Moses Hess before them, based their solutions of the Jewish question on the assumption that "no dignified Jewish self-dissolution was possible in conditions of racist xenophobia." 108 While Cohen shared this analysis, he proposed a solution based on social reform and moral education of the society as a whole. Racist xenophobia was not to be dealt with as if it were an ineradicable evil but rather as a curable social decease.

More than twenty years before the mainstream journal Allgemeine Zeitung des Judentums even dared to admit "that the Social Democrats had a clear record with respect to anti-Semitism" despite which it "saw hope for the future"109 Cohen took his first steps towards a synthesis of ethical idealism and Judaism which became not only characteristic for his neo-Kantian ethics but was to generate a whole school of non-Marxist reform-oriented socialists, represented by such individuals as Kurt Eisner ${ }^{110}$ and also Eduard Bernstein in his later years. ${ }^{111}$

Yet Cohen went further than any other member of the "small but active" socialist circle around Johann Jacoby'112 in the attempt to demonstrate the ethical content of biblical Judaism. The trajectory of Cohen's earliest essays is discernibly that of a quest for the vindication of Jewish values within the larger cultural consciousness. In other words, the defense against anti-Semitism-which is often claimed to have "caused" Cohen's return to Judaism-was neither his first nor his sole concern. ${ }^{113}$ Love and respect for the Jewish tradition, and belief in its inherent moral and religious values, were at least equally powerful stimuli for Cohen's writings on Judaism. Before the challenge of antiSemitism arose, Cohen saw this particular religious heritage as a source of the pursuit of social justice.

${ }^{107}$ Cf. op.cit., ibid. and p. 76. On Bernstein see further Eggert Winter, op.cit., p. 29, note 71, and Meyer, Bernsteins konstruktiver Sozialismus (Berlin/Bonn, 1977). Bernstein formulated the principles of revisionist socialism in Die Voraussetzungen des Sozialismus und die Aufgaben der Sozialdemokratie (1899). On Cohen's later influence on Bernstein see Thomas Meyer, "Eine unzeitgemäße Intervention, die an der Zeit war,- Hermann Cohens neukantianischer Sozialismus und die sozialdemokratische Ideologie im Kaiserreich" in Brandt, pp. 257-269.

${ }^{108}$ Wistrich, op.cit., p. 44.

${ }^{109} \mathrm{AZdJ} 1891,157-8$ (quoted in Wistrich, op.cit., p. 68).

${ }^{110}$ See Cohen's letter to Eisner here in the appendix.

${ }^{111} \mathrm{Cf}$. Wistrich, op.cit., p. $78 \mathrm{f}$. Also see Thomas Meyer, op.cit.

${ }^{112}$ Cf. Richarz, op.cit., p. 63.

${ }^{113}$ See below. 


\subsection{Defending Judaism (1880 and 1888)}

In the 1880's Cohen is repeatedly compelled to leave a fulfilling and relatively sheltered academic life and career to raise his voice in a new type of political struggle, the struggle against anti-Semitism. As mentioned in the introduction, it has been claimed that Cohen himself dated his "return to Judaism" to the set of events which caused him to write and publish his "confession in the Jewish question" (Ein Bekenntnis in der Judenfrage, 1880). As indicated above, however, Cohen's later selfdesignation as a baal t'shuvah may refer to something entirely different from what Franz Rosenzweig and his followers read into it. The significance of anti-Semitism for the course of modern Jewish history should not be underestimated but it should not serve as a convenient tool for monocausal explanations of each and every turn of relatively assimilated Jews to a renewed affirmation of Judaism and Jewish values. In Cohen's case, we have seen that his considerations on the reconciliation of the values of "old Israelite religion" with the modern consciousness did not begin with the essay he directed to Heinrich von Treitschke. For the development of Cohen's thought, however, and for a determination of where he stands in matters of religion, ethics, general (public) culture, and Judaism, the essays of this period are most significant. The theoretical issues Cohen tackles in Ein Bekenntnis in der Judenfrage provide a necessary background for the ideas which will take center stage in the essay on Versöhnung.

\subsection{1 "Ein Bekenntnis in der Judenfrage" (1880)}

\subsubsection{Political and Social Background}

The period following the proclamation of the German Kaiserreich in Versailles on January 18,1871 , is characterized by momentous developments and changes. ${ }^{114}$ Built on a weak alliance of the nationalist and the liberal movements, Bismarck's "chancellor-dictatorship" increasingly sought support for its authoritarian regime in a coalition of the old Prussian Junkertum with other conservative forces. Catholics and socialists were the prime targets of deliberate campaigns against the "enemy within" (Kulturkampf, Sozialistengesetz) and the liberal hope of integrating all societal groups into a unified nation state remained unfulfilled. Bismarck's campaign against the "ultramontane" Catholic Zentrum party was supported by the Protestant liberals. Among them was Adalbert Falk, the Prussian minister of culture between 1872 and 1879, who signed Hermann Cohen's letter of appointment (1876) to the

${ }^{114}$ For the following cf. Deutscher Bundestag (ed.), Fragen an die deutsche Geschichte, pp. 155-234. 
chair of philosophy which Friedrich Albert Lange had occupied from 1872 until his premature death in 1875.

The position Cohen held from 1876 until 1912 was exceptional in the Kaiserreich. ${ }^{115}$ Jews were legally emancipated but were nevertheless systematically prevented from holding higher government positions in the judiciary, at the university, and in the military. In 1911 a survey published by the Verband der Deutschen Juden supplied the statistical evidence that, following the brief liberal phase of the Falk era, the pace of Jewish integration with the academic community decreased rather than accelerated. The study compares three academic years $(1874 / 75$, before the rise of political anti-Semitism; 1889/90, at the height of the antiSemitic movement; and 1909/10, when the data were collected) and shows how unusual it was for a Jew to achieve a tenured position. While Jews were represented in the academic community at about the same or a higher ratio as they were in the total population (about $1 \%)^{116}$ their upward mobility within the academic ranks followed the pattern neither of Christians nor of baptized Jews. In fact, there are incidents where the number of Jewish non-tenured professors decreased as much as the number of baptized tenured professors increased.

For the duration of his whole academic career Hermann Cohen was the only tenured Jewish professor in Marburg. In all of Germany, the number of Jewish tenured professors more than doubled from 10 in $1874 / 75$ to 22 in $1889 / 90$ while the number of Christian tenured professors rose only from 664 to 742 (an increase of only $11.2 \%$ ). In the period between $1889 / 90$ and $1909 / 10$, however, the ratio is reversed. The Christian tenured faculty grows from 1539 to 2335 while the Jewish tenured faculty grows only from 22 to 25 ; i.e., there is a $51.72 \%$ increase of the non-Jewish as against an $1.14 \%$ increase of the Jewish tenured faculty. Within the philosophical faculties the number of Jewish tenured professors rose from 3 to 15 (from 1 to $21 / 2 \%$ of the total number of philosophical faculty; in the medical and law faculties the ratio actually decreased between 1889 and 1910; see op.cit. table 3a), but most of those, as well as most of the Jewish non-tenured professors, were

\footnotetext{
${ }^{115}$ For the following cf. Bernhard Breslauer, Die Zurïcksetzung der Juden an den Universitäten Deutschlands. Denkschrift im Auftrage des Verbandes der Deutschen Juden, Berlin: Berthold Levy, 1911.

${ }^{116}$ The relative overrepresentation of Jews in the academic community (mostly among the group of Privatdozenten, i.e., lecturers who were paid directly by the students) and, more significantly, in the professions (jurists, medical doctors) as well as in the media must be considered not in relation to the whole population but in relation to the middle class, namely that part of the society to which the majority of Jews belonged in terms of education, social habits, political orientation and culture.
} 
mathematicians and scientists, i.e., they were almost exclusively outside the disciplines of philosophy, philology, and history (cf. ibid. tables $3 \mathrm{c}$ and $5 \mathrm{c}$ ). In 1874/75 there was no Jewish professor of philosophy, tenured or non-tenured, anywhere in Germany. With his appointment in 1876, Cohen achieved a position which his friends and supporters, Steinthal and Lazarus, along with many other intellectual luminaries of the time had been seeking in vain. ${ }^{117}$ Cohen's unusual personal success was the fruit of a moment of liberalization in Prussian cultural politics, yet it was not to be the harbinger of lasting change. In 1909/10, two years before his retirement at the age of seventy, Cohen was again the only Jew among 45 tenured professors of philosophy (proper) in all of Germany.

\subsubsection{The Berlin Antisemitismusstreit}

The great economic boom following the proclamation of the Reich (Gründerjahre) was halted by the first stock market crash, in May 1873, which led to a major recession. The political rhetoric developed by conservative journals (Gartenlaube, Kreuzzeitung, et al.) overemphasized the importance of the Jewish element in the imprudent fiscal speculations responsible for the "great depression." What was to be only the beginning of political scapegoating of the Jews and of political antiSemitism seemed a fringe phenomenon at the time and could be perceived as one of many indicators that the ideal of social unity and integration of the various religious, ethnic, and other minorities into the nation state had not yet been realized.

The anti-Semitic forces first carried their message into public assemblies in 1879. The court preacher Stoecker was perhaps the one who most conspicuously turned anti-Semitism into a tool for improving the appeal of his Christian Social Party to the masses. Still, it was only in 1887 that the anti-Semitic parties were able to send their first representative to the Reichstag (elected-of all places-in Marburg and its rural surroundings). ${ }^{118}$

While it was easy for the liberal elite to dismiss Stoecker, Marr, and their ilk as insignificant characters trying unsuccessfully to appeal to the base instincts of the underclass by targeting the Jews as the cause of all evils endured by a nation state in the process of industrialization and modernization, Heinrich von Treitschke's interpretation of the antiSemitic movement as an expression of "an awakening of the people's conscience" had to be taken more seriously ("Unsere Aussichten" Nov.

${ }^{117}$ Cf. Breslauer, op.cit., p. 9.

${ }^{118} \mathrm{Cf}$. Ulrich Sieg, "'Der Wissenschaft und dem Leben tut dasselbe not: Ehrfurcht vor der Wahrheit.' Hermann Cohens Gutachten im Marburger Antisemitismusprozeß 1888" in Brandt, pp. 224-228 
15, 1879). ${ }^{119}$ This was an attack by a member of the Prussian elite, an elected representative, a member of the National-Liberal Party, and an acclaimed historian. ${ }^{120}$ In the context of a broad spectrum of musings about the future of Germany, Treitschke offered an interpretation of the rabble-rousing activities of the anti-Semites which was perceived by proponents and opponents alike as an unprecedented endorsement of a hitherto relatively insignificant movement.

Treitschke's statements on what he calls a "passionate movement against Judaism"121 are a strange mixture of truths, half-truths, rumors, and covert and overt invective. The tenor of the text surprised Treitschke's contemporaries, especially since it gave no clue as to why its author had overcome his "inevitable disgust" aroused by the elements of "dirt and vulgarity" enmeshed with "this eruption of a long contained anger" (op.cit., p. 7). In a study on Treitschke and his period, Hans Liebeschütz characterized the evolution of his political and religious world view as a shift from a secular, even anti-religious and democratic historicist stance to an embrace of the Christian religion and a turning to a political ideology that endorsed monarchism and the idea of a Christian people. Seen in this light, Treitschke's interpretation of the antiSemitic movement loses much of its apparent crudeness, and it is with respect to such underlying fundamental issues that Cohen chose to respond to it. ${ }^{122}$ Cohen was alone among the many respondents to Treitschke who tried to meet him on the highest possible moral and intellectual grounds; a strategy which gained Cohen few friends and turned former friends into foes. It also helped to inaugurate the opinion that Cohen harbored a life-long naive German nationalism that blinded him to the best political interests of the Jewish community.

\subsubsection{Cohen's "Confession"}

This is the first text on Judaism Cohen published under his name. ${ }^{123}$ Franz Rosenzweig later deemed it to rank "among the most brilliant ever

119 "Unsere Aussichten" in Preußische Jahrbücher Nov. 1879, reprinted in part in Walter Boehlich (ed.), Der Berliner Antisemitismusstreit, Frankfurt: Insel, 1965, pp. 5-12; quote on p. 5.

120 On Treitschke see Hans Liebeschütz, Das Judentum im deutschen Geschichtsbild von Hegel bis Max Weber (Tübingen: Mohr, 1967), chapters 5 and 6.

121 "Unsere Aussichten" in Boehlich, op.cit., p. 5

${ }^{122}$ Liebeschütz, op.cit., p. 182 note 46 , refutes Boehlich's reduction of Treitschke's motivation to a psychological one.

${ }^{123}$ Ein Bekenntnis in der Judenfrage, Berlin: Ferdinand Dümmler, 1880. The same house had also published Cohen's previous philosophical works and was also the publisher of Moritz Lazarus' reply to Treitschke, Was heift national? (1880). The sketches of the two letters Cohen wrote to Treitschke before this publication are mentioned in Bruno Strauss's edition (o 2, 470 and cf. Rosenzweig, "Einleitung" J 
written by Cohen." 124 In the form of an open letter, he focuses on the religious aspect of the discussion triggered by Treitschke and assures him that his own thoughts on religion are not formulated ad hoc.

The background of the whole affair leading up to this publication is important inasmuch as it sheds light on Cohen's rhetorical posture, which determines the scope and nature of the religious confession he makes on this occasion. The peculiar pathos of the author (opening with a statement implying the necessity to accept the old burden of martyrdom "Es ist also doch wieder dahin gekommen, daß wir bekennen müssen" and concluding with the Latin formula "dixisti et animam meam salvavi") impressed both his Jewish readers as well as Treitschke. However, Cohen's attempt to rescue or recreate the common ground between Germans, Jewish and Christian, was unsuccessful. Treitschke ignored Cohen's request to publish his first open letter (a predecessor of the Bekenntnis written on December 13, 1879) in the Preußische Jahrbücher, effectively denying Cohen the symbolism of a discussion between enlightened academic equals. Instead of publishing Cohen's letter, he merely mentions it as an expression of someone irritable who nevertheless "means well." ${ }^{125}$ Cohen's subsequent publication of a revised version of the letter prompts Treitschke ${ }^{126}$ to agree with Cohen on the point which most irked the latter's Jewish readers, namely his presumed concurrence with the demand for the Jews to fully assimilate, as if the Jews were the only deviating group in an otherwise homogenous nation-state. ${ }^{127}$

The Bekenntnis failed to convert Treitschke and it did not comfort Jewish readers either. In December 1879, while some responses were already being drafted or awaited publication, Ludwig Philippson's journal called upon Jewish academics and politicians to respond to

1, XXVIff) and the actual letters were published by Helmut Holzhey, "Zwei Briefe Hermann Cohens an Heinrich von Treitschke" in Bulletin 46-47 (12. Jahrgang/1969), pp. 183-204. The originals were preserved among Treitschke's papers (Deutsche Staatsbibliothek Berlin); cf. Holzhey, op. cit., p. 186. In the same context, Cohen also wrote to Ludwig Philippson. This letter is here published for the first time (below in the Appendix).

${ }^{124}$ Rosenzweig, "Einleitung," J 1, XXVI.

${ }^{125}$ Heinrich von Treitschke, "Noch einige Bemerkungen zur Judenfrage" (January 10, 1880; Boehlich op.cit. p. 77f): "ein jüdischer College an einer kleinen Universität hingegen, ein wohlmeinender Mann ... spricht mir die Hoffnung aus, es werde der beleidigende Name Jude ganz abkommen und künftig nur noch von Israeliten die Rede sein." This is a response to Cohen's letters, not to the Bekenntnis which had not yet been published.

${ }^{126}$ Preußische Jahrbücher, Febr. 1880, p. 225, quoted in J 2, 471.

${ }^{127} \mathrm{Cf}$. Ludwig Philippson, Review of "Ein Bekenntnis in der Judenfrage" in AZdJ 44 Nr. 10 (March 9, 1880), p. 149. 
Treitschke's insinuations instead of leaving the defense to rabbis like himself. ${ }^{128}$ Cohen concurred with Philippson and expressed his appreciation of this initiative in a personal letter. ${ }^{129}$ Yet when his own publication appeared it set itself apart from others not because it tried to raise the level of the discussion but because it was not perceived as a polemic at all. ${ }^{130}$ Cohen wrote in a tone which differed from all of the Jewish authors who had previously taken up the challenge. In his Bekenntnis Cohen criticized two prominent Jewish scholars and historians. He took issue with Graetz's view of modern Jewish history ( $\mathrm{J}$ $2,86)^{131}$ and disagreed with Lazarus' characterization of nationality (ibid. $81 \mathrm{ff}$ ). Such criticism violated the tacit rule of prudence that, when attacked by "them," one was expected to display solidarity. Instead of his Jewish solidarity Cohen invoked his "official duty to teach the academic youth about problems which are not religiously indifferent." The standpoint Cohen chose was that of a national religious duty, the perspective not of "the spokesman of a Jewish party but as the representative of philosophy at a German university and a confessor of Israelite monotheism" (p. 74). From this vantage point the insult dealt to the Jews was their categorical exclusion "from the hope" to participate in "a 'purer form of Christianity" (ibid.). But it was news to his Jewish readers that they had hoped for any such participation. The state was to remain religiously neutral; any religious preference was an unrepublican and undemocratic act of discrimination, and Christianity had no higher claim to leadership in modern culture than any other religion.

Instead of defending Jews and Judaism from the charge that they, more than anyone else, needed to increase their readiness to merge with the Christian majority in customs and ideas, Cohen endorsed a scheme of religious convergence based on mutual indebtedness of Christians and

${ }^{128}$ Korrespondentenbericht (Dec. 25,1879 ) $A Z d J ~ 24 / 1880$, p. 22 f. By that time, Lazarus had already given his lecture ("Was heißt national?" Dec. 2, 1879), but not published it, while Cohen had sent an open letter which Treitschke did not publish. Heinrich Graetz, the main target of Treitschke's invectives, responded twice. Others who responded were the historian Harry Breslau and the politicians Ludwig Bamberger and H.B. Oppenheim. The most curious defense came from an unexpected source, the theologian Paulus Cassel, a convert whose tract was perceived as a poorly camouflaged missionary sermon. Manuel Joël's response, although one of the earliest and strongest, was "only" that of a rabbi. See the (incomplete) lists in Boehlich, op. cit., p. 265f, which could be easily augmented from the contemporary journals.

${ }^{129}$ See here in the appendix.

${ }^{130}$ Cf. Philippson, op.cit., p. 148.

${ }^{131}$ Graetz's anti-German and anti-reform positions were equally rejected and declared as unrepresentative for German Jews by Philippson and others. Cf. $A Z d J$ 24/1880, p. 20. 
Jews. In the view of Philippson and others, Cohen strove for an illicit and unrealistic merger of Judaism with an idealized German religion, which could only be understood as implying a fusion with the actually existing Protestant church, an aspiration that was heretical and unacceptable to his fellow Jews. Cohen's defense, Philippson insinuated, was grounded in the fact that, as a man of conscience, he could no longer "defend German philosophy, German theory of cognition and German ethics" were he to encounter "irreconcilable differences." 132

In this insinuation, however, Philippson simply restated what Cohen himself had written. The difference between their positions lies in the fact that Philippson assumes there will always remain irreconcilable differences while Cohen seeks to ascertain the common cultural foundation of Jews and Christians in a society in which religion plays an increasingly divisive role. While the liberal ideal of 1848 was still championed by the left wing of the National-Liberal Party (the ideal, namely, of the constitutional state; Rechtsstaat), Treitschke-in his later years-turned to the ideal of a Christian people. Cohen, however, did not argue for a separation of church and state and defend Judaism on the basis of constitutionalism. He sensed the change in the political mood of the time, swinging from a liberal concept of the state to a more conservative and religious one.

The Christian foundation for the state that Treitschke and the right wing of the National-Liberal Party were beginning to champion was an answer to the rift in Germany that had opened when Bismarck united Germany under exclusion of the Catholic countries of the AustroHungarian Empire, and widened in the wake of the Kulturkampf. As a result of the leveling of the formerly emphasized differences between Catholics and Protestants the Jews were brought into relief as the only true outsiders. Treitschke had initiated nothing less than a new Kulturkampf which, this time, turned against the Jews.

In 1880 , this strategy was still quite unconventional. The contemporary public was surprised by the direction and intensity of Treitschke's charges against the Jews, not least because, until that time, Treitschke had not been known as a champion of the Christian state. Accordingly, all first reactions to his rather clumsy attempt to extract a valid message from the anti-Semitic events on which he comments zeroed in on the obvious exaggerations and unsustainable inferences from an alleged Jewish domination of the press, the massive immigration from the East, and the character differences between Ashkenasic and Sephardic Jewry.

132Philippson, op.cit., p. 161, and see Cohen's language in the letter to Philippson where he calls Graetz' attitude undeutsch. 
In his first letter Cohen hopes to persuade Treitschke to distance himself from the anti-Jewish agitation. He assumes that Treitschke cannot possibly want to lend his authority to a reactionary trend in the development of religion. ${ }^{133}$ In a captatio benevolentix Cohen observes an analogy between recent anti-Semitic rhetoric and the "Hep! Hep!" riots of 1819 and is confident that Treitschke would not want to endorse such an expression of political reaction. ${ }^{134}$ Cohen draws out the ramifications of the anti-Semitic movement in order to move Treitschke to change his mind and recant.

\subsubsection{Culturally Speaking, We are all Christians ...}

\section{a) Context}

Cohen's Bekenntnis deserves detailed attention for two reasons. First, there is Rosenzweig's assertion of the importance of this text, both in its own right and in Cohen's intellectual biography. Compared to the anonymous essays that we looked at above, however, the Bekenntnis contains nothing substantively new. ${ }^{135}$ However, in this and in other texts of the same period-a period of transition to an increased public involvement in writing and speaking on Judaism and religion-Cohen begins in earnest the work on a clarification of his understanding of the cultural and political relation between Judaism and Christianity within the nation state. Writing a text in which he publicly declared his hitherto private views on religion was a political act. It was also a necessary act if he was to retain his intellectual and religious integrity. Circumstances forced him to reveal-perhaps prematurely, in his own perception-and thus to shape his views on religion and nation (not identical with church and state), Judaism and Christianity.

The second reason why I find this text intriguing and extremely relevant for this study is the following: beginning in 1892, Cohen adds the idea of Versöhnung to the stock of permanently relevant ethical ideas discovered by the biblical prophets. With the discovery of the moral self in the individuality of culpability the ground is laid, according to Cohen, for the development of the idea of ethical autonomy. (See below.) Here, in 1880, however, it is not the biblical prophets but the Christian dogma of incarnation that is credited with the very same merit, namely with

${ }^{133}$ Letter, Marburg, Dec. 13, 1879, in: Holzhey, op.cit., p. 195.

${ }^{134}$ Cf. ibid., p. 197.

${ }^{135}$ Rosenzweig saw the "decisive event in Cohen's intellectual development" in the statement that "the two ideas of the spirituality of God and of the messianic promise had found each other" and that they "both grow from each other," a clear precursor of the later concept of correlation. Yet, as Rosenzweig also admits, this idea does not play a major role in Bekenntnis. Cf. "Einleitung," p. XXVIII. 
providing the basis for the idea of autonomy of the moral law in a way in which it had not been developed within Judaism. In 1880 Cohen states a dependence of Jews on Christianity in cultural terms; in subsequent writings, however, the relation is reversed and Judaism is recognized in its originative cultural value.

The analysis of the position on religion which Cohen presents in Bekenntnis in der Judenfrage can, therefore, focus on a few fundamental statements which Cohen advanced only in the final version and which are absent in the earlier letters to Treitschke. In Bekenntnis, the central issue is the Jew's relation not to Judaism (which has not been called into question; although the ethical value of Judaism has been called into question) but whether a Jew can have any inner agreement with a culturally purified, demythologized Christian faith which was to be the ground for the unity between the Christian majority and the Jewish minority. The classical challenge to Jews since Dohm and the discussions leading to emancipation (e.g., in the French Assemblé Nationale in 1791) had been whether Jews posed a threat to the nation because of their representing "a state within the state." Now the challenge is renewed in Treitschke's criticism of Graetz, whose anti-German attitude he holds to be representative of the attitude of the majority of German Jews-a claim unanimously rejected by all Jewish reviewers, including Cohen. Yet the charge is also recast and thus requires a different answer. Given his different kind of religion, can a Jew be a full and loyal equal within the Christian Volksgemeinschaft?

The theme of religion had been introduced into the discussion by Lazarus (in Was heißt national?). Treitschke's response ${ }^{136}$ made Cohen feel that "the basis for the most stubborn and entreating urge for understanding has finally been eliminated" and that "to testify had become a duty in the religious as well as in the national sense." (J 2, 74) The possibility of invoking a national duty also indicates a change from earlier situations in which the Jewish attitude towards their Christian fellow citizens was questioned. Here not only emancipation but assimilation is already a fact and the idea of a common basis in the state serves as the possibility of a common ground. Treitschke's and similar attacks are therefore typical for anti-Semitism as a post-emancipatory phenomenon.

Lazarus had claimed that the essence of national cohesion consisted in the feeling of unity. ${ }^{137}$ Treitschke retorts that Lazarus failed to indicate

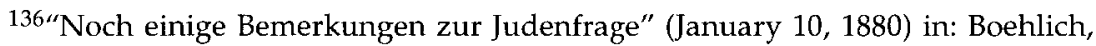
op.cit., pp. 77-90.

${ }^{137}$ Cf. Boehlich, op.cit., p. 85. 
how this feeling of unity was possible if the "religious feeling was completely different."

But although he speaks with eloquent pathos about the meaning of religion he does not address the difficult question how a consciousness of unity [Bewußtsein der Einheit] is possible when the religious feeling is completely different. ${ }^{138}$

For Treitschke, Judaism is "the national religion of a tribe originally alien to us which tends naturally towards defense rather than towards conversion and is therefore essentially limited to the members of the tribe."139 The religious development of Judaism had not been influenced by German culture, and its ideas, to the extent that they had not passed into Christianity, were entirely irrelevant for the state and for the morality of its population (cf. ibid.). Therefore, while Christiansnotwithstanding their interdenominational quarrels-must not give up hope of an eventual realization of unity on the basis of "a purer form of Christianity," 140 Judaism represents a different religion (not merely a different Konfession, i.e., Bekenntnis) and will remain an exception in Western Europe, a negligible minority.

All these and similar claims amounted to a total separation of the cultural history of Judaism and Christianity in Europe and to a reduction of the antagonism between Catholicism and Protestantism from its true historical dimensions to a format that made possible a reconciliation of the warring parties within the realm of the German nation state, while excluding the Jews from such a reconciliation. The brutal nature of this attack was not sufficiently counterbalanced by the assurance that no one in his right mind would want to revoke legal emancipation.

Cohen argues with Treitschke not by resorting to the liberal safehaven of the Rechtsstaat but by addressing the question of religious values. With Kant, ${ }^{141}$ he differentiates between Religion and Glaubensart and claims that with respect to the "scientific concept of religion" he can

\footnotetext{
${ }^{138}$ Ibid., p. $85 f$.

139“(D)ie Nationalreligion eines uns ursprünglich fremden Stammes, seinem Wesen nach mehr zur Abwehr als zur Bekehrung geeignet und darum auch wesentlich auf die Stammesgenossen beschränkt." lbid. p. 86. This quote can be called classical in its mimetic character: anti-Semitism charges the Jews with exactly the attitude itself displays in the moment of charging the Jew.

${ }^{140}$ Ibid., p. 87.

${ }^{141}$ I have not found the source of the quote but statements on religion similar to the one Cohen quotes $(\mathrm{J} 2,83)$ can be found in Religion innerhalb der bloßen Vernunft (cf. Malter (ed.) Stuttgart: Reclam, 1974, 134 and 139f).
} 
find "no difference between Israelite monotheism and Protestant Christianity." 142

The "representative of philosophy at a German academy and confessor of Israelite monotheism" seeks to restore the educated and enlightened consensus among those who ought to share the common "national attitude which is filled with the intellectual content of the national culture" (ibid.). Intellectual (geistig) does not mean non-religious but replete with the responsibility to extract the ethically valuable ideas from the historical heritage necessary for the advancement of civilization.

In order to reappropriate historical religious ideas in an ethically responsible way, the intellectual content of these ideas had to be identified-a problem of intellectual history (Geistesgeschichte) dealt with by all historians since Hegel. ${ }^{143}$ There had to be fundamental agreement on this score among those academic citizens responsible for the education of the people and entrusted with the teaching of matters which were not religiously indifferent. ${ }^{144}$ If, on the other hand, one supported the reactionary religious trend, a trend which contradicted all better religious impulses, one cut oneself off from the modern educated consensus. ${ }^{145}$

Cohen outdoes Treitschke when it comes to religion. He claims that the problem of religion in the battle for the integration of the disparate groups of German society was not that there was too much of it and too close an association of church and state but that there was too little genuine religious enthusiasm, without which no new historical epoch could be initiated. ${ }^{146}$ Moreover, if the religious foundation of the new nation were not cared for and developed on the idealistic basis described above, the result would be continued divisiveness and the kind of favoritism shown by the Prussian administration, which disenfranchised Catholics and Jews and prevented religion from playing the unifying role in the development of the nation which Cohen meant to assign to it (see $\mathrm{J} 2,78$ and 94$)$.

142 "Vor Männern von religiöser, protestantischer Gesinnung, vor Männern einer nationalen Gesinnung, die von dem geistigen Inhalt nationaler Kultur erfüllt ist, wage ich zu bekennen: daß ich in dem wissenschaftlichen Begriff der Religion zwischen dem israelitischen Monotheismus und dem protestantischen Christentum eine Differenz nicht zu erkennen vermag" (J 2,75).

${ }^{143}$ Heinrich Graetz-the one teacher in Breslau with whom Cohen did not get along-was perhaps the first to raise this methodological problem for Jewish history. Cf. Liebeschütz, Das Judentum im deutschen Geschichtsbild, pp. 138ff. Also cf. Rosenzweig, "Einleitung," J1, p. xxviii.

${ }^{144}$ Cf. J 2, 74.

${ }^{145} \mathrm{Cf}$. J 2, 93. In the second letter (Dec. 27, 1879) Cohen still counted Treitschke among "wir Gelehrte" (Holzhey, "Zwei Briefe," p. 202, and introduction, p. 186).

${ }^{146}$ Cf. J 2, 78. 
The legal character of the state was non-negotiable, and where Treitschke had questioned the principle of the Rechtsstaat, Cohen opposed him with no less determination than any other of Treitschke's opponents. Emancipation, he says, although something to be grateful for, should nevertheless not be regarded and upheld as a gift but as the expression of national maturity. ${ }^{147}$ Yet even legal emancipation was endangered by a re-primitivization of religion if religion was made an obstacle to full integration. The discrimination against Jews forced them to betray the very principle which was supposed to provide the ground for equality and acceptance into the society.

Cohen provides an alternative which was to allow not only for the development of a common religious culture of the people but also for the preservation and advancement of distinct historical traditions. The common religious foundation was something every citizen should share if he wanted to belong to the people, while the pedagogical and scholarly aspects of the historical development of the denominations was to aim at strengthening that very same common religious bond. (Ibid. p. 78)

The projected convergence of Christianity and Judaism in the process of developing these Glaubensarten towards the ideal Kulturreligion gains its plausibility and appeal by a kind of historical demonstration of the fact that this development had already been on the way, namely in Protestantism (since Luther) and in the process of Jewish reform (since Mendelssohn). (Ibid. p. 79) The cross-fertilization of Judaism and Christianity on German soil, however, had its ultimate justification not in history but in the ideal contents of both religions, i.e., in their value for the ethical process of civilization. ${ }^{148}$ This claim of a historical crossfertilization of Christian and Jewish culture on German soil is in direct

${ }^{147}$ Cf. ibid., p. 89. Similarly Theodor Mommsen ("Auch ein Wort über unser Judenthum" in: Boehlich, op.cit., p. 221f): "'Von einer Zurücknahme oder auch nur einer Einschränkung der vollzogenen Emancipation kann unter Verständigen gar nicht die Rede sein', sagt Herr v. Treitschke; 'sie wäre ein offenbares Unrecht.' Schlimm genug, daß man dergleichen schon sagen muß!"

${ }^{148}$ The closest model for Cohen's idealization of traditional religion as a function in the process of civilization is that of F. A. Lange in his Geschichte des Materialismus. See "Vierter Abschnitt. Der ethische Materialismus und die Religion," esp. "III. Der theoretische Materialismus in seinem Verhältnis zum ethischen und zur Religion" and "IV. Der Standpunkt des Ideals" (Wohlfeile Ausgabe, Iserlohn and Leipzig: 1887, pp. 786-821 and 821-845). Cohen's great mentor was not only one of the most important initiators of the neo-Kantian movement in general (cf. Köhnke) but also represents a typical approach to the integration of religion into the world view of ethical idealism. At least there was no other non-Jewish philosopher in Hermann Cohen's earlier years with whom he was in such total agreement on the ethical value of an idealized prophetic socialism. Cf. Rosenzweig, "Einleitung," p. xxvf. 
opposition to Treitschke's claim of a total de facto historical separation. Cohen was so convinced of the usefulness of this idea that he reiterated and elaborated it in several essays, all the way down to the much maligned "war-essays" (Kriegsschriften) on Deutschtum und Judentum. ${ }^{149}$

\section{b) Idealization of Judaism and Christianity}

One of the most puzzling aspects of modern cultures is the fact that religions have proved resilient despite all attempts to replace them. Religions were able to survive in part by resisting modernization, in part by becoming one of modernity's motors. Religious thinkers of all stripes often infused the various Enlightenment movements with a pathos and moral energy that resulted from their conviction that true religion (as opposed to this or that religious institution with its corrupted and corrupting exertion of power) was also an authentic expression of the human spirit, no less than science or art. In order to adapt to modernity and its founding notion of the sufficiency of human reason, religious thought utilized the distinction between true and false religion, between institutions corrupted by base human instincts and expressions of the free spirit that lived in religion no less than in other works of genius. It could adopt this distinction between true and false with added facility because it was already at home in Western religions. It is part of the founding myths of Judaism no less than of Christianity in general and of Protestantism in particular. For this reason, all Western traditions, including medieval Islam, generated within themselves movements of enlightenment and rationalism. ${ }^{150}$ On the other hand, such movements were limited by the conservative side of the religious political system within which they operated. In traditional societies, enlightenment is a pursuit for members of elites who often write in ambiguous terms in order to avoid censure.

The situation in which Cohen operates indicates, however, that even though the secular modern nation state has provided a different basis for dealing with issues of religion, science, and freedom of expression, the public can nevertheless impose certain restrictions on the religious or philosophical self-expression of those who argue for a more radical realization of the very principles on which this state is founded. The similarity to the traditional situation is striking. As religion is based on truth, so is the modern state. As religious power tends to stand in the

${ }^{149}$ Deutschtum und Judentum. Mit grundlegenden Betrachtungen über Staat und Internationalismus, Gießen: Töpelmann, 1915 [= Von deutscher Zukunft, 1. Stück], second ed. 1916 (= J2,237-301), and "Deutschtum und Judentum" in: Vom inneren Frieden des deutschen Volkes. Ein Buch gegenseitigen Verstehens und Vertrauens. Hg. Friedrich Thimme, Leipzig: Hirzel, 1916, 541-562 (= J2,302-318).

${ }^{150} \mathrm{~A}$ similar argument could be made for non-Western traditions as well. 
way of the pursuit of the truth on which it is founded, so the modern state tends to limit the range of freedom and thus of the very notion whence it derives its legitimacy.

Moses Mendelssohn was the first Jewish author who entered the maze of writing and publishing in a secular enlightenment spirit in a situation where religious censorship was enforced by an irreligious state. In him we find already assembled all the dichotomies and contradictions that are so typical for this age of transition. He encouraged the Hebrew enlightenment movement (Haskalah), which was concerned with introducing secular knowledge and taste into the ghettoized world of Judaism, but he also argued that, ideally speaking and with the right care, Judaism is itself a particular tradition of cultivation superior to the Christian one. Of course he could not argue so openly. He was forced to write his only treatise on religion, Judaism, or On Religious Power, by a public challenge to defend the rational character of Judaism or convert to Christianity. But he could not defend Judaism, which in the late 18th century was a more difficult task than a century later, without criticizing both Christianity and the secular Enlightenment. Nor could he defend Judaism without idealizing it which means that a truly serious expression of religious thought is really an insult to everyone: to philosophy, to one's own co-religionists, as well as to other religions.

Without being able to avail himself of the arsenal of Kantian critical reason which became the most popular tool of Jewish apologetics in the 19th century, Mendelssohn nevertheless inaugurates a complex logic of defense which is constituted by three factors: the state as an association based on the free decision of individuals, the limitation of religious and political power of coercion, and the reinterpretation of (one's own) religion as an idealizing force in the life of individuals and the community. Without Kant, without a concept of historical development, and without challenging the authenticity and authority of revelation Mendelssohn is able to present a case for a peaceful balance between individual, state, and religious community.

Mendelssohn's grounding of Jewish reform in a rationalist interpretation of the rabbinic tradition of orality, however, was insufficient in the face of 19 th-century historicism. Historicism is not a unified phenomenon. But always at its root is the persuasion that history is the matrix of culture. Whether one believes, with Hegel, that the "spirit" comes to itself by means of a historical dialectics or whether one believes, with Ranke, that each epoch is "immediate before God," Kant and the historicization of truth undercut the Enlightenment faith in a natural religion. The question of cultural value demands an accounting for both continuity and change, and there is little agreement on the 
factors responsible for either one. In the Kantian and Fichtean tradition where the "spontaneity of the intellect" is seen as the first cause of knowledge, inventiveness and ingenuity account for change. But what is it that provides continuity and stability in the progress of humanity and who is the substantive carrier or agency of this continuity? It could be institutions such as law or the state. Hegel and Cohen are equally drawn to this objective solution to the problem of continuity. Or it could be a similarity of feeling among human beings that causes the formation of communities in which certain historical forms of religion or culture are perpetuated. Schleiermacher could be named as the inaugurator of this Pietism-inspired model. Where Hegel believes in ecclesiam, Schleiermacher believes (at least on an intellectual level) in ecclesiolam in ecclesiam. It is not difficult to see the change in the mind of Treitschke and other former liberals as a switch in the determination of the agency of continuity from the idea of a voluntary and commonly human interest in mutual beneficence to a quasi-material grounding in the cultural substance of a people, here conceived as warranted by a common religious heritage.

In Ein Bekenntnis, the ideas of religion have a practical moral purpose and their adoption into the canon of moral ideas shared by a coexisting culture depends on moral considerations and is controlled by scholarly and pedagogical principles. The interesting twist, however, is that only if, and in so far as, religions have contained such ideas have they exerted an ethically meaningful function in the development of culture and deserve to be preserved and furthered in the context and under the principles of a modern consciousness. The essence of an historical religion and of the moral tendency revealed in its secularized modern ethical potential are identified with each other. As much as this seems to be a "scientific concept" of religion in which Cohen cannot perceive a difference between Israelite monotheism and Protestant Christianity (J 2, $75)$, it ultimately rests on a mandate of political responsibility.

This political article of faith can be formulated as follows. The state and its organs (especially those entrusted with research and education) are responsible for the development, flourishing, and peaceful coexistence of the citizens. Such flourishing and coexistence depend not only on social justice (through equality before the law, equity of chances for the individual pursuit of happiness, etc.) but also on the development of a common national culture, including the gradual convergence of religious traditions capable of embracing common ideals, including the religion of a minority. A scholarly and pedagogical (including journalistic) treatment of religions is always to be conducted so as to serve the above purposes. 
It is obvious that, in Cohen's view, Treitschke had violated this educational mandate. However, the deeper challenge was elsewhere, namely in the disagreement on whether Judaism was capable of embracing the ideals set forth in the common creed of German liberal nationalists. Although liberal Protestants no longer believed in a literal rejection of the synagogue, supersessionism was still in full swing. Judaism continued to serve as a tradition overcome by its successor, perpetually proving the superiority of the latter, in this case of Protestant Christianity as the "absolute religion." By definition, Jews who walked and talked like modern men should be Protestants at heart and should have shed their Judaism. Those clinging to the religion of their fathers demonstrated an inherited obstinacy which prevented them from full acceptance into the society. Since emancipation had already been granted, the charge against the Jews becomes inquisitory. It is directed against the inner authenticity and personal dignity of a whole group of citizens; it concerns not the service of the limbs but the duties of the heart. This insinuation of an incongruous interior and a foreign mentality is continuous with pre-emancipation anti-Judaism in the Christian source and phraseology of the charges. But it is aggravated by the fact that now the individual Jew is seen as completely tainted by a communal culture that is resistant to integration.

Cohen's idealization of both the Jewish and the Christian creeds tries to overcome the apologetic situation in a quasi-Pauline move. Just as the apostle transcended the historical dichotomy between the special revealed law of Moses and the natural revelation in the hearts of men (of the Stoa), just as he envisioned the unity of Jews and Greeks on the basis of the cancellation of both tradition and wisdom in the word of the cross, Cohen sought the resolution of the millennial conflict between Judaism and Christianity in the tertium of an intellectual synthesis, in the philosophical and religious world view of the modern nation state.

This synthesis is not simply a formal but also an historical one. The vindication of either Judaism or Christianity in the modern state cannot consist in the application of the religious forms of prayer or sermon to the purposes of the state (e.g., in special Jewish or Christian prayers and sermons for the well-being of the Kaiser, or special services in times of war). On the highest level of reflection the question was identical for Jews and Christians, namely by virtue of what content did the specific religion contribute to the conception of the modern state. This contribution was to be twofold, namely historically as the origin of an idea leading to the modern state and its societal achievements, and pedagogically by continuously encouraging and sustaining the pursuit of this particular idea. The goal is the mutual enhancement of religion and civic development. 
The historical creed underlying such reflections is the assumption that both Judaism and Christianity have actually produced such ideas in their history and-if they are properly kept within rational and moral parameters-are capable of exerting such important civilizing functions at an historical moment when the inner cohesion of the peoples and groups inhabiting an emerging nation or a nation in crisis is called into question.

Cohen employs a wide range of aspects to support the assertion that the actual development of the German nation and the actual development of the Jewish religion have fed on each other and make it possible for Jews to genuinely feel German. The basis for such assertions is a particular view of the history of German nationalism which sees the origins of the construction of a distinct German nationality in the reformation of the 16th century, and its culmination and fulfillment in the establishment of a nation state headed by a Protestant sovereign. The inner development of "Israelite Monotheism with its single dogma of the Unique God" —especially in Germany-had "unmistakably" proceeded in an alliance with "the Protestant kind of religious culture" (J2, 79).

All assertions of this kind are, however, auxiliary to a characterization of the ideal contents of Judaism and Christianity. Idealization, based on a "deeper historical interpretation of the religious problems," is to unveil, or construe, the two religions as complementary. Israelite monotheism is here determined by two ideas: "the spirituality of God and the messianic promise." The former concerns the "essence of God," the latter "the historical task" of a "moral ideal of humanity" (J 2, 75). "Both," as Cohen continues "emerge from each other" (ibid.). This article of faith is the only one Judaism unambiguously embraces: in a nutshell, ethical monotheism. Cohen supports the universal ethical implications of the monotheistic creed from Jeremiah 10:10, a verse whose context he characterizes as a "Shakespearean ironization of the living God taking place in the fine arts" (ibid. 75f). This alludes to the prophet's pouring out his scorn over the worship of hand-crafted idols, juxtaposing these objects of worship with the totaliter aliter of $\mathrm{YHWH}$ as the true God: "he is the living God and an eternal king; the earth trembles from his wrath and the peoples cannot endure his anger" (Jer. 10:10).

The choice of prooftext is deliberate and rests on a well known liturgical usage of the verse. Cohen's reference to "God, who is the truth" is based on a musical connection made by the precentor between the end of the third recitation after the "Hear o Israel" (sh'ma yisrael, Num. 15:3741) and the first word of the benediction "True and confirmed" (Emet veyatsiv). The reading from Numbers ends in "I am $\mathrm{YHWH}$, your God" (ani yhwh eloheikhem). Read without interruption and combined into the 
one sentence that is spoken aloud at this point while the rest is read quietly, it means: "YHWH your God is Truth." According to the Babylonian Talmud (Berakhot $14 \mathrm{a} / \mathrm{b}$ ), it is prohibited to pause between yhwh eloheikhem and emet veyatsiv. This injunction is justified through Jeremiah 10:10, the verse which contains the closest biblical parallel to the phrase created by the liturgical rule. ${ }^{151}$ The same God "Who is Truth" is further determined by a number of liturgical epithets of majesty, indicating a development from metaphysical to ethical implications, corresponding to the universal meaning of the messianic idea. Thus the "king of the universe" (a rabbinic epithet rather than a biblical one) and "creator of all" (boreh et ha-kol, cf. the first benediction before the sh'ma of the morning prayer) becomes the "father of human beings who, at the end of the days will collect all his children, as One shepherd his flock." The father-title as such is commonplace in the Bible $\mathrm{e}^{152}$ and is found in rabbinic and liturgical contexts as well. The closest parallel to the phrase "father of men" is found in Malachi 2:10 "Do we not all have but one father? Has not one God created all of us? Why do we betray one another, desecrating the covenant of our fathers"). The shepherd motif 153 is likewise prominent in the Tanakh (cf. Ps 23, Isa 40:10f), as is the eschatological phrase, "the end of days."154 As far as I know, however, the literal origin of "Ein Hirt seine Herde" is the New Testament, where it occurs in John 10:16. It seems as if Cohen intended to tie the development of early Christian theologumena to the development of the Jewish religion and its essential ideas, instead of adhering to a dogmatic boundary obfuscating historical continuities for ideological reasons. This historical blurring of the dogmatic boundaries was perhaps intended to add to the argument that there have always been more intricate connections between Judaism and Christianity than the dogmatists on either side care to admit and that the historical conscience has a different account of the religious history than have those concerned with keeping their faiths apart. In other words, such a conflation of sources advocates the idea of a historical continuity between Christianity and Judaism which-as long as they affirm their respective religions-should force them to recognize the common ground.

But such an account seems to do little or nothing to help the Jewish reader to find much in his own tradition which is not also present in Christianity, which is what Treitschke had claimed. Even a religious

${ }^{151}$ Cf. Elie Munk, Die Welt der Gebete. (Basel: Victor Goldschmidt, 1975), vol. 1, 140f., where kabbalistic interpretations of this ruling are cited.

${ }^{152}$ Cf., e.g., Deut. 32:6, Isa 63:16, 64:7, Jer 3:19, 31:8, Ps. 103:13.

${ }^{153}$ Also cf. Aristotle, Nicomachean Ethics 1161a 10ff.

${ }^{154} \mathrm{Cf}$. Gen 49:1, Num 24:14, Dtn 4:30, 31:29, Isa 2:2, Jer 23:20, 30:24, 48:47, 49:39, Mic 4:1, Ez 38:16, Hos 3:5, Dan 10:4. 
socialism based on the biblical precedent that the foreigner has equal right of prayer in the Solomonic Temple (cf. J 2, 76, referring to 1 Kings 8:27.41-43) has entered the Christian canon in Jesus' driving the merchants from the Temple.

Finally, Christianity excels in one respect which it develops in a way not fully expressed in Judaism. Cohen uses the most disturbingly mythological and at the same time most central Christian dogma-the incarnation of God in Christ--as the historical idea which laid the ground for a new epoch.

This is the fundamental idea which facilitated the connection of the
modern nations with the Greek spirit, thus generating a new
culture: in the incarnation of God the idea of a relation between
human being and God is internalized, and in the dogmatic form of
the humanization of God it accomplishes the cultural-historical
mission of the humanization of religion. (J2, ibid.)

The essence of Christianity is here not found in the vicarious death and resurrection of Christ, i.e., not in the dogmatic topoi of justification, reconciliation and redemption. Rather, it is found in the "humanization of religion" which is "the"-that is, our modern-"cultural historic mission" which consists in a synthesis of modern ideas and those of Greek antiquity-a synthesis which could not have taken place without the mediation of the Christian religion. The difference between Judaism and Christianity is that Israelite monotheism cannot and does not want to bridge the absolute gap between the divine and the human while Christianity-through the dogma of incarnation-"internalized" (i.e. immanentized? pantheisized?) "the idea of a relation between human being and God."

Where does this leave Judaism? And does this not imply that Judaism is lacking something necessary for participation in modern culture as long as it does not adopt the principles which emerged from a synthesis of Greek and modern idealism with Christianity? And what kind of Christian denomination, one must add, ${ }^{155}$ answers to such a description of its creed?

Cohen continues by spelling out the particular idea he is referring to when he sees as the result of this cultural process the foundation of the program of the humanization of religion. The idea which cannot be understood historically unless through its emergence from the said synthesis is the idea of "the autonomy of the moral law" in the sense of "the freedom of submission under the unconditional moral imperative" (ibid. 76). It is this idea alone which is declared to be the tangible

155Philippson posed a similar question in his review when he asked with which of the Christian denominations Cohen actually intended to merge Judaism. 
foundation of the ideal religious merger, the one foundation which, according to Cohen's idealizing and prescriptive rather than descriptive account, all Germans ought to recognize as their untouchable sanctuary.

\begin{abstract}
This idealistic meaning of morality - what we as Germans honor as the intangible sanctum of Kantian doctrine, where all approaches meet, what we maintain as the most precious treasure of national wisdom and, against all modern nations, as Germanness [Deutschheit] - viewed from the depth, from the intimacy with God, from the fervor of the moral enthusiasm of the prophets, it appears sudden [unvermittelt ]. (lbid.)
\end{abstract}

It becomes abundantly clear that all the apparently apologetic assertions about the inner closeness of Jewish reform and Protestant culture are really not just an historical accident but a kind of Jewish reintegration with the historical process, a step which not only has been already consummated by all "modern Israelites" but which can be commended to all Jews; for not only does it not contradict the essence of Judaism, it eliminates every shadow of a doubt as to whether a full and intimate community between Jews and Germans is possible.

Two practical problems are eliminated by this construction. Jews are encouraged to participate in the creation of a popular unity with their fellow citizens without any mental reservations and without fear of detracting from their religion. Judaism has "but One 'permanent task', i.e. the preservation of monotheism, separately until that 'purer form of Christianity' is achieved, and, once it is achieved, in community with all monotheists" (ibid. 87). This is in opposition to the notion of a Jewish cosmopolitanism that Lazarus made a characteristic of Jewish national identity. Cohen instead advocates the pursuit of a full nationalization of Judaism. On the other hand, as long as such a purer form of Christianity has not been established, as long as Jews are edged to conversion, as long as, therefore, the rather utopian level of religious universalism within a particular state has not been achieved, Jews have not only no cause to abandon their religion but a duty to work for its preservation and idealization. Unity is therefore an incentive for development and cultural work rather than an immediately attainable goal.

The most important point Cohen is making here, however, is the historical abruptness of the idea of moral autonomy from the point of view of biblical prophetic ethics. While "the content of the Kantian imperative coincides with the rigorism of Israelite moral teaching" and while the aggadic tradition "contains sentences which are surprisingly similar to some of Kant's ... nevertheless, the foundation of that imperative, the derivation of the moral law from the concept of legislative reason, this character of autonomy appears-according to our way of conceiving thoughts within historical connections- 
incomprehensible without the christological form of humanizing the divine. This kind of Christianity is shared by all of us modern Israelites whether or not we are aware of it."

While this confession of a Christian faith immanent in all "modern Israelite" consciousness was bound to antagonize Jewish readers, and may have induced Lazarus to write a whole book trying to demonstrate that not only the wording but the principle of autonomy was contained in rabbinic ethics, the next paragraph swings Cohen's dialectical pendulum back to its point of origin. Namely, Cohen denies that a cultural recognition of the world-historic role of Christianity necessitates that one also "confesses the 'gospel of the son of God'." This is so because, just as modern Jews confess an immanent Christian dogma, so too do all Christians attest to the truth of Israelite monotheism as long as they resist the denial of theistic faith which results from either "ethical enthusiasm" or from "a materialist or metaphysical disbelief or speculative fantasy." The affirmation of resistance against such a world view is the center of Israelite monotheism.

For we know that despite all necessary humanization of morality there needs to remain a core of the God of the ancient prophets which remains inaccessible to humanization. "To whom then will ye liken me, or shall I be equal?" In this eternal and not at all merely cosmological core of belief in God all Christians are Israelites. (lbid. 77)

With this reference to the prophet Isaiah (40:25), Cohen exceeds the rationalist limits he had erected earlier and confesses Judaism in a joyfully paradoxical affirmation of God's uniqueness.

\subsubsection{Defending the Ethics of the Talmud (1888)}

The consolidation of the anti-Semitic movement on the German political scene reached its first climax with the election of Otto Böckel to the Reichstag in 1887. Marburg, where Böckel had been a librarian at the university, and its environment had turned into one of the hotbeds of anti-Jewish political agitation. ${ }^{156}$ Political anti-Semitism was not just a local phenomenon, nor was it limited to the borders of the German Kaiserreich. The early 1880s marked a turning point in modern Jewish history all over Europe. After decades of progressive legal emancipation and social integration, which found their most tangible expression in the Congress of Berlin in 1878 and its imposition of emancipation laws on

${ }^{156} \mathrm{Cf}$. Barbara Händler-Lachmann and Thomas Werther, Vergessene Geschäfteverlorene Geschichte. Jüdisches Wirtschaftsleben in Marburg und seine Vernichtung im Nationalsozialismus, Marburg: Hitzeroth, 1992, p. 25 and see the bibliography on Marburg's Jews and their political history ibid. pp. 266-268. Also see Sieg, op.cit. 
the newly independent Romanian state, a Czarist backlash set in, triggering mass migration towards the West and raising new questions about Jewish integration into European societies.

In the face of mounting waves of refugees, dreams and hopes for a return to Zion began to seem more realistic and emerged as a major source of hopeful inspiration. The Hibbat Zion movement (early 1880s) nourished the idea that Jews could once again take their collective political future into their own hands, while for others Zion was to become a center for the spiritual renewal of Jews all over the Diaspora. ${ }^{157}$

In response to anti-Semitism, Hermann Cohen had formulated an idealization of religion which was to be the foundation of a totally different kind of Judaism, a Judaism which was to develop on the trajectory of reform and integration with a majority of Protestants within the German nation state. The focus and framework of his political, ethical and religious thought was the particular state in which Jewish life had to be preserved and developed along with the general aspects necessary for the cultivation of civilization on the basis of a separation of "faith and state." 158 Despite the overwhelmingly negative reaction to his Bekenntnis, Cohen finds several occasions to reiterate and expand some of its views and ideas during the early 1880s and again between 1888 and 1890 .

All the relevant texts of this period share an emphasis on the cultural and political function of religion in and for the specific political situation in which they are written. Cohen follows the hypothetical imperative pronounced by his mentor F. A. Lange regarding the duty of the philosopher to warn against the diminution of religion in a particular society in case such a diminution were a threat to morality. ${ }^{159}$ Yet Cohen's first attempt to openly suggest his own version of the essential religious ideas of Judaism (and Christianity) had transcended Lange's explicit limitation of the task of a philosopher in such matters. As we have seen above, Cohen had earlier voiced his intention of spelling out those ethical ideas of prophetic Judaism which had yet to be absorbed into the general culture. The Treitschke debate gave him the first

\footnotetext{
${ }^{157}$ The roots and precursors of Zionism are much earlier than that, yet they need the right external circumstances and the right amount of inner readiness of a large number of Jewish individuals in order to take hold and to move to concrete action. The gentile world, especially in Great Britain, noted these developments before the 1880 s as well. E.g. the protagonist of George Eliot's (1819-1880) Daniel Deronda (1876) could give Theodor Herzl a perfect model for his own leadership persona.

${ }^{158} \mathrm{Cf}$. review of Ernst Laas, Kants Stellung in der Geschichte des Conflicts zwischen Glauben und Wissen (1882) in: Deutsche Litteraturzeitung, 1883 Nr. 23 (June 9), p. 806.

${ }^{159}$ Cf. Lange, op.cit., p. 779.
} 
opportunity to address a larger audience, and to address it from a vantage point which Cohen characterized as the justification of the possibility of reconciling the educational task of a German professor of philosophy with the faith of someone professing Israelite monotheism.

The responsibility of the academic philosopher Hermann Cohen included the task of conducting the mandatory philosophical examinations for Gymnasium teachers of Hesse-Nassau, including teachers of religion. ${ }^{160}$ In the Maimonidean spirit of "accepting the truth from whichever source it arises" - Cohen writes ${ }^{161}$ - it had to be possible to admit openly that Jewish reform was being conducted in close cultural exchange with the values of a Protestant culture without implying an abdication of Judaism.

Despite the fact that his Bekenntnis caused him to lose important friends, Cohen proceeded in 1881 to publish his 1869 lecture on the Sabbath, augmenting it with a postscript in which he suggests an additional practical step towards the religious merger he had proposed in 1880, namely to move the Jewish Sabbath to the Christian Sunday. ${ }^{162}$ As he expected, however, this suggestion was rejected by the majority of his Jewish contemporaries. ${ }^{163}$ If his objective was to convert his nonJewish contemporaries to a more respectful attitude towards Judaism and to its recognition as a religion equally valid, useful and necessary for the religious education of the nation, there was no indication that he had succeeded. In 1890, he expressed his utter frustration with this situation when he wrote that even "the most well meaning ones deny Judaism the character of a religion" ( 2,345$)$. On the whole, in the decade between 1880 and 1890 , Cohen felt the he was out of step with the times, a radical and dissenting voice. ${ }^{164}$ This changed in 1888 , when Cohen was called upon to testify as an expert before a provincial court on occasion of a libel suit against the Talmud. Here was the first occasion at which the philosopher received widespread recognition as a powerful and reliable defender of Judaism. ${ }^{165}$

${ }^{160}$ Cf. "Zur Vertheidigung" in Der Zeitgeist (Egg Harbor City, N.J.) Vol.1 No.16, 8/5/1880 pp. 256-7 (= J2, 95-100) and cf. Orlik, op.cit., p. 59.

$161 \mathrm{~J} 2,100$.

${ }^{162}$ Cf. J 2, 71.

${ }^{163} \mathrm{Cf}$. ibid. 470 , letter of May 3, 1881.

${ }^{164}$ Cf. "Zur Vertheidigung" J 2, 95 and, similarly, in "Der Religionswechsel in der neuen Ära des Antisemitismus" (1890) in J 2, 345: "in einer Schrift, für welche damals das öffentliche Verständnis noch nicht reif war."

${ }^{165}$ Cf. J 1, 338f where an orthodox Jewish journal is quoted describing the deep impression Cohen's answers made on those present at the court hearing. The text printed in J1, 145-174 was not read in court but Cohen answered freely to "a rapid sequence of questions" (ibid. p. 339). 
In the published version of his testimony, ${ }^{166}$ Hermann Cohen describes his training in the Talmud as the classical compendium of Judaism.

I was already taught Talmud as a boy by my father and I continued the study of Talmud during Gymnasium until my third academic semester so that more than ten years of my youth were partly dedicated to this pursuit. Later I did not study Talmud in a continuous fashion and only opened the old tomes when induced by certain moods. Therefore, I am not a specialist in the sense demanded here and highly desirable for the breadth and certainty of a purely scholarly determination in this field: I do not read the Talmud as a Semitic philologist and specialist in the classics.

Nevertheless, and despite this disclaimer, Cohen was able to answer the "rapid sequence of questions" hurled at him during the session of the court in such a way that for the first time in his life he established himself as a defender not of a particular branch but of Judaism as such. He was able to do so not by means of the elaborate ideal constructions of a modern Jewish faith but by means of an exposition of the literary character and ethical dimension of the talmudic literature, an exposition which excelled in erudition and convinced through lucidity.

While this expert testimony gained Cohen the recognition of the Jewish community, judgment and sentence pronounced by the court in the case of the accused Marburg primary school teacher who had slandered the Talmud were so mild that they only increased Cohen's sense of frustration. In his first letter to Treitschke (Dec. 13, 1879), Cohen had expressed the fear that an "old sense of unease" may be rekindled among those Jews who wished for nothing more than complete integration. The Bekenntnis pronounced that such "alte Beklommenheit" had indeed been reawakened. In 1888 Cohen expresses this feeling less dramatically but perhaps all the more intensely.

Then, on April 25, I invoked the so-called science for the first time in my life and, since the judges seem to think it more comfortable to question me than to study my expert opinion and have it read in public, I answered to the judges in a defense that lasted $11 / 2$ hours, which some newspapers reported with the utmost lack in precision. Then came the pronouncement of the verdict with a preliminary presentation of the findings. Very perturbing. The court decides in no way on the inner reliability of the two expert opinions-my colleague Lagarde in Göttingen professes himself an anti-Semite

${ }^{166}$ See Ulrich Sieg, op.cit., pp. 223-247. The text of Cohen's statement was first printed in response to the fact that Paul deLagarde had his statement (for the defense) published. See the text in J 1, 145-174 and notes ibid. p. 338f. The background, circumstances, and consequences of the court case are described by Sieg, op.cit. 
even in his expert opinion-and fails to use even such an admission. However, I have gradually calmed down again .... ${ }^{167}$

This event most likely had a considerable emotional impact on Cohen. It may be assumed that Cohen's feeling of "unease"reawakened in the course of the Berlin Antisemitismusstreit-grew stronger rather than weaker during this period of consolidation of antiSemitism in German society. As a consequence, Cohen's attitude towards German culture became utopian in the sense that it ceased to be the heartfelt affirmation of actual characteristics inherent in the normal social experience. ${ }^{168}$ Whatever Cohen writes on the affinities between Germans and Jews is, from this point on, an expression of idealizing intentions and political responsibility rather than of his immediate feeling.

\section{3 "The Messianic Idea" (1892):}

\section{Ideal of World-History and "Touchstone of Religion"}

Two essays, one on the idea of Messiah and the other on the idea of Versöhnung, mark the end of the first and the beginning of a second phase in the development of Hermann Cohen's understanding of Judaism, Christianity, modernity, and religion. The second essay, Die Versöhnungsidee, is of particular importance because it reflects a fundamental shift in Cohen's view on the historical relation between Judaism and the notion of moral autonomy which, according to Bekenntnis, was mediated through the Christian doctrine of incarnation. There, Cohen had presented modern Judaism as culturally indebted to the Christian dogma of the incarnation as the historical origin of the otherwise "abrupt" principle of the autonomy. In the essay on Versöhnung, the Jewish roots of individual culpability and the possibility of restoring the moral character of the individual are demonstrated as emerging within Judaism itself. This intellectual declaration of independence from the historical significance of Christianity indicates the beginning of a new construction of Jewish thought in Cohen's writings.

The form and function of this exploration of a new dimension of "prophetic Judaism" are equally different from those of the texts discussed above. We do not know what the particular occasions were for

${ }^{167}$ Letter to his friend August Stadler (May 16, 1888) in: J 1, 338.

${ }^{168}$ The letters published by Helmut Holzhey $1986 / 2$ contain ample evidence that the "Anti" (i.e., anti-Semitism) was a threat Cohen increasingly sensed behind any adversarial uttering from any non-Jewish person. There are also passages demonstrating that Cohen's idealization of German culture was just that, a conscious idealization which, by 1916 (i.e. after the infamous Judenzählung), was totally devoid of emotional content. 
Cohen to compose the essays on Messiah and Versöhnung. For us, they represent a kind of record, a documentation of the changes Cohen's religious philosophy was undergoing. Perhaps this is the reason why they remained unpublished during his lifetime. 169

The editor of Hermann Cohen's Jüdische Schriften (1924) published the two essays "Die Messiasidee' and "Die Versöhnungsidee" for the first time (in the first volume, with the subtitle: Ethische und religiöse Grundfragen). In his notes, Bruno Strau $\beta^{170}$ mentions that the manuscripts were among a number of hitherto unpublished lectures from different periods. "Die Messiasidee" has as its date of composition "presumably February 1892" (J 1, 338), "Die Versöhnungsidee" is dated even more vaguely ("presumably beginning of the $90 \mathrm{~s}^{\prime \prime}$ ). However, on the basis of a comparison of the essays with each other, with manuscripts on Versöhnung from the Natorp archive, as well as with subsequent writings it will be quite evident that the relative date is accurate and that "Versöhnungsidee" was most likely written sometime in the early to mid-1890's, after "Messiasidee." 171

The essay on the messianic idea is interesting in two respects. It summarizes nicely the moral content of Judaism as it appears in Cohen's early writings and continues to be maintained throughout his work. The value of the messianic idea, as presented in this text, is continuous in Cohen's thought. But the essay also shows that Cohen must have developed his understanding of the doctrine of atonement after this composition. The essay on the messianic idea is therefore a document that marks the end of Cohen's early Jewish thought and the transition to its maturation.

"The idea of Messiah is the hope for the future of humanity" (J 1, 116)-in this thesis Cohen summarizes the ethical foundation of history as an ideal which has grown out of the Jewish tradition. In a beautiful introduction, Cohen identifies hope as the foremost emotion (Gemütsbewegung) which even "the strictest moralists do not deny all right and value." Hope is characterized as a sentiment particular to some

${ }^{169}$ In a letter to his friend August Stadler (May 8, 1886) Cohen once noted playfully that he wanted to write about his view of "the meaning of Christian world history as the idealization of the human in the myth of the incarnation" (Briefe, p. 60f), not for publication during his lifetime but "perhaps for my posthumous works."

${ }^{170}$ Strauß cooperated in the edition with the widow, Martha Cohen, as well as with Julius Guttmann, Santitätsrat Dr. Bradt and Benzion Kellermann. See his "Vorwort" in J1, VIII. On the two essays from the early 1890 s see ibid. p. VI.

${ }^{171}$ These texts have been translated in part by Eva Jospe in Reason and Hope. Selections from the Jewish Writings of Hermann Cohen. New York: W.W. Norton \& Comp, 1971. 
cultures rather than to all humankind at all times. Hope may also serve as the touchstone by which to distinguish idolatry (Götterglauben) and the belief in God (Gottesglauben).

The context of Cohen's meditations on the intricate connection between the biblical understanding of time with its "principle" of messianic hope on the one hand, and the modern idea of "world-history" on the other, may have been considerations about the construction of the systematic ethics. The 1890s are the decade when Cohen worked mainly on the problem of logic, which he gave its definitive form in Logik der reinen Erkenntnis (first edition 1902; LrE). ${ }^{172}$ However, logic with its correlative-the mathematical sciences (mathematische Naturwissenschaften)-represents but one direction of culture. All directions of culture are independent in the generation of their own contents, and the unity of all these directions is the task of the system of philosophy to address. This unity is the unity of the cultural consciousness as the correlative fact of the system ("Bezugs'faktum" philosophischer Systematik"). ${ }^{173}$ Insofar as logic is the basis of the system as a whole, Cohen has to consider not only the construction of the logic of cognition as such but also its consequences for the construction of the humanities. ${ }^{174}$

It should, therefore, not be surprising to find Cohen simultaneously engaged in reflections concerning not only the Bezugsfaktum of logic but also of the other parts of the developing system of philosophy. The second part of the system-Ethik des reinen Willens (first edition 1904; ErW)-was published only two years after LrE. Nor was this the first occasion for Cohen to consider the historical and systematic relation between religious ideas and ethics. This is the basic question addressed not only in the Bekenntnis but also in the "Biographical Preface" to the 1881 edition of Lange's History of Materialism. While Cohen thinks about the construction of his own systematic ethics he also composes essays like the ones from the early 1890 s where he determines the ethical ideas he intends to make cornerstones of the philosophical ethics. The soughtafter unity of the cultural consciousness is construed in close examination of its relation to the biblical Jewish tradition.

In 1896, Cohen gave the emerging system a first expression in a text published as a postscript to a new edition of Friedrich Albert Lange's Geschichte des Materialismus, "Einleitung mit kritischem Nachtrag"

${ }^{172}$ Cf. Helmut Holzhey, "Einleitung" (WW 6) pp. Xv"-xviii*, abbr. LrE.

${ }^{173}$ Holzhey ibid. p. viii*.

${ }^{174}$ Cf. Part II, below. 
$(E m k N) .{ }^{175}$ The philosopher Karl Vorländer deemed this introductory essay "nothing less than a ... new foundation of critical idealism." 176 In it Cohen determines the relation between ethics and religion so that religion is to be "resolved" into ethics. In contrast to the preface of 1881, religion is no longer considered the primary Bezugsfaktum of ethics. Instead, Cohen suggests the historical sciences as the domain in which morally valid cognition is to be ascertained. ${ }^{177}$ In the Ethics of Pure Will finally Cohen settles on law rather than on history as the primary quasiempirical source for the ethical formation of the concepts of will, action, and self-consciousness. In the EmkN of 1896 which, according to our chronology, is composed in close temporal proximity to the essay on Versöhnung however it seems as if religion is to play a very preliminary if not marginal role in the construction of ethics. But this impression may be based on a wrong interpretation of the motto of a "resolution of religion into ethics." What we can state here quite clearly is the following. Firstly, the problem addressed in this motto is the relation not between Judaism and culture but between ethics and religion. Cohen works on both problems at this stage, and gives them such definition that the historical and "eternal" ideas of Judaism are to be justified in the context of a systematic ethics. For the sake of maintaining the claim of ethics to universality the particular historical concepts of Judaism are however resolved into the history of problems that enter into the formation of ethical ideas and concepts. Once they become part of what "we all" should embrace in our pursuit of the Good, they are no longer the exclusive possession of a particular community. As mentioned above and developed further below, Cohen began in the 1890s to identify a direct problem-historical lineage between the sources of Judaism and the principle of autonomy. But one can also reverse the order of this examination. Once the Jewish context and construction of the idea of Versöhnung is clarified, the whole problem of moral autonomy may be seen in a different light based on how it functions within a particular religious tradition.

On the other hand, the relation of ethics and religion that is formulated in 1896 involves a downgrading of religion from cultural fact (Kulturfaktum) to concept-historical origin (problemgeschichtlicher Ursprung), as well as to one among many cultural phenomena considered from an ethico-historical perspective. Such downgrading of religion may have resulted from Cohen's frustration over the divisive

${ }^{175}$ See WW 5, which is a reprint of the 3., enlarged, edition of 1914, with a critical apparatus and an index (by Peter Schulthess) and an introduction by H. Holzhey. 176 See ibid. p. $7^{*}$.

${ }^{177}$ Cf. WW 6 (LrE), p. 495. 
uses of religious difference in the public discourse. The program of a resolution of religion into ethics is not modified until 1914 when, in a further edition of EmkN, Cohen softens the expression from Auflösung (resolution, dissolution) to Aufhebung (sublation, preservation). This is in line with the effort, manifest in the 1915 treatise on religion (Der Begriff der Religion im System der Philosophie), to do more justice to religion vis-àvis the other directions of culture, an effort in which Cohen responds to criticism voiced within his own philosophical circle. Similar to 1880, the 1915 treatise is written with the intention to generate a foundation for social peace between the religious factions. Yet Cohen does not return to a reaffirmation of a Jewish cultural dependence on Christianity. It is here for the first time that the conceptual arsenal established in the 1890's essay on Versöhnung is fully employed in a philosophical assessment of the cultural value of religion that is at the same time a defense of Judaism as religion of reason.

In the essay on the messianic idea the concepts of sin, repentance and atonement are not yet fully developed. They appear in the context of the final third of the essay describing the post-biblical rabbinic elaboration of biblical messianism. Repentance, for example, is merely something taking care of "moral entertainment" (moralische Kurzweil) in the days of messiah when-according to the rabbinic sources quoted ${ }^{178}$-all ceremonial laws will be lifted except for the laws concerning the day of atonement.

Here Cohen also summarizes the Jewish teaching of Versöhnung focusing on its differences from the Protestant one. Its first characteristic is that $\sin$ is a recognized fact of the human condition and its confession an integral moment of Jewish prayer.

The sinfulness of the human being is a factor (Moment) in the moral concept of the human being. It is certainly not absent in Judaism either. ${ }^{179}$

${ }^{178}$ Sanh. 99a, 98a, Nidda 61b, Midr. Qohelet ad 2:1 and ad 11:8; cf. J 1, 120. Cohen's general assessment of the talmudic period is unambiguous during this whole period. He shares the general cultural prejudices of those who had shed the authority of the Talmud. In this essay, for instance, Cohen deems rabbinic messianism a "less brilliant achievement" than that of Philo (ibid. 119).Similarly, in his defense of the Talmud in court, Cohen showed little appreciation of midrashic elaborations. In the 20th century they have found much more appreciation as a literary genre and as a genuine expression of religious thought even and especially among those who-just as their predecessors in the Wissenschaft des Judentums of the 19th century-would not recognize the Talmud as an ultimate religious authority.

${ }^{179}$ Ibid. 121. 
This recognition and self-projection of the human being as a lowly being is a denial of Selbstbewußtsein and, insofar as it is "a moving basic characteristic of our prayers" ("erschütternder Grundzug unserer Gebete"), the confession of guilt removes the Israelite from the world (cf. ibid.). In this respect, Protestant and Jewish understanding agree. The difference, however, is seen in the resolution of the condition of sin. The morality of the Jewish religion consists not only in the "ought" of the moral law, which "seems almost impossible" to fulfill, but also in the other aspect, namely in the basic affirmation that "the good is possible." Sin is merely "preparation" (not in the sense of Luther's usus elenchticus), namely preparation for the "moral task," a term which needs "a clear definition" in order not to endanger the "realizing moment" of morality by cheap "optimism and opportunism." The precondition for this construction is that there is no mediation ("die Erlösung erfolgt ohne Mittler"). ${ }^{180}$ Here Cohen also quotes-to my knowledge for the first time-a passage from the Mishnah which, from then on, becomes a steady refrain, namely Yoma 8:9: "Blessed are you, Israel, who is it that purifies you? And before whom do you purify yourselves?" (Cf. below)

Sin and morality as conditioned by sin are here seen as somehow inherent in a messianism which was gradually universalized within the history of Judaism and changed from a term for the anointed successor to the throne (pre-exilic) to an increasingly idealized and de-personalized idea ("the messianic age"). The argument for "messianism as the pivot and the touchstone of religion" (121f) has two explicit purposes, one pedagogical, the other political. This is in keeping with the program of idealizing religion that we saw at work in the texts from 1880 and earlier. Messianism is to play into religious education in public schools which Cohen suggests should be based on such principles as messianic universalism as the trail-blazer of modern society (cf. p. 122f). The second more political purpose concerns Judaism at the crossroads. Jews have to choose between a universalistic and a particularistic conception of their tradition. ${ }^{181}$ Cohen's stress on the universal character of Judaism and its deeply felt hope for a universal salvation reveals some of its immediate motivation, namely the defense against the insinuation of a yearning of Jews for a commonwealth on earth beyond and outside of their current fatherland. The object of Jewish hope is indeed a Jerusalem on earth and not, mainly or entirely, in heaven.

Of course we yearn for Jerusalem and suffer insult and sorrow for it so all the world shall yearn for such Jerusalem, but not alone or

\footnotetext{
${ }^{180} \mathrm{Ibid}$. and cf. notes from Nachlaß Natorp Ms. 831 (below in the appendix). ${ }^{181}$ The "modern movement" Cohen is referring to is the movement of Hibbat Zion, founded in the early 1880 s.
} 
preferably for the heavenly one but rather for that in which, again according to the Talmud, "the Holy One, Blessed be His Name, shall renew his world." This renewed world is our Jerusalem ... (J 1, 123f).

In this essay the messianic idea has permeated all major ideas and institutions of Judaism, including medieval Jewish philosophy of religion and liturgy (yigdal and alenu), and determined the basic meaning of the days of awe (cf. p. 123). Aside from the aspect of $\sin$ in relation to morality, the essay summarizes what Cohen, until then, considered the basic moral content of Judaism. Yet the issue of sin and atonement is here clearly not yet sufficiently distinguished in its possible cultural value. Hence the essay on Versöhnungsidee must have been composed later. In it, Cohen picks up the thread of the discussion of sin but elaborates the doctrine of atonement into a cornerstone of Judaism in which the universalistic ethical perspective of messianism finds its individual correlate. Messianism and atonement will from then on be the poles keeping the balance spring of religion in motion. This duality will also allow Cohen to distribute the labor of humanization between ethics and religion: ethics will care for the universal problems of human transformation, while religion is the concrete cultural setting where individuals are to experience their own transformation which ethics can only demand but not produce. At the beginning of this construction, however, stands the idea of Versöhnung.

\section{Turning Point: "Die Versöhnungsidee"}

With the essay on atonement from the early to mid-1890's which remained unpublished until 1924 and went unnoticed in its significance for a genetic study of the development of Hermann Cohen's thought until my dissertation (Brandeis University, 1994), we are turning to the core discovery around which Cohen's mature philosophy of religion grew. To do this essay justice, I read it closely and provide ample context and explanation of each and every move Cohen makes in order to ascertain the historical and philological dimensions of a philosophical claim. In this essay which shows Cohen among others as a versatile Bible scholar, the biblical Jewish doctrine of atonement is retrieved as a source of the modern Western idea of autonomy. We shall see in Part II that this discovery has repercussions also for Cohen's philosophical system. More specifically, the idea of atonement is relevant for the ethical concept of self-consciousness. The character of moral self-constitution in the context of Jewish religious practice allows Cohen to establish a new distribution of labor between religion and ethics. The thread of his concept of atonement reaches deeply into the construction of both philosophical 
system and religious philosophy, allowing Cohen to seek a reconciliation of Judaism and the cultural consciousness that maintains the distinction of both in a web of mutual dependencies and cross-fertilizations.

\subsection{Introduction}

Religion, morality (in law and state), and art are the "three main areas of human culture" to which the idea of Versöhnung pertains (J 1,125). As with the messianic idea (world-history) and the Sabbath (social justice; see "Der Sabbat in seiner kulturgeschichtlichen Bedeutung" 1869), Cohen seeks to determine the value of an idea which developed within the biblical culture and which is equally important for the modern Jewish as well as for the general consciousness. The system of meanings constructed in this way does not regard the religious meanings of the idea as a mere thing of the past. Religion ranks not merely as the historical origin of ideas whose validation must be sought in their demythologized or secularized reinterpretations. To a certain extent such idealization of religious concepts still appears reductionist, namely to the degree that religion is absorbed into a broader history of ideas. The program formulated in 1896 seems to indicate such a reduction. Yet, as indicated above, it can also mean the reverse, namely a dependence of generalizing and idealizing cultural values on a concrete historical source.

In addition to the relation of religion and ethics the essay on messianism as well as that on atonement are concerned with the relation of art and religion. ${ }^{182}$ In the case of messianism, this relation is reflected in the possibility of a pedagogical role for art as education towards the love of mankind. However, Cohen rejects this as a distortion of both art and religion $(J 1,122)$. Neither can replace the other.

The idea of Versöhnung unfolds in three sets of relations: between human being and God (religion), human being and fellow human being (ethics), and the human being in relation to herself (esthetics). Despite the disciplinary connotations of these relations with religion, ethics, and esthetics, none of these relations can be exhausted in a single cultural sphere but draw on all of them. While the functions can be distinguished conceptually they are, in fact, inseparable and only when they come together is Versöhnung present (cf. J 1, 125).

Cohen sees a convergence of art and religion as peculiar not only for a contemporary understanding of Versöhnung but for the emergence of moral thinking in general, especially in Greek culture, as can be seen in the history of Greek tragedy. In this view, moral thinking-be it in

${ }^{182}$ This is also the case in several of the manuscripts from Nachlaß Natorp Ms. 831. 
religious/biblical Jewish or dramatic/classical Greek terms-emerges in a decisive cultural advance that unites, synthesizes, and reëvaluates earlier, more disparate and less sophisticated notions in a creative act of reason. This synthetic progress of ideas may be triggered or advanced by cross-cultural encounters. An example for such cross-cultural fertilization in Greek cultural history would be the influence of "oriental speculation" on the development of orphic theology. ${ }^{183}$ In light of the political debates on the Jewish question, Cohen implicitly advocates a hybridization of culture against purity and separation.

The main body of the essay on atonement consists of an exposition of the origin of the idea of Versöhnung in biblical Israel and its development down to the literature and liturgies of the tannaitic period (until ca. 220 $\mathrm{CE}$ ). This historical framework alone indicates, if not a complete shift in Cohen's appreciation of rabbinic literature, certainly a stronger sense of the unity and continuity between the theological ideas of the biblical prophets and their rabbinic reinterpretations. In earlier texts, prayers and liturgical institutions of the talmudic age had at best preserved the ideas of the biblical prophets. Now, the conceptual creativity of the sages is appreciated on a deeper level. ${ }^{184}$

Another innovation is a more intricate conception of the development of biblical Israelite religion. While in "Die Messiasidee" the development from a straightforward political term towards a universal moral idea is described as a gradual spiritualization and delimitization, the development of the idea of Versöhnung is more complicated and is not a linear process. As will be shown in detail, Cohen adopts the basic periodization of Julius Wellhausen's history of Israel, ${ }^{185}$ yet he

${ }^{183}$ The oriental influences on the development of Greek and Roman religion had been documented and described for instance by Friedrich Creuzer (Symbolik und Mythologie der alten Völker, besonders der Griechen, neue verbesserte Auflage, Leipzig/Darmstadt: C.W. Leske, 1842-43) and was a commonplace in classics, the field Cohen had studied both in Breslau and in Berlin. On 19th-century research in classical Greek and Roman religion see Martin P. Nilsson, Geschichte der griechischen Religion vol. 1 [Handbuch der Altertumswissenschaft vol. 2.1].

${ }^{184}$ Cf. Zank, "Hermann Cohen und die rabbinische Literatur," in: Hermann Cohen's Philosophy of Religion. International Conference in Jerusalem 1996 (= Publications of the Franz Rosenzweig Research Center for German-Jewish Literature and Cultural History), ed. Stéphane Moses and Hartwig Wiedebach, Hildesheim/Zürich/New York: Georg Olms, 1997 (= Philosophische Texte und Studien Band 44), pp. 263-291.

${ }^{185}$ Julius Wellhausen was Ordinarius for semitic philology in Marburg from 1885 until 1892 when he received a call from the university in Göttingen. On his significance for Old Testament scholarship see Hans Joachim Kraus, Geschichte der historisch-kritischen Erforschung des Alten Testaments, 3. enlarged edition Neukirchen: Neukirchener Verlag 1982, 255-269 and cf. Hans Liebeschütz, Das 
understands the relation between the periods as steps in a continuous development rather than as an instantiation of historical dialectics. Wellhausen sees the priestly theocracy of the second Temple period as a phenomenon of decline during which the erstwhile popular religion of Israel is forced into the mold of a proto-Catholic priestly institution that dominates through an elaborate sacrificial law and practice. ${ }^{186}$ Cohen presents an alternative interpretation to Wellhausen's "flawed" philosophy of history ${ }^{187}$ while building on the latter's theory of the sources of the Pentateuch. In this reconstruction of the development of Israelite religion he relies, among others, on David Einhorn's Princip des Mosaismus. ${ }^{188}$

Cohen may have regarded Wellhausen's concept of the development of the religion of ancient Israel as an instantiation of vulgar Hegelianism ${ }^{189}$ but he shared with the great Protestant Old Testament scholar the perception that, as Hans Joachim Kraus put it, the "essence of the religion of Israel" was not to be found in any particular one of its periods but in "the development as such-this exciting process of becoming" (cf. Kraus 1982, p. 264). In a late reminiscence, Cohen remarks that Wellhausen was ultimately skeptical towards world-historical questions. The friend and colleague who had left Marburg in 1892 was remembered as a thorough exegete and philologist but not as a philosopher with a deeper appreciation of history. ${ }^{190}$

Judentum im deutschen Geschichtsbild von Hegel bis Max Weber, Tübingen: J.C.B. Mohr (Siebeck), 1967, pp. 245-268.

${ }^{186}$ First edition (under the title Geschichte Israels ) 1878, 2. edition 1883 (English 1885), 3. ed. 1886, 4. ed. 1895. I compared the excerpts Cohen made of the Prolegomena zur Geschichte Israels (see Appendix B) to the editions of 1895 and later, none of which matched the page numbers on the excerpts. Dr. Wiedebach kindly shared with me that the first edition, 1878, is a perfect match. Hans Joachim Kraus calls the Prolegomena "a work which may perhaps be rightly considered the highest intellectual achievement of Old Testament research in the 19th century" (op.cit., p. 269). My quotations are from the fifth edition (Berlin, 1899).

${ }^{187} \mathrm{Cf}$. "Julius Wellhausen. Ein Abschiedsgruß" in: NJM II, 1918, Heft 8, 10./25.1.1918, 178-181 (= J2,463-468).

${ }^{188}$ David Einhorn, Das Princip des Mosaismus und dessen Verhältnis zum Heidenthum und rabbinischen Judenthum. Leipzig: C.L.Fritzsche, 1854 . See here in the appendix. ${ }^{189}$ Wellhausen's Hegelianism is still being debated. Cf. Kraus, op.cit., p. 264, Liebschütz, op.cit., p. $80 \mathrm{ff}$ and Lothar Perlitt, Vatke und Wellhausen (1965). On the general question underlying Liebeschütz's study of. also Christhard Hoffmann, Juden und Judentum im Werk deutscher Althistoriker des 19. und 20. Jahrhunderts, Leiden: Brill, 1988 [=Studies in Judaism in Modern Times, ed. J. Neusner vol. 9].

${ }^{190}$ See "Julius Wellhausen. Ein Abschiedsgruß" (1918) J 2, 463-468 and see my commentary on Cohen's excerpts from Wellhausen here in the appendix. 
In Cohen's attempts to characterize the proprium of the Jewish religion the Bible plays the role of the primary document. This is true throughout his Jewish writings, from the essay on the Sabbath (1869) to Religion of Reason (1919). With the essay on Versöhnung, however, Cohen enters into the discussion of biblical religion more deeply than before. From now on his arguments take into account contemporary biblical scholarship which, then and now, is dominated by the interests and perspectives of Protestant theology. His contributions to Jewish philosophy of religion are therefore in a very concrete sense written in response to and in cognizance of the modern Protestant view of the Bible. ${ }^{191}$ More often than not, Cohen takes Protestant Bibelwissenschaft seriously in its methodology and results but distinguishes from such results their philosophical and historical interpretation. In this fashion he lays the groundwork for the 20th-century Jewish tradition of scholarship on the Bible that has its main representative in Yehezkel Kaufmann.

Cohen's method in approaching Jewish sources is determined by his interest in linking modern ideas and principles of ethics historically and systematically with their antecedents in classical Judaism. This method is always in danger of subverting the prooftext and forcing it to testify to the ideas one has first carried into it. Yet Cohen is far from pretending that is not so. One might say that, as a Jewish exegete, he is less interested in an Urtext, Ur-meaning, or Ur-revelation than his Christian colleagues. The scientific pathos of modern Protestant Higher Criticism roots in a self-understanding wherein the Lutheran sola scriptura is mimicked by a critical sola sensus originalis. In contrast, the Jewish exegetical tradition found it more appropriate to the idea of revelation to imbue sacred text with esoteric meanings found between the lines than to reduce it to its literal meaning. The character of revelation demanded one to seek its meaning actively, by bringing one's owns insights to the text so that its meanings were increased rather than reduced.

${ }^{191}$ This was pointed out already by Wendell Dietrich in Cohen and Troeltsch. Ethical Monotheistic Religion and Theory of Culture, Atlanta, Georgia: Scholar's Press, 1986. The debate between Christians and Jews on the character of the canon of Hebrew Scriptures has not abated. For a recent discussion see Jon D. Levenson, "Why Jews are not interested in Biblical Theology" in: The Hebrew Bible, the Old Testament, and Historical Criticism: Jews and Christians in Biblical Studies. Louisville, Ky.: Westminster/John Knox Press, 1993, pp. 33-61. The latter contribution is particularly poignant in that, despite his criticism of the Christian perspective, Levenson is among the foremost Jewish biblical theologians today. Also see Rolf Rendtorff, "Toward a Common Jewish-Christian Reading of the Hebrew Bible" in: R. Brooks, J. Collins (ed.), Hebrew Bible or Old Testament? (Notre Dame: University of Notre Dame Press, 1990) pp. 89ff, followed by a reply by Levenson. 
In addition, one of Cohen's favorite Kantian bon mots is that one finds in things only what one has first put in them; the transcendental method in general operated under the assumption that valid knowledge of objects could be reached with any degree of precision if judgment was exerted. Judgment however is not an operation of perception but of intellection. The object of knowledge is constituted in thought. The meaning of revelation is constituted in reason.

What seems like methodological arbitrariness on the part of the Jewish exegete who-not despite but because of his insistence on philological accuracy - establishes the meaning of the text becomes an important critical act when seen in light of the scholarship of his time. Around the turn of the century, Protestant scholars dominated the field. This field was divided in several trends. The majority of critical scholars construed the relation between Old and New Testament as discontinuous. This could either mean that one regarded the OT as a whole as a plagiarization of other, more ancient Ancient Near Eastern cultural products. (Cf. the pan-Babylonianism of the Assyriologist Friedrich Delitzsch (1850-1922) which was very popular with Kaiser Wilhelm II.) Or, with Wellhausen, it meant that one characterized the Pentateuch as the founding document of post-exilic Judaism distinguishing it from the pre-exilic folk religion of Ancient Israel. The New Testament represented for the latter school a restoration of the original religion of Israel or of a religion on its par: the expression of a simple, immediate, and popular religiosity as opposed to the sickly sophistication of priestly or rabbinic institutions. The third camp was characterized by a supra-natural presupposition expressed in the providential linear concept of a history of salvation (Heilsgeschichte), based on the dogmatic axioms of Protestant orthodoxy, sola fide, solus Christus, and sola scriptura.

At that time, a scholarly understanding of the Bible could not ignore the results of Higher Criticism. Cohen must have been familiar with this scholarship at least since his studies at the university in Breslau. But he found that he could not base his attempts to validate prophetic Judaism on the ideological presuppositions of any one of the Protestant schools. Cohen is one of the earliest Jewish authors who, though not a specialist, tackled a field which had been all but left to the Protestants. It is clear that the ideological foundations of Protestant scholarship determined both the presuppositions and the results of their "scientific exegesis;" not only the superstructure of their reconstruction of the history of Israel and its religion but the critique of the sources themselves. Cohen's search for an alternative reconstruction of the development of this religion, however, is limited to working with the exegetical results of others. Relying on the scholarship of these others meant to meet them on their 
own ground. Whatever measure of success he had in demonstrating the possibility of an alternative reconstruction of the religion of Israel-one that established continuity within itself and with rabbinic and modern Judaism - was sufficient because he did not attack any of the seemingly objective scholarly results. On the other hand, his contributions to the field of Old Testament scholarship are limited to the area of a philosophical theology. ${ }^{192}$

\subsection{The Development of Biblical Religion: Sacrifice and Atonement}

According to Cohen, Israelite religion begins on a level with that of its neighboring societies. With Wellhausen he portrays ancient Israelite religion as a "natural" religion in which cultic institutions such as the slaughter of animals were joyous occasions, family meals in the presence of the tribal God Yahweh. That Israelite religion developed historically rather than fell from heaven is taken for granted. The distinct character it takes on over time, however, calls for an identification of some of the basic ideas that steer and guide this development. One such idea is that of the God of Israel who takes on ever more profound meanings and grows into a universalistic conception of monotheism. ${ }^{193}$ Wellhausen's study of the history of Israel raised the question of the position in it of the Mosaic law. Synthesizing the source-critical results of his predecessors Reuss, Graf, and Kuenen, Wellhausen gave an eloquent expression to the "Copernican revolution" that the scholarly view on the Old Testament had undergone: the Mosaic law (the Pentateuch) is the point of departure "not for the history of ancient Israel but for that of Judaism, i.e., the religious community surviving the people destroyed by Assyrians and Chaldeans" (cf. Prolegomena p. 1).

With the determination of the Torah as a composition not taken into exile but undertaken in exile, there arises the possibility of interpreting it as a document of faith, as the cultural achievement of a community interpreting its historical experience in the light of its covenantal religious tradition. It is this kind of theological understanding that Cohen seeks in "Die Versöhnungsidee." From a modern (Protestant) perspective the main obstacle to an understanding of the Torah as a progressive step in the development of Judaism is its emphasis on priestly rules and

${ }^{192}$ Only once Cohen's (later) philosophical definition of religion as opposition to idolatry was taken up by specialists in the study of the Hebrew Bible and made into a heuristic presupposition for Higher Criticism was a Jewish alternative to Protestant Old Testament scholarship really possible. This alternative was subsequently established by Yehezkel Kaufmann whose first draft of a history of the Israelite religion as well as the fundamental thesis of his opus magnum is guided by Cohenian principles of biblical interpretation.

${ }^{93} \mathrm{Cf}$. Kraus, op.cit., paragraphs 62 and 64. 
regulations. The preponderance of priestly institutions was taken as proof for the assertion that ancient Judaism was a phenomenon of decline. Compared to the heights of prophetic ethical teachings, the detailed casuistry of vicarious animal sacrifices seemed of inferior value. The political and social criticism of the prophets had given way to the hierarchical institution of a proto-Catholic church.

In his search for an alternative interpretation of the sources Cohen had to tackle the position of the sacrificial institutions in the context of Israelite and Jewish religion. His solution was to correlate the intensification and regulation of the sacrificial cult during and after the Babylonian exile with the emergence of the idea of atonement. Atonement is doubtlessly the aim of biblical sacrifices, and attributing to Versöhnung a comprehensive role in Israelite religion and early Judaism provides sacrificial legislation and practice with a constructive and valuable role.

Cohen's argument begins with the assertion that, at the earliest stages of Israelite religion, the idea of atonement was unknown. ${ }^{194}$ (J 1, 125) This can be deduced from the nature of the earliest sacrificial cult in Israel, when animals were slaughtered in order to be eaten at festive meals in which the deity participated by receiving the best, namely the fattest, parts of the animal. This view has remained undisputed among biblical scholars, with few modifications. ${ }^{195}$

The Hebrew Bible knows sacrificial and profane slaughter of animals as well as meal offerings. ${ }^{196}$ The sacrificial offerings are not always associated with the elimination of guilt or with purification but are sometimes simply meals in a holy place, i.e., a form of communion with the deity on joyous occasions and seasons. There is not one allencompassing term for sacrifice but summary expressions which differ in different periods and reflect some of the developments in the changing perception of sacrificial practice and its meaning. The animals used for slaughter are domesticated animals which are also considered fit for consumption (par and par ben bakar = bull and young bullock, para = heifer, 'ail $=$ ram, keves $=$ lamb, se'ir 'izim $=$ he-goat) and-in $\mathrm{P}$ as a

${ }^{194}$ While I frequently compare Cohen's assertions regarding the history of biblical religion with contemporary scholarship, my main goal here is to present Cohen's argument.

${ }^{195} \mathrm{Cf}$. the recent essay by Wolfgang Zwickel, "Zur Frühgeschichte des Brandopfers in Israel" published in the Festschrift on occasion of the 65. birthday of my former teacher Martin Metzger, Biblische Welten (ed. Wolfgang Zwickel) [=Orbis Pictus et Orientalis 123], Freiburg/Switzerland, Göttingen: Universitätsverlag and Vandenhoeck \& Ruprecht, 1993, p. 237.

${ }^{196}$ Cf. Anson Rainey, s.v. "Sacrifice" in EJ xiv:599-607 and Rendtorff, Studien zur Geschichte des Opfers in Israel (1967). 
substitution for the hattat of the poor-turtledoves (tor) or young doves (b'ney yonah; cf. Lev 5:7-13). This excludes from sacrifices all impure and work-animals and contrasts with practices in neighboring cultures. ${ }^{197}$

Corresponding to Wellhausen's characterization of the earliest Israelite sacrifices ${ }^{198}$ Cohen sees the idea of a covenant between God and the people grounded in the mythical experience of the communal meal in which the deity participates. (Cf. J 1, 126)

At this stage, the idea of atonement cannot arise because of the absence of a feeling of difference, of a gap not only between a person and her God but also within the soul: "First he must learn to feel two souls residing in his own chest before he can distinguish from himself God as a higher being: in order to regain in this way the lost unity within himself" (ibid.). ${ }^{199}$

The assumption is that feelings which we may find natural and assume to be inherent in all human culture, such as guilt or shame, are the result of cultural conventions and social enforcement. To Cohen, guilt and shame are not innate but mediated through institutions and literature. The philosophical value of such notions consists not primarily in the possibility of their genetic explanation but in their utility for cultural progress. The question Whence guilt? is thus guided by the interest in identifying the cultural uses of religious concepts. By interrogating the ancient sources for their cultural trajectory Cohen confirms that philosophical knowledge is always indebted and inextricably linked to cultural facts. Religion begins to emerge here as a cultural fact in its own right.

The second phase of the Israelite religion begins with the early literary prophets (Hosea, Amos, etc.) who arouse this "inner gap of the human being with himself." This is not to say that bloody sacrifices did not exist at the time of these prophets. But in their critique of the cult, sacrifices are associated with fear and superstition and are therefore rejected. Cohen correctly asserts that the character of sacrifices at the royal shrines at the time is different from those conducted in traditional popular piety. They are "national sacrifices" (ibid.) and serve as an evasion of the responsibility to enforce the moral standard of the covenanted nation.

${ }^{197} \mathrm{Cf}$. the reference to the slaying of an ass in Mari, ARM II No. 37, 11, 5-124 quoted by Rainey, op.cit. col. 600 . For a description of the hattat of the poor see Rendtorff (1967) p. 226.

${ }^{198}$ See Appendix B, Text 9.

$199 "$ Erst muß er zwei Seelen in der eigenen Brust fühlen lernen, um als ein höheres Wesen Gott von sich $\mathrm{zu}$ trennen: um dadurch wieder die verlorene Einheit in sich zu finden" $(J 1,126)$. 
The confusing incoherence in the history of sacrificial institutions is quite evident to Cohen. He recognizes the fact that pre-exilic sacrifices are not exclusively those associated with festive meals. With the prophetic age there arises the problem of the connection between the institution of the kingdom and its official national religious rites. The sacrifices associated with atonement and purification are those which first functioned in the context of national emergencies (cf. 1 Sa 14:33-35 and 1 Sa 13:7-15) and which have their parallels in Ugarit and other ancient Near Eastern cults. Their main purpose is to placate divine wrath or to win the support of the deity for battle. This institution is made a central aspect of the cult in Jerusalem only with the erection of an altar for burnt offerings by king Ahaz (after $732 \mathrm{BCE}$ ). ${ }^{200}$

The prophetic idea of God serves for Cohen as a principle by which the prophets brought unity, coherence, and rational morality into the religious foundations of Israel. The morality of Israelite religion is contained in the prophets' idea of God. ${ }^{201}$ More specifically, with his sermons against moral corruption, Amos attacks not only the abuse but the very principle of a theurgic worship which aims at manipulating the deity instead of instituting and following the laws pronounced by it. With the prophets the idea of God matures from that of a protective city god or tribal deity to that of a supreme legislator. Prophetic polemics against the mechanism of national sacrifices transform God from guardian of Israel to guardian of morality whose extension of mercy for Israel is conditioned by the nation's conduct in accordance with the divine virtues of justice and love (ibid.). While the expression taken by the prophetic world view is still anthropomorphic and theurgic, the cause and effect relation between human conduct and divine providence is transformed into a motor of moralization. ${ }^{202}$

\footnotetext{
${ }^{200}$ Cf. Zwickel, op.cit., p. 231.

${ }^{201}$ Cf. J 1, 114 ("Die Messiasidee") where the universalization of the idea of messiah is also attributed to the unity of God (not yet, incidentally, to the "uniqueness" of God).

${ }^{202}$ Cohen's interpretation of the biblical prophets corresponds to that of Duhm, Wellhausen and other progressive liberal Protestant scholars of the time, who regarded the biblical prophets as brilliant individuals, men of religious genius, writing or preaching messages which are rational and meaningful. Thus in this phase of biblical scholarship the supra-natural premise is unanimously rejected while the later view, advanced in the history-of-religion school, of the ecstatic and irrational elements in prophetic speech is as yet unknown. The prophets are incomprehensible if they are viewed as "post-Mosaic" (Duhm 1875). They are distinguished by their strong emphasis on morality, and a reconstruction of the development of the religion of Israel is based on the prophets. See Kraus, op.cit., pp. 277 and 282.
} 
The monotheistic concept of atonement emerges from this prophetic idea of God. The prerequisite for a "new sin" and a "new expiation" is the "recognition of injustice in the relation between human beings" (ibid. 127). The source of injustice is not outside human beings. This realization is the origin of the idea of an interiority of the human being and it is immediately correlated to the new idea of God. God commands justice. Injustice is transgression not of ceremonial laws but of the Ten Commandments, whose essence is seen in the social aspect of the law of Sabbath. The command generates a gap between human being and God; it also brings about the fissure within the human being into "two souls or two inclinations." Conversely, reconciliation between human beings, which overcomes the social effects of the transgressions of social laws, also leads to the reconciliation of the human being with him/herself. The reconciliation with God is enacted in this dual reconciliation (cf. ibid.).

Cohen's point gains plausibility from a comparison with the development of Greek religion. With respect to Greek culture it had long been accepted among scholars to regard the connection of religion and ethics as a relatively late achievement of the classical period. Wellhausen and Cohen were both familiar with this historical view. ${ }^{203}$

The higher development of religion is implied in the expansion of the idea of God inasmuch as the God of the family (what Albrecht Alt later described as Vätergottheiten) is in effect part of the family and does not inaugurate a social fabric beyond it. The national God of the monarchic period is only a quantitative expansion corresponding to the growth of the family into a tribe and of the tribe into a nation. The first qualitative step forward in the development of the idea of God rests on the prophetic association of religion and morality. In Cohen's view, this proves that the development of religion cannot be separated from the development of politics and ethics culminating in a new, moral concept of the human being (instead of the morally indifferent membership in a tribe) implied in the new concept of atonement. The integration of morality and religious worship is the essence of prophetic monotheism.

But what happened to the moralization of the concept of God in exile and return? Cohen regards the latter period as one of great creativity and as producing a major step in the development of the idea of atonement. Instead of merely preserving the morality of the God-idea of the preexilic prophets, the exilic priest and prophet Ezekiel clarifies a central aspect of the idea of atonement by eliminating the last remnants of collective culpability. Assuming a unity of authorship for the Book of Ezekiel, Cohen urges that the same prophet's interest in the reform of the

${ }^{203}$ Wellhausen's closest personal and intellectual friend was the great classics scholar Wilamowitz. Cf. Kraus, op.cit., p. 255. 
cult ought not to be taken as an obstacle to the advance of prophetic morality. Rather, the mutual augmentation of individual culpability and ritual atonement makes a strong case for the continuity of post-exilic Judaism (including the Priestly law) with the undisputed moral heights of pre-exilic prophecy. ${ }^{204}$

\subsection{Guilt and Individuality in Ezekiel 18}

The decisive progress in the history of the idea of atonement is ascribed to the prophet Ezekiel. In chapter 18, the prophet presents an elaborate account ${ }^{205}$ in which he innovates the traditional understanding of crime and punishment, repentance and life. The source of Cohen's interpretation of this passage as an innovation within the Bible is the Talmudic passage Makkoth 24a to which he already referred in his expert testimony on the Talmud in $1888 .{ }^{206}$

Makkoth 24a presents several sequences of verses where statements from the Torah are juxtaposed with statements from the prophetic books. The first list describes a numerical reduction of commandments from the 613 contained in the Books of Moses to the one formulated in Amos 5:4: "Seek me and live!" Two themes are combined here. One is the relation of Torah with its extensive legal body of texts to the prophetic books. The other is the conceptual tension between an approach that takes all details of the law as equally important and the possibility of generalizing and subsuming the details of the law under a single principle. The second list is the one relevant for Cohen. ${ }^{207}$

Four incidents are listed where verses from the Pentateuch can be construed as threatening Israel with destruction. In each case, the "evil decree" is canceled by a prophetic verse.

R. Yose bar Hanina said: Four edicts Moses our teacher decreed over Israel; four prophets came to cancel them. Moses said: "Israel shall dwell in safety, alone the well of Jacob" (Dtn 33:28). Then came Amos and canceled it: "Cease, I beseech Thee! By whom shall

${ }^{204} \mathrm{Cf}$. Kraus, op.cit., p. $277 \mathrm{ff}$. Cohen is closer to Duhm than to Wellhausen because for the former the ethification of Israelite religion is not a negative process (i.e., not a loss in Natürlichkeit). Cohen deviates from both when it comes to the evaluation of the exilic post-exilic development. (Wellhausen speaks of Verholzung.)

205Zimmerli calls it " kasuistisch."

${ }^{206} \mathrm{Cf}$. J 1, 157f. The reference on p. 158 is misprinted (Ez. 16:4 instead of 18:4).

${ }^{207}$ The passage may be rooted in the tradition associated with the school of Hillel the Elder, who was ready to summarize the Torah in a single rule of wisdom, declaring all of Torah its interpretation, yet with the shrewd advice attached, "now go and study!" Cf. bShab 31a. Note that the context of this passage consists of conversations with potential converts who demand exaggerated accommodations. 
Jacob arise? for he is small." And it says further: "The Lord had mercy because of this" (Amos 7:5-6).

Based on the possibly negative connotations of the word badad ("alone," cf. Jer 15:17), Moses' blessing of Israel/Jacob (Dtn 33:28) is read as a curse. Amos 7:5 is adduced as an intervention with God preventing the evil decree from materializing. Then the text continues in the same pattern:

And Moses said: "Among these nations shalt thou find no ease" (Dtn 28:65). Jeremiah came and said: "Israel came to its rest" (Jer 31:2).

And Moses said: "Visiting the iniquity of the fathers upon the children" (Ex. 34:7). Then came Ezekiel and canceled it: "The soul that sinneth, it shall die" (Ez 18:4).

And Moses said: "And ye shall perish among the nations." (Lev. 26:38) Then came Isaiah and said: "And it shall come to pass in that day, that the great trumpet shall be blown (, and they shall come which were ready to perish)" (Isa 27:13).

R. Yose bar Hanina, amoraic scholar in Palestine (second half of the third century CE), whose name is attached to a wide range of legal and non-legal traditions, was also known as a judge interested in legal thinking above and beyond a mere literal application of the law. ${ }^{208}$ In this homiletic text of consolation, the prophets cancel harsh decrees and pronounce the end of punishment. In the case of Amos, the prophet, as it were, commands God to halt punishment and causes Him to have mercy.

In his defense of the Talmud, Cohen uses this text as one of the examples demonstrating the "tendency of the Talmud to move the center of gravity of the law towards the teaching of morality" $(J 1,158)$. For our purpose the text of Cohen's testimony is interesting also in another respect. Cohen emphasizes that despite its interest in promoting morality the Talmud nevertheless endorses "works." In light of Cohen's later Ethik des reinen Willens, such "justification through works" does not seem such an inferior notion. In 1888, however, Cohen uses the word Werkheiligkeit, criticizing the Talmud for falling below the level of the Pauline idea of grace. This is in agreement with the attitude expressed in Bekenntnis where the interiorization of sin and atonement are attributed to the Christian doctrine of atonement. In 1888, then, Cohen still sees the New Testament as superior to certain problems left unsolved in the Talmud. These problems concern nothing less than the "concept of the human being."

${ }^{208}$ Cf. EJ $16: 850$. 
For the Talmud, this general religious conundrum is aggravated because it had to legitimize as divine law the connivances and means of repression which jurisprudence cannot easily avoid. As a result, in such passages the concept of the human being appears even more enclosed and obscured. (J 1, 158)

This paragraph occurs at the transition from a general introduction and a few quotes illustrating the obvious moral side of talmudic Judaism to a more thorough investigation of its moral principles and of the relation in it between law and ethics. The very fact that the divine law is made to include punishment creates the difficulty described in the quote above. The ethical aspects (i.e., the purer aspects of ethics compatible with the principle of moral autonomy) are eclipsed where they are mixed with the principle of reward and punishment even when, on the other hand, a "holiness from works" is denied and the inwardness of the worship of God is emphasized (cf. ibid.). I think it is fair to say that Cohen is trying not to denigrate the Talmud but to tackle one of the fundamental issues which occupied the sages of old just as much as contemporary halakhic scholars and specialists on the ethics and jurisprudence of the Talmud. ${ }^{209}$ It also testifies to the scholarly objectivity with which he conducts his defense of the Talmud.

In 1888 Cohen nevertheless also finds an ethical counterbalance to the disadvantages of talmudic legalism when he extrapolates a concept of the human being from the rabbinic concept of the Noahide. The member of Noahidic humanity represents for him the concept of the human being within the context of the state; a citizen granted equal rights without being forced to become a co-religionist (ibid. p. 159f). "Alien" (ger), Noahide (b'ney noah), and "righteous gentile" (hassidey umot ha'olam ) are identified in the Talmud to form a legal concept which was to exert great influence on the natural-law theories of the 17th century (ibid. 160f).

Now, with the reading of Ezekiel 18 in light of the idea of atonement (J 1,127ff), a new concept of the human being emerges from the sources of Judaism.

Cohen understands the book of Ezekiel as a coherent whole, representing the consensus, or at least the decisive voice, of the early exilic period. This assumption is shared by the majority of the OT scholars of the time. Ezekiel stands therefore at the important transition from pre-exilic Judah to post-exilic Judaism. Zimmerli surmises that critical scholarship started relatively late to discern various strata within

${ }^{209}$ Cf., e.g., A. Lichtenstein, "Does Judaism Recognize an Ethic Outside of the Halakha?" in Marvin Fox (ed.), Modern Jewish Ethics in Theory and Practice, pp. 155-168 and the discussion on the meaning of the formula Lifnim mishurat hadin. 
the book because it makes the "overall impression of good order." 210 Ezekiel was considered a Schriftsteller rather than a prophet (Ewald 1841). In 1880 Smend could still write: "The whole book is ... the logical explication of a series of ideas according to a well thought-out and in part quite schematic plan; one could not remove a single part without destroying the whole."211

In some studies (e.g. Jahn 1905), the tensions in Ezekiel are explained from a history of the redaction of the book wherein the original prophetic text is again taken as superior to its later revisions. This follows the classical modern pattern which sees the earlier as the purer. More specifically, Ezekiel, "perhaps the most passionate of all prophets," is seen as having been domesticated and distorted by the post-exilic Jewish scribes (soph'rim), who "pulled his teeth ... in order to reduce him to a senile pulpit preacher." The anti-Semitic tendency of this characterization is obvious.

While in 1897 Bertholet still argued for the unity of the book, the turn of the century sees an increase in interpretations suggesting the existence of parallel versions (ibid. p. $6^{*}$ ). The beginning of a more critical understanding is marked by Cornill (1886) who sees the book as a carefully planned "collection of pieces conceived at various times."212 The primary tool for emendations of the text is the Greek translation (LXX). With Hölscher's Geschichte der israelitischen und jüdischen Religion (1922) - an elaboration of his study on the prophets (Die Profeten, 1914) which was the first to apply the method of the psychology of religion to biblical prophecy (irrational and ecstatic elements as the characteristic of true prophecy) ${ }^{213}$ - there is for the first time a distinction between the prophet Ezekiel (late pre-exilic and early exilic) and the author of the book (post $515 \mathrm{BCE}$ ): "The real Ezekiel stands with both feet on the ground of the earlier prophetic period; he was turned into the teacher of law and father of the later nomism only through the author of the book

${ }^{210}$ Walter Zimmerli, Ezechiel, 1. Teilband Ezechiel 1-24, Neukirchen-Vluyn: Neukirchener Verlag des Erziehungsvereins 1969 [Biblischer Kommentar Altes Testament Band XIII/1]p. $4^{*}$.

211"Das ganze Buch ist ... die logische Entwicklung einer Reihe von Gedanken nach einem wohlüberlegten und $z$.Th. ganz schematischen Plane, man könnte kein Stück herausnehmen, ohne das ganze Ensemble zu zerstören." Quoted in Zimmerli, ibid.

${ }^{212}$ The work is "nicht in einem Zuge auf der Studierstube niedergeschrieben, sondern eine allerdings von ihm selbst und nach einem grossartigen und kunstvollen Plane angelegte Sammlung, deren einzelne Stücke jedoch zu sehr verschiedenen Zeiten concipiert wurden." Zimmerli, p. $5^{*}$.

${ }^{213}$ Cf. Kraus, op. cit., paragraph 75. 
that was named after him who was writing in the fifth century." 214 With Hölscher the understanding of Ezekiel undergoes a total change.

By liberating the poems of Ezekiel from their jejune prosaic pattern into which they had been forced by redaction the poet Ezekiel with his dazzling, imaginative, and passionate rhetoric emerges into a bright spotlight. Now the image of Ezekiel is completely changed also from the perspective of the history of religion. Now he is no longer the stiff priestly author and trailblazer of legalistic-ritualistic Judaism for which he is taken but a true prophet of Judaic antiquity, a spiritual relative of the authentic Jeremia. 215

Wheat is sorted from chaff, and the valuable and original material is restored by means of substantial cuts. The ipsissima vox of the original prophet is audible only in passages preceding chapter 32, and chapter 18 is not among them. ${ }^{216}$

One cannot deny the value of psychological observations on the prophetic phenomenon. However, the book of Ezekiel marks a particular synthesis of priestly and prophetic elements put together for a purpose, elements that-in this form-exerted their influence on the course of Jewish intellectual history. The differentiation between the "steife priesterliche Literat und Bahnbrecher des gesetzlich-ritualistischen Judentums" and the "echter Prophet der judäischen Antike" (Hölscher) results only in part from the search for historical origins and literary differentiations. It also contains a caricature of Judaism based on a preconceived notion of the historical development of the religion of Israel. Pitting ecstatic classical prophecy and literary authorship against one another, as done by Hölscher and his contemporaries says perhaps less about the phenomena of biblical literature than about the ideological purposes of an intellectual elite turning against its own rationalist traditions.

Cohen is fully aware of the low esteem in which legal and ceremonial institutions could be held. If we are not over-interpreting the

214“Der echte Hesekiel steht mit beiden Füßen auf dem Boden der älteren prophetischen Zeit; zum Gesetzeslehrer und Vater des späteren Nomismus ist Hesekiel erst durch den im fünften Jahrhundert schreibenden Verfassers des nach ihm genannten Buches geworden." Quoted in Zimmerli, p. 7*.

215“Durch die Befreiung der Gedichte Hesekiels aus der öden prosaischen Schablone, in die die Redaktion seine Gedichte eingespannt hat, tritt der Dichter Hesekiel mit seiner blendenden, phantasievollen und leidenschaftlichen Rhetorik nunmehr ins helle Licht. Auch religionsgeschichtlich verändert sich das Bild Hesekiels ganz und gar: es ist nicht mehr der steife priesterliche Literat und Bahnbrecher des gesetzlich-ritualistischen Judentums, für den man ihn hält, sondern ein echter Prophet der judäischen Antike, ein Gesinnungsverwandter des echten Jeremia." Quoted in Zimmerli, ibid.

${ }^{216}$ Cf. Zimmerli, p. 8*. 
essays from 1880 and 1888 , he himself had not then discovered the value of legal thought for a construction of ethics and was quite taken by the Protestant preference of a spiritualization and interiorization of ethical principles to the exteriority of "works." In the essay on atonement he goes at least one step further and denounces the common contempt for the sacrificial cult as "unhistorical thinking." Instead of a decline, the exile can also signify an "uplift" for religious culture.

The great revival of the people and its prophets in exile is accompanied by a vigorous interest for the priestly cult. However, it would indicate a flaw in one's historical thinking if we regarded this cultic development solely as an obstacle to prophetic morality. (J 1,127$)$

Ezekiel's significance is recognized in his ability to reform ritual ceremony and morality at the same time and through each other. ${ }^{217}$ The basis for this interpretation is the midrash quoted above which Cohen had used in his defense of the Talmud. Ezekiel brings about the "cancellation" of a Mosaic decree which Cohen determines as ambiguous. In the Jewish tradition, the threat of punishment of future generations (Ex 20:5 and Dtn 5:9) is translated not as "those that hate me" but as "if they persist in the work of their fathers" (cf. ibid. and Rashi ad loc.). ${ }^{218}$ In other words, the Jewish exegetical tradition eventually adopted the principle, suggested first by Ezekiel, of ruling out punishment on the basis of culpability linking several generations. Ezekiel (18:1) refers not to the decalogues of Ex 20 and Dtn 5 but to a metaphor (mashal) current in the land of Israel (admat yisrael):219 "The fathers have eaten sour grapes, and the children's teeth are set on edge."

Cohen is interested in but one aspect of this chapter, namely the very thought implied in R. Yose's midrash: "And Moses said: 'Visiting the iniquity of the fathers upon the children' (Ex 34:7). Then came Ezekiel and canceled it: 'The soul that sinneth, it shall die.' (Ez 18:4)"

The Israelite saying, the statements from the decalogues, and the passage from Ex 34 imply collective culpability, a concept of sin which is not limited to the individual. With Ezekiel's restricting of crime and punishment to the individual without regard to the good or evil behavior of his immediate relatives, a new concept of the individual emerges: "the soul that sinneth." "On this idea," Cohen now proclaims, "rests the

${ }^{217}$ This significance does not depend on whether or not one assumes the Book of Ezekiel to be a literary whole composed by one author. The book rather than the author is what has been exerting the Wirkungsgeschichte which Cohen is interested in.

${ }^{218}$ Also cf. bBerakhot 7a.

${ }^{219}$ Cohen erroneously refers to Jerusalem $(\mathrm{J} 1,128)$. 
morality of self-consciousness; and the comprehension of this notion constitutes the most fundamental progress in the whole doctrine of the atonement." 220

Thus a topos makes its first appearance that will from then on be fundamental for Cohen's understanding of the immediate relation between Judaism and the modern notion of an ethics of selfconsciousness grounded in the principle of autonomy. The exegetical ground that is laid in this essay makes its reappearance not only in Cohen's late philosophy of religion but already in his Ethics of Pure Will (see below, Pt. II).

There is also no doubt that Cohen's reading of the significance of Ezekiel 18 is rooted in the effort to overcome his own earlier assertion that Judaism is culturally indebted to the Christian dogma of the incarnation. The idea of atonement as the guiding principle of the development of biblical Israelite religion generates a vision of this development that allows one to regard Christian and Western history in direct filiation to it rather than in a relation based on a negative dialectics. With the idea of atonement, Cohen begins to develop a direct path from ancient Judaism to the modern consciousness without a Christian detour.

But we still need to see how Cohen establishes a biblical foothold for the modern concept of moral autonomy from Ezekiel's text. Looking at Ezekiel 18 one finds an elaborate, carefully construed argument based on casuistic lists of transgressions (cf. vv. 5-8, 11-13, 15-17) that culminate in statements pronouncing life or death in enigmatic generality. ${ }^{221}$ For Cohen neither the particular transgressions nor the meanings of "life" and "death" are at stake. The point of this chapter, its great innovation, lies in the fact that God's justice is preserved even if only an individual is punished. Furthermore, even the individual can evade punishment if only he "returns" (v. 32) from his previous evil ways. It may also be noted that the transgressions include sins of idolatry (cf. v. 6a) as well as transgressions against one's fellow man (cf. 6b), sins of ritual impurity (cf. ibid.) as well as transgressions against social and criminal commandments and prohibitions. From each of these the human being can recover, repent, return, and live. Ezekiel pronounces this as a new principle which contradicts traditional perceptions of justice (cf. vv. 19, $25,29)$. When it comes to culpability, common opinion does not recognize the possibility of distinguishing a man from his father or from

220"Auf diesem Gedanken beruht die Sittenlehre des Selbstbewußtseins. Die Erfassung dieses Gedankens ist der fundamentalste Fortschritt der ganzen Versöhnungslehre" (J 1, 128).

${ }^{221}$ Cf. Zimmerli, op.cit., pp. 391-416. 
his son. Culpability and righteousness connect the generations inseparably (cf. Ex 20:5 and Dtn 5:9). Originally, this must have implied collective punishment, for otherwise it would not have been necessary to explicitly prohibit it in Dtn 24:16 (cf. Jer 31:29).

The individual is "discovered" in order to exonerate God from the charge of unjust punishment. The notion of collective guilt no longer satisfies the moral perception of a community in exile. Ezekiel 18, written presumably by a member of the priestly elite rather than by an outsider like the shepherd from Tekoa, makes the individual responsible for his or her own well-being. Each person suffers for his or her own transgression, but each is able to overcome evil. Sin and return from sinful ways are limited to the individual sphere which, in this assignment, is first distinguished as the origin of all morally relevant action.

The new concept of sin thus generates a concept of self.

The Soul, that is the person, the individual. The person distinguishes the human being from a member in the chain of his species. This concept of the moral individual was discovered through sin. It was discovered for the sake of virtue, but in virtue it could not be discovered. This is the great ethical achievement in the sentence, "The soul that sinneth ..." The individual sins. (J 1, 128)

In other words, Cohen reads the sentence ha-nefesh hahotet he tamut as a definition: ha-nefesh (the soul) = ha-hotet he (that which sinneth). "Sin demands an individual." And on this basis, the possibility is created for the individual also to become the condition of virtue: "Hence this soul, this person, this individual can also gain the power and freedom for morality" (ibid.).

On the basis of $\mathrm{Ez} 18$ it also becomes possible for Cohen to give a new meaning to the sacrificial cult which became central to the Jewish commonwealth only after the Babylonian exile when the community of former expatriates reconstituted itself in and around Jerusalem as a theocracy under Persian rule rather than as an independent monarchy. The Book of Ezekiel and the contemporaneous Priestly Code reflect this institutional shift. Cohen argues that individuation of sin and the newly inaugurated sacrificial practice should be interpreted as mutually constitutive. He suggests that Ezekiel's personal union of priest and prophet may provide an important clue to the religious thought of the period (ibid.). He then applies this reasoning to other major aspects of post-exilic Judaism such as prayer. The rise of prayer as a communal activity suggests to Cohen a step towards the universalization of Judaism (cf. ibid. 130). The much derided theocratic institutions of the early second Temple period are therefore interpreted from a perspective that seeks to integrate them with the spiritual achievements of the time rather than in opposition to them, as if the spiritual core of pre-exilic Judaism 
was being forced into a Procrustean bed from which it was to be liberated yet again in a revolutionary founding act of a religious genius that would lead to the destruction of its inappropriate form. To Cohen, it was unnecessary and historically unconvincing to sort out the spiritual from the institutional in this fashion. Thus even the rise of priests to the position of primary actors in the spectacle of communal sacrifices should not be taken as an intrinsic contradiction to the newly found importance of the individual. After all, if the atonement of a person with herself is the centerpiece of the new concept of sin, then not even God can atone for sin. God provides the ideal of purity and moral perfection in a holiness that permeates as well as transcends the purpose of the sacrificial institutions.

Once the connection between Ezekiel's advance in the idea of atonement and the exilic development of the sacrifices has been made the heuristic principle of exegesis, a tool has been won for an alternative interpretation of the biblical and post-biblical Jewish concept of atonement. While the focusing on this concept is still dictated by the cultural circumstances of the particular apologetic situation (made up of the two front-lines of Christian presuppositions pertaining to the Jewish teaching of salvation-Werkheiligkeit--and the modern ethical principle of the autonomy of the moral law), it nevertheless enables Cohen to construct an exposition characterizing the development of Judaism as an advance from the "naturalistic" ancient Israelite to the prophetic period, and further to the post-exilic period where the texts, ideas, and institutions where founded on which Judaism has been based ever since. Cohen therefore clearly follows the Protestant scholarly consensus on the dating of the sources but he views the development inherent in the texts through a different lens. Where Wellhausen sees degeneration and decay, Cohen finds a sequence of institutions and ideas that testify to a common ground that provided the foundation for the work of further development. Where Protestant Old Testament scholarship is guided by a dialectic view of history, Cohen is guided by the modern Reform Jewish interest in continuity with rabbinic sources.

Wellhausen's dating of the sources of the Pentateuch is accepted but the sacrificial cult is interpreted as a meaningful vehicle for the monotheistic spirit rather than as its imprisonment. The cult becomes an institution for the moral education of the community in the spirit of the prophets. Moreover, the ritual and moral organization of the religious community becomes the social basis for the idea of humanity beyond the boundaries of the state without, however, endangering the meaning and sovereignty of the state.

The sacrificial institution gains its first significance in this moral education of the community by enforcing the idea "that the relation 
between God and human being should be constituted not in a festive hour and not on accidental personal occasions; rather, it should permeate a person's life." (128) While "sin sought expiation through sacrifice directed to God" it is the function of the new form of worship to increase the awareness of morality by increasing the awareness of $\sin$ (ibid.). ${ }^{222}$

In the light of this functional understanding of sacrifices, other aspects of post-exilic Judaism are also assigned their functions. Prayer complements the reform of the sacrificial cult. ${ }^{223}$ The Psalms, ritual hymns performed at the temple, contribute to the moralization of the sacrifices. They express poignantly the split within the human personality that the individualized concept of sin has generated, the inner conflict between fear and hope, between realism and confidence. In the Psalms God is addressed as the "rock to which moral far-sight clings."(129) Pilgrimage to the temple, worship through sacrifices, and prayer together bring about a unification of the soul. ${ }^{224}$ This distinguishes the post-exilic sanctuary in Jerusalem from its pagan predecessor which is a house for the idol. Where many gods are worshipped the unification of the soul is in danger. The synagogue which eventually replaces the temple and which, as we know now, began to do so by augmenting temple worship even when the latter was still in existence, is even more self-evidently a place for the community rather than for God. ${ }^{225}$ According to Cohen the first step in this direction consisted in the abolition of the "high places" (bamot) and in the limitation of sacrifices to Jerusalem (cf. p. 129). Cohen does not think of the centralization of the cult under King Josiah (2 Kings 22f), however, which is presumably reflected in Dtn 12 . Rather, he speaks of an exilic/post-exilic concentration of the cult reflected in Leviticus $17 \mathrm{ff}-\mathrm{a}$ text which, since A. Klostermann (Der Pentateuch, 1893), has been called the Holiness Code $(\mathrm{H})$. Leviticus 17 does not even allow for profane slaughter outside of Jerusalem, as opposed to Dtn 12:15f, 20-25. ${ }^{226}$

Cohen interprets the absolute limitation of sacrificial worship to Jerusalem (Lev. 17) as implying a certain form of spiritualization. While its original impulse was one of national yearning for return and renewal,

${ }^{222} \mathrm{Cf}$. Zimmerli ad Ez 18, who observes that-as opposed to Amos-repentance ( $t$ 'shuvah, Umkehr) signifies not turning away from idolatry and turning towards God but turning away from iniquity and turning towards the good.

${ }^{223} \mathrm{Cf}$. also Appendix B, Texts 10,11,12, 18 and notes.

${ }^{224}$ Cohen frequently alludes to Jewish liturgical or literary formulæ. Here, for example, the idea of yichud is alluded to as it is expressed in prayer veyahed levavenu le'ahava ul'yir'ah etc.

225 Similarly already in 1880; cf. J 2, 76.

${ }^{226} \mathrm{Cf}$. Rudolf Smend, Die Entstehung des Alten Testaments, Stuttgart, Berlin, Köln, Mainz: Kohlhammer, 1978, p. 62 and 76-81. 
it springs from a situation in which there is already a factual distinction between worship and sacrifice. ${ }^{227}$ The same text which limits sacrifice to Jerusalem disrupts the traditional identity of worship and sacrifice (cf. p. 129). To Cohen, the ideas contained in $P$ and $H$ are embedded in constitutional drafts drawn up during the exile. While the Pentateuch therefore represents the founding document of a theocracy, it also contains the seeds of its own dissolution by negating a fundamental difference between priests and commoners: all Israel is to be a nation of priests (Ex 19:6). This tendency is enhanced and foregrounded by late exilic and post-exilic prophets who emphasize messianic universalism. Their view of the new Jerusalem (Isa. 56:7) becomes the point of departure for rabbinic eschatology. ${ }^{228}$ By juxtaposing the technical concerns of priestly texts with the lofty visions of Deutero-Isaiah Cohen takes redactions and canon decisions as his point of departure. The scribes and sages of antiquity responsible for creating texts and canon saw no irreconcilable oppositions either between the seeming particularism of the priests and the breathtakingly inclusive visions of some of the prophets or between the individuation of guilt and the elaboration of sacrifices. The resolution of conceptual tensions such as the ones inherent in these topics also became the foundation for rabbinic exegesis.

According to the Talmud, 70 festival-whole-offerings are commanded for the 70 peoples. Thus, the particularism of national unity which was to be strengthened by the centralization of the cult was simultaneously shaken by the mutual influence of messianism and sacrificial legislation. (J 1, 130)

In this process of a gradual constitutional transformation the social form of a religious community emerges that makes itself the model for

${ }^{227}$ Cohen's observations on the character of the Holiness Code are interestingly confirmed by the recent work by Israel Knohl who, however, sees the Holiness school as an opposition to the Priestly school reflected in P. Knohl thus follows the Protestant interpretation of the Priestly source while rescuing the "religious" value of the Pentateuch for Judaism by making the Holiness school the predecessor to the Pharisaic movement. With the Kaufmann school, Knohl presumes a pre-exilic origin of both $\mathrm{P}$ and $\mathrm{H}$, which generates the impression that the late Second Temple conflicts between priests and scribes/Pharisees has roots in pre-exilic Israel. See Israel Knohl, [Mikdash ha-demamah. English] The Sanctuary of Silence: The Priestly Torah and the Holiness School. Minneapolis: Fortress Press, 1995.

${ }^{228}$ Cohen refers to seventy whole-offerings on the festival of Sukkoth that were an atonement for the seventy peoples of the earth (i.e., for humankind); cf. bSukkoth 55b. Also cf. Einhorn, Das Princip des Mosaismus, p. 144n and here Appendix B, Text 12. 
messianic humanity (ibid.). ${ }^{229}$ Cohen takes this characterization from Wellhausen who, viewing it from a different perspective, takes this social development as corollary to a gradual removal of the people from God who, in this process, becomes increasingly abstract. ${ }^{230}$ This change in worship, seen as typical for the Judaic religion, is crystallized in the priests' taking center stage.

Since participation in the sacrifice of the community of the "sons of Israel" was essentially ideal, this too contributed to it that the holy act became complete by itself, namely by the priest doing it even when no one was present. (Prolegomena p. 78) ${ }^{231}$

Despite his impeccable credential as a student of Semitic religions, Wellhausen speaks here less from comparative knowledge of the elaborate purification rites and cults of the Ancient Near East (much important archeological and paleographic evidence was not yet available until later) but as a Prussian anti-Catholic. For the Jewish exegete and philosopher, whose anti-Catholic bias was equally strong, ${ }^{232}$ this was nevertheless an unacceptable way of dealing with the phenomenon of the priesthood. Still, Cohen takes on the challenge.

The most objectionable matter in the whole sacrificial system is the priest as an estate and a caste, especially the High Priest with his political power. But here, too, what seemed an obstacle to free morality led to its most profound advance. (J 1, 130) 233

The challenge is to give the priest a function within the cult that enhances rather than limits the moral symbolism ${ }^{234}$ of the sacrifices. ${ }^{235}$

${ }^{229} \mathrm{Cf}$. Wellhausen, Prolegomena, p. 78: “Jetzt verlieren sich die kleinen Sakralgemeinschaften, die bunten Kreise des Lebens verschwinden in dem Schatten der universalen Gemeinde " (kahal, edah). "Der Begriff derselben ist dem hebräischen Altertum fremd, durchdringt aber den Priesterkodex von vorn bis hinten." And see Appendix B, Text 9.

${ }^{230} /$ Wie endlich alles dies zusammenhängt mit der judaistischen Fernrückung Gottes vom Menschen, ist klar." Prolegomena, p. 78.

${ }^{231} \mathrm{Cf}$. Cohen, almost literally (p. 130): "sie braucht nicht einmal dabei zu sein."

${ }^{232}$ See the letter to Eisner in the appendix; Strauß did not include the letter in his 1939 edition for political reasons.

${ }^{233}$ For the following cf. Appendix B, Text 25.

${ }^{234}$ The method of symbolic interpretation of ancient religions had been developed in the first third of the 19th century. See especially Friedrich Creuzer, whose Symbolik und Mythologie der alten Völker, besonders der Griechen (3. edition, Leipzig: Leske, 1842f), was one of the first successful efforts at interpreting the phenomena of religion as a symbolic language. On Creuzer cf. Arnaldo D. Momigliano, "Friedrich Creuzer and Greek Historiography" in Studies on Modern Scholarship (Berkeley: University of California Press, 1994), pp. 1-14. For Creuzer's theoretical framework and its implications for Creuzer's views on Judaism see in particular "Vierter Theil. Drittes Heft" (1843) pp. 768-771, "Anhang. Drittes 
Sacrificial rituals are performed by priests without the common individual having much of a role to play. Cohen interprets such performance as the symbolic enactment of a judgment. Aside from other, primarily hygienic, functions concerned with the well-being of the community, ${ }^{236}$ the priest represents the community's concern with the possibility of a reform of the condemned (cf. J1, 131). He plays the role of a punitive judge who-without freeing the transgressor-transforms just punishment into the condition for future good. ${ }^{237}$ The priest does not

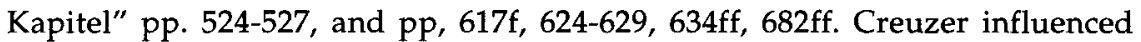
theologians such as the young F. Chr. Baur as well as Karl Bähr (Symbolik des mosaischen Cultus, Heidelberg: 3 vols, 1837-39). Bähr was an important source for Einhorn's Princip des Mosaismus, a book Hermann Cohen studied when he worked on "Die Versöhnungsidee"; see Appendix B, Text 12. Among the recent studies on atonement in the OT, Janowski's comes closest to that of Bähr with respect to method, theological interests and results, except that Janowski seems to understand the blood-rite as sacramental rather than as symbolic. Cf. Bernd Janowski, Siihne als Heilsgeschehen. Studien zur Sïhnetheologie der Priesterschrift und zur Wurzel KPR im Alten Orient und im Alten Testament (Neukirchen-Vluyn: Neukirchener Verlag, 1982). Incidentally, it is unlikely that Cohen read Creuzer who had a very different view of the history of prayers even within the Bible. See, e.g., op. cit. pp. $624 \mathrm{ff}$, esp. 627 where Creuzer cautions against Philo's sweeping assertion (De monarchia lib. II, p. 825, p. 227) that the Jewish prayer was the most human and most liberal one, against which Creuzer points to the necessity of considering all Psalms including their theurgic elements "and other abuses." Essentially, Creuzer asserts the high age and universality of prayer in all cultures as part of the Urmonotheismus in which he believes but which he does not necessarily want to make the principle of critical historical inquiry. This differentiation between historical research and his own belief makes Creuzer one of the pioneers of the history of religions.

${ }^{235}$ One should remember that Hermann Jecheskel Cohen not only associated great importance to his namesake but, as his family name indicates, was of priestly extraction. I find it quite plausible to believe that Cohen was fully aware of the fact that a defense of Ezekiel and of the priestly institution amounted to an apologia pro vita sua, albeit in a posture diametrically opposed to Augustinian individualism. As a cultural return to Judaism this may be compared to the brief vita narrated by Sh'muel Yosef Agnon on accepting the Nobel Prize in Literature in 1966 where the modern Hebrew novelist derives his talent and calling from the singers at the temple in Jerusalem, the Levites.

${ }^{236}$ This interpretation of the laws of purity as rules of hygiene is a common but not necessarily historically warranted rationalization. Some contemporary scholars emphasize the magical aspects even in the rites of atonement, based on linguistic and cultic parallels between Ancient Near Eastern cultures and the accounts of the atonement in Leviticus. See, esp., Baruch Levine, In the Presence of the Lord. A Study of Cult and Some Cultic Terms in Ancient Israel (Leiden: Brill, 1974), Part Two: "Sacrifices of Expiation," pp. 55-91.

${ }^{237}$ The idea of "reform" as the purpose of the punishment for the guilty individual suggests the context of discussions about the reform of criminal punishment since the latter half of the 19th century. 
replace the ordinary judge, nor are sacrifices commanded as an antidote to transgressions of the ceremonial law alone. ${ }^{238}$ Rather, the priestly judge addresses what one may call the invisible aspects of all transgressions. Among such invisible aspects are those that concern the individual's relation to herself (as in the question of one's motivations), as well those which concern social relations (as in the restoration of the presumption of innocence). Sacrifices do not eliminate the consequences of crimes committed against one's fellow human being. Nevertheless, beyond the restitution of damages, atoning sacrifices are demanded. Cohen interprets this fact by means of the term sh'gagah, the inadvertent $\sin$.

The priestly formula declaring a transgression "inadvertent" (as opposed to those committed "high-handedly," be-yad ramah) is ki (...) sh'gagah hi ("because it is in error;" Num 15:25.26 and cf. Qoh 5:5). Leviticus 4:2 introduces the term as a matter of course in a summary statement of any transgression demanding the smaller blood-rite described in the chapter, a rite which is identical with that of the Day of Atonement but limited to the actions connected with the sacrificial altar. In Lev. 4 several cases of sh'gagah are listed. The first (vv. 2ff) pertains either to any single individual or, more likely, simply summarizes all the following cases (cf. Num 15:27ff). In vv. 13ff, the whole community may have committed an inadvertent sin causing a state of unexpurgated sin or impurity (v'ashemu). The moment the sin becomes known, the rite described before becomes necessary. The result is that the priest "makes atonement over them so that they may be forgiven" (v.20). Similarly the cases of prince (nasi, head of the community; v.22) and commoner (am $h a^{\prime}$ arets, v.27) are listed and identified as either one having committed an inadvertent transgression or of "it being brought to one's attention" (vehoda elav). Lev 5:15 singles out the case of inadvertent eating of sacred meat (cf. 22:14), while v. 18 summarizes the function of sacrifices necessitated by inadvertent sins. Here the text emphasizes that until a proper sacrifice is offered the guilty person "carries his sin" (nose 'avono) despite the fact that he did not knowingly transgress; or, without knowing, he was "carrying a sin" which needs to be removed to achieve "atonement" (kapparah) and "foregiveness" (s'lihah).

Cohen translates sh'gagah as "sin without knowledge" (Sünde ohne Wissen) and sketches the historical development of the concept. Presumably it originated in the necessity for ritual purification of the land in case of an unavenged murder whose perpetrator remains

${ }^{238}$ Here Cohen takes up ideas he found in Einhorn's Princip des Mosaismus. See my comments on Einhorn's discussion of Bähr's limitation of the sacrifices to "theocratic" transgressions (Appendix B, comments on Text 12). 
unknown (cf. Dtn 21:8 and 2 Samuel 21:3). ${ }^{239}$ The second step is the institution of havens for individuals guilty of inadvertent killing, thus suspending the need for blood-revenge (Num 35:11.15: makkeh nefesh bish'gagah). In this second stage, "sin without knowledge" has turned into sin without intent, a case in which "a man ... feels desecrated without being able to accuse himself" (131). The liberation from "this weight and the fear of conscience" is reached only on the third level. "Looking from a higher vantage point," Cohen asks, "are not all sins committed more or less unwittingly? Is not everyone's knowledge darkened by passions or even not developed into freedom at all?" (ibid.)

Of course, there is also a counter-argument. Where sin and ignorance are identified, the door is opened widely to rashness and a lack in responsibility. Yet the concept of "sin without knowledge" in the sense of unintentional sin is for Cohen an irresistible notion because it constitutes a striking parallel to a principle ascribed to Socrates and central to classical ethical theory: virtue as a form of knowledge. ${ }^{240}$ The notion of sh'gagah is pregnant with comparative possibilities. Where the Socratic ascription of the character of knowledge to virtue opens up the possibility of "scientific ethics" the notion of sh'gagah inaugurates "the thought of prophetic religion" (J 1, 131). The latter synthesizes two otherwise irreconcilable aspects of the deity.

God represents law and justice, but also love and reconciliation. Justice demands punishment; love demands reconciliation. There would be a contradiction in this and therefore in God's essence if it were not resolved (aufgehoben) in the thought: that every transgression (Vergehen) - as much as it deserves to be punished-is but inadvertence (Versehen), and, therefore, suffers atonement (Versöhnung). (J1, 131f)

The "intervention of voidance" (Nichtigkeits-Einwand) that leads to a cancellation of guilt and a restoration of innocence, clearly a central religious concern, must not diminish the seriousness of guilt nor tarnish the sense of responsibility of the individual. Therefore it has to come from the "highest instance (...): no court of law is competent" (132). It lies beyond the reach of judicial authorities. The purpose of the "external sacrificial institutions" is to enhance both, the "political representation of this, the deepest idea of human morality, and, to no lesser extent, the idea of God." (ibid.)

${ }^{239}$ The connection between the passages is not the word sh'gaga but kippur for guilt of unknown origin.

${ }^{240} \mathrm{Cf}$. Meno $87 \mathrm{~b}$, Protagoras 356 seq. Cf. Ethik des reinen Willens [WW7], 49, 84, 116, 286, 337, 343f, 458, 470, 503, 553f; and see below. 
Up to this point, the effect of atonement on the idea of the human being has been characterized as a negative precondition only. The parallel between Socratic virtue as knowledge and biblical sin as ignorance gives biblical law a philosophical dimension. In biblical religion, however, the effort goes not towards knowledge but towards action. ${ }^{241}$ If divine forgiveness is not to lead to passivity, inaction, and thus immorality, the human being herself must be involved in the accomplishment of atonement. This involvement is not delegated to the priest. One might even say that the delegation of the sacrifice forces the individual to focus on interior processes that aim at a reconciliation of the person with herself. Although God's forgiveness is essential and indispensable, it is not the exclusive condition for a restoration to life. The subject matter of prophetic religion is not the restoration of a primal state of sinlessness in anticipation of eschatological redemption, but the uninhibited this-worldly pursuit of the good. God's decree of voidance must collaborate with human agency in bringing about redemption. The human side of this process of transformation is indicated in the term $t^{\prime}$ shuvah. ${ }^{242}$ After the divine decree which eliminates guilt and exacts forgiveness (implied in the term sh'gagah and following the sacrifice performed by the priest) no further act of redemption is necessary in order to eliminate any sense of insufficiency on the part of the former sinner. She is not considered habitually evil, nor is the restoration complete without a human's turning away from evil by doing good (t'shuvah).

The usual German translation of the rabbinic term $t^{\prime}$ shuvah (Buße) is rejected here as misleading. ${ }^{243}$ Originally it refers to punishment and is thus similar to kofer ("ransom," from the same root as kipper). ${ }^{244}$ The English "repentance" is likewise inadequate since it fails to catch the immediate associations of "turning back" (shuv) which Cohen paraphrases as "turning around, turning away, returning to the good, turning in to oneself"245 (132). The only biblical source Cohen refers to for the notion of $t^{\prime}$ shuvah is the same chapter in the prophet Ezekiel

\footnotetext{
${ }^{241}$ On the other hand, Cohen is obviously familiar with the Maimonidean interpretation of biblical law which has, as its ultimate purpose, the achievement of intellectual virtue. One might even say that Cohen's idealism has the fundamental task of connecting intellectual and ethical virtue in a system, e.g., when scientific cognition is only achieved through "truthfulness" or when only with the help of ethics logic is able to conceive of truth, while ethics is construed in methodological analogy to logic. But see below.

${ }^{242}$ Cf. J 1, 132 and Appendix B, Texts 21 and 22.

${ }^{243}$ Cf. Appendix B, ibid.

${ }^{244}$ See J 1, 132 where Cohen erroneously refers to hattat instead of to kofer.

245"Umkehr, Abkehr, Rückkehr zum Guten, Einkehr in sich selbst."
} 
which also contains his teaching of sin and individuality (chapter 18). The significance of this reference is its emphasis on the unity of cultic reform and moral implication.

\section{4 $T^{\prime}$ 'shuvah as the Center of Gravity of Jewish Thought}

$T^{\prime}$ shuvah (repentance) is a rabbinic term conceptualizing the biblical notion of "turning" (shuv) away from evil (idolatry, sin) and towards God or towards doing good. Repentance is "a prerequisite for divine forgiveness." ${ }^{246}$ Cohen points out that the term denotes one of the central elements not only of the relationship between God and human being but also of the inter-human relationship and of the attitude towards oneself. We begin to see the full scope of Cohen's idea of atonement.

We saw above that Cohen had earlier distinguished the messianic idea as a cultural achievement in which modernity was indebted to biblical prophetic religion. At the same time, Judaism was in need of augmentation, at least culturally speaking, by the Christian idea of incarnation which provided the historical origin for the notion of moral autonomy, in which all philosophically modern contemporaries participated. With the idea of atonement, the architectural construction "Judaism" receives a second cornerstone. The claim it is to support is an immediate relation between Judaism and modernity, without having to rely on Christianity as a cultural historical medium. The cultural immediacy of the Jewish idea of atonement, its up-to-date-ness, so to say, then also provides a perspective from which to examine the culturally problematic aspects of the Christian doctrine of incarnation as well as of the notion of moral autonomy that is derived from Christian sources. It is quite possible that Cohen originally intended to work on atonement in order to provide a Jewish lineage for the modern (Kantian) concept of autonomy. But by the time he wrote his Ethics of Pure Will, he had parted company with some of the most basic aspects of Kantian ethics. The notion of a substantive self that is given to inner experience and that is the origin and ground for all reflection on the direction of its will is reversed. In line with the argument given in his Logic, Cohen makes selfconsciousness the achievement of will and action. Instead of a substantive self, he introduces the self of ethics as correlational with the other, as "experienced" in legal relations. Cohen's ethics as philosophy of law can function without distinguishing morality from legality. He can construe such an austere messianic ethics only because he is confident that he has made room for the moral transformation of the individual in the religious concept of atonement. Ethics is therefore stripped of the

246J. Milgrom, s.v. "Repentance" in: EJ 14:73. 
possibility to give account of individual morality. But in return it receives the ability to provide the rational ground for a political philosophy of reasoned messianism. In this respect, ethics absorbs religion and religion is resolved into ethics. By the same token, the particular individual within her individual historical community is made the concern of religion as a matter of applied ethics. The idea of atonement as developed here therefore provides Cohen with a justification of religion outside of and beyond ethics, that will become the cornerstone of his 1915 treatise of religion, as well as of Religion of Reason. Both, Cohen's Ethics and his Jewish philosophy of religion, have their point of origin in the essay on atonement.

The biblical roots of the notion of $t^{\prime}$ shuvah are stated only briefly. Instead, and for the first time in Cohen's work, a rabbinic concept becomes central to his meditations on religion. With the term t'shuvah, Cohen also transcends what may at least have seemed to be the immediate context associated with the term Versöhnung. While the Day of Atonement and its liturgy are central for the authentication of Cohen's idea of Versöhnung, the essay on atonement is not just a homily related to a particular holiday: "In all of our religious constitution and literature, repentance represents the center of gravity" (J 1, 133; emphasis added). This centrality is illustrated with a midrash dealing with the primordial sinner: Cain. Seemingly beyond redemption, Cain exclaims " $\mathrm{My}$ sin is greater than can be borne" (Gen 4:13). "The Talmud"-Cohen explains"recognizes this as a sign of remorse, and lets him say: 'Lord of the universe, Thou bearest heaven and earth, yet my sin Thou bearest not?'" 247 By accusing God or gods, the primordial sufferers Cain, Job, and Prometheus become cultural heroes. The sinner, the righteous one, and the hero are "suffering individuals" 248 who enter the path that leads to the idea of atonement. In the framework of rabbinic thought, the following answer is returned to the accusation of God: "Repentance and Torah were both made before the creation of the world. Repentance and cognition are prerequisites of the moral world" (J 1, ibid.). ${ }^{249}$

Cohen illustrates and authenticates the meaning of t'shuvah by looking at its function in the context of the liturgy of the Day of Atonement. First he asserts that the Day of Atonement was instituted during the exile and that it represents the most significant of the festivals

${ }^{247} \mathrm{~J} \mathrm{1,} \mathrm{133;} \mathrm{the} \mathrm{source} \mathrm{Cohen} \mathrm{is} \mathrm{referring} \mathrm{to} \mathrm{is} \mathrm{presumably} \mathrm{Bereshit} \mathrm{Rabba} \mathrm{22,}$ Siman 11 and cf. Tanhuma (Buber) Bereshit 25 (vol. 1, p. 19).

${ }^{248}$ Cf. J 1 ibid and Appendix B, Text 15 where Cohen refers to Job and Prometheus: "Eine Stufe in der Versöhnungsfrage ist die Anklage der Götter und Gottes: Prometheus und Hiob, also die Theodicee. Die Schwäche des irdischen Menschen ..."

${ }^{249} \mathrm{Cf}$. Genesis Rabba 1,4 and Urbach, The Sages (Hebr.), 412 text and note 75. 
developed then. The emergence of the festival interests Cohen only to the extent that it confirms the trend of exilic thought to combine theological reflection with sacrificial institutions. He is certainly correct in pointing out the relatively late origin of the festival as we know it. Whatever its origins, by the time of the Second Temple the Day of Atonement had become one of the most important if not the most important of the holidays. ${ }^{250}$

Cohen, however, simplifies the problem of the origin of the Day of Atonement when he mentions that the feast "originated as a pagan sacrificial ritual as still reported by the Mishnah" (J 1, 133). ${ }^{251}$ However, if the passage he has in mind is Ta'anith $4: 8$, his conclusion seems not altogether unwarranted. Although the mating ritual described there has nothing to do with sacrifices, it seems unrelated to a solemn occasion for collective and individual atonement connected with fasting. Neither the Sages nor their medieval commentators, however, had any problem reconciling the mating ritual with the Day of Atonement since it simply means that the solemn day ended in a joyous festival of the youth, a reaffirmation of life after a brush with death. 252

Cohen continues not by explaining any of the specifics of the biblical rituals but with an exposition of facts and ideas associated with the manner in which the Day of Atonement has been celebrated since the talmudic era. The liturgical prayers and institutions of the services are in agreement with the Temple rites and-where they do not surpass them in spiritual significance-they are their fully congenial continuation.

Furthermore, the exilic sacrificial legislation is interpreted as a perpetuation of the prophetic spirit. This continuity is expressed in the prophetic readings for the Day of Atonement. ${ }^{253}$ In the morning portion (Isa 57:14-58:14) the topic is the ethic of fasting where the pious ones are

${ }^{250} \mathrm{Cf}$. Moshe David Herr, s.v. "Day of Atonement" in: EJ 5:1377.

${ }^{251} \mathrm{Cf}$. RV p. 252f. For the problem of the origin see Jacob Milgrom, "Day of Atonement as Annual Day of Purgation in Temple Times" in: EJ 5: 1384-1387, whose solutions are, however, less than satisfactory. In the decisive points (late extension of meaning of the rite of purgation and the ethical implications of those rites) Milgrom's summary of contemporary scholarship still agrees with Cohen's assessment. Further down in his argument, Cohen also refers to some of the specifics of the sacrificial legislation for the atoning rituals $(01,137)$.

${ }^{252}$ Cf. Elie Munk, op.cit., vol. II: "Die Sabbat- und Festtagsgebete," p. 281.

${ }^{253}$ See Louis Isaac Rabinowitz, s.v. "Haftarah" in: EJ 16:1342ff. As on all public fast-days, there are two prophetic readings on the Day of Atonement, one after the morning and one after the afternoon reading from the Torah. The readings from the Torah on the Day of Atonement are Lev 16:1-34; Num. 29:7-11 (Maftir) in the morning and Lev 18:1-30 in the afternoon. The prophetic readings are Isa 57:14-58:14 in the morning and the complete book of Jonah as well as Micah 7:1820 in the afternoon. 
admonished not to turn their back on those who, for lack of food, are forced to fast every day. Religious ritual and social justice are to be linked. As Cohen emphasizes, this reference to a text scolding religious hypocrisy is institutionalized not in order to criticize the ritual fasting but simply because it indicates "how much we feel in agreement with the spirit of the prophets on this day" $(\mathrm{J} 1,133)$.

This agreement with the prophets is further emphasized in the afternoon reading of the Book of Jonah with its emphasis on the efficacy of the repentance of non-Israelites. Cohen also mentions the prayer Ata noten yad ("Thou givest the hand to transgressors and thy right hand is stretched forth to receive the repentant") which is part of the liturgy concluding the Day of Atonement (Neilah, at the time of day when the gates of the Temple used to close while those of heaven remained open). Ezekiel 18 and other passages with similar intent are mentioned in this prayer. 254

In the following passages it becomes evident that Cohen believes the idea of atonement to be able to carry the whole edifice of Judaism, namely when he makes the messianic perspective emerge from the perspective of atonement. Cohen associates the Neilah service with a passage from the prayers for the New Year festival (Rosh Hashanah) which "establishes the perspective: 'Now therefore, O Lord our God, impose thine awe upon all thy works and all thy creatures prostrate themselves before Thee, that they themselves may all unite in one covenant" $(J 1,133) .{ }^{255}$ The content of this benediction is messianic and looks ahead to a reconciliation of all human beings through universal recognition of God's sovereignty. ${ }^{256}$ Thus the prayer Uv'khen ten pahd'kha ("And so set Your fear") represents the central aspect of New Year, namely its emphasis on the kingdom of God. ${ }^{257}$ This kingdom comes about as a result of the universal "fear of God," the feeling of human insufficiency implied in the prayer Ata noten yad referred to before. The New Year prayer expresses the messianic hope ${ }^{258}$ that the fear of God

${ }^{254}$ Cf. Munk, op.cit., pp. 284-287.

${ }^{255}$ The Uv'khen ten pahdekha is contained not only in the morning prayer-as Cohen erroneously suggests-but in all prayers on occasion of both, the New Year holiday and Yom Kippur; more specifically, it is part of the enlarged form of the third benediction of the Tefilla (Keddushat Hashem ). Cf. Elbogen, Gottesdienst, p. $141 f$ (Par. 24, A. 3) and Munk, op.cit., pp. 192-196. Cohen, incidentally, translates relatively literally. However, he emphasizes the autonomous aspect of the universal covenant far beyond the literal meaning.

${ }^{256}$ The prayer $U v^{\prime} k h e n$ is an old form of the malkhiot typical for Rosh Hashanah. See Elbogen, ibid.

${ }^{257}$ Cf. Elbogen, ibid.

${ }^{258}$ Cohen connects elements of universalist messianism (cf. "Die Messiasidee" J 1, 105 and Zank (1994) p. 288) which are particularly associated with Rosh Hashanah 
will materialize in an elimination of "all wickedness" which is to "be wholly consumed like smoke, when thou makest the dominion of arrogance to pass away from the earth." ${ }^{259}$ In other words, the kingdom of God, the elimination of evil, the idea of Versöhnung and the universal "covenant of nations" are all tied together.
This one covenant of the messianic age comes into being when all human beings form it by themselves. It is this covenant, entered into by humans themselves, which is transformation and end ( $\mathrm{Ziel}$ ) of the covenant which God once made with Israel. The day of repentance is the day of this covenant. (J 1, 133; emphasis added)

In other words, when the nations repent and turn away from wickedness, i.e., when they form a covenant with each other, wickedness-at least with respect to the lives of nations-will be eliminated, war will be replaced by justice, and thus God's kingdom will be established. The period extending from the New Year to the Day of Atonement are called the "ten days of repentance" (aseret y'mey t'shuvah). For Cohen, this whole period gains messianic meaning through the yearning for the day when Jewish prayer and hope will be the prayer and hope of all humanity.

The day of repentance is the day of this covenant. Hence our holidays of repentance are, in the strictest sense, messianic holidays. They interlace the fervor (Inbrunst) ${ }^{260}$ of prayer with the notion that the synagogue of the Ghetto will someday open and transform itself into the temple of humanity ... (ibid.)

In the fashion of a homilist, Cohen tickles the connection between repentance and messianic hope out of various liturgical prayers. The point he is making is that the idea of Versöhnung, is linked not to one occasion alone but that it permeates all of the "religious constitution and literature" $(J 1,133)$. The larger idea is constituted by and realized in the particular prayers which echo one and the same motif in many variations and thus attach to it ever more far reaching implications. ${ }^{261}$

with aspects of the Day of Atonement. Cf. Appendix B, Text 27 where this connection is explicitly stated. On the other hand, the aim is also to highlight the independence of the idea of Versöhnung from that of Messianism.

${ }^{259}$ Translation by Arthur Davis in Herbert M. Adler, Service of the Synagogue. New Year. New York: Hebrew Publishing Co., s.a., p. 15. I use this edition throughout, unless indicated otherwise.

${ }^{260} \mathrm{Cf}$. Appendix B, Text 11.

${ }^{261}$ I do not think that I am reading too much into Cohen's paragraphs. Cf. the string of prayer titles associated in (below, Appendix B) Text 28 which evidently

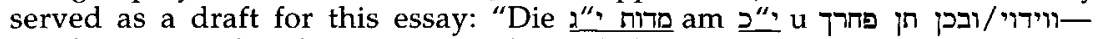

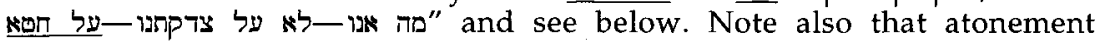
exerts its function and establishes its meaning in the mind of the 
The most telling example for a messianic dimension in prayers usually associated with atonement is kol nidre, the opening prayer on the eve of the Day of Atonement. This liturgy was a topos in anti-Jewish literature where it served as proof for the unreliability of Jews as business partners for whom oaths were not binding. The text of the prayer was also controversial among Jewish scholars ever since its first mention. ${ }^{262} \mathrm{Kol}$ nidre is a declaration which annuls vows concerning the individual and God. ${ }^{263}$ In order to avoid any impression that this formula annuls legally binding oaths, the verse from Numbers 15:26 is added in order to stipulate that only oaths which were or will be rashly sworn and cannot be fulfilled are considered as sh'gagah and will therefore be forgiven: ${ }^{264}$

And it shall be forgiven, all the congregation of the children of Israel, and the stranger that sojourneth among them; seeing all the people were in ignorance. (KJV)

Cohen takes the quotation of Num 15:26 as a motto for the Day of Atonement as a whole rather than as a gloss on the problem of oaths. This shifts the emphasis to the universal aspect, pronouncing forgiveness for the Israelites as well as for the stranger sojourning among them, "seeing all the people were in ignorance." In this manner the verse turns into a dramatic proclamation that provides the solemn day of fasting, contrition, and confession with a spirit of confidence in divine forgiveness. ${ }^{265}$ Of course, as Cohen reminds us, with respect to sins between a person and her fellow human being, the Day of Atonement is efficacious only if one has already reconciled with one's fellow human

observant Jew not through doctrinal exposition but through participation in a liturgy which, in the manner of an elaborate musical composition, gradually fleshes out the dimensions of its Leitmotiv.

${ }^{262}$ Cf. Herman Kieval, s.v. "Kol Nidrei" in: EJ 10:1167 and Munk op.cit. pp. $250 \mathrm{ff}$. Cf. Naz. 5:3, Nedarim 3:1 and cf. bNedarim 22a and 23b.

${ }^{263}$ This is the opinion of R. Jacob Tam; cf. Munk ibid. 252. Cohen does not make use of this aspect.

${ }^{264}$ Cf. Munk, op. cit., p. 251. Kol Nidre precedes the actual Yom Kippur service. See Munk ibid. also for the complicated halakhic problems arising from this issue.

${ }^{265}$ The similarity to the no less dramatic moment in the passion narrative ("Father, forgive them; for they know not what they do" Lk 23:34) is striking, but I do not know whether Cohen had this parallel in mind. Jesus's prayer for the Roman soldiers who execute him is clearly modeled on priestly declarations in the context of the atonement liturgy. Moreover; if Jesus (or the early Christian tradition responsible for Lk 23) was aware that only sins between man and God can be forgiven as sh'gagah, the passage emphasizes not only forgiveness but expresses the assumption that Jesus was himself God but could not be recognized as such by anyone but the believers. 
being. Without such reconciliation between human beings reconciliation with God is impossible (cf. J 1, 134). ${ }^{266}$

Cohen can justify his reading of Num $15: 26$ on a rabbinic text ${ }^{267}$ which makes atonement contingent on the confession of sin. ${ }^{268}$ According to a baraita (a tradition from the tannaitic period, transmitted in the Talmud), R. Meir declared that confession turns all sins into inadvertent ones which are to be forgiven. This is rejected by Raba Bar Shmuel in the name of Rav only because it is based on a literal reading of the Torah, an exegetical method which seems to defy rabbinic authority. However, in a different passage-this time undisputed-the view propounded by R. Meir is also held by Resh Lakish (bYoma 86b).

While the tradition values equally individual and public confession Cohen puts the emphasis on the halakhic decision to limit personal confessions to silent prayer while the public confession is collective and poetically dramatized. ${ }^{269}$ Cohen interprets the public aspect of confession as a pronouncement of human sinfulness which, being collective, generates a sense of human equality. ${ }^{270}$ In the tradition, al het, an alphabetized list of transgressions, is likewise not seen as an enumeration of actual sins committed by individuals because the text is the same for all. ${ }^{271}$ Cohen characterizes al het as a list of virtues and their opposites. Here, too, the emphasis is almost without exception on the relation between a human being and her neighbor. ${ }^{272}$ It is noteworthy

${ }^{266} \mathrm{Cf}$. Mishna Yoma 8:9 and Maimonides, Yad, Sefer Hamadda, Hilkh. Teshuva 2:9. If one were looking for New Testament parallels, the appropriate one here would be Mt 5:23-24.

${ }^{267}$ But see below, Appendix B. Cohen invariably emphasizes that foregiveness applies to both Israelite and ger.

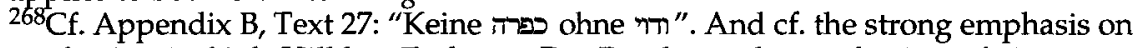
confession in Yad, Hilkhot Teshuva. For Rambam, the confession of sins is an integral part of repentance (see the summary opening statement of Hilkh Teshuva). The positive commandment to confess with words is derived from Num 5:6-7, i.e., it is not specific to the Day of Atonement but to the general act in connection with repentance for sin (see 1:1). Repentance and confession are necessary in any case, including inadvertent and spitefully committed sins (sh'gagah, zadon); neither the death penalty nor corporal punishment can replace them. Even when transgressions demand the payment of penalties, repentance and confession are still necessary. Confession is usually public, yet sins between human beings and God are not to be confessed in public (2:5). Cf. Munk ibid. $263 \mathrm{f}$ (based on S. R. Hirsch).

${ }^{269} \mathrm{Cf}$. Elbogen, op.cit., 149-151 and Munk, op.cit., 260-273.

${ }^{270}$ This messianic aspect of the confession of sins is stated explicitly in Text 27 (Appendix B), not however in "Die Versöhnungsidee."

${ }^{271}$ According to R. Moses Isserles, quoted in Munk, op. cit., p. 264.

${ }^{272}$ One has to keep in mind that all of the transgressions listed are classified as sins against God. But see below. 
that these virtues describe morality from a subjective perspective, putting the emphasis on the hidden motivations of the individual.

Humility, conscientiousness in regard to one's neighbor's reputation and honor, the sinfulness of thought, the root of the evil inclination and of a wicked tongue. Arrogance is branded, and slander is not only struck as a lack of feeling of the heart but by a deep expression which can be neither admired nor taken to heart enough: hatred is called vain, baseless hatred. $(\mathrm{J} 1,134)$

Where a transgression against God is specifically named (the desecration of the divine name), it is the "flip-side" of "the cardinal virtue", namely "the sanctification of the divine name" which, "at the same time, is the highest human virtue." The "sanctification of the divine name" (kiddush hashem) is mainly associated with two passages in the liturgy, both of which invoke and pronounce the unity of the divine name, and both of which are associated with incidents of martyrdom which, in rabbinic language, is itself designated as kiddush hashem. Aside from sh'ma yisrael (Dtn 6:4-5) it is the prayer aleinu le-shabbeah. Cohen mentions the latter with its messianic associations and references to the kingdom of God in a transition leading to the final point of the essay, Versöhnung with God. 273

After having emphasized the human side of atonement through a sustained and intricate argument, the divine side seems to have vanished completely.

We have now arrived at the point which concerns the atonement with God. We saw that the sacrifices generated the profound notion of $s h^{\prime}$ gagah. For malice committed intentionally there were no sacrifices. Sh'gagah is also the foundation of the Day of Atonement. It does not atone for real injustice. It does not dispense from the obligation to seek human reconciliation. ${ }^{274}$ Sins against God, however, are not even mentioned in the confession of sins. Should this mean that there are no such sins? What, then, does reconciliation with God mean? (J 1, 135)

${ }^{273}$ Cohen erroneously refers to "Aboda." If this is not an error committed by the editors who prepared the manuscript for print, then I can't think of a good reason for confusing such different prayers as Aleinu and the 17th benediction of the Amida with each other. Cf. Elbogen, p. 80f, Munk, op.cit., vol.II, p. 221f, and vol. I, 243ff, esp. 246, where he, like Cohen, mentions the association of Aleinu and martyrdom. Cf. also Editorial Staff/Hanoch Avenary, s.v. "Aleinu le-shabbe'ah" in EJ 2: 555-559. Cohen is also aware of the meaning of the term Avodah as the general designation of the service (based on the Temple service); cf. Appendix $B$, Text 18. In another one of the notes (not published here, but cf. also Text 10), Cohen characterizes "kiddush hashem = kabbalat 'ol malkhut hashamayim" as the "general form of all prayer."

${ }^{274}$ Cf. Rambam, Hilkhot Teshuva 2:9,Yoma 8:8-9, bYoma 85b-86b. 
One may expect that at this point the author will leave the realm of human self-determination and turn to the proprium of religion in the reconciliation with God. And although Cohen fulfills this expectation, he does so in a manner peculiar to his interest in preserving the intricate connection between morality and faith, ethics and religion, which prevails in all of his thought. First, he denies that morality exhausts itself in the statement of the principle that the moral law emerges from human reason. Rather, the cognitive character of virtue implies that "all human virtue is insufficient" $(J 1,135)$. This is the essence of the idealist interpretation of "the commandments of morality" that they constitute "tasks which can only be fulfilled by approximation." 275 The notion of an autonomy of reason does not mean that the moral law is ever fully realized in actu. Religion makes the difference between the real and the ideal its basis. For religion, "morality is not the self-revelation of the human spirit but rather the revelation of God." 276 Because human insufficiency is the basic premise of religion, Cohen continues, "it derives all reconciliation among human beings as well as of the human being with himself from the reconciliation of the human being with God" ( 1 , 135-6). While this is an unspecific definition of religion which could also apply to Christianity, 277 Cohen rejects not so much this association but rather the inherent general danger of "one-sided religiosity in so far as it furthers pious contemplation (andächtiges Schwärmen) more than virtuous conduct (gutes Handeln)" (ibid. 136). Religion has achieved its universal power by this function: that in the reconciliation with God "the human being searches not so much for the augmentation of his own powers but for the reason of his weakness: he declares his finiteness." The idea of Versöhnung turns into a fundamental principle of religion, in which the human being expresses and experiences her own condition. Cohen sees such a basic psychological meaning of the concept of repentance expressed in a discussion between the schools of Shammai and Hillel, "the former declaring that it had been better for man not to have been

275"Alle Gebote der Sittlichkeit sind und bleiben Aufgaben, die nur annäherungsweise zu lösen sind." (ibid.) Note that he does not say "zu erfüllen", i.e. he is talking not about the execution of particular duties but about the more general intellectual "Aufgaben" which need "solutions," i.e., matters of jurisprudence and politics. For a possible interpretation of Cohen's term "approximation" in an ethical context cf. Norbert M. Samuelson, "Hermann Cohen" in: An Introduction to Modern Jewish Thought (Albany: SUNY Press, 1989), pp. 165-176.

276 "Die Unterscheidung entsteht vielmehr erst darin, daß die Religion diesen Gedanken zu ihrer Voraussetzung hat. Daher ist ihr die Sittlichkeit nicht sowohl die Selbstoffenbarung des menschlichen Geistes, als vielmehr die Offenbarung Gottes" (ibid.).

${ }^{277}$ Cf. Romans 3:23-24. 
created than to have been created, and the latter maintaining that it was better for man that he was created rather than not created" (bEruvin $13 \mathrm{~b}){ }^{278}$ In the Talmud, this unusual ${ }^{279}$ discussion is ended after two and a half years by an unusual procedure (vote of the majority), stating "that it had been better for man not to have been created, but now that he has been created, let him examine his (past) deeds; others say let him consider his (future) actions." Cohen translates the conclusion according to the commentary of Rashi: "Now that the human being has been born he must seek his salvation in repentance."

In my view, the deviations from the talmudic text give an indication that Cohen did not write with an open book in front of him, nor was he concerned with literal accuracy in order to make unusual exegetical points. Rather, he fell back on common knowledge and consensual interpretation which he acquired in his youth from his father and later in Breslau. This accounts for the fact that he presents the combination of a talmudic text (akhshav shenivra yefashpesh $b^{\prime} m a^{\prime} a s a v$ ) and Rashi (yefashpesh b'ma'asav. she'asa kvar v'yivdok aveirot sheb'yadav veyitvadeh veyashuv). Rashi's mention of confession and repentance is what triggered Cohen's memory of the passage. Had he looked up the text to refresh his memory he would have noticed the absence of a biblical reference. This confirms an overall trend in Cohen's use of Jewish sources, namely that he builds on texts which are common knowledge to someone who has grown up with a traditional basic talmudic curriculum. In addition, Cohen's emphasis on liturgy brings to mind the fact that he was not only a cantor's son with a thorough grounding in this craft, well acquainted with words and musical emphases in the liturgy, but that he was a close friend to one of the most significant composers of liturgical music of the 19th century, Louis Lewandowski, who was also Cohen's father-in-law. It would be an interesting task for a musicologist to study the connections between the Westernization which traditional melodies underwent in Lewandowski's compositions and the connections Cohen establishes between traditional themes of prayers and ethical notions. It seems to me that Cohen's interpretation of the messianic and atonement motifs in prayers on different occasions are themselves almost musicological in nature, in that they deal with the prayers as coherent and meaningful compositions, oratorios composed and rearranged over

${ }^{278}$ Transl. in Urbach, Sages, p. 252. Cohen erroneously indicates that the discussion between "Hillel und Schamai" is based on a biblical verse.

${ }^{279}$ Urbach (Hazal, pp. 224-226) discusses the passage in great detail because, on the surface, it seems to imply a pessimistic world-view which contradicts much of rabbinic thought. There is also neither a direct parallel to this baraitha nor any interpretation of it in bEruvin where the discussion is transmitted. 
the centuries to give expression to the Jewish faith as well as to educate the participants in the avodah. 280

On the Day of Atonement, the human self-understanding of moral insufficiency is expressed through repentance. "Repentance created the image of the divine judgment" $(\mathrm{J} 1,136)$, therefore, it is before $\mathrm{God}^{281}$ that human being faces and acknowledges her condition. The prerequisite for the restoration of moral integrity is that she emerge from this experience as justified. Therefore, while "God is judge(,) ... repentant human being is" both "judged and reconciled," leaving no one "condemned" (ibid.).

Thus, Cohen continues, on the day of reckoning God's love and mercy are emphasized and invoked ${ }^{282}$ in the words of the "thirteen attributes" (yud"gimel middot). ${ }^{283}$ What he is referring to here is the quotation of Ex. 34:6-7 in liturgy. The text itself, when read in its biblical context, expresses the notion that God is both merciful to those who love him and exacting revenge unto those who hate him. In the liturgy, the last verse is cut off in the middle of a figura etymologica. The decontextualized absolute infinitive is then interpreted as a homonym, turning even the word for revenge (venakeh) into one of forgiveness. Even where punishment is meted out, when suffering is imposed as a means of atonement, there is "no condemnation and no eternal punishment in hell." (ibid.) $)^{284}$

On the day which is dedicated to justice, only mercy is supposed to be called upon. Both are identical. Hence there is no condemnation and no eternal punishments in hell. This notion is rejected. Even punishment is mercy. It consists in the chastisements of love. 285 God judges the human being who is flesh and blood, dust and ashes. The mercy of God is the synonym of human weakness. (ibid.)

\footnotetext{
${ }^{280} \mathrm{Cf}$. Appendix B, Text 18. Aside from the meditations on the relation between art and religion, which are frequent in the manuscripts as well as in the first paragraph of "Die Versöhnungsidee," Cohen was familiar with the early musicological theories of the 19th century and his esthetics (WW 8/9) established him as one of the leading German estheticists. Also cf. J 3, 127.

281"Lifnei yhwh" (cf. Lev. 16:30). Although this expression is already referred to by Cohen here (J 1,136f and 139!), it seems even more emphasized in RV (see ch. XI par. 41; p. 233). But cf. also Appendix B, Text 25.

282The traditional metaphor is that God moves from the throne of judgment (din) to that of mercy (rahamim).

${ }^{283}$ Cf. Elbogen op.cit. p. 222. The 13 Attributes were revealed to Moses when he received the second tablets (Ex 34:6-7). The rabbinic term for this and similar texts used in all penitential prayers is seder s'lihot. On Yom Kippur they occur several times. The 13 Attributes are also mentioned by Cohen in Appendix B, Text 28. ${ }^{284} \mathrm{Also}$ found in one of the manuscripts from "Nachlaß Natorp" not given here. ${ }^{285}$ Chastisements of love (yissurim shel ahava), see bBerakhot 5a-b and cf. Urbach Hazal 392-396.
} 
The assertion that justice and mercy are identical in God leads up to one of the central theses about the relation of God and the human being in Judaism, touching a theme which-in the history of Jewish Christian relations - has played a fundamental role, and which Cohen, therefore, cannot do enough to emphasize. In Judaism, God's mercy needs no mediation in order to reach man.

The dispensation of mercy is not tied to any further arrangement. Any mediation of mercy is not only rejected but rejected as inappropriate. The mercy of God in and of itself accomplishes the relation to the human being. There must not be an intermediary for this relation which exists by itself. The immediacy of God is the fundamental notion of redemption ${ }^{286}$ and reconciliation. God is love, ${ }^{287}$ and he has nothing else to do to impart it. And human beings have nothing else to do but repentance with its consequences and testimonies in order to receive mercy. The concept of God as that of love excludes an intermediary. And likewise the concept of the human being in relation to God contradicts the concept of an intermediary. The immediacy of God demands an immediate and independent morality of the human being. (J 1, 136-7)

With this paragraph Cohen has reached the final purpose of this essay, the exclusion, refutation, and denial of the notion that one needs the idea of a divine mediator in order to arrive at a full concept of "immediate, independent morality" (unmittelbare, selbständige Sittlichkeit des Menschen). In other words, the central and most controversial assertion of Ein Bekenntnis in der Judenfrage (1880) is now rejected and refuted. God's immediacy as that of a God of mercy is the single condition for the human being to realize her full moral consciousness. ${ }^{288}$

In the final paragraphs of "Die Versöhnungsidee" Cohen returns to the theme of the sacrifices as they were instituted and regulated in and after the exile. The deepest contradiction to the idea of moral selfdetermination seemed to lie in the institutions of priest and sacrifice. The Christian history of interpretation latched on to the Jewish priestly tradition in order to give expression to the salvation wrought by Christ. In this process, the actual sacrifices eventually became spiritualized and allegorized. In the period following the destruction of the temple, the

${ }^{286} G^{\prime} u l a h$, a term which also occurs in the manuscripts; e.g. Text 21 in the context of $t$ 'shuvah and kapparah with an emphasis on the collective redemption in the days of messiah; Text 29 "Versöhnung und Erlösung." Also cf. Texts 14 and 17. ${ }^{287}$ Cf. Appendix B, Text 20.

${ }^{288}$ The exclusion of the mediator is also a prevalent theme in the manuscripts; see, e.g., text 37, a note in Hebrew associating the resurrection of the dead with a midrashic passage quoted most prominently in the Pessah hagaddah : "lo al y'dei malakh v'lo al y'dei shaliah." 
rabbis similarly had to provide for a replacement of the function of the sacrifices. They too sought to identify the essence and meaning of the earlier ritual and attach it to something else. ${ }^{289}$

In contrast to the Christian history of interpretation, Jewish tradition does not and cannot speak of an abrogation of the sacrifices. They, or the function they exerted, needs no replacement or refinement because they are already a refinement and an elaborate auxiliary institution that is not an end in itself. According to this view, monotheistic sacrifices had a decisive influence

even on this inner development of the Jewish religion. We said earlier that man becomes more distant in favor of the priest. Yet, not only does the individual become more distant-God does so as well. The priest sacrifices and the priest atones. This does not represent a relation between God and human being. In this way the Israelite learned to wean himself from the idea that God is a partner in his offering of a sacrifice. During the sacrifice he faces only his relation to the priest, who helps the individual to practice a paganhuman ${ }^{290}$ kind of abstinence as well as gratefulness and remorse. God enters this relationship only when the individual repents. Nowhere in the Holy Scripture is God called the atoner in the context of the sacrifices; only the priest is so described. The other motto of the Day of Atonement, next to that of sh'gagah, is this: "For on that day he will atone you in order to purify you from all your sins. Before the Eternal shall ye be pure." 291 This "he" is not God but the high priest. He atones. ${ }^{292}$ God is the one before whom the pureness is supposed to be executed. God is the focal point ("Zielpunkt") of purification and repentance. He is the God of love. The sacrifice neither arouses nor merits this love. The sacrifice is not satisfaction for his Divine Judgment. He is completely latent during sacrifice. On occasion of the sacrifice the priest functions. $(01,137)$

The basic exegetical observation on which this view rests is that God is never the subject of the verb kipper (to atone) in the context of sacrifices in the Pentateuch. Cohen found this observation in Einhorn's Princip des Mosaismus (1854). ${ }^{293}$ By translating kipper and its derivations (with Einhorn) as sühnen, Sühne, etc., Cohen distinguishes between the ritual origins and the wider theological implications and elaborations of the

${ }^{289}$ It seems to me that these final paragraphs were inspired by Cohen's reading of Einhorn's Princip des Mosaismus. Cf. my comments on his excerpts in Appendix B. Both authors have the tendency to read rabbinic meaning into biblical texts and, especially in Einhorn's case, contrary to their explicit methodological principles.

${ }^{290}$ Cf. Appendix B, Text 29.

${ }^{291}$ Lev 16:30; I am translating Cohen's German as literally as possible.

292"Er sühnt." Cf. Appendix B, Text 25. Note the differentiation between "sühnen", "Sühne," and "Sühner" where Cohen refers to the Hebrew kipper while Versöhnung stands for the larger idea.

${ }^{293}$ See my notes in Appendix B, Text 12 and cf. Einhorn, op.cit., p. 197. 
idea of Versöhnung. ${ }^{294}$ Ritual purification is understood as a symbolic act (as opposed to a sacrament) which for the individual becomes an expression of renunciation as well as of gratitude. The wider purpose is to represent individual and community as purified before God. The end of purification, however, is achieved through confession and repentance as well as through the true divine prerogative, namely forgiveness, rather than through the acts performed by the priests.

Thus the sacrificial institution contributed to the moral education of the human being instead of making the human being the passive receiver of divine grace. The human being is encouraged to seek not only purification but pureness "before God" who becomes the archetype of moral pureness, the "ideal" of humanity (ibid.). ${ }^{295}$ This climactic relation of purification and self-purification Cohen sees expressed in the concluding statement of Mishnah Yoma (8:9), where R. Akiva praises Israel: אשריכם ישראל! לפני מי אתם מיטהרין? ומי מטהר אתכם? אביכם שבשמים-Here and elsewhere ${ }^{296}$ Cohen reads the sentences in the reverse order: "Blessed are you, Israel! Who purifies you? And before whom do you purify yourselves? It is your Father in Heaven." (J 1, 137-8) ${ }^{297}$

Cohen puts the climactic stress on the self as the agent of purification whereas in the original the sentences culminate in "your father in heaven." The reversal of the order of the clauses emphasizes the idea of self-purification more than seems warranted by Akiva's statement. The prooftexts cited in the Mishnah, however, support Cohen's interpretation at least in one respect, namely in that Akiva's reference to purification associates ritual with hope in divine redemption, ceremony with meaning. The first quotation (Ez 36:25) occurs in a context dealing with the renewal of the hearts and spirits of Israel. The second prooftext is related through a play on the word mikveh which can refer either to a ritual bath of purification or to "hope." In Jer 17:13 God is literally the hope (mikveh) of Israel. Akiva's pun paradoxically makes the seemingly trivial and exterior rituals of purification the far-reaching grounds of hope for redemption.

Cohen sees in Akiva's statement support for the notion that purification is not to be taken as a rote ceremony but a root idea of faith

\footnotetext{
${ }^{294}$ As in the case of the rabbinic abstract noun $t^{\prime}$ shuvah, there exists also a rabbinic abstract noun for the action or result of kipper, namely kapparah.

${ }^{295}$ Cf. Appendix B, Text 29.

${ }^{296} \mathrm{Cf}$. RV, pp. $260 \mathrm{f}$.

297 "Heil euch, Israel, wer reinigt euch und vor wem reinigt ihr selbst euch? Es ist euer Vater im Himmel." Cf. Appendix B, Texts 26 and 27. The editors of Cohen's Jewish writings of 1924 were concerned about Cohen's idiosyncratic quotations and it is thanks to Franz Rosenzweig's intervention that quotations were not silently corrected. See letter to Bruno Strauß (August 24, 1923), BT II, p. 919.
} 
whose meaning extends to the change of human hearts and spirits. He goes a step further when he bends the text towards its ethical edge declaring the "second clause (viz. 'before whom do you purify yourselves') a correction of the main clause" (J 1, 138). No divine purification without human agency of self-purification. Cohen takes the holiness or purity that is to be achieved in this process as a moral value. This is not unusual for 19th-century interpretations of the holy. To Cohen, holiness is rational. It denotes moral purity for which God is the paradigm. Taking purity and holiness as synonyms, one can indeed find biblical support for an interpretation that puts the emphasis on selfpurification, namely Leviticus 11:44 and 20:7 where it is commanded to "sanctify yourselves and be ye holy." The "statutes" (hukkim) referred to in these passages, however, speak of ceremonial rather than of moral laws (Lev 11: purity, dietary laws; Lev 20: idolatry). Cohen acknowledges here that in his interpretation of the sacrifices he is guided by a Maimonidean principle which postulates that all commandments are rational, except that we do not always understand their rationales. "From this perspective Maimonides interpreted the whole ceremonial law" (J 1, 138). Maimonides defined as hukkim all those ceremonial laws for which he could not find a reason. But even those laws are not rejected but taken as pedagogically motivated by the intent to wean Israel from idolatry. ${ }^{298}$

In Cohen's view as in Reform Jewish doctrine in general, the fact of a historical grounding of some of the ceremonial commandments should allow us to accept change in the mode of worship without fear of losing the substance of the matter. The sacrificial service of the temple was replaced by the prayers of rabbinic literature not because the temple was destroyed but because it had outlived its usefulness. Far from universally accepted Jewish doctrine, this is a polemical statement against the importance which the idea of the atoning sacrifice took on in Christianity.

Christianity, however, made the notion of sacrifice the basis of its atonement. In it God sacrifices himself in order to redeem the human being. This sacrifice of God is the content in mass and eucharist. And thus the notion of sacrifice is the most important substance of all Christian liturgy. (Ibid.)

Conversely, "our divine service rests upon the belief in the God of love whose essence is love, and who is removed from the idea of sacrifice."

The Jewish God as the "God of love" and Christian worship as the perpetuation of a preliminary state in the development of religion-a

${ }^{298} \mathrm{CF}$. Guide of the Perplexed III:25-34. 
perfect reversal of the classical Christian position. While Cohen is hardly concerned about whether or not he does justice to the Christian position, he can authenticate his characterization of the Jewish view on sacrifice from rabbinic sources. The last paragraphs allude to a number of rabbinic passages in which his views are confirmed.

During the crisis following the destruction of the Second Temple the ancient services were not abrogated in principle. Nor was it an easy and unambiguous process which produced considerations such as the ones collected in Avot de R. Nathan (commenting on Mishnah Avot 1:2). ${ }^{299}$ The sacrifices (avodah) are divinely instituted service at the one and only temple and the world rests on it just as much as on Torah and merciful conduct ( $g^{\prime}$ milut hasadim). However, a certain hierarchy is established between these elements when the study of Torah (talmud torah) is seen as preferable to the Lord even over the highest kind of sacrifice (talmud torah haviva liphney ha-makom me'olot) because it leads to knowledge of God (yedi'at da'ato shel ha-makom). This is a similar thought as that expressed in a legendary account of Rabban Yohanan ben Zakai's plea with Vespasian to grant him the establishment of a school to teach Torah in Yavneh. ${ }^{300}$ Furthermore, despite his own distress and mourning over the destruction of the Temple, R. Yohanan ben Zakai is able to comfort his friend $\mathrm{R}$. Yehoshua who feels desolate over the fact that Israel has been deprived of its means of atonement. ${ }^{301}$ To this $R$. Yohanan replies with kindness: "My son, let this matter not appear evil to you, for we have yet a kapparah like this one which is merciful conduct, as it is written: 'For I desire mercy, not sacrifice' (Hosea 6:6)."

Quoting Mishnah Avot 1:2, Cohen summarizes this traditional interpretation by identifying the essence of the sacrificial service (avodah) with repentance ( $t$ 'shuvah): "The world rests on three things: on the Torah, on the service which is repentance, and the works of love." 302

Torah and repentance are the two "sources from which deeds of love necessarily spring" $(\mathrm{J} 1,139)$. Next to these central aspects of Judaism, "faith" (emunah) is relatively secondary. ${ }^{303}$ It refers mainly to the virtues of "truthfulness" and "firmness of intention." The sacred service is no longer limited to the holy precinct and it has overcome the vestiges of priestly mediation: "We have no priest. 'The table in every house makes

\footnotetext{
${ }^{299}$ AdRN (A) 4 (ed. Schechter, p. 9b-13a).

${ }^{300}$ AdRN (B) 6 (p. 10a) and cf. bGittin 56a and Urbach, Hazal, p. 534f.

${ }^{301}$ AdRN (A) 4 (p. 11a).

302"Auf drei Dingen besteht die Welt: auf der Thora, dem Gottesdienst, das ist die Buße, und den Werken der Liebe."

${ }^{303}$ Cf. Appendix B, Text 21.
} 
atonement.' The table of family discipline and family custom which, at the same time, is the table of charity, has become the Jewish altar." ${ }^{304}$

The essay on the idea of atonement ends in praise and hope: praise of Versöhnung as the "guiding star of the Jewish wanderings," and hope that "the true sacred service, cleansed of the slag of historical transience, be recognized" when "the principle of Jewish atonement will become the pure universal teaching: through the human being himself, and only through himself before God" (J 1, 139).

The only "pure" and "universal teaching" is that which, if not identical, is at least congruent with philosophical ethics. In "Die Versöhnungsidee" Cohen has found and described an idea of Jewish thought and religion which speaks and contributes to a problem of ethics which, hitherto in his thought, had been seen as growing historically from the Christian dogma of incarnation. From the point of view of Judaism, every "modern" Jew was supposed to be indebted to this cultural achievement of Christianity and, insofar as Jews were German/modern/Kantian, i.e., insofar as they shared belief in moral autonomy, they affirmed a creed which was historically Christian rather than Jewish. The idea of becoming human (incarnation) had seemed as the mythic and propædeutic idea in the education of humankind towards its true meaning: the Menschwerdung (becoming human) of the human being in the ethical principle of the autonomy of moral reason. ${ }^{305}$

In the essay on atonement the historical dependence of the modern human being on the Christian myth of the incarnation for the idea of humanization is replaced by the recognition that Judaism is not only the true historical source of homo noumenon 306 - the ethical idealization of a person-but in its ever renewed and reformed liturgy, in the basic meaning of its sacred service, it is a perpetual source of a morality paradigmatic for and congruent with universal ethics. ${ }^{307}$

The term Versöhnung is a conceptual vehicle which, in the religious context, is experienced prayer by prayer, as a Leitmotiv is recognized through its variations. It also combines within itself elements of the Hebrew terms kippur/kapparah, t'shuvah, sh'gagah, etc. and gives them an

${ }^{304} \mathrm{~J} 1,139$. The quote is found in bBerakhot $55 \mathrm{a}$ and, in a different context, in bHagiga 27a. It refers indeed to the charitable table as a means of atonement replacing the sacrificial altar. Cf. also Avot 3:3 and see excerpts from Einhorn, below Appendix B, Text 12 .

305 "Menschwerdung" cf. letters to Mathilde Burg (1886) in Briefe p. 63 and to August Stadler (Marburg, 8.5.1886) in op.cit. p. 60f: "Meine Ansicht von dem Sinne der christlichen Weltgeschichte als der Idealisierung des Menschlichen in dem Mythus der Menschwerdung ..."

${ }^{306} \mathrm{Cf}$. letter to Stadler, op.cit., p. 65 (July 17, 1890).

${ }^{307} \mathrm{Cf}$. Appendix B, Section 4. "Idea of God and Moral Ideal." 
historical and ethical tendency. Through this interpretation, the Jewish sources become not only the origin of a set of liturgical ideas. Rather, they testify to the discovery of an idea that is basic to the development of Israelite and Jewish monotheism and which corresponds to the fundamental problem of ethics: the self as a moral agent.

\section{Renewing Jewish Philosophy of Religion}

The essay on atonement articulated Cohen's discovery of a direct path from ancient Judaism to the central idea of modern ethics. Individuation of guilt, reconciliation of self with self, God, and others, and the self-purification of repentance are moments in a transformative practice that provides the practical religious source for the selfconsciousness of moral autonomy. The latter would remain a theoretical construct and its political implications a mere utopia were it not for the religious practice of atonement. Religion, that is Judaism in its reflected self-awareness as a religion of reason, ${ }^{308}$ is a vehicle for the realization of the ethical ideal and thus necessary for the progress of humanity. Cohen's philosophical exposition of this idea in the context of his system of philosophy will occupy us in Part II (below). We are now at the point where we can observe how the newly won concept of the moral philosophy of the Jewish religion becomes the point of departure for Cohen's contributions to the reinvigoration of the Wissenschaft des Judentums and, in this context, specifically to the renewal of Jewish philosophy of religion and ethics.

\subsection{Jewish Philosophy of Religion and Ethics}

In 1898 Cohen spoke to the Vienna Politischer Volksverein during a communal election campaign. His services as a speaker had been solicited to influence voters to turn against the tide of support for the Zionist faction. ${ }^{309}$ Vienna's chief rabbi was Moritz Güdemann, a fellowalumnus of the Jewish Theological Seminary in Breslau and co-signer of the protest letter in support of their teacher Zacharias Frankel. Cohen's speech casts "Judaism as a Weltanschauung" 310 whose dignity is grounded in its philosophical and ethical dimensions.

${ }^{308}$ Cf. "Die Errichtung von Lehrstühlen" (1904) (J 2, 118): “Es gibt nur Eine Religion, welche von allen Zaubern der Mythologie sich grundsätzlich frei macht, das ist die Religion der Propheten, das ist die Religion des Judentums."

${ }^{309}$ Cf. ibid. pp. 223 and 242.

310"Das Judenthum als Weltanschauung. Vortrag, gehalten von Geheimrath Universitätsprofessor Dr. Hermann Cohen im "Politischen Volksverein" in Wien" in: Dr. Bloch's Oesterreichische Wochenschrift. Centralorgan für die gesammten Interessen des Judenthums (Wien, 25. März 1898) Nr. 12, Jg. XV, pp. 221-223 and Nr. 
Several aspects of this popular presentation are noteworthy. In it Cohen touches on all the major ideas of Judaism we have seen him address so far (messianism, prophetic religion, the Noahides, the Sabbath, the unfathomable otherness of God) but not, however, on the idea of atonement. Yet he programmatically formulates the need for a contemporary exposition of Jewish "dogmatics," a discipline neglected "for over fifty years" 311 but necessary for the preservation and advancement of Judaism. The most recent representatives of this type of literature cited by Cohen are Solomon Formstecher's Die Religion des Geistes (1841) and Samuel Hirsch's Die Religionsphilosophie der Juden (1842). ${ }^{312}$ This list is small and it might be an interesting question in its own right why Cohen did not mention such authors as Krochmal, Steinheim, and Philippson. ${ }^{313}$ The fact remains that Cohen perceives a lack in the pursuit of Jewish dogmatics which affects the Jewish religion as a whole. It is missing its inner cohesion and a sense of direction that was to provide it with a deeper understanding of its principles and thus guide Jewish communities through difficult times of political and cultural strife and disorientation.

By neglecting the dogmatics of Judaism and letting the wellspring run dry which, in the Middle Ages, had kept Judaism alive and made it the teacher of Christian theologians, by loosening and undoing the connection between religious Judaism and worldly

13 (1. April), pp. 241-243. The editor notes that his printed version gives only parts of the actual speech.

${ }^{311}$ The possibility of Jewish dogmatics was and remained contentious. See Alexander Altmann, "Are There Dogmas in Judaism?" (1937) in: Alfred Ivry, The Meaning of Jewish Existence (transl. by Edith Ehrlich and Leonard H. Ehrlich), Hanover and London: Brandeis University Press, 1991, pp. 105-114.

${ }^{312}$ The full baroque title is Die Religionsphilosophie der Juden oder das Prinzip der jüdischen Religionsanschauung und sein Verhältniß zum Heidenthum, Christenthum und zur absoluten Philosophie dargestellt und mit den erläuterten Beweisstellen aus der heiligen Schrift, den Talmudim und Midraschim versehen (Leipzig: Heinrich Hunger, 1842, reprinted Hildesheim: G. Olms, 1986, and New York: Arno Press, 1980). Cohen refers to it as "Religionsphilosophie der Juden für Theologen aller Confessionen" but remembers correctly that it was written in Dessau; cf. S. Hirsch op.cit. ("Vorwort") p.x.

${ }^{313}$ Arthur Hyman (s.v. "Philosophy, Jewish" in: EJ 13:456-9) lists the following works as Cohen's predecessors: Solomon Formstecher (1808-1889), Die Religion des Geistes (1841, reprinted New York : Arno Press, 1980); Samuel Hirsch (18151889), Die Religionsphilosophie der Juden (1842); Nachman Krochmal (1785-1840), Moreh Nevukhei ha-Zeman (1851); S.L. Steinheim (1789-1866), Offenbarung nach dem Lehrbegriff der Synagoge (4 vol.s, 1835-1865) and, finally, Moritz Lazarus (18241903), Ethik des Judentums (vol.I, 1898 and vol.II, posthumously, 1911). Ludwig Philippson, Die Israelitische Religionslehre (Leipzig, 1861ff) is not mentioned here either. Only the mentioned works by Lazarus, Philippson, and Steinheim have been translated into English. 
wisdom one had become so naive as to think that meager morals could replace a doctrine of faith. Thus one presented a collection of moral sayings and norms which could perhaps defend us against a vicious popular assembly but which cannot contain the foundation of a living religion which must always be the expression of a world view ("Das Judenthum als Weltanschauung," loc. cit.).

Cohen postulates that "under the pressing circumstances of our time we have to focus our attention on gaining and spreading a clear understanding of the world-view of Judaism, of the living system of faith of Judaism." 314

The growing concern with a systematic exposition of dogmatics as an account of the inner principles of the historical development of Judaism is also evident when, one year later, Cohen restates this objective in his critique of Lazarus' Ethik des Judentums. Again it is an association with his alma mater that provides him with the setting for the publication of his review which appeared in the journal of the Jewish Theological Seminary in Breslau, the Monatsschrift für die Geschichte und Wissenschaft des Judentums (MGWJ), then edited by Marcus Brann. ${ }^{315}$

And so we hope that there shall finally arise for us again a scholarly exposition of our religion, on the foundation of a historical study of the sources, including our dogmatics, and in living unified connection with academic philosophy. (J 3, 35. My emphasis.)

Thus in his speech about Judaism as a Weltanschauung and in his review of Lazarus' Ethik ${ }^{316}$ we find Cohen's first programmatic calls for reestablishing the discipline of Jewish dogmatics: based on the results of

314"Unser Hauptstreben in dieser unserer bedrängten Zeitlage muß daher vor allem dahin sich richten, daß wir Klarheit erlangen und Klarheit verbreiten über die Weltanschauung des Judenthums, über das lebendige Glaubenssystem des Judenthums." ("Das Judenthum als Weltanschauung" p. 222).

${ }^{315}$ Beginning 1899 , Cohen published a number of theological articles in MGWJ. Some of his correspondence with the editor can be found in the National and University Archives in Jerusalem, Ms Var 308/24. The review of Lazarus' book had been suggested by Cohen himself to Brann's colleague, the eminent historian of Jewish philosophy David Kaufmann (1852-1899). See letter to Brann, Appendix A, 3 .

316"Das Problem der jüdischen Sittenlehre. Eine Kritik von Lazarus' Ethik des Judentums" MGWJ 43 (1899), 385-400, 433-449, repr. in J 3, 1-35. Despite Cohen's devastating critique, Lazarus' work was, in fact, the major work in the field until Cohen's own posthumous magnum opus. Rosenzweig (J 1, "Einleitung") tries to show that Lazarus' effort is not as meritless as Cohen perceived it to be. Rosenzweig characterizes Lazarus' work as an early attempt to describe religion sociologically. The methodological controversy between Cohen and Lazarus is discussed in E.E. Urbach, The Sages. (Jerusalem: Magnes, 1979) p. 317; and cf. H. Liebeschütz, Von Georg Simmel bis Franz Rosenzweig, pp. 10-15 and 44-47, as well as in Belke, vol. I (1971), LXXIII-LXXX. 
Higher Criticism, on medieval Jewish philosophy, and "in a living and unified connection with scientific philosophy."

At first sight, it seems as if the idea of Versöhnung plays no role whatever in the context of these pieces. On the other hand, Cohen's dissatisfaction with Lazarus' Ethik rests on its failure to recognize the function of atonement as that Jewish tradition upon which the principle of morality (freedom, autonomy) rests historically and practically.

Cohen's review essay contains an extended characterization of the philosophical concept of autonomy as the principle of ethics. Its purpose is to distinguish between morality and ethics, the first concept being a function of religion while the second belongs to ethics as a philosophical discipline. Lazarus identified the Jewish principle of moral responsibility with the Kantian concept of "autonomy," i.e., instead of staying true to the sources he interpolated a concept whose function was determined by its strictly philosophical context.

In Cohen's view, Lazarus not only obfuscates the fundamental difference between ethics and religion but he derides all attempts to appreciate general philosophy from inside Judaism. In contrast to this attempt to filter out purely rabbinic ethics, Cohen expresses his hope for the renewal of religious philosophy (as quoted above). ${ }^{317}$

In other essays of the same period (between 1898 and the publication of Ethik des reinen Willens in 1904) Cohen pursues a literary element of his dogmatic program which he had hitherto neglected. Aside from various scattered hints to and assertions of the importance of Maimonides' teaching about divine attributes (especially in the essay on Lazarus), Cohen thematizes the attributes of "love" and "justice" as aspects of the Jewish concepts of human being and God ("Liebe und Gerechtigkeit in den Begriffen Gott und Mensch"). ${ }^{318}$ The distinction between religion and esthetics (based on the problem of "myth"), which ties religion even closer to ethics, is dealt with in the fragment "Der Stil der Propheten" (1901; J 1, 262-183). All these short pieces continue to explore the very

${ }^{317}$ The essay on Versöhnung reverberates not only in the general theme of the 1899 review but also in some references, such as that to "self-sanctification" as well as to the dictum from R. Akiva (J 3,22) which summarizes the issue of "autonomy" in Judaism. Also note the cryptic emphasis on the Day of Atonement on p. 29 and the differentiation between prophet and priest (p. 30). For the development of the idea of a correlation between the concepts God and man cf. p. 26: "Die Bedeutung und Leistung des Gottesbegriffs für den Begriff des Menschen, für das Individuum wie für die Menschheit ..."

318Published in 1900 in Jahrbuch für jiidische Geschichte und Literatur, see J 3, 43-97. Cf. letter to Brann (June 28, 1900; see appendix) where Cohen complains that the essay was ignored "by all camps" and that he thought it deserved better. 
field of medieval Jewish philosophy as the ground upon which all philosophical expositions of Judaism must build.

Cohen also continues to elaborate the topic he had raised in the essay on Lazarus, i.e., the difference between "freedom" and "autonomy" as a distinction between religion and ethics. "Autonomie und Freiheit" $(1900)^{319}$ is the first publication in which the theme of Versöhnung is explicitly addressed. (See below). The way in which Cohen refers to ideas set forth in "Die Versöhnungsidee" eliminates any doubt about its date of composition. ${ }^{320}$

Most prominently, the ideas of 1892 are presented in the first edition of Cohen's systematic ethics, Ethik des reinen Willens (1904; abbr. ErW), ${ }^{321}$ which I will discuss later.

Between 1898 and 1904, Cohen's efforts are directed towards exploring the larger structure which has been opened up through the recognition of 1892, namely that a convergence of systematic ethics and the ideas of Judaism can be achieved without recourse to the Christian tradition. The ethical problem which seems to be solved in a practical manner within the context of Judaism is the problem of human freedom. More precisely, within Judaism the idea of Versöhnung - as exegetically ascertained by Cohen in 1892-represents a precise conceptual and practical counterpart to the basic problem of theoretical ethics. In the essay on "autonomy and freedom" (1900), Cohen makes "freedom" the "precondition" (Voraussetzung) of atonement. But in Judaism this axiom of freedom is represented not as an essential human trait but through God's judgment (especially on the Day of Atonement). The revelation of God is a revelation of the moral state of the human being. $(\mathrm{J} 3,42)$

Atonement enters a new stage here which becomes decisive for the confidence with which Cohen proceeds over the following years to work for the renewal of religious philosophy. This process is introduced in the

\footnotetext{
${ }^{319}$ First published in Gedenkbuch zur Erinnerung an David Kaufmann (1900), see J 3, 36-42. Cohen wrote it within one week as a "small postscript" to "Problem der jüdischen Sittenlehre." See letter to Brann, June 28, 1900, National Archives Jerusalem Ms. Var 308/240; here in Appendix A, 3.

${ }^{320}$ See especially J 3, 40 where he refers to Ezekiel 18 as the source for individuality of sin and freedom and p. 42: reference to the Jewish service in contradistinction to the Christian eucharist and reference to the Day of Atonement and the motto "Before God shall ye be pure."

${ }^{321}$ WW 7, 299: "... in der Sünde ist das Individuum zur Entdeckung gekommen" etc. and 365: "den Zusammenhang von Ethik und Recht begründet: die Sünde ohne Wissen (Schegaga)" etc.
} 
assertion of 1904 that "to be a Jew means to confess the one unique God as the foundation of existence, as the anchor of the world." ${ }^{322}$

What is different from 1892 and what does this difference contribute to the pursuit of a comprehensive construction of Jewish dogmatics? The answer to both questions lies in the emphasis on the idea of God, more specifically, in setting for Jewish dogmatics the task of unfolding the idea of God. Not only should one resist the "modern superficiality which generally regards the concept of God as an antiquated superstition" but "the more precise meaning of the Jewish idea of God, which we must retrieve, should convince us that one can judge the concept of God only in its specific versions." ${ }^{323}$

Since the content of the Jewish idea of God is human morality, 324 modifications to the idea of God have to be understood as modifications to the idea of human morality. The progress in the biblical and rabbinic sources concerning atonement was, therefore, of importance not only for the discovery of human individual responsibility but for the God of religion, who changes from the archetypal ancestor of the clan to judge and source of human morality.

In the essay on autonomy and freedom, Cohen makes God the origin of human freedom. Without the idea of a divine judgment, human freedom would be meaningless. Without divine forgiveness, humans could not perceive themselves as "pure" in the sense of the capability of doing the good. Freedom is the constitutive idea of the homo noumenon of ethics.

While autonomy is the eternal task of creating the law of morality out of our own resources, the hope for its realization hinges upon the assumption that humans are not only theoretically free (autonomous) but practically free to act according to the self-imposed moral imperative. For this purpose, Cohen claims, God is necessary. The rituals of atonement have the purpose of bringing the human being before God. If God accuses, then the human being must be fully responsible for her actions. Atonement however presupposes freedom not only in the sense

${ }^{322}$ Ethik und Religionsphilosophie in ihrem Zusammenhange (Berlin: Alkalay, 1904) p. 20 [ = "Die Errichtung von Lehrstühlen für Ethik und Religionsphilosophie an den jüdisch-theologischen Lehranstalten", J 2, 122f].

${ }^{323}$ Ethik und Religionsphilosophie (1904) p. 19: "Wir sollen uns nicht des Bekenntnisses zu dem Gotte Israels, zu der Gottesidee Israels schämen. Wir sollen uns nicht der modernen Oberflächlichkeit hingeben, welche den Gottesbegriff überhaupt für einen alten überwundenen Aberglauben hält. Die genauere Bedeutung, welche wir von der jüdischen Gottesidee wieder zu gewinnen haben, soll uns zu der Einsicht bringen, dass man den Gottesbegriff nur in seinen speciellen Gestaltungen beurteilen darf."

${ }^{324}$ See ibid. passim. 
of culpability but also in the sense of an ability to "be pure." 325 What the Christian dogma of a putative justification fails to provide is the idea that, "despite all worldly wisdom," the human being has "the infinite possibility of improvement." 326 This is the function of freedom in ethics as well as in the symbolic representation of the Jewish ritual of atonement.

The ideals of the sacred service represent the ideas of Jewish dogmatics. For Cohen (as for Maimonides before him) the content of Jewish dogmatics hinges upon the sole dogma of God's uniqueness, which is the negative logical precondition of the only positive contents of the God-idea, the attributes of action or ethical attributes. ${ }^{327}$

In two passages of the essay on the divine attributes of love and justice, the idea of atonement is presented again. First, Cohen differentiates the divine attributes from human virtues. In God, even the designation of virtues creates ambiguities through an apparently analogous relation with human virtues. Instead of an archetype, God's virtue is the absolute negative idealization (negation of privation) which human action can but approximate. ${ }^{328}$

Two basic attributes are described here, that of love and that of justice. The construction of attributes based on love and justice is full of meaning which cannot be described here. Note, however, that love stands for a "religious" attribute of God, while justice stands for an "ethical" one. Therefore, the intricate relations of religion and ethics, emotion and action, grace and responsibility are grounded in the divine attributes. This is the fundamental justification for the possibility of a resolution of religious doctrine into philosophical ethics. ${ }^{329}$ The idea of atonement provides the basis for this program.

In contrast to what might be expected if we were dealing with a Christian theology, it is not the attribute of divine love which provides the background for the ideas of reconciliation and atonement; rather, Versöhnung is the result of divine justice. While love recognizes human insufficiency, the "ethical attribute" of justice generates the ethical concept of humanity, the human being as a moral being. (J 3, 76)

Justice is the idea of law. And the law consists in the enacting of legal relations which presuppose legal subjects. The attribute of justice signifies, therefore, the recognition of the free human

${ }^{325} \mathrm{Cf} . \mathrm{KBE}^{1}(1877)$ pp. $202 f$.

${ }^{326} \mathrm{lbid} .203$.

${ }^{327} \mathrm{Cf}$. "Liebe und Gerechtigkeit in den Begriffen Gott und Mensch" (1900) in J 3, 43-97.

${ }^{328}$ Ibid. p. 75.

${ }^{329}$ Cf. EmkN 1896 p. LIX: "Auflösung der Religion in Ethik" and WW 5/II p. 21* (Holzhey): "Einzulösen ist diese Forderung im Gottes gedanken." 
individual vis-à-vis the sovereign of the world. The fatherly power recedes, and the children become masters in their own house of their world history. (ibid. 76f)

The ensuing paragraphs are but an extensive summary of statements from "Die Versöhnungsidee" culminating in the discovery of the individual in Ezekiel's concept of sin (78). Justice, however, entails not merely the discovery of the individual in her full responsibility for her actions. Atonement is completed in the transformation of the guilty person into a renewed and purified one through repentance and prayer (78f). This opens the door to continuous self-improvement, culminating in the messianic realization of justice on earth (84).

Thus atonement and grace are distinguished from each other. Both establish a relation between God and human being, as between human beings. ${ }^{330}$ Yet it is God's justice which enables the human being to perceive herself and act as a fully responsible and capable moral individual within humankind as a moral community.

Furthermore, atonement is reconsidered in light of the problems of retribution (Vergeltung) and justification (Rechtfertigung) (cf. ibid. 84-89). The religious imagery of retribution is quickly set aside because, according to rabbinic tradition, the fulfillment of duty becomes its own reward (84f). What is important to Cohen is that the connection of atonement with retribution and justification generates not only a moral meaning but a legal one. In his observations on the legal implications of the religious idea of Versöhnung, Cohen unfolds ideas which become important in his systematic ethics. ${ }^{331}$

The moral significance of retribution consists in the fact that a person knows that she must justify herself (since justice will eventually be meted out). The justification of the individual, a moral logon didonai, brings the Jew into the presence of God as justice. This occurs in the daily prayers as well as on special occasions throughout the year (85f). 332

Beyond individual morality, atonement and retribution become fundamental concepts of law (86). What is important here is that Versöhnung contains the element of love without which penal law would be reduced to the sole and merciless principle of the ius talionis (cf. 90-96).

${ }^{330}$ The relation of man towards himself seems to vanish into the background, yet it is presupposed in the "discovery" of individual guilt.

${ }^{331}$ Cf. J 3, 86-97 and WW 7, 490ff ("Ehre"), as well as the discussions of punishment and penal law ibid. pp. 352, 368f, 374 .

${ }^{332}$ Cohen polemicizes against Wellhausen's claim that the idea of moral reckoning is remote from "real Judaism." Gfrörer is adduced as the counterexample of a Christian scholar who overcame his "unnatural" misinformation about Judaism by studying with the young Samson Raphael Hirsch. (J 1,85) Cf Appendix B. Texts 10 and 11. 
Instead, retribution has a dimension of love because it protects the weak in society. Likewise, the wrathful God who demands symbolic acts of atonement is quite different from the "envious gods" who demand appeasement. ${ }^{333}$ The institution of justice on earth is not only a law pertaining to Jews but it is contained among the seven Noahide commandments.

Beyond the idea of a morally responsible individual, Versöhnung also constructs a community (87). Cohen speaks not merely about the religious community as in 1892 , but about the legal community which itself is a subject. With this extension of the meaning of the community Cohen prepares the ground for the ethical conception of the state. ${ }^{334}$ Without such a legal community the single "human person" is "but the empty abstraction of an isolated individual."

The legal analogue of the "person" of religion which emerges from $\sin$ is the idea of "honor" (87). Perhaps one would have to correct this statement somewhat and to seek an analogy between the purity of the individual in religion and the honor of the legal person. But Cohen seems to mean something else, namely, the "soul" of the legal person.

The juridical origin of justice is honor. Honor is the idea of the legal existence of a person, the soul of this life. And honor belongs not only to the isolated particular but is also the honor of a house, a family, a tribe. It is also the hallmark of the individual in society (lbid.).

The wording of this paragraph reveals the logical background on which Cohen builds the construction not only of his ethical concepts but also of his religious concept of the individual. "Honor" as the "origin" of justice corresponds to "sin" as the "origin" of the individual. Within the legal framework, the honor of human individuals or collective individuals is met by respect (Achtung). It expresses the unconditional recognition of the humanity of the other (87). The fundamental crime against this recognition of honor is the capital crime of murder which, both in the biblical tradition as well as in world literature, is the prime problem for the notion of expiation (Sühne) or atonement (in the sense of making an atonement for something). The story of Cain creates the precedent of a murderer who is protected from losing his humanity. Not vengeance but penal law is the basis of justice for those who are created in God's image (cf. 88). While the Bible provides for the death penalty, the purpose of this provision is not protection or deterrence for the rest

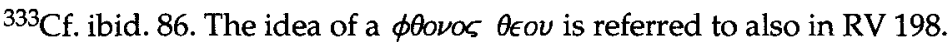

${ }^{334}$ In $\mathrm{ErW}$, on the way towards the ideal of mankind as the ultimate Allheit, the state is a concrete Allheit, a legal subject, which defines individuals as its members. 
of society but the restoration of the humanity of the criminal himself: death makes atonement for his sin. Furthermore, involuntary bloodshed is distinguished from murder, breaking the chain of revenge (cf. ibid.). In contrast to Greece and Rome, where murder remained an offense of private law, ${ }^{335}$ the Mosaic law prohibits taking ransom (kofer) in the case of a murder (Num 35:31). Together with other similar cases, ${ }^{336}$ the principle of law abrogates the necessity to avenge all bloodshed indiscriminately. This is a legal side of the term sh'gagah first discussed by Cohen in 1892. The "character of atonement" affects the legal construction of the community by preserving the humanity of both victim and perpetrator of the very crime which contradicts the inherent axiological principle of the law. In this way, atonement has become a principle of the law beyond the realm of sacred symbolism (cf. p. 97).

What Cohen sets forth in this essay on the divine attributes of love and justice leads in several directions. First, the ethical foundations of the law become the basic problem of Ethik des reinen Willens. When Jewish readers immediately recognized the defense of Judaism implied in this book of systematic neo-Kantian philosophy, Cohen responded enigmatically, or perhaps not so enigmatically, "im Zusammenhange meiner wissenschaftlichen Einsichten steht mein Judentum." 337 The role the idea of atonement played for Cohen in the construction of his ethics has at least been hinted at. Beyond this recognition of a connection between Judaism and philosophical insight we have found that Cohen at the same time advocated the re-establishment of Jewish philosophy of religion or "dogmatics." This was meant not only as a suggestion to introduce faculties of Jewish thought into the existing institutions of higher Jewish learning or Jewish studies into the curriculum of state universities. ${ }^{338}$ First and foremost, Cohen formulated an imperative for himself. And the few texts we looked at briefly demonstrated that it was not idle talk when he continued in the letter quoted above by expressing the following hope.

Therefore I consider myself particularly fortunate for having been able, even before publishing major works on the idea of Judaism, to demonstrate its significance within a philosophical system. (J 1, 333)

${ }^{335}$ Cohen refers to S. Mayer, Die Rechte der Israeliten, Athener und Römer, vol. III, p. 47. Cf. Nachlaß Natorp Ms. 831 (text not given here).

${ }^{336}$ Atonement for bloodshed in which the murderer remains unknown (Dtn 21:19), the establishment of cities of refuge to evade blood-revenge in case of inadvertent killings (Num 31:9ff, Dtn 4:41f).

${ }^{337}$ Letter in answer to the Frankfurtloge upon publication of Ethik des reinen Willens quoted in J 1, 333

${ }^{338}$ See "Zwei Vorschläge zur Sicherung unseres Fortbestands" (1907) J 2, $139 \mathrm{f}$. 
The pronoun "it" refers not to the "idea of Judaism" in general but to "our idea of God" of whose "ethical value" Cohen is convinced and which is the basis of his enthusiasm. Furthermore, in this letter it is clear that Cohen regards the smaller writings as studies leading up to more comprehensive expositions of the Jewish idea of God in its ethical value.

The late philosophy of religion, Religion der Vernunft aus den Quellen des Judentums, grows from programmatic formulations which, according to the sources discussed above, Cohen began to make publicly in 1899 . The concept of a correlation between the ideas of God and the human being which is central to Begriff der Religion im System der Philosophie and determines the structure of RV likewise begins to appear early in the new century, when Cohen locates the center of Jewish philosophy of religion and ethics in the moral dimension of the idea of God. The gradual unfolding of the meaning of the idea of God for the problem of the human being culminates in the idea of atonement where the human being is discovered as an individual. Begriff der Religion and Religion der Vernunft are the results of an intellectual process that begins with the very first essay on the idea of atonement which marks the inception of Cohen's intellectual journey toward a philosophically reflected exposition of the value of the Jewish idea of God as a humanizing principle.

\subsection{Institutional Framework:}

\section{Die Gesellschaft zur Förderung der Wissenschaft des Judentums}

Cohen's intention to contribute to the renewal of Jewish philosophy of religion was more than a vague idea. Rather, it was part of a more comprehensive program which he helped to conceive and which turned into one of the most productive literary enterprises in the history of modern Jewish scholarship. In 1902, a pamphlet was sent around to a wide range of recipients, scholars, rabbis, and dignitaries all over the Continent, inviting them to the inauguration of a new society, the Gesellschaft zur Förderung der Wissenschaft des Judentums. Authors of "An unsere Glaubensgenossen" were the rabbi of Gross-Glogau in Lower Salesia, Leopold Lucas, and Hermann Cohen. While Lucas, from a Marburg family, was the young and energetic spokesperson of this new endeavor, Cohen was its mastermind. ${ }^{339}$ Among the signers of the call we find two of Cohen's fellow-students who had once also signed the letter to Hirsch: Moritz Güdemann and Jacob Guttmann, the former now

${ }^{339}$ I owe my awareness of Cohen's role in the organizational history of the Gesellschaft to Dieter Adelmann's presentation to the conference on Cohen's Religion der Vernunft in Zürich, Sept. 98. Dr. Adelmann also kindly pointed me to some of the sources referred to in this chapter. 
chief rabbi of Vienna, the latter chief rabbi of Breslau. In addition we find the eminent scholar of talmudic history Wilhelm Bacher, the cultural historian Ludwig Geiger (son of Abraham Geiger), and other luminaries of liberal and conservative scholarship. Most astounding, however, is the signature of Moritz Lazarus. The energy and inspiration of Leopold Lucas had managed to persuade the aging Lazarus that the enterprise was important enough to overcome all personal animosity and lend his prestige to the ambitious project.

The founding meeting took place on December 2, $1902^{340}$ when the assembly elected a board which included Cohen and Lazarus, ${ }^{341}$ discussed a first draft of the statutes, and determined its fundraising strategy. The first annual report of the activities of this "society for the promotion of the science of Judaism" lists an impressive set of achievements. Hermann Cohen had drafted calls for support which were distributed to rabbis, communities, various Jewish lodges, and potential individual sponsors. A total of 43 smaller and larger Jewish communities, among them very small ones, responded to the call and made donations, in addition to support pledged by B'nai B'rith, the Zunz-Foundation, and other communal and fraternal organizations.

The goal of the society was to be pursued on two levels: promotion of a comprehensive program of research and expository writing as well as appreciation for the science of Judaism in the communities. To promote scholarship, the society was to provide research grants for individual scholars, ${ }^{342}$ as well as to publish reviews and original research. In order to evaluate the proposed research competently and critically, the society established twelve committees of specialists, covering the following areas: 1 . Systematic theology, 2. ethics and philosophy of religion, 3. Hebrew linguistics, 4. biblical exegesis, 5 . Talmud and legal codes, 6 . history through the destruction of the second temple, 7. history from 70 until the end of the geonic period, 8. history of the middle ages up to the time of Mendelssohn, 9. contemporary history, 10. History of literature and of religion, 11. practical theology (pedagogy), 12. apologetics.

${ }^{340} \mathrm{On}$ this and the following see "Erster Jahresbericht der Gesellschaft zur Förderung der Wissenschaft des Judentums" in MGWJ, Neue Folge, 12. Jg., Breslau, 1904, 52-64.

${ }^{341}$ Lazarus did not himself attend the inaugural meeting but was elected to the board in absentia. Cf. his letter of support, quoted in "Jahresbericht" p. 53. Lazarus died in 1903.

${ }^{342}$ Among the first beneficiaries was Leo Baeck whose work on the Jewish philosophy of religion the society supported and whose answer to Adolf Harnack's Wesen des Christentums it commissioned and published. 
The board agreed to utilize the well-established scholarly journal Monatsschrift für die Geschichte und Wissenschaft des Judentums, whose current editor, Marcus Brann, was already a member of the board of the Gesellschaft zur Förderung der Wissenschaft des Judentums. As a more popular organ, the board chose the annual of the Verband der Vereine für jüdische Geschichte und Litteratur.

Among the most ambitious and lasting contributions of the Gesellschaft is its extensive program of publication. At its meeting of April 21,1903 , the board decided to publish what it called a Grundriss der gesamten Wissenschaft des Judentums, a comprehensive series of introductions to all the disciplines of Jewish knowledge. Similar to the above list of areas of research but in more specific detail, this organization of Jewish scholarship into distinct areas is based on the taxonomy of August Boeckh's Encyklopädie und Methodologie der philologischen Wissenschaften. ${ }^{343}$ The whole project of the Grundriss is thus an application of the very principles of Wissenschaftlichkeit that Cohen had been seeking to realize in his own work and which he was now bringing to bear on this major project of collaboration through which the knowledge of Judaism was to be established on the most rigorous scholarly basis.

The organization of knowledge which the Grundriss projected is impressive and comprehensive by any standard. The basic categories are A) Linguistics, B) Historical and Literary disciplines, C) Systematic disciplines, and D) Practical disciplines. The series was to comprise a total of 36 volumes to be completed by 1905. By the end of 1904 all of the authors were contracted with the publisher, including Hermann Cohen, who was responsible for "Ethics and Philosophy of Religion." Among the other authors and topics were Leo Baeck (general history of the Jewish religion), Moritz Güdemann (apologetics), Ismar Elbogen (liturgy), Benzion Kellermann (comparative religion: Judaism and Christianity). In the area of post-talmudic history of literature and religion Jacob Guttmann was to treat Jewish philosophical literature, Gustav Karpeles in association with Solomon Buber, Adolf Büchler, and others were to deal with poetic, mystical, and other literature.

In addition to the Grundriss, the society inaugurated Germania Judaica, a comprehensive history and documentation of Ashkenazic culture, a Corpus tannaiticum, as well as publications on occasion of the 700th commemoration of the death of Maimonides. ${ }^{344}$

\footnotetext{
${ }^{343}$ My source of information is, again, Dieter Adelmann.

${ }^{344}$ Cf. "Protokoll der Ausschuss-Sitzung der 'Gesellschaft zur Förderung der Wissenschaft des Judentums' Breslau, den 31. Oktober 1904" in MGWJ (1904), p. 751-754.
} 
The ambitious, extensive, and systematic program of the Gesellschaft für die Wissenschaft des Judentums was realized only in part and over a much longer period than anticipated. What is significant for us is that Cohen was not only involved in the planning, inauguration, and steering of the organization from its inception but that he lectured and published with the agenda of the Gesellschaft on his mind. A paper on ethics and philosophy of religion originated as a presentation to the society's board arguing for the establishment of lectureships in Jewish philosophy at religious seminaries. ${ }^{345}$ An essay on Maimonides's ethics was part of the society's Maimonides jubilee. ${ }^{346} \mathrm{He}$ contributed another programmatic essay on the significance of Jewish philosophy of religion to its more widely accessible series of publications. ${ }^{347}$ The list goes on. ${ }^{348}$ The most significant contribution, however, is Cohen's volume for the Grundriss, his exposition of ethics and philosophy of religion. It should by now be obvious that the posthumous date of publication of Religion der Vernunft aus den Quellen des Judentums (1919) can no longer count as an indication of a late return to Judaism on Cohen's part. Important books take time. Neither a change of heart, mind, or philosophical outlook, nor external historical factors must be forced to account for the sequence in which Cohen realized his literary works. If the program took seventeen years to come to fruition, the intermediate years, dedicated mainly to a system of philosophy, were not spent in forgetfulness of the earlier intentions but in preparation for the task.

\footnotetext{
345“Die Errichtung von Lehrstühlen für Ethik und Religionsphilosophie an den jüdisch-theologischen Lehranstalten" Vortrag gehalten 6. Januar 1904, in: MGWJ 48/1904, 2-21 [= Ethik und Religionsphilosophie in ihrem Zusammenhange, published by the Gesellschaft zur Förderung der Wissenschaft des Judentums, Berlin, 1904 (= J2,108-125 under the original title).

346"Charakteristik der Ethik Maimunis" in: Moses ben Maimon. Sein Leben, seine Werke und sein Einfluß. Zur Erinnerung an den 700. Todestag des Maimonides, ed Gesellschaft zur Förderung der Wissenschaft des Judentums (W.Bacher, M.Brann, D.Simonsen with J.Guttmann) vol. I, Leipzig: Fock, 1908, 63-134; separate printing Leipzig: Fock, 1908 (= J3,221-289). Cf. the forthcoming monograph by Almut Bruckstein which contains a philosophical commentary on Cohen's commentary on Maimonides.

347"Religion und Sittlichkeit. Eine Betrachtung zur Grundlegung der Religionsphilosophie" in: JJGL 10/1907, 98-171 (= J2,98-168).

${ }^{348}$ See here in the bibliography.
} 


\subsection{Realization of the Program: Religion of Reason Out of the Sources of Judaism}

\subsection{1 "Late" Philosophy of Religion or Maturation?}

Hermann Cohen's "late" philosophy of religion is contained in two works, Begriff der Religion im System der Philosophie (1915) and Religion der Vernunft aus den Quellen des Judentums (1919). The two works were completed in short sequence and represent the last phase in the literary work of the philosopher. It has been common to speak of these works as Cohen's "late" philosophy of religion to distinguish it not from an early philosophy of religion but from an earlier systematic philosophical stance towards religion. According to this opinion, Cohen modified the disposition of his system to make room for an annex on religion that was not initially planned. This opinion is based on literary evidence in Cohen's published works. In the widely noted 1896 version of his Einleitung mit kritischem Nachtrag (EmkN, "Introduction and critical postscript" in: Friedrich Albert Lange, History of Materialism), Cohen outlined the plan for his own system of philosophy. Here he states that religion was to be "resolved" into ethics (Auflösung der Religion in die Ethik). The system was to be divided into a logic, an ethics, an esthetics, and a psychology, a plan he followed until 1914 when in a revised edition of EmkN a slight change in the wording indicates that the program of "resolving" religion into ethics is no longer to be maintained. In 1915, Cohen publishes Der Begriff der Religion where he further specifies the modifications to his concept of religion in relation to the system of philosophy. In the posthumously published Religion der Vernunft, however, the relation between system and religion is not even the central issue. Cohen appears here to have left behind all need to justify religion from an idealist perspective. Instead, religious philosophy stands on its own. The work was published by a different publisher and in a different series, an exposition of Jewish philosophy of religion and ethics, without formal dependence on the systematic works for which the author had become famous.

Various explanations were advanced for what seemed a departure from the structure of the system. The most famous and influential explanation is the one given by Franz Rosenzweig in his 1924 introduction to Bruno Strauss's edition of Cohen's collected Jewish writings. Here Rosenzweig contends that concern for Judaism and the Jews had played an ever increasing role in Cohen's life beginning with his defense against Treitschke in 1880 and culminating in his last years when, in 1912, he retired from Marburg University and moved to Berlin 
to teach at the Lehranstalt für die Wissenschaft des Judentums, dedicating his last years to teaching and writing on Jewish philosophy. Those who followed Rosenzweig further simplified this intellectual biography, interpreting the move from Marburg to Berlin as symbolic of Cohen's "late return to Judaism." 349

Given this evidence of Cohen's own writings and of a great number of anecdotes highlighting the aging Cohen's sentimental attachment to Judaism, ${ }^{350}$ it seemed warranted to speak of "extra-philosophical" (Dreyer) influences on Cohen's thought that originated in the human experience of a retired professor disenchanted with the largely antiSemitic attitude of his non-Jewish environment and led to a reaffirmation of the religious convictions of his youth.

This psychological explanation of a significant literary opus was augmented by a further fact. Part of the motivation for Cohen's seeming change of mind regarding religion can be located within the Marburg School itself. More specifically, Cohen's philosophy of religion, especially Begriff der Religion, responds to certain challenges posed from within the school as represented by his closest colleague, Paul Natorp, as well as by the Protestant theologian Wilhelm Herrmann. In the second edition of Ethik des reinen Willens, in the 1915 treatise on religion, in letters, and in an important passage in RV, Wilhelm Herrmann is acknowledged as an important interlocutor who forced Cohen to go further in recognizing the a priori value of religion. Begriff der Religion is in fact dedicated to the "Marburg School."

Cohen's late philosophy of religion therefore seemed best explained as a series of responses to distinct challenges. In the 1915 treatise on the concept of religion, Cohen speaks to his philosophical colleagues and readers about why he feels philosophically compelled to depart from his original plan of "resolving" religion into ethics, a departure by which he "hoped to bridge the gap" between himself and his Protestant colleagues. ${ }^{351}$ In Religion of Reason, on the other hand, a work dedicated

${ }^{349}$ Among those who followed Rosenzweig's interpretation were most prominently Emil Fackenheim, Nathan Rotenstreich, and Shmuel Hugo Bergmann. This finds expression, for example, in the notes and comments to the Hebrew edition of Cohen's Religion der Vernunft, Dat ha-tevunah mi-mekorot haYahadut, transl. by Zvi Wislavski and Hanokh Kalai, with notes by S.H. Bergmann and Nathan Rotenstreich, Introduction by Sinai Ucko and Postscript by Yosef Ben Shlomo, Jerusalem: Mossad Bialik, 1971. Cf. also Emil L. Fackenheim, "Hermann Cohen: After Fifty Years," in: Yearbook , 1969, pp. $10 \mathrm{ff}$.

${ }^{350}$ Hartwig Wiedebach and Dieter Adelmann kindly shared with me their recent translation from the Hebrew of a reminiscence by Zvi Idelsohn, the great Jewish musicologist, who visited Cohen in Berlin in his last years. In this as in other similar pieces Cohen's famous sacrificium emotionis emerges quite clearly.

${ }^{351}$ More on BR in Part II, below. 
to his father, the erstwhile melamed and hazan of Coswig, Cohen presents a well rounded, fully fledged exposition of the doctrine of Jewish faith that adheres to the principles outlined in 1915 yet goes far beyond it in concrete references to the "sources of Judaism." In it Cohen had found his way back to Judaism beyond and before philosophy.

This view on Cohen's philosophy of religion has not remained unchallenged. Alexander Altmann raised serious objections to the biographical romanticizing underlying this reading and pointed to continuities between the system of philosophy and the conceptualization of religion in the late works. Altmann correctly described that Cohen's concept of "correlation," the basic conceptual tool found in BR and RV alike was a philosophical principle that maintains the tenets of Cohen's systematic thought and applies them to the exposition of the doctrines of the Jewish faith. According to Altmann, Cohen's concept of religion and his interpretation of Judaism augment and complete rather than displace the rational method of his system. In this view, the full title of the work, Religion of Reason Out of the Sources of Judaism, is reinstated as intending what it says: to argue for the possibility of establishing a religion of reason while doing so from the sources of a particular faith.

Steven Schwarzschild went further than Altmann and others by not merely calling attention to the rational underpinnings of $R V$ but by interpreting Cohen's philosophy of religion as if the imperative of "resolving" religion into ethics were still in place while dismissing Cohen's own statements to the contrary as mere rhetorics. All assertions that religion deserved consideration beyond ethics Schwarzschild interpreted as rhetorical rather than real. Judaism, to Schwarzschild's Cohen, was ethical monotheism, and ethical monotheism was monotheistic ethics. In BR and RV, so Schwarzschild, Cohen rehearses the very content of Ethics of Pure Will in the language of religious ideas without adding anything substantially new.

In this sustained debate, two basic issues have been at stake, namely our understanding of Hermann Cohen as a thinker whose integrity and intellectual development remain blurred behind two diametrically opposed perspectives; and, more importantly, a full appreciation of the character, merits, and limitations of Cohen's philosophical argument for the validity of religion in modern culture and society. To the degree that the argument for religion is part of Cohen's overall philosophical thought, one must make up one's mind about it in order to come to an informed judgment on his approach to philosophy in general. The first issue at stake, then, is Cohen's personal integrity as a thinker, the second issue is the integrity of his thought. Franz Rosenzweig and other contemporaries cherished Cohen's influence as a teacher and as a philosopher, a towering figure on the philosophical scene despite his 
small, rotund built, and so were equally concerned with his personal integrity as with the provenance of his philosophy. As we approach Cohen's posthumous work, it is important to remain mindful of the complex forces and intentions Cohen sought to reconcile in his life and work, forces that were self-evident to some of his acquaintances and that only careful weighing and interpretation of the historical evidence can retrieve for us.

The contemporary responses to Cohen's philosophy of religion are naturally of particular interest here. These sources are apt to highlight some of the tensions encountered and tackled by the author in his attempt to establish religion within the context of philosophy and to do so by establishing Judaism and Jewish sources as a wellspring of religious knowledge and practice with universal significance. The primary problems to be considered in this context are also the ones which make it both interesting and difficult to read Cohen today without completely misunderstanding some of his intentions. Judaism, Germanism, religion, and philosophy are the seemingly heterogeneous domains clashing in Cohen's late religious thought. It is immediately clear that these terms are not of the same category. But it will become clear that Cohen regarded it as one of the tasks of his philosophy of religion to resolve the tension between the domains indicated in these terms. Before coming to a more general understanding of these terms as the parameters of Cohen's later philosophy of religion it might be useful to look at some of the contemporary testimony that accompanied the publication of Cohen's philosophy of religion like the murmurs of interpretation that accompany any great texts.

The first sample of contemporary voices comes from within the Marburg School, commenting on the publication of Begriff der Religion. The two interlocutors are Nicolai Hartmann and Heinz Heimsoeth, students of Cohen's who later became recognized philosophers in their own right. The time is late November/early December 1915, the occasion is the celebration of Cohen's fiftieth doctoral anniversary, which neither of them attended nor used as an opportunity to congratulate their former teacher. Instead, they avoided him when the war allowed them to travel to Marburg where Cohen was holding his "beloved lecture on Kant," as Heimsoeth reports with more than a hint of sarcasm. ${ }^{352}$ Reporting further on the most recent Marburg gossip, Heimsoeth writes (in sensationalist newspaper style):

${ }^{352}$ Letter from Nov. 14, 1915, Nicolai Hartmann und Heinz Heimsoeth im Briefwechsel, (Frida Hartmann/Renate Heimsoeth ed.), Bonn: Bouvier, 1978, p. 205. 
Cohen publishes systematic foundations of the philosophy of religion (subtitle: Systematic defense of Judaism as the chosen people with the aid of the tool of rationalism, distorted and driven to absurdity to that end. Note: Everything important is written-as with all great men-between the lines!) Motto: Now I told them! Final result (between the lines): "We'll eat you all up!" 353

One should not read too much into these passages. Heimsoeth may have vented the type of disgruntlement that is not uncommon among graduate students with overpowering teachers. More importantly, his flippancy prompted Nicolai Hartmann to express a much more cautious assessment of the work in question.

As to Cohen's philosophy of religion, this book is more interesting to me than his esthetics or even, at this point, his ethics. Firstly he knows more about it and secondly it is finally an opus where he drops his mask. 354

The friction between Cohen and his former students is evident. The ill-will palatable from Heimsoeth's remarks and the insinuations implied in Hartmann's retort are aspects of a larger picture that has been documented and analyzed in great detail by Helmut Holzhey ${ }^{355}$ and Ulrich Sieg. ${ }^{356}$ Holzhey analyzed the relation between Cohen and Natorp, the founders and figureheads of the Marburg School of neoKantianism, a study which has provided the first detailed differentiation between the philosophical approaches of Cohen and Natorp and thus laid the foundation for a more sophisticated and justified assessment of both as original philosophers who agreed to disagree on many questions. Holzhey also published letters and other documents highlighting the tensions concerning faculty, students, university administration, and the Prussian government office in charge of running Marburg's Philipps University at the time. Sieg utilized this and other archival material to paint a detailed picture of the "rise and fall of neo-Kantianism" at the department of philosophy of this provincial university, showing that the many indignities and aggravations Cohen and those considered close to him suffered were the expression of an anti-Semitism that was pervasive at the university, in the town of Marburg, and in the Prussian administration.

However, behind Hartmann's statement one can also find the philosophical appreciation of a thinker who had finally faced up to a

${ }^{353}$ Op.cit. p. 208 (letter from Nov. 28, 1915).

${ }^{354}$ Hartmann to Heimsoeth (Dec. 6, 1915), op.cit. p. 211; my emphasis.

${ }^{355} \mathrm{Cf}$. Holzhey, Cohen und Natorp, vol. 2 (1986).

${ }^{356} \mathrm{Cf}$. Ulrich Sieg, Aufstieg und Niedergang des Marburger Neukantianismus (Würzburg, 1994), reviewed by this author in: Journal of Jewish Studies vol. xlvii, No. 1, Spring 1996, pp. 185-189. 
hitherto concealed truth, who had finally found his own voice. Heimsoeth and Hartmann felt that when Cohen returned from retirement to lecture on Kant, replacing some of the conscripted younger members of the faculty, he seemed blinded to the reality of German imperialism. He seemed eager to strengthen the German war effort when he wrote essays that emphasized the deep cultural agreement of Jews with Germans and of both with Kant, ${ }^{357}$ yet his behavior appeared to be a strategy of Jewish apologetics. When Cohen finally began to write on religion and Judaism, a formerly hidden agenda was finally revealed. He had "dropped his mask."

This view implies further that Cohen's Ethics, and hence his whole system, had concealed Cohen's true agenda behind a veil of rational and idealist universalism. Far from condemning Cohen's new religious philosophy as a continuation of an apologetic agenda, as does Heimsoeth, Hartmann endorses it as a justified philosophical move, a kind of existentialization of philosophy, the taking of an individual stance as the proper mode of philosophical truthfulness.

We see, then, that Rosenzweig was not the only one who saw it as a critical step in the right direction when Cohen's writing turned to Judaism. The underlying affirmation and rediscovery, on the other hand, frightened Cohen so much that he hid this Ereignis and Erlebnis behind the jejune term "correlation," which-as Rosenzweig once told Martin Buber-meant the same as the latter's "not much more German word 'relation'" (Beziehung). ${ }^{358}$ Yet the discovery had been made nevertheless.

Other readers, too, felt that Cohen was making a bona fide attempt at describing religion proper, expanding the limits of reason to include at least the outlines of a phenomenology of the religious experience as one transcending the limits of reason. Yet they also felt that this attempt had failed. Cohen had expressed the hope that his philosophy of religion was to "bridge the gap" between himself and his Protestant Marburg colleagues Natorp and Herrmann, a gap which consisted in the difference between ethics as a propedeutic to religious immediacy and self-generation versus ethics and religion as mutually augmenting

${ }^{357}$ See, e.g., Über das Eigentümliche des deutschen Geistes (S1,527-570); Vortrag, Berlin. Reuther \& Reichard, $1914(45 \mathrm{pp})=$ Philos. Vorträge der Kantgesellschaft , Nr. 8, 2. und 3. Aufl 1915, Deutschtum und Judentum. Mit grundlegenden Betrachtungen über Staat und Internationalismus (J 2,237-301); 2. Aufl. Durchgesehen, ergänzt und mit einem kritischen Nachwort als Vorwort, Gießen: Töpelmann, 1916 (59pp) = Von dt. Zukunft, 1. Stück, and Kantische Gedanken im deutschen Militarismus (S2,347-354); Frankfurter Zeitung, Nr 8, 9.1.1916.

${ }^{358}$ Letter to Buber (without date), BT II, p. 825f. Similarly to Rudolf Ehrenberg in a letter of March 5, 1918 (BT I, p. 514): "Er sagt leider "Korrelation", wo er Bund meint. Dabei ist-trotzdem-die Sprache vollkommen Sprache." 
correlates (perhaps in the sense of Natorp's correlation between subjectivation and objectivation) ${ }^{359}$ If Cohen believed that there was finally an agreement between them, he must have been wanting to express something far more personal and immediate than what Herrmann was able to discern. For years, Herrmann had challenged Cohen to come up with a philosophical justification of religion as distinct from ethics. Herrmann believed that Cohen's obvious personal piety was real, but that the stated program of "resolving religion into ethics" could not possibly do justice to the true opinion of a pious believer. With Begriff der Religion, Cohen tried to give religion a philosophically tenable expression that, at the same time, did justice to the religious experience. The reviews of BR and of RV written by Herrmann and others show that such an agreement had not been achieved. The Protestant Marburg colleagues and students read both works as a continuation of the system rather than as reasoned expression of Cohen's faith. What "concerns us immediately" ${ }^{660}$ continued to evade Cohen's prose. The controversies over Cohen's philosophy of religion that provided the point of departure for the composition of the 1915 treatise thus continued after its publication and have not been settled since.

Rosenzweig believed that Cohen's existential affirmation of Judaism was more pronounced and had greater philosophical independence in the posthumous work than anywhere else. He read Cohen as reaching "beyond" the system. There are good reasons to treat Rosenzweig's interpretation with a hermeneutics of suspicion. His reading should be based on evidence in the work itself. Instead, and in line with the imperative he formulates in his own magnum opus, the Star of Redemption, Rosenzweig categorically dismisses such positivistic hermeneutics and points "to life" as having to bear witness and testify to one's true intentions. Hence in his 1916 correspondence with Eugen Rosenstock, Rosenzweig takes great care in distinguishing the written from the oral Hermann Cohen. Based on his intimate knowledge of the latter, he takes the liberty to make far-reaching claims about the former.

Rosenzweig heard Cohen in Berlin in the fateful years 1913 and 1914 after he had almost converted to Christianity. He encountered Cohen as a true philosopher (not just a professor of philosophy), a charismatic figure, and an ardent Jew, a unique combination in Germany at the time. Being himself in the process of sorting out what it meant to him to be

${ }^{359}$ This was a problem Natorp considered at the time when Cohen published Begriff der Religion. See Nicolai Hartmann und Heinz Heimsoeth im Briefwechsel, p. 210.

${ }^{360}$ Tillich's notion of religion as "was uns unmittelbar angeht" is a notion first expressed in Herrmann's writings. On Herrmann cf. Zank (1994), pp. 268-280. 
Jewish and German, Rosenzweig no longer believed that the aspired reconcilation should be sought in cultural terms. In fact the juxtaposition of Germanism and Judaism was to be replaced by one of Judaism and Christianity. Religion had just begun to become the ground of reality to Rosenzweig, and he felt that Cohen was undergoing a similar transformation without having yet given this profound insight its proper philosophical expression. Here was the overwhelming example of a living and breathing Jewish genius, no matter how barren his previously published philosophical works had been. Here was someone concerned about the fate of the persecuted Russian Jews, someone who did not endorse the genteel Western contempt for the Ostjuden. Rosenzweig, having barely escaped the baptismal font, was helped in his reconstruction of a Jewish identity by a man who took a place in his life which had been vacated by the death of his uncle Adam, the only traditional Jewish figure in his early life. Philosophically however, Cohen and Rosenzweig were and remained worlds apart. ${ }^{361}$ In their effort to rejuvenate Jewish learning they were absolutely united and gave each other strength. After Cassirer, ${ }^{362}$ Rosenzweig became Martha and Hermann Cohen's second Jewish philosopher-son.

When Rosenzweig wrote his introduction to Cohen's Jewish writings (1924), he gave expression to his own Cohen, the one he knew personally, for whom his admiration grew the better he knew him and who wished to preserve this Cohen for posterity. ${ }^{363}$ His intention was to save Cohen as a Jew for future generations by modeling him after his own image (and that of many of his contemporaries) as that of a great baal t'shuvah. He intended to pry Cohen loose from his neo-Kantian image and make him a "revolutionary of thought." 364 Rosenzweig pursued this purpose even though he had to contradict evidence to the contrary which he himself had elicited from the object of his reinterpretation. ${ }^{365}$ On the other hand, he could admit that he did "not

\footnotetext{
${ }^{361}$ Cf. Franz Rosenzweig, letter to Margrit Rosenstock, August 18, 1918, quoted (in translation) by Harold M. Stahmer, "Franz Rosenzweig's Letters to Margrit Rosenstock-Huessy, 1917-1922" in Yearbook xxxiv, p. 400f. Similarly, in 1916 Rosenzweig defends his respect for Cohen not with reference to his books but to his intimate acquaintance with his personality. See letter to Eugen Rosenstock, September 5, 1916, BT I, p. 223. Also see the letter to Martin Buber from Sept. 16, 1923: "Dabei verstehe ich ihn noch nicht mal." (BT II, p. 923).

${ }^{362}$ Cf. Toni Cassirer, Mein Leben mit Ernst Cassirer, Hildesheim: Gerstenberg, 1981, pp. $89 \mathrm{ff}$.

${ }^{363}$ Letter to August Mühlhausen, July 15, 1927, in: BT II, p. 1168. Also cf. ibid., p. 918.

${ }^{364}$ Rosenzweig, letter to his mother, Sept. 14, 1928 in BT II, p. 1198 and cf. ibid., pp. 983 and 1190.

${ }^{365}$ See to Jakob Horovitz (April 1924), BT II, pp. $957 f$.
} 
even understand him" and that, therefore, "hardly any sentence" of the introduction was written "without a guilty conscience." 366 In fact, Rosenzweig had already shaped his opinion about the difference between RV and the previous system before he had even read any of Cohen's systematic works! ${ }^{367}$ Cohen, incidentally, seemed to have been aware of Rosenzweig's dialectical skills. He once told Adele Rosenzweig that her son had "quite a way of caressing while slapping one in the face with one and the same word." 368

Rosenzweig's portrait of Cohen was plausible and meaningful for the generation which came out of the war, and it helped to salvage Cohen as a great Jew after the demise of Marburg. ${ }^{369}$ Cohen seemed to have outgrown Marburg neo-Kantianism. By moving from Marburg to Berlin and from ethics to Judaism he had left it behind long before it finally collapsed. ${ }^{370}$ This Gestalt (as Rosenzweig's fellow-student Viktor von Weizsäcker might have called it) seemed persuasive not despite but because of its conversion narrative, casting, as it did, the bourgeois existence of Professor Cohen's life in terms of radical departure. A variant to this narrative is implied in an account by Jürgen Habermas on the German idealism of (some) Jewish philosophers. According to Habermas, Cohen's "turn" to a form of religious existentialism emerges as a turn to a more decidedly Jewish philosophy. The wording of the following quote is unthinkable without Habermas relying on the accuracy of Rosenzweig's account.

But finally the wrapper of civilization to which the Zivilisationsjuden, as they were called, seemed to have so completely divested themselves breaks apart. The aging Cohen is driven to the edge of his system by the question of the binding force of the Mosaic word of God. ${ }^{371}$

${ }^{366}$ Letter to Buber, Sept. 16, 1924 in BT II, p. 923.

${ }^{367}$ See the letter to his mother, shortly after Cohen's death and only one month after he admitted to Cohen that he was ignorant of his system. BT I, p. 538 (\#508) and see ibid., pp. 521-524 (\#493).

${ }^{368}$ Ibid.

${ }^{369} \mathrm{Cf}$. one of Rosenzweig's last essays (May 1929), "Vertauschte Fronten" in: Z, pp. 235-237.

${ }^{370}$ The symbolic event which marked the demise of Marburg was the disputation between Cassirer and Heidegger in Davos, in 1929. See Jürgen Habermas, "Der deutsche Idealismus der jüdischen Philosophen" 1961 in: Philosophisch-politische Profile, Frankfurt: Suhrkamp, 1971, pp. 52f, Toni Cassirer, op.cit., 181ff (who erroneously dates the meeting in 1931). Rosenzweig refers to this event in "Vertauschte Fronten."

${ }^{371}$ See Habermas, op.cit., pp. $42-47$; here: p. 46 
But all depends on the perspective. For Toni and Ernst Cassirer, for example, Cohen represented an unusually Jewish Jew, long before the "breakdown of the ceiling of "civilization"' alleged by Habermas.

It was something completely new to me that a scholar of Cohen's stature (Cohen the neo-Kantian, Cohen the fervent German patriot) was entirely tied to Jewish tradition and identified himself completely with the suffering of the Jewish people in all its earthly appearances. The Judaism into which we were born was to us a matter of course to which we felt we belonged. But essentially we knew very little of what it meant for Cohen. For us there were Jewish Germans, Jewish Poles, Jewish Russians, etc. For Cohen the emphasis was elsewhere. For him there were German Jews, Polish Jews, Russian Jews, etc. We had grown up in liberal families with Jewish family traditions but with imprecise knowledge of Jewish history. In contrast, Cohen was the son of a Jewish teacher and, while still a little boy, he was chosen because of his abilities to study theology and to become a rabbi. Later he discovered his philosophical talents and decided to renounce the theological career. But he grew up on a different soil than we and although this fact did not prevent him from becoming the most important German philosopher of his time, from rediscovering Kant, and, stranger still, from becoming a fanatical, shortsighted, German patriot during the First World War, he remained most intimately attached to the deepest roots of his heritage.

It was touching to witness his pain over the fate of the persecuted Jews in Poland and in Russia. The last time we visited him at his sickbed it was Passover. Cohen was raised high in bed and breathed with difficulty. On both sides of his pain-racked face his snow white locks rested damply on the pillow and he could hardly speak. Then the nurse brought him a cup of coffee with a piece of matsah. Cohen looked, took the matsah, and his expression changed completely. With an angry voice and raised arm he began to denounce the blood libel. "This vicious lie that no one who spread it ever believed in was invented in order to destroy us," he suddenly cried very loudly. "But they will never succeed-believe me my friends, and hold on to our religion." We shook his hand and left the sickroom. A few hours later Cohen died. When I heard this I told Ernst: 'Don't you think that today we saw a prophet die?" Fifteen years later, in April of 1933, we fully understood along what path Cohen's mind wandered during his last hour. (Toni Cassirer, op.cit., p. 94)

These moving reminiscences illustrate that some of Cohen's closest friends perceived the secret of his personality as the strength to reconcile within himself the philosopher and the Jew. Far from Rosenzweig's portrait of Cohen as a precursor of a "new thinking" 372 and a baal

${ }^{372}$ Cf. "Das neue Denken" in Z, p. 152. 
t'shuvah, Cassirer simply describes a rare personality remembered with nostalgia for a bygone era of innocence.

When trying to understand how Rosenzweig's strong reevaluation of Cohen squares with some of the other testimony one must note that Rosenzweig never claimed that Cohen had consciously left behind his system when he wrote his final opus. Rather, he states that Cohen "had no clue" (he was ahnungslos) that he was in fact leaving idealism behind. $\mathrm{He}$ was unaware that he was "flying into the land of a future philosophy." 373 This suggests that Rosenzweig's "Einleitung" to the 1924 edition of Cohen's Jewish writings should be regarded largely as a piece of creative writing, a historical document in its own right, and an important implicit statement of Rosenzweig's understanding of philosophy, ${ }^{374}$ not, however, as a bona fide contribution to the study of Hermann Cohen's philosophy of religion or his Jewish thought.

In spite of the evident tendentiousness of Rosenzweig's "Einleitung," it may be possible to justify at least some aspects of this idiosyncratic interpretation of Cohen's intellectual development. There may be something within RV that gave Rosenzweig sufficient justification for a reading that claims (following a time honored tradition of philosophical interpretation that had been practiced by Cohen himself as well) to understand the author better than he understood himself. Whatever Rosenzweig found in RV, it was not necessarily something which inherently contradicted Cohen's previous systematic philosophy. Rosenzweig was never trained in the Marburg neo-Kantian tradition and made up his mind about Cohen before reading his philosophical works. In contrast, in 1916, his friend Eugen Rosenstock tried to read Cohen's Logic although he did not seem to get very far whereas Rosenzweig, at that time, only invokes his intimate and dear knowledge of the "unwritten" Cohen. Rosenzweig had been trained and influenced not by the Marburg School but by the Southwest German school of neoKantianism (Rickert, Windelband). The source of his incipient Hegelianism and post-Hegelianism was his older cousin Hans Ehrenberg. Thus, when Rosenzweig appropriated the "elements of experience" of his magnum opus Star of Redemption from Cohen's Logic

${ }^{373}$ Letter to Ernst Simon, (fall 1922), BT II, p. 845. Similarly in the essay "Das neue Denken" in Z, p. 152.

${ }^{374}$ Cf. Rainer Wiehl , "Logik und Metalogik bei Cohen und Rosenzweig" in: Wolfdietrich Schmied-Kowarzik (ed.), Der Philosoph Franz Rosenzweig (1886-1929). Internationaler Kongress-Kassel 1986 vol.2: "Das neue Denken und seine Dimensionen"), Freiburg/München: Karl Alber, 1988, pp. 623-642, here especially p. 624 note 5 
he did so in an act of "conscious transformation." 375 Three or four years later he composed the "Introduction" to Cohen's writings of 1924. It is therefore plausible to assume that Rosenzweig's own extrication from the idealist tradition implied a departure from the model of neoKantianism represented by his immediate teachers rather than from one represented by Cohen. As regards Rosenzweig's understanding of Cohen's intellectual development, he was torn between two models of interpreting the relation between RV and Cohen's system: on the one hand he emphasized the radical departure of Cohen's philosophy of religion, on the other hand he highlights the unity of the personality of the thinker who gradually, and phase by phase, speaks of what concerns him, with germs of later developments often being evident in earlier statements. Rosenzweig's intuitions can be fully explicated only if one demonstrates what sets apart Cohen's late philosophy of religion from Rosenzweig's understanding of philosophy from "Ionia to Jena," an analytical effort which cannot be provided here.

What is clear even without a broad analysis of Rosenzweig's understanding of the history of philosophy is that he saw at the core of Cohen's philosophy of religion/Jewish thought the very problem which he and others had discovered for themselves as the most burning philosophical issue of the time and that Cohen sought its solution in the same direction as they did. The problem is the constitution of concrete subjectivity and its solution is sought in the I and Thou of God and human being. ${ }^{376}$ For Rosenzweig, this recognition of the "individual quand même" 377 entailed a breakthrough from the realm of idealism (from Parmenides to Hegel) to a "new thinking," an overcoming of thought by experience, and a shift from the esthetic religion of

\footnotetext{
${ }^{375} \mathrm{Cf}$. Hans Martin Dober, Die Zeit ernst nehmen. Studien zu Franz Rosenzweigs "Der Stern der Erlösung," Dissertation, Eberhard-Karls-Universität Tübingen, pp. 51-63. And see Rainer Wiehl, op.cit. passim, and Norbert M. Samuelson, "The Concept of 'Nichts' in Rosenzweig's 'Star of Redemption'" ibid., 643-656

${ }^{376}$ Martin D. Yaffe, who was the first to recognize the value of comparing Cohen's and Rosenzweig's account of the (Day of) Atonement, goes further than I think is sustainable from Rosenzweig's intellectual biography when he writes that "Rosenzweig's thinking remains dependent on Cohen, in that the very individual with which Rosenzweig starts is a result bequeathed to him by Cohen's prior analysis." ("Liturgy and Ethics: Hermann Cohen and Franz Rosenzweig on the Day of Atonement" in: Journal of Religious Ethics 7/2 (1979), p. 217. Cf. Rosenzweig's explicit statement in "Das neue Denken" in Z p. 152A more recent study on the role of Yom Kippur in Rosenzweig's Star is Emil L. Fackenheim, "The Systematic Role of the Matrix (Existence) and Apex (Yom Kippur) of Jewish Religious Life in Rosenzweig's Star of Redemption"in: SchmiedKowarzik op.cit., pp. 567-575.

${ }^{377}$ Rosenzweig, "Vertauschte Fronten," in: Z, p. 237. I am told that, in idiomatic French, the expression should be soi même.
} 
Schleiermacher to Kierkegaardian faith. The new thinking also called for a new conception of time which was no longer taken as the pure inner form of perception but as qualitatively determined by unique experiences. Rosenzweig and his contemporaries (including the later Heidegger) also rediscovered the prerogative of spoken language over thought. Most importantly, they shifted from the transcendental subject as the condition for the possibility of cognition to the Ich, Vor- und Zuname, that is born in the moment of being called upon by, and answering to, a Thou. Rosenzweig finds inklings of all of these traits of new thinking in Cohen's late philosophy of religion. To him, Religion der Vernunft is nothing short of a "linguistic turn" from logic to language and from thought as the ground of being to the language experience of liturgy as the origin of the particular self in correlation with God. ${ }^{378}$

\subsubsection{Religion of Reason Out of the Sources of Judaism}

In the following paragraphs I describe the structure and argument of Religion der Vernunft, the work which brought Cohen's project to realization. A full philosophical and philological commentary is not intended here nor necessary for the purpose of this study. I am merely interested in verifying that the late philosophy of religion indeed builds on what I have described above as the major breakthrough in Cohen's religious thought, the discovery of the idea of Versöhnung as an authentically Jewish theologumenon with a peculiar philosophical depth. Cohen's continuous preoccupation with a) the systematic task of coordinating ethics and religion, and b) with concrete subjectivity as a problem of thought to be dealt with in the context of religion. The idea of Versöhnung gives expression to this set of problems. All of these matters come together in RV. Whatever else this work was intended to do, it contains Cohen's solution to these problems.

As a final preliminary remark, note that Cohen's opus posthumum was first published under the title Die Religion der Vernunft (The Religion of Reason), as if Judaism was the only rational religion. Had this been Cohen's intended meaning, however, he could have chosen a title such as Das Judentum als die Religion der Vernunft. The introduction makes it clear that this was not Cohen's intention. ${ }^{379}$ In addition, Bruno Strauß pointed out that Cohen wanted to name the book Religion der Vernunft

${ }^{378}$ Cf. Dober op.cit. p. 61 and see Rosenzweig's letter to Buber, BT II, p. 825. This approach to interpreting RV has found particular attention in recent Catholic philosophies of religion, especially in the studies of Ollig and Schaeffler.

${ }^{379}$ See below and cf. Cohen's explicit ecumenism, ibid., pp. $39 \mathrm{f}$ 
aus den Quellen des Judentums, i.e., without the definite article (see RV p. 625). ${ }^{380}$

\subsubsection{The Table of Contents}

The table of contents is usually a good indicator of the structure of a book. In the case of RV, however, the subject headings are at first confusing. Apart from the introduction which explicates the major themes named in the title (reason, religion, and the sources of Judaism), the book consists of twenty-two chapters. The number of chapters corresponds to the letters of the Hebrew alphabet. This number does not seem unintentional, not least because number symbolism has a rich history in the Jewish tradition. The Torah, made up of combinations of the twenty-two letters of the Hebrew alphabet are the basic tools of both creation and revelation through divine speech $(=\log o s)$. Furthermore, the range of the alphabet indicates an encyclopedic method which, if not aiming at completeness, indicates comprehensiveness. The philosophy of Judaism, as presented by Cohen, represents the full range of basic systematic issues "from A to $\mathrm{Z}$," alpha et omega. In this encyclopedic character of the exposition which is grounded in systematic thought, Cohen pays homage to his teachers Boeckh and Frankel. ${ }^{381}$

Far from limiting himself to terms taken from the Jewish tradition, Cohen highlights the systematic character of the work by using both traditional and philosophical formulations to indicate the content, progression, and relation between the chapters. This is what makes the table of contents confusing, a seemingly incongruous assemblage of terms. "Creation" (III), "Revelation" (IV), "The Holy Spirit" (V), "The Atonement" (XI), "Messiah and Humanity" (XIII) are relatively traditional theological notions or dogmatic topoi found in Jewish and especially in Christian expositions of religious doctrine, albeit not necessarily in the same order. (See below) The systematic exposition of Jewish religious doctrine is, of course, in itself a modern invention and has not really found much acceptance outside the Wissenschaft tradition.

${ }^{380}$ If not indicated otherwise, page numbers refer to the 1978 edition of RV; references combined of Roman and arabic numerals refer to chapters and paragraphs (e.g., XI, 16 refers to chapter XI, paragraph 16).

${ }^{381} \mathrm{Cf}$. August Boeckh, Encyklopädie und Methodologie der philologischen Wissenschaften, ed. Ernst Bratuscheck (2. ed. Rudolf Klussmann) Leipzig: Teubner, 1886, and Zacharias Frankel, whose Darkhey ha-Mishnah categorized the Mishnah as an encyclopedic work in the sense of the word developed by Boeckh. 
The legitimacy of this enterprise is itself one of the primary questions to be raised in the attempt of justifying the pursuit of Jewish philosophy. ${ }^{382}$

Other chapter headings are short paraphrases of the contents to which they relate. Some of these are quite idiosyncratic so that they do not really provide much of a clue. Chapter II, for example, deals with "the creation of the human being in reason," and chapter VIII similarly enigmatically announces "the discovery of the human being as fellowhuman being." Chapter IX is devoted to a classical aspect of religion rather than theology, "the problem of religious love." Chapters I "the uniqueness of God") and VI ("the attributes of action") deal with themes familiar from medieval Jewish philosophy. Chapter XII (on the Day of Atonement) is the only one dealing with a specific holiday, while chapter XIV gives an exegetical exposition of prophetic passages on Messianism. Chapter XV juxtaposes myth and religion in the terms "Immortality" and "Resurrection." This is followed by chapters on Law (Torah/Halakhah) and Prayer.

The last set of chapters, on "virtues" in general (XVIII) and in particular (XX-XXII) mirrors the conclusion of Ethics of Pure Will, dealing with the conditions of the realization of ethical theory. Three of the virtues in RV (justice, courage, and faithfulness) ${ }^{383}$ correspond to those in ErW (courage, faithfulness, justice). The table of contents of RV does not refer to those virtues which, in ErW, are distinguished as "virtues of thought," namely "truthfulness and modesty" (ErW 552). Furthermore, the ethical virtues culminate in "humanity" (Humanität), while the religious virtues culminate in "peace." 384

I have not mentioned one chapter, namely chapter $X$ : "The Individual as I." There are clearly no traditional terms in this heading. Rather, this chapter formulates the problem which, as we know, indicates the systematic link between ethics and religion. And it is this chapter which sets the stage for chapter XI, on "Atonement."

Despite the seeming incoherence, RV follows a very carefully conceived plan. Anticipating the more detailed exposition below, I propose the following progression and order of contents. Chapters I through IX introduce the moral principles of Jewish monotheism, chapters $X$ through XII deal with the constitution of concrete individuality as the principal task of religion for the sake of the

${ }^{382}$ Cf. Alexander Altmann, "Are There Dogmas in Judaism?" (1937) in: Alfred Ivry, The Meaning of Jewish Existence (transl. by Edith Ehrlich and Leonard $\mathrm{H}$. Ehrlich), Hanover and London: Brandeis University Press, 1991, pp. 105-114.

${ }^{383}$ Gerechtigkeit, Tapferkeit, Treue.

${ }^{384}$ Note that Albo's Sefer Ha'ikkarim ends with a chapter on peace as well. Cohen's attention to this chapter is also evident in the excerpts among the notes from Nachlaß Natorp Ms. 831 (Appendix B, Texts 2-5). 
realization of ethics. Chapters XIII-XV deal with Jewish ethics, namely in its particular vision of the future for the human universe (XIII, XIV) as well as in its belief for the future of the individual (XV). Chapters XVI through XXII indicate the means by which Judaism provides for the steadiness of this infinite process towards the messianic future. Such provisions concern the community (XVI: Law) as well as the individual (XVII: Prayer). Finally, chapters XVIII through XXII ascribe to religious virtues the same function for the continuity of morality in a particular religious community as the corresponding chapters in the Ethics ascribe to the primary moral virtues that relate to the development of states.

Religion der Vernunft therefore shows a two-part structure.

Part one (I-XII) presents the correlation of God and human being in three steps, namely

- the determination of the uniqueness of God, the implications of this idea for the continuity of nature, and the continuity of nature as a precondition for the futurity of the ethical perspective (I-III),

- the correlation between God's attributes of action and human morality (IV-IX), and

- the correlation between the unique God and the concrete individual in the doctrine of atonement as the condition for the possibility of philosophically true and ethically meaningful personhood (X, XI, XII).

In the latter triplet of ,chapters, the correlation of God and the human being reaches its apex and the unique contribution of religion to culture is retrieved from the sources of Judaism. The chapters on Versöhnung (chapter XI, on the idea) and Versöhnungstag (chapter XII, on the liturgical setting of the idea) are in the very middle of the book and at the center of its argument.

The last chapter of the first part is also the first book of the second part (XII-XXII). In the latter half, conditions for the realization and perpetuation of the ideas of the first half come into focus. Part two lays out the beliefs, institutions, and virtues which provide the steadiness and direction for a continuous process to an otherwise isolated event of selfconstitution. Just as the second part of the Ethics of Pure Will concerns realization of ethical theory, so the second part of Religion of Reason concerns the practical aspects of the philosophy of Judaism.

Furthermore, the narrow focus on the individual that provides the pivot of the correlation in the first part is immediately turned around towards the principle of universalism when Cohen lets a chapter on messianism follow those on the atonement. Concrete subjectivity is 
sublated, its direction reversed, by turning away from inward-looking spirituality and towards the ethical purpose of the exercise of religion.

The path of RV therefore leads from the first universal condition in God and his creation, to the social world of the human being and its apex in individual redemption, to the vision of universal peace. There is more than a faint echo of traditional dogmatics in this progression. The classical triplet of themes (God/creation, revelation, and redemption) is preserved and interpreted in a modern idiom. Joseph Albo's Sefer Ha'ikkarim comes to mind, which Cohen consulted as we know from excerpts preserved among the manuscripts on Versöhnung. Albo who wrote in a Christian environment and took part in one of the famous religious disputations of his age reduces Maimonides' Thirteen Principles of Faith to three essential characteristics of a truly divine law, following Averroes in this categorization: the existence of God, revelation, and reward and punishment (Ikkarim 1:4).

Cohen also anticipates the structure of Rosenzweig's Star of Redemption which begins with the elements of all experience, climaxes in the description of individuality as a language-based experience, and ends in the perpetuation of this experience in religious liturgy. Rosenzweig, of course, was familiar at least with the first part of Cohen's work when he conceived the plan for the Star. ${ }^{385}$ But there are even deeper agreements between these thinkers. Liturgy provides the speechreality in which the concrete subject is constituted in both its radical individuality as well as its direction towards community. This constitution of concrete subjectivity is in both Cohen and Rosenzweig recognized as a philosophically legitimate problem that has its origin in particular religions. But there are also clear differences between Cohen and Rosenzweig. Where the latter includes Christianity in his purview of religious experience, ${ }^{386}$ the former limits himself to recognizing the theoretical possibility and the practical necessity for other religions to explicate themselves as reasonable religions. In accordance with this more limited historical perspective, however, Cohen is also forced to construe Jewish philosophy in its relation to ethics in a fashion that allows to draw political conclusions. The future of the Jewish community is made contingent on its ability to preserve, elaborate, and develop its political existence in the context of the Diaspora without losing its religious character. While limited to such religious communal existence,

${ }^{385}$ See Rosenzweig's letter to Rudolf Ehrenberg from 5.3.18, BT I \#487, p. 514 and cf. Z, p. 152

${ }^{386}$ Cf. letter to Eugen Rosenstock (without date, presumably December 1916), BT I, \#330, p. 317, referring to a poem by Novalis: "... aber so Ich und so Du sagen und das Ich und das Du durch Haben zu verbinden, das kann nur Jude und Christ, sonst niemand -." 
however, Judaism and Jews are given a historic cultural mission that determines their engagement within society and humanity at large. Rosenzweig, on the other hand, eliminates the historical trajectory of Jewish self-development and hands the theory of a mission over to the Christian community which invented and claimed it for itself in the first place. Participation in history is a matter of general morality, not of Judaism. As a member of several worlds, the Jewish individual can and should be politically engaged but this must not be taken as a surrogate for the liturgical intimacy in which the Jew finds herself taken out of history and into the perspective of the eternal. It would be false to charge Rosenzweig with abandoning history and forcing Judaism into a spiritual enclave. However, as his own decision indicates to publish essays of general interest under a pseudonym, the essence and being of the Jew, her authentic self-experience, is not to be found in expressions of participation in matters of general concern. This seems quite radical and extreme and even theatrical a posture to assume, and it is certainly in no way similar to the one assumed by Cohen.

Returning to the table of contents of Religion der Vernunft, the order of topoi points to a fundamental difference between this Jewish and various possible Christian perspectives. Christian dogmatics is derived from the order of the creed which, in turn, is determined by the trinitarian conception of God. Here the topos of atonement stands between creation and fall on the one hand and the giving of the holy ghost and final redemption on the other. This order in the articles of faith has eminent sociological implications. Faith in the efficacy of atonement wrought by Christ is the condition for entering into the circle of the communio sanctorum.

For Cohen, the holy spirit (ruah ha-kodesh) means the "spirit of holiness." This spirit is a shared attribute of God and human being (cf. Lev. 19:2). Each human being, male and female, has the potential for holiness. This is manifest in the performance of God's commandments (both moral and ceremonial, cf. Lev 19:3). In the poetic language of the Psalms, the fear is expressed that, as a consequence of sin, the spirit of holiness may be taken away from a person (Ps 51:13). This presupposes the possession of the holy spirit as a given of normal human experience. The inherent goodness of human beings that the notion of the holy spirit expresses can, at times, be so strongly emphasized that, in contradiction with the majority of Jewish literature, the need for atonement can be almost completely suppressed. For example, an important exposition of Jewish faith in the liberal tradition, Philippson's Die israelitische Religionslehre (Leipzig, 1861), plays down the doctrine of atonement. To Philippson, this topos seemed too determined by its Christian connotations and practically irrelevant for the pursuit of ethical 
monotheism as he understood it. ${ }^{387}$ Cohen was not troubled by the fact that atonement played a central role in Christian dogmatics. Rather he had learned to take it as a challenge to distinguish the Jewish concept of atonement both historically and systematically from its Christian counterpart and thereby provide it with its unique philosophical profile.

Jewish philosophy of religion is not the exposition of the implications of a set and concise text. The text it explicates is the Bible and the commentaries and discussions thereon, i.e., it is the ever contemporary step into the infinite process of appropriation and participation. While certain texts such as the Maimonidean formulation of 13 principles assumed in Judaism a status similar to the creeds in Christianity, they do not fulfill an identical function. Membership in the community is not contingent upon affirming specific principles of faith. Furthermore, the formulation of principles (ikkarim) is the result of a long tradition of oral debates, exegetical and philosophical discussions and individual effort at bringing this tradition onto a formula which is subsequently accepted by some and rejected by other communities. But the negation of these principles determines communion neither between individuals nor between communities. Whatever it is that determines in Judaism the boundaries between the accepted and the deviant, the formulation of creeds plays a marginal role in it. This is, in fact, also the reason why dogmatics is central to Christian theology while it is marginal in the Jewish literary tradition.

\subsubsection{The Introduction: Reason, Religion, and the Sources of Judaism}

The introduction provides a set of preliminary definitions of the terms whose interrelation determines the task of the book. The original subtitle of the work was "Jewish philosophy of religion and ethics." The introduction shows what this subtitle was to indicate, namely that the task of this philosophy of religion is to determine the "and" that unites and separates religion and ethics. This union, although it has its foundation in reason, is a concrete one, because it deals not with religion in general-this is in itself a problem, i.e., a concept and therefore not a "given" but a task—but with the "sources of Judaism." Conversely, the sources and their history do not yield their secret inner tendency and meaning without being questioned, without a Grundlegung.

\section{a) "Reason"}

From the outset, the task of RV is methodologically defined as a problem of knowledge, cognition (p. 4), or Wissenschaft (p. 1), i.e., as a problem of conceptualization. The subject is religion and Judaism "in so

${ }^{387}$ Cf. Philippson op.cit., vol. III (1865), p. 146. 
far as it poses a conceptual problem and in so far as the problem of the concept needs to be solved in order for the literary sources not to remain permanently a book with seven seals" (p. 4). The concept of religion is to be determined by looking at the "literary sources of the prophets," yet these sources

remain silent and blind if I do not approach them-of course after being instructed by them, but not absolutely guided by their authority-with a concept which I myself have first presupposed before having been taught by them. (ibid.)

Cohen meanders in a manner reminiscent of his own definition of thought (as the unification of distinction and unification) when he seeks to mediate between the concept as the origin of a knowledge of the sources and the sources as the origin of conceptual knowledge.

Insofar as religion, insofar as Judaism poses the problem of a concept, and insofar as this problem of a concept must be solved in order for the literary sources not to remain forever sealed, the exploration and exposition of these concepts, of religion and of Judaism, must be derived from an understanding of the concept itself. .... (I)f I am pointed to the literary sources of the prophets already when dealing with the concept of religion they nevertheless remain dumb and blind unless I approach them with a concept (albeit instructed by them while not completely guided by their authority), a concept which I subsumed my being instructed by them. ${ }^{388}$

This definition indicates that the same principle of reason which applies to all other tasks of conceptualization also provides the point of departure for the conceptualization of the literary and historical material of religion. This principle consists in the supposition that one cannot know anything unless reason first provides the foundation (Grundlegung) for such knowledge. Scientific knowledge, the object (Gegenstand) of cognition, is constituted in reason. More narrowly speaking, Cohen invokes the "logic of the concept" (Logik des Begriffs; cf. LrE pp. 376ff), i.e., the rules of concept formation that apply not only to scientific objects but also to problems of history (cf. ibid. pp. 386-392). Historiography, including the historiography of religion, claims to derive its concepts

388“Sofern die Religion, sofern das Judentum das Problem eines Begriffs darbietet, und sofern dieses Problem des Begriffs gelöst werden muß, wenn die literarischen Quellen nicht immer nur ein Buch mit sieben Siegeln bedeuten sollen, so muß die Erschließung und die Darstellung dieser Begriffe, der Religion und des Judentums, aus dem Verständnis des Begriffs selbst gewonnen werden. ... (W)enn ich schon für den Begriff der Religion auf die literarischen Quellen der Propheten hingewiesen bin, so bleiben diese doch stumm und blind, wenn ich nicht, freilich von ihnen belehrt, aber nicht schlechthin durch ihre Autorität geleitet, mit einem Begriffe vielmehr an sie herangetreten bin, den ich der Belehrung durch sie selbst erst zugrunde gelegt habe." pp. $4 \mathrm{f}$ (my emphasis). 
from the historical phenomena which emerge in the course of their "development" (Entwicklung). Just as in Logik and throughout the systematic works, Cohen argues here that it would be foolish not to recognize that the key to historiography, the idea of a "development," was an intellectual presupposition (cf. RV 1-2 and LrE 386, 530f). The concept is a tool of thought by which a particular set of problems is brought under the universal rules by which thought "unifies distinction and unification" (Vereinigung von Sonderung und Einigung, cf. LrE pp. 60$65,383)$. In history the task is to combine and organize the manifold of particulars within a totality of conditions under the guidance of an idea of the whole, i.e., to generate a teleological system of concepts which allows the advance of historical understanding (as well as the progress of history) to be construed in analogy to the process of scientific cognition, i.e., by trial and error (analogous to research). As concepts, Judaism and religion are instantiation of the historical question ti esti? (cf. LrE 378) which asks for the "essence" (LrE p. 350) and the ethical "purpose" or telos (cf. ibid. p. 353-363) of an historical "individual." As in the science of forms of life (biology), historical individuals are the individuals of a system of classification, not absolute individuals (cf. ibid. p. 350, 363ff). Historical conceptualizations deal with the problem of the human being as defined through action (cf. ibid. 351f). Posing the problem of action also raises the issue of the purpose and end of an action (cf. ibid.).

The difference between "purpose" in history and ethics must not be "evened out." In historiography purpose functions as a principle of organization (Ordnungsbegriff), whereas in ethics it is a principle of norm (Normalbegriff) (LrE p. 386f). Nevertheless, ethics is conceived as a guiding principle of history. Namely, if history is to deal with the human being not as the inhabitant of a behaviorist black box but as an ethical being, ethics becomes a principle of history in the sense that the ethical character of human actions is itself historicized. As much as ethics is a problem of reason, history has to be read as the record of the development of this basic presupposition of the human being and her actions. This is obvious in the history of legal theory and of constitutional science (cf. ibid. 388f). Here it is most evident that the "purpose" in its relative historical formulation is itself the "means" by which the ethical principle is continuously dealt with as the inner principle of history. By definition, this is also the case in religion. The history of (any) religion unfolds in the actions and literary productions which imply or reflect particular statements about its own purpose and the purpose of the human being. Inasmuch as religion is to be studied under the auspices of the concepts and methods of historiography it is necessarily an ethical subject, i.e., the "purpose" discloses religion because it is a matter of the human being as an end in itself, and thus a matter of further 
development. Because the human being is always an end in itself, the purpose of religion-as-a-problem-of-history cannot be absolute, beyond history and beyond the ultimate ideal of history. Religion contributes what it does from within and towards the unity of the cultural consciousness. Religion is questioned as to its contribution to the constitution of the human being as a member of the human community conceived as a totality of ethical persons (cf. LrE p. 392).

Notwithstanding the emphasis on the prevalence of reason, the "induction of religion to the realm of universal philosophy" (p. 5) suggests what Cohen then spells out not much later, namely that the concept of reason and the realm of the cultural consciousness are modified. The original blueprint of his system did not provide for a specific philosophy of religion. But nothing less is introduced here ( $p$. 6). ${ }^{389}$ Moreover, because reason itself widens its horizon by including religion rather than "resolving it into ethics" the attention is not primarily on the multifaceted world of historical varieties of religion but on a problem of reason itself, the "religion of reason." This religion of reason is said to "generate itself and verify itself" in a "historical selfgeneration of problematic reason" which is to be "demonstrated" in the "material" of the "sources of Judaism" (ibid.). Insofar as there can be a concept of Judaism and a concept of religion, there exists a "necessary relation" between reason and these historical entities. But the religion of reason is assumed to have "generated itself" within the sources of Judaism. Therefore, reason is the first source (Quelle) of religion (p. 6) namely in the sense of a Grundlegung in thought.

As in the case of the other parts of the system, reason does not enlarge its scope by means of free speculation. Philosophical argument serves the general function of "giving account" (logon didonai) of the conditions of validity of certain cultural facts which are "given" only to the extent that they can be derived from rational acts of hypothesis or Grundlegung. Reason is not "given" other than in its actual operations, nor can cognition be had without the objects constituted in it. The task of reason is to determine epistemological conditions of validity (Geltungsgrund). Reason is the inner condition and touchstone of culture which philosophy must bring to the level of consciousness. If religion is to be understood as religion of reason it must be "found" in a type of

${ }^{389} \mathrm{Or}$, more accurately, re-introduced. The same argument is already found in Begriff der Religion (1915) which we discuss in detail in Part II as the philosophical counterpart to Cohen's Jewish philosophy of religion. The motif of a modification of the system is to a certain degree rhetorical. 
material analogous to the "facts" of science, law, and art. ${ }^{390}$ Must not the phenomena of religion in general, i.e., the multifaceted world of religions, become this fact and source for the religion of reason? This seems the inevitable consequence if religion is to become a "universal function of human consciousness." Cohen clarifies his meaning by adding "of consciousness as a human one" (p. 8). What other consciousness is there? What he is referring to here as allgemeines menschliches Bewußtsein is characterized as "unfolding in the manifold which the people represent in their consciousness" (ibid.). In other words, he refers to a human consciousness which is but the general term for particular cultures, their languages, myths, and other factors by which they formulate and generate their common cultural identity. All human cultures share this type of consciousness. Each of them contributes in its own way to reason and to the religion of reason. In other words, the consciousness he is talking about is distinguished from the "unity of the cultural consciousness" which consists in the unity of reason in its different directions.

This generality of consciousness notwithstanding, Cohen makes a particular culture, namely Judaism and its religious literature, the "source" of the religion of reason. ${ }^{391}$ Cohen justifies this apparent departure from the rational directive by comparing the merit of Judaism with respect to religion with the merit of Greece with respect to the history of philosophy (p. 10). Judaism is considered the Urquelle of other sources of the religion of reason (p. 9). Ancient Judaism is the source of principles which have determined the history of religion as the history of the religious aspect of reason. It has the merit of having bequeathed to world culture the rules (Gesetzlichkeit p. 11f) which determine religion as the religion of reason. ${ }^{392}$ Even if it is granted that the historical merits of

${ }^{390}$ Already in the second edition of KBE (1910), Cohen acknowledges Kant as having considered the relation between ethics and religion on the basis of the biblical documents as "gleichsam ein Faktum" (KBE ${ }^{2}$ p. 20; similarly p. 459).

${ }^{391}$ The intense going back and forth between reason and history sounds intensely Hegelian. Rosenzweig already commented on this and found it as objectionable as he found Hegel himself. The Hegelian aspects of Cohen's philosophy have received some attention in the past and need further consideration. Cf. Manfred Pascher, "Cohens Ethik im Spannungsfeld zwischen Kant und Hegel" in Brandt pp. 95-109. Cohen does not refer to Hegel here, however, and he saw the attempt to derive the religion of reason from a historical religion (i.e., a Konfession) as the problem which Kant already wanted to solve in Die Religion innerhalb der Grenzen der blosen Vernunft (1793). See $\mathrm{KBE}^{2}$ p. 461. See ibid, 462ff, for Cohen's criticism of Kant's shortcomings.

${ }^{392}$ This is not the first instance in which Cohen refers to the historical priority of Judaism (the topos of the "mother-religion"). The same affirmative tenor determined, e.g., Cohen's address to the Unitarian World Congress in Berlin in 
Judaism in the history of (Western) religion as well as in Western cultural reflection on the validity of religion as a cultural value are beyond doubt, the question remains whether Judaism continues to exert its function as a religion within culture or whether it is to be displaced by something else. To the degree that a book can answer this question, Religion der Vernunft as a whole rather than its introductory chapter on the formal conditions of the conceptualization of the contents of a religion must answer it.

The first part of the introduction, then, deals with the general conceptual character of the religion of reason in its dual origin in reason and in history. It is determined in its epistemological character as beyond a simple disjunction between deduction and induction. As in all historical induction, ${ }^{393}$ the concept/problem of religion has been discovered in history, yet, in order to be recognized as such, it must be rediscovered as a problem of reason, and the historical "sources" must be interpreted from the perspective of a conceptual history which has as its end the integration of the concept into the infinite work of the unity of the cultural consciousness.

\section{b) "Religion"}

Concepts are determined by their range (Umfang; ambitus) and by their content (Inhalt; complexus). ${ }^{394}$ Religion seems to conflict with ethics with respect to both content and range because, like ethics, it refers to the human being (RV p. 13). Insofar as religion brings the human being under a kind of rule (Gesetzlichkeit), ethics and religion cannot conflict with each other. Such conflict could be avoided if religion and ethics simply referred to different aspects of the human being. But this seems contrary to what we have hitherto found in Cohen's thought. It would also contradict the idea that religion is historically prior to ethics and that it bequeathed certain notions to the making of the ethical discourse. Ethics is elsewhere, especially in ErW, conceived as inheriting and bringing to a theoretical solution certain aspects of humanity first discovered in religion. Of course, the relation of religion and ethics is one of augmentation in that ethics develops its concepts under the directive of the logic of cognition which possesses no concept of the individual soi même. Religion, however, cannot just begin where ethics leaves off. If what religion contributes to culture is to agree with ethics, it must include and endorse the universal concerns of ethics while augmenting

1910. See the echo to his speech in Weltkongress, p. 50. Also cf. "Die Liebe zur Religion" in Gemeindeblatt der Jüdischen Gemeinde zu Berlin 1.Jg. Nr.2 (Febr. 10, 1911). These texts show that there is no difference in selfassurance between Cohen's affirmation of Judaism extra muros and intra muros.

${ }^{393}$ Cf. LrE pp. $373-376$ and $512-594$.

${ }^{394} \mathrm{Cf}$. Hoffmeister, p. 108. 
and completing them with respect to particular communities and individuals. Ethics contains the principles of the state; the religion of reason contains the principles of the religious community and of the individual insofar as it is not just the particular case of a universal law.

Religion and ethics are congruent to the degree that to both nothing human must remain alien ("all questions of men become questions of religion" ibid.). But as a cultural force religion must help ethics overcome its inherent inability to deal with the human being as an individual soi même. In other words, ethics does not deal with the whole range of problems entailed in the concept of the human being. The trouble with such an assertion is that it generates the impression as if ethics itself were insufficient, as if it failed to do justice to the domain it sets out to conquer.

The content of religion which Cohen has derived from the Jewish sources is explicated not in a philological or historical but in a systematic manner. This is in agreement with the principle of Grundlegung. From within the context of the system, from within the Ethics of Pure Will, the ground is prepared for the religion of reason. In this way, Cohen dispels the impression that religion could or should be construed in a methodological vacuum, or as a direction of culture in its own right. Instead, what is intended is a critical review of the limits of ethics, a review which ethics itself demands for the sake of its own certainty as the principle of moral and historical progress.

That argument unfolds as if Cohen were making a relatively unanticipated discovery, as if he "were taken by surprise"-as Rosenzweig says-to find that ethics does not cover the complete problem of the human being. ${ }^{395}$ It is as if suffering and the Thou that is neither just a "he" nor an "it" had never occurred to Cohen before as a challenge to the limits of science and conventional ethics. But not only was Cohen fully aware of "Ezekiel's discovery of the individual in the concept of sin" (cf. RV 23, 25) when he wrote his Ethics (cf. ErW 299, 365 and see below, Part II) but he construed his Ethics in the full confidence that the concrete individual, the problem of evil, and all other inevitable challenges to the reality of the moral self-consciousness could be dealt with adequately in religion; not necessarily in a general philosophy of religion, to be sure, but in an exposition of "Jewish philosophy of religion and ethics."

Rosenzweig considered it necessary to take into account the full range of emotions and sentiments that were part of Cohen's personality when judging his philosophical texts. It is well attested that Cohen had a deeply passionate and emotional attachment to Judaism which does not

${ }^{395}$ The same rhetoric can be found also in the 1915 treatise on religion. See below. 
necessarily surface in his philosophical works. He was well aware of the incalculable, the ineffable, the arcane, and the irrational side of life. But he denied it the label of "culture." His critical idealism establishes an island of rationality in a sea of untamed wildness; it reaches for orientation in the struggle for a steady exertion of moral energy that is to benefit the lives of individuals, communities, and states. This, if anything, is also the point of correlating philosophy with "facts" of culture. The source of Cohen's methodologically guarded optimism is the possibility of verification. The success of scientific progress means that nature is being brought under the rules of reason. To a lesser degree of certainty but no less importantly, the legal framework of human societies does promise a realization of the principles of justice; and art does touch us and elevate us. Thus "the ideal has (..) life and reality" (p. 24) and its sufficiency as the ground of our cultural confidence must not be doubted. The philosophy of religion Cohen attempts to construct is based on the optimistic presumption that if religion is constituted in relation to the ethical problem of the human being, the mythological and primordial powers associated with religion can be turned into a kind of moral energy. Not only is religion "tamed" in this way, but religion becomes a taming agent without necessarily turning into an agent of slave-morality.

It is in keeping with these observations that the transition from ethics to the proprium of religion is made from within ethics. What Rosenzweig regards as a complete metabasis eis allo genos is here conceived as the difference between the naiveté of the ethical ideal which has only an ideal principle of its realization (the idea of God) and the critical role of religion which is called upon to handle the doubts arising from the gap between the ideal and the actual human condition, doubts which ethics cannot dispel. If the problem is posed in terms of a homogeneity of the individual of religion and the individual of ethics, Cohen proposes to assimilate one to the other by making the individual of religion the precondition for the realization of ethics, just as ethics becomes the precondition for a proper conceptualization of the proprium of religion. Nowhere does an absolute individual come into existence; individuality is generated and limited to the ethical concern for the actualization of the moral law.

Cohen's steering a course between the Scylla of idealistic ethics and the Charybdis of existentialism is a significant philosophical move, on a par in ingenuity with his "discovery of the idea as hypothesis" and with his logic of origination based on the paradigm of the infinitesimal calculus. Just as Plato ranks as the originator of critical idealism and Kant as the philosophical conscience of Newtonian physics, Ezekiel and 
Socrates are combined in their founding contribution to the pursuit of a truthful concept of the human being (cf. RV p. 23).

The discovery of the Thou as the other that is not merely another example of myself or the representative of the social All, the Thou of spoken or contractual language which prevents me from confusing Thou with him or it (p. 17), becomes a condition for the discovery of individuality in a new sense, a sense in which the "share" of religion in reason will be determined (p. 18). This Thou does not cease to be an element of humankind (ibid.), yet it indicates a "new problem" (ibid.). The grammatological orientation of these preliminary statements does not lead Cohen to a type of "speech-thinking" (à la Rosenstock) or to an immediately evident duality of human experience as in Buber's ontology of the "in-between." ${ }^{396}$ Nevertheless, it indicates a sociological bent which is already present in Cohen's Ethics. The other individual is disclosed in suffering (p. 19). The other's suffering is the source of one's compassion. Thus an affect that Cohen himself identifies here as the "deepest meaning of Christianity" (p. 19) and that was denounced as an illusion by Spinoza and Schopenhauer (p. 20) becomes the means by which the individual is discovered in a new sense, namely "when I make it (viz. the other's suffering) a question mark for my whole orientation within the moral world" (p. 21). The suffering of the other makes the moral character of the human being doubtful and can even destroy interest in one's own existence (ibid.). This is not a theoretical challenge but a challenge "to the whole meaning of ethics as the teaching on humanity and human value," a challenge which, given the ubiquity and concreteness of suffering, must lead to despair if suffering is indeed taken as the hallmark and essence of the human condition.

Nor must one ignore one's own suffering (p. 22). But the causality of suffering needs to be parsed carefully. Suffering seems to be the consequence of evil, just as well-being is believed to be consequent upon virtuous conduct. This type of reasoning turns an existential question into a theoretical one and so the "Thou which has been won with great effort is immediately lost" (ibid.). Instead, the question of evil is to be directed to oneself. Thus, also, one is to "spare one's contemporaries one's own possible self-righteousness" (p. 23). The "deepest reason" of religion lies in "self-recognition" of the human being. Ezekiel becomes the founder of religion as "human self-recognition through sin" (ibid.).

${ }^{396}$ Cf. I and Thou (second edition, transl. R.G.Smith), New York: Charles Scribner's Sons, 1958, Between Man and Man (transl. R.G.Smith), New York: Macmillan, 1965 (ninth printing, 1975) and see Gabriel Marcel in The Philosophy of Martin Buber, ed. Paul Arthur Schilpp and Maurice Friedman, LaSalle, Ill.: Open Court, 1967, pp. 41-48. 
The "discovery of the human being through sin is the source from which all development of religion" must be derived (ibid.). With this assertion the cycle of Cohen's philosophy of religion has returned to its point of origin, the essay on atonement from the 1890's.

There is nothing entirely new about the phraseology of I and Thou. Operations with the logic of the personal pronouns similar to the ones we just noted are present already in ErW (cf. pp. $248 \mathrm{f}$ and 493 and see below). "Prayer as the speech-act" by which religion becomes more than theory ${ }^{397}$ likewise reminds one of the Ethics where the idea of speech-acts (Sprachhandlungen) is similarly first suggested (pp. 194, 196). This should not come as a surprise, considering that, according to Cohen's Logic, even thought can and must be determined as a type of action in which it "generates the generation" (Erzeugung als Erzeugnis; LrE passim). The insistence on Cohen's reach towards the existential must not be denied. It must, however, be quite clear that his reach does not introduce any type of ontic affirmation that is not warranted by the principle of thought itself. If it were not for the "proper language of religion," i.e., prayer, the "correlation" would remain theoretical (cf. RV p. 463). Regardless of its meaning for Cohen, the correlation does not destroy the "unity of the cultural consciousness."

Even God-"soul-guide (Seelenleiter) on this path towards the human being" (p. 23)-is not just a concept of religion. The idea of God functions as the "capstone" of Ethics (ibid. and see ErW 428ff), namely of its theoretical part. There-as Cohen paraphrases here-God completed "just the teaching of humankind" (RV p. 23), namely in the meaning of the God-idea as the "guarantor of humanity" (ibid.). Not God's existence is of relevance for the ethics-what kind of an idea can exist?-but the "transcendence" of God which is understood as the logical condition for the "immanence" of morality (ErW 463ff). The God-idea is necessary to conceive of morality and nature as congruent, as harmoniously united. What unites logic (nature) and ethics (morality) is the "basic law of truth" (cf. ErW 83ff and 465). Wahrheit, as we know from Cohen's Bekenntnis of 1880, is for him the epithet of God in Jewish liturgy. The idea of God as the condition for the possibility of the realization of morality in nature (or: of the methodological agreement of ethics with logic) is the principle of Cohen's ethics, a principle conceived as entirely rational yet entirely in agreement with Jewish monotheism. Ethics, however, as "but the teaching of humankind" (RV p. 23) could go no further than to determine the ideal. It is "not responsible for anything

${ }^{397}$ RV p. 463 , and cf. Richard Schaeffler, "Die Vernunft und das Wort. Zum Religionsverständnis bei Hermann Cohen und Franz Rosenzweig" in: ZThK 78/1, 57-89 (esp. p. 78). 
happening beyond the limits of the autonomy of reason." It appears, therefore, as indifferent to the success of its principles in reality. Religion "objects to this fiction of indifference" (p. 24). It objects to the notion that "morality and lawful conduct are but duties which are never human reality" (ibid.). Just as the Logic of Pure Cognition eliminates the "gap" (chorismos) between idea and thing in the hypothesis, religion is construed so as to end the dual prejudice of the reality of evil and the illusory nature of goodness. What is rejected here is a pseudo-Platonic complacency that comes to the fore in the claim that "evil cannot come to an end since it has to prevail as the opposite of the good" (p. 24). ${ }^{398}$ Religion, more specifically, Judaism, believes there will be a time when evil will vanish from the face of the earth. This is not expected to be the result of a miracle but of the repentance of the sinners (cf. Psalm 103:35 and bBer. 10a). The pivot of monotheism, Cohen continues, is therefore messianism as the belief in the "dominion of the good on earth" (ibid.). ${ }^{399}$ The "difference between ideal and reality must not be placed in the world of shadows and, in this sense, perpetuated" (p. 25).

"For the sake of historical clarification" Cohen adds that only this aspect of God has been "relocated" (verpflanzt) out of the Jewish texts as one of its many literary sources into the Ethics. In other words only one aspect of God was dealt with there. But the religious idea of God is clearly not exhausted by this transfer. What we find in the Ethics is "an ethical God, not yet, however, the proper God of religion." While "monotheism pivots in messianism, its center of gravity lies in the relation between God and the individual" (ibid.). And again it is Ezekiel who "diverts from the main trajectory of messianism, closing his eyes to the world by looking at the individual within" (ibid.).

This should not be understood as if, all of a sudden, the messianic God were only an ethical God and not also the God of religion. Rather, the correlation of God and human being that is unpacked in RV gradually delineates a systematic content that coincides with a historical development. The history of the religion of Israel is read as the record of a gradual self-transformation which has its historical and systematic center of gravity in the discovery of the individual. This is, at the same time, a step forward from a moral content of the correlation to the actual discovery of the proprium of religion. In this way the whole content of morality is discovered and contained in the correlation of God and

\footnotetext{
${ }^{398} \mathrm{Cf}$. Theætetus $176 \mathrm{a}$.
}

${ }^{399} \mathrm{Cf}$. the contrast in the continuation of the speech of Socrates: "That is why we should make all speed to take flight from this world to the other, and that again is to become like the divine so far as we can..." ibid. (see Plato, The Collected Dialogues (Princeton, 1989), p. 881). 
human being (drawn from within the sources of Judaism). In addition, the religion developed from within Israelite culture turns into a vital augmentation to the rational task which is developed by systematic ethics in its descent from its Greek origins.

What are the implications of Ezekiel's discovery of the human being in sin? Only a few answers to this question are given in this introduction. Anti-mythological consequences are that the God of religion is neither a concept of fate satisfying our curiosity about the origin of sin, nor a mythological judge concerned with the just apportioning of reward or punishment. God becomes the "mirror" of morality; before him, I recognize myself in my moral insufficiency. All this, however, must return and integrate itself into the political idealism of the prophets. The suffering Thou is the poor, the neighbor enslaved by social injustice; the trajectory of prophetic messianism is directed towards the overcoming of social misery and political injustice. The God of the prophets is the advocate of the poor. Monotheism is this particular construction of the realization of moral teaching (cf. p. 27). In this construction religion attests to its "peculiarity (Eigenart) as a "conceptually necessary consequence" (ibid.).

The issue in this part of the introduction is to avert the misunderstanding as if the Eigenart of religion could and should be developed by diminishing the significance and authority of ethics. Just as logic could not "invent" the contents of ethics and of the sciences morales, so too ethics cannot "invent" the "material insights" (sachliche Einsichten; p. 27) by which religion affirms its share in reason. Conversely, religion would lose its share in reason if "the handling of these concepts" did not "integrate itself into the universal method of ethics" (p. 27).

c) "The Sources of Judaism"

Why does Cohen need to write an extra paragraph on the sources of Judaism? Couldn't he have put q.e.d. underneath the second paragraph of the introduction and left it at that? If he had done so, he could have saved himself the effort of writing another book after Der Begriff der Religion im System der Philosophie (1915). What he does in RV goes beyond the earlier work in that it finally presents the Jewish dogmatics that he intended to write since the 1890 's. Why, however, does there have to be an extra paragraph in the introduction dealing with the sources for this dogmatics?

What distinguishes RV is that it deals not just with a necessary contribution of religion to the problem of the human being, but with "the spirit of Judaism" (p. 28), with "a more accurate formulation of the concept of Judaism" (p. 35), with Judaism as a "uniform concept (einheitlicher Begriff) which concerns not only the ethnic unity but the 
unity of the religion" (p. 37), with the "Jewish consciousness" (p. 38). We will see how these various terms are understood and related to each other. What all of them have in common, however, is that they deal with Judaism as a "whole" as it emerges from its literary sources (cf. p. 28).400

Here Cohen addresses the question: what is Judaism? and determines that the answer to this question can only be gleaned from the history of Jewish literature. "The written sources are the immediate spirit" of a nation. Such a Nationalgeist creates its unique and original literature which "also becomes the Urgrund for the individuals" (p. 28). The history of the literature of a nation engenders the continuity of a unique national culture as well as grounds the formation of individual character. The literature of the Jews is such a national literature, and it has its unique and characteristic origin in the "idea of the unique God." The national spirit of Judaism is inseparably connected with this idea (cf. ibid.).

The method of determining Judaism in the "spirit" of its literature harks back to convictions Cohen formed under the combined influence of August Boeckh and H. Steinthal in Berlin and that are present in all of his work, beginning with the earliest publications. ${ }^{401}$ According to this hermeneutical method, Jewish literature, while historically contingent, is nevertheless the product of a culture from which its spirit can be reconstructed. ${ }^{402}$ In Cohen's reading of Jewish literature the difference of historical and philosophical hermeneutics vanishes, since Judaism and its source become the origin of the religion of reason and, hence, play the same role for religion (and its share in reason) as Greek "literature" plays for the "history of problems" (Problemgeschichte) of philosophical concepts.

Out of such a problem-historical perspective, Cohen construes the difference between Greek and Jewish culture. While Greek philosophy is the origin of theory, Judaism is the origin of a religion which denies the

${ }^{400} \mathrm{Cf}$. Ismar Elbogen's definition of the science of Judaism in "Ein Jahrhundert Wissenschaft des Judentums" in: FS (1922) p. 141: "... es ist die Wissenschaft vom lebendigen, im Strom der Entwicklung stehenden Judentum als soziologischer und geschichtlicher Einheit. Die Wissenschaft des Judentums ist demnach eine Zweckwissenschaft ..."

${ }^{401}$ See "Mythologische Vorstellungen von Gott und Seele, psychologisch entwickelt" (1868/69) (S1,88-140) and "Die dichterische Phantasie und der Mechanismus des Bewußtsein" (1869) (S1,141-228), both published first in ZVPs. Similarly, the notion that the inner continuity of Judaism is based on its idea of God is already the basis of "Heine und das Judentum" (1867) (J 2,2-44).

${ }^{402} \mathrm{Cf}$. above in the chapter on "Cohen's Theory of Hermeneutics;" and cf. Cf. J. Wach, "Die hermeneutische Lehre Boeckhs" in: Das Verstehen. Grundzüge einer Geschichte der hermeneutischen Theorie im 19. Jahrhundert, vol. I: Die großen Systeme (1925), Hildesheim: Olms 1966 (reprint), p. $181 \mathrm{f}$. 
differentiation between religious theory and practical morality. It is the hallmark of Judaism to overcome this false dichotomy. The characteristic property of Judaism is what makes it the religion of reason par excellence and the historic precedent of all rational religion. This property is that it does not distinguish between religion and morality: "In the Jewish consciousness there is no separation between religion and morality."403 This historical construct that denies the possibility of separating religion from morality is not only taken as essential to Judaism but is made the basis for the concept of the religion of reason. In this concept, religion provides the setting for the human being as the member of a community through which the individual learns to realize itself in correlation with God, a God whose very being is known only to the extent that it functions as the model and archetype of goodness.

\subsubsection{Versöhnung in Religion der Vernunft}

A commentary on RV would have to do for each individual chapter what we have done for the essay on the idea of atonement. For each topic it would have to work out both sources of Cohen's philosophy of religion, his own systematic philosophy and the religious literature (and other literature) that he uses to establish his argument. Such a commentary is not our purpose here. What remains to be done for us is to see how the idea of Versöhnung affects the architecture of a book which has as its weight-carrying beams the correlative ideas of God and human being.

a) The Unfolding of the Correlation of God and Human Being in the Chapters of $R V$

Within RV atonement takes center stage in the gradual unfolding of the correlation of God and the human being. This correlation is the principle by which Judaism constructs its conception of humanity, namely as the gradual unfolding of the ideal of the human being based on the ethical and religious significance of certain aspects of the idea of God. While the first two aspects of this correlation introduce the notions of reason ("creation of the human being in reason") and morality ("the discovery of the human being as fellow human being"), the third aspect, indicated in the idea of atonement, addresses the problem of the self, or, as Cohen formulates it, "the individual as I."

In the introduction to RV atonement is not especially emphasized nor is the concept of correlation. However, the whole of paragraph $B$ ("the religion") addresses the central constructive problem upon which Cohen's systematic organization of religion is built, namely the relation

${ }^{403 /}$ Es gibt für das jüdische Bewußtsein keine Scheidung zwischen Religion und Sittlichkeit" (RV p. 38). 
between ethics and religion. Both ethics and religion have the human being has their content. But, as Cohen wants to demonstrate, religion generates a value which ethics merely presupposes in the abstract. This value is the concrete individual as a moral agent. The problem of the constitution of concrete subjectivity is the central element in the differentiation between ethics and religion. Atonement is that idea in Judaism which brings about this single most important achievement of religion: the possibility for the individual to become a self through sin and repentance ( $t$ 'shuvah) "before God"-the very act by which it constitutes itself-as the conditio sine qua non of the realization of the good.

Through the gradual unfolding of the idea of God and its meaning for the idea of the human being, a kind of religious anthropology emerges. Its structure is determined by the overarching principle of the correlation of God and human being. Any modification in the idea of God affects the idea of the human being and vice versa. In a kind of dialectic progression, the religious (i.e. monotheistic, i.e. correlative; cf. VIII, 52) anthropology emerges in a tightly knit argument.

One could characterize the process of the argument (up to the point which is of interest here) by paraphrasing the chapters as follows.

\section{I "Uniqueness Of God"}

The logical principles as well as the main themes of the whole argument are implied in the biblical names of God (example: Exodus 3, the revelation of the tetragrammaton, identifying God and Being) and in their conceptual summary expressed in the liturgical proclamation of the "uniqueness of God" (Dtn 6:4).

\section{II "Idolatry"}

The right attitude towards the unique God is not merely cognition but love. A kind of hierarchy is introduced, declaring reason as the precondition of ethical maturity, and the love of God as a primal act of the moral conscience. This is what transforms the logical determination of the oneness of God into the uniqueness of God underlying Jewish monotheistic worship. The difference of monotheism from polytheism and pantheism is thematized.

\section{III "Creation"}

The logical consequences of chapter I are applied to the idea of creation. Being (God) is juxtaposed with becoming. Cohen identifies the Maimonidean replacement of traditional negative attributes by the 
negation of privation with his own concept of "origin." 404 By identifying the negation of privation with the logical principle of origination, creation becomes the primal attribute of God. The actual significance of this, however, is ethical because the main concern of religion is God's relation to the human being.

\section{IV "Revelation"}

This chapter articulates revelation as a stage in the economy of creation which is continuous rather than temporally located at a primordial beginning. Creation thus completes itself in revelation as "the creation of the human being in reason," again as an "eternal task" rather than as a once and for all accomplishment. As task "revelation" is a further aspect of the doctrine of attributes which, up to this point, serves to prepare the ground for its correlate, human morality. Rationality in itself is not yet ethics.

$\mathrm{V}$ "Creation of the Human Being in Reason"

This is the first component of the correlation. In the preceding chapters the logical function of God as creator was determined. The significance is now spelled out in its correlative effect on the concept of the human being which, at this point, is the concept of a rational being. The foundation of religious anthropology in the (correlative) idea of the human being as rational, however, is only the beginning.

VI "The Attributes of Action"

The teleological problem of the purpose of the human being introduces moral destiny as determined in the attributes of action. The quintessential divine attribute of action is that of holiness.

VII "The Holy Spirit"

The correlative in human being of the holy God is the "spirit of holiness," which Cohen sees as the Jewish analogue to the Platonic discovery of the Idea of the Good. In monotheistic religion, human morality originates in God (VII,1). Spirit is a process-concept in which the correlation shows its fertility. In paragraphs 4 and 5, Cohen sees himself forced to "jump the gun" and reveal what only the third aspect of the correlation will secure, namely that it is "sinfulness" as expressed in the penitential Psalm 51 which shows the full meaning of the "spirit of holiness." The purpose of the "spirit of holiness" is to lead to an understanding of sin and forgiveness. God and human being are "united" in the "spirit of holiness." The measurement and criterion of this spirit is moral action (par. 14). In this respect, the Jewish solution to the problem of morality

${ }^{404}$ Here Cohen explicitly directs the reader to LrE, namely to the "logic of the origin" and the "judgment of the origin." 
exceeds even the Platonic Idea of the Good, which is indifferent to its realization. God and human action are brought into the closest interaction with respect to the moral perfection of humankind.

VIII "The discovery of the Human Being as Fellow Human Being"

Human experience is experience of the self among others. Ethics and religion (as far as it has a share in reason) turn the "among others" (Nebenmensch) into the problem of the individual fellow human being towards whom we extend solidarity. Just as ethics culminates in the idea of humanity and its rational and legal form of a league of nations based on the recognition of the fundamental equality of human beings, Judaism, too, develops a terminology which equates Israelite and nonIsraelite on the basis of their fundamental equality before God, expressed in terms such as ger toshav, Noahide, or, most substantially, in the hasidey umot ha'olam (righteous Gentiles). The most eminent motifs are God's love for the foreigner (par 17) and the extension of solidarity towards the poor. The latter motif, especially prevalent in the pre-exilic prophets, represents the discovery of the poor as the sufferer par excellence. This implies that not sin but injustice causes suffering of this kind. The religious expression of this idea is that God is the protector of the orphan and the widow. Poverty is the suffering of humankind as a whole (par. 37) and it is caused by the tolerance of injustice by the human community. The recognition of poverty as suffering caused by injustice of the community arouses compassion. It is through this that the "among others" is turned into fellow-man. The prophets try to arouse human compassion which, beyond any kind of rational analysis, is the drive and impulse towards moral action. With the impulse of solidarity, the prophets conceive the idea of human being as a universal (beyond the common distinctions between Greek and barbaroi, Israelite and stranger, etc.).

IX "The Problem of Religious Love"

As in $\mathrm{Ch}$. II, the unrivaled proprium of religion is love. Love towards humankind indicates "the inner difference between even the ethical morality of idealism and monotheism" (par. 1). In this praise of love, God's love, love towards God, and the love towards one's fellow human being are taken not as natural impulses but as creative acts. Social love is a creative human act made possible by the fundamental aspect of correlation in which human morality is founded in God's holiness. The apparent exception from universal love, Israel's election, is addressed and reaffirmed by reference to the idea of Israel being chosen as a symbol of suffering (Isa 53). Responding to contemporary polemics against such universal interpretations of biblical Israelite religion (Troeltsch), Cohen highlights the tendency of biblical laws to extend solidarity towards the 
poor. It is through the commandments that God evokes compassion for the poor and suffering (par. 25).

While religious love towards one's fellow human being is the beginning, the next step is the love towards God which itself is commanded and which is closely related to the cognition of God (par. 2 and $26 \mathrm{ff}$ ). In a few movingly focused and intense paragraphs Cohen summarizes the inseparable unity between the pursuits of philosophy and religion, while refuting the latest personalist theological ideas of his former colleague, the theologian Wilhelm Herrmann. 405

The main point for this correlative anthropology is that love towards God warrants the purity of the impulse of moral action (par. 36).

b) Concrete Subjectivity as the Completion of the Correlative Anthropology: "The Individual as I" (Ch. X)

Cohen begins X,1 by stating that "so far, for the correlation of God and human being, the human being has been generated as a rational being and, further, as fellow human being." The concept of the "spirit of holiness" (VII) gives the idea of a rational being a more precise meaning, namely that of a moral being. This being, however, is an abstract and not a concrete subject. This abstraction functions as the condition for the moral law, or, religiously speaking, for the revelation of the precepts and commandments of the divine law. The moral law, as well as the idea of God as the archetype of human action, are directed towards individuals in general but not to any individual in particular, namely in the sense that the validity of the moral law does not depend on anyone actually meeting or failing its demands. The postulate of the autonomy of practical reason is the entirely abstract condition for the assumption of a moral law. Likewise, the individual is only the one enjoined to do the commandments.

With this as background, it becomes evident that the abstract individual may be a sufficient basis for the construction of a moral law but not for any other sense in which we may speak of an individual and his/her relation to such a law.

Even the correlation between "I and Thou" $(X, 2)$ is so far merely that of the singulars of a plurality ("Einzelwesen der Mehrheit"), based on social love as it underlies the ethics of the pre-exilic biblical prophets.

It remains to ask whether the concept of an individual has any meaningful function above and beyond that which is derived from the social and ethical spheres. $(X, 3)$

${ }^{405}$ The keyword here is provided by Herrmann's work Die Wirklichkeit Gottes [=Die christliche Religion unserer Zeit, vol.1], Tübingen: Mohr (Siebeck), 1914. 
Which concern or duty can it be that ascribes to the human being in his correlation towards God an isolation and absoluteness differentiating him from the concepts of the human being hitherto discussed? His eminent task, consisting in moral action, he has already received and he seems to have been endowed with the means to carry it out, namely the social forces. Can there still be further tasks for him aside from those summarized in moral action? (193)

The wording of Cohen's question reveals the utmost care he takes when he widens the concept of the individual without damaging its ethical character. Since the unique God is the correlative of the absolute individual in question, and since God is never known other than by the attributes of action (VI,1), the human being, God's correlate, is in question as an individual only insofar as his actions are concerned. Accordingly, Cohen continues,

(i)f, however, the problem of the fellow human being needs to be complemented by that of the I-individual it follows that the tasks of the moral action are not exhausted by the social problems. (Ibid., my emphasis)

What is at stake here are, as Cohen emphasizes, the "fulfillment of the correlation of human being and God" which has not been reached in the "ethical problems of action," and the Eigenart of religion which "is put into effect only when the correlation of God and human being takes on the more specific sense of the human being as an individual and I."

At this point, Cohen's argument takes a characteristic and significant turn. The possibility of significance for the concept of the "individual as $I^{\prime \prime}$ lies in its generating function for a problem of moral action which it alone can provide. Hence there must be such "moral problems for action after they have been put into effect with respect to the fellow human being." The "question of the possibility" of such problems is solved by

providing moral action with legitimization, preparation and safeguarding not only in connection with ethics but also beyond its problems, things which ethics cannot provide within the limits of its methodology ...

The convoluted and nevertheless careful wording of this sentence leaves no doubt about the fact that Cohen is not concerned with empirical actions. The objective is to determine the significance of the correlation of God and human being. Methodologically, this determination is sought in the relation between ethics and religion. So far, all that has been demonstrated from the sources of Judaism is a set of religious questions and solutions (concepts) which have counterparts in philosophical ethics. The only aspect qualifying the relation of ethics and religion as other than parallel is the aspect of religious love. 
Cohen is concerned with widening the function of the correlation (i.e., of the reciprocal setting of purposes of the correlated terms "God" and "human being") beyond the generation of social ethics. Yet, the proprium of the religious anthropology is nevertheless sought "from the methods of ethics and in analogy to them" (ibid.). The objective is to integrate the phenomenon of individual existence into the realm of the rationally fathomable and to make it reasonably manageable in order for moral action to be practically possible and not merely theoretically commanded and desirable. Cohen's task is, therefore, first to demonstrate the necessity of such a concept of the individual which ethics presupposes but cannot produce by itself and then to demonstrate the constitution of concrete subjectivity from the sources of Judaism. With this demonstration the relevance of religion for the cultural consciousness and the share of religion in reason are established, and Judaism is determined as a religion of reason.

In chapter $X$, paragraphs 4 and 5, Cohen returns to the problem of guilt which has, already been designated as the vehicle of transition from ethics to religion. ${ }^{406}$ Within religion (par. 4), compassion as a prime form of religious love was developed by eliminating the identification of suffering and guilt. By liberating the poor from the automatic blame for their condition, guilt was demythologized and located within the realm of law and justice. Guilt is discovered as that which causes the suffering of the poor. Clearly, Cohen shies away from the shortcut suggested by this line of argument, namely that the poverty of some is caused by the wealth of others. Instead, he asserts that even the wealthy deserve compassion, in order not to be reviled unjustly and collectively. Commiseration with the wealthy, however, seems to endanger the notions of law and justice. Neither ethics nor religion can annul the problem of guilt. Could it be, Cohen asks, that the correlation of God and human being makes it necessary to deviate from the demands of law and justice when, in religion, the idea of forgiveness is proposed? This cannot be. It is impossible for religion to contradict ethics: "Gegen diese Möglichkeit richtet sich die Eigenart der Religion bei ihrem bleibenden Zusammenhange mit der Ethik."

Paragraphs 5 and 6 reëstablish that in whatever sense religion may depart from ethics, it does so through a methodology conceptually

${ }^{406}$ See chapter VII and "Introduction" B. paragraph 11 . While my thesis rests on the significance of these chapters and of the issue of concrete subjectivity, I disagree with S.H. Bergmann and N. Rotenstreich when they characterize chapter $X$ as Cohen's "breakthrough from ethics to religion" and further claim that "this chapter indicates with respect to Cohen's biography the additional and decisive development which occurred while Cohen was writing this book of his old age." (Dat Hatterunah, 1971, p. 202, note 1). 
related to the foundations of ethics. ${ }^{407}$ This assertion would not come as a surprise and would not be remarkable at all if it were not for the tendency to imbue religion with powers that are not only above and beyond the realm of ethics and law but entirely separate from them. This tendency is perhaps as old and as primary a force as any other aspect of human culture, yet it must surprise us that it has found such strong support within 20th-century theologies. For our understanding of Cohen's philosophy of religion it must be kept in mind that he was acutely aware of this tendency which, to him, not only contradicted the construction of a responsible ethical culture but also ran counter to the experience of an essential unity between morality, the law, and religion underlying the Jewish faith.

It is a clear understatement when Cohen pretends merely to refer to a special problem of criminal justice in this context. This problem cannot be understood fully without considering the construction of Cohen's ethics as a whole. (See below, Pt. II) In ErW, chapters 1-7, Cohen differentiates between the concepts constituting ethics, pure will and action, as well as self-consciousness. A second set of chapters (cf. ErW 389 ) concerns the ideal, the idea of God, and the virtues. Selfconsciousness is constructed in its constitutive functions for law and ethics. While the task of accounting for law and morality in a systematic way is modeled on Kant's attempt in Metaphysik der Sitten, ErW introduces Jewish biblical legal categories which provide the basis for a much broader and bolder construction than Kant presented. The most obvious systematic limitation of Kant's Metaphysik der Sitten consisted in the division of his work into two separate inquiries ("Metaphysische Anfangsgründe der Rechtslehre" and "Metaphysische Anfangsgründe der Tugendlehre"). After Kant (and Hegel), Cohen's was the first attempt to synthesize the philosophy of law with a theory of common morality. Cohen's ethics is superior to that of his predecessor in that it realizes the programmatic ideal of demonstrating the common principles of law and ethics. It succeeds in doing so by establishing ethics as the critical foundation of the law. While extending legal theory effectively into political theory, however, Cohen deprives ethics (temporarily) of the supposition of the concrete individual. The self comes into question as a building block of an ethics of pure will only, the autonomy of the consciousness of the self, which is differentiated into the aspects Selbstgesetzgebung (autonomy in the sense of the condition of the

${ }^{407} \mathrm{Cf}$. the concluding statement p. 195: "When we said that the Eigenart of religion is determined by the problem of guilt, specifically in the problem of the individual, we now see that this Eigenart of religion is accurately related with the foundations of ethics." And see the first sentence of paragraph 7 (p. 196). 
possibility of a moral law as opposed to the dogmatic presumption of "freedom"), Selbstbestimmung (self-determination as the determination of individual intentions), Selbstverantwortung (the self taking responsibility for its actions by recognizing itself as their origin), and Selbsterhaltung (the indelibility of the self as an ideal restored within the criminal when he accepts the justice of punishment). ${ }^{408}$

Against this background it becomes clearer what Cohen intends with his reference to criminal punishment in the context of the problem of "the individual as I." The justification of criminal justice is based on the differentiation between "guilty in the sense of the law" and individual guilt. Punishment is measured by a judge in terms of the severity of a crime. The criminal is "but the grammatical subject of the crime" (ErW 373). The judge is responsible not only to determine whether a crime has been committed and who committed it but to determine the punishment (ibid.). This juridical responsibility is, however, limited. Its limit is the guilt of the individual as far as it is unknowable except to the individual him/herself. The judge "has to know that the causal connection in the actions, deeds and events of no human being in no minute of his existence is known to us in the methodological form of knowledge" (ErW 381). ${ }^{409}$

In keeping with the Ethics Cohen writes:

In the final analysis, for ethics man is-one can see this clearly now-just the point of reference of its problems, just as for the sciences he is but the individual case of its laws. ... The case of the law, however, is not the individual which addresses itself as an I. (195-6)

The problem of guilt leads to the recognition of the limit of ethics and to the determination of a function of religion postulated by ethics (par. 7).

\footnotetext{
${ }^{408}$ Hans-Ludwig Ollig makes the problem of Selbsterhaltung the central issue not only of Cohen's ethics but also of his philosophy of religion. While he does not distinguish the theme of Versöhnung and Umkehr as continuous in Cohen's thought, his approach leads him to draw conclusions that are quite similar to mine. Cf. "Hermann Cohen und das Problem der Selbsterhaltung" in: ThPh 56. Jg., Heft 4, 1981, 507-534, esp. p. 526. I am not convinced of the merit of interpreting Selbsterhaltung as an affirmation of Jewish ethnicity, as Ollig does. He relies, too much for my taste, on Rosenzweig's "late-shift-to religion" paradigm. Cf. S. Schwarzschild, "Franz Rosenzweig and Martin Heidegger: The German and the Jewish Turn to Ethnicism" in Wolfdietrich Schmied-Kowarzik, op.cit., pp. $887 \mathrm{ff}$, and see my discussion of various approaches, including Ollig's in Zank, "The Individual as I' in Hermann Cohen's Jewish Thought" in: The Journal of Jewish Thought and Philosophy, vol. 5, No. 2, 1996, pp. 281-296.

${ }^{409}$ The context of this statement is Cohen's refutation of the death penalty.
} 
c) Versöhnung as the "Pivot of Monotheism" 410 (Ch. XI-XII)

Chapters XI and XII are an extensive exposition of the ideas we have seen developed first in "Die Versöhnungsidee." Here, the issue is distributed over two chapters. The first one deals with the principle of atonement (foundation of the concept of sin before God as the method of "generating the individual as I" XI,14). The second one deals with the concrete setting of ethico-religious individuality in the liturgy of the Day of Atonement. This holiday is wholly dedicated to the purpose of "claiming and preserving the self-consciousness of the I of the individual despite sin through his correlation with God." ${ }^{111}$ On this occasion the "quintessence of all particular laws and of the whole adherence to the law" is made explicit, namely the purpose of "guiding to repentance, to self-examination ${ }^{412}$ in correlation with God" (XII, 13 p. 262).

We find all those, by now familiar, motifs which Cohen associates with the idea of atonement. Here they are brought together in a way that leaves no doubt that-for Cohen-Versöhnung is the "pivot of monotheism" (p. 251) and the Day of Atonement the "symbol for the redemption of humankind" (p. 275).

The chapters on Versöhnung present little if any new exegetical material beyond that of the essay from the 1890's. The only real difference is that here atonement is embedded in the framework of the correlation between God and human being and it is this idea of a correlation ${ }^{413}$ which serves as the basic structure by which Cohen is able to hold together the whole of religion which would otherwise fall into a number of disiecta membra. In the gradual process of determining the concept of the human being, atonement emerges as the "center of gravity" and the "pivot" of the correlation with God. Nevertheless, atonement is not allowed to represent the "highest triumph" which religion (i.e., the religion of reason, i.e., Judaism) has achieved. Such triumph is that the "idea of humanity emerged from religion alone" (p. 278). True to his earliest and deepest convictions, Cohen turns from the most ardent and heart-felt affirmation of the love of God, of the most intimate self-examination of human being "before God" (233ff, 237), after the "bliss of a moment" (p. 238), after an Aufschwung zur wahren Individualität (219), and proclaims the superiority of religion in its idea of universal messianism (Ch. XIII). Nothing could be truer to Cohen's

${ }^{410} \mathrm{Cf}$. RV p. 251: “Die Versöhnung wird daher zum Angelpunkt des Monotheismus" (X, 64).

411 "... im Ich des Einzelmenschen durch seine Korrelation mit Gott sein Selbstbewußtsein der Sünde entgegen zu behaupten und zu erhalten." (XII, 22, p. 299).

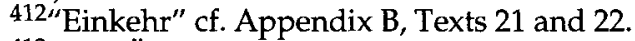

${ }^{413} \mathrm{As}$ in $\mathrm{ArG}$, vol. 2, p. 418, the correlation is one between two Grundlegungen. 
vision and to his imperative of reconciling Judaism and the cultural consciousness than this bringing together of the poles of faith: the individual and humankind, and both from the sources of Judaism. 


\section{Part II}

\section{No Self Without Other. Substance, Self-Consciousness, and Concrete Subjectivity in Cohen's Logic, Ethics, and Philosophy of Religion}

\section{Orientation}

\subsection{Philosophy and Religion}

Unlike its predecessor which emphasized Cohen's intention to reconcile Judaism and "cultural consciousness," 1 this study is organized around the observation that one should nevertheless distinguish in Cohen's work between his Jewish religious thought and his systematic philosophical concept of religion, if only for reasons of a didactically perspicacious exposition. Part I of the present work accordingly deals primarily with the emergence and fulfillment of Hermann Cohen's project of a renewal of Jewish thought. In contrast, Part II introduces to the major issues surrounding the concept of religion within the system of philosophy.

Cohen's Jewish thought emerged as the creative response of an individual to what he perceived as challenges to Judaism and Jewish thought that arose from the cultural and intellectual but also from the historical, social, and political situation of the time. Hence in Part I, aside from presenting close readings of pertinent texts, I embedded the program of Jewish thought in the historical, cultural, and biographical context without which it cannot be fully appreciated.

\footnotetext{
${ }^{1}$ Michael Zank, Reconciling Judaism and "Cultural Consciousness:" The Idea of Versöhnung in Hermann Cohen's Philosophy of Religion, Ph.D. Diss., Waltham/Mass.: Brandeis University, 1994.
} 
The concept of religion in the system of philosophy can be similarly characterized as a response to crises involving both religion and philosophy. The similarity does not end here. Cohen's thought can be generally characterized as philosophy in a historical dimension. An exposition of Cohen's philosophy of religion therefore invites reflection on the historical dimensions of his thought. Religion is addressed in most of Cohen's works, in pertinent passages strewn throughout his system of philosophy, in shorter pieces written throughout his life, and in the most structured and elaborate fashion in the late work Der Begriff der Religion im System der Philosophie (abbr. BR, 1915). Throughout these writings, religion is thematized from the perspective of certain philosophical concerns, not all of which are simply in defense of religion. Rather, within the context of the system we find Cohen first and foremost arguing for the freedom of philosophy from doctrinal bias. In this intention Cohen stands firmly in the tradition of the European Enlightenment. In Ethics of Pure Will in particular, along with the programmatic texts that surround its composition, the primary thrust of Cohen's writing pushes the agenda of ethical reasoning as independent of religious doctrine. As a neo-Kantian ethics, it rests on the principle of autonomy and whatever accommodation takes place between ethics and religion must be one of the latter to the former.

But Cohen also defends religion from a philosophical perspective especially when he introduces specific Jewish doctrines into the discussion on ethics. Such a defense of the Jewish religion within the context of a system of philosophy involves reason in historical doctrinal questions and matters of religious practice and affiliation. This gives Cohen's Ethics the character of a statement that can be understood in the context of contemporary conversations on religion, Judaism, and political philosophy. More importantly, however, this raises the question of methodological justification. How can Jewish or other religious doctrine enter into philosophical reflection without compromising its claim to universality? Of course, Cohen was not the first modern philosopher to retrieve religious doctrine. Particularly the German idealist tradition provided a model within which the use of religious terminology was retained. One might go as far as saying that the decision for an idealist approach to philosophy more often than not implies an interest in retrieving the truth contained in revelation. The major question of interpretation in this respect that surrounds the works of Kant and Hegel, to name the most obvious examples, is whether or not the language and fact of revelation are recognized for what they are from the religious perspective or whether they serve as metaphors for the limits of human wisdom. The very provenance of modern philosophy is in question when we ask for its religious dimension. Surely it is not Cohen's 
examination of religious language and thought and its integration into the system that sets him apart within the idealist tradition. Rather his distinction results from the fact that he makes Judaism the paradigm for the religion of reason. In this sense, Cohen's philosophy represents the attempt of a Jewish philosopher to come to terms with the Christian paradigm in Western thought as well as to retrieve the distinct voice of Judaism as an integral part and core source of Western culture, past and future.

\subsection{Religion and Critique}

The connections and distinctions between Cohen's Jewish thought and his system of philosophy are manifold. Below, I make the relation between them evident by focusing again on the conceptual apparatus associated with the idea of atonement which functions in the system as well where Cohen uses the term in both senses highlighted in the introduction: the narrow religious meaning and the broad philosophical sense.

Cohen's Jewish thought accounts for the meaning of Jewish tradition in conceptual terms. Philosophy here reflects on the rational contents, functions, and meanings of a specific religion, but by what right? Such radical reinterpretation of the Jewish sources is legitimized by the general assumption that religion is to play a role in the establishment of culture. It is assigned a part in the transformation of human beings into humane beings. While this may seem an arrogation of power on philosophy's part, the call for philosophical accounting can be shown to be just as strong from within the religious tradition.

In Part I we see Cohen argue on the basis of the assertion that the idea of atonement not only first took shape in Judaism but that it continues to exert its important ethico-religious function for the individual within the Jewish community. Yet the religious community is made to become conscious of the meanings of its practices only when it is prompted to consider them from a wider perspective, especially from the universal perspective of philosophical reason. Such prompting usually signifies a moment of crisis. In other words, if and when philosophical reflection on the validity of traditional practices or concepts is called for, then we are dealing with a moment of crisis in the life of a religious tradition, for while reason might be indigenous to religion, philosophy is not. This crisis is usually associated with challenges of a political nature, especially if and when the impulse to self-examination involves not only other traditions but a situation of political threat or imbalance of power, a common situation for Jews and Judaism. Where power is involved, however, the crisis is aggravated by the possibility of distortion and loss 
of authenticity for the sake of accommodation. Accordingly, as long as religious debates are entirely conducted within the ghetto and removed from the eyes of the gentile public, dissent and deviance can be tolerated more easily than when Jews are in some respect integrated into a larger community (language, culture, state). Then the philosopher is viewed with a suspicion that turns his potential to innovate and renew tradition into a leaning towards accommodation for the sake of convenience. Modern Judaism has been haunted by this suspicion despite the fact that Judaism has always been rich in moments of crisis, self-examination and transformation. The challenge to modern Jewish thought involves the task of more widely accessible self-explication while at the same time restoring the fundamental difference to Judaism that alone justifies Jewish apartness in a religious sense. The latter is so much an inherent characteristic of Judaism that it has been characterized by Jan Assmann as the "counter-religion" par excellence in Western culture, a dialectic first given full expression from the Jewish perspective by Franz Rosenzweig. A religion which has exile as the norm of its existence experiences times of opening and exchange with others as times of crisis and self-examination (so, e.g., the ages of Hellenism and of postEmancipation Europe).

Cohen's agenda is a quintessentially modern one in that he does not consider Judaism as a nation apart but as a religious community within a multi-religious nation state on the way towards the philosophical telos of a league of all nations (Kant's adaptation of Jewish messianism in the concept of universal peace). Thus the philosopher examines the sources of Judaism not merely for the sake of a politically motivated minimal adjustment to the culture of the majority. Rather, he determines how to understand and practice Judaism without the Jew having to remain in a ghetto, convert, or live with a split identity. His Jewish thought aims to restore to the Jew the ability to achieve an equilibrium between Jewish authenticity, philosophical contemporaneity, and political acceptability.

What, however, are Cohen's objectives as a philosopher of religion? His agenda is not fully described by the general pursuit of the freedom of philosophy from dogmatic encroachments, religious or otherwise. Rather, especially in the context of the ethics, he is unique in articulating his defense of philosophy in terms of a debate on religion that takes Christianity and pantheism as those factors which hitherto prevented idealist philosophy from achieving a truly critical self-understanding. The introduction of Jewish terms into the discussion aims to identify Christianity as the blind spot in the Western philosophical perspective. It is irrelevant in this context to ask whether he is not replacing one blind spot by another. Critique, after all, must begin somewhere. With a different set of religious metaphors as his point of departure, for 
example, Cohen rigorously restrains the idea of revelation within the context of religion and philosophical thought. Where and when Cohen introduces religious concepts into his ethics, he cannot wish to do so merely for reasons of religious apologetics. He is not on the defensive, but on the attack. The idea of God and the idea of atonement play a role in the very construction of his systematic ethics for the sake of the truth of philosophy. Cohen the philosopher of religion thus is the critical philosopher to the core.

The connection between religion and critical philosophy can further be illustrated as follows. While philosophy examines religion from a critical perspective, in doing so it applies what it is taught by the religion of reason itself, i.e., by Judaism which, in Cohen's view, is a symbolic and ceremonial form of perpetual reflection and self-examination. Crisis, confession of sin, atonement-these are the tasks of the homo religiosus ioudxus. But this very task is also the condition for the actualization of the imperatives of ethics. Moreover, the history of Judaism evolves in terms of constant self-examination which is built into the legacy of the Hebrew prophets with its fight for the elimination of idolatry. The prophets of Israel and Judah associate the worship of other gods with foreign practices, especially with practices violating the most fundamental taboos of monotheism, murder, incest, and idolatry. Thus the share of Judaism in reason can be said to consist in its establishing a connection between worship and morality.

This legacy implies further rational consequences. The notion of idolatry judges between truth and error. Thus the biblical idea of God as the only divine being as distinct from all other beings emerges as a fundamental rational principle, a non-conceptual expression of the truth of critical idealism. If God is the only God, and if all else is his creation, we have in the creed of Judaism the essence of all wisdom from Plato to Kant. Not that this understanding appeared immediately by an act of God or that it has been preserved in full self-consciousness in all of Jewish tradition and literature. It is a doctrine that, like all philosophical truths, is in need of constant retrieval and conceptual purification. To Cohen this need is also the motor of the history of religion. In contrast to a method of the history of religion(s) which conflates religion and mythology, Cohen distinguishes between the two, making the former a rationally reflected form of the latter. ${ }^{2}$ Myth is here preformation, adumbration (in a Pauline/Goethean sense of a dunkles Ahnen), that religion, especially the religion of the Hebrew prophets, elevates to an

\footnotetext{
${ }^{2}$ Note that this understanding of the relation between myth and religion became the foundation for Yehezkel Kaufmann's Religion of Israel. Kaufmann is in this respect a true Cohenian, perhaps the only one there ever was.
} 
agent of humanization and culture. The rational force of religion is evident in the critique of its mythological predecessors. Religion itself thus invites critique of religion as its most radical continuation. Philosophical critique of religion guides reflection on such aspects of a tradition that contain the precious metal of cultural value. Philosophical method thus discovers in the mythologically clothed elements of a religious tradition that rational value which can and should continue to exert a function necessary for the advancement of a morally reflected civilization. It is easily recognizable that the same method of critique is also used with respect to the critical examination of the history of all other concepts. It is a rational method and, to the degree that it has been cultivated in the Jewish tradition, Judaism participates in the making of Western rationalism.

\subsection{Philosophy as Problems in Motion}

In contrast to the philosophy of Plato or Kant and in concert with that of Hegel, Cohen's thought must be characterized as fundamentally historical. The historical character of Cohen's thought emerges not only because of a particular historical problematic associated with the conceptual solution he proposes to the problem of religion within the system of critical idealism. Rather, Cohen approaches concepts as "problems" (in the etymological meaning of the word, as in German "Vor-wurf") and analyses them in light of their respective "history of the problem" (Problemgeschichte). If concepts are placeholders for problems of metaphysics, of the constitution of objects of knowledge, of agency in the context of ethical action or creative work, etc., then philosophical reflection first demands identification of the problem that a concept represents. The result of such historical examination is a clarification of meaning of the concept with a view to the current state of the scientific problem on the one hand and with a view to its conceptual environment within the system of philosophy on the other. Qua problems, philosophical concepts are in motion through a history which must come alive in the philosopher. In contrast to Hegel, however, Cohen predicates actualization of truth neither to any moment in the history of revelation nor in the development of philosophical problems. Philosophical truth, like scientific knowledge, is approximation. True, for Cohen as for Hegel the real is rational. In this they are idealists. Yet for Cohen reality is itself merely a rational judgment. At the heart of the difference between Hegel's idea of a system and Cohen's may be the difference between the Christian and the Jewish model of redemption. In addition, however, we must think of Cohen as a philosopher post Schopenhauer and Feuerbach who retains a goodly portion of mid-nineteenth-century skepticism 
towards philosophical speculation. Similarly, as the editor of F.A. Lange's History of Materialism and his life-long admirer, he also absorbed a goodly portion of Millsean pragmatism. For this reason, Cohen saw as the major achievement of the Marburg school not the establishing of a particular system but the developing and applying persuasively of a philosophical method, namely the method of "critical idealism."

Equally, if not more, important than the influences mentioned above, a few figures associated with the University of Berlin in the 1860's helped to shape Cohen's approach to philosophy before he ever turned to Kant. So, for example, Cohen learned from his teacher Trendelenburg that philosophy's primary task is not to generate objective knowledge but to reflect on the validity of "facts." Philosophy receives its content in certain "facts of culture" (Kulturfakten) whose origin, legitimacy, and validity are determined by philosophical reflection. From his teachers Boeckh and Steinthal, Cohen learned that philology similarly takes its point of departure from that which others first understood and expressed and seeks to understand again what was once understood. From Trendelenburg, Cohen advances to take Kant seriously as the founder of a philosophical method that, as it reflects on the transcendental grounds of certainty, discovers thought as the origin of being. Contra Trendelenburg and the psychological school of interpreting the Kantian Apriori, Cohen makes reason not only the "organ of the laws" but the origin of the very facts whose validity it determines. All "facts of culture" are products of reason, giving the term "fiction" a decidedly affirmative connotation. Cultural productivity implies certain kinds of fiction, i.e. "makings" or products, that are human inventions yet necessary in their functions within the cultural whole. "Fiction" thus is not merely a genre of literature but a philosophical or cultural method. The realm of "facts" addressed by the system of philosophy is diminished by the whole range of immediate sense perceptions which fall outside the purview of philosophy and are left to the methodology of scientific research. But the realm of "facts" is also enriched by the range of cultural "makings." Philosophy's task is to distinguish between "mere" fiction and such that advances us towards a greater good for all, expressed in the idea of a civilization that is humane and lawful.

From Boeckh and Steinthal Cohen proceeds to interpret Kant's transcendental method as one step in the age old conversation of philosophy that begins with Plato and in which we must participate actively and creatively in order not to fall beneath the level of cultural sophistication that we are called upon to inherit. It is therefore misleading to call Cohen a neo-Kantian and not also a neo-Platonist, neoLeibnizian, or neo-Maimonidean. Philosophy turns the history of culture, including the arts, the sciences, and religion, into an ongoing 
conversation concerned with an ever more accurate clarification of the terms used in it from its inception. One is tempted to say with Bloch that the civilizing task of philosophy is warranted by the "unfulfilled utopia" present in the history of its problems.

The method of a "history of problems" goes beyond mere etymology by means of an interrogation that aims to distinguish the conceptual content, the "inner" form, from the mythological or linguistic shell of a concept or term. Cohen adopted this method from the Berlin school of hermeneutics, i.e., from Boeckh and Steinthal, and applies it to philosophy. The recognition of the inner form demands an identification of the problem. ${ }^{3}$ For example, the meaning of the concept of "substance" can be determined by the question of which problem in the history of science it once addressed. One discovers that "substance" (Gr. hupokeimenon) reflected the Greek philosophical search for the eternal or permanent substratum of an ever changing reality. Modern science emerged as Newton and others were able to shed the mythological implications of thinking in terms of substances and displaced it by means of mathematical functions that, within the discourse on astronomy, do justice to the principle of continuity. This move was recognized by Kant and is rediscovered and generalized by Cohen and Cassirer as the move "from substance to function." While the concept of "substance" could function in both idealist and materialist philosophies of nature, Cohen argues that Newtonian science and Kantian metaphysics make it imperative to discard the materialist concept of substance and return to the Platonic model in which ideas, numbers, and relations are the grounding of being.

The philosophical conversation does not end with the realm of nature but proceeds to reflect on the human position as within yet distinct from it. The transition from a dogmatic to a critical understanding of substance reaches beyond the mathematical functionalization of the physical universe to raise questions about the human substance, its rationality, its morality, and its creativity. One could say that Cohen wants philosophy to consider the implications of the changes in our understanding of the physical universe for other discourses in which unexamined language otherwise compels us to

\footnotetext{
${ }^{3}$ The distinction between ideational core or truth and visible form of language and other symbols can be traced back to Moses Mendelssohn and the esthetic theory of the Enlightenment. Mendelssohn in turn received major impulses from the Cambridge neo-Platonists who in turn are part of a discourse on the relation between the Mosaic law and the wisdom of Egypt that stretches back to Renaissance adaptations of Hellenistic ideas. This discourse as a major theme in Occidental thought has been described most recently by Jan Assmann in Moses the Egyptian (Harvard University Press, 1997).
} 
perpetuate a dogmatic understanding of reality. Philosophy is systematic when it concerns itself with negotiating the tensions in the language by which we communicate what we know, what we ought to do, and what we may hope. Truth indicates the hope that harmony between this realms of communication can be achieved.

In this perspective, reason is both generative and reflective, being is constituted in thought and philosophy is reflection on the constitution of being in thought. Critical idealism, as conceived by Cohen, is thinking of the origin (Ursprungsdenken), philosophical reflection as explication of the role and functions of reason in the production of valid knowledge, good laws, beautiful works of art, as well as true religion.

\subsection{From Psychological to Transcendental Method}

A major step in Cohen's philosophical development is the one which takes him from the psychological to what he calls the transcendental method. The early writings deal with the psychological substratum of ingenuity in literature, mythology, and philosophy. Investigating both individual and collective innovations (Plato's theory of forms as an example of individual achievements and mythology as collective ones) Cohen analyzes the environmental influences (language, culture) and internal processes (observation, analysis, synthesis, etc.) that make the emergence of a new insight, a new theory, and thus cultural progress, plausible. The step beyond such psychological analysis was for Cohen associated with the rediscovery of the historical Kant and with a gradual disentanglement of the Kantian understanding of the Apriori from its 19th-century psychological interpretations. For Cohen this rediscovery was no less than revolutionary. It meant to attack the then prevailing communis opinio which interpreted the Apriori as psychologically (and hence physiologically) conditioned. Cohen gradually overcame this category error and broke a path towards retrieving transcendental philosophy. This allowed for philosophy to reassert its dignity vis-à-vis the sciences while Cohen's emphasis on mathematics and physics (à la Leibniz) made the new metaphysics nevertheless accountable to their paradigm.

Cohen's reading of Kant aimed at a restoration of philosophy to a dignity it had not enjoyed since the collapse of Hegelianism. Whether or not it was ill conceived, it fell on fertile ground in the Continental academy at the turn of the century. Cohen was part of a broader movement "back to Kant." In fact, this "being part of" is one of the hallmarks of the style and conviction of an age in academic philosophy which sought an alternative to the fashionable aphoristic world view philosophy as well as to the Hegelian type of know-it-all/can-account- 
for-all hubris of deduction. "Being-part-of" meant to establish philosophy on the model of the sciences as a discipline that could give objective account of its merits, methods, and limitations. Going back to Kant meant to restore a reliable rational and "scientific" basis to a discipline in disarray. While neo-Kantianism may have produced few works of enduring impact and appeal it had the merit of forcing overly well-trained historians of philosophy to confront the systematic issue of philosophy, i.e., to confront the question of truth. If truth is at stake, historical accuracy is not enough. From the perspective of the trained philologist and hermeneutical theorist, Cohen further realized early on that even for the sake of the history of philosophy more and different skills were called for than those of the neutral observer. In philosophy, in order to understand what others understood, the historian needs to become a philosopher. Participation in the philosophical problem is made the requirement of understanding. Yet if this is so, the result is no longer mere understanding but understanding an author better than he did himself, a maxim already advanced by Kant and Schleiermacher. To understand is to know, and to know is to reflect on the grounds of knowledge. In an almost Schopenhauerian interpretation Cohen makes knowledge an artificial construct rather than the dual product of sense perception and reason Kant seems to have aimed for in his First Critique. If knowledge and certainty are seen in this fashion whence the confidence that it is nevertheless potentially reliable, valid, and real rather than illusory or arbitrary? The return to Kant involves a choice in the work of Kant of such theorems that lead to a persuasive answer to this question. In other words, Cohen's historical works on Kant, his "Kant-philology" (Kants Theorie der Erfahrung, Kants Begründung der Ethik, and Kants Begründung der Ästhetik) are not disinterested restorations of the historical Kant in a historicist sense but first steps towards the retrieval of a comprehensive philosophical method for Cohen's own time and purposes.

In the process of rereading Kant, Cohen not only transforms his master into a theorist of science (reading Kant, as he does, more from the Prolegomena of Any Future Metaphysics rather than from the First Critique) but he also curtails Kantian reason at those extreme ends where speculative idealism had most powerfully thought out the consequences of Kantian thought. More specifically, Cohen's critical philosophy wants to avoid speculation both on the transcendental subject (Fichte's I) and on a realized totality of knowledge (Hegel's encyclopedia, the objective spirit). How can the task of philosophy be delineated in such a fashion as to represent a complete reflection on the conditions of truth without having to account for Hegel's concrete absolute? Cohen achieves this limitation by taking his point of departure not from common perception 
but from "facts of culture" whose validity is grounded in the agency of the origin of culture. Reason, however, is manifest not as spirit but in the concrete performance of originative thought as well as in the process of reflection that discloses it. It is manifest in the perpetual and sufficient effort of the "idea," here interpreted as axiom or hypothesis, i.e., in the logic of scientific cognition. What sciences can teach as certain knowledge is knowledge, and it is philosophy's task to parse the character and limits of such knowledge. Philosophy, thus limited to reflection on the origins of scientific (and analogous) noëmata, is "noëmatic reflection" (Wagner). Things in themselves, on the other hand, have no place in this activity. They are mere nothings, problems, and, where successfully described as lawful phenomena, the result of an "anticipation of perception."

\subsection{Unity of the Cultural Consciousness}

While this science oriented model may be immediately convincing for a philosophy of science, Cohen casts the net of philosophy much wider, as did his predecessors and contemporaries. The greater challenge taken on by neo-Kantian philosophy is to restore coherence and mutual agreement across the fundamental divide between science and humanities, or, as Heinrich Rickert put it, Naturwissenschaft and Kulturwissenschaft.

Again starting from Kant, and trying to avoid the compelling force of Hegel's grand schematizations of the dialectics of the spirit, Cohen examines different "directions of culture" that, independent (selbständig) yet following the general directives of the logic of cognition in their claim to validity, merrily advance in a quasi liberal-imperialist conquest of the knowable and malleable world and thereby gradually extend the limits of the sphere of influence of "culture." Science, law/morality, as well as the arts, the trivium classical since the European Enlightenment, all proceed on their own yet are reflected in the system of philosophy as to their mutual augmentation so as to coalesce in the ideal of humanity. The unity of the differing directions of culture and of the philosophical disciplines that reflect their validity is expressed in the idea of a "unity of the cultural consciousness" (Einheit des Kulturbewußtseins, also Einheit des kulturellen Bewußtseins). The description of this unity has as its content the system as a whole and in its parts as viewed from the perspective of their unity. Cohen assigns a fourth part of his system to the completion of this task, a part he calls psychology and which he was unable to complete.

Even though the psychology was not completed, the directive of a unity of the cultural consciousness permeates the system just as concern 
with giving an account of subject and subjectivity is central to Cohen, if only negatively. One might say that knowledge, goodness, and beauty are reflected in their manifestations and in the transcendental conditions of such manifestations, all in such a way as to avoid a substantive understanding of either the originating subject or of the totality of culture. Cohen's account of the world of spirit in terms of its activities involves a radical negation of even metaphorical references to the spiritual substance. This negativity, compared to the excessive use of Christian metaphoric in Hegel, applies Maimonidean rationalism in the context of modern transcendental philosophy.

\section{Early Writings on Religion: Cohen and the Berlin School of Hermeneutics}

One of the connections between Cohen's Jewish religious thought and his philosophy of religion is provided by his theory of the relation between language and thought. This is instantiated in the very title of his late work, the "Religion of Reason," evidently a conceptual construct, out of the "sources of Judaism," i.e., from the literary and ritual-liturgical language tradition that is Judaism. The theory that examines the relation between language and meaning is hermeneutics. One of the strengths of Cohen's philosophy of religion is that his approach to determining the systematic philosophical meanings and functions of religion is steeped in hermeneutical theory and testifies to a lived experience with texts and traditions. Moreover, Cohen does not begin his work as a philosopher but as a rabbinic theologian and a classical philologist. He is a texttrained scholar before he becomes a systematic philosopher. Texts, language, and hermeneutics are the grounds from which his philosophical conceptualizations spring.

Cohen's reading of Jewish sources and his contribution to their appropriation within the context of the modern consciousness is based on two intellectual resources, both of which he acquired before he became the founder of a school of neo-Kantian philosophy. He received the training of a rabbinical student at the Jewish Theological Seminary in Breslau, and he studied philology as a comprehensive historical methodology, first at the university in Breslau and later in Berlin. In Part I, I described Cohen's Jewish education. Here, I want to consider the origins of the combination of hermeneutic and philosophic method which is so characteristic of Cohen's work. From here a few important insights will emerge regarding Cohen's programmatic understanding of the system of philosophy as well as of the position of religion within it.

Like Wilhelm Dilthey, Cohen graduated from Berlin University where the question of hermeneutics, of Verstehen as the principle of the 
Geisteswissenschaften (humanities), had received paradigmatic form and scope through the lectures and works of August Boeckh. Boeckh is the founder of the modern study of the classics and was teacher to several generations of outstanding scholars such as Steinthal, Dilthey, and Cohen. Like Dilthey, Cohen published some of his first essays in Zeitschrift für Völkerpsychologie und Sprachwissenschaft, the journal founded and edited by Steinthal, Boeckh's master student, along with Steinthal's friend and brother-in-law, Moritz Lazarus. While Dilthey developed the theory of understanding (hermeneutics) further in the direction of a methodological principle underlying all humanities, ${ }^{4}$ Cohen shifted from the study of the mechanism of consciousness as manifest in its poetic conceptual constructions (Begriffsdichtung) to transcendental philosophy, hoping to restore appreciation of the "historical" Kant at the same time as restoring Kant's method of philosophy.

Before Cohen's turn to Kant, he had worked on Plato and the Greek mind in terms of "ethnic psychology," i.e., he studied the development of, for example, the theory of forms as genetically developing from the context of the totality of the creative moments produced within the same language community. When he turned his attention to Kant he did so from the same methodological perspective. The occasion to do so was the outbreak of a literary feud between Cohen's teacher Friedrich Adolf Trendelenburg and the Heidelberg historian of philosophy Kuno Fischer who argued over the interpretation of the transcendental esthetic in Kant's First Critique. The question was whether or not Kant's philosophy was based on a kind of psychological empiricism or not. Cohen's contribution to the feud aimed to retrieve the intentions of the historical Kant in such a way that the systematic implications of Kant's position would be fully reëstablished. ${ }^{5}$ During this phase, and within the context of reading Kant "philologically" (in the full sense of the term given it by

\footnotetext{
${ }^{4}$ Boeckh himself asserted that philology could not recognize an absolute difference between sciences and humanities. It has to study (the history of) both. Cf. August Boeckh, Encyklopädie und Methodologie der philologischen Wissenschaften, ed. Ernst Bratuscheck (2. ed. Rudolf Klussmann) Leipzig: Teubner, 1886, p. 9f: "Die Wissenschaft überhaupt ist nur Eine ungetheilte und zwar im Gegensatz gegen die Kunst, welche zusammen mit ihr die ideele Seite des Lebens und der menschlichen Thätigkeit bildet, die begriffliche Erkentniss des Universums. Die gesamte Wissenschaft als ein Ganzes ist Philosophie, Wissenschaft der Ideen. Aber je nach der Betrachtungsweise, ob das All von materieller oder ideeler Seite genommen wird, als Natur oder Geist, als Nothwendigkeit oder Freiheit, ergeben sich, abgesehen von formalen Disciplinen, zwei Wissenschaften, die wir Physik und Ethik nennen. In welche gehört nun die Philologie? Sie umfasst gewissermassen beide und doch keine von beiden." etc.

${ }^{5}$ Cf. Geert Edel, "Einleitung" in Hermann Cohen, KTE ${ }^{3}$ (WW 1.1), p.10*ff
} 
Boeckh, namely as a methodologically established theory of understanding which, albeit coming from a different direction, had a task identical to that of philosophy), ${ }^{6}$ Cohen boldly postulates a new method of reading the history of philosophy. After criticizing the shortcomings of both Fischer and Trendelenburg, Cohen stresses that the basic task of the historian of philosophy must be to identify the "basic thought" (Grundgedanken) of the subject he tries to understand. The question of how to identify this "basic thought" is the key methodological problem. ${ }^{7}$ Cohen suggests a "psychological method" but emphasizes that the word is unimportant. What counts is what "the history of philosophy actually wants to achieve in the final analysis":

It wants to represent the continuous connection of the philosophical problems within the whole of human culture. How one system emerges from the best of the other, and carries within its own shortcomings the seed for the next one! How questions become ever deeper and goals reach ever higher! And nevertheless progress happens only gradually! And how always and everywhere there is a communion with all other directions of human thought which you can never neglect without hurting the unity of the whole because the realm of thought can only be made an aspect, not an epoch. $(271)^{8}$

At this point, Cohen is still fully convinced that this task can be achieved by looking at the "psychological process" from which the "thought" resulted, by analytically differentiating a historical idea into its components. But the synthetic aspect of the proposed method contains the germs of what would later replace the psychological approach. To counter the dangers of an empty or arbitrary reconstruction of the philosophical idea from its previously established historical component parts, Cohen proposes what he sees as the only means of avoiding aberrations: "The historian shall be philosopher." should not attempt to be objective in a false sense because the

${ }^{6}$ Cf. Boeckh, op.cit., p.9-11, 16-20.

7 "Zur Kontroverse zwischen Trendelenburg und Kuno Fischer" in: Schriften zur Philosophie und Zeitgeschichte (1928) vol.I, 229-275; the relevant passages are on pp. 268-275.

8 "Sie will den fortlaufenden Zusammenhang der philosophischen Probleme im Ganzen der menschlichen Kultur darstellen. Wie ein System aus dem Besten des andern wächst, und in dem Mangel des eigenen den Keim des neuen trägt! Wie die Fragen sich vertiefen und die Ziele höher gehen! Und wie doch die Steigerung stufenweise erfolgt! Und wie immer und überall eine Gemeinschaft besteht mit allen anderen Richtungen des menschlichen Denkens, von denen man nimmer absehen kann, ohne die Einheit des Ganzen zu verletzen, weil aus dem Kreise des Denkens nur ein Ausschnitt gemacht werden darf, nicht ein Abschnitt." The influence of Herder's reflections on history is clearly discernible. 9"Der Historiker sei Philosoph." 
philosophical problems he tries to describe are themselves not solved. Therefore the historian must participate in the debate over the problem itself. Only by subjectively acknowledging and understanding that which is valid in an historical position can one do justice to its objective value. Speaking of Kant as the problem at hand (and polemicizing against Fischer and his historical description of Kant) Cohen illustrates his point.

One may aspire to complete objectivity, yet if one does not become a critic in one's own philosophy one will unavoidably charge even Kant with "apriorical magic", "imagined concepts" and lecture him with other, similar, pseudo-objective statements. $(272)^{10}$

The task Cohen sets here for himself is that of an historian of philosophy in the larger context of a "psychological" understanding of all "directions of human thought" (271). Philosophy is not a "stage" but an "aspect" of the "unity of the whole" of culture (ibid.). Curious, however, is the relativization of the objectivity resulting from the emphasis on the subjective participation in the debate over the philosophical problem. Cohen goes so far as to claim that "the historian's philological truthfulness to a document becomes more sophisticated the more he participates in the systematic problem" (272).

The objectives of this shift from historical objectivity to subjective participation are the following. The historicization of philosophy, the emphasis on the distance between the historian and her subject matter, makes doubtful the progress of philosophy as a science, or on the model of the sciences (as demanded by Trendelenburg and practically by all the ensuing neo-Kantian programs). Cohen formulates a principle which he later reiterated untiringly, namely "philosophy should not start from scratch in every head but build on related efforts." More than with the history of philosophy for its own sake, Cohen is concerned with the history of philosophical problems for the sake of pursuing their solution in a concerted effort and in a critical and appreciative appropriation of the whole history of philosophy. Warning against the danger of historicization, he writes:

Of all reductions of the human being caused by the division of labor the historical is perhaps the most dangerous one. The more an individual, or a whole age, dedicates itself to scrutinizing the past the more likely it is that the harmonious development of the

10"Man kann noch so sehr objektiv sein wollen: wenn man in der eigenen Philosophie nicht Kritizist ist, so wird man es nicht vermeiden können, in der geschichtlichen Darstellung einem Kant selbst 'apriorischem Zauber', 'phantastische Begriffe' und andere ähnliche Objektivitäten mit den entsprechenden Belehrungen vorzuwerfen." 
future-both of the individual spirit and of the culture in generalwill be neglected. ... If, therefore, an age lets itself be dominated by the historical urge it will soon be fully satisfied by gratifying it and, with time, it will be less touched by the question: What will be? and even less by the more urgent: What ought to be? ${ }^{11}$

At this early stage, and in this first essay-which gained him the recognition of Friedrich Albert Lange, the man who decisively helped to launch his career-Cohen reveals some of the basic tenets which he fully develops only later. While applying the psychological method he shared with Steinthal to the subject matter of systematic philosophy and its history, he already puts the emphasis on the problem of the validity of historical philosophy in terms of its contribution to the progress of philosophy built on the model of the sciences. The question "what ought to be?" is the hermeneutic interest guiding a proper understanding of the historical document. It is also important that philosophy is perceived as but an aspect of the cultural "whole" in which we can easily identify the predecessor of Cohen's later notion of the "unity of the cultural consciousness" which was to be dealt with by "psychology" as the fourth part of the philosophical system.

Cohen follows his own program in the subsequent years in his interpretation of Kant and Plato. Having subjected both to his "psychological" reading of the history of philosophy, he focuses more and more on the development of the basic tenets of "critical idealism." In this process, Cohen gradually abandons the approach of psychological Zergliederung (Herbart's method of psychology; still present in the first edition of Kants Theorie der Erfahrung; 1871) and, leaning on Plato, Leibniz, and Kant, develops his own "logic of pure cognition," the first part of his system of philosophy. ${ }^{12}$ In other words, while continuing to combine historical and systematic approaches, the prevalence of the systematic interest-expressed as early as in 1870-becomes the overruling force in Cohen's thought.

It is ironic that many of the later students who emerged from the Marburg school deviated from their teachers Cohen and Natorp over the question of broadening the philosophical task to include the hermeneutic

${ }^{11 "}$ Von allen durch die Teilung der Arbeit bedingten Einseitigkeiten des menschlichen Wesens ist die historische vielleicht die gefährlichste. Je emsiger der einzelne wie das Zeitalter der Erforschung des Vergangenen sich hingibt, desto leichter kann die harmonische Ausbildung der Zukunft, wie des eigenen Geistes so der allgemeinen Kultur, verabsäumt werden. ... Wenn daher ein Zeitalter von dem historischen Triebe sich beherrschen läßt, so wird es bald an der Befriedigung desselben sein volles Genügen finden, und je länger, je weniger von der Frage berührt werden: Was wird sein? geschweige von der dringlicheren: Was soll sein?"

${ }^{12}$ See below. 
issue. It would make more sense to look at the modifications which the hermeneutic task underwent as it moved from the teachers to their students. Perhaps Ernst Cassirer could perceive his philosophy of symbolic forms as a deviation from Cohen only because he underestimated the hermeneutic undercurrent in Cohen's system, to which he was indebted. By the same token, Hans-Georg Gadamer was contradicting the Marburg school less than he thought when he developed hermeneutics as the inquiry into the relation of "truth and method." Denying any indebtedness to Cohen, Gadamer simply forgot that, in philosophy and history, a dialectical dependence is still a dependence. ${ }^{13}$

In the 1920's Marburg neo-Kantianism was criticized from several directions which applied labels to a school from which a younger generation of thinkers wanted to emancipate itself. From one direction, the Marburg method of the history of philosophy was criticized for simplifying and falsifying historical positions in two ways. First, it judged the historical position (presumably) only on the basis of whether or not it contributed to the problem in which one was currently interested and, second, one's own interest and perspective were not sufficiently brought to attention. ${ }^{14}$ Another charge was that Marburg neo-Kantianism was devoid of metaphysical power (see Heinz Heimsoeth in his letters to Nikolai Hartmann) or that it neglected the primacy of being by overemphasizing thinking as the constructive source of all valid cognition (Hartmann, Heidegger).

As a result of such charges, Cohen's works have subsequently been grossly underestimated and the high regard in which he was held even by his most critical contemporaries remains a riddle when the thrust towards the "unity of the cultural consciousness" is neglected, the very thrust that prevented Cohen from falling into a purely constructivist conceptualism. In Cohen's basically teleological attitude towards the history of culture ("what ought to be?" as the primary question of all cultural efforts), as in the encyclopedic method of philology of his teacher Boeckh, the task of the sciences was characterized as infinite

\footnotetext{
${ }^{13}$ Gadamer and Marburg is a separate issue, which cannot be dealt with here. For his familiarity with and his critique of the Marburg method of Problemgeschichte see Hans-Georg Gadamer (ed.), Festschrift für Paul Natorp zum Siebzigsten Geburtstage von Schïlern und Freunden gewidmet, Berlin/Leipzig: Walter de Gruyter, 1924, pp. $56 \mathrm{f}$ and 74f. It seems an irony of intellectual history when Gadamer later refers rather positively to Steinthal's method of ethnic psychology in Hermeneutik I. Wahrheit und Methode. Grundzüge einer philosophischen Hermeneutik, [Gesammelte Werke Band 1], Tübingen: J.C.B. Mohr (Paul Siebeck), $1986,19 f$.

${ }^{14}$ See Gadamer (1924) ibid.
} 
progress. ${ }^{15}$ In Boeckh's hermeneutic theory, philology (= hermeneutics) and philosophy are differentiated not by their subject matter but by the way in which they proceed: "philosophy cognizes in an original way, philology re-cognizes."16 Boeckh, student of Schleiermacher and devout Platonist, revives and reinterprets the notion of knowledge as anamnesis to minimize the difference between the historical and the philosophical task. For us, the important observation is that Cohen inherited the conviction inherent in Boeckh's theory of "understanding" that a unity of history and philosophy, viewed as branches of a universitas litterarum, is possible if their tasks are properly coordinated and correlated. What follows is Joachim Wach's description of the relation of philosophy and philology in Boeckh's hermeneutics, a description which could also be valid for Cohen.

The difference [viz. between philology and philosophy] consists not in the subject matter but in the perspective and understanding. The purpose of philology is purely historical. As Boeckh says, it represents the knowledge of the known objectively. In philosophy and other sciences one does the same, however in order to build upon it further. Ultimately one cannot be without the other: both are mutually dependent upon each other and condition each other: one cannot know what has been known nor arrive at any knowledge at all without knowing what others knew. Thus the inner opposition is determined in that philosophy takes its point of departure from the concept while philology begins with what happens to be there. Now, when philosophy wishes to grasp conceptually what is essential to certain historical experiences it needs to penetrate their inner meaning. To this end, however, it needs knowledge of the phenomena that are to be viewed as the external impression of this essence. In order to reconstruct the spirit of the Greek people one needs to be acquainted with its contingent appearance. $(181 \mathrm{f})^{17}$

\footnotetext{
${ }^{15} \mathrm{Cf} . \mathrm{J}$. Wach, "Die hermeneutische Lehre Boeckhs" in: Das Verstehen. Grundzüge einer Geschichte der hermeneutischen Theorie im 19. Jahrhundert, vol. I: Die großen Systeme (1925), Hildesheim: Olms 1966 (reprint), 180: "Gerade in der Unendlichkeit liegt das Wesen der Wissenschaft, mit jener hört diese auf." And 181: "So ist die Philologie, wie jede Wissenschaft, eine unendliche Aufgabe für die Approximation."

16 Wach, op.cit., 181.

17"Nicht im Stoff, sondern in der Ansicht und Auffassung liegt ... die Verschiedenheit [scil. von Philologie und Philosophie; M.Z.]. Der Zweck der Philologie ist rein historisch, sie stellt, wie Boeckh sagt, die Erkenntnis des Erkannten objektiv für sich hin. In der Philosophie und in den andern Wissenschaften tut man das nämliche, aber um darauf weiter zu bauen. Schließlich kann keines ganz ohne das andere sein: beide sind aufeinander angewiesen und bedingen sich wechselseitig: man kann das Erkannte nicht erkennen und kann andrerseits zu keiner Erkenntnis schlechthin gelangen, ohne zu kennen, was andere erkannt haben. So wird der innere Gegensatz dahin
} 
The most obvious convergence, interdependence and even coincidence of the disciplines is visible in the philosophy of history and the history of philosophy. ${ }^{18}$

Boeckh establishes philology as the fundamental and comprehensive discipline of studying a culture as a whole. The phenomena of language, the culture of a people, including its philosophy, are studied as an organic unity. The objective of Boeckh's theory of hermeneutics is the same as that of Cohen's history of philosophy, namely the "assimilation of that which is to be understood."19 Like his student Cohen, Boeckh maintains that the task of the philologist is not exhausted by "assimilation" of the object; it is fulfilled only when understanding is objectified as the result of the philological study: "Again therefore a knowing of the 'knowledge of that which was known and which is shaped into a whole,' a processing in one's own thought" (Wach p.183). ${ }^{20}$

It is this step beyond the mere critique of past thoughts that makes for the strongest parallel between Boeckh's and Cohen's intentions and shows that Cohen was "standing on the shoulders" of this great 19thcentury humanist. ${ }^{21}$

In Cohen's systematic philosophy, the term Einheit des Kulturbewußtseins (unity of the cultural consciousness) addresses the ultimate unity of all cognition. ${ }^{22}$ This indicates an idea corresponding to that of philology in the following sense. The philologist strives to

bestimmt, daß die Philosophie vom Begriff ausgehe, die Philologie dagegen vom zufällig Vorhandenen. Wenn die Philosophie nun das Wesentliche an historischen Erscheinungen im Begriff erfassen will, so muß sie in deren inneren Gehalt einzudringen verstehen. Dazu aber bedarf sie wieder der Kenntnis der Erscheinungen, die als der äußerliche Abdruck dieses Wesentlichen anzusehen sind. Um den Geist des griechischen Volkes konstruieren zu können, muß man mit seiner zufälligen Erscheinung vertraut sein."

${ }^{18}$ Incidentally this issue makes for a close proximity between Hegel, Boeckh and Cohen, between the historical unfolding of the spirit (namely in concepts), the cultural phenomenology studied in archeology and history, and systematic philosophy built on the continuous history of its problems.

${ }^{19}$ Wach p. 182: "Wenn die Forderung erhoben wird, Erkanntes zu erkennen, so ist das Ziel so lange nicht erreicht, als das Erkannte etwas Fremdes bleibt: das Fremde ist als Eigenwerdendes zu reproduzieren. Es darf nichts Äußerliches bleiben. In dieser Forderung nach Assimilation des zu Verstehenden berührt sich Boeckh wieder ganz eng mit Humboldt, tritt er durchaus in die Fußstapfen Schleiermachers."

20"Noch einmal also ein Erkennen von der 'zu einem Ganzen formierten Erkenntnis des Erkannten', eine Verarbeitung im eignen Denken."

${ }^{21}$ Wach p.183f shows how impulses of Hegel, Humboldt and Herder are converging in Boeckh's philosophy of history.

${ }^{22} \mathrm{Cf}$. Dieter Adelmann, Einheit des Bewusstseins als Grundproblem der Philosophie Hermann Cohens, Heidelberg: 1968. 
understand what has been understood (in a particular culture of the past), including all products of the human spirit. The understanding of a particular Volksgeist is based on the general definition of the hermeneutic theory which must be valid no matter what the object of cognition is, and it is applied to and unfolds in the study of all products of human culture from archeological artifacts to inscriptions, texts, etc. The result is a reconstruction of a particular culture of the past.

The task of philosophy is modeled on this art of understanding a culture in that it also aims for an understanding of the whole. And just as the picture of a past culture undergoes constant revisions as our knowledge of the past increases, so too the philosophical system is fundamentally incomplete and tentative. New branches of science and new academic disciplines are invented based on specific new questions and methods. In spite of this incompleteness, academic philosophy could be viewed as the organ of the unity of an expanding universitas litterarum, a task certainly no less honorable and meaningful as that of understanding the cultures of the past.

The limitations and dangers of this pursuit of a synthesis of the cultural consciousness are obvious. An attempt to span the whole range of disciplines in an expanding universe of knowledge runs the risk of reducing this knowledge to that which a particular philosopher is able to comprehend. Cohen himself was not consistent in his application of the idea that each part of philosophy needs to coordinate its particular task with an actual science. While logic was coordinated with mathematics as the foundation of the sciences, while ethics was coordinated with law as the foundation of the humanities (this is not as immediately convincing as the coordination of logic with mathematics and the sciences), esthetics, the third principal "direction" (Richtung) of culture was not to be coordinated with art-history or art-criticism. In Cohen's system it is a theory of "pure feeling" (reines Gefühl) implied and operative in both artistic production and in the perception or appreciation of the arts. The product and fact correlated with "pure feeling" which realizes itself in it is art itself. Hence the disciplines mentioned earlier which regarded themselves as the guardians of esthetics are simply left out of the picture. For this reason, the work on esthetics (Ästhetik des reinen Gefühls, 1912, 2 volumes) was perceived by some of Cohen's students as too idiosyncratic, based on the Geheimrat's personal taste rather than on an objective account of the transcendental condition of the realization of the beautiful in the work of the artist and the critique of judgment.

This apparent deviation from what is often regarded as a basic structural device in the architectonic of Cohen's philosophy is less upsetting if the task of the philosopher is understood as analogous to that of the philologist. There is no inherent need for the philosopher to 
forgo direct access to the primary facts of cultural consciousness, and just as the archaeologist and encyclopedic philologist in Boeckh's theory is obliged to understand the full gamut of expressions of the spirit in order to synthesize them in an objective understanding of the inner life of a culture, so too the philosopher may have to liberate himself from the limitations imposed by scholarly disciplines whose methodological justification is far less evident than that of the natural sciences. Moreover, as noted by Gadamer as early as 1924 in a Festschrift for his teacher Paul Natorp, the founders of Marburg neo-Kantianism arrogated to themselves immediate access to culture on a much more fundamental level-namely in that they had no hesitation to claim full mastery of the history of ancient, medieval, and modern philosophy. In Cohen's as in Natorp's case another immediate access to facts of culture can be adduced albeit with considerable variation in its conceptualization. I am referring, of course, to their respective philosophies of religion. Natorp believed, with Wilhelm Herrmann, that every person is a specialist on religion. For him religion meant an immediate knowledge that was the dialectic corrective to the cultural abstractions cast on experience by critical idealism. Cohen on the other hand was a trained theologian and a student of the history of religion. In his writings on religion he, therefore, never defers to specialists. Instead he takes issue with their judgment where it concerns the philosophical implications of their field. In a sense, given that the study of religion was still in its methodological infancy, Cohen must be understood not only as a philosopher of religion but as one of the major players in the very debate from which the discipline first emerged and is still emerging. ${ }^{23}$ One might even say that the reason why Cohen's philosophy of religion has received sustained attention over the past century while his system was virtually forgotten is that his understanding of the phenomenon of religion was perceived as a sophisticated and original contribution grounded in experience.

Contrary to the common assumption that it played no role in Cohen's systematic thought until late in life, religion is distinguished as a fact of culture ${ }^{24}$ already at the very time when his systematic philosophy began to take shape. This is illustrated in a passage of his biographical introduction to Friedrich Albert Lange's Geschichte des Materialismus. It

${ }^{23}$ It is from this perspective namely from its contribution to the variety of approaches to the religious phenomenon that Cohen's "late" philosophy of religion is read in the work of Catholic theorists of religion. See, e.g., Richard Schaeffler, Religionsphilosophie [Handbuch Philosophie, ed. E.Ströher, W.Wieland], Freiburg/München: Alber, 1983. And see the work of Johannes Hessen, Die Religionsphilosophie des Neukantianismus, 2nd enlarged ed., Freiburg: Herder, 1924.

${ }^{24}$ Cf., e.g., KBE ${ }^{2}(1910)$ 
represents one of the earliest positions on the relation of ethics and religion published by Cohen in a philosophical text.

In the "Biographisches Vorwort" (dated "Marburg, am 8. Oktober $\left.1881^{\prime \prime}\right)$ Cohen introduces the life and work of Lange, yet he adds critical notes on Lange's psychological understanding of Kant's transcendental philosophy and practically summarizes in six pages his own systematic position as far as it has evolved up to this point.

What is particularly interesting in this short text is the importance Cohen attributes to religion as a cultural fact and its relation to ethics. The task of the "transcendental method" is briefly characterized as "searching not for the principles of human reason but for the foundations of the sciences which are the condition of scientific validity." 25 This is the fundamental definition of epistemology as the critique of the validity of the judgments constituting scientific knowledge. Scientific knowledge, however-this too Cohen will repeat many times in the future-is contained in printed books. ${ }^{26}$ The transcendental question is the methodological question of how to determine what it is that makes these communicable facts "scientific":

What makes them sciences, wherein rests the character of their universality and necessity, from what concepts can be deduced the value of cognition that is valid within their area, which characteristics and ways of knowing explain those historical facts of cognition, the sciences, as to their validity, this is the question of method that the sciences themselves raised whenever they felt the impulse to become mindful of their principles. This and nothing else is the transcendental question. (p.X; my emphasis) ${ }^{27}$

In the following paragraph, expanding the same topic, Cohen's formulation echoes what first appeared in Kants Begründung der Ethik (First edition 1877; $\mathrm{KBE}^{1}$ ) and which is even more prominently stated in the first part of his system of philosophy (Logik der reinen Erkenntnis, First edition 1902) namely the elimination of the "thing-in-itself." Cohen differentiates between the object of the transcendental method (the

25"Die transcendentale Methode forscht nicht nach den Principien der menschlichen Vernunft, sondern nach den die wissenschaftliche Geltung bedingenden Grundlagen der Wissenschaften."

26"Die Wissenschaften aber liegen in gedruckten Büchern vor."

27"Was sie zu Wissenschaften macht, worin der Charakter ihrer Allgemeinheit und Nothwendigkeit beruht, von welchen Begriffen ihr innerhalb ihres Bereiches geltender Erkenntnisswerth abgeleitet werden kann, welche Züge und Weisen des Erkennens jene geschichtlichen Facta der Erkenntniss, die Wissenschaften, in ihrer Geltung erklären, das ist eine methodische Frage, welche die Wissenschaften, wo immer sie sich auf ihre Principien zu besinnen den Anstoss fühlten, selbst gestellt haben,-das und nichts anderes ist die transcendentale Frage." 
sciences, based on the axiom of their comprehensibility-Begreiflichkeit) and nature:

Not common sense perception ... but the science of nature reveals to the philosopher what nature is. Only this must be comprehensible to us; thus no powers nor principles may demand validity but such that further our scientific comprehension. Nature itself, howeverwho should hope to comprehend it! Who would want to be as tasteless as to force Doctor Faustus into paragraphs! (Ibid.) ${ }^{28}$

Clearly, nothing would be more absurd for this author than the allegation that he was eliminating sense-perception or even denying the existence and reality of nature. Obviously, what this is about is the determination of the principles of cognition in the sense of scientific validity which is indeed independent of sense-perception. Metaphysics, Cohen continues, quoting Lange, is "conceptual poetry" (or "poetics," namely Begriffsdichtung).

If we want to do philosophy instead of making poems it is of no concern to us what nature is. But what natural science means, what makes it into science, into cognition, this is the question of that philosophy which liberated itself from the bibliographic title of metaphysics. (p. XI) ${ }^{29}$

The eloquence of the passages quoted here testifies to the certainty of someone who has found a new and reliable foundation of philosophy and who is enjoying the spring of his intellectual life. With this selfconfidence and without any major twist of the mind, Cohen proceeds with his criticism of Lange's psychological foundation of practical philosophy, which he juxtaposes with his own view or, rather, with "the ethical side of transcendental apriorism." ${ }^{30}$ It is worthwhile to follow his argumentation closely.

The concept of the transcendental method, insofar as it is directed towards the conditions of scientific validity, implies that it can be applied to the ethical question only in a figurative sense. This is so because there

28"Was Natur sei, offenbart dem Philosophen nicht die gemeine Sinneswahrnehmung ... sondern lediglich die Wissenschaft von der Natur. Nur diese muß uns begreiflich sein; also dürfen keine Kräfte noch Principien gelten wollen, als welche unser wissenschaftliches Begreifen fördern. Die Natur selbst aber-wer wird hoffen, sie zu begreifen! Wer will so abgeschmackt sein, den Doctor Faust in Paragraphos zu bringen!" The allusion is to Goethe, Faust I, the scene involving Mephisto and the student, where the scholastic mode of exposition (esp. as perpetuated by Christian Wolff) is ridiculed.

29 "Aber was Naturwissenschaft bedeutet, was sie zur Wissenschaft, zu einer Erkenntnis macht, welche die Gewissheit des Wissens in Anspruch nimmt, das ist die Frage derjenigen Philosophie, welche von dem bibliothekarischen Titel der Metaphysik sich befreit hat."

${ }^{30}$ Here he refers to his Kants Begriindung der Ethik (1877). 
are no sciences corresponding to the ethical problems for which one can seek foundations of validity. In his Ethics of Pure Will (Ethik des reinen Willens, First edition 1904) this is modified when Cohen determines the humanities (Geisteswissenschaften, sciences morales) as the field of factual knowledge corresponding to natural sciences, while using the terminology of jurisprudence as the analogue to mathematics. ${ }^{31}$

It is all the more significant that in the earlier work Cohen does not entirely dispense with a cultural fact (Cultur-Factum) either by which to generate an analogy between the structure of logic and ethics. Here the field in which all moral issues are already combined is religion. This is, however, less of a strikingly different position from the one espoused later. For here as later the field by which ethics becomes possible as the transcendental reflection on conditions of validity in the specifically human realm and which immediately establishes a connection with scientific thought is the law. To Cohen, religion is established out of the sources of Judaism and thus manifests itself most strongly in terms of laws with a moral and educational dimension. His concept of religion is rooted in a religion of law. Thus he can speculate that "(e)ven law with its root in the liberty of the moral being nourishes itself from this source (viz. from religion)." (Ibid.)

This sentence-written only a year after Cohen's Bekenntnis in der Judenfrage-is the seed which grew into the tree of Cohen's philosophy of religion. The correlation of ethics and religion in the problems of law and freedom-the theme which is conceptualized in what Cohen calls the Versöhnungsidee - grows from this first formulation through the system of philosophy and determines the Concept of Religion in the System of Philosophy (BR 1915).

\section{Substance, Self-Consciousness, and the Realization of the Good in Cohen's Logic, Ethics, and Philosophy of Religion}

While the term Versöhnung is virtually absent from the system (preceding $\mathrm{BR}$ ), the terminological and even exegetical arsenal Cohen associates with it is present, including its central historical element, Ezekiel's "discovery" of the individual in the concept of sin. In other words, while the term Versöhnung rarely appears, the idea and the problems it addresses clearly have a significant function, especially in Cohen's

\footnotetext{
${ }^{31}$ First in "Einleitung mit kritischem Nachtrag zur 'Geschichte des Materialismus' von F.A. Lange" (1896/97), see 5. edition [= Werke Band 5], "Einführung" by Helmut Holzhey p.18* ff, and later-most prominently-in the construction of Ethik des reinen Willens [= System der Philosophie. Zweiter Teil] (Berlin, 1904).
} 
philosophical ethics. ${ }^{32}$ Cohen had written his essays on messianism and Versöhnung at a time when he had also begun working on what was to be published in 1902 as the first part of a system of philosophy. ${ }^{33}$ The coincidence of Cohen's pursuit of Jewish dogmatics and that of a philosophical system, however, is not merely a temporal one. "Im Zusammenhang meiner wissenschaftlichen Einsichten" - the renewal of a philosophical heritage connected with the names of Plato, Descartes, Leibniz and Kant ("critical idealism")—-"steht mein Judentum."

Cohen systematically studied and interpreted certain religious terms (especially those of messiah and atonement) in order to make them the basic conceptual arsenal for his future Jewish dogmatics. Before Cohen went on to writing such a dogmatics he constructed a system of philosophy with the objective of laying the groundwork for a methodological connection between all directions of human culture. ${ }^{34}$ In view of what has been said so far, it is evident that Cohen intended to provide the groundwork upon which to establish the possibility of a harmonious development of Judaism and of the general culture surrounding it. Both Judaism and the German academic and political culture within which Cohen tried to operate had to be developed according to a standard of reconciliation between particular cultures. This standard is that of a humane civilization, the standard of the ethical ideal. The basis for all future developments in such a direction must be the determination of the direction itself. In this way, the existential and political quest turns into a philosophical problem. It calls for the clarification of the foundations of ethics and religion. Hence the question dealt with in the following is how Cohen determined the cognitive or ethical value of religion and religious terms within the context of a systematic philosophy.

But this question, too, can take on different forms. Could it be that Cohen tried to bridge the gap in such a way that his apologetic Jewish intentions overpowered his philosophical conscience? Is it possible to see ErW as more of an affirmation of Judaism than as an honest attempt to give account of the ethical ideal? ErW would then represent something other than a work on ethics. It has been suggested that it contains a philosophy of Judaism, that it represents teachings of Jewish ethics, ${ }^{35}$ or that it is really more of a "systematic theology" than a philosophical

${ }^{32}$ Cf. ErW (WW 7) pp. 298f ("Der Monotheismus und das Individuum"), 364f ("Das Geschlecht und das Individuum" and "Tragödie und Katharsis").

${ }^{33}$ Cf. Helmut Holzhey, "Einleitung" in: WW 6 p. xv*.

${ }^{34} \mathrm{Cf}$. Cohen's letter to Natorp quoted by Holzhey ibid. p. vii*

${ }^{35}$ I am referring to Stephen S. Schwarzschild's essays on Cohen's ethics (see bibliography). Similarly, the works of J. Klein and M. Dreyer also suggest that Cohen's Judaism interfered with his strictly philosophical reasoning. 
ethics. ${ }^{36}$ Such interpretations should perhaps be used with caution in so far as they may be reading undisclosed intentions into a work or impose far-fetched models on it while the work itself might be perfectly straightforward about its intentions and limitations. Most importantly, the suspicion that Cohen gave imbalanced hearing to a particular religious tradition and too much weight to religion in general may presuppose an understanding of the relation between culture and philosophy contrary to that suggested by Cohen himself. What good is philosophy if it is incapable of mediating between what we might call Scheingegensätze of culture? In other words, the structure of Cohen's ethics and the rules of its construction may suggest a closer relation to and a stronger reliance on certain cultural facts and terms as they have emerged in the past than any of its interpreters have hitherto suggested. Furthermore, the underlying concept of Judaism applied by Cohen may in itself have a stronger tendency towards self-universalization and ethification than may be suspected by interpreters who rely on a concept of religion modeled upon the image of a certain Christian tradition. It may very well be that the convergence of Cohen's Jewish thought with his systematic ethics is made possible by certain fundamental characteristics of Judaism, such as the relation of halakhah and aggadah. ${ }^{37}$ After all, Cohen discovered his concept of Versöhnung in biblical contexts of legal, even cultic legal character. And it should not be thought that it is contrary to halakhah to base legal provisions on certain fundamental concepts which can be found in them. In other words, in his exegesis of the traditions of Versöhnung Cohen applied the very rules by which he

\footnotetext{
${ }^{36}$ For a Christian author who suggested this line of interpretation see $\mathrm{M}$. Baumotte, "Hermann Cohens 'Ethik des reinen Willens' als durchgeführte systematische Theologie" in: Neue Zeitschrift für Theologie und Religionsphilosophie $17 / 1975,33-38$. Baumotte's application of the paradigm of a "systematic philosophy" to Cohen's ethics presupposes the fundamental changes in German Protestant theology caused by the Barmer Bekenntnis which has become a milestone for the introduction of social ethics into the foundations of Christian thought. This development has its parallels in other churches and theologies as well, especially in the Catholic theologies of liberation. In this sense, a convergence between Protestantism and Judaism may have taken place along the lines anticipated by Cohen when he hailed Ritschl as a model for Protestant theology. Examples for the impact of Barmen can be seen in Wolfgang Huber, Folgen christlicher Freiheit. Ethik und Theorie der Kirche im Horizont der Barmer Theologischen Erklärung, 2. Auflage, Neukirchen-Vluyn: Neukirchener Verlag, 1985, Ulrich Duchrow, Weltwirtschaft heute. Ein Feld für Bekennende Kirche? München: Chr. Kaiser, 1986. Also cf. Heinz Eduard Tödt, "Zum Verhältnis von Dogmatik und theologischer Ethik" in Perspektiven theologischer Ethik, München: Chr. Kaiser, 1988, pp. 12-21 and W. Schweitzer, s.v. "Sozialethik" in: RGG 6:159167.

${ }^{37}$ Cf. RV, p. 33f.
} 
constructs his philosophical ethics which is based on a correlation between law and ethics. A correspondence to the relation of halakhah and aggadah obviously needs further explication which cannot be attempted here. It is equally obvious that a method of reason and the principles of halakhic thought can only be reconciled if the revelatory character of Torah can be viewed as not contradicting the rational explication of its principles. Since the latter seems to have been Cohen's opinion it should not strike us as odd-from the viewpoint of ethics or of religion-that, in his ethics, Cohen attempts to vindicate Judaism as a source of moral ideas which have contributed to the making of Western culture and have the potential of doing so in the future.

On the way to understanding the form and content of Cohen's philosophy of religion, it is relevant to see how he deals with the previously established central Jewish concepts within the system of philosophy. This is important because we need to find out whether meaning and function of these terms underwent any changes and whether these changes reflect a development either in Cohen's philosophical method or in his understanding of religion. The question of the Jewish authenticity of relevant terms is here no longer central. Rather, we shall see how traditional Jewish terms (sh'gagah, kapparah, etc.) are used to infuse the discourse on ethics with a meaning and depth that would otherwise be lost. More specifically, without awareness of the Hebrew ideas behind Cohen's philosophical discussions one would miss many a point in his argumentation. But this examination of the presence of Jewish doctrine within the system of philosophy also serves to bring into relief the unique profile of Cohen as a philosophical thinker whose position in modern thought is lost to us unless we realize the Jewish dimensions of his philosophical work. Were we to remain unaware of this dimension we would lose not only a source of appreciation for Cohen individually but for the presence of Judaism as a tradition within Western thought.

Wherein consists the presence of Judaism in Western thought that Cohen recognizes, reasserts, and attempts to reintegrate into the philosophical discourse? The arsenal of forays into Jewish tradition and doctrine-what Cohen usually calls "monotheism" or simply "religion" - contains a number of aspects that deserve attention, among them most prominently the idea of God which, in his ethics, receives a chapter in its own right to complete the discussion of the "reality" of an ethics that culminates in "the ideal." Aside from the appearance of this most evident character-the God of the Hebrew prophets as conceptualized in the tradition of medieval Jewish rationalism which, to Cohen, boils down to Maimonides with a "Platonic twist" (Bruckstein)other terms and ideas play a less emphasized yet no less significant role 
in Cohen's attempt to provide a sound foundation for practical philosophy. At the core of Cohen's ethics is the idea of the human being as a moral entity, i.e., as beyond the reach of scientific knowledge. Thus his practical philosophy reflects back onto his logic wherein the limits of knowledge are delineated. On the other hand, idealism as the methodological foundation of the system wishes to link ethics to logic so that morality must not forgo the character of certainty that the logic of cognition is to extend to it. Thus logic and ethics belong together but are to be distinguished. Cohen seems to have operated under the command of harmonizing the great imperatives that impressed themselves over and over again onto his mind and which are inextricably linked with his effort to come to terms with the fundamental question of the position of Judaism in the historical genealogy, the political reality, and philosophical potential of Western culture. Thus, not by chance we are confronted with a set of mirrors in which not only the same duality frequently reappears but, more importantly, so does the same attempt at harmonization or reconciliation between the two that both unites and differentiates the two. It is this duality and its inherent stimulation towards ever new attempts at resolving it that defines, determines, propels, shapes, prefigures, and mirrors Cohen's thought. Not only his thought, but also his very definition of thought! Cohen's philosophy is the fully self-conscious attempt to raise the tension between Judaism and Greek philosophy to the center that propels Western culture forward towards ever new stages of self-perfection. Western culture has no identity, no essence beyond and outside this tension. This tension is the essence of Cohen's own self which he projects onto the plane of Western cultural history and philosophy. Thus one might say that Judaism is present in Western thought through those Jewish thinkers to whom the tension between Athens and Sinai is essential and who attempt to give account of their struggle in philosophical terms.

My claim that the fundamental effort and interest of Cohen's philosophizing consists in the reconciliation of Judaism and Greek thought is not to say that he deluded himself that his own thought should be regarded as the principle of the development of Western thought. The history of occidental culture is too diffuse to obey a single law or to be brought under a single simple formula. Matters change, however, if the philosophical task consists in determining whence one may find the healing sources for the modern ills of capitalist egoism and philosophical nihilism. In contrast to the Logic of Pure Cognition, Cohen's ethics is a mere experiment (Versuch), one into which he enters with trepidation and awareness of the charge of immodesty that must attach itself to anyone who, during her lifetime, dares to publish a work of ethical theory. If, in the course of such an experiment the philosopher 
listens to the Jewish tradition as well as to other sources, the philosopher must be able to command the continued attention of his peers, especially and if his listening enables him to speak with authority to impasses of modernity that are of a broad concern.

A number of themes and terms could provide us with a useful focus for an examination of Cohen's philosophy of religion. Among such major topics are the theoretical and ethical implications of the Jewish doctrine of God's uniqueness, the theory of language that emerges from Cohen's understanding of the characteristics of the Hebrew language as well as of the ethos shaped by Hebrew literature and liturgical practice, and other fundamental philosophical problems. The main focus for this study, however, is the theme of atonement with its implications for the construction of ethics and for the role of religion within the system of philosophy. We begin by looking at the provisions for the ethical problem made within the Logic of Pure Cognition (LrE). From here we proceed by examining the Ethics of Pure Will (ErW) as a project of displacing individual ethics by philosophy of law. This will lead us to an interpretation of Cohen's philosophy of religion as represented both in the ethics and in The Concept of Religion in the System of Philosophy (BR).

Finally, a remark on the style of the later writings (beginning with $\mathrm{LrE}$ ). Cohen is not so much a cryptic writer as he is no writer at all. The later writings, i.e., the main philosophical works commencing with Logik der reinen Erkenntnis (1. edition 1902), are the products of collaboration between himself and his wife, Martha and bear the characteristics of lectures. Orality imposes shorter, less convoluted, sentences and a seemingly clear structure. Yet it leads to a lack in footnoting, the use of a repertoire of key terms that are rarely defined, and references to literature from memory which he quotes directly or indirectly without explaining how he arrived at his interpretation of its meaning and significance. In short, much is taken for granted. The effect of this style is that if one reads Cohen expecting any degree of exposition of problems one is frequently disappointed and disenchanted. Even passages that look like expositions are often polemical positions within a particular debate. He simply thinks aloud in a way that is comprehensible mostly to himself.

Reading Cohen, therefore, always demands research into the background he presupposes and a repeated reading of his texts which leads to an acquisition of the terminology he applies to analyzing problems. One cannot just read him; one needs to study him. One of the reasons why his later works had little impact on the history of philosophy and why translating them is difficult is this stylistic peculiarity, that is, the discrepancy between a seemingly conversational flow and the great difficulty of understanding exactly what is being 
communicated. It must be kept in mind also that both Logic and Ethics were meant to lay the groundwork for their disciplines; their elaboration and application was to follow in second volumes which, however, were not written. For the Logic this was attempted by Cohen's student Ernst Cassirer whose important early work on substance and function can be taken as the second volume to Cohen's LrE. For the Ethics this was similarly attempted by a number of his students (esp. Benzion Kellermann, Albert Görland, et al) none of whom however produced work that matched the depth and originality of their teacher.

\subsection{From Substance to Function:}

\section{Logical Provisions for the Subject of Ethics}

\subsubsection{The Human Being as an Analogue to Nature}

In order to understand Cohen's claim that the principles of the humanities (Geisteswissenschaften) and their "logic" (i.e., ethics) are determined by rules, i.e., by provisions made in Logic, one needs to clarify the basic principles of Logik der reinen Erkenntnis. ${ }^{38}$ If we fail to reconstruct the groundwork Cohen is laying in his logic we would forgo the possibility of placing within their systematic context those religious terms that are functioning within the ethics as well as within the philosophy of religion. We would also fail to produce the background necessary for the determination of the systematic or anti-systematic (or post-, meta- or para-systematic) profile these terms may or may not gain in the late philosophy of religion.

Among the recent studies on Cohen's theoretical philosophy, Geert Edel's Von der Vernunftkritik zur Erkenntnislogik is the most detailed and, at the same time, most instructive account of the development of Cohen's philosophical program as it evolves from its first incomplete and largely inconsistent presentation in Kants Theorie der Erfahrung $\left(1871\right.$ KTE $\left.^{1}\right)$ to its mature formulation in LrE. Edel's work takes seriously Cohen's explicit claim that, from the outset of his participation in the debates on Kantian philosophy, he was not satisfied with retrieving the original meaning of the historical Kant but, rather, wished to revive philosophy through returning to the original program given it by Kant. While this systematic interest on Cohen's part was not immediately evident to the readers of KTE, Edel's study shows how Cohen followed a coherent philosophical

\footnotetext{
${ }^{38}$ ErW, "Vorrede zur ersten Auflage," WW 7, p. vii: "Die Logik der reinen Erkenntnis hatte als erster Teil eines Systems der Philosophie nicht nur auf den zweiten Teil hingewiesen, sondern auch in ihrer Anlage und in ihren Ausführungen zugleich für die Geisteswissenschaften eine grundlegende Vorsorge getroffen"; cf. also LrE (WW 6), p. 42-45.
} 
agenda that involves an orientation not only towards Kant but towards Plato and Leibniz as well. In the course of the publications written between 1871 and 1902 Cohen reformulates the program of his philosophy of critical idealism, gradually emancipating himself in the process from the way in which Kant's First Critique had formulated the problem of philosophy. While Cohen remained in constant critical exchange with the architecture and terminology of Kantian philosophy, he departed from Kant as he developed his own program and theorems. Edel uses Cohen's own terms when he designates this process as suspended between "critique of reason" (the Kantian term) and "logic of cognition." The latter refers to the result of Cohen's reinterpretation of Kant's method as a critique of the validity of knowledge represented in certain sciences as opposed to the former which rests on the assumption that Kantian philosophy was primarily concerned with theorizing the act of cognition. It may be useful to illustrate this disjunction further. ${ }^{39}$

Philosophy can be defined as a discipline which sets itself the task of determining the fundamental conditions of all cognition (noësis, Erkenntnis). ${ }^{40}$ Cognition, however, is an ambiguous term in that it may refer either to certain operations of the mind or to the result of such operations (knowledge). For much of the nineteenth century Kantian philosophy was understood as analyzing the subjective psychological conditions which human reason imposes on the raw material of sensual perception. Thus philosophical inquiry can be viewed as beginning with the act of cognition, focusing on its subject and on the way in which cognition is constituted within it, i.e., in the cognitive faculty. As the operations of the brain became increasingly the object of empirical studies, the idealistic foundations of philosophy tended to be absorbed by a materialist principle (the physiology of the brain). The role of philosophy as the fundamental discipline determining the rules underlying all knowledge was called into question from a theoretical perspective by the materialist implications of the psychological interpretation of the Apriori as well as in practical terms by the policy of appointing experimental psychologists to chairs in philosophy. ${ }^{41}$

\footnotetext{
${ }^{39}$ For the following cf. Edel, op.cit., 265ff; also cf. Hans Wagner, Philosophie und Reflexion, München/Basel: Ernst Reinhardt, 1959 and cf. Wolfgang Cramer, review of Hans Wagner, Philosophie und Reflexion, in Philosophische Rundschau (11/1963), 68-90.

${ }^{40}$ Cf. LrE p. IX, and I.Kant, Logik (ed. Rosenkranz, Leipzig: Voss, 1838), p. $169 f$.

${ }^{41}$ There are many useful and interesting recent accounts of the fate of philosophy in the 19th-century. Koehnke looks at the rise of neo-Kantianism in response to the materialism debate in the mid-century and illustrates the famous return to Kant by means of statistics. Similarly, although focused on Marburg alone, Sieg shows the general trend as manifest in a single department of philosophy. For the
} 
An alternative approach to philosophy, also associated with a "return to Kant," begins with the result of cognition, i.e., with its object. ${ }^{42}$ Cohen's path begins with his first work on Kant $\left(\mathrm{KTE}^{1}\right)$ in which he seems to waver between agreement and disagreement with the assumption that Kantian philosophy exhausts itself in determining experience as the synthesis of raw material supplied by sense perception and a priori conditions imposed on it by reason. Cohen's discomfort with this interpretation becomes more evident as he turns against the psychological interpretation of the a priori and develops his own methodological understanding of transcendental philosophy.

This turn consists in directing the "transcendental method" from inquiring into the conditions of the possibility of all experience to the problem of the conditions of the "certainty" (Gewißheit) of scientific cognition. ${ }^{43}$ This, too, has its precedence in Kant. As a general philosophical directive this program corresponds to that presented by Kant in his Prolegomena zu einer jeden künftigen Metaphysik, die als Wissenschaft wird auftreten können. In contrast to the basic question of the First Critique (inquiring into the possibility of synthetic knowledge $a$ priori), the question of the Prolegomena is analytic and implied in the definition of a science. ${ }^{44}$ Where the Critique of Pure Reason takes as its point of departure common experience, the Prolegomena limit philosophy to an analysis of the transcendental analysis of the condition of the validity of knowledge represented in the sciences. From here Cohen takes the key to his own program where philosophy is reflection on the origin of certainty of scientific knowledge as represented in mathematical terms. ${ }^{45}$ Critique of cognition (Erkenntniskritik) is now defined as the task of determining the principles of the validity of cognition. The paradigm of science in this sense is modern, i.e., Newtonian and post-Newtonian, physics and astronomy. The logical principles of scientific cognition become the paradigmatic foundation of all validity.

general background of the scientistic trends of the time as they determined institutional policy the works of Michel Foucault are perhaps most instructive in that they show the pervasiveness of the phenomenon and thus provide an illuminating backdrop to Cohen's claim that his philosophy was going against the grain of his times in practically every respect. The latter claim should caution against simply subsuming Cohen under the heading of neo-Kantianism; a mistake evident in the otherwise most useful study of Koehnke.

${ }^{42}$ Cf. Edel, pp. $266 f$.

${ }^{43}$ Cf. $\mathrm{KTE}^{1}$ (WW 1.3), p. 1.

${ }^{44}$ For Kant's differentiation between a synthetical and an analytical approach and Cohen's use of this differentiation see Jürgen Stolzenberg, "Oberster Grundsatz und Ursprung in Hermann Cohen's theoretischer Philosophie" in: Brandt, pp. $78 \mathrm{f}$.

${ }^{45}$ Cf. Prolegomena (ed. Rosenkranz) p.33f and see Edel, op.cit., p. 269. 
A brief look at the contents of LrE shows how this correlation of logic and scientific cognition is translated into an open system of judgments ${ }^{46}$ that are analytically extracted from the sciences and function as pure conditions for the generation (Erzeugung) of their object (Gegenstand). The basic logical structure expressing scientific knowledge is that of an equation which formulates a law. The logic of the validity of scientific certainty is therefore the logic not of sentences (correlating rules of grammar with those of logic) but of mathematical functions.

The first class of judgments contains the qualitative judgments of "laws of thought" (Urteile der Denkgesetze); here we find the judgment of origin (Urteil des Ursprungs), of identity (Urteil der Identität), and of contradiction (Urteil des Widerspruchs).

The second class contains the judgments of mathematics (Urteile der Mathematik), among which Cohen includes the judgment of reality (Urteil der Realität), of majority (Urteil der Mehrheit), and one he calls that of "allness" (Urteil der Allheit). The latter is a type of judgment which is represented, for example, in an infinite series of numbers.

The third class is that of the judgments of the mathematical sciences (Urteile der mathematischen Naturwissenschaft) where we find the judgments of substance (Urteil der Substanz), of law (Urteil des Gesetzes), and of concept (Urteil des Begriffs).

The erstwhile judgments of modality Cohen defines as a fourth class, namely that of judgments of methodics or of critique (Urteile der Methodik). Of these there are the judgments of possibility, reality (Wirklichkeit; as opposed to Realität which ranks among the judgments of mathematics), and necessity. Here Cohen deals with problems of scientific verification and falsification, i.e., with the methodological logic of research. In this context Cohen also discusses the value of syllogistic logic.

Whatever else is implied in this system of judgments, its structure is hierarchical. It begins with thought and, via the judgments of mathematics and of the sciences, arrives at the empirical reality as it is represented and shaped by the logic of scientific experimentation and verification. The fundamental tool of scientific progress, the hypothesis, is also the primary evidence for the constitution of being in thought. Aside from this being-as-constituted-in-knowledge we have no knowledge of being which, therefore, has no room in the logic of pure cognition.

The system of classification of judgments is open-ended since, in search of new scientific explanations of phenomena, ever new

${ }^{46} \mathrm{Cf}$. LrE, pp. 50ff. By contrast, Kant's disposition of judgments (KdrV, ed. Rosenkranz p. 71) is based on scholastic schemata (see Hoffmeister, s.v. "Urteil"). 
hypotheses and models of representation are invented. Yet the idealistic presupposition upon which such invention rests cannot be substituted. This is the principle of "origin" (Ursprung). It is taken for granted that the sciences are undergoing constant improvements of their methods and means. Hence, the contents of logic (the number and arrangement of judgments) cannot be determined once and for all. Yet, the fundamental cognitive relation between the idealistic principles of the sciences and the certainty of their results cannot be overturned. The principle of origin is non-negotiable which makes thought the origin of being, an absolute beginning for Cohen's philosophical logic. ${ }^{47}$ Philosophy must focus on the critical inquiry into the rational principles of the validity of the claim of certainty made by the sciences. This is the meaning of the definition of logic as the logic of "pure cognition." Philosophy has the task of finding the conditions of validity of cognition, conditions which are already inherent in such cognition. ${ }^{48}$

Cohen's criticism of empirical psychology as the explanation of how cognition actually takes place in the apparatus of the human brain does not render this line of research meaningless. Rather, he fights the materialist assumption to which it leads if taken as the ultimate wisdom about human knowledge. He agrees with the assumption that philosophy is to be given a fundamentally scientific basis. However, the apparent successes of the sciences seemed to suggest that one had to try and find the origin of all human thought and cognition in the operations of the brain. For Cohen, making psychology the fundamental discipline of philosophy, and hence of the sciences and the humanities, meant establishing the materialist world view at the core of academic and cultural life. In Cohen's view, the struggle for the task of philosophy was a fight between two fundamentally opposed and mutually exclusive principles, only one of which could be conceived of without contradicting itself. Materialism has its undeniable value as a heuristic principle in opposition to an ill-conceived spiritualism. Thus the thesis of Lange's History of Materialism which Cohen published in several editions after the author's death and whose introduction he used to voice the state of his own philosophical program. According to Lange and Cohen the materialist assumption about the natural world was in itself an example of the exertion of the generative power of the mind, a hypothesis meant to make scientific cognition possible, in other words,

${ }^{47} \mathrm{Cf}$. Stolzenberg op.cit., pp. 86-94.

${ }^{48}$ In the motif of criticizing the psychological aspect of a philosophy of consciousness as well as in the coordination of philosophy and the mathematical sciences Cohen's thought anticipated certain aspects of analytical philosophy. Cf. Geert Edel, "Cohen und die analytische Philosophie der Gegenwart" in: Brandt, pp. 179-203. 
evidence for rather than against critical idealism. In contrast, replacement of transcendental logic by experimental psychology appeared not only as philosophically flawed, a matter about which one could have leisurely debates, but morally problematic. With materialism as the principle of the system of knowledge it seemed impossible to gain a solid foundation of ethics. As an ethicist, Cohen seeks the middle between the equally unacceptable alternatives of a repristination of absolute idealism and the fashionable pessimism of the mid-19th century.

The project of critical idealism would thus be insufficiently characterized as a logic of the sciences. Rather, its full pathos and appeal rests on the combination of efforts in logic and ethics, taking the autonomy of mathematics and the sciences as seriously as the challenge to ethics of the welfare of the industrial proletariat.

How are logic and ethics associated by Cohen? In answer to this question it is helpful to follow the way in which Cohen introduces the content of ethics-the concept of man-into his logic. The problem of a conceptualization of the human being, in a sense which satisfies both logical (scientific) and ethical (legal and political) demands, leads to the center of Cohen's thought. One of the structural demands made by the logic of pure cognition is that judgments on reality, including the reality of the human being, are to be guided by a critical appropriation of the "powerful pattern of the analysis of the infinite." (LrE p. 34) The infinitesimal calculus, simultaneously invented by Leibniz and Newton, was recognized by Kant as a model by which reality is constituted in thought, namely as "intensive magnitude." For Cohen, the infinitesimal calculus functions as Exhibit $\mathrm{A}^{49}$ for a new approach to everything that can be regarded as certain knowledge, an approach which takes nothing as given. In other words, what is taken as given, what becomes the only absolute origin of all cognition, is itself a "no-thing," an "adventurous detour" (LrE p. 84) of reason by which itself becomes the origin of the cognition of an object. Leibniz's infinitesimal calculus as well as Newton's theory of fluxions are "examples" (LrE 124f) of the fertility of the judgment of origin (Ursprungsurteil) but they are also the mathematical models in which Cohen finds a new and comprehensive meaning of the judgment of reality (Urteil der Realität; LrE 126ff). The non-sensual infinitesimal becomes the origin of all finite reality (ibid. p. 135).

For Cohen, the "principle of the infinitesimal-method"50 -once invented to solve specific problems (the geometric problem of tangents,

${ }^{49} \mathrm{Cf}$. LrE, pp. $124 \mathrm{f}$.

${ }^{50} \mathrm{This}$ is the title of Cohen's book on calculus published in 1883 (see note below). 
the algebraic problem of series, and the dynamic problem of speed and acceleration)-becomes the lever for the reorganization of transcendental logic. It is his Archimedean dos moi pou sto. What is important here is to understand the function assigned to the paradigm of the infinitesimal method in the context of a critique of cognition. ${ }^{51}$ On the other hand, the strictly mathematical value of either Leibniz's or Newton's version of the calculus is secondary to its function as a model for the fundamental relation of mathematics and science which is at the core of Cohen's logic of cognition. ${ }^{52}$

The infinitesimal method plays a pivotal role at least since his study on the "principle of the infinitesimal method," Das Prinzip der Infinitesimal-Methode und seine Geschichte (1883; abbr. PIM). Contrary to the wording of some of Cohen's later recollections, ${ }^{53}$ this work was perhaps not a totally new beginning of Cohen's systematic intentions but rather an important step toward their realization. ${ }^{54}$ Be that as it may, the book on calculus was not written in order to contribute to an ongoing discussion of the arithmetization of a mathematically problematic concept. Rather, Cohen is interested in the philosophical reconstruction of the judgment of reality ${ }^{55}$ which corresponds to the reality not of sense perception but to that represented in "laws of nature" that are construed by means of non-sensual mathematical models.

Within the context of his logic, Cohen not only attempts the exposition of the implications of the new concept of reality for mathematics and physics but also aspires to demonstrate its fertility for the foundation of the humanities, i.e., for morality (Sittlichkeit) and ethics. This is made plausible in the following way. While a proper definition of "reality" is the obvious problem for all philosophy of nature, morality is even more, namely inherently, dependent on the possibility of being understood as real. Even for common sense it is absurd to deny the "reality" of nature while the reality of morality is always in question. In the case of nature the problem of cognition arises only because there is something. If there were nothing the problem would not arise. In the case of morality, however, the "reality of cognition" is in question: "if

\footnotetext{
${ }^{51} \mathrm{Cf}$. Peter Schulthess, "Einleitung" in Das Prinzip der Infinitesimal-Methode und seine Geschichte (WW Bd. 5, 1984) pp. $7^{*}-46^{*}$, especially pp. 21*ff.

${ }^{52}$ Cf. Geert Edel, Von der Vernunftkritik zur Erkenntnislogik (München: Alber, 1988), pp. 257ff. Cohen himself explicitly states (LrE p. 135) that the mathematical rigorization of the infinitesimal may be necessary but that this problem does not concern the basic principle which is "that the finite must have its origin in a nonsensual."

${ }^{53} \mathrm{Cf}$. Peter Schulthess, "Einleitung" in Cohen, WW 5/I, p. $7^{*}$ and ibid. note 1.

${ }^{54}$ Cf. Edel, op.cit., p. 257-259.

${ }^{55}$ Cf. Schulthess, op.cit., pp. $26 *-37^{*}$, Edel, op.cit., 291-319.
} 
(morality) did not exist as cognition its value seemed negligible" (LrE p. 141). "Morality" - Cohen further elaborates-"is neither dead nor living nature. Morality flowers and withers, comes into being and vanishes as cognition" (ibid.). Thus the quid facti, the determination of the empirical ground of ethics as a field of certain knowledge, is here located in thought and cognition rather than in experience of any sort. We shall see that, in the Ethics of Pure Will as well as in the philosophy of religion, the question of the reality of ethics continues to be the crux of Cohen's intellectual efforts.

In LrE this problem is turned into its own, admittedly formal, solution. The reality of morality-qua logical judgment-corresponds to something which is analogous to the reality of nature. I.e., reason produces morality as a way of determining an object that extends beyond the realm of nature. This other field is the human being.

The human being is this analogue. That he is analogue and only analogue to nature emerges from his relation to nature. The human being is an object of morality not simply as a natural being; yet of course neither should it be conceived of in contradiction with nature. (LrE, p.143)

The problem of morality is founded upon a concept of the human being which has two basic properties. It is to be a) non-contradictory to the progressing scientific definitions of a human being (which are subject to the logic of infinite judgments) and b) it must function as the "absolute reality" upon which morality can be founded (cf. ibid., p. 142). This reality is "absolute" in the sense of Plato's definition of the idea of the good as epekeina tes ousias, i.e., as the anhypotheton (cf. ibid., pp. 87f., 212218). The "individual" - as referring to the moral person, i.e., to the origin and source of the moral law -is the analogue of its Greek original, the a-tomos, itself another "example for the infinite judgment, for its meaning as the judgment of origin" (ibid., p. 142). These few citations may suffice to indicate the intricacy of the relation between logic and ethics. The human being is a microcosm in the sense that all problems of science and philosophy, of nature and its idealist constitution in thought, converge in this concept.

As "the teaching about the human being" (die Lehre vom Menschen), ethics becomes the "center of philosophy." 56 In the other direction, namely in the direction not of the principles of philosophy but of the manifold sciences dealing with the products of human action (economy, law, the "humanities" in general), ethics takes on the task of laying the groundwork. All areas of human culture presuppose an orientation

${ }^{56}$ ErW, p.1. 
about what man is, which is the task of ethics to define. Ethics becomes "the positive logic of the humanities." 57

In this way, logic literally lays the groundwork for the ethics. As far as ethics functions as the framework for the understanding of religion, the foundations for such an understanding are laid here, too. But what about such a specific religious tradition as that of the atonement? Is it possible that Cohen even considers preparing the ground for a specific religious concept within a philosophical logic? When Cohen determined (in the essay of 1892) that the idea of Versöhnung was the religious expression of an ethically justifiable concept of individuality (anticipating the function by which religion was to be integrated with universal culture) he had to imply a correspondence between the ethicoreligious idea of the (re)constitution of the self in the act of repentance (historically speaking: the discovery of the individual in Ezekiel's concept of sin) and the logic of the subject of ethics. In other words, if in fact the concepts of repentance and atonement are an integral part of Cohen's ethics and if they are not to be mere appendages to it (or pious afterthoughts in the sense of Rosenzweig's Anbauten), if, in fact, Cohen's religion is not to call into question the validity of his logic, we must expect the logic to provide room where Cohen can eventually locate these religious concepts as the system unfolds. Even if such room were not specifically provided by the logic, however, it should be kept in mind that the circumference of the logic is limited only by the current state of human knowledge. The system of judgments is open and can be widened whenever this proves necessary. Thus little depends on whether or not Cohen determined a specific "room" for the idea of Versöhnung within his logic.

Logic and ethics are seen to be methodologically related and make up the basic theoretical parts of the system. They address the principles of the two general fields in which a constitution of objects takes place, namely nature and history. These fields also determine the subject matter of the arts, where nature and history are sublated into the correlative components of the ideal of beauty, the sublime and the humorous. ${ }^{58}$ They become the material for the artist in her individual pursuit of giving expression to pure feeling. The fourth part of the system, psychology, has as its problem the system itself or, more precisely, its harmonization or unification. Philosophical psychology addresses the task of describing how all of the above can be understood as functions of "the unity of the cultural consciousness." Religion, however, is not understood as an independent direction of culture. There is no religious $a$

57Ibid.: "sie wird zur positiven Logik der Geisteswissenschaften."

${ }^{58}$ WW 9, p. 418. 
priori, nor a religious "faculty" of the mind. More to the point of Cohen's method, religion is not envisaged at this point as playing a role in the constitution of an object that can otherwise not be accounted for within the unity of the cultural consciousness. Nevertheless, even from this philosophical perspective, religious terms and traditions are potentially valuable, namely to the extent that they can be elevated to the level of ethics where, however, they are stripped of their particularity. Whether or not religion also exerts a function in the actualization of ethics is undetermined at this point. The process by which religious terminology is elevated to the level of the ethical discourse on the human being is programmatic. Cohen calls this program "the dissolution (Auflösung) of religion into ethics," an expression he later modifies to "the inclusion (Aufnahme) of religion in ethics." 59

In the Logic of Pure Cognition Cohen frequently distinguishes contributions of logic to the construction of ethics and the science morales. Most significant among such contributions are logical provisions for the definition of the ethical subject. ${ }^{60}$ Some of these provisions are constructive, others impose limitations on what kinds of claims are possible in the context of a critical idealist ethics. As part of a system of philosophy, ethical concepts must adhere to the general directive of the logic of cognition which is that of the logic of origin. The function of a concept is determined in the context of an examination of the transcendental conditions of the validity of a certain type of knowledge or action. This procedure allows one to recognize as problematic rather than self evident such basic concepts as, say, the individual.

So, for example, contrary to popular usage of the term, the judgments of mathematics do not allow room for the individual to be construed as "singular" (cf. LrE 168ff). Within scientific reason singularity is not a principle, or, as Cohen formulates, "(w)ithin the literature of these principles (i.e., of the principles of the mathematical sciences) one will look in vain for a symptom which may justify singularity (Einzelheit) as a unity (Einheit) or, rather, unity as singularity" (ibid., p. 169). "Singularity" is something used only by "common thought" (das gemeine Denken). The logic of cognition nevertheless recognizes singularity, but only as the element of a majority (Mehrheit). It "belongs to" the mathematical "judgment of majority" (ibid.). In the process of generating the individual thing, conceived as a fully validated object of cognition, the individual $\mathrm{A}$ is not conceived by means of a

\footnotetext{
${ }^{59}$ EmkN p. 106, cf. p. 140.

${ }^{60}$ The relevant passages in LrE are, inter alia, pp. 40f, 140ff, 171ff, 202-205, 252ff, 299ff, 386ff.
} 
singular judgment. ${ }^{61}$ Therefore, inasmuch as singularity must nevertheless be generated in pure thought, it becomes "the hardest problem and it would be the highest triumph of thought if it were capable of deciding this question" (ibid.). In LrE, Cohen only hints at a solution. Instead, the argument here serves to exclude the possibility of solving the problem by making it a quantitative judgment (cf. p. 170). The intention of excluding singularity from the realm of quantitative judgments is immediately evident when one considers that Cohen's logic is an argument against empiricism. The prejudice of "common thinking" - that the singular individual thing "actually exists"-is the prejudice of all empiricists and contradicts the directive of constituting objects (Gegenstandskonstitution) in thought.

But the utility of this aggressive exclusion of the dogmatic prejudice of singular existents reaches beyond the logic of cognition and into ethics. The logical priority of the many or the all over the individual speaks to the necessarily social character of the moral individual. Logic biases ethics towards social theory. Furthermore, the singular in the sense of the unique is a veiled reference to the monotheistic idea of God which, aside from the philosophy of religion and Jewish writings, makes its most prominent appearance in Cohen's ethics. The idea of God as a unique being functions to keep nature and history open for a harmonization of the demand of logic (intelligibility of nature) with the purpose of ethics (the perfectibility of the human being).

In LrE, the concept of the individual corresponds to that of the atom not only as its translation but, like Democrit's atom, it is conceived as the particular non-sensual "nothing" correlated to a set of specific problems of being which originate in it. In the context of this logic the individual that later becomes relevant for ethics makes its first appearance in the context of an area of inquiry that serves as the subtext or precondition for the problem of morality, namely the human being as a biological phenomenon. The turn from astronomy to biology as the paradigmatic science, from observations on the fundamental identity of laws governing sublunar and supralunar bodies to observations on "life" is highly characteristic of the 19th-century and its pursuits. Michel Foucault has made it abundantly clear that the great themes of mid-and late-19thcentury scientific thinking, present especially in the popularization and institutionalization of science, were biology and hygiene. Cohen's interest in biology and his attempt to set apart ethics from all biological notions of humanity, his very attention to the possible connections

\footnotetext{
${ }^{61}$ According to Cohen (LrE, p. 168), this is meant to avoid the complications with sensual perception usually associated with the singular (e.g., in the rule of singulare sentitur).
} 
between these two fields, is not only characteristic of the greater trends of his time but rather, and more importantly, it signifies the major intellectual challenge one faced were one to attempt an idealistic grounding of ethics. In this sense, Cohen's moral philosophy is an extended critique of biology as a world view, i.e., of social Darwinism.

If social Darwinism is the enemy, Darwinian biology is the scientific precondition that must be taken into account if and when ethics is to be construed in "harmony" with science; the human being of ethics has "natural man" as her presupposition. The constitution of objects in the context of biology demands additional considerations to those developed in the context of theories of energy and mass. In the problem of the individual organism the individual becomes the basic conceptual tool since it stands for the basic unit which needs to be described not only individually but in relation to all other organisms. Darwinian theory of the origin of species is based on the ideal of a complete system of forms of life which are related to each other in a systematic way. The organizing principle of the system of species is the system of concepts. ${ }^{62}$ When the concept of the individual based on these problems of biology and its purposes is applied to the humanities it becomes the origin of a different set of concepts. The individual as organism is described in terms not only of origin but of telos. The notion of organismic perfection (health, physiological completeness) is presupposed but it also changes when it is applied to the human being as a being that determines its own telos (autotely) and makes its own laws (autonomy).

These examples of logical provisions for the ethical concept of the individual begin to indicate the critical role Cohen assigns to logic for the methodological foundation of ethics. In the following, I examine two more passages in LrE before addressing the ethics itself. One concerns the problem of the subject. The other deals with the will. Both terms are of significance not only for ethics but for law as well as history. Law, history, politics and economics operate under the assumption of causality both in terms of laws and principles as well as in terms of voluntary agency of subjects. ${ }^{63}$ While causality is a tool of the sciences, voluntary action calls for an examination of the underpinnings of a

${ }^{62}$ Cassirer's works on the history of epistemology are an elaborate commentary on Cohen's correlation of specific scientific theories and the logic of cognition. For Cassirer's view on the epistemology of Darwin and modern biology see "The Ideal of Knowledge and its Transformations in Biology" in The Problem of Knowledge. Philosophy, Science, and History since Hegel (transl. William H. Woglom and Charles W. Hendel), New Haven and London: Yale University Press, 1969, pp. 118-216.

${ }^{63} \mathrm{Cf}$. Cassirer, "Fundamental forms and Tendencies of Historical Knowledge" in op.cit., pp. 217-325, esp. 256-280 (on Mommsen and Burkhardt). 
subject that is conceived as a free agent. Freedom as "the miracle in the phenomenal world" as Kant called it, is the subject matter of ethics, not of logic; it belongs solely to the realm of culture, not to nature as conceived in the sciences. Hence, the problems of ethics-the human being beyond its physiological and psychological condition and action (Handlung) as the manifestation of free agency-are fundamental to our understanding of the "cultural sciences" (Rickert: Kulturwissenschaften) in general.

Furthermore, assuming that moral subjects are the cause of their actions generates the idea of a will as the origin of such action. Even thinking itself manifests itself primarily as "movement" in which thought distinguishes and unites; thought consists of thought-acts (Denkakte) so that agency is involved in the most intimate operations of the intellect. Yet still, once agency manifests itself beyond intellection, in actions of mouth and hand, we speak not of intellect but of will as the condition for actions to make the transition from the "inside" to the outside world, even if this outside world may just be a part of our body which we intentionally move. Intention conjures up the concept of will. Yet, the will has to be distinguished from any form of reflex or bodily urge if it is to function as an ethical principle which can be distinguished from a function of nature.

Is the good a matter of taste, as Maimonides has it in the Guide for the Perplexed, or can one achieve a degree of certainty with respect to ethics? Is there an evidently moral dimension to law and constitutional government or is jurisprudence a self-contained and self-regulating system of positive laws without recourse to irrefutable norms? Is there a standard by which to measure progress and regress in history, or are we merely generalizing the underlying prejudices of our most pervasive discourse? With the emergence of statistics and sociological methods in the 19th century and with the notion that behavior is determined by social circumstances (the milieu), the idea of free agency has become most contentious. It appears to be a figment of pious or romantic imagination that deserves the attention of poets and educators but not of policy makers and scientists. Marxism has been only one of several possible theories which made society an analogue to nature determined by relentless laws indomitable by individual resolve. For ethics, more than for any other discipline of philosophy, it has been necessary to defend itself against the onslaught of ideologies which make man into an organismic phenomenon whose actions are mere reactions determined by forces beyond its control.

Cohen and the neo-Kantian movement in general respond critically to the skepticism and determinism generated by the popular type of absolute materialism which makes the heuristic and methodical 
principles of sciences and social theories into a Weltanschauung. First, however, Cohen concedes to the modern scientific consciousness that the ethical subject or the very existence of a will cannot be taken for granted. The same is true with respect to the subject of theory. The Cartesian ego cogito is shunned as the basis of all certain knowledge. Even the Kantian subject of cognition (the unity of transcendental apperception) is disposed of, or, rather, reconstructed as a problem of consciousness. As such it is relegated to the end and completion of the system where the unity of the various directions of culture is to be determined as the unity of the cultural consciousness. ${ }^{64}$ Consciousness as "cultural consciousness" is not a given but a task, namely the task of pursuing the various cultural directions under the presupposition or hypothesis of their unity.

\subsubsection{Substance and Subject}

The first direct comments on the problem of the ethical subject are found in the context of the "judgment of substance," the first judgment of the third class (judgments of mathematical sciences) (LrE 210-403). The traditional as well as the Kantian tables of categories know of a category of substance. It is unusual, however, to find substance as a judgment. "Category" is a statement or predicate, a "class-name or concept under which the subject is brought" (A. Wolf). Aristotle's and later philosopher's systematic accounts of categories try to list a complete set of "ultimate modes of being" (idem). For Kant, rejecting any immediate knowledge of being as such, categories are pure concepts of thought by which the material supplied under the conditions of the pure forms of perception (space and time) are cognized in the form of synthetic judgments. Judgments are the forms of propositions wherein subjects and predicates (categories) are brought together either in such a way that the predicate explicates something which is already contained in the definition of the subject (analytic judgments) or by adding a predicate which is not as such inherent in the definition of the subject (synthetic judgments). ${ }^{65}$ Furthermore, it is not immediately evident how the category or judgment of substance is related to the problem of the subject.

${ }^{64}$ This is the task of the fourth part of Cohen's system, the psychology. See LrE pp. 606-612, ErW pp. 73, 75, 569, Ästhetik des reinen Gefiihls (ÄrG) vol. II, WW 9, pp. 425-431, and cf. Dieter Adelmann, Einheit des Bewusstseins als Grundproblem der Philosophie Hermann Cohens, Heidelberg: 1968.

${ }^{65}$ The basic question of $\mathrm{KdrV}$ is "how are synthetic judgements a priori possible?" See (ed. Rosenkranz) p. 24. Cf. Abraham Wolf, s.v. "Category" in EB (14) 5:28f. 
In general, the extent to which a concept can be meaningful for the logic of cognition must be defined or co-defined according to the particular function it can and must fulfill in the context of judgments constituting our knowledge of being. (210) Cohen develops the meaning and function of each type of judgment in elaborate discussions. One of the tools employed in these discussions is conceptual history. More specifically, if the logic of cognition is the logic of scientific cognition, the terms that qualify for problem historical examinations are those which have been instrumental in the history of science and philosophy. The usefulness of a term depends not just on the fact that it serves as a kind of paleontological record of thought but whether it allows one to identify and advance the scientific and philosophical problem that is recorded in its paleontology. Thus even the most time-honored concepts of metaphysics, and especially those, turn into an ever renewable source for the connection between the problems of science and philosophy under the aspect of the logic of cognition. ${ }^{66}$

By turning concepts into problems-in-motion, Cohen elevates concepts to the level of a judgment. Terms, where useful, contain combinations and associations of problems and can thus be spelled out to contain not one but several terms in form of full statements that, where they prove useful to the logic of origin, enrich the stock of judgments. The utility is determined by the contribution of a problem/concept/judgment to the constitution of an objective of cognition. Gegenstandskonstitution is the goal to which all judgments and categories contribute. Thus Cohen gradually reconstructs the "letters of mathematics" by which "philosophy is written in the book of nature." 67 Finally, he addresses the way in which this newly ascertained type of judgment can be applied to the ethics as the logic of the humanities, or, to extend the image, the question is raised how the problem of man can be spelled in this alphabet.

The category of substance, as predicated to the individual being, cannot be the "first" category it had been for Aristotle (Categories 2a 15; see LrE 213). Instead, the being of objects of the sciences is determined in thought, namely, when thought is the Grundlegung of being. The very term Grundlegung, literally the laying of a foundation, is a translation and recasting of the Platonic action of hypothesis which turns into the resultative noun hupokeimenon (that which is beneath, the foundation, or "sub-stance.") The Platonic term hypothesis, which Cohen identifies with Plato's idea or form, is the basis for the function of substantia (211). Retrieving, as it were, Plato's original critical intention (a matter on

${ }^{66} \mathrm{Cf}$. LrE xf, 39, 116f. See above for the classes of judgements in LrE.

${ }^{67}$ Cf. ibid., pp. 49, 207-209, 567. 
which there is much debate), Cohen liberates the term hypothesis from the dogmatic and essentialist burden of an actual substance (Grundlage) and replaces it with the act of Grundlegung. Instead of a material basis of reality, an ideal one is established. All being is grounded in the intellectual activity of laying-the-foundation; being is grounded in thought (213).

Cohen's understanding of the Platonic idea as hypothesis is one of the major building blocks of his system. This aspect of his systematic approach was first developed in an essay on the mathematical aspects of Plato's theory of ideas (Platons Ideenlehre und die Mathematik, 1878). Though purporting to deal with Plato's theory of ideas, not only the topic but also the result of this historical study grows from and reflects Cohen's systematic interests. Here, Cohen first develops his theorem of the "idea as hypothesis." 68

For our purposes, the question of the historical accuracy of Cohen's references to intellectual history or the history of science is secondary to the question of what sense his "historical discoveries" make as they contribute to the construction of his own attempt to "renew" the task of philosophy. This is not to say that Cohen falsifies intellectual history more than anyone else who, even without explicit systematic interests, must engage in reconstruction, emendation, and the reinterpretation of historical material in order to arrive at a coherent account of historical positions. This is particularly true with respect to interpretations of Platonic philosophy. ${ }^{69}$

With respect to the Platonic idea itself, it may suffice to point out that Cohen's identification of idea and hypothesis, while contrary to several explicit Platonic passages (cf. Edel pp. 224f), serves as an attempt to solve a systematic problem which, at least in the "written" Plato, is not resolved, namely the tension between the idea as ousia (true "being," existing separately from everything else, i.e., their existence as choriston) and that of the idea as ontos on (regarding ideas as noëmata that have their place in thought).$^{70}$ The alternative between the Platonic ideas as separately existing "substances" on the one hand and pure noëmata in the sense of intelligible entities (at the root of Kant's regulative ideas as postulates of practical reason) is resolved by Cohen when he combines

\footnotetext{
${ }^{68}$ Cf. Edel, op.cit., $205 \mathrm{ff}$.

${ }^{69} \mathrm{Cf}$. the reference to W. Wieland in Edel, op.cit., p. 220.

${ }^{70} \mathrm{Cf}$. Edel, op.cit., pp. 205-214. The neo-Platonic concept of nous, had its illustrious carrier in Western thought due to its apparent ability to resolve the tension between ideas as existing separately and ideas as thought. Nous makes the ideas thoughts in the mind of God.
} 
"the noëmatic character of the idea and its rank as ousia" (Edel p. 218). This combination is achieved by identifying hypothesis and idea. ${ }^{71}$

Aristotle transformed the Platonic idea by assigning its role in the constitution of being to the individual substance. One of the consequences of this turn was the dislocation of the Platonic idea of the good. What Plato determined as the ultimate limit of knowledge and the source of all being, the anhypotheton, the Aristotelian tradition turns into the "absolute." In the monotheistic philosophies of the middle ages, God becomes the absolute and only true being, the substance which is the origin of both nature and morality, which are mere accidents (LrE 212). The absolute substance necessarily fulfills itself, i.e., its entelechy, in the manifestation of its accidents, the world (213).

In the modern period, thought and consciousness are made the substance of all being. The subject in the modern sense is the $\mathrm{I}$, as in Descartes' ego cogito. In scholastic philosophy, "subject" referred to the thing not as it "throws itself against" our perceptive faculties (what we now call the "object") but as it is in itself, i.e., as an essence unto itself. Where in the Middle Ages, the essentiality of subjects prevailed over any attempt to retrieve the critical scientific tool of the hypothesis, in modernity the privileged subject, the thinking I, nevertheless preserves its medieval character when it is at first conceived as a substance, called by its traditional name "soul," or res cogitans (LrE 213f). This subject is distinguished from all being (res extensa) lending the soul the dignity of a separate and fundamental substance, namely that of the erstwhile "absolute." Yet, this model generates not one but two absolute substances (thought and matter). In addition, the old absolute substance, God, also retains some of its validity so that the term begins to be hollowed out. The development of a different understanding of the relation of thought and being is already contained in the fact that thought itself (qua geometry) is the substance which extends itself into space. Thought and being are not as absolutely separate as the terminological distinction between res cogitans and res extensa seems to suggest (214f). The path is open from Descartes to Spinoza.

By making geometry the substance of spatial extension Descartes renewed the Platonic cognitive relation between being and the ideas of mathematics. Following the same tendency, Leibniz develops the term of "inextensive substance" for the physical problem of force. He seems, however, to renew the idea of an absolute substance in the form of his monads which unite and harmonize in themselves all the traditional functions of absolute substances. On the other hand, this aspect is balanced by the fact that the energy of the monad can be either potential

${ }^{71}$ Cf. ibid., pp. 226-257. 
or actual. Therefore, Leibniz dissolves the absolute unit into a relational category (216).

The Aristotelian relational category (pros $t i)^{72}$ is a category which affects accidents only. Substances are not in relation to each other. Plato, in contrast, augmented his theory of ideas (as the absolute substances of the individual things) by a "communion among concepts" (koinonia ton genon). ${ }^{73}$ Still Aristotle contributes to the modern idea of the cognitive relation between thought and matter in that he conceives of the relation as that of arithmetic proportions (e.g., half, double, larger) (LrE ibid.). If the proportion is a relation then it can be expressed as an equation. Equations are the tools by which science expresses the relation between forces which, as we could see in the case of Leibniz, are identical with the substance. The question is, how can one state that equations expressing relations, such as acceleration or rate of growth of energy, do not concern mere accidents of a substance but involve the thing or object itself, which, in a way, is virtually generated in an objectively measurable mode? Cohen connects the problem of force with that of substance (following Leibniz). The "essence of the things" must be fully involved when the "letters" of mathematics are "combined" into the "sentences" of science. "The opposition" between substance and relation "must be overcome" (217).

This is where the Kantian reform sets in for the category of substance. Kant lists substance as a category which corresponds to the categorical relation of judgments. ${ }^{74}$ Yet, it only seems as if the whole history of the concept of substance had been aimed at the Kantian category. ${ }^{75}$ Cohen regards as the fundamental merit of the Kantian critique the destruction of the absolute substance. Applying this philosophical achievement to the problems of physics Cohen further narrows the categorical function of substance to that of conservation (Erhaltung) in correlation to motion (Bewegung). ${ }^{76}$ By turning substance into a "precondition for relations" this category can continue to serve as a viable description of the solution to a host of problems inherent in the categories of inertia (Beharrung) and transformation (Verwandlung) ${ }^{77}$ In this respect the new category of substance is construed in analogy to the subject of a proposition which has "to wait for its predicate if something

\footnotetext{
${ }^{72}$ Categories $11 \mathrm{~b} 15-35$.

${ }^{73}$ Cf. Sophist $253 \mathrm{bff}$.

${ }^{74}$ LrE 217, cf. KdrV B, p. 106, A p. 80 (ed. Rosenkranz p.79).

${ }^{75}$ Cohen's opposition to Kant's system of judgments and categories and their relation to formal logic is most tangible in his Kommentar zu Immanuel Kants Kritik der reinen Vernunft, (5. Auflage), WW 4 pp. 46-51. See also LrE, pp. 45-52.

${ }^{76} \mathrm{Cf}$. LrE, pp. $233 \mathrm{ff}$.

${ }^{77}$ See ibid., pp. $239-246$.
} 
is to become of it." Meanwhile, what becomes of substance in its function as "absolute?" Far from simply abandoning the term as useless or misleading, Cohen assigns it a new value in his metaphysics. Where it refers to the totality of being it is integrated into the world view of critical idealism as "the world as an idea." In the sense of this selfcontained unity of the totality of relations that we call the world, the "absolute substance" may thus serve to enhance the "objectivity" (Gegenständlichkeit) of the world as an object of science (218).

After the historical orientation, which leads to the assessment of the Kantian achievement for the category of substance, Cohen turns to mathematical and physical functions that the renewed category may represent. The results of these considerations are of immediate relevance for ethics, namely, where it addresses the function and meaning of the subject.

If modern thought from Descartes to Sartre has a common denominator it is most likely the problem of consciousness (Selbstbewußtsein).$^{78}$ For Cohen the problem of consciousness cannot be detached from the problem of scientific cognition for which the foundations are laid in operations of thought which he characterizes with the Platonic term of hypothesis. As stated above, where the schoolmen sought to determine substances as things in their own right (subiectum), things which can be recognized not in their essence but only through their predicaments which are contingent accidents, since Descartes the foundation of cognition is sought in consciousness. The revolution of modern epistemology turns the subjective consciousness into the foundation of cognition. The subject takes on the fundamental function of the erstwhile substance. Yet this is only one aspect of the problem of the subject in the sense of consciousness. The modern subject also becomes a type of object, or, more accurately, it takes on the function of the substance for the humanities ( $\operatorname{LrE} 252)$. Here another aspect of the conceptual history of the problem of substance, the immortal human soul, finds renewed meaning, namely when it is applied to the problem of the substance of the human being..$^{79}$ Pre-Kantian metaphysics operated with the assumption-enhanced by religious dogmatics-of the absolute substance of an immortal soul, a notion which to this day continues to invite strong reactions ranging from ridicule to ardent affirmation. Equally remote from both of these extremes, Cohen's seeks the middle ground between dogmatic metaphysics and materialism. The

\footnotetext{
${ }^{78} \mathrm{Cf}$. Manfred Frank, "Fragmente einer Geschichte der SelbstbewußtseinsTheorie von Kant bis Sartre" in: Selbstbewußtseinstheorien von Fichte bis Sartre, Frankfurt: Suhrkamp, 1991, p. 415.

${ }^{79} \mathrm{LrE}$, pp. 253.
} 
mythological soul and essence of man is reconsidered in its possible function in the context of an idealist system of cognition. This philosophical elevation of traditional terms, despite their apparent grounding in metaphysics, myth, poetry, or religion, is most characteristic for Cohen's method of problem history and we shall observe it again on further occasions.

The subject cannot only be understood as Bewußstsein but it can be seen as the origin of its actions. The new correlative substance is an "S for $\mathrm{p}$, " or the variable $x$ for the construction of a function. ${ }^{80}$ It is a variable waiting to be defined and capable of "self-transformation." ${ }^{81}$ The ground for the plausibility of such a new concept of the ethical subject is prepared by the materialist concept of "society" (Gesellschaft) as the agent of history. By focusing on abstract collective forces acting in unison instead of on individuals or on the intention of monarchs, the "mechanics of the humanities" (Mechanik der Geisteswissenschaften) have moved beyond the assumptions of traditional metaphysics and are on their way towards a scientific methodology analogous to that of physics. Just as the old substance of physics is transformed into the dynamic substance of the Newtonian laws of motion (LrE 244), the substance of the ethical $(=$ historical $=$ political $)$ subject is determined neither in the intellect nor in consciousness but in its actions (Handlungen) (ibid. 253). "Human" is the correlative substance of "action," the $x$ for its $y$, in ethics and in the humanities. Accordingly, in the introduction to Ethik des reinen Willens, Cohen identifies two terms and their correlation as the basic problems of ethics, namely "the human being" (pp. 1-63) and "action" (64-82).

What is it (...) that really matters in ethics? (...) (T)he single most important matter must be what I must do if my doing (Tun) is to receive the value of a human act. The concept of action consists in the unity of an act. The unity of an act is the foundation for the unity of the human being. The unity of the human being is exacted and consists in the unity of the act. (ErW p. 80$)^{82}$

${ }^{80} \mathrm{Cf}$. LrE, pp. 249 f.

${ }^{81}$ Cf. ibid., p. $246: S$ is no longer conceived as being qua substance but as condition for the generation of an object of valid cognition (not of Kantian "experience") which is determined in relations.

82 "Was ist es denn im letzten Grunde, worauf Alles in der Ethik ankommt? ... darum allein darf es sich handeln, was ich zu tun habe, auf dass mein Tun und Treiben den Wert einer menschlichen Handlung erlange. Der Begriff der Handlung besteht in der Einheit der Handlung. Die Einheit der Handlung begründet die Einheit des Menschen. In der Einheit der Handlung vollzieht sich und besteht die Einheit des Menschen." (Emphasis in the original.) 
Whether the term "human being" (Mensch) refers to an individual or to a society or to a state, the entity in question is defined by its actions. This entails another aspect of the new concept of substance. The moral subject is understood as determining itself in its actions. The subject, however, does not possess the intelligible character of Schopenhauer's pessimism. It is not an absolute subject with an essence that is revealed in its actions (e.g., making one who steals a thief). Substance provides the precondition of transformations. The human being can change. Morality can be acquired. "Virtue can be taught" (LrE 254 and passim). ${ }^{83}$

\subsubsection{Energy and Will}

Where the subject of ethics is correlated to its action, the substance of the ethical individual is dissolved into the abstract unit of manifest relations. Nothing seems as yet in sight that may serve as a standard for the right or wrong, good or bad of the actions themselves. After Cohen deconstructs the metaphysical subject, how can he find a way out of historical relativism? How can he identify an ethical basis for the law? Whence the ought that distinguishes ethics from the is of nature?Returning to our study of LrE, we find Cohen continuing his examination of the idealist metaphysics of modern scientific thought for their implications for the construction of the "moral sciences."

As Leibniz's concept of substance as force becomes the first step towards a correlative concept of motion and conservation, as this correlation is further turned into the self-transformation of substance (292), the concept of energy is developed to make sense of the fact that "force" is preserved despite its undergoing changes in form (288-292). Theoretical and experimental physics dismantled the earlier presuppositions about heat (abandoning the notion of caloric substance) and determined it as "a kind of motion" (Rumford). Carnot's cyclical model, which settled the problem of conservation of energy, was a striking example of the power of deduction. And more recent advances in theoretical physics dealt a heavy blow to the traditional category of substance by bringing about the abandonment of a fundamental assumption of astronomy-that of a matter at rest (the assumption of an ether).

Cohen identifies the conditions for these scientific advances in their common logical principles, in the idea of "laws" as applied to nature, in the hypothetical judgment, and in the arithmetical type of causation underlying the theory of functions (see below). All these contribute to the

${ }^{83}$ Statement ascribed to Socrates by Aristotle. See Nicomachean Ethics III, 8 (1116b 4), VI, 13 (1144b 18), VII, 2 (1145b 23) et al. Cohen refers to it frequently (cf. ErW $49,84,116,286,337,343 f, 458,470,503,553 f$ ). 
generation (Erzeugung) of a new type of "object" (Gegenstand), the generation of which is the product (Erzeugnis) of thought (cf. LrE 28f, 53f, $60,69,148,167$, et al.).

The certainty of scientific cognition is based on the assumption of causality. Causality, in the scientific and epistemological sense of a condition of scientific certainty, is something other than a succession of "ideas" (in the Lockean sense of Vorstellungen). Instead, causation is the task scientific thought sets itself in order to be able to understand the connection between a certain phenomenon and its cause. We speak of a law when the hypothetical judgment (if A then B), which brings together and creates a causal connection between elements, is affirmed by experimentation. By correlating the elements in a function with the basic form $y=f(x)$, the elements are themselves homogenized to each other. Thus the logical difficulty of causality which arises when one thing is made the cause of another while neither of these "things" have the certainty of a scientific object is avoided. Furthermore, in contrast to the objects of common perception that are the point of departure for Kant's First Critique, objects of science are generated in the complicated and constricted manner described above. The general purpose of the logic of cognition is to refute objectivity to objects that are taken as given by common perception and, instead, describe the manner in which certainty is achieved in the context of the sciences. Modeled on the problems of energy and motion, the "object" which is constituted in a law is neither the $x$ nor its function but the "point" (the "intensive reality") which is intended and constructed by the correlation of $x$ and $y$ (294ff).

The judgment of "law," the form of the hypothetical judgment, and the function as the expression of a continuous causation are Grundlegungen of thought which therefore become the "sufficient reason" (der zureichende Grund) for the particular laws of physics (304-310). Cohen's view of causality is perhaps most clearly expressed in the dictum that "cause must not be title to possession rather than a title to a task of thought. The law of thought of reason (Grund) must be the ideal law of thought" (305). ${ }^{84}$

The cognitive relation between the judgment of law and the generation of the scientific object (e.g., energy) is applied to the a priori of morals. In ethics, the problem of causality appears as the problem of freedom. A traditional approach might expect that the problem of the law (the hypothetical judgment as the "type" for the rules applied in

84"Der Grund darf nicht sowohl ein Besitztitel, als vielmehr ein Aufgaben-Recht des Denkens sein. Das Denkgesetz des Grundes muß das Idealgesetz des Denkens bedeuten." 
history and in economics) $)^{85}$ is addressed in the problem of autonomy and in the question of moral or legal responsibility. The determination of the functions of freedom and autonomy is necessary in order to distinguish the moral realm from that of nature. However, while this distinction can be postulated as an a priori condition of ethics, this would not be a satisfying procedure for Cohen. Instead, Cohen begins again with the supposition that the quid facti is of no doubt. History, historiography, and economics are; they are based on jurisprudence ("as their mathematics") ${ }^{86}$ which has ethics as its logic (299). Insofar as the idea of causality is the basis of certainty in all of these fields, it underlies the same rules and provisions that are operative in the logic of scientific cognition. Hence, as noted earlier, the subject of ethics has been assigned to its correlation with moral action (300). Action becomes more than a mere "fiction" by having an effect on the certainty of the subject itself. The latter corresponds more to the "conservation" rather than simply to the $x$ of the substance (ibid.). "Action" as opposed to mere doing "in fact excludes-according to its pure concept-erratic arbitrariness and fortuitousness." The concept of action leads to the "continuity of character" in which "the unity of the personality is rooted." In action, a character not only "testifies" to itself (bezeugt sich) but generates itself (erzeugt sich) (ibid.).

The scientific paradigm for this relation between the fact of action and its implied origin in the subject is physical "energy." What corresponds to energy in the determination of subject and action? What is the analogous element to the way in which the energy signifies the unity of substance and motion in its continuity despite all transformations? Energy represents the identity and continuity of force. In ethics, the substance of the subject cannot represent continuity and identity in and of itself. It is not absolute. Nor is the moral Self identical with the concrete subject of which we do not know anything as yet. Furthermore, the problem is to determine how the correlation of subject and action can become the basis of law, history, and economics. In other words, how can these fields be conceived of as neither determined by some descendant of the older idea of causality-making it a crude copy of an outdated version of empiricism-nor as fields to which thought in the form of rules and conditions cannot be applied at all? Cohen suggests that the conceptual tool to imbue law, history, and other sciences humaines

\footnotetext{
${ }^{85} \mathrm{Cf}$. LrE, pp. 299; the reference to economics is an addition of the 1914 edition.

${ }^{86}$ The understanding of historiography as correlated to the law and state has its precedent in the Romantic school of history. Cf. H.G. Gadamer, s.v. "Historismus" in RGG 3:369-371.
} 
with an ethical dimension, to the degree that such dimensions be indispensable for their disposition, is the presupposition of will.

Will suggests itself in the sense of an alternative to mere Begehrung (desire, lust, greed, covetousness). "The actual difference lies in the connection and in the unity of the action of the will. This connection and unity presuppose in turn the subject whose actions, in all their variety, must be recognized along with their value and must be perpetually regarded as transformations, as self-transformations of the subject" (ibid.).

Furthermore, energy transforms the correlation of substance and motion into a higher unity and thus eliminates the necessity of regarding them as causally related (in the sense that if substance is one thing and motion is another, then changes in one have an effect on the other). Instead, the $x$ and its function generate a frame of reference for the determination of the actual "thing" which can be measured and empirically ascertained. Like energy for substance and "conservation," so too the will becomes the necessary precondition for the assertion of a continuous identity of the ethical will. The will becomes "the principle of the forms of transformation of the subject" (301).

The will not only warrants the identity of the subject but also the equality of the value (Ebenbürtigkeit) of all its forms (301). The word Ebenbürtigkeit has the connotation of an equal origin, an "equal birth." In this way, the principle of the will becomes the principle of the origin for the subject, its actions, their correlativity and continuity.

Every moral agent and every moral action originate in the same principle-the will. All are, in this sense, equal to each other. This kind of will is to be ascribed to all moral agents even if their actions differ in "natural respect" or "in the exertion of the moral direction." (301) If the latter provisions sound obscure, the continuation makes the matter even more obscure. In analogy, namely, to the laws of "energy," all transformations of the subject must be understood as reversible or, literally, " $(t)$ he will as the principle of the moral forms of energy subsumes them all under the principle of reversibility."

While it is clear what principle of reversibility is referred to in thermodynamics (one of the principles of the conservation of energy, demonstrated by Carnot and applied in thermochemistry), it is not clear to what Cohen refers in the application of this principle to the problem of the will. It does not become much clearer when he adds that one should not be confused about the certainty of this analogy if it turns out that it is not possible in every case to return to the previous state of transformation of the moral subject. Rather, one may find a further confirmation of the rule in such exceptions. The whole matter seems nothing but an aside which Cohen understands but finds unnecessary to explain further. 
The matter does become clearer when we consider that the principle of reversibility is an inherent principle of the conservation of energy and of the peculiar characteristics which distinguish energy from the traditional understanding of substance. In other words, reversibility is one of the essential properties of energy, something by which energy is known for what it is. Applied to the will as the principle of forms of moral energy this means that the will must have the property of "turning around" and changing its direction without calling into question the identity or continuity of the subject as a moral subject. As we know from the essay on the idea of Versöhnung, the precedent and source for this type of relation between the constitution of a moral subject and the "turning around" is the biblical concept of $t$ 'shuvah.

Furthermore, in an earlier passage Cohen states that even though it might be impossible for energy to always revert to its previous form ( $\mathrm{LrE}$ 294), reversibility as a principle of conservation simply means that energy might turn into forms which "we simply had no need to know yet" (ibid.). Thus Cohen's final remark on the reversibility of the direction of the will implies that the principle of moral energy may be confirmed and known in its characteristic and essential properties even though the transformation necessitated by a "reversion" may have to take on a new form rather than an earlier one, confirming or even generating rather than canceling the moral subject. What Cohen may have in mind here is that the energy of the will-unlike heat or other forms of physical energy-can only transform itself into new forms. While the subject is generated in its actions (and vice versa), the subject may err. But the morally wrong action is an immoral action. Does it cancel the existence of the moral energy, the will? The will generates the individual subject action by action. Incidents of immorality are not absolute negations of the will, nor incidents of absolute evil. They are incidents of error (sh'gagah). Therefore the subject in its continuity is generated by the assumption that it may and must revert its direction. In order to do this it need not undergo a switch of subjects (as in the mystery cults of antiquity). In ErW, the principle of reversibility supports the notion of the future as the proper time of ethics. In RV, "conservation" of the possibility to do good returns as God's daily promise to the human being, who receives her soul each morning in pristine purity.

\subsection{The Correlative Self-Consciousness of Ethics}

Hermann Cohen's Ethics of Pure Will can be characterized in a number of ways. In bibliographic terms it is the second part of a system of philosophy. But Cohen himself thought it rather bold and even 
misleading to label his major works a "system of philosophy." "System" sounds as if the architecture of written works could give an accurate representation of major structures of reality while Cohen's philosophy was more interested in method than in representation.

Since antiquity, "ethics" is suspended between the theoretical problem indicated in the Platonic idea of the "good" and the Aristotelian solution that regards the discipline as one of reflection on the practical use of reason. This division was sublated into the hierarchical systems of medieval thought where the Platonic "good beyond being" gave a philosophical expression to the truths of religion while the Aristotelian principle of the mean ruled in practical respect, i.e., in the human realm. Kant's second critique restored theoretical dignity to the discourse on ethics. This was literally revolutionary in that it put human reason in the position of the origin of the good while demoting religion to the secondary realm of the realization of ethics through its role in the formation of character. In the wake of the First Critique the spontaneity of the intellect is not only the origin of knowledge, in its limitation to all possible experience, but, in practical use, it becomes the sufficient cause of morality. The modernism of Kant's position consists in this legitimization of human freedom as the capability of human selflegislation (auto-nomy) against the Christian doctrine of primordial sinfulness. Yet, in his work on religion, Kant preserved the structure of Lutheran pietism by identifying the morally good (das sittlich Gute) with the inward motivation of action while denigrating the mere outward manifestation of "good morals" (gute Sitten). Thus a human being can be regarded as evil despite all good action because evil is not merely a phenomenal reality but an intelligible deficiency in the principles of one's actions (cf. Kant, Religion pp. 35ff "Vom Hang zum Bösen"). Kant retrieves the Christian core doctrine of the "fall of man" in philosophical terms by giving the peccatum originarium the distinction of an intelligible fact that explains the empirical reality of evil. Redemption, in turn, is the "restoration of the original disposition for the good" in contrast to an "acquisition of a lost motive (Triebfeder) for the good." The latter distinction moves Kant's rational religion from a purely Pauline and Augustinian to a Pelagian form of Christian doctrine and places him in the realm of the religious Enlightenment of his time. Still, by internalizing the problem of ethics and making religion an outward expression of the individual's inner struggle for the "sufficient motive of the will" to prevail over all outward motivations, Kant perpetuates a pervasive Christian logic according to which one's motivation is of greater concern than one's "works."

Cohen generally and frequently acknowledges his indebtedness to Kant, yet he takes issue often and vehemently with the Christian 
structure of the latter's conception of ethics. The focus of Kant's ethics on the subjective origin of action, and thus on the moral character of thought preceding action, openly reveals its correspondence to the Protestant tradition in, among other works, Religion Within the Limits of Reason Alone. As Cohen sought to give account of the possibility of a philosophical ethics, it fell to him to examine not only the philosophical heritage but also the Christian perspective that had determined the Western discourse on morality and legality. The supersessionist historical schema underlying this perspective overlooked by default the possibility that Jewish ethical monotheism could function as a source in the effort to rejuvenate this discourse. Cohen's task is therefore from the outset one that engages not only a philosophical problem but one that is to engage value judgments that result from a religious bias and lead to the neglect, misrepresentation, or suppression of another tradition.

The structure of Judaism is such that it emphasizes heteronomy over autonomy, legislation over morality, community over individuality. From this perspective, for example, the Kantian distinction between legality and morality appears highly problematic. Cohen's philosophical construction of ethics in light of the modern and classical idealist traditions is thus faced with the challenge of reëvaluating the fundamentals of politics and religion, revelation and reason, society and personality, ethics and law-in brief, of redefining the Western concept of the human being in light of the teachings of the Jewish tradition and the practice of Jewish religion. This is far more than an apologetic enterprise. The claim that "Judaism is connected with my scientific insights" means that Torah, to the degree that it can function as a source (Quelle, Ursprung) of culture, is to be integrated into the philosophical and cultural effort of determining what is good.

Such an evaluation of the rational "surplus value" and philosophical potential of the sources of Judaism must not be confused with a philosophy of religion. Cohen was troubled by the very idea that an independent discipline should be claimed for the philosophy of religion, so as if ethics were not to function as the primary factor in the determination of the concept of religion. The preferred model is a mutual constitution wherein religious concept formation is guided by ethical thought and the stock of ethical concepts is enriched by the moral content of religious ideas. There are, of course, correspondences between Cohen's Judaism and Kant's rational religion. But where Kant must bend Christian doctrine to conform to his philosophy, Cohen retrieves Judaism as a source of religious concepts which Kant, not having derived his concepts from specifically Christian sources, reads into the Christian tradition by means of allegories. From the perspective of late nineteenth and early twentieth century critical theology, the core texts of Judaism, 
especially the biblical prophetic heritage, are much more immediately congenial to ethical reasoning than the doctrines of Christianity in their classical interpretation. ${ }^{87}$

As proudly self-conscious as this elevation of Judaism to the status of a source of modern cultural self-consciousness may be, the danger of hubris is offset by the acknowledgment of the tentative nature of the experiment. Cohen recognizes that the publication of an ethics during one's own lifetime borders on intellectual immorality. Indeed, even in the most favorable of circumstances, i.e., in a private conversation among friends, it is a delicate task to speak of goodness, truth, and justice. One can imagine how much more difficult it was for a Jewish philosopher living in a distrustful environment to generate the confidence within himself that was necessary to publish a work of this kind.

Ethics of Pure Will (abbr. here either as Ethics or ErW) is a philosophy of law. But it is also a philosophy of virtues. On the surface it thus resembles Kant's Metaphysics of Morals more than the Critique of Practical Reason. Similarly, Cohen's Logic of Pure Cognition had taken its cue from Prolegomena to Any Future Metaphysics rather than from the rhetorical procedure of the First Critique. The transcendental method, or the method of "purity," must proceed from a cultural "fact," a firmly established cultural practice that allows critical reflection on its "pure," i.e. transcendental, presuppositions. Conversely, a discourse on the problem of the will, which has been the traditional content of ethics, cannot begin in earnest without anchoring itself in a correlation between the ideal assumption of the will and those actual problems and concepts for which this assumption provides the transcendental condition of validity.

$\mathrm{ErW}$ is an attempt to hinge the ethical problem on the conceptual apparatus of law and jurisprudence. Ethics is thereby provided with a quasi-empirical substratum while law receives a moral foundation. Where in Kant's Metaphysics of Morals, however, sets of virtues are construed from noumenal underpinnings and in turn guide judgment on sets of legal rules (inner motivation firmly ruling over outer manifestations), in Cohen's Ethics the virtues are classified among the problems of the realization of ethics while their direction is determined from a heteronomous construction of the ethical self-consciousness. The legal context of this philosophy is meant to counter the confusion that

${ }^{87} \mathrm{Cf}$. Benzion Kellermann, "Die philosophische Begründung des Judentums" in: Judaica. Festschrift zu Hermann Cohens Siebzigstem Geburtstage, Berlin: Ernst Cassirer, 1912, pp. 75-102. Kellermann's essay is particularly interesting in that here a student of Cohen's extrapolates Cohen's Jewish philosophy before the latter wrote either his own major treatise on religion (BR) or his "Jewish philosophy of religion and ethics," i.e., Religion der Vernunft. 
arose and continues to arise over the difference between transcendental philosophy and empirical psychology. Cohen attempts to liberate morality from its traditional religious and psychological settings in order to retrieve the possibility of a rational discourse on ethical judgments. Law allows one to transpose the ethical problem from the realm of motivation to the realm of action, so that the moral self-consciousness can be conceived of as a task rather than as an existent. In the latter respect, Cohen's Ethics is sustained by the elimination in his Logic of the very possibility of referring to the Self in terms of a substance. If the self has a valid function within the unity of the cultural consciousness, this function must be determined in its potential to serve as an origin, that is, as an idea that generates concepts and relates them to one another so that a network of functions establishes a domain whose relevance and utility are beyond doubt. Such a domain is law. Just as science construes the totality of conditions that we call nature through law, so the human realm is eminently determined through law and jurisprudence. The social and political spheres, not the solipsistic individual, are in question. In this way, ethics concerns itself with the nature and potential of sociality and politics as spheres of moral action in which selfconsciousness constitutes itself as a moral agent. In contrast to mere virtue-ethics, functioning as a guide for moral self-perfection, the Ethics of Pure Will functions as a philosophy of law in the sense of a normative guide for progressive legislation in which the moral dimension of the state manifests itself as a form of self-consciousness. Ethics is thus a guide towards political or public morality, a theory of political reform that seeks to determine the principles of the perfectibility of action. This is in contrast to Kant who determined the morally good in reflective acts of consciousness. In following the paradigm of a religion of law-books rather than that of a religion of transformative mysteries Cohen's Ethics therefore represents an eminent example for his attempt to reconcile Judaism and the cultural consciousness.

\subsubsection{Introductory Questions}

The basic task of ethics is to determine the sense in which the human being can be conceived of as the subject of her actions. By posing the question in this way, Cohen arranges the disposition of ethics in an exact relation with his Logic. The idea of the human being as a free agent does not arise in the context of the natural sciences. Yet the subject of ethics is construed in analogy to the logical problems of causality and continuity while the difference between nature and culture is one of perspective alone. Where the human being is studied in terms of natural causality, the notion of freedom becomes illusory. In light of biological, 
psychological, and sociological constructions of human behavior the ethical perspective runs the risk of being a hopelessly romantic or religious projection of mythological dreams onto a poetic screen of humanity that cannot be maintained as a legitimate idea.

The subject of ethics, the I, is therefore not to be taken for granted. It is not an object of experience. Rather the sought-for subject or selfconsciousness is precisely that which is not given. The point of departure therefore takes the form of an infinite judgment: 'not non-I.' The realm in which this 'not non-I' is manifest is not nature. The realm of such nonnature is culture, though not in the sense of a historical culture but rather as one which is as yet non-existent, a culture that ought to be rather than is. The manifestation of the not non-I in its agency is thus a matter not of ordinary causality which rules in the domain of being but rather of a causality of the 'ought.' The "being of the ought" (Sein des Sollens), however, is not non-being in the absolute sense of not being. Rather the 'ought' is "beyond being," as in the Platonic epekeina tes ousias. This surplus of the 'ought' reflects back on the definition of being as constituted in thought. Thought, as mapped in the Logic of Pure Cognition, is characterized as a movement of unification. Thus the thinking of the difference and correlation of logic and ethics is itself an instantiation of thought as described in the Logic. The difference lies in the object, however, which reaches beyond the being of nature. It could not do so legitimately if the rational method of construing the ethical problem emancipated itself from logic: we would cease to maintain the unity of the cultural consciousness. Cohen calls the effort to maintain this unity the "fundamental law of truth" (Grundgesetz der Wahrheit).

Since the subject of ethics is not a given, the task of ethics is to begin with the possibility of determining how such a transcendental subject manifests itself. The ethical self-consciousness appears in its "actions." If a phenomenon is to be conceived of as an action, it presupposes agency and thus an agent as its causal origin. But the very assumption of agency with its implication of conscious and responsible choice is an idealizing one. The realms of politics, religion, and history can be subjected to positive historical, psychological, and sociological study that finds only what itself first puts in it: data connected by rules of causality that reproduce the world of the human being in terms analogous to that by which we construe the natural world. But this is not ethics. Nor is ethics immediately evident in the moral ideas and ideals in which human cultures cast the material conditions of life. Were it so, ethics would be nothing but an orderly exposition of the stock of moral notions of one or several historical societies, indistinguishable from matters of taste, as already stated in Maimonides's Guide. Rather, the question of ethics is how can what we conventionally see as caused by human agency, i.e., 
the manifold efforts at a transformation of the material conditions of life, be conceived as the expression of an ethical self-consciousness? This turning of the question can perhaps be illustrated by comparison with the work of Ernst Bloch whose Principle Hope was informed by Cohen's ethics. Bloch presents a tour d'horizon through the history of cultural institutions involving myth, religion, art, and politics, aiming to show that each new step in the development of history is not a total sublation of the previous stage but that history is a repository of utopias that have yet to be fulfilled (unabgegoltene Utopie). Cohen similarly examines philosophy, history, sociology, art, and religion in order to determine how the institutions of human culture, in particular the institutional framework of the state, can be conceived of as generated by moral agency. The morality of the human being is, however, both manifest and hidden. It is manifest in history but in such a fashion that historical institutions must be interpreted towards a good that lies "beyond being." It is "not yet" but it ought to be. The ethical reading of history is thus not accomplished by historistically determining what was but only by asking for the future moral potential in cultural accomplishments of the past. This reading aims at realistic optimization of that which was and is. Since it is itself part of the ethical task this hermeneutics of optimization cannot be confused with naive optimism.

History, religion, sociology, art, and psychology cannot satisfy the need of this ethics for a simple formal definition of the moral agent. Rather, these disciplines are themselves in need of critical reflection on the problem of agency, a reflection ethics is to provide. All scientific thought aims to unify a manifold. If the basic problem of cultural sciences is human agency, the question is how to conceive of agency as the unity of the subject and the object of an action. Rather than postulating such unity speculatively, Cohen's ethics suggests employing legal concepts of subject and object of agency. According to Cohen, the advantage for ethics of this correlation with jurisprudence consists in the fact that the latter operates with a concept of the subject wherein the universal and the particular coincide. If community (koinonia) and cooperative can act as "legal personx," an ethics that commences by interpreting such a composite person can achieve what the logic of pure condition has demanded: the subject must not be an absolute but, qua idea, it must function as the enabler of relations. Ethics can thus turn into a critique of myths of individuality and of the absoluteness or givenness of a moral self, a critique which is pursued in the interest of providing a moral dimension to the historical realm of institutions. Given this interest in revealing the state as a moral subject in which all individuals and communities participate, the idealist underpinnings of this ethics (as 
expressed in the notion of a purity of the will) must not detract from its realism, i.e., from its energetic insistence on the realization of ethics.

In keeping with Cohen's overall critical idealist program of philosophy, therefore, the Ethics of Pure Will correlates cultural fact and transcendental constitution in such a way that the possibility of a realization of the Good is grounded in transformative action and its condition in the ideal disposition of will as agency. In the Logic, the correlation of theory and empirical verification was reflected in the twopart structure of the book. Similarly, the correlation of ethical theory and the conditions for the possibility of its realization in political action determines Ethics of Pure Will whose first part deals with the definition of will, action, and self-consciousness, while the second part provides the groundwork for an application of this ethics in chapters on freedom, the ideal, the idea of God, and virtues.

\subsection{2 "Resolving" Religion into Ethics}

What is the role of religion from the perspective of this ethics? When the system is first outlined (EmkN 1896), the philosophy of critical idealism is to "resolve" (auflösen) religion into ethics. If ErW is the realization of this program it should provide us with an answer as to what a "resolving" of religion into ethics is supposed to mean. While Cohen avoids the Hegelian term of "sublation" (Aufhebung) the similarity is evident and thus calls for a comparison and careful distinction. For the problem is in both cases one of relating a historical "revealed" teaching and religious practice to philosophical reflection on truth. In both Hegel and Cohen truth is not in existence other than in the historical process of becoming. And both philosophers attribute a major role to law and the state as the quintessence of a legally founded social reality open to development. Yet to Cohen history does not proceed dialectically nor can the real and the ideal ever meet in time other than, in a manner of speaking, in the future. Cohen's criticism of Hegel is at the core of his frequent association of Christianity with pantheism. On the other hand, Hegel's philosophy, especially his philosophy of law (Grundlinien der Philosophie des Rechts), rarely surfaces in the frequent problem-historical (problemgeschichtlich) examinations permeating the ethics. Cohen's defense of socialism would bring him into the company of the leftist Hegelians were it not for his critique of materialism. And his defense of the state as a rational and moral institution would bring him into the company of the right-wing Hegelians were it not for the socialist critique of the real existing state. He engages Hegel directly, however, in the context of the problem of the realization of ethics in "the ideal" (Ch. 8 pp. 
$389 \mathrm{ff}$ ). Here, too, the role of religion is prominently examined (see below). 88

The word Cohen uses to indicate the general task of ethics with respect to religion (auflösen) is ambiguous. It can mean to "dissolve" as in to dissolve an assembly; and it can mean to "resolve" as in a resolution of sugar in water. This ambiguity is quite intentional. For religion is both a body of ideas and a body politic. Just as the ideas are to be integrated into the reflection on ethics, the social body constituted through ethics, the state of the future, is to be the home of those religious communities whose particular traditions are congenial to the realization of that very state. This agenda assumes an intricate relation between religion and ethics, one that steers clear of two extreme modern positions. The first extreme it avoids is that of the liberal Enlightenment distinction between public and private wherein the liberal state is completely self-sustaining and separate from all religious association. This, to Cohen, seems as unrealistic as the assumption on which it rests: the abstract freedom of all individuals. On the other end of the spectrum are variations on the theme of identity of state and community, with community being defined either by its religious allegiance (the Christian, Jewish, or Islamic state), by its national character (Volksstaat), or by ideological unity (identity of party and state as in Fascism, Bolshevism, and Nationalsocialism). Religion and nationality (birth) are associated in Cohen's thought from early on ${ }^{89}$ and are elaborated in both his ethics and in his philosophy of religion. The religious community is the particular community par excellence and, by reason of its inherent tension with the messianic ideal of a trans-national human community of communities, it must not take itself for the "all" of state or humanity. It is founded on a mere judgment of "majority" (more than one, less than all). The ideal of a "dissolution" of particular communities into a state and into a peaceful world society therefore involves both the preservation of religious difference and the development of agreements in principle.

\footnotetext{
${ }^{88}$ There has been a long-standing hermeneutic suspicion of a "Iatent Hegelianism" in Cohen. Cf. Jacob Gordon, Der Ichbegriff bei Hegel, bei Cohen und in der Sïdwestdeutschen Schule hinsichtlich der Kategorienlehre untersucht. Erster Teil: Der Begriff des Denkens bei Hegel und Cohen, (Dissertation) Hamburg, 1926. More recently, ErW has been subjected to a study of its Hegelian character. Cf. Helmut Holzhey, "Hegel im Neu-Kantianismus. Maskerade und Diskurs" in: il cannocchiale. rivista di studi filosofici, 1-2/1991, pp. 9-27. That Cohen had read Hegel is beyond doubt. References to Hegel are found as early as in his doctoral dissertation, Philosophorum de antinomia necessitatis et contingentiæ doctrinæ (1865), reprinted in: $\$ 1,1-29$. It is unimaginable for a student of philosophy in the mid19 th-century not to have read Hegel.

${ }^{89} \mathrm{Cf}$. Wiedebach, Die Bedeutung der Nationalität.
} 
Religion and ethics sustain each other (cf. BR). Religion contributes to the stock of ethical ideas but it is also guided in its particular selfdevelopment and self-preservation by ethical reasoning. Otherwise it would lose the character of religion and revert to the throes of myth whence it hails. Using Hebrew prophecy as the historic paradigm, Cohen defines religion as critique of myth and resistance to the immorality that results from the mythic world view. ${ }^{90}$ Religion is therefore itself an integral moment of culture, marking the creative transformation of the mythic heritage of particular communities into the source and wellspring of a moral knowledge and practice. ${ }^{91}$

The multiplicity of religions within a commonwealth is less problematic than the different state of reflection within those communities. Some are closer to their mythological way of thinking than others and ethics is therefore called upon to stir religions forward in the process of transformation towards the ethical ideal. There is more than a faint echo in this assessment of matters with which the Jews had to contend since the age of Enlightenment and Emancipation. After all, the debates on an extension of citizenship rights to Jews had involved the call for their "amelioration" as if the Jewish national character had to be improved before the members of this nation could be integrated into the emerging nation state (cf. Dohm, Bürgerliche Verbesserung). Their religion was subjected to classical anti-Jewish suspicions even after Emancipation (cf. Napoleon's "Great Sanhedrin"). And following German unification under Bismarck such prejudicial attitudes flourished again and even became acceptable in serious political discourse. Countering this interminable prejudice, Cohen distinguishes Judaism only as a religion, namely as a religion that is paradigmatic, rational, originative, and consistently anti-mythological and therefore a model to be emulated by Christianity. Accordingly, when Cohen discusses religious aspects of the key terms of will, action, and self-consciousness, Christianity is the decisive representative of the Western religious tradition but as such it is critically examined from an ethical perspective and, more often than not,

\footnotetext{
${ }^{90}$ The interpretation of the religion of the Hebrew Bible, esp. of the laws of Moses, as rational resistance to mythology and immorality has ancient roots and is at the heart of Maimonides's interpretation of the ceremonial laws (hukkim). See, among others, the most recent account of this discourse in Jan Assmann, Moses the Egyptian (HUP, 1997).

${ }^{91}$ This is not to say that myth itself is not an important well-spring of culturally fertile ideas and thus itself an ever present fertile albeit preliminary stage of culture. One could say that, in Cohen's view, we are all usually guided by mythology, namely if, when, and to the degree that we fail "to give account" (after the Platonic logon didonai). Myth in this sense is the stage before theoretical culture, before purification, but in its productivity it is the well-spring of perceptions that provides cultural work with its material.
} 
it is severely criticized. On the other hand, where religion functions as the source and well-spring of ethical ideas, the reference is to the ethical monotheism of the Hebrew prophets.

The foremost contribution of religion to ethics is its concern with the individual (ErW 51f). This thematization is consistent throughout Cohen's works but while the emphasis on individuality has been widely noted as a major component of the late works on religion, it has not been considered carefully enough in its role for the construction of the Ethics. The religious question of individuality is adopted by the Ethics and thereby brought to a certain resolution which religion, steeped as it is in myth and dogma, cannot achieve on the level of theoretical certainty (p. 52). It needs Greek-type logic along with Hebrew-type religious content in order for a such a hybrid concept of individuality that conceives of the moral self as a task in the context of a unity of the cultural consciousness to emerge. In the attempt to sketch such a conceptual hybrid, Cohen employs several conceptual "dictionaries:" the Latin dictionary as a source of Roman law; the German vocabulary of esthetic theory for the esthetic dimensions of self-consciousness; Hebrew terminology for the

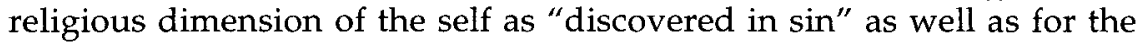
idea of God; and of course Greek as the language of idealism. The achievement of a unity among these distinct traditions involves a cultural multilinguality that is more than Esperanto because it preserves and constantly reëvaluates the constitutive languages brought into conversation. The unity of the cultural consciousness is an "eternal" task, one which takes on the messianic character of a redemptive practice of unification of nations who, in their particular originality, are taught, and teach themselves, to worship the One shepherd. The method of ethnic psychology and linguistics (Völkerpsychologie und Sprachwissenschaft) is here, indeed, applied to a normative philosophical discourse.

In the context of the chapter on "the ideal" in the second part of ErW, where Cohen addresses the superstructure ( $A u f b a u$ ) of the human being as a free agent in analogy to the legal person of the first part of the Ethics, he questions whether such a formalistic ethics can be valid for real human beings (p. 390). Here the Hegelian question returns with a vengeance: how can the rational be real? In contrast to vulgarizations of Hegel's philosophy Cohen does not recognize existing institutions of state and law as proof for the validity of his ethical theory. Is the "kingdom" of this world or is it of another? Is it "in heaven" and thus completely beyond us, and should the "ought" thus have no "being" at all? Or, if it is not in heaven, does this mean that it is on earth? In the "ideal" it is present while being absent. The continuity of the ethical realization manifests itself in the transformation of reality. Where the 
first part of Cohen's ethics is thus a philosophy of law, the second part is a theory of the time for the practice of political reform.

Here we find perhaps the most striking instantiation of Cohen's argument against classical Christianity ${ }^{92}$ and for Judaism as a religion of reason and a moment of cultural rationality. Christianity (especially Christian apocalypticism) tends to separate radically this world from the realm of grace (regnum gratiæ, p. 394). Thus the distance between this world and the moral concern of the individual is increased rather than diminished. The Christian heritage thus tends to work against the notion that it is meaningful, efficacious, and morally imperative to work in the realm of politics for increased justice on earth. Cohen's clearly one-sided account of the Christian (as well as of the Jewish) heritage is motivated by the fact that he sees an undue dependence of Kant's "realm of ends" (Reich der Zwecke) on the Christian notion of a regnum gratiæ. The role Kant assigns to religion and to the idea of a highest good in the Critique of Practical Reason (e.g., in Part I, II. Book. 2., "On the dialectic in the definition of the concept of a highest good") and elsewhere is, to Cohen, informed by a Christian symbolism that misleads the whole direction of Kantian ethics. The latter, in Cohen's view, favors ethics as a kind of selfexamination of the maxims of the actions of particular individuals without any warrant for a realization of moral progress in the social realm. Between the extremes of Hegel (the law in its reality as the realization of the rational, i.e., the good) and Kant (the good cannot be the object of possible experience and is therefore radically beyond being which, despite all rhetoric to the contrary, tends to force it beyond realization), Cohen locates the possibility of realization in a notion he borrows from the neo-Platonic tradition and its modern heir, esthetic theory: the ideal (cf. p. 419). What this concept may mean for the realization of ethics is then discussed not in esthetic terms, however, but by means of an extended analysis of the religion of the Hebrew prophets and their understanding of time. Without going into further detail here, it should be noted that Cohen nowhere highlights the contribution of Judaism to the cultural consciousness more openly and assertively than when dealing with the realization of ethics. Ethics, stretching toward realization, is in need of religion and Judaism provides the repository by which ethical reflection moves towards such realization. At the same time, the Jewish tradition allows him to avoid certain widely recognized pitfalls of Kantian and Hegelian philosophy and reveals those shortcomings as resulting in part from misguided pious dependence. While Cohen's thought is thus informed by a particular religious

\footnotetext{
${ }^{92}$ Modern Protestantism is usually exempt from this verdict. See below on Religion.
} 
tradition it puts this tradition to use critically and constructively in a specific cultural context where all idealist systems are revealed to have been nourished from a certain variety of historical religious sources. This seemingly biased procedure allows Cohen to show that the dominant Christian influence not only prevented much of the Western tradition from seeing Judaism for what it is but, more detrimentally, it prevented philosophy from accomplishing its critical and constructive tasks. Such integration of religion into ethics, far from demoting religion to popular pedagogical handmaiden to critical philosophy, elevates Jewish sources to the level of rational thought and makes them a well-spring for critical cultural and political philosophy.

\subsubsection{The Law of Truth}

Religion and ethics are construed so as to preserve them both in their distinctness while bringing them into a fertile reciprocal relation. This relation is here not one between equal members of a system but one between a fundamental aspect of theoretical culture (ethics) and cultural fact (religion). This is not to diminish the value of religion but to secure it. Similarly, logic and ethics are bound together although the relation is here not one between theory and cultural fact but between two aspects of theoretical culture. Ethics is not contained in logic since the problem of knowledge, which to Cohen determines the task of logic, does not extend beyond the realm of necessity and universality. What remains within this realm is correct or accurate in a scientific sense yet devoid of moral value. On the other hand, were ethics construed without respect to philosophical method, it would remain mere sophistry and dialectics. Idealist ethics is the attempt to examine the domain of logic for the possibility of extending its validity to a realm that cannot be expressed in terms of necessity and universality. The main problem of classical ethics is therefore that of freedom which Kant poetically and succinctly called "the miracle in the phenomenal world" (cf. ErW p. 89f). Chaining logic and ethics to each other, attempting to harmonize them within a system, aims to give meaning to the idea of truth. Truth is the harmony of logic and ethics, of being and ought, of nature and culture. How can truth be? Only "beyond being," that is, only in the idea of truth which is the condition of relations. In Cohen's sense of the idea as hypothesis truth therefore remains the perpetual task of searching for truth. Philosophy, in this vein, is the effort of making friends out of seemingly irreconcilable opposites. Its effort is one at reconciliation and atonement. This endeavor which Plato describes in analogy to sexual attraction (eros), is given a 
religious connotation when Cohen associates it with "purity."93 The method of purity, as Cohen also calls the transcendental method, is one by which prejudice is overcome and myth is critiqued. But the relation it establishes is not merely cognitive. It refers to the motion and action that the Aristotelian tradition called the "active intellect." This method is thus as much of the Platonic and Kantian tradition as it is a fertile universalization of the fundamental principle of Judaism that has its most poignant representation in the proclamation of divine uniqueness.

Truth determines Cohen's thought as the quintessence of the systematic method. This foregrounding of the method of critical idealism prizes the search for truth over its acquisition, as Lessing put it, and serves as a point of distinction between critique and metaphysics (cf. p. 428). Critique of myth is conceived as the eternal task of reason, in religion as in science and the logic of cognition. This precursor of the "dialectic of enlightenment" has its epicenter in the idea of the uniqueness of God.

It is not a case of over-interpretation when our account of ErW commences with the claim that Cohen associates the fundamental law of truth as manifest in the methodological ideal of an agreement between logic and ethics with the religious sources of Judaism. We must keep in mind that Cohen's project of renewing Jewish philosophy of religion and the composition of his system of philosophy occur at the same time. The very structure of the argument of the Ethics suggests that Cohen was driven by the vision that the two could be more than reconciled, that one could generate ethical theory in full agreement with an idea of truth that draws not only from the Platonic tradition but that is equally informed by the Jewish tradition. The manifestation of being that is indicated in the term "truth" draws on two sources: Platonic paideia that is to lead to Being in its un-concealedness (a-letheia) and the monotheistic revelation of the true God as opposed to all deceitful deities (adonai eloheinu emet). ${ }^{94}$

The "fundamental law of truth" (Grundgesetz der Wahrheit; ErW Ch. 1) not only provides Cohen with a theoretical foundation but also with a practical conclusion to his ethics. Like Religion der Vernunft, the fully developed "Jewish philosophy of religion and ethics," ErW culminates in a correlative account of the human being who has the ideal before herself in religion and who emulates it in the virtues that guide the process of becoming good. The ethical self-consciousness that manifests itself in action is correlatively determined in the mutual constitution of state and individual. Why does Cohen still need the idea of God to complete this

\footnotetext{
${ }^{93}$ P. 92, and cf. the motto of RV from Mishnah Yoma 8:9.

${ }^{94} \mathrm{Cf}$. above, Part I, chapter 4.1.4 "The Relation of God and Man and the Autonomy of the Moral Law."
} 
picture? How is it that the fundamental idea of metaphysics returns in this elsewhere so radically critical philosophy? What is the value of the idea of God in a system of critical idealism?

In the metaphysical tradition, God stands for a grounding of being in something that is neither subject to the characteristics of the physical universe nor within the grasp of human thought that derives all its knowledge from the characteristics of the physical universe. In the idea of God as the ultimate hypothesis or, more accurately, as the "unhypothesized" (an-hupotheton), reason, in an act of self-ironization (429), imposes a limit onto itself. The order we perceive or generate must either be radically transcended by something independent of our acts of generation, or transcendence must be radically denied. Thus the basic inventory of classical metaphysics. What is there to be gained from the history of metaphysics? asks Cohen (431f). Can the cause of ethics be promoted and furthered by a heritage that is grounded in myth and religion? The answer he proposes towards the end of the Ethics associates the idea of God with a "rest" in the problem of a realization of ethics that the "ideal" alone cannot solve. This is not to say that Cohen began his construction of an ethics without foreseeing the problem he now addresses. Rather, the whole argumentative structure of the work was meant to culminate in the idea of God (cf. p. 432). How so? We return to the fundamental law of truth.

Ethics was to be construed so as to be neither identical with logic nor completely independent. The rules of object constitution and thus of the generative role of thought are to set the limits for ethical concept formation as well. At the same time, by means of infinite judgments, the distinct subject of ethics is characterized as beyond the being of nature: will, agency, and self-consciousness as the constituent aspects of the theoretical grounding of ethics are generated in accordance with the demands of logic without ranking as objects of scientific knowledge. Ethics is a fragile discourse not only because its subject falls outside the realm of scientific certainty but because it also must forgo the advantage of psychological self-evidence. This is not to deny that, just as common and pre-scientific experience gives rise to natural philosophy, the stirrings of emotion and appetite are the condition for the problem of will to emerge. Ethics has the disadvantage of having to negate both the logic of cognition as well as the appetitive faculty when it sets out to discover its own concept of self-consciousness. The idealist character of this concept however demands an anchor in the world of cultural facts. But the world of cultural facts demands the continued existence of a natural world that is open to cultural transformation. How can we be certain that there will be a world within which the eternal futurity of ethics can be enacted? The plausibility of an idealist ethics is thus 
insufficiently established unless the realization of its perpetual imperative, and thus its optimism, is anchored in the idea of a common ground to nature and history. This ground cannot be material. Nor must history be reduced to an extension of nature. Between materialism and pantheism, Cohen finds the God of monotheism to provide this common ground and enabling hypothesis in which logic and ethics are reconciled without being collapsed into one.

Cohen's work towards the renewal of Jewish philosophy of religion gave him the sustained confidence that the God of prophetic literature and liturgical practice was just that: creator of the natural world in the sense of a daily renewal of the works of creation for the sake of a realizable demand to hearken to his voice. To Cohen this idea of God was necessary in order to counter Schopenhauerian pessimism and political quietism (450). Good action is a way out of hopelessness, but why is good action not hopeless? Because the future is there for us to shape. But the existence of the future is beyond our agency. The idea of God expresses the confidence that nature can sustain the human effort of self-transformation. The history of nations, empirically a proof to the contrary, can be viewed as harboring the promise of greater perfection (or less imperfection). This is not because the nations are good but for the sake of their improvement. This "transformation" (Umwendung, i.e., $t^{\prime}$ shuvah) of nations, a process of political reform that is a mere potentiality, stands in lieu of a proof for the existence of God. Evil is determined as non-existent although it has, as it were, immediate evidence in popular consciousness. Evil is denied its reality by the God who is but an idea and by its correlative ethical self-consciousness in individual and state. The good originates as philosophical reasoned resistance to the myth that evil surrounds and possesses us. And without the idea of God, the ethical self-consciousness would remain fragmented by the irreconcilable opposites of a materialistic premise of science (including the social sciences) and an irrationalist premise of religion. Cohen's position, decried by Heidegger as representative of Wilhelminian bourgeois ideology, is as harsh and demanding as any existentialism. Its "truth" is not in the past. It has its Being in the task of realization.

\subsubsection{Will and Action}

What thought is to logic, action is to ethics. Although thought is itself a form of movement (cf. ErW 124), ethics is not merely a form of thought. In logic, thought is the substratum of the object of cognition and origin of the law that constitutes it. The logic of cognition analyzes the transcendental conditions of valid cognition as opposed to constituting 
itself vis-à-vis objects of experience given in sensual experience, as in Kant's First Critique. The subject of scientific thought is not selfconsciousness or a thinking ego but it is the scientific consciousness that is correlated to the scientific knowledge of which it is the subject. The self-consciousness described in the ethics is correlative with its object, i.e., action. In specific difference yet guided by the thought of Logic, selfconsciousness is the agent of its action and is as such exempt from the causality of nature. But it is constituted not by a mysterious agency outside or before its actions. The self-consciousness of ethics is beyond being in that it is its own agency. Thus it deserves the predicate of consciousness more immediately than the abstract scientific consciousness (as in the "we know" of scientific literature) 95 but it does not manifest itself other than in its actions. The good that is beyond being originates in an ethical self-consciousness which is itself constituted in its action. There is no absolute self that could function in analogy to the neoPlatonic nous where a superabundance of goodness overflows and thus produces the world of experience.

Action must have its origin in an impulse that must be of its own making if ethics is to avoid absorption into psychological or sociological causality. To be homogeneous to the problem of self-generated action, this impulse (Cohen uses the word Antrieb by which he renders the Hebrew yetser in German) must be constituted in correlation with the action rather than in the seemingly relevant internality of an intention (Absicht) or an attitude (Gesinnung) (p. 103). The problem of the will that is sought for is thus formally defined as correlative to the action of which it is the origin and negatively by what it is not, namely a psychological mechanism of the conscious or unconscious mind. Herein lies the most interesting aspect of Cohen's ethics. The manifestation of the will in its actions is to be featured against the internalization that has been the overruling interest of theories of the will not so much in the Greek but in the Western Christian tradition. Against such emphasis on "faith," Cohen wishes to establish an ethics of "works" (cf. pp. 118-120).

Action is to ethics as the object of cognition is to logic. Neither is given to immediate experience; they are the result of work. The focus of this philosophy on the constitution of objects shines a spotlight on something centered between the raw material of experience and the transcendental conditions of the possibility of the constitution of objects.

\footnotetext{
${ }^{95} \mathrm{Cf}$. ErW p. 413 . One could say that thought is unselfconscious for a self appears only as an aspect in the determination of the will. It enters into the general philosophical discourse through the mythological interest in the duration of life, cast as the immortality of the soul. In Plato, the myth of metempsychosis also solves the problem of the acquisition of knowledge.
} 
Logic of cognition has as its fact the accomplishment of knowledge, whence it can begin its reflective journey. Ethics is not in the same fortunate position. The raw material that is transformed in a process analogous to the sciences are the fundamental human strivings, emotions, and desires. Cultivation and civilization are those processes in which humans transform themselves from wild beasts to beasts that are able to coexist. Whether or not one can locate the desire to socialize in a particular gene, humanity is still the result of an effort, no matter which underlying biologically determined conditions provide the material condition for such self-transformation. The latter is still a cultural effort and must go through the filter of reason that distinguishes good from bad. Cohen, perhaps surprising in the context of an idealist ethics, emphasizes the affect as an essential motor of action. For if it sufficed to reflect on motivations, if there were no good and efficacious motor involved, action would lie outside the possibility of ethical reflection. Not the success of the action, which is beyond will power, but the action itself must be determined in its ethical nature. But the will is more than a mode of thought; it needs affect to be put in motion. This anthropological aspect of the ethics rests on the optimistic premise, in agreement with the morning blessing of Jewish prayer, that the energy that fuels human activity is beneficial. The soul is pure. Yet it needs to direct itself.

How does human civilization achieve the direction towards greater civility? How is it that we associate the word "human" with humaneness, despite the fact that the latter does not seem an intrinsic characteristic of the former? What is in us must have entered into us first. The Platonic solution is the myth of metempsychosis. The Aristotelian solution is the effect good action has over time on the agent. In this case, Cohen sides with Aristotle (cf. p. 170).

The will is located in the no-man's-land between thought (will must be related but not identical with thought) and affect (cf. p. 122 and passim) as a hypothetical source of possible relations that are grounded neither in thought nor in affect alone. The necessary proximity between thought and affect is established in the fact that thought itself is characterized by time and motion (p. 124). Moreover, action has its analogue in the thought of pure cognition, namely in the "task" (Aufgabe) that leads to concept formation which, if concept is understood as "problem," is itself a perpetual task (p. 170). In other words, thought and affect are not taken to represent the polar opposites of consciousness and matter but, as aspects of the will, they can be harmonized. The will, as it were, is the harmonization and reconciliation of thought and affect. Cohen goes even further when he determines the function of the will in thought itself as the agent of unification (thought being defined as the "unification of separation and unification"). Thought judges and 
distinguishes but it also brings the manifold under one denominator. In this respect, will appears as an aspect of thought (p. 136-7).

Nevertheless, in its homogeneity with the affect, the will tends towards action. Action (Handlung) rather than thought or desire for material goods is the object of the will if it is to be a "good" will. In Kant, the content of will is the maxim of action (164). Cohen however construes the will as the unification of thought and affect in order to move beyond mere thought and intention. The apparatus by which the correlation of will and action is established is taken from law and jurisprudence. It should be noted that this move, too, reflects back on the thought of cognition and generates homogeneity between logic and ethics. For the terminology of logic is itself informed by the rhetoric of law (judgment/Urteil, laws of nature/Naturgesetze, laws of thought/Denkgesetze, ground of justification/Rechtsgrund, etc.). Action (Handlung) is conceived so as to generate "familiarity" between will and thought (171). Cohen therefore points quite favorably to Fichte whose Wissenschaftslehre aimed to overcome the Kantian duality of pure and practical reason (169).

After the congruity of will and thought is established the distinction between them becomes more subtle. First Cohen tentatively suggests that one could differentiate between them using the spatial metaphor of inner and outer. Action, one might say, is Äusserung (uttering). (174) Here Cohen intentionally uses an ambiguous term that suggests a spatial movement (nach aussen, towards the outside) but also refers to language. Language is indeed the intended meaning (cf. 190-199) but this is not immediately revealed. First the spatial metaphor is subjected to critique. Thought itself aims towards the "outside" in the action of object constitution. It generates the outside world. The difference between thought and will is determined by a reversal in the functions of action and object. In thought the object is purpose and content while action is the means by which the object is constituted. In the will, action is the purpose while the object is the means by which the action is constituted (p. 175). Both pure thought and pure will generate in acts of immanent reflection rather than in random acts of blind utterings. It is thus misleading to distinguish between thought and will in spatial terms unless will is the "outer side of an inner." What unites the inner and outer is language. The objectification of the will, its manifestation, is executed in speech acts (p. 194).

The will itself is not unconditional but moved by its condition. This condition must be relative rather than absolute. The content of the will is action, and only art bordering on insanity can conceive of a will to create an absolute work of art (cf. Thomas Mann's Doktor Faustus). If the sought after action is a kind of speech act, the condition of such action is a 
speaker. But is this speech that of a particular individual? No one speaks primarily to herself. We speak because we are spoken to. The universe of language is a social one. Moreover, since Hamann ${ }^{96}$ we understand that language speaks us more than we speak language. How, then, is the unit of the person to be defined that is the condition for the will as expressed in speech acts? (cf. 182-189) Thus Cohen broaches the key problem of ethics: the subject as the individual self-consciousness as the condition of will and action.

\subsubsection{The Self-Consciousness of Pure Will}

No less than four chapters of ErW are dedicated to the elaboration of the problem of the self. The introduction and chapters one, two, and three which I have so far represented are no more than cautionary and preliminary way-stations that help to introduce the crucial issue of individuality from the perspective of critical idealism. The question of the human being is at the center of philosophy since Socrates. Who are we? To Cohen, the question of the human being is also at the center of the "religion of reason." Even the Jewish idea of God focuses on how to make us human and does not usually become an object of speculation in its own right.

Self-consciousness is not an empirical reality. Established as the condition of pure will it participates in the purity of the will; it is pure self-consciousness. But it also participates in the action in which the will is manifest; it is therefore also in and through self-generated action or action of self-generation. The self exists only through such action and in correlation with it. This self-consciousness is not mine other than by way of the virtues that guide my own fragmented self towards continuity of moral self-transformation. More to the point, my own individuality in its experience of moral failing and the need for the renewal of my moral energy and direction belongs in the realm of historical religious communities and their respective language traditions of atonement. Religion is, to some extent, applied ethics. But so is politics. Ethics provides the guidelines for a self-consciousness that is to be concretized in the individual as well as in the state. No particular historical state can claim to have accomplished the realization of pure self-consciousness. Rather, in the legislative, executive, and judicative effort to reduce injustice states confirm their potential as moral agents.

\footnotetext{
${ }^{96}$ Johann Georg Hamann (1730-1788), Lutheran pietist critic of the Enlightenment, regarded as forerunner of the Romantic movement; of discernible influence on Herder, Jacobi, Goethe, Hegel, Kierkegaard, and the movement of dialectic theology.
} 
Cohen's characterization of self-consciousness proceeds as follows. Chapter Four describes self-consciousness construed as the condition given itself by the pure will. Similar to Fichte, yet in a typical reversal, Cohen correlates I and non-I but makes the latter the condition for the former. Non-I as an infinite judgment generates the problem of the I which is to be determined further. Thus, however, the non-I-the other person-is the only necessary presupposition and hypothesis necessary to generate the I. This other person is further defined not as "another" person (one of a majority) but as a specific other (or: the Other), namely that person with whom I enter into a contractual relation (pp. 211-212). Contractual law elevates this discussion from the seemingly immediate experience of human self and other to the level of a cultural artifice which becomes the guide for the determination of the ethical selfconsciousness. The pre-contractual human being is not of concern for this ethics which thus not only becomes a philosophy of law but a philosophy of culture, namely a philosophy of the human being as a cultural agent or agent of culture. To draw out further the logic of the Enlightenment metaphor of a "state of nature" in contrast to a contractual state, the alternative attempt would be to establish ethics as emerging from the wild and untamed Enkidu-like creature that does not even speak human language and whose influence on us ethics is meant to curtail. Ethics is about Enkidu's transition to civilization as well as about Gilgamesh's judgment on himself. The problem of ethics is the human being insofar as she is not in a state of nature. Cohen's reference to legal subjects entering into a contract also explains his earlier allusion to language as the uttering of will beyond mere thought. It needs the Other with whom I enter into negotiation and contract who moves me from thought and intention to speech and action. While this illustration through the experience of language makes Cohen's procedure plausible and provides it with evidence, the legal and thus formal character of contractual speech acts (similar to the liturgical speech acts of the Day of Atonement) preserves the norm of purity: not the experience of language but its regularity provides guidance to the phenomenology of pure will and self-consciousness. The individual comes into play only as member of a Rechtsgemeinschaft (legal or contractual community) (225).

Thus another characteristic of the condition of pure will is introduced. Community, not thought (as in the reflection on the maxim of one's action) or intention (Gesinnung), is the basic characteristic of selfconsciousness. Law presupposes a notion of unity of legal subjects that can be taken to include all human beings. Historically, this inclusiveness is "discovered" not in the Greek but in the Hebrew tradition, more precisely in the first creative exchange between the two traditions, with the first Jewish philosopher, Philo of Alexandria. Cohen distinguishes 
the sociological regions that the Hebrew and Greek systems respectively refer to in their moral reflections. Socrates discovers ethics in the question of the "what?" of man; he wishes to learn the answer to this question by visiting the professions and classes in their variety. This leads to a unified concept of virtue, of the good, but not to a unified concept of the human being. This, in contrast, is the achievement of the messianic idea in Judaism which grows out of a variety of sources and experiences, from legal protection of the "stranger among you" to the notion of universal worship of the one God (210-214). From this perspective the fall of man does not occur in Eden but with Babel: the confusion of languages and the end of mutual translatability is the rift among human beings that prophetic messianism overcomes in its vision of the future (cf. p. 211). For Philo, the unity of human beings beyond differences in language is indicated in the unity of ideas (as, for example, in the agreement between Moses and Plato) (210).

While Jewish philosophy thus appears as the source of one of the fundamental notions of idealist ethics, the idea of humanity, "religion" (i.e., Christianity) is criticized for its misleading emphasis on "love thy neighbor" that results from a mistranslation (217-8).$^{97}$ Here and on many other occasions, the critique of "religion" concerns a Christian concept of the self that, according to Cohen, takes the "bodily representation of a person" and makes the task of religion (and metaphysics) the spiritualization of this physical entity (222), in other words: an impossible task. (Hence, perhaps, the dictum ascribed to Cohen by Rosenzweig when the latter told him about the faith of his friend Eugen Rosenstock and his cousin Hans Ehrenberg, both of whom had converted from Judaism to Christianity: "No one has ever believed in it!") Christianity, to Cohen, is almost inextricably tied to the individual's desire for perpetuity. The effect of redemption through intervention allows the believer the gratification of a wish without linking myth, hope, and its fulfillment sufficiently and necessarily to the task of

${ }^{97}$ Namely, when the Hebrew term rea'-here translated as der Andere-is turned (first in Greek and then in Latin) into the blood relative, leading to the affirmation of a tribal attitude which both the Hebrew ger and the Christian faith-based idea of community meant to overcome. The whole context of this passage deserves much attention. For example, Cohen emphasizes, against the seemingly sentimental connotation of love, the rational side of the commandment, associating-with the medieval tradition and its interpretation of the biblical term da'at (knowledge/sexual intercourse)-love with knowledge. "Love thy neighbor" is thus taken to speak to the problem of the constitution of the self as related to an other. If the other is reduced to the similar (as in the tribal, familial understanding of $\mathrm{rea}^{\prime}$ ) moral self-constitution is lost. The emphasis in all of these considerations on religious language rests on method rather than simply on content. 
generating a moral self-consciousness. The God-man myth leads to an idea of deification of the human being that tends to exhaust its meaning in a spiritual realm. The introduction of saints makes the achievement of sainthood on earth an even more remote goal by declaring it an exception. In contrast, the ideal of the legal system of Torah and halakhah aims to make all Israel a nation of priests and a holy people.

Against this religious background and in the effort of bringing it to the level of a methodologically reflected consciousness, it is not surprising to find Cohen arguing against individual ethics and for social ethics. While the philosophy of religion shows greater concern with the individual, it ties the individual into a correlative system wherein the individual is taken through the very stages of self-constitution described in ErW (with the exception of one further step that the Ethics itself cannot but hint at occasionally as a desideratum that must be relegated to religion). Religion thus receives its Eigenart (so the term in Begriff der Religion) without achieving systematic "independence." Aside from this peculiarity, however, all the themes of the Ethics are preserved in the philosophy of religion. The major difference is, as it were, sociological. In the Ethics, relative communities (such as the ethno-religious minority) are distinguished from the state. And the lists of virtues that appear at the end of ErW and Religion der Vernunft, respectively, are divided into those that correlate individual and the "all" of state and humanity and those that correlate individual and relative community. Both ethics and the Jewish philosophy of religion together, then, elaborate the theory of moral political behavior wherein allegiance to community and allegiance to state and humanity must not contradict each other. Cohen's moral and religious philosophy is thus a political theory in response to the challenge of Jewish Emancipation and its unfulfilled promises. It is a political theory of diasporatic life that is grounded in the 19th-century Jewish assumption that Diaspora is not a preliminary but an enduring condition whose beneficial potential (the theory of a Jewish "mission" to the world) must be worked out. Here, again, the deep connection between Cohen and figures like Ludwig Philippson emerges clearly. The difference between mere defense and philosophical reflection, however, also becomes evident in that Cohen's Ethics turns historical circumstance into a source for a new configuration of the ethical problem with possible implications far beyond the specific situation out of which it was conceived. The diasporatic perspective allows him to look at the Western philosophical tradition and its political dimension in a different light.

More specifically, the endeavor to determine the relation between Judaism and Germanism that surfaced in the exchange with Treitschke and that had been the fundamental effort of Cohen's philosophizing from the outset, is brought to clarity in the ethical reflection on the 
relation between the individual, the nation (Volk), the state, and humanity. In the chapter on the self-consciousness of the will Cohen interprets national self-consciousness as the unifying consciousness of the state. The state, as a legal "fiction" (247) or as a "spirit" (246), has the task of generating unity among its members. It is both subject and object of unification. As moral self-consciousness it must not suppress any of the particular moral wills that it is to unite within itself (245). But those particular wills are the subjects of their unification in the state, and thus moral agents, only to the degree that their will is aimed at such unification. Echoing the rabbinic phrase of "taking upon oneself the yoke of the kingdom of heaven," Cohen writes that it is the task of the particular to "take upon itself the task of the all" (die Aufgabe der Allheit auf sich zu nehmen) (ibid.). Cohen takes issue with Ferdinand Tönnies, a fellow-member in the Society for Ethical Culture, when he rejects the concept of Gemeinschaft as fundamental to the problem of the state. Community is the characteristic of relative social bodies, such as a nationality or ethnicity (Volksgemeinschaft) (256). By contrast, the model for a particular body that enters into a contractual rather than emotional relation is the cooperative (Genossenschaft) (250). By the same token Cohen also rejects the concept of a national spirit (Volksgeist) which, according to the conservative legal historian Savigny and his school, manifests itself in the legal tradition of a nation. In contrast the socialist concept of society is legitimized to the degree that it functions as a corrective and critique of nationalism. (254) Reading ErW there is no doubt as to what Cohen's much maligned "Germanism" refers to. It is a patriotism that directs itself to the idea of unity, that is, that idea of unity that had been the rallying call of the liberal movement of the Vormärz and that had found its institutional expression in the Frankfurt Paulskirche parliament of 1848-49 (and which was eventually abandoned in Bismarck's Greater Prussian solution to the German question). In the early 20th century, a liberal or even socialist definition of national unity also aimed to subvert the romantic revisionist idea that Germany should expand to include the whole German race within its borders (and to exclude foreigners from its soil). In this whole argument one also discerns the reason for Cohen's rejection of Zionism. Blood relations or ideologically founded commonality are the source of communal cohesion, not the stuff from which an ethically viable state is made. The category error of tribalist constructions of a state is that it conceives of a legal fiction in terms of a natural entity. But, in Cohen's view, the state is not to be nature-like (256). Without this political background it remains incomprehensible why Cohen insists so much on the "task of selfconsciousness," a task that is modeled on the transformation of the 
"stranger" of early Israelite law into the "Thou" of the contractual partner.

\subsubsection{The Law of Self-Consciousness}

According to Gershom Scholem and, more recently, David Novak, the Jewish view of history is retrospective and commemorative rather than revolutionary. Only in the margins, among the radical adherents of mystical messiahs, does one find harbingers of the modern idea of progressive history as fundamental chance. Is it not possible, however, that Scholem, Novak, and others who envision Jewish history through the lens of a "law of return" are constrained by a naturalistic understanding of the law? Law is an expression of continuity and identity despite change. It determines the essence of a thing, its substance. Thus the myth of aeons, or its Kabbalistic variant in the shemittot, appears as a threat to order because it relativizes the authority of the law. For the new age there will be a new law. Ethics cannot establish itself in opposition to law, but it must transcend positive laws without invalidating the positivity of law. This is in keeping with the decision among the rabbis following the destruction of the Temple to arrogate to themselves the right to legislate rather than merely to adjudicate based on the transmitted legal corpus. ${ }^{98}$ The open-endedness of the legal process generates a sense of time that is eschatological but not apocalyptic. Legislation takes on the character of an innerwordly tikkun (repair) that provides both continuity (the law) and change (the adaptation and thus perfection of the law). It is not preliminary, existing for the time of exile until redemption through outside intervention, but a means of redemption. Even if not all Judaisms equally emphasize this redemptive character of the law, it is at least a legitimate possibility of interpretation and not an uncommon one.

According to Cohen, the greatest disservice of the widespread ignorance about Judaism is not rendered to the Jews but to law and jurisprudence. Thus Kant's separation between legality and morality (cf. 267ff) and thus the modern Protestant opposition between ethics and religion, rooted of course in the Pauline polemic against the law of Moses (267). The idea of natural law (derived from the Greek idea of an "unwritten law," nomos agraphos) as opposed to the laws of tyrants greatly advanced the possibility of establishing the law not only as a tool of oppression but as a remedy to it. The effort at an internalization of the natural law that characterizes late-18th- and 19th-century European

${ }^{98} \mathrm{Cf}$. Menahem Fisch, Rational Rabbis (Indiana University Press, 1998). 
cultural institutions ${ }^{99}$ that is also present in Kant's idea of duty, on the other hand, leads to an overemphasis on attitude (Gesinnung) and, in association with the idea of a free-floating absolute self in whose selfconsciousness morality is supposedly located, to the well-known and much lamented excesses of liberty. What served as a necessary "fiction" (to use Cohen's language) in the context of a critique of authoritarian rule turned into a dogma.

It cannot be emphasized strongly enough that Cohen recognized the highly problematic character of the modern liberal self. To Cohen, law is neither the condemning "law in my limbs" nor an innate moral sense nor knowledge of one's duty. Rather law is what it always has been: external to the self. Yet this heteronomy is nevertheless one that we seek to maintain for the sake of the other as much as for our own sake. Literally:

This is the new path that the principle of self-consciousness leads us: that we do not seek the law primarily as our own but as a seemingly alien one. This is the paradox in this concept of selfconsciousness. We know no I without a Thou, and thus no self without Thou or We. Therefore we do not seek the law in an absolute self. (266)

The ethical self-consciousness is thus distinct from an immediate or empirical sense of self. In fact, it is an act of emancipation from a natural perception of self. The latter is psychologically determined by memory and thus by the past. Ethics, however, is tied to the future. It has its mode in possibility, and the constitution of its object, action, is always a turning away from the past (280f). In other words, it is t'shuvah. Here we have both the idea of messiah and the idea of atonement together in ethical terms: futurity and transformation as characteristics of the moral selfconsciousness. ${ }^{100}$

The Kantian distinction between external force (legality) and internal self-determination (morality) is collapsed in the idea that self-legislation (autonomy) originates in an Other (heteronomy). This was already hinted at in the chapter on the self-consciousness of pure will (Ch. 4) where the Fichtean constellation of I and non-I was interpreted as a judgment of origin: the I originates in the non-I (in the form of an infinite judgment) (211). In contrast to Fichte, origination does not mean an act of positing, so as if in the end, or rather in the beginning (in the dual sense of arche, principle and authority), it was I after all who originated the I

\footnotetext{
${ }^{99}$ Cf. Michel Foucault, The History of Sexuality. Vol. 1: An Introduction. Transl. by Robert Hurley (New York: Vintage Books, 1990), pp. 60ff.

${ }^{100}$ The concept of time is more broadly discussed in the chapter on the "ideal," ErW pp. 398ff. Here, too, the context involves an interpretation of Israelite prophecy and its critique of myth and culminates in the idea of God's uniqueness.
} 
and the non-I. The thinking I (Descartes' ego cogito or Kant's "unity of transcendental apperceptions") is displaced by the unity of the cultural consciousness which is the psychological (or: encyclopedic) representation of the mutual translatability and correlativity of the whole of the system of cultural philosophy in its various directions. It is the thematization of what unifies the modes of unification and separation.

Instead, therefore, the ethical correlation between I and non-I is what emerges from the attempt to describe the theoretical underpinnings of the way in which legal subjects enter into the union of a contract (212). In a contract, the subjects are concrete but the norm of the relation established in contracts must be universally valid. It is this normativity that provides the model for the ethical self-consciousness. Here, then, the relation is the same no matter whether individuals, cooperatives, or states enter into contracts with each other. They all follow the pattern of the same norm and thus can all rank as self-consciousness. The rights of the other to whom I tie myself contractually establish me as an ethical self-consciousness. Without such partnership I would remain in a state of nature, a wild beast, not a spirit or self-consciousness. More importantly, before the legal relation, the Other is a mere other, a Nebenmensch. But through contract, he becomes Mitmensch, Thou. Only through the agency of this Other does the individual self enter into the purview of ethics. The law conditions a self which is therefore "heteronomous." The I and Thou of Cohen's Ethics is thus quite distinct from Martin Buber's differentiation between two types of experiences. While the latter's distinction between I-Thou and I-it is based on Kant's doctrine of "ends" (the I-Thou is a moral relationship in that the Thou is not reduced to an object or means but always an end in itself), it nevertheless seeks to describe a phenomenology of experience that is not in any way conditioned by law and morality. In Cohen, on the other hand, the Thou is generated by the contract. How so? Here we do indeed find similarities between Cohen and the various grammatological thinkers of the later 20th century, namely where Cohen derives the Thou from the character of law as direct speech. Contract is Anspruch ("demand") and Ansprache ("address") (248). The word Anspruch actually combines claim or demand with speaking to. The contract involves both and it is this which transforms the he or she into a Thou: "Thou is not he" (ibid.).

Thou and I are united in one self-consciousness which suffices to overcome enmity and alienation and thus becomes the foundation for the realization of the good in the legal community of the state. I-Thou is not a form of consciousness but an effect of the fiction or hypothesis of selfconsciousness that is generated by the contract. The result is that Thou and I can get along with one another (sich vertragen) without engaging in 
acts of suspicion or violence. Self-consciousness is thus not immediate but given in action and in the task of unity (249).

\subsubsection{Freedom of the Will}

A notion of heteronomy is also contained in Kant's ethics, namely in the aspect of legislation itself. To overcome the antinomy contained in the notion of freedom, Kant distinguishes between the human being in phenomenal and in noumenal perspective. Phenomenally, the human being is caught in the causality of nature. However, as a "thing in itself," he obeys the law of freedom that is determined by reason. Given the incomprehensible fact of evil, however, the self-legislated good is indeed a "miracle in the phenomenal world." The idea of freedom as the origin of our good actions generates "enthusiasm" on our part and a sense of the sublimeness of our task. ${ }^{101}$ Self-legislation is distinguished as the sole origin of that kind of law whose maxim can be called moral. The idea of freedom, in contrast to autonomy, is meant to generate in us the moral energy to activate self-legislation, a process in which moral religion (for Kant: Christianity as opposed to the statutory cult of Judaism) is seen as providing a paradigm (Christ). Freedom thus stands for an aspect of the affective capacity of the human personality that can and must be energized in augmentation of the steep command of self-legislation.

The lawful aspect of autonomy is often obliterated and displaced by the simpler idea of freedom as an innate human characteristic. In this view, radical Enlightenment gave modern man the notion of a sinless self, a self that needs to be asserted against unjustified infringements upon its range of action on the part of society and state. ${ }^{102}$ In somewhat Cohenian terms, one could say that what began as a hypothesis and an infinite judgment (the human being is not subject to total control by outside forces, be it by a sovereign or by God) turned substantive by an act of the imagination which transforms ideas into myths and dogmas.

What is freedom beyond the function by which it limits the power of coercion? In Kant, freedom is more than the freedom of philosophy advocated by Spinoza or Mendelssohn. As autonomy it indicates the task of generating maxims of action in accordance with the demands of reason (universality and necessity). As in the classical concept of freedom, however, Kantian autonomy is not immediately political, for this would speak to the realm of history and change in the public sphere and thus seemingly to the success of ethics which is clearly beyond the reach of good intentions. Rather, in line with the Pietist tradition from

${ }^{101}$ Kant, Religion, p. 63.

${ }^{102}$ I choose "man" in this context because woman and other "minorities" have begun to enjoy this gift only much later. 
which Kant hailed, it remains private when it amounts to the influence one has upon one's becoming a morally good person.

Cohen attempts to overcome the Kantian restriction of morality to the private sphere by eliminating the barrier between morality and legality. Accordingly, the notions of freedom and autonomy need to be redefined as well. His procedure in approaching the meaning and function of the concept of freedom is the same that he applied to all other historically mediated concepts: he examines the history of the problems that are associated with the term in question.

The chapter on freedom (Ch. 6) is preliminary to the more elaborate exposition of the concept of autonomy (Ch. 7) in that the latter absorbs freedom in the sense of the origin of action in self-consciousness. Yet the former continues to remain useful as the affective ground and motor of ethical self-transformation.

Historically, the origin of freedom is determined in Platonic philosophy as an opposition to lust as the motor of human selfmotivation. Freedom is therefore associated with the idea of the soul as the principle of movement. It indicates movement that originates in us, i.e., in the self (auto). We act; we are not acted upon. Yet this selfpropulsion remains undetermined. It is a hypothesis that begins with the infinite judgment: not with lust/passivity/passion.

In Aristotle Cohen finds two important notions: voluntary action (hekousion) ${ }^{103}$ and intention (285f). ${ }^{104}$ The former stands for self-generated agency, the latter concerns the problem of intentional action which ranks centrally in Cohen's understanding of both ethics and religion. One of his favorite quotations from Socrates (transmitted by Aristotle) is one in which virtue and knowledge are identified. ${ }^{105}$ We saw already in the context of the religious idea of atonement how important it is for Cohen that $\sin$ must be unintentional in order to be forgiven. To Maimonides and the rationalist tradition, $\sin$ is a consequence of ignorance and thus a lack of the exertion of reason. Evil has no being because it is merely a lack of reason. Quite in opposition to other biblical traditions that had a greater impact on the common opinion, the possibility of intentional evil is thus eliminated. In the Christian tradition, for example, sin and sinfulness are associated with human passion, a notion that agrees with the Greek philosophical notion that intellectual activity alone can determine voluntary action. "Enslavement" to sin can be taken as a mythological expression of the same idea, except that liberation from this

\footnotetext{
${ }^{103}$ Eud. Ethics $1223 \mathrm{ff}$.

${ }^{104} \mathrm{Ibid}$, and cf. Plato, Nomoi $860 \mathrm{e}$. Cohen was aware of these passages from the time of his Latin dissertation on necessity and contingency in Plato and Aristotle. ${ }^{105}$ And cf. Kant, Religion, p. $61 \mathrm{f}$.
} 
enslavement is eventually made not a problem of gnosis but of the administration of the redemptive merit of Christ, replacing one kind of dependence by another. To Cohen, the common denominator of ancient Greek and medieval Christian notions of ethics is the preponderance of the polis/ecclesia over the individual (296f).

Cohen seeks to determine the problem of "what moves us" in a kind of (collective or correlative) autonomy wherein the self is energized in exchange with an Other. In this economy of motivation, the passions must not be demonized to the degree that morality is identified with Stoic apatheia or religious asceticism. The latter is again a goal that cannot be achieved except by saints and is thus useless for ethics. Rather the "affect" as a synthesis of attraction and repulsion (Lust and Unlust) should be preserved and utilized in its beneficial effect as a "motor" of moral action. On the other hand, the achievement of wish fulfillment or eudemonia, must not be made the purpose and end of moral action either (with Kant, against Aristotle's teleology). Whatever freedom means, then, it must neither lead to enmity against one's "affective soul" nor to its opposite, its satisfaction as an end in itself. Put differently, how can freedom be conceived of without leading either to a total rejection of feeling or to self-indulgence? (cf. 292)

The chapter on freedom thus sets out by justifying the affective aspect of action by defending the affect of "joy" (Freude), i.e., the modern notion of a "pursuit of happiness." Freiheit and Freude (the latter was exchanged for the former in Schiller's Ode to Joy for reasons of censorship) are seen to belong together as an expression of the "socialist" impulse of achieving happiness for all. What moves ethically motivated politics in the modern age is therefore very much associated with a pleasure safe from confusion with classical eudemonism in that it means the joy of the brotherhood of men. Freedom is thus an aspect of political optimism and an antidote to Schopenhauerian pessimism that leads to apathy and a politics of restoration (296).

In terms of the problems of will, action and self-consciousness, freedom is here the end and objective that is striven for collectively and in political and legislative action. In the late 18th and early to mid 19th century as the age of revolution, such resultative freedom and happiness was justified as the outward manifestation of the nature of man who legitimately strove for the political realization of the freedom that he had first acquired inwardly. To Cohen, the major source of the inward freedom of the individual that comes to fruition in its correlation with the modern state is religion. Religion is the source of an idea of freedom in that the religious idea of sin first isolates the individual in her ability to choose between good and evil. More precisely, as we know from the essay on atonement and as we find it again in the chapter on freedom in 
ErW, the individual is "discovered" in the causal reduction of suffering to individual $\sin$. The purpose of this reduction is not the death of the sinner but her life which emerges through the transformative process of t'shuvah/repentance (ErW 298ff). This achievement which Cohen attributes to Ezekiel is of considerable cultural value and on a par with the Socratic discovery of virtue as knowledge.

The Western concept of individuality that results from the notion of subjective agency in the causality of suffering is mediated through the Christian religion which is thus recognized as a decisive cultural source of modernity. This understanding of Christianity can already be found in Cohen's response to Treitschke, as we saw above. While monotheism, i.e., Israelite prophecy, has the merit of discovering the individual, Christianity exerted the cultural influence that allowed for an exploration of "the private labyrinths of morality" (298). This is in contrast both to Greek philosophy, with its primarily political perspective, and to polytheism, where following the demands of one god means transgressing the commands of another. The idea of the unique God was necessary in order to generate an integrated human being. Oneness of God is the precondition for a conception of the moral problem as that of the integration of the moral impulses of the human being.

The modern state (308ff) is thus constituted in a combination of the Greek political idea of a state and the monotheistic idea of the individual. The precondition for its emergence was the destruction of the universal (i.e., Catholic) church that had prevented the state from becoming a selfsufficient representation of the well-being of all citizens as well as the individual from seeking her and everyone's well-being in the state (308). This correlative politicization and individualization begins therefore with the Protestant Reformation of the 16th century.

In the context of modern society and its economic relations, however, the philosophical problem of an origin of agency is no longer central. As we noted above, freedom represents the goal of political action rather than the origin of action. The latter is preserved, however, in the question of the legitimacy of the modern state. This question is posed in terms of the origin of the law. The law as the sovereign can be anchored within the citizenry of a republic only if it can be shown that, in some sense, each citizen is, at least potentially, the source of the law. Kant determines the origin of law as the self-legislation of reason (cf. 317-319), i.e., in the idea of autonomy, rather than a recurrence to a state of nature (a term that, to Kant, suggests necessity rather than freedom).

The chapter on freedom seems to me to serve two purposes. First, it explains the origin of the idea of autonomy as historically rooted in the religious notion of freedom which, secondly, is however not completely displaced by its secular offspring. Freedom stands for the individual 
origin of action, autonomy for the self-sufficiency of human agency in originating moral law. The shift in emphasis from freedom to autonomy is a shift to the political problem of ethics. But the religious problem of individual agency is not dismissed. Instead it is left to be resolved in a "deeper religiosity" in which ethics and religion are to be "reconciled" (388). Namely, in the transition of ethics from Grundlegung (the laying of foundations) to application, the contemplation of "the ideal," "the idea of God," and of the virtues, is introduced as a "second floor" (neues Stockwerk) where this reconciliation is to be accomplished. Here, Cohen actually uses the term Versöhnung (388) and his intention of correlating religion and ethics seems nowhere more evident than in the intention to preserve the notion of freedom in the idea of autonomy and to determine the connection between them (323).

Even though the essentialist notion of freedom that had prevailed in the medieval concept of a person is no longer meaningful, the question of the origin of action must still be posed even for the "modern socialist person." Does freedom indicate the notion that the moral agent is to be regarded as an end in itself or does it have other significance as well? Cohen aims to distinguish freedom from autonomy in order to find "the inner secret (...) which from the beginning determined the deepest meaning of freedom" (ibid.).

With this reference to the religious core in the metaphysical problem of freedom and the promise to bring it to a solution that can stand up to the modern consciousness as determined by the methodology of the logic of cognition, Cohen gives us a clearer sense as to why he believes that the ethics as a whole was meant to culminate in the concept of an ideal and in the idea of God as its capstone. It is clear now that the program of "resolving religion into ethics" has as much to do with an ethical interpretation of religion as it has with a religious interpretation of the ethical problem. The socialist person should not be deprived of religion. But religion is not an illusion or an opiate for the masses. Ethics benefits from religion to the degree that religion can be conceived of as the source of individualization that its own politicization can presuppose but not generate. Autonomy integrates the socialist person into the state as the correlative institution of the very law that proceeds from the rational will of the individual citizen. But this citizen remains an abstraction, one of many, at her most concrete the legal partner of another legal partner, unless ethics is able to retrieve the notion of freedom as it concerns the problem of the individual as the origin of action. Ethics thus stretches from transcendental foundation to the problem of realization which is incomplete unless it can reconcile itself with the forces that present themselves in the religious notion of freedom understood as the actualization of moral self-constitution: the sinning 
and repenting individual. This augmentation out of the monotheistic religious tradition is possible only, however, if religion can be authentically shown to work without recourse to a substantive self. In Cohen's view, Judaism can be demonstrated to be a paradigmatic religion of (socialist) reason in that it originates historically and actuates liturgically that freedom which, above and within the modern notion of autonomy, is necessary for a full realization of ethics on the individual and communal level. Freedom, in Judaism, means a "fear of heaven" that, in contrast to the Stoic fear of the gods (294), leads to a daily renewal of the moral energy of the human being. The unique God not only enables the individual by providing the condition for the possibility of uniting all moral energy within the individual's ability to turn around and transform herself, but God also stands for the confidence that nature can sustain such transformation.

But why does Cohen need to go to such great length to hide religion in ethics? Others (not least among them his Marburg colleagues Natorp and Herrmann), too, associate religion with the problem of the self, individuality, and subjectivity. But where for Natorp religion comes to stand in for a correlation between the individual and a totality that appears on the limit of reason, Cohen wants religion to be recognized in its ability to sustain the realization of ethics. And where Herrmann aims to make ethics propedeutic to the experience of the real self, Cohen cannot approve of what he perceives as the stealth return of an absolute individual through the door of a religious Apriori. More fundamentally, the rhetorical difficulty arises in a universe of discourse where all concepts are determined by a Christian experience and where communicating the Jewish experience in more general terms poses the almost insurmountable obstacle of having to dismantle the Christian connotations of the terminological apparatus first before providing it with alternative connotations. The living source of this alternative formation of concepts is not an alien religion, but a misunderstood and thus unknown symbolic system.

Further, Judaism imposes a different perspective on almost every problem since its concept of the human being emerges from a different context. Once the task of translation into general terms is accomplished, however, the result is not only a philosophy of religion but a new approach to ethics, one that allows fusion of the problems of legality and morality. Just as Judaism is a religion of law, the Ethics of Pure Will is a philosophy of law. Just as Jewish messianism forces Jewish nationalism to embrace a concept of humanity, ErW establishes the state in its moral nature as founded on a correlation with the dignity and equality of all. Just as sin and repentance provide the liturgical means by which individual agency can be maintained in a system in total mutual 
responsibility, freedom is maintained in the notion of autonomy. Just as religion must have its center of gravity in a correlation of God and the human being that focuses on the problem of human morality, so ErW is construed from the "fundamental law of truth" through the idea of God and human virtues on the presupposition that the ideas of God and freedom must be maintained if an idealist ethics is to find its path to realization. This description is oversimplified to the degree that Jewish concepts are already part of Western cultural history. But the task of the philosopher is not merely to determine the biblical influence on past Western concepts but to make Jewish religious philosophy fertile for concept formation in light of modern scientific, philosophical, and political revolutions.

\subsubsection{Autonomy of Self-Consciousness}

The chapter on freedom is somewhat fragmentary and a kind of excursus into the history of the notion of freedom. At the same time it is most suggestive as to the overall religious intentions of the ethics. In contrast, the chapter on autonomy is the most systematic elaboration of both the psychological and the political aspects of self-consciousness. Here we find more fully developed the notion that, in the modern state, politicization and individualization are mutually constitutive. Where religion actuates freedom in the correlation of individual and God (set in the particular liturgical community that comes with its own set of community related virtues), ethics establishes the direction of the task of self-legislation that is actuated in a correlation of individual and state. Since the latter is moral only to the degree that it preserves the ideal of humanity in its members it also contains an element of transcendence towards the larger humanity in a league of nations. Ethical virtues are thus political virtues that apply equally to the citizen as to the state. As in Kant and the ancients, virtues concern the continuity or steadiness of the direction of action; in Cohen, they contribute to the realization of will, action, and self-consciousness in accordance with the "eternity" of the task.

The chapter proceeds in four steps, distinguishing four aspects in the term autonomy: self-legislation, self-determination, self-responsibility, and self-preservation.

\section{Self-legislation (Selbstgesetzgebung)}

Originating from the Aristotelian meaning of freedom as voluntary action (hekousios), autonomy concerns freedom from heteronomy. The heteros against whom autonomy is established, however, is not an Other but the sensuality that compels us to act involuntarily. Freedom is what emancipates us from the animal instinct and is thus that first "no!" from 
which all culture and civilization arise. Desire is "pathological;" it is a passive influence that should not be mistaken for the origin of moral action if the latter is defined as autonomous. Such rejection of libido as lawgiver is mitigated, however, in that Cohen wishes to preserve and justify sensuality to the degree that it follows and boosts reason as the moving principle of the will (cf. 326). The real opponent is not sensuality but egotism, the opposition to the social direction of the will and its constitution in a We. The ability to resist egotism rests on trust in the sufficiency of reason to achieve what it sets out to do (say, to establish virtue as knowledge), on trust that it can prevail. The converse would be to distrust reason and expect that inter-human relations be steered towards greater good if guided by universal instinctive egotism.

Self-legislation as trust in reason is the fundamental characteristic of idealism in general. It gains its political relevance if one takes reforms and revolutions in religion and politics as an expression of ethical idealism, namely of idealism as the struggle for rational self-legislation against the obscurantism of religious and political power. Just as scientific revolutions proceed on the basis of the hypothesis, political revolution is based on the application of the hypothesis to history in the form of a "historical attempt" (historischer Versuch). "Reforms and revolutions are the periods of experimental ethics" (328, cf. $\left.423^{106}\right)$.

In contrast to Hegelian and Marxist attempts to identify concept and history or, respectively, economic law and history in a way that subjects historical development to the mode of necessity, Cohen tries to give political action towards change an ethical justification. By giving political action the ethical dimension of an attempt to realize the morally good, he integrates history with theoretical idealism in the mode of possibility. This is not to endorse political experimentation as an end in itself. Although ethical idealism wishes to provide a critical foundation to political engagement, Cohen nevertheless cautions that experimentation is in need of theoretical justification. Experimentation alone leads to an increase neither in knowledge nor in the good. On the other hand, in union with the kind of ethical reflection provided in ErW, political reform could progress with greater certainty. Thus one might see Cohen's intention as an "attempt" (cf. preface p. VIII) to elevate to the level of conscious reflection that rationale which unreflectedly fuels reform movements in religion and politics. Seen from this perspective, Cohen's ethics again foreshadows Ernst Bloch's "principle hope" to the degree that the latter intended to bring to the level of the consciousness of principles those utopian hopes that fuel revolutionary political action.

${ }^{106}$ In the latter passage, p. 423, the notion of "Versuch" (attempt) is shown to be borrowed from the context of esthetics. 
The difference between Bloch and Cohen is that the latter's optimism is based on the self-sufficiency of reason whereas the former's optimism is founded on faith in the very self-healing forces of human nature that Cohen deems an expression of heteronomy. For the belief in the selfhealing forces of nature, all theoretical or historical naturalism, is to Cohen a form of idolatry (329). The very point of monotheism is to indicate the eternal transcendence of the agreement between nature and freedom, practice and theory; it is to deny the human spirit the illusory Faustian moment of rest.

This means that the self cannot be taken for granted or as a given naturally or historically. Autonomy is legislation that has the self as its result rather than as its presupposition (hupokeimenon). Autonomy generates self in legislation that not only determines and holds responsible the self, but also preserves it against all claims of nature, law, religion, or state to the contrary. As a hypothesis, autonomy exerts its founding function by providing a critique of legislation, denying validity to any principle that was to establish heteronomy over the self of reason.

\section{Self-determination (Selbstbestimmung)}

The self as the purpose of self-legislation needs to be further determined. So far it has only come into question as a formal, even negative, directive for legislation. In the interest of its realization, the will must become determinate in particular action. What aspect of a determinate action concerns the self? The self of autonomous agency concerns the determination of the subject to act, i.e., the aspect of voluntary action that we call intention (Vorsatz). What is the relation between intention, self, and action? Autonomy determines this relation so that the intention of the self is manifest in the action. But this statement can be taken to mean one of two things. Either the substance of the self is primary and can be known from its attributes (voluntary action). In this case, Kant's notion of an empirical character is taken in the sense given it by Schopenhauer. The person who steals is a thief. Stealing is the empirical manifestation of the character of a thief. Thus if one can draw conclusions about the substantive intention of a continuous self from its manifestations the self is subject to a naturalism that eliminates the very possibility of the ethical confidence that ErW is after. But the above sentence can be taken to mean something quite different, namely: the action that is determinate and concrete becomes the origin of the self. The self is generated in specific actions that are correlative to specific intentions but in such a manner that the self itself is not determined other than through its manifestations (cf. 392).

Against St. Paul (and Kant) and with St. James, faith is determined from action rather than the other way around. The possibility of a formal 
immorality despite material morality cannot arise because the intention is manifest in the act. What you do or say is what you wanted to do or say. On the other hand, if autonomy is to work at all, there is no need to do or say now as you did or said yesterday. The empirical character is open to development and its destiny not determined until the day of death. The self of autonomy never is, yet always ought. It develops perpetually in the pursuit of the task of generating itself. This is its intention and its perpetual self-determination. The possibility of such ever-renewed agency is the meaning of freedom (349-352).

Self-determination is therefore also an emancipation from one's past, an emancipation that can be accomplished only through intentional action. Such action always presupposes foresight and taking into account of the effect of one's action on others. Therefore, each specific act of selfdetermination is accomplished in the face of others rather than in some sort of splendid isolation. The self is thus determined only and always in relation to others and its existence as an isolated self-consciousness impossible (352-356). A self that is generated in the determination of intentional action and presupposes the presence of others takes into account both the ability to reason and anticipate the consequences of one's actions as well as the reality of others towards whom the action is directed.

This priority of the Other is unavoidable but it is not necessarily already an ethical fact. If it is prior to autonomous self-generation it allows autonomy to be couched in a heteronomous environment. The latter can be maintained only if what we are dealing with is not merely a closed psychological system of perception and representation. Perhaps it is for this reason that God must enter into the picture because only if the psychological environment includes the presence of (the idea of) God can it be expected that all cunning of reason must come to an end. Psychologically speaking, self-determination needs a kind of interruption of the endless games of representation one can play in order to avoid real responsibility. Cohen seems confident of the otherness of the Other that one represents to oneself in anticipation of the consequences of one's actions. He can feel confident of this realism of representation because he anticipates the need to atone that provides the human being with a reality check of the autonomous self in the face of the Other. In this reality check one's wishful representations of others are revealed as illusions and projections of egotistic desires. Sin is what I have committed by reducing others to projections of myself. But what I failed to achieve, because I sinned, was my Self. I was driven by desire rather than by reason that takes into account the otherness of Others. In the process, I lost my Self and am in need of the restoration of the direction in which I must pursue it. For I can have it only as a pursuit. 
While I missed its pursuit, I was in error because I thought I was actuating myself and my own interests. But by doing so I missed it. Sin is error. Repentance is self-generation through transformation and change of the direction of my pursuit of Self.

As a result, self-determination means determination of Self through intentional action. The Other is present in self-determination as the object of my intention. As such he is prior to the self that is constituted. This self is therefore the element of an asymmetric correlation. The self that is distinguished from an organism animated by its desires has its being only in determinate legislative action that maintains rather than destroys the Other. Self-determination is always moral because immorality always implies loss of the correlative self. Hence sin is indeed error, for in order to sin intentionally reason must be applied towards the goal of self destruction which presupposes insanity in the legal sense that propels the perpetrator beyond the pale of culpability.

\section{Responsibility (Selbstverantwortung)}

The question of the freedom of the self, in intention and action, arises in opposition to natural causality. It expresses the notion that consciousness be more and other than a mere "mechanism" (357ff). The mechanistic concept of consciousness, as we remember, was not only the heuristic assumption of scientific psychology in the 19th century but it had become the scientific creed that rendered philosophy superfluous. The neo-Kantian movement aimed to retrieve the legitimate business of philosophy by distinguishing psychological and transcendental method, the function of thought being logically prior to the discovery of the laws guiding the mechanism of consciousness.

In ethical and religious terms the notion of freedom traditionally answers to a more specific problem of causality, namely the causality of evil. Freedom of choice means that no one is to blame for evil but the one who does evil. Kant demythologizes the notion of primordial evil which, with Christian interpretation, he reads into the pages of Genesis 2-4, by allowing for the fact that the ultimate cause of evil is beyond rational comprehension. It is, therefore, a given of experience and part of the mystery of freedom. Cohen, in a move typical of his optimizing hermeneutics, rejects the mythological remnant in the concept of freedom that accounts for the origin of evil but still asks for a further constructive meaning. In Kant and the Christian tradition in general, evil is substantive and freedom provides it with a transcendental foundation (362). In contrast, Cohen asks whether freedom in the sense of the origin of evil can still make good sense in reflecting on the constitution of the moral consciousness. Although it exempts from the law of causality, 
freedom should function in the context of determining the law of selfconsciousness rather than as an exception to it (361).

The religious origin of the concept of freedom concerns the problem of individual responsibility in contrast to fate and the causal nexus between generations. The discussion therefore turns to the historic shift from the collectivism of mythologically founded cultures to the individualism in the concept of atonement as it emerges in Israelite monotheism. Mythology presupposes the good as cosmic order into which evil unaccountably enters (362). By implication, Kant's philosophy of religion is here criticized as remaining caught in the mythological concern with death rather than serving the interest of religion in enabling life.

The manuscripts on Versöhnung ${ }^{107}$ show that Cohen's concept of atonement and thus of the problem of individuality in religion is developed in constant discussion of the differences between Greek and Hebrew conceptualizations of the problem of freedom. The problem of guilt as the origin of the notion of freedom thus turns into a fundamental topic in the emergence of culture out of myth (364). The philosophical dimension of this history consists in the effort of making past transformations from myth to culture perspicacious, allowing them to be re-cognized so that they can serve the purpose of overcoming the mythological mentality in our contemporary concepts.

Here in ErW, the chapter on responsibility represents the difference between Greek and Hebrew cultural transformations of the common mythological heritage in terms of lyricism (Poesie) and religion. Freedom and the individual are the core problems in poetry and religion, and it is the task of "theoretical culture" to bring these problems to a resolution. But there are eminent differences in the way in which the problems of freedom and the individual are handled in lyric poetry and in religion. The tragedians recognize that the individual must be made the bearer of his own fate by making him the origin of his own misdeeds. Despite the lack of knowledge, the cathartic moment of anagnorisis (cf. Appendix B, Text 14) means recognition of responsibility and thus produces an isolated individual. The character of this individual is heroic. The moment of recognition leads to a response of relief and purification not so much in the actor, whose inner life is beyond representation, but in the spectator (365). Thus art moves the audience by inviting it to emulate the excellence (arete) of the hero (366). Religion similarly provokes movement, albeit of an utterly unheroic sort. It generates the moral individual out of the realization of the weakness of the human being. Sin

${ }^{107}$ Notes by Cohen on Versöhnung from Nachlaß Natorp Ms. 831; see here, Appendix B. 
is without knowledge (sh'gagah). Sacrifices atone for sin, purifying the individual who has unintentionally become impure or guilty and must not be left to bear the consequences. Forgiveness presupposes that guilt is forgivable and must not henceforth determine the fate of the sinner. In that the individual is to be called to give account in the context of the law only responsibility remains: concrete transgressions demand that the concrete transgressor be called to justice. The problem of guilt (culpa) is resolved before God so the problem of responsibility (dolus) can be resolved by legal means. This leads to a separation of cultural functions. Guilt remains an ideal problem of poetry and religion, but responsibility can be resolved concretely in legal terms (ibid.).

Mindful of both Hebrew and Greek sources of poetry and religion, the unity of the cultural consciousness integrates heroic and religious aspects of freedom and individuality. To the degree that these concepts contribute to the ethical problem of a responsibility of the self, their difference is mediated in theoretical culture whereby the problems of freedom and the individual are brought to a resolution.

Selbstverantwortung, responsibility of the self, concerns the self that responds to an accusation not by blaming others but by blaming oneself: I am responsible. I did it. The person who accepts the guilty verdict is thus, somewhat paradoxically, not evil but good. While responsibility is here acknowledged only in hindsight, this recognition is the condition for the transformation from which the moral self is to emerge.

In a court of law, it is the judge who pronounces guilt. This pronouncement must not be mistaken for a moral judgment. It is merely a legal judgment. Here the individual is a case of the law. The moral judgment, however, must be pronounced by the self that (re)generates itself as a moral individual by judging itself. Taking responsibility for one's past actions is not equivalent to self-condemnation to the point of self-destruction (see below, on self-preservation). Rather, the recognition of (past) guilt is the beginning of (future) morality. Virtue as knowledge begins here with the recognition that oneself is the origin of one's action. Sin as error and the notion of redemption must not eliminate this kind of knowledge of self-responsibility. Ethical self-responsibility also transcends the judicial concept of responsibility in that it concerns the self even where the jury finds the defendant "not guilty" (370f). Here and only here does Cohen thematize an inner self that is beyond the "limits which are set for the innermost property of the self" behind which even the judge must not probe (372) because it is the very condition of all legislation. 


\section{Self-Preservation (Selbsterhaltung)}

Has the idea of autonomy in the sense of responsibility led Cohen to the affirmation of an ineffable and absolute core of the self after all? Or is the "innermost property of the self" a further condition in the sense of a hypothesis? What is it the condition of? One could consider an alternative first. If the self were construed without a core that lay beyond the reach of a court of law, the legal system would be in possession of an absolute right over the life and death of the individual. Cohen's argument for the ethical transcendence of self-consciousness therefore has the effect of limiting the power of the state over the lives of individuals. The death penalty cannot be justified because it leads to an "annihilation of the moral person." It extends the reach of legal authority to include the right to destroy the very kind of self that is the source of its own legitimacy. Death imposed on the transgressor of the law is thus morally self-destructive in that it annihilates the very self it is meant to maintain and in which it finds its Other. In Ezekiel, as in rabbinic law since the destruction of the second Temple, the death of the sinner is in opposition to the interest of religious life. The material maximization of life forces, however, is not the point, rather, that repentance and selftransformation are possible as long as the breath of life is within a person. To destroy life means to arrogate to the law a divine prerogative: foreknowledge. For the self as a task is a matter of the future which cannot be determined from its past. Autonomy of the self is not fact but pursuit, not being but ought (382).

The problem of the preservation of the self therefore calls for a theory of the purpose and limits of punishment (374ff). After guilt as culpa has been entirely appropriated to the cause of moral selfresponsibility and thus to subjective concerns beyond the law, the interests of the law itself are as yet unresolved. We know the peculiarity of the moral self as a limit to the range of punishment but what is its objectively necessary aspect? Must punishment not function as a deterrent and as retribution? In Cohen's discussion of these matters, the preservation of the self still provides the measure of justice. Instead of wondering whether the punishment of one can have the effect of deterring another, a matter which cannot be resolved in theory, Cohen justifies punishment as an objective representation of guilt to the guilty. Even more original is his notion of retribution. The German word Vergeltung is interpreted as Abgeltung and Aufhebung, i.e., gradual diminution and elimination of guilt. The whole purpose of the judiciary, as of the ritual of atonement, is the restoration of the moral person. A well known talmudic anecdote, an exchange between Rabbi Meir and his wife Bruria on the meaning of Psalm 104: 35 " "let sinners vanish from the 
earth"), points in this very direction. Rabbi Meir, perpetually bothered by ruffians in his neighborhood prays for their destruction. Bruria, however, takes issue with his anger as much as with his literal interpretation of scripture. Changing the vocalization from "sinners" to "sins" she points to the fact that if sins vanish, the "evil-doers will be no more" either. R. Meir is converted, he prays for the repentance of the sinners, and they, in turn, are converted.

Applied to the theory of punishment, Cohen argues that instead of condemning a transgressor to "carry his sin" (la-set avono), punishment must be understood as allowing the sinner to "vanish" the moment he begins to take his punishment upon himself. The objectivity of the punishment provides the emerging moral subject with the claim of an exact retribution that counterbalances the objectivity of the crime. Both guilt and punishment are concrete and limited. Beginning at the very moment punishment is pronounced, the sinner begins to turn into the innocent and purified individual who emerges in renewed potential for future moral action (383). Punishment ends guilt and thus the guilty is no more. Subjectively it is necessary for the guilty party to accept her guilt and begin the work of moral self-determination anew. The fundamental presupposition, however, is that the law deals with cases of relative evil only and that human judges have only limited knowledge of the causal entanglements and guilt of human beings. Within this purview there is neither absolute good nor absolute evil $(381,383)$.

In a characteristic turn, one that we are familiar with from Religion der Vernunft where the chapters on individual and atonement are followed by a discussion of messianism, praise of the universal perspective augments the narrowing of the focus on the particular (36888). The judiciary can function as an agent of morality and selfdevelopment only within a larger culture that takes itself as such an agent. Ethics is here the expression of an educational mandate of theoretical culture promoting as its core concern a political morality that is within the reach of human efforts. In analogy to Kant's sphere of ends (Reich der Zwecke), the reach of ethics extends to include morality and legality, self and legislation, within the correlative political sphere in which citizen and state, state and citizen, pursue one and the same task. The same law determines the well-being of individual self and universal all (Allheit); the same law also determines the direction of development of particular religious communities within the state to the degree that they are guided by the ideal of a reconciliation between religion and reason. It is to this possibility of reconciliation (Versöhnung) between pure ethics and a "deeper religiosity" that Cohen turns in the remaining chapters of ErW (388). 


\subsubsection{The Ideal}

In chapter eight, on "the ideal," Cohen describes the structure of his Ethics as twofold, dividing it into a theoretical foundation of pure ethics in its constitutive concepts of "pure will," "action," and "selfconsciousness" and a practical application of these concepts to the problem of realization in which he examines how idealist ethics can become real for real human beings (389f). The ethical self-consciousness is characterized in its four aspects, but how do those aspects relate to the concrete reality of states and individuals? While the theoretical part of idealist ethics defines a task, the practical part addresses the conditions for the realization of this task. The task itself, however, is inherently such that it can never be absolutely completed. It would cease to exist as a task if this were possible. Rather, an inherent characteristic of ethics (as of knowledge) is its infinity (411). It is infinite in the sense not of an unfulfillable ethics of saints but as an "eternal" task, one that cannot be exhausted and that never loses its validity or urgency. The sense of time generated in ethics is determined by the openness of the future through the transformation of the past (400ff). This is to be distinguished from the myth of an eternal return that leads to the ennui and detachment that are the very opposite of the political activism this ethics intends to justify. The idea of the unique God means, among other things, that the principle of uniqueness also applies to this world and the possibility of its transformation. The messianic Now! and the prophetic You! unite in the certainty that the transformation of the world into what it ought to be depends on Us, and therefore on Me (cf. 406f).

Cohen characterizes the realization of ethics as hovering "between heaven and earth." Like the Torah, the good is "not in heaven" (Dtn 30:12). The phrase "it is not in heaven" is prominently quoted in an episode located at Yavneh (home of the Sanhedrin following the destruction of the Second Temple in 70 C.E.) that deals with the question of rabbinic authority to legislate rather than merely adjudicate divine law. In this story, often referred to as "The Oven of Achnai," R. Eliezer ben Hyrkanos, who represents reliance on oral tradition, calls on divine intervention as testimony to the legitimacy of his opinion. If he is right, the walls should bend, and so they do, culminating in a divine voice confirming that the halakhah is in accordance with Hyrkanos. To this his opponents reply: "It (viz. the Torah or the authority to decide halakhah) is not in heaven!" God has the last word, ironically endorsing the latter opinion by saying: "my sons have vanquished me" (bBava Metsia 59b). In the context of the ideology of Jewish reform, which Cohen shared, the passage has been read as an endorsement of the rational character of the rabbinic tradition. The verse from Dtn 30, however, is also quoted in 
Romans 10, where it is interpreted in opposition to the "righteousness of Moses" which Paul aptly summarizes "that the man which doeth those things shall live by them" (Rom 10:5, KJV). Cohen's ethics, to the degree that they are a polemic against Christianity, can be understood as a defense of the Mosaic law in its life-giving quality as a sufficient source not only for ethics but also for the "deeper religiosity" that is in complete agreement with ethics.

In the immediate context, arguing for the conditions of the realization of ethics, "not in heaven" is first of all augmented by the claim that it is not on earth either. The concepts of practical reason are not the forms of natural reality. Self-consciousness is not homo noumenon, for it is not correlative to a phenomenon (393). The intelligible character is not an aspect of nature that appears as the origin of action (contra Schopenhauer) but a goal and direction of action (392). Not even law can count as the realization of the essence of freedom (against Hegel; 393).

Neither merely in heaven (but surely of a heaven-like origin) nor as yet on earth (without entirely being beyond our reach), the good is teachable. It can be known. Yet it is neither merely pure thought nor pure actualization, but-similar to what is implied in Plato's simile of the cave-it calls for a concept of self-education. In contrast to theoretical paideia, the education of the will proceeds in acts of self-transformation in which the good is "anticipated" or realized in reiterated tentativeness. This discussion of the tentative nature of realization is reminiscent of the second part of Logic of Pure Cognition where the methodology of scientific research, especially the relation between hypothesis and experiment, is developed in terms of an applied logic. Where the logic of scientific research is guided by the syllogism that allows the scientist to describe unambiguously the anticipated result of an experiment, the step from theoretical to practical ethics leads to the problem of education. The common linguistic ground between scientific research and ethical attempt associates both of these spheres with a third one, namely esthetics. The word Versuch indicates the subjective aspect of praxis in relation to theory: in science, ethics, and esthetics. In practical terms the ethics is thus a theory of the attempt to determine the good and of pursuing it to the best of our ability. The esthetic context supplies Cohen with a term that indicates both the objective nature of the product of an attempt - the work of art-as well as the characteristic of this "work" in relation to the "attempt." The completed work is always the mere "attempt of a work" because it was formed after an "archetype" (Urbild) or "ideal" (cf. 404, 419, 423).

For ethics, the problem of the human being is one of action and direction. The fulfillment of the ethical imperative is the attempt. The attempt is neither a mere thought nor an absolute and final realization 
but an action in which the human species stretches towards greater perfection and thus transforms itself act by act, accomplishment by accomplishment, repentance by repentance, individual by individual, community by community, state by state. But the result of this transformation is only readiness for more transformation. The reward of a commandment must be-a commandment. In contrast, the dreams of immortality and of a historic golden age, classic images of the reward promised to individual and community, merely express unhappiness with the actual circumstances without turning hope into a ground of action (401). The hoped for perfection must not be a vain affect but must drive us to active participation in transformative politics (404). Cohen anchors his notion of hope as an ethical motive in the monotheistic idea of God which functions to enable the pursuit of this-worldly morality. There is nothing sentimental about this "deeper religiosity." With the medieval doctrine of attributes on his mind, Cohen can claim that God teaches what a human being is (403). The prophets force the perspective of the people away from nature and onto history as the realm of their own agency. They are not interested in culture (hence there is no Prometheus myth in the Bible) (405). Instead, they direct human vision towards the end of history through the ideal of peace. The prophetic notion of the future transcends national boundaries (406) and in this way determines the direction of national politics. Prophetic messianism therefore supplies "the primordial moral force; the most powerful idea that ethics must borrow and adopt out of a field that is foreign to philosophical methodics" (407).

Ethics adopts the messianic idea in form of the notion of progress. The effort to end war, not the notion of an "end of history," is the driving principle of peace. The development of world history cannot come to an end even in a state of peace between nations because at no stage of its realization is morality realized. This futurity is expressed in the notion of "eternity" (407, 410). For the key terms of will, action, and selfconsciousness it means a principal impossibility of their materialization. The concern with the realization of ethics is not exactly one with the reality of its concepts. Strictly speaking, concepts are not subject to the modality of reality (421f), but it would be destructive to deprive ethics of a relation to reality.

The adoption of the religious idea of messianism into the Ethics also exerts an important critical function vis-à-vis Kant in that it displaces the postulate of an immortality of the soul (413ff). The immortality of the soul belongs in an ethics of conscience where it serves the function of maintaining future reconciliation in the face of present failure and unhappiness. In contrast, the messianic idea of world peace generates the energy that is necessary to move the political process forward in the 
eternal effort of improvement. To Cohen the immortality of the soul is ultimately a theoretical problem of the nature of the human being generated by the imagination and it is impossible to resolve it into ethical meaning. Were one to preserve it in the context of ethics one would question the sufficiency of ethics to address the problem of the human being insofar as it reaches beyond problems of nature. Whatever it is about the human being that cannot be answered by the sciences, including those questions that arise in the context of religion, must be resolved in ethics (413). Hence religion must not be cast as a higher ethics entitled to address those human questions that are beyond the reach of theoretical and practical reason. Ethics does not decide the theoretical question of the duration of human existence after physiological death. Instead it decides whether or not it contributes to the problem of its realization. Cohen dismisses the theoretical problem of individual immortality with the words: "I cannot know it, therefore I do not want to need to know it." 108

Instead the aspect of the human being that reaches beyond nature without losing touch with its natural aspects is identified as the ideal. In Cohen's notion of the ideal, the character of the human being as image (following the biblical story of creation, Gen 1:26ff) is augmented by neoPlatonic typology $(404,419)$. The prophets as poets generate an ideal that is characterized by a combination of the good and the beautiful, whose material is natural and whose ideal character is a representation of the idea that remains elusive. The ideal is not an effect that the beautiful has on the artist but is creation ${ }^{109}(420)$. The work of art is peculiar in that its essence is not present. Neither the idea alone, nor the material in which it is represented is the essence of the art. The sought after being of the ought is in the ideal that expresses perfection, archetype, and universality-all necessary for the sake of emulation. Without the ideal there can be no attempt to achieve it. Conversely, the attempt at political reform would remain blind and arbitrary were it not guided by the ideal. But as an attempt, all ethical work remains imperfect. The ideal pursued in the attempt, not the realized work, represents morality. In this sense, following the model of the arts, the realization of ethics is suspended between heaven and earth (424).

108 "Ich kann es nicht wissen, darum will ich es nicht wissen müssen" (415).

${ }^{109}$ In this view the Continental esthetic tradition since Mendelssohn and certainly since Kant have parted ways with the 18th-century Cambridge neo-Platonists who inaugurated the modern discourse on esthetics. I owe this insight to Dr. Leah Hochman and her Ph.D. dissertation on Mendelssohn's esthetics. 
The ethical ideal divides into three moments: perfection (noun), perfection (verb), and the imperfection of perfection (verb). ${ }^{110}$ This configuration of the relation between idea, ideal, and work takes the place of the tentative formulation of a "being of the ought" that stands at the beginning of the inquiry (424, cf. 24). Cohen thus reformulates the relation between thought and will. The ideal differentiates thought and will in that thought generates being and will generates ideal. The aspect of realization therefore belongs in the context of an ethics of "pure will" in that it is the will itself that remains insufficiently defined if it is deprived of a careful consideration of the limits of its agency. This agency includes the origination of the ideal in the work of its pursuit. Will is that aspect of consciousness that generates something that does not originate in thought alone and that is "beyond being" (425). Thought is the origin of nature, will is the origin of eternity. The idea of truth, however, which, as was stated in the beginning, was to unify thought and will, knowledge and ethics, nature and eternity, means for the will that it must not be driven by an unbound imagination. Instead it "operates in the generation of veritable being" (426).

Finally, the ideal is an expression of the world view of ethical idealism in that it establishes the perspective of peace as the mother of reality against the perspective of war as the father of all things. Cohen's ethics is a statement against the Darwinistic ideologies of his time (442f). Political action can be guided only by one of the two models. Our view on the nature of history decides on the ends we pursue and on the means those ends justify. If nature prevails in our definition of the human being, and if nature is reduced to the principle of war for survival between biological substances, mass murder and ethnic cleansing are the necessary consequences. From the perspective of critical idealism such a view of nature is flawed. Scientific models of causal explanation must not carry the weight of moral decisions. Where reason stretches "beyond being," on the other hand, we are able to discern an alternative, a better world and better selves.

\subsubsection{The Idea of God}

Freedom, immortality, and God-the great themes of the Western metaphysical tradition-barely survived the Kantian revolution. In its wake, the two latter ideas in particular took on the shadowy character of postulates of practical reason. Freedom continues to generate poetic and political enthusiasm but, in light of critical idealism, the confidence one can invest in the idea must be limited and excludes a substantive notion

${ }^{110}$ Die Vollkommenheit, die Vervollkommnung, die Unvollkommenheit der Vervollkommnung. 
of freedom and self. Cohen preserved freedom in and besides autonomy with a view to the coordination of religion and ethics in the individual experience of self-transformation. The immortality of the soul was rejected as a theoretical problem unrelated to the ethical selfconsciousness. Instead it was displaced by the idea of messianism fueling the ideal of historical progress. Finally, Cohen examines the idea of God that is both most fundamental to Western culture and least plausible to the modern consciousness.

The plausibility of God of course depends on the idea itself as much as on the consciousness that wishes to amalgamate it. The God who becomes man and saves us from our sins always functioned as an irritant to reason. And undoubtedly for this reason the Christian trinitarian God precipitated the release of tremendous intellectual energy that fueled Western arts and philosophy much as it contributed to the moral discourse. The cultural and humanizing effects of the Christian ideas of unselfish love and compassion that are promoted in the imitation of Christ have had no less profound an influence on morality than the neoPlatonic character of trinitarianism had on metaphysics. Further, the responses to the Christian message are many and Christianity is made up of a wide variety of movements. From the outset, moreover, the Christian God had to compete with other monotheisms, philosophical and religious, so that the content and meaning of the Christian God idea has remained unstable and open. Until the advent of humanism the discipline of theology was therefore the mother of all sciences. The involvement of Christian motives in the promotion of humanistic culture is complex and the two must not be construed as pure opposites. Religious reform, scientific revolution, and philosophical subjectivism all contributed to the decline of religious authority, but the idea of God is largely retained in whatever mitigated rationalist versions. While the lingering of God, rendered harmless by the disarming of his priestly agents, can be dismissed as an expression of fear of state-sponsored censorship or vestigial retribution anxiety, the decision to justify the idea of God in the context of a modern ethics must be founded on more constructive grounds. For Cohen's attempt to resolve problems generated in religion into ethics is peculiar not because it involves a critique of religion, which it certainly does, but because it also gives a religious dimension to his philosophy. In order for such resolution to be possible, we saw that the religious tradition must be homogeneous to the ethics of critical idealism, i.e., it must contain or address a problem that contributes to theoretical or practical aspects of moral philosophy. On such grounds the notion of freedom was defended while that of immortality was dismissed. What then is the point of God in the context of the Ethics of Pure Will? 
The task of the Ethics, as stated before, is to resolve the problem of the human being, defining the humanity of the human being as a task that leads "beyond being," i.e., beyond nature as constituted in thought. Ethics is about Menschwerdung, becoming human. For the human being is not complete. We are to become human. The humanity of humans is also the point of religion. More precisely, as we also saw before, it is the whole purpose of God to teach the human being what it means to be human. God is not subject to speculation. In contrast to the Christian tradition where accounting for God (theo-logy) provides the central theoretical concern, Hebrew prophets and Jewish legal traditions avoid the theoretical problem of God and make the human being the center of attention. ${ }^{111}$ Yet it is the human being "before God" that is the center of attention. Thus while Hebrew theology is anthropocentric (even anthropomorphic), Hebrew anthropology is messianic and redemptive. From the ethical perspective the Jewish heritage is thus exceedingly useful in that here is a religion that excludes the theoretical aspects of God for the sake of its moral aspects. Limiting access to theoretical knowledge of God is of course in itself a precursor to the modern critique of Western metaphysics, but the positive meaning of God engenders knowledge of the good. Since the Torah reveals such knowledge even to the multitude, the good must not be beyond realization. God teaches a good that can be pursued.

But whence does the idea of God arise? Cohen begins with a look at the origin of the philosophical idea of an absolute (419). Plato's anhupotheton is here a "self-ironization of reason" in the quest for a ground that reaches beyond rational foundation. Similarly, Aristotle speaks of amesa in the sense of "eternal, innate foundations that rest in and of themselves." The very act of defining these grounds submits them to an inappropriate subjectivization. The point is that consciousness (nous) is seen as containing an awareness not only of the foundations it generates but also of being and its groundedness in something other than consciousness. This unresolved contradiction is enriched by the prophetic notion of a transcendent God (430f) so that the Western tradition vacillates between affirmation and denial of transcendence (supernaturalism and pantheism).

In Kantian ethics the postulate of God was correlated to the idea of immortality of the soul. The former was necessary in order to make the latter possible which in turn was postulated for the sake of the

${ }^{111}$ Kabbalah, medieval Jewish mysticism, is the noteworthy exception. The precise nature of the degree to which messianic anthropocentrism also applies to the various kabbalistic trends is a matter of a debate recently renewed by Moshe Idel in Messianic Mystics (New Haven: Yale University Press, 1998). 
maintenance of a moral energy that would otherwise despair of realization. In order to be able not to expect the success of moral action in this life, the hope for an afterlife had to be retained. With the elimination of immortality (which incidentally is classic doctrine neither in Christianity nor in Judaism) the idea of God must find different correlates as well. The religious correlation described in Begriff der Religion (see below) and guiding the construction of Religion der Vernunft (see above) does not enter into this discussion. In religion atonement augments the realization of ethics in a fashion that is beyond the pale of the universal direction of political and legislative attempts at greater perfection. Instead, from the perspective of the Ethics, the idea of God is correlated to the messianic ideal as the warrant of the possibility of its realization. In God, nature and history, thought and will, power and goodness, are reconciled. This means first of all that they are reconciled in God alone, making all human work a mere attempt. But this also means that they should be reconciled, thus indicating the direction of all human work. The idea of God is the ground of the assumption that nature will not forestall the realization of ethics. Nature itself is not the absolute but it is the limited totality of our knowledge of being which itself must not be conceived as excluding the possibility of the realization of the good. We must not be persuaded by our knowledge that it is the actual ground of being but that being (and our grounding of being) is grounded in something else that we call God in order to indicate the goodness of the anhupotheton.

The idea of God thus regulates the use of reason to impose unity on the principles of our conceptualization of nature and culture. This unity is generated in the negative function of the idea to deny validity to both extremes of the metaphysical tradition: pantheism and supernaturalism. In most cases the identity of God and Nature leads to a materialist absoluteness of nature and thus to an elimination of ethics. If, on the other hand, God is radically separate from nature, the project of philosophical truth and a harmonization between nature and morality becomes a humanistic dream that is to be superseded by suprarationalist religiosity. In negation of both metaphysical extremes, the idea of God correlates nature and history, logic and ethics: Natura, necnon Deus (45).

Philosophical theology is usually a polemical enterprise in that it not only involves the synthesis of different traditions (e.g., Greek and Hebrew) but also reflects competition among several such syntheses. This competition is aggravated when debates on ultimate philosophical truths are conducted in a political situation of unequally distributed power. Metaphysics is made to carry the weight of legitimization of power and of resistance. Whether it affirms and supports the given social and political state of affairs or whether it subjects it to criticism, theology, 
even the most spiritualized kind, cannot be judged without taking into account its political implications. Hermann Cohen's philosophical theology not only has decidedly political dimensions but it claims that the metaphysical tradition of the West more often than not supported one of two theories of ultimate grounding whose implications prevent giving an ethical grounding to responsible political action. Furthermore, he refuses to debate theology as a theoretical issue and makes it a cornerstone of an ethics that is part philosophy of law and part political ethics. All three of these characteristics, the political dimension of ethics, the critical negation of pantheism and supernaturalism, and the rejection of speculative theology, are in keeping with the medieval Jewish philosophical theology of Maimonides. Maimonidean theology is based on a radical denial of an analogia entis; it limits divine attributes to the function of archetypal goodness; and despite its praise of the life of theoria it makes the Torah a political constitution with a cultural educational purpose that includes the multitude in the project of enlightenment (i.e., critique of idolatry at least on a practical level). To Cohen this philosophical theology is a living tradition and really the beginning of modernity from the Jewish perspective. It is the expression of a rational enlightenment that needed no fundamental updating. It should be evident that it is one and the same life dream that fueled Cohen's Jewish philosophy of religion and his system of philosophy whose centerpiece contains a justification of the Jewish concept of God, of religion, and of ethics.

\subsubsection{Virtues and the Realization of the Moral Self}

The self of Ethics is not real but a task of self-direction towards realization. To the degree that the will unifies affect and thought in action, self-consciousness achieves reality; strictly speaking, however, this reality never is but becomes. It is never a matter of the past and it has no being but one that is made. It is an artifice, a creative work of emulation in which we become what we should be: human. In this attempt we are "children of God" (b'ney elohim): judges of goodness, and divine agents in the social sphere. The Promethean self-consciousness that generates humanity in the image of the divine agent thus produces an ideal of perfection. This is the first step in the realization of ethics. The second step is to keep our concept of nature open to the possibility of a realization of perfection (Vervollkommnung) by correlating nature and morality in the condition of their connectedness, in the idea of divine perfection (the unique God as the only Being in contrast to all becoming; divine agency as the model of perfection; negation of the negation of the possibility of perfection). But this is not enough for a philosophy of law 
and politics. The possibility of a realization of ethics by real people also needs an indication of the means by which human agents can turn themselves around to face the future. For the Good is realized in transformations. It is not an essence we possess and merely need to activate but it is direction and directive towards improvement; it presupposes an absence of Goodness. Hence it is realized in transformations of egoistic materialists into moral human beings; of societies engaged in sustained internecine warfare into states ruled by law. "Only in the transformation of reality," as Cohen puts it, "does the reality of ethics appear" (391). This t'shuvatic reality is fully enacted only if the "divine law" drives human beings to adopt a certain attitude that gives their process of making decisions steadiness in the choice of its direction. This steadiness is traditionally called "virtue."

The correlative self of this ethics needs correlative virtues or virtues of correlativity, i.e., the steadiness of the direction of legal and political action is provided by the principal demand that it connect particular and universal selves so that they mutually sustain each other. It should be remembered that particulars are construed not as unique but as members of a class, just as classes are conceived as the members of a totality. Citizens are taken into account not as unique individuals but as members of groups as well as of the "all" of the state. Far from relying on the cerebral notion of duty, Cohen anchors virtue in feeling and affect. In the virtues, therefore, the meaning of the above preservation of sensuality is disclosed. Rather than making the mental strain of duty against the inclination of the senses the primary sign of morality, this political ethics utilizes the "natural" feeling of belonging and enthusiasm that individuals feel for their community as an impulse that is not only irrepressible but that may be ennobled. The core of the political animal is here identified as emotional. The optimism of the notion that political emotions or feelings of belonging can and thus should be cultivated rather than eradicated seems saner and more realistic than, e.g., the recent attempt by Jürgen Habermas to persuade Germans to seek their salvation in the detached civic cerebralism that was the hallmark of the Bonn republic before reunification. Optimism, in this context, means that the logic of perfection (Vervollkommnung) must operate with the unavoidable (such as the fact that most of us are primarily rooted in relative communities) and seek to optimize it. Cohen's optimism is really deeply pragmatic.

The basic affect that is to be ennobled in this teaching of virtue is that of love. Love is the focus of Cohen's general introduction to virtue. This choice of focus is especially telling in that it echoes the religious commandment, basic to Judaism, to love God. Love appears here, however, not in the traditional sense of the appropriate human response 
to God as rooted in Hebrew law, but it primarily concerns the problem of coordinating loyalties towards community and state. In defense against anti-Semitic insinuations that had accompanied Jewish emancipation as a cantus firmus ${ }^{112}$ love of one's neighbor was in need of careful parsing and examination. To deny loyalty towards one's kin and tribe, to deny the force of tribalism altogether, would be useless. It would be futile and rightfully deemed untrustworthy were one to deny such basic loyalty. Renewed suspicion would arise against such assurances and forestall the task of ennobling the natural social impulse. Love is a valuable affect in need of responsible guidance; it needs to be made to see into the future and submit to critique of its nature and consequences if it is to act as a cultivating force leading toward stable peace and manifesting itself in solid contracts. Emancipation is a particularly striking example in that it instantiates the case of communities of different origins agreeing to love each other as fellow citizens of a common state. Clearly, the love one feels towards one's own community will always be different from the love one feels towards the state or the differently-rooted fellow citizen. But the main point is that the state itself is transformed in the act of granting emancipation. More accurately, Cohen interprets the legal and constitutional effects of emancipation as effects on the character of the state itself rather than merely on the group that is allowed in. The undecided matter is, of course, the very problem that haunted the patriarchal model enacted in the edict of the French Assemblée Nationale in 1791 that extended citizens' rights to the individual Jew rather than to the community. ${ }^{113}$ Cohen's model is in direct opposition to the half-truth of a patriarchal emancipation that forces the state to identify with the interests of one group into which members of another group are to be legally and culturally integrated. The issue raised by Treitschke is still recognized by Cohen even in his mature philosophy. The problem of Jewish integration is real. Yet the solution must not consist in Jews giving up their loyalty and love for their own religious community, history, and ethnicity. Communal loyalty must be subject to critique on all parts. The love for one's particular community is to be regulated by loyalty to the moral self-consciousness of the state which acts in the interest of all, as well as by the notion of individual responsibility which is likewise constituted in the search for that which benefits all members of the state rather than merely the members of one's tribe. Finally, group identity is subject to moral critique in that the particular (religious) community or

\footnotetext{
${ }^{112} \mathrm{Cf}$. above, Part I, on Cohen's defense of the Talmud in 1888.

${ }^{113}$ The irony of it is that individuals were not asked whether they liked or qualified for this extension of citizenship; in other words, emancipation was de facto granted to a community rather than to individuals.
} 
party must seek not only the good of its members but must seek this good as regulated by the ideal of a perfection of coexistence and peace. The "ways of peace" (darkhey shalom) are a regulative principle already in rabbinic law; they suspend halakhah in cases where it endangers the prospect of peaceful neighborly relations. This is, of course, not an emotional but a pragmatic principle fueled by interest in the perpetuation of one's own community which cannot survive without being mindful of the relativity and fragility that coexistence with other groups imposes.

Cohen extracts from this rule of coexistence a general principle in his distinguishing primary from secondary virtues. Primary virtues are "feelings of thought" (489) that attach themselves to the object generated in moral thought, i.e., to the state as conceived in the Ethics of Pure Will. The affective basis of this rational feeling is "honor," and the honor of a human being is founded in the notion of the image of God. It is the potential for good that demands that we preserve the honor of each individual, for in the eyes of moral judgment each individual always retains the potential for self-transformation (490). Neither can the individual nor the group be legally or morally deprived of this assumption of goodness without violating its basic human honor (491f). The secondary virtue of love that moves us, or provides us with "feelings of movement," (486) is one that our families and primary communities instill in us. To the degree that such first socialization is done responsibly it should prepare us for the acquisition of the primary virtues by which we attach ourselves to the greater good of all.

Here the role of the Thou as primary to the I (493) is fully evident in that no particular community associated by common descent is forced to develop the primary virtue of trans-ethnic solidarity as long as it is not fully and totally confronted with the Other as a potential fellow human being. Behind this insight stands the narrative of the experience of exile and restored political integrity of the Jewish commonwealth out of which grew the important legal norms of a protection of the equality of the foreigner within one's borders and messianism as the community of nations. The human being is discovered not in isolation but out of the need to achieve self-preservation in a situation of political dependence. The invention of the Noahide couches in narrative terms the conceptual achievement of a universal recognition of the honor of human beings in their responsibility towards each other and before God which, in modern political theory, gives rise to theories of inalienable human rights as regulative limits of national interest politics. Cohen's theory, however, extends beyond the correlativity of individual freedom and constitutional law by addressing the relation between individuals, groups, and the state. The original model in Jewish history is therefore 
not the situation of an integrated nation state and its citizens but the Jewish community in exile, in a situation of multi-ethnic coexistence, in an empire that Jewish monotheism casts as a penultimate reality. Even theocratic restoration in the Second Temple period could not erase the knowledge that nations are preliminary realities compared to divine government of history and the overall importance of the Torah as the life enabling constitution of infra- and inter-communal human coexistence.

\subsection{The Concept of Religion in the System of Philosophy}

Cohen's philosophy of culture critiques the validity each major direction of cultural activity with a view to what generates progress and increases perfection. This tentative definition must be augmented by further observations. The separation into independent (selbständig) directions of culture is a construct of philosophical analysis, an operation in the transformation of cultural fact into theoretical culture, as is the concept of culture itself. The division between the theoretical disciplines is an attempt to generate clarity and hierarchy that must not prevent ever new attempts at organizing sets of questions around new areas of research that lead to new results. We need to be free to conceive of new fields of investigation by identifying problems that we had not been aware of and to make new and original connections between areas that had not yet been subjected to the transformative and generative work of cultivation. Conceptualization and critique of the validity of conceptualizations means to examine the authority of reason in its past accomplishments. This philosophy therefore does not pretend to begin with a quasi-neutral and objective reality given in perception. Rather than reading the book of nature or of the soul, it reads books on nature and the soul, examining their value in form of a critical commentary that helps us to appreciate the cultural genius of the fathers and mothers on whose shoulders we stand and asserts the philosophical task in its necessity as well as in its utter dependence. The humility of this philosophy is that it teaches us that in order to emancipate ourselves we must first recognize ourselves as epigones.

In Ethics, the work of culture turned to the transformation of the raw material of cultural history in the problem of the human being. In a philosophy that aims at harmony between various directions of culture, a harmony that arises from the directive of the unity of the cultural consciousness, the ethical task and the task of ethics is "systematically central" (BR 11). In the Socratic tradition, one might say that the philosophical task in general is posed in terms of human self-knowledge, including knowledge of virtue. The Ethics concerned the knowledge of self that unfolds guided by the logic of cognition but that differentiates 
itself from the objects of nature constituted in it. In order to avoid a merely speculative point of departure, the recognized cultural fact of law and, in it, of legal personhood, was examined for the possibility of being grounded in the sought-for set of problems that are specific to the self as it distinguishes itself from nature. This "attempt" unfolded in the draft of the concepts of pure will, action, and self-consciousness that, in light of the experience of sociality and communication, were construed as the condition of the possibility of an ethical dimension to government, political action and history. Law and politics were thus retrieved in their potential as spheres of human cultural self-consciousness. The ethical discourse is thus organized to generate harmony and agreement between the logical notion of origin and specific recognized spheres of culture. The directive of the unity of the cultural consciousness can therefore be reformulated as the task to befriend and make peace between seemingly alien and foreign cultural spheres that arise from different origins and may conflict with each other unless subjected to the task of unification. The ideal of peace is therefore not only a directive for political action and relevant among the virtues of action but it is also to be distinguished as a theoretical value, namely as a principle of the psychology of theory. Just as the vision of messianic world peace does not obliterate the particular states that it unites, however, and just as the ethical task continues to be relevant in the sphere of political action under the condition of peace, so the different and originally heterogeneous sources of a unified cultural consciousness must be preserved in their Eigenart, as well as continue to transform themselves as separate entities following the imperative of unity and harmony.

The sources of culture are many, and the task of philosophical conceptualization is to find the points of meeting and identify their potential for the development of the task of cultural development. From the perspective of their unity on the other hand, the principle directions of culture appeared as mere modes were it not for the distinction between theoretical and practical culture, unity in principle and separation in practical work of self-transformation. The medium of both unity and difference is language. In the course of countless problemhistorical (problemgeschichtlich) orientations Cohen draws on philosophical as well as on religious sources of the language of modern social and political questions. Western cultural history is the open book in which to read before determining the cultural value generated by past generations. This value informs the language that we speak before we even begin to ask "what is?" and from whose mythic and dogmatic implications we can emancipate ourselves only to the degree that we examine and judge it. Such emancipation, rather than mere understanding, distinguishes the philosophical from the philological 
enterprise. The hermeneutic rule that guides the deciphering of cultural value from within the book of culture follows an ethical demand. Just as ethics is generally characterized by a rule of optimization or perfection (Vervollkommnung), so is the method of reading in the book of cultural history.

Yet when it comes to religion, Cohen's ethical assessment is often mixed. Some religious notions are affirmed, others are criticized. More often than not, the religious notions he criticizes are specifically Christian doctrines, while, when he points to the moral utility of a religious idea, he usually refers to an aspect of biblical Israelite religion. Thus, however, the cultural character of religion is in question. What is religion to the unity of the cultural consciousness? That depends on the religion one practices. Is there no unifying, underlying, "eternal" value to religion? Is there Religion at all or are there only religions? What determines the value of religions? And why should religions be interested in such cultural assessments? Are they not perfectly happy within themselves? If unity of the cultural consciousness is to be achieved in a theoretical, political, and psychological sense, the question of religion needs to be addressed in its own right. In the taxonomy of philosophical disciplines the directions of culture (theory, ethico-politics, esthetic feeling, psychology) can be multiplied but not reduced. One of the peculiarities of religion is that it seems to interfere not with one aspect of culture alone but surfaces in all of them. Religion thus threatens to become a second philosophy, a second source of unity within consciousness, or perhaps even a first principle that determines merit and limit of culture as a whole. After political fanaticism is contained by an ethics of law, a second source of fanaticism threatens to disrupt the coordinated progress of cultural unity and peace.

To Cohen, the prophetic, legal, and philosophical traditions in Judaism provide the model of a religion that retains both uniqueness and a character sui generis as well as perpetually seeks to reconcile itself with theoretical culture. Judaism, as it were, is a model for the cultural technique of identity preservation within the context of universal integration. In its historical practice and following the inherent principle of its monotheism, Judaism thus represents the ideal of a particular culture.

The Jewish tradition is also the source for the hermeneutics of cultural diversity and unity. The technique of resolving dissonances among rabbinic traditions, perfected by the Babylonian amoraim, is based on preserving all the words of the predecessors while generating new ideas by means of ingenious reinterpretations. The written and oral traditions are conceived as a giant fugue progressing towards resolution without ever becoming resolved. Generation after generation brings it 
further in an unfinished movement towards harmonization wherein both this and the other can be conceived of as "words of the living God." Thus, in the Ethics, for example, Cohen asserted that religion was a source of notions that could not be resolved within religion itself and which therefore had to be taken on by ethics in order to be transposed into the key of theoretical culture. The religious difference, however, was retained for the sake of a transformation of practical culture in accordance with the ethical ideal. Theoretical and practical culture are related to each other as philosophy and practice of religion are, whereby philosophy itself must be mindful of the concepts inherent in the religious practice. This is in keeping with the fact that, for the most part, Jewish exegetical practice has rejected allegorization whereas Christian exegesis could not but allegorize the Hebrew heritage.

The major source of Jewish religious concepts is the prophetic heritage. We know already that Cohen reads this tradition in light of the theory of Higher Criticism while replacing Hegelian supersessionist dialectics (wherein the later represents the culturally higher) with his own pragmatic hermeneutics of optimization. Post-exilic and rabbinic religion are taken as the paradigm of this very hermeneutic technique. Thus, Cohen offers the model of continuity and optimization as an alternative to the Christian hermeneutic model of displacement and supersession. ${ }^{114}$

Among other things, prophetic religion is critique of myth. ${ }^{115}$ In this respect it is homogeneous to the method inaugurated by Greek philosophy and Hellenistic interpretations of Homer. Yet the Jewish religion is an ongoing practice that is perpetuated in a particular community and that has as its purpose the perpetuation of communal particularity while promoting universal ethical consciousness. Or, conversely put, religion has the purpose of promoting universal ethical values from within, and primarily for the sake of, a particular community. Philosophy, by contrast, aims at universality in both form and content, and thus becomes the advocate of the "all" in theoretical terms. It is therefore warranted to speak of a convergence in the tasks of philosophy and religion in the common rational impulse of critique as well as in their ethical value. One can even say that philosophy is fully aware of its ethical dimension only once it learns to integrate within the orbit of its problems the temporal aspect of progress, i.e., the messianic

${ }^{114} \mathrm{Cf}$. BR p. 2 where a method of the history of religion that takes the developmentally later for the philosophically truer is criticized. And cf. Wendell Dietrich, Cohen and Troeltsch. Ethical Monotheistic Religion and Theory of Culture, Atlanta, Georgia: Scholar's Press, 1986.

${ }^{115} \mathrm{Myth}$ itself is understood as an expression of reason, albeit one that precedes the level of theoretical reflection. 
heritage of Hebrew prophecy. This notion is, of course, hardly contentious. Rather, what needs to be examined in a separate work on religion is the "beyond ethics" of religion. Does religion stand for a theoretical problem that lies outside the realm of ethics and, if so, does it not destroy the whole neat architecture of a system of the cultural consciousness? While The Concept of Religion answers to the first part of this question in the affirmative, it negates the second part. If the above description of the formal and psychological unity of the cultural consciousness is accurate, the problem of religion does not need to be entirely resolved into ethics in order for harmony to be preserved within the whole of theoretical culture. Were it not so, how could one reconcile one's participation in a religious practice with one's conscience as a citizen or as a philosopher? It would be perfectly absurd to believe that Cohen ever wanted to argue for the practical abrogation of religion. Perhaps he advocated a lessening of social friction between religious practices within a society (in the support of the proposal to move Sabbath observation to Sundays expressed early and later withdrawn), but certainly not disloyalty to one's religion.

The theme of Cohen's 1915 essay on The Concept of Religion in the System of Philosophy is the mutual permeation and correction of religion and philosophy. In the Ethics, this problem only arises on the margins in that religious traditions are subjected to problem-historical critique in order to determine their possible contribution to the ethical problem of the human being. It also appears in the political asides that are richly scattered throughout the last part of ErW, in the chapters on the virtues. ${ }^{116}$ The chapter on "Loyalty" (Ch. 14 "Die Treue") is especially pertinent in that it raises the question why one is to hold on to religion after its contributions to ethics have been ascertained and thus resolved into theoretical culture (586-590). In other words, it addresses the problem of the relation between historical existence and its idealization. Loyalty indicates here not continuity of adherence to one's religion but continuity in the direction of idealization pursued from within one's religion. Religion is to be made superfluous from within by the steady transformation of its mythological heritage into ethical knowledge and practice, but this is merely the goal of historical development, not a description of historical reality. Things being as they are, religion continues to be an aspect of practical culture in which the ethical interest

${ }^{116}$ For the sake of simplicity I ignore the many shorter pieces Cohen wrote in the last two decades of his life that deal with the relation between ethics and religion. Most of these essays have a polemical purpose and it would lead us too far afield to take them all into account. While they would enrich this discussion they do not contribute anything fundamentally new to the substance of ErW and BR in terms of how to relate ethics and religion. 
must be steadily pursued, but it must be pursued from within! Religions may be preliminary institutions but, qua religion in its theoretical value, they are open to development. In the ethical context, loyalty is also claimed as the natural moral attachment of love towards one's particular ethnicity, especially where one's nation exists without independent statehood. Cohen therefore justifies Jewish national self-awareness within the Diaspora and in "obedient" attachment to the state as a moral institution (598) while arguing for the preliminary nature of religious separation. For loyalty as continuity in one's direction is first defined as the effort to generate unity within oneself. In other words, loyalty is the core virtue of the unity of the cultural consciousness that needs to reconcile between the varying demands made upon the particular self by voluntary relations (friendship, marriage), relative communities (religious, ethnic), and the state. The unifying bond that is developed and furthered in the steadiness of commitment to ethical idealization thus leads to a common culture without denying the natural right and moral potential of various individual and social impulses.

In ErW, the virtues concern the realization of ethics, while religion comes into consideration from the perspective of practical culture. In the eleven years between the publication of the first edition of the Ethics and that of The Concept of Religion, Cohen produced a second edition of ErW, a two-volume treatise on esthetics, a revision of the Logic, a commentary on Kant's First Critique as well as numerous minor writings on religion, politics, and culture. The 1915 essay on Religion treats the subject of the relation of religion and philosophy on a much more fundamental and general level than any of his previous writings. Furthermore its publication is announced by the 1914 revision of Einleitung mit kritischem Nachtrag in which the program of "resolving" religion into ethics is replaced by a program of "adopting" religion into ethics. A subtle change, but the mood of the time (one year into the war) prepared the readers for a new and bold statement by the neo-Kantian who, based on the Ethics, on the minor writings, and on numerous lectures, had already begun to emerge as a major philosopher of religion. Cohen's speech on the "global historic significance of Judaism" was a key event at the 1910 world congress on progressive religion in Berlin,117 and Cohen's intellectual leadership among the German Jews and beyond Germany's borders was recognized even by the German government that considered him an asset in its propagandistic efforts. Cohen's complex

117 ‘Die Bedeutung des Judentums für den religiösen Fortschritt der Menschheit. Vortrag, gehalten auf dem 5. Weltkongress für Freies Christentum und religiösen Fortschritt am 10. August 1910" in: Weltkongress; and as separate printing BerlinSchöneberg: Protestantischer Schriftenvertrieb, 1910 (16pp); (J1,18-35). 
and ambivalent situation as a philosopher, Jew, and public figure in times of a war (a war whose impact on the national mood was powerful but not necessarily an expression of ethical idealism) all contributed to making his essay on religion a much noted work. Hartmann's phrase of a "dropping of the mask" shows that The Concept of Religion was greeted as a kind of coming out of the philosopher, as an overcoming of the guardedness with which he had hitherto spoken to the subject. In one sense the essay discernibly allows a view into recesses of Cohen's personality that he had shielded from exposure. But his strong commitment to the philosophical validity of the religion of his fathers is only one aspect and not the most striking one. Rather, it seems to me that $B R$ is Cohen's most openly impatient treatise, an almost aggressive attack on the foolishness of the mystifying language with which his colleagues tried to salvage religion in an age of disorientation. The polemic character-in stark contrast to the irenic style of Religion of Reason which was imposed by editorial policy -is barely hidden under the surface of superbly competent interrogations as to the philosophical underpinnings of recent methodologies in the study of the history of religion, which make the book an original contribution to the then emerging field of the study of religion. Yet it also expresses the unhappiness of an author compelled to produce a work that could have been left unwritten were it not for the persistent misunderstandings pursuing his concept of religion. Most ironically, of course, BR not only did nothing to dispel those misunderstandings but provided the point of departure for new ones. As if jinxed, The Concept of Religion is introduced to the system of philosophy in order to create harmony but instead immediately releases disorder.

This disorder arises from the fundamental ambiguity that Cohen creates in the formulation of a modification of his program. On the one hand he maintains that a discrete direction of culture should not be claimed for religion and that a separate discipline of philosophy of religion should be avoided. After the model of medieval Jewish philosophy and based on the nature of their difference and relation, religion and philosophy should really permeate each other. On the other hand such mutual permeation is a philosophical problem above and beyond the resolution of religious notions in the theoretical work of ethics. Furthermore, religion itself, not only certain particular religious concepts, is to be given philosophical distinction. Thus, it seems as if religion is to be recognized as a principle of culture, a fact whose a priori provides it with the status of an "eternal" and irreplaceable position in the context of theoretical culture. On the other hand, Cohen cautions that the concept of religion must not be determined independently but be kept under the systematic prerogative of ethics (9). But then, as we stated 
above, from the perspective of the unity of consciousness, none of the spheres of culture can claim full independence and all are united under the systematically central ethical directive of peace and harmonization (9-10). This torturously cautious back and forth is merely the initial expression of the problem of a concept of religion. Where is it to be located within the whole of the cultural consciousness, i.e., within the architectonic of a classificatory system of culture? Is it "independent?" But then, not even logic and ethics are independent of each other but reflect one onto the surface of the problems the other is to work through. All cultural spheres are then again mere modes of one and the same consciousness whose principal operations are merely distinguished by "peculiarity" (Eigenart) rather than "independence" (Selbständigkeit). The topic of this treatise is therefore not primarily an apologetic defense of Judaism, as Heimsoeth stipulated, but a discussion of the relation of religion and system. Judaism provides the historical source, to be sure, but it is only relevant to the degree that it provides a model in the search of an amalgamation of philosophy and religion that both generates unity and retains difference. In extension of the ethical question, specifically of the role of religion in the realization of ethics, religion is thus recognized and dealt with as an aspect of the unity of the cultural consciousness.

The harmony of religion and culture that is aimed for must be reached in theory before it can be pursued in practice. It is all the more troublesome to Cohen that agreement seems elusive even in theory. For different religious traditions provide different models of a relation between philosophy and religion that not only compete with each other but pose almost insurmountable obstacles to successful communication even within the small circle of Marburg philosophers. As Cohen indicated to his student Knittermayer, he hoped to "bridge a gap" between himself and Wilhelm Herrmann. He goes as far as twisting the structure of his philosophical system in order to come to an understanding but it is the same message that he tries to convey across this bridge. A relatively small book (164pp), The Concept of Religion is dedicated to the "Marburg School in Gratitude and Confidence." We know that because of his religion Cohen was quite isolated within the wider faculty of Marburg as well as in the world of Prussian and other German universities. The "anti" was ubiquitous and the effort to generate the image of a common philosophical ground with his Protestant colleagues even on the question of religion was a political hope. At least among philosophers, the Burgfrieden Wilhelm II had declared in his incomparably awkward rhetoric, was to be restored and maintained. 


\subsubsection{The Problem of the Concept of Religion}

The difference in the treatment of the problem of religion in ErW and in BR consists in the fact that ErW operates without a "concept" of religion; religious concepts are elevated by integration into the systematic framework. Yet the rational ground of religion, religion itself as a wellspring of reasoning, is not thematized. Would it be overstating the case if we nevertheless assumed that $\mathrm{ErW}$ presupposes a concept of religion that is fully justified and developed in its own right only in BR? ErW clarified the role of ethics in its effort to bring problems discovered in religion to a solution on the level of theoretical culture. In critical reviews of the history of the formation of specific concepts, ErW asserted its overruling interest in the idealization of relevant cultural values and discoveries. But the agency of religion as a source of concepts, the possibility and justification of religion as a cultural force was not itself a matter dealt with in the Ethics. The justification of religion in this sense is furthermore complicated by the role religions played in the development of Western philosophies, by the modern methodological critique of metaphysics, as well as by religious dogmatics. The task of justifying the problem of religion in its philosophical nature also faces the competition of the modern methodology of a history of religions where inductive empirical methods are advanced in contrast to the deductive methods prevailing in the philosophy of religion (in the wake of Hegel) as well as in theological dogmatics. Cohen generally defends the right of philosophy against the positivist assumption that science is inherently philosophical and needs no reflection on the transcendental grounds of its validity. So, too, with respect to the study of religion. He argues that the right of philosophy to speak to the problem of religion is inherent in the need of any history of religion for conceptual generalizations. Historical study, so Cohen, presupposes a concept of religion that it verifies in the phenomena it examines even though the procedure seems quite the opposite. For the range of data collected and examined in the history of religion presupposes a homogeneity that only a concept can provide that is first, however heuristically, presupposed. Cohen specifically takes the emerging discipline to task for its extension of the phenomena examined to include all symbols of human self-expression. In this inclusive fashion, however, gods, God, aspects of nature, rites, myths, and any number of other characters all turn into symbols of psychological realities. The history of religion thus becomes a "history of the soul" (Seelengeschichte) (BR 4) while religion is made a "cult of the soul" (5). Cohen does not state in this context what may be wrong with this encompassing conceptualization of religion. Why should not the soul indicate the common ground to all religious symbolism? Although it 
would be possible to produce a detailed Cohenian critique of such conceptualization of religion, here is not the place to do so. Suffice it to say, that the concept of the soul whose permutations unfold in the history of religions is too broad and ambivalent to serve as a self-evident conceptual justification of the task of this discipline. The concept of the soul first needs to be interrogated from the other end of the classificatory hierarchy where ethics is already determined as the "logic of the humanities" and law as its "mathematics." Thus it would have to be asked whether a concept of the soul can indeed meaningfully function as the unifying principle of the history of religion. As we saw in ErW, however, the concept of the soul is the principle of movement and thus closely related to the problem of freedom. To Cohen, therefore, even as a phenomenology of the symbolism of psychic desires and projections, religion cannot be properly examined without giving account of the relation between symbols and their underlying relation to the cultural problems of freedom and autonomy. By spelling out briefly what Cohen only implies we immediately arrive at the core problem the philosophy of religion is to resolve: to determine the relation between particular symbolic systems and their contribution to the ethical problem of selfconstitution. It should be maintained, therefore, that far from rejecting the value of the history of religion, Cohen accepts it as a point of departure for the philosophical inquiry into the function of religion.

Just as the historical conceptualization is made a critical point of departure, so the deductive philosophical method is subjected to critique. Cohen rejects the Hegelian extreme where religion is absorbed into "the schema of subject and object" (2) which deprives it of all determinate content. Yet without philosophical work, concept formation would be arbitrary. The search for a critically justified concept of religion is thus located in a relation between history and philosophy that takes into account the mass of data supplied in one discipline while entrusting their conceptual unity to the other. The philosophical concept of religion thus relates to the history of religion as ethics relates to sociology. Like ethics, the philosophy of religion reflects on the parameters of critical judgment that is necessary to organize the phenomena described in the historical study of religion. If sociologically describable phenomena are to be considered as open to transformation and if the virtue of humanity is to remain an option for sociologically evidenced human nature, ethics must both presuppose and overcome the sociological point of view. The case is similar in religion. The critical study of religion describes the religious projections of the desires and inclinations of the human soul but cannot itself provide the criterion of philosophical judgment on those phenomena. To be sure, Cohen's critique of the empirical discipline is somewhat limited by the fact that the only methodology in existence 
then, and one truly biased in its unreflected idea of culture, is the history of religion. In contrast, his own execution of a Jewish philosophy of religion and ethics, Religion of Reason, contributes material to the emerging field of a phenomenology of religion by articulating the association, peculiar to religion, between symbolic ritual action and ideal intent.

Furthermore, the role Cohen attributes to ethics in the process of the self-transformation of actual religious cultures stipulates an interest in carrying the insights of theoretical culture to the plane of practical cultural work. His theory of culture is therefore not only interested in contemplation but in action on the political and communal level. His theory of religion is thus burdened by the ethical stipulation that you cannot know and understand a phenomenon without contributing to its transformation. To study religion means to change it. Here the program of the science of Judaism that informs Cohen's Jewish thought has become the criterion for the science of religion in general. Religion is to turn into an active source of civilization. Thus it must take note of real existing religious systems and sources. But by doing so in a philosophically reflected manner it inevitably provides the foundation for an engagement in the idealizing and optimizing work of their cultivation.

In a procedure that we have seen at work before, Cohen locates the task of the conceptualization of religion between two extremes and relies on the plausibility of his proposal for a proof of its tenability rather than going to great lengths in the refutation of the opposites of inductive and deductive formations of the concept of religion. The mean that is chosen here as a procedure for the determination of the character of a cultural fact whose scientific nature is in question (1) allows one to maintain, however, that religion is to preserve the character of the specificity of its content as well as receive its conceptual frame from within the context of the unity of the cultural consciousness. In other words, the question of religion is posed so as to make it possible to relate a specific historical religious content to the various branches of theoretical culture while neither changing the balance between the latter nor distorting the authentic character of the former. The essay on religion follows exactly this structure. After a preliminary orientation that sets the parameters for an articulation of the concept of religion within the system of philosophy, Cohen proceeds to examine the Eigenart of religion in relation to each of the branches of philosophy: logic, ethics, esthetics, and psychology.

The presupposition of an elevation of religion to the level of philosophical ideas is its function as a principle. In the many utterings of the history of religion a prevailing a priori must be identified that contributes something original and irreplaceable to the range of 
philosophical problems (5f). All originative contribution to the unity of the cultural consciousness involves both historical discovery and rediscovery in the conceptual determination of historical and originative content and function. In ErW religion is not itself an originative principle but a source of original problems whose conceptual resolution is expected of ethics. From the perspective of ethics, religion was an aspect of practical culture that one needed to accept and live with nolens volens and gradually idealize it in order to prepare the ground for its historical evaporation. Here in BR, however, religion becomes a cultural domain in its own right with a function that is both irreplaceable and limited by its relation not to one but to all directions of culture.

In order to understand how Cohen's critical understanding of the $a$ priori affects his concept of religion it is helpful to distinguish it from other more or less contemporary attempts at justifying religion that likewise emphasized the possibility of a religious a priori as, for example, that of the Lundian school. ${ }^{118}$ These efforts to retrieve the philosophical significance of religion in terms of transcendental philosophy are rooted in the revival of Schleiermacher's thought towards the end of the nineteenth century, ${ }^{119}$ in the neo-Kantian movement in general, and in Ritschl's efforts in particular. The common basis in all aprioristic conceptualizations of religion consists in the distinction between three fundamental elements that can be differently related: one's feeling of dependence (on the universe, etc.), the casting of this dependence in an originary founding act, and the role of tradition that attaches itself to the latter in the history of dogmatic interpretation. The merit of Schleiermacher was to interpret the act of founding a religion (Religionsstiftung) in analogy to esthetics. Thus he provided a model by which revelation could be retrieved in immanent terms. The historical and dogmatic expression that a newly founded attitude towards the universe receives in subsequent generations is secondary to the new attitude itself that must be preserved and rediscovered despite and beyond the varnish of its various historical expressions. The substance of the attitude prevails over the accidents of its historical clothing. At the same time, the fundamental fact of dependence on the universe is somewhat uncritically taken as a given. Cohen agrees with some of the elements but rearranges and reinterprets them fundamentally, turning to

${ }^{118} \mathrm{Cf}$. William Alexander Johnson, The Religious A Priori. A Critical Evaluation of the Philosophy of Religion of Anders Nygren, Ph.D. thesis, Columbia University, 1960. It would be interesting to compare and contrast the Cohenian method of a history of problems with the Lundian method of a typological history.

${ }^{119}$ One indicator of the influence of this Schleiermacher revival on the emerging field of religious phenomenology is the fact that it was no lesser than Rudolf Otto who edited the centennial edition of Schleiermacher's Reden. 
Kant and critical idealism and away from Schleiermacher's branch of Platonism. ${ }^{120}$

To Cohen the a priori is a function of the idea as the ground we lay in determining the validity of cognition rather than a given of consciousness. Where one assumes the latter one is caught in a psychological prejudice that attaches substantive character to something that is merely an achievement of method. The concept of religion is nevertheless to be given an "eternal" function, one that surpasses all development, in that it serves as a principle for the examination and interpretation of experience (5). Like Schleiermacher, Cohen emphasizes the historical and quasi esthetic act that is at work in all discoveries, including the founding of religion, but what the prophet or founder discovers is not a new attitude towards one's "dependence on the universe" but religion itself, not a new light that is shed on a constant of consciousness, but a critical and original new attitude towards myth. ${ }^{121}$ It is an attitude of cultural critique rather than a modulation in the feeling of utter dependence, a point of departure for active transformation rather than an acceptance of the source of our dependence as beneficent rather than maleficent. Cohen therefore not only replaces a Christian with a Jewish paradigm of religion but, in such replacement, changes the meaning and function of religion in its relation to other aspects of culture. ${ }^{122}$ While retaining a close relation with esthetics in its concern with "feeling" (cf. BR 16f and 85ff) religion is given its primary direction by ethics.

${ }^{120} \mathrm{He}$ commends Ritschl here and on many other occasions as engaging in a similar move; cf. BR p. 3 , and see exerpts among the mss from Natorp archive here in the appendix.

${ }^{121}$ One should take into account in this context that one of the fundamental differences and asymmetries between Judaism and Christianity consists in the fact that, while both claim to distinguish true from false religion, Judaism has as its negative point of departure myth and polytheism whereas Christianity takes its origin from another monotheism which it supersedes.

${ }^{122}$ In Moses the Egyptian (Cambridge/Mass: Harvard University Press, 1997), Jan Assmann has unearthed much of the historical pedigree of the idea of religion as a counter-culture in a Moses/Egypt discourse that surfaces especially strongly in the Renaissance (Hermetic literature) and Enlightenment (particularly among the Cambridge neo-Platonists), and that can be traced back to echoes of a suppressed and hence distorted memory in Hellenistic literature of the ancient Egyptian monotheistic predecessors of the Mosaic revelation. According to Assmann, many motifs of ancient and modern anti-Judaism can be derived from the inadvertent identification of the Hebrews with the forgotten Akhen-Aten. The Moses/Egypt discourse stands behind the famous idea of a primordial monotheism (Urmonotheismus) which is particularly popular in Platonizing philosophical circles in the 18th and 19th century. How exactly this tradition reaches Hermann Cohen is not yet clear to me. 
A further difference between Cohen and Schleiermacher concerns hermeneutics. Where Schleiermacher naively identifies the modern concept of a beatific dependence on the universe with the founding of the Christian religion by Christ himself, Cohen freely acknowledges that the historical sense of the biblical revelation is that of a "primitive literary product" characterized by a certain "naïveté" whose deeper meaning is discerned only in its interpretive afterlife, in the "development" such initial texts have taken in the history of religion (BR 21). Far from downgrading the history of dogmatics, Cohen turns to commentary and interpretation as a source of religious creativity rather than pursuing an elusive Urtext or Uroffenbarung.

The immediate setting of the discussion on religion is not provided by Schleiermacher but by the philosophical theologies of Natorp and Herrmann. Natorp makes religion the expression of a correlation between the concrete subject and the totality of culture, a variant on Schleiermacher's universe. ${ }^{123}$ Herrmann sees religion at work only where ethical self-realization grounds to a halt (in sin) and is displaced by a Kierkegaardian recognition of the reality of God as beyond culture. For Cohen, the sought-after concept of religion must not be the founding principle of an independent or totalizing experience of the self. Nevertheless, in agreement with his Marburg colleagues, he attributes to religion a function in the process of becoming a self. Yet the self that religion helps the individual to become is and remains the selfconsciousness of ethics. The latter being a task rather than a reality, religion is given a function in the realization of ethics.

The difference between ErW and BR can now be more accurately described. In the Ethics, Cohen examined the religious tradition of the West, more specifically Judaism and Christianity (and occasionally Islam), in light of their contributions to ethical concept formation. In most cases this led to the recognition of a founding function of ethical monotheism, i.e., of Hebrew prophetism, in the conceptual history of God and individual. Ezekiel discovers the individual in sin; the unique God as the fundamental law of truth. God and individual; individual and God. But only to the degree that these discoveries were relevant for ethics.

Now religion itself is thematized, or better: conceptualized. But the paradigm of religious conceptualization remains ethical monotheism. And it is paradigmatic for the concept of religion because it could serve as the source of concepts that were to be resolved in ethics. For what makes Judaism paradigmatic for the concept of religion, in Cohen's

${ }^{123}$ On Natorp's philosophy of religion see Judy Deane Saltzman, Paul Natorp's Philosophy of Religion, Hildesheim/New York: Olms, 1981. 
mind, is that in its sources and in their history of interpretation it demonstrates an elective affinity with problems posed not only in ethics but in all directions of culture. Certainly since the first meeting between Jewish sources and the Greek philosophical tradition, Jewish philosophers sought to promote a harmonious world view wherein philosophy and religion permeated each other. In the pious work of Jewish philosophers, the pursuit of theoria is commanded and the ancient struggle against idolatry is continued in the mode of philosophical theology. In its religious heritage as well as in the traditions of its philosophical interpretation Judaism becomes paradigmatic for a critical philosophy of religion also in that it withstands the alternatives of superand subordination of philosophy and religion.

From the confrontation between Hebrew and Greek thought in Philo of Alexandria it is also evident that Judaism, and thus religion as its cultural contribution, is not simply coextensive to Greek philosophy. There is a moment of heterogeneity and it remains intact in the Jewish philosophical tradition. If harmony is to be generated among the factors of culture, the purpose of the philosophy of religion must be to understand this heterogeneous factor as "akin" (gleichartig) to philosophy (7-8). Greek philosophy alone, therefore, is not a sufficient source for what philosophy in the Kantian tradition is to achieve. The function of Cohen's philosophy as a whole can therefore be described as bringing to methodological awareness the Jewish contribution to Western philosophy, an awareness it has been deprived of as long Christian religion was the only or prevailing religious paradigm. From the formation of concepts to the hermeneutics of optimization, from the ethical character of the Jewish concept of God to the practice of selftransformation through repentance, from the legal formalism and political dimension of his ethics to the moral character of his esthetics, Cohen's philosophy effortlessly meanders back and forth between Greek conceptualizations and Hebrew sources without bringing this method to full expression. What he does must speak for itself. When Kuno Fischer stated that Cohen's writings contained "more Judaism than philosophy," when Hartmann discerned that Cohen was "dropping his mask," or when Troeltsch called him "Philo modernus" they all discerned something quite accurate without being able to define it. Without being too extreme one might say that Cohen's philosophy of the unity of the cultural consciousness is the first articulation of Judaism in the language of modernity, by making modernity speak in a Jewish language. But, as is the case with all translations, neither Judaism nor modernity remained unchanged. In this philosophical enterprise Judaism is transformed into a Western philosophy that is both source-conscious and original. Likewise, as Western philosophy, this is the first articulation of 
systematic philosophy that is not guided by a Christian paradigm and into which the philosophical substance of Judaism has been integrated as a positive source for the formation of philosophical concepts.

Religion is therefore inducted to the exclusive roundtable of culture where, as it turns out, she has been at home all along. And the haughty ignorance of philosophy would have continued to mistake her for a lowly handmaiden but for the princely deviant who defies convention and asks the former slave to sit with the lords at the table of truth, the altar of knowledge. Unrecognized as the servant of the LORD, she was despised and rejected. Religion is the foreign virgin, described by Gottfried Keller, that the European knight elevates to unite with her in marriage (ErW 583); she is the maidservant who sat at the table in Cohen's father's house. As in any Jewish marriage, the fickle inclination of the heart must receive the form of a contract in which the objective conditions of a union are determined. But the objective continuity rooted in law becomes the precondition for a steadiness of development only if augmented by the virtue of loyalty (emunah, cf. ErW 571) as the subjective correlate to the law. The Concept of Religion in the System of Philosophy is the marriage contract that, in the dry language of critical origination, regulates the possibility of peaceful coexistence, fertile union, and friendship for the benefit of all. Religion must not remain a foreign element in culture; religion and culture must befriend each other. This is possible because they are "akin" to each other. The elevation of religion is supported by its internal force of self-idealization, but culture, too, must be converted to accept the new friend and partner as an Other who is like oneself. The reconciliation of religion and culture is therefore not a result but a task for future development whose legitimacy is justified in this treatise.

Finally, it should be noted that religion is dealt with only to the extent that it enters into a relation with the various branches of culture. Hence the chapter headings of the treatise on religion: "Das Verhältnis der Religion zur ..." Religion from within its own perspective is not the issue here. That is rather the task of an exposition of Jewish philosophy of religion and ethics, i.e., the task of the book Cohen had been contracted to write since 1904, and which he left behind as his final legacy in Religion der Vernunft aus den Quellen des Judentums.

\subsubsection{The Relation of Religion to Logic}

The peculiarity of religion is grounded in the relation between its content and that of culture, philosophy, and consciousness rather than in a lack thereof. Religion contains claims to truth (e.g., emet) and knowledge (e.g., $\left.d a^{\prime} a t\right)$ and thus demands recognition as a legitimate child of logic. Even if 
the primary philosophical association was with ethics, the logical basis would be maintained in that ethics is tied to it in the fundamental law of truth. Even if one focused on the esthetic problem of feeling that is inevitably central to religion, the ethical and logical dimensions of esthetics would retain its religious sister within the circle of cultural unity. Ubiquity not heterogeneity is the first obstacle. Religion is everywhere and nowhere. (Cf. 16-18)

The content of religion is indicated in the concepts of "God and the human being" (Gott und Mensch). Together these concepts determine the range of problems in which religion is to unfold its generative function although other terms may be introduced to indicate what is being correlated therein. In the terminological pair "universe" and "soul" for example, the relation of God and human being is preserved but given a direction towards the problem of cognition (19).

In Cohen's terminology, logic is the logic of cognition. Cognition correlates logic with being as the object of cognition as its origin. If being is founded in thought, it is limited to that which can be justified from the point of view of logic as valid cognition. Being is founded in logic as valid cognition. The being of nature thus is a term of the quintessence of the laws of nature that are founded ( $g$ rundgelegt) in thought. Logic in and of itself has no immediate relation to religion unless religion engages in a founding relation to being. Logic is then at work in religion, and religion can be determined as congruent with logic to the degree that both are concerned with being. In the biblical text and the history of its Jewish philosophical interpretation such a relation is indeed stipulated when the divine self-revelation is stated in terms that relate God and being. The etymology of the YHWH name in Exodus 3:14 provides a "new name" for the God of the fathers, in form of a sentence: Ehyeh asher ehyeh. "I am who I am" or, more accurately, "I shall be who I shall be" generates the center of gravity for all future efforts at interpreting what this revelation, what this God, what this religion is supposed to mean. It formulates a "demand: God is Being; and what this thesis is to mean becomes the content of religion" (20-22).

In LrE, Cohen defines thought as the unification of separation and unification. The unitive aspect in which thought unites religion and logic is here justified in the koinonia of the concept of being, a communion that involves separation, "difference" (23). In the concept of God itself, the unitive aspect is not central so as if God were the synthesis of a number of divine aspects. "God is One" is rather to be interpreted as a proclamation of the "uniqueness of being" in which God's being differs (ibid.). In this sense, the religious source and source of religion participates in the rational problem of being which is the mother of logic itself (ibid.). Cohen turns to pre-Socratic philosophy in order to show this 
connection. Here, too, the term "god" functions as an indicator of the unity of being. It is interesting that Cohen lets the row of Greek thinkers on this problem begin with Xenophanes whose critique of the anthropomorphism of the Homeric gods puts him in an exact parallel to the Hebrew prophets and their polemics against idolatry $(23,25,26)$. In contrast to the radical enlightenment critique of religion and its successors, Mosaic monotheism appears here itself as a rationally motivated critique of religion. This view is neither unique nor merely modern. Rather, Cohen taps into an ancient tradition that understands the Mosaic revelation as a variant of other monotheistic speculations that concern the unity of the universe and the role of the human being within it. 124

The most significant characteristic of the parallel discovery of the unity of being in Greek and Hebrew sources is the recognition of the implications it has for the self-consciousness of thought. The unity of being cannot be perceived with one's senses. The ancient pantheistic identity of god and the unity of nature leads to a self-distinction of the spirit from sensual perception and emphasizes the spontaneity of thought. The divine being of nature subjects nature to unitive thought which firsts manifests itself in the conception of god as one. The second implication of this identity of hen kai pan is the recognition of nature as unique which displaces the notion of many worlds and heavens. Thirdly, if cosmic nature is singular so is the spirit that comprehends it. Thus unity connects being and thought (23-25).

But how are we to understand this proximity between Moses and Eleatic philosophy? Has Cohen made peace with pantheism? Rather, the difference between Mosaic religion and pre-Socratic philosophy fully emerges as the nature of the unity is further considered. Thought and being are to be united in thought, and only through thought in being. Cohen approaches the difference by reintroducing the religious tradition where knowledge is commanded and equated with love. The word in Hebrew that refers to knowledge ( $\left.d a^{\prime} a t\right)$ also means conjugal union (25). Cognition is commanded as an act of union in which thought unites with being, i.e., with God. But it is a commandment rather than a statement of fact. What in Cohen's logic and ethics is expressed in terms of tasks, the Mosaic law and its philosophical interpretation call "commandment." If, therefore, the Jewish tradition makes the love of God the first commandment it means knowledge as a task. The difference between unity stipulated as a task and the "pan of nature" is fundamental. For the

${ }^{124}$ In the above mentioned study Jan Assmann points out that Platonizing interpretations of the Moses tradition tend to take the philosophical hen kai pan of Greek pantheism as the hidden meaning of Mosaic monotheism. 
uniqueness of being means in one case the being of God as distinct from nature whereas in the other case nature is All. Hence: "there is no reconciliation between monotheism and pantheism. The pan of nature is the absolute contradiction to the uniqueness of God" (27). While pantheism thus exerts a beneficial effect on the development of the natural sciences (cf. the "materialism as hypothesis" thesis in Lange's History of Materialism) it must not be taken as the only valid or exclusive rational perspective on the world (ibid.).

There is, Cohen points out, an ambiguity or double entendre (Doppelsinn) in the notion of being as it is introduced in pantheism, an ambiguity that is glossed over in the equation of God and nature (deus sive natura) so that the full logical complexity of the relation between nature, god, thought, and being remains unconscious. Instead of one identity, two identities should be differentiated and maintained in both separation and unity, namely the identity of thought and being (as the condition of possibility of logic) and the identity of God and being (as the condition of the possibility of ethics) (ibid.).

The identity of God and being therefore discloses its full meaning and function only in the context of ethics. Cohen therefore limits the discussion of the relation of religion to logic to the discussion of the parallel discovery of the unity of being in Hebrew Bible and pre-Socratic philosophy. The ethical dimension of the Mosaic God is, as we know, associated with the Platonic idea of the Good as "beyond being." The Platonic idea itself however is a principle of the logic of cognition where it is identified with the "hypothesis." "The idea is the hypothesis and the hypothesis is the idea," (29) and it is Plato who brings the problem of the unity of being discovered by his predecessors to full methodological selfconsciousness. In preparation for the chapter on ethics as well as in completion of the problem of being in the context of Greek philosophy, Cohen thus concludes with the reintroduction of Plato's discovery of the idea as the solution to the riddle of the power of thought (28) without, however, determining in this context how the idea of God relates to this discovery of the idea as hypothesis. It is nevertheless of interest to us how he characterizes the Platonic idea. For the purpose of the discussion is to show the homogeneity of religion with the various directions of culture in those respects where culture and religion overlap. It is therefore of great relevance to Cohen's understanding of religion when, here and repeatedly since one of his earliest essays, ${ }^{125}$ he associates prophetic and Platonic vision. The imagery of Hebrew hazon and Greek idein is one and the same, as Fichte already pointed out (29). Distinguished from both is the Latin translation that gives rise to the

${ }^{125}$ "Die platonische Ideenlehre, psychologisch entwickelt" in: ZVPS 4/1866. 
notion of intuition. What is described here? The Platonic idea is itself a riddle in that it speaks of a vision when referring to the intellectual perception of something that is on principle invisible. One might say that the explication of this riddle has been the sole content and driving force of the Western philosophical tradition just as the intimate (innig) knowledge of the being of God has been the task of religion. In this communion of the tasks and nowhere else lies the very core of Cohen's confidence in the possibility of a reconciliation between religion and philosophy.

\subsubsection{The Relation of Religion to Ethics}

This is a decisive chapter. It has always been felt that here, if anywhere, the difference between the systematic philosopher and the religious thinker must emerge. More accurately, if the 1915 treatise on religion is to offer a new insight into religion, one that warrants speaking of a modification in Cohen's program (as indicated in the changed wording of EmkN 1914 with respect to the relation of ethics and religion), it is to be found here. Although, if our understanding of "system" in Cohen's sense is accurate, and if it is guided not by a logic of deduction but by the transcendental analysis of cultural facts, the very integration of religion into this system must not be considered a departure from the system as such, only from certain programmatic theses that were formulated under the impression of one task and that are now modified in order to do greater justice to a new task without invalidating the old one. For the claim to attribute peculiarity or even a certain independence to religion in the context of culture does not necessarily contradict the earlier claim that religious truths are to be translated into the language of ethics. It just means that ethics comes to a limit beyond which it can only reach if there is something beyond that corresponds to its demands while this beyond is not itself grounded in ethics or only negatively in ethics. Religion is given charge of another "beyond being," a being beyond the reach of ethics. This new anhupotheton, however, is not declared in order to overthrow the method of origination but rather to complete the magic circle of idealism while keeping it permeable. It is worthwhile to examine this chapter in detail. ${ }^{126}$

${ }^{126}$ The numbers at the beginning of the paragraphs below correspond to the numbering of Cohen's paragraphs. This makes more sense than having an "ibid." after every quotation. Only where passages are referred to from outside the paragraph do I supply the page number or work cited if other than BR. 


\section{PARAGRAPHS 1-25: THE CORRELATION OF GOD AND THE HUMAN BEING}

The aim of the chapter is to examine "the connection of religion with ethics" and "demonstrate" from this connection "the share (Anteil) of systematic philosophy in religion." From this very formulation one can gather that Cohen is keenly interested in determining the contribution of religion to philosophy in terms that allow both religion and philosophy, and ethics in particular, not only to remain intact but also to show that religion as something quite distinct from other directions of culture receives its distinctness and its distinction from the very sources that are at work in all other directions of culture. Religion itself has not only its rationale but reason. But this rational core of religion is revealed only to the degree that it enters, out of its own rational impulse, into a relation with ethics. At the same time, the two remain apart, distinguishable, and both necessary. From the perspective of the systematic examination, then, the initial programmatic directive of "resolving religion into ethics" is being corrected as, at least, one-sided, namely as seen from the perspective of ethics only without regard to its own incompleteness and need for augmentation from elsewhere. Can it be that, when preparing two editions of Ethics of Pure Will, Cohen was himself unaware of the kind of augmentation he proposes here? Was his own consciousness so absorbed by the matter of ethics that he could not imagine the need for a separate philosophical justification of religion to arise? Was the notion of the eventual superfluousness of religion as it does the work of ethical transformation of particular communities into homogeneous members of a morally grounded state associated with an expectation of a coming of such a messianic state of affairs "soon, in our days?" Or is the latter posture as much a liturgical as an ethical necessity, i.e., is it not to be maintained even after religion is justified from the perspective of philosophy, that ethics must urge religions to transform themselves towards eventual superfluousness? The question remains: Who or what is to vanish, and what sense of time attaches to this vanishing act?

\section{Correlation}

Cohen begins his examination by restating the difference between monotheism and polytheism in terms that are already familiar from the Ethics. The "concept of monotheism" is distinguished as having its "main content" not as much in God than in the human being. From the point of view of the Ethics religion acquired its philosophical birthright in the oft quoted words of Micah 6:8 where the center of gravity of Israelite prophecy is identified in the association of God, the human being, and the good. The resolution of religion into ethics was thus grounded in the conviction that Israelite monotheism and Socratic philosophy share the 
common impulse in shifting the center of gravity of cultural work onto the determination of the concept of the human being. Yet there clearly is a difference between Socrates and Micah, and it is their difference rather than their agreement that is now moved into focus.

Monotheism, so Cohen, is characterized by the fact that it concerns not "God alone and in himself but only in correlation with the human being, as of course therefore also in accordance with the correlation: not the human being alone but always also in correlation with God" (BR 32). I have used the term correlation before in characterizing Cohen's method of associating concepts that are mutually constitutive and whose erstwhile substantive meaning is displaced by their function in the constitution of an object. This use of the term before the "late" philosophy of religion is justified by the fact that "correlation" is "a scientific basic form of thought in (the) terminology of judgment" in Cohen's Logic (BR 47). However, Cohen himself feels the need to distinguish this term anew. Indeed, where the term "correlation" is used in ErW, a lesser degree of methodological self-consciousness seems to be at work than here where the correlation of human and being and God is the main point. Thus Cohen reflects in a later paragraph (nr. 29, BR 47):

\begin{abstract}
We have attributed a fundamental significance to the notion of correlation which we then attempted to prove; but why does this notion occur to me at all? Correlation is a fundamental form of thought in our terminology of judgment. Its general name is that of purpose (Zweck). Where one begins the formation of a concept (Begriffsbildung), the setting of a purpose (Zwecksetzung) is established. We apply (ansetzen) a relation of purpose (Zweckbeziehung) between God and the human being as between God and nature. When we asked how we arrived at the correlation of God and human being, the answer is: this is how judgment proceeds in the setting of purpose whose general form is concept formation (Begriffsbildung). When I want to form the concept of God accordingly I must perform (vornehmen) a setting of purpose between God and human being and thus distill (gewinnen) the concept of the human being from the structure in the content (Gliederung im Inhalt) of the concept of God and vice versa. The purpose has such elemental meaning for concept in general. And from this respect alone a denial of purpose proves to be a deficiency in one's understanding of logic. (BR 47)
\end{abstract}

Correlativity is thus not a new form of thought but one called upon to determine the difference between two concepts of the human being. But the difference in the content and function of the respective concepts of the human being depends on the possibility of a communion between these concepts which is established in the correlation of the correlative concepts and thus in the correlation of the purposes of ethics and religion. Correlation thus warrants not only the separation but also the 
union of these separate spheres of concept formation. It is this which Cohen hints at when he concludes the above paragraph with the following, in itself somewhat enigmatic, hint.

But purpose pursues its own purposes aside from those of concept (-formation); or at least it rounds out its conceptual apparatus in new problems and new logical solutions. (ibid.)

The ethical concept of the human being was established by correlating self and human other, while the religious concept of the human being is formed in a correlation with the concept of God. The ethical self has its purpose determined by its correlativity with the other human being. The religious self has its purpose determined by the divine Other. The meaning of the ethical concept of God is not congruent with the meaning of the religious concept of God. The same must be true for the meaning of the respective concepts of the human being. Yet the purpose of their correlation in religion is correlated to the purpose of their correlation in ethics. One augments and demands the other so that only both together can achieve what they must, namely contribute to the advancement of a full content of humanity in the context of the unity of the cultural consciousness. The ultimate purpose of correlation is therefore the establishment of harmony, peace, and union in theoretical culture as a precondition for its pursuit in practical culture.

Another matter can be anticipated from these initial remarks on the correlativity of religion and ethics. Here, namely, we find a most striking example for Cohen's attempt to give his whole philosophy a direction that is grounded in the depths structure of Jewish thought in opposition to Christian theology. ${ }^{127}$ In this view the Christian tradition makes law the negative condition to be overcome by redemption and thus achieves

127I ignore here for a moment the important question whether Jewish philosophy depends on the antithesis of Christian theology in order to come to full methodological self-consciousness. The correlativity of ethics and religion that is claimed by Cohen and many other modern Jewish thinkers would thus have to be regarded as mediated by the apologetic need to counter the opposite claim that takes either the negative form of charging Jews with misanthropy or the positive form of a Christian claim to exclusive ownership of a higher morality. For traditional Christian faith the very thought of a continuity between ethics and religion amounts to a "counter-religious" claim (cf. Assmann, op.cit.). However, it could then be argued that such counter-religiosity is at the very heart of Mosaism, and thus predates the confrontation with Christianity. Early Christianity itself absorbed both the pagan revulsion for Jewish counterreligiosity and the Jewish counter religiosity. In Cohen's case it would be wrong to foreground anti-Christian polemics. His whole philosophical enterprise aims at making the existence of the Jew in a Christian culture not only possible but politically fertile. His private judgments on "them" are very much suppressed in his idealizing thought. 
an internalization of the law as the guilty verdict that makes morality a perpetual propedeutic to the religious self-consciousness that aims at trans-worldly happiness. Judaism, in contrast, insists on a continuity between the purposes of moral and ceremonial law that is grounded in their correlated contribution to the realization of humanity before God, a realization that manifests itself not primarily in hope for individual continuity after death but in acts of unification of the self in its various correlations: between self and self, self and other, and self and God. However, in order to distinguish the religious apriori, Cohen addresses the very problem that is also the center of Christian doctrine: sin, in the sense of the gap between the ideal established in ethics and the real experience of human beings. From the perspective of the Ethics of Pure Will, therefore, the path to religion is opened up when the realization and thus the realism of ethics is in question. The Ethics is thus in a certain sense incomplete and cannot complete itself by means of its own conceptual apparatus. The task of ethics was to determine the concept of the human being in a sense that reaches beyond the being of nature. It completed its task in identifying the structure in which human society is to seek its perfection: the law and the state. But ethics fails to account for failure. Failure is individual, particular, concrete. Nevertheless it is also universal. It is universal in its particularity. Can the singularity that is meant here be conceptualized and addressed in terms that redirect it towards the purpose of a realization of ethics? Can religion augment ethics? Religion thus contributes a new and different concept of the human being correlated to a new and different concept of God. The human being is the singular and concrete subject that emerges as negatively correlated to the realization of the ethical self-consciousness. The individual is discovered in the concept of sin. For sin is not an immediate experience. Rather, it is a culturally mediated knowledge, a self-knowledge that, if conceived as originating in the individual, leads to individuation. But we should return to Cohen's procedure of exposition by which he approaches the religious apriori.

\section{Beyond Fear of the Gods}

The correlation of God and human being that, to Cohen, provides the criterion for the concept of religion is to be distinguished from the relation between god(s) and human being(s) in polytheism. However, both polytheism and monotheism are expressed in form of cultic ceremonies. Hence, cult in and of itself must not be made the criterion for the concept of religion for its meaning is different in both systems. Without making this explicit Cohen can rely on the precedent of Maimonides who stipulates in the Guide for the Perplexed, that the sacrificial cult in general as well as any number of particular laws that 
defy the attempt of rational interpretation (hukkim) were given in accommodation to the habit of the Israelites who, like their contemporaries, could not conceive of divinity without sacrifice. In addition, Cohen asserts that the attitudes inherent in polytheistic and monotheistic sacrificial cults differ fundamentally so that the cultic form itself cannot be made a criterion for the ideational content associated with it. In the case of polytheism, the envy and wrath of the god(s) must be placated. Here the motivation for sacrifice is fear and its purpose is propitiation. The human being experiences herself as subordinate to fickle and unpredictable powers. In monotheistic religion, however, the human being "steps to God's side as it were of equal birth" (gleichsam ebenbürtig zur Seite tritt). The newly found dignity of the human being that is rooted in the correlativity of God and human being does not express itself in an abandonment of sacrificial practice but achieves a new phenomenology of cultic action while retaining the ancient means of expression.

In this chapter which deals with "The Relation of Religion and Ethics" Cohen introduces his theory of sin and atonement, the very theory that he had developed as early as the 1890 s but which had surfaced only in remarks whose full implications could not possibly be understood. For example in the Ethics, Cohen referred to the discovery of the individual by Ezekiel. Which one of his contemporary readers could know what he was referring to? The confidence and certainty that religious concepts bring necessary contributions to the construction of ethics was grounded in a religious philosophy that had surfaced in various essays but whose central idea is introduced here for the first time publicly and in the context of a work directed primarily to his philosophical readers. It is therefore all the more interesting to trace the rhetoric of this exposition and follow the argument Cohen is making. For nothing in this chapter (or elsewhere) is left to improvisation. The content is not invented ad hoc, and the exposition is directed at persuading readers who are looking for an argument for religion and that are curious as to whether and how such an argument can be made from the perspective of a devout Jew.

\section{Correlation and the Good. Micah 6:8}

A further difference between religion and its mythological precursors consists in the shift in attention from the essence and fate of gods and humans to the problem of the Good. As in ErW (and RV), Cohen quotes Micah 6:8 as the prooftext where

the three concepts are united: the human being has appeared and takes the place of the Israelite. And God called him in order to inform him (Kunde zu geben ) —about what? Perhaps about himself? 
Or about the human being? About neither one. The information (Kunde) refers to something wholly different, a new concept, a concept with the heavy weight of abstraction: the Good. (33)

Cohen sees the foundation of monotheism expressed in this sentence where God and human being "seem" to find their correlative legitimization in the concept of the Good. It is important to note that Cohen speaks here in the deliberate tone of the rabbinic hyperbole which uses a cautionary "as it were" (kiveyakhol) to signal a particularly daring anthropomorphic reference to God. Cohen sees the daring of the Hebrew prophets as contained not so much in their idea of God as such, or in their concern with social ethics, but rather in their discovery and revelation of "the unique God of the One humanity." The messianic idea whose radical imposition of a genuine futurity Cohen made a wellspring of his own ethical thought is here distinguished again as the discovery of the Hebrew prophets. Humanity (Menschheit) is content of theoretical as well as applied ethics. It is also the common Good for human being and God (ibid.).

\section{The Time of Correlation: Messianism and Future}

"Prophetism" thus has no other purpose and no lesser merit than the "realization of the One humanity in the messianic age." The "content of the new religion" is the "confidence in this future of humanity," a content which cannot be falsified by the empirical facts of world history. Cohen explicitly parallels thought and religion in this move away from sense perception.

As thought turns away from perception and the reality that represents itself in it so the religion of messianism turns away from the past to the presence; it creates a new concept of time for the human being in correlation with God: Future.

The underlying allusion to the simile of the cave is even more evident when Cohen continues:

It (viz. future) alone fulfills time; it alone makes time alive, true, and meaningful. What otherwise appears as temporal content is merely shadow image (Schattengebild) - it crawls along and bloodlessly limps behind whereas future alone has the pulse of life - of truthful being (wahrhaftes Sein), just as to the Eleatics it arises in thought.

Messianism and atonement belong together in Cohen's mind. The combination of these themes is evident in the unpublished essays from the 1890s, in Ethics, as well as in Religion of Reason. Whereas in the latter the exposition of the individual aspect of the atonement precedes that of the universal perspective of humanity in the idea of messianism, here in $\mathrm{BR}$, messianism sets the stage for the contribution of religion and ritual 
in its monotheistic setting to the constitution of an ethically directed constitution of the individual self. Coming from the chapter on logic and religion this procedure not only makes sense but it helps to recognize the truly profound significance of the messianic idea to a full concept of time. The discovery of the future as logically prior to the past, as the lifeinfusing principle of time, and thus as the being of time, is seen as an achievement on a par with the Eleatic discovery of cosmic oneness. The human being of Hebrew prophecy is fully developed only in the conceptual pair of messianism and atonement, but already here we sense the deliberate emphasis on uniqueness as against oneness. The element of religion that cannot be absorbed into the thought of logic, the selfconsciousness of ethics, or the reflective self of esthetics is the element of uniqueness: the Here, Now, You that emerge from the anticipation of reality that is given its ethical direction through the common ground of God and human being: the Good or humanity.

One can also immediately sense that while the prius of future before past speaks to the same philosophical concern with concrete subjectivity that springs up elsewhere and eventually becomes one of the possible points of departure for a new philosophy, the new philosophers were to be less than satisfied by the fact that the future Cohen speaks of is both indeterminate and determinate. The ancient problematic of divine providence and predetermination arises as the primary concern for a philosophy that "breaks through the veil of idealism" to retrieve the ultimate groundedness of being in an unforethinkable future. Again, I would argue, we arrive at the fundamental difference between an apocalyptic and a non-apocalyptic eschatology. Existentialism and its variants are ultimately a nihilistic variant of apocalypticism in that the disaster and destruction that is anticipated is heroically faced and yet denied in every moment at which we project ourselves into the future. In contrast, Cohen's non-apocalyptic eschatology anticipates that which in such anticipation is realized: the Good! Evil, recognized as being in apocalypticism, is denied reality in Cohen's messianic religion and only thus can its appearance be overcome. This is anything but cheap optimism and naive faith in the progress of history.

\section{5.-6. T'shuvah and Paideia}

The ethical dimension of the very core discovery of religion, the messianic idea and its grounding of a correlation of human being and God, calls for a further comparison with ethics in the philosophical tradition of Greece as well as with its further development in philosophical history.

The first parallel in Greece to Micah's association of God, human being, and Good is Socrates' conceptual focus of philosophy on the 
human being. The question "what is?" as the form of the concept is discovered by asking for the underlying commonality to the various pursuits of citizens of Athens of the property of goodness. This line of inquiry is completed by Plato who seeks the foundation of the concept of the human being in a goodness that is described in the collective entity of the state (polis) and thus as a form and ideal foundation that precedes all experience. The common move in Hebrew prophecy and Greek philosophy is one away from empirical reality and towards an ideal reality (in Micah, adam; in Plato, polis). It should be noted in this context that it is a characteristic of thought wherein the parallel between Hebrew and Greek discoveries are established. So, e.g., on p. 34: "again the same fundamental force of thought" (etc.). One should also keep in mind in this context that the Hebrew word for "turning away/turning towards" is shuv from which the noun t'shuvah is derived that refers, narrowly defined, to repentance and which Cohen evidently sees as a fundamental form of thought. T'shuvah indicates the very motion of turning away from idols that in the simile of the cave is described as an illustration of paideia and, thus, as the quintessence of philosophy. It is this parallel Cohen has in mind here, i.e., a method of thought that is equally discovered and applied in its religious as well as in its philosophical sources.

\section{7.-10. epekeina tes ousias}

The "analogy" (35) of ethics and religion can be pursued further. Religion, in the fashion of Philo and Saadia, has now become the harbinger of thought which gradually achieves the height of revelation. The question, then, is that if philosophy as the secular sister has achieved an understanding of the significance and methodological nature of the Good, can it also discover the meaning and function of the monotheistic idea of God. And while Plato himself may not have used the term in this sense, is it not possible that he understood and determined the problem that God will indicate in the Western metaphysical tradition as soon as Athens resumes its dialogue with Jerusalem and vice versa? In other words, in light of a history of interpretation that determines backwards the original and originative meaning of a text, since Western tradition identified the Platonic idea of the Good with the God of the prophets, what is it that warrants this identification that is the heartbeat of the metaphysical tradition? In the Platonic context, this problem is contained in the task of "drawing the limits among the ideas, and among them for the idea of the Good, and thus between ethics and logic." Thus the function of the prophetic idea of God is seen in analogy with the very task of systematic philosophy, the unification of the distinct spheres of theoretical culture. 
Here we stand at the genuine gate of metaphysics that lies at the crossroads where natural science and humanities (Geisteswissenschaft) part ways, where logic ends and ethics begins. This test was put also to the theory of ideas and Plato passed it.

As in ErW, therefore, God indicates the "question of truth" as the possibility of unifying Is (nature) and Ought (ethics) while keeping them distinct. It seems as if both traditions, Hebrew and Greek, were necessary and that only in their combination a full sense of this tension and its resolution in the futurity of the Good could be generated. But this is not the meaning of this passage. Cohen is not about to endorse metaphysics in its displacement of the idea of the Good by a transcendental God. For the latter is a philosophically questionable substantivization of a problem at the limit of idealist thought that, in Plato, arises from the desire to distinguish the value of the idea of the Good as the "greatest knowledge" (megiston mathema) in "power and dignity" (dunamei kai presbeia) (36f). Only in the insistence on a "difference of the problems" of logic and ethics (36) lies the justification of the "methodical formulation" (ibid.) of a "beyond being" of the idea of the Good. (37)

\section{Teleology and Theology}

The metaphysical tradition is not only fueled by the idea of the Good in which "beyond being" is turned into substantive transcendence but it also retains Plato's interest in ethics. Aristotelian teleology, the concept of "purpose" (telos, Zweck) has exerted its important value in the science of biology (see above, on LrE) where it united the quest for a concept of the human being in its physical and metaphysical aspects. However, medieval thought severed the God of metaphysics and the teleological ethics which had the effect of eliminating the concept of God from the range of problems dealt with in the context of ethics. The advantage of this division between ethics and metaphysics was that ethics as a discipline could be entirely devoted to the problem of the human being. In Kant, this autonomy of ethics was further enhanced by making it the presupposition and foundation of religion, limiting theology to "ethicotheology" even though he allowed for religion to represent a "particular behavior of consciousness" (38).

\section{2.-13. Idea and Vision}

With the reference to Kant, Cohen returns to the overarching question of the treatise, the character of religion as a concept in the system of philosophy, its relation to the primary parts of the system, and thus the systematicity of philosophy itself. In Kant, this kind of inquiry is found most prominently in the Critique of Judgment (1790) where, for the first time, the concept of reason and the range of philosophy are extended to 
include a postulate of systematic completeness. Esthetics as a critique of "common sense" is the mediating institution between theoretical and practical reason and thus systematic thought par excellence. The problem tackled by Kant is of great import to Cohen's concept of religion not only because esthetics had similarly permeated theoretical and practical philosophy throughout history before achieving systematic distinction. But the esthetic tradition was also from its inception complicated and tied up with religion.

From a different angle, Cohen raises here the very issue that was first dealt with in his early essay on the formation of Plato's theory of ideas, ${ }^{128}$ an echo of which we already noted earlier in the parallel between philosophical idea and prophetic vision. In both, the early essay on Plato and the 1915 treatise, esthetic aspects are in evidence. Further, as Cohen also points out in ErW, the neo-Platonist who contributed to a new appreciation of the idea of beauty, Plotinus, associates it with the idea of God (39). There is, thus, throughout the idealist tradition an association between religious form and esthetic content that can even be perceived as a "collision" (ibid.). To Cohen, this collision, or perhaps collusion, rests on the fact that the same aspect of consciousness, feeling, is recruited by both esthetic judgment and religion. However, the collision is undermined, and the seeming identity avoided, where, as in monotheism, the concept of God is radically critical of representation.

\title{
14. Esthetics and Religion
}

The connection between esthetics and religion is, however, not limited to the fact that, in Greek tradition and other mythologies, art generates images of divinity. Rather the connection is grounded in the fact that art is primarily a representation of the ideal of the human being. This is so central to esthetics that Cohen can write that

\begin{abstract}
human being seeks human being; this desire (for him) drives towards discovery (kommt seiner Auffindung entgegen) and enlivens (beseelt) and inspires (begeistet) its contemplation. The human being is itself the creation of its art, this is true for all art. If there were no religion, art would be the revelation of the human being, and if there were no ethics, art would be the imprint of this revelation.
\end{abstract}

This loaded passage is apt to remind us not only of the Platonic tradition (e.g., beseelt = empsuchos) but it points backward to the logic in the motif of a discovery of something that is grounded in a desire to know that precedes and thus constitutes what is being discovered for what it is. It also points forward to the chapter in Religion der Vernunft

128 "Die platonische Ideenlehre, psychologisch entwickelt" in: ZVPs 4/1866, 403 464 (=S1,30-87). 
where revelation is made the creation of the human being in reason. Here and throughout his works, Cohen sees a positive and constructive mutual relation between esthetics and religion.

\section{Esthetics and Religion in Cultic Ceremony}

Cohen pursues this relation further in the topic of cultic ceremonial practice and in the ideal of humanity, the former being characteristic of Jewish religiosity, the latter of Christian faith. Cultic ceremony merges (verschmelzen) esthetic form and religious content to such a degree that "to the modern human being it became doubtful that his religiosity was anything but an esthetic attitude" and thus one was tempted to think that "art may be called upon to replace the old religiosity." Similarly, the 19th-century estheticization of the Christian religion (esp. in Schiller) was supported by the fact that the birth and suffering of Christ had all along embraced a strongly esthetic component so that the estheticization of the ideal of humanity brought about a similar transformation of the idea of God.

\section{The Religious Apriori}

Cohen thus enters into the discussion of the modern Christian idea of a religious a priori from an esthetic angle. Grounded in the notion of the love of God towards the human being, estheticized religion involves the assumption of a fundamental attitude of consciousness that is specific to religion and which has its positive content in a feeling of being loved. Cohen does not deny that this feeling is inspired in part by the religious feeling of love towards God and the fellow human being yet its esthetic origin generates the danger of "resolving it in esthetic feeling" (in Kunstgefühl sich aufzulösen). This tendency is even more evident, as Cohen writes in unmistakable allusion to Schleiermacher, when not love but desire to reach beyond the limitation of one's earthbound existence elevates one's feeling towards the infinite (p. 41).

\section{The Difference of Religion}

Religion is not to be "resolved" into esthetics. Instead, its association with feeling must be turned into a well-spring for a proper understanding of the difference of religion. Esthetics is not to be deprived of its "ownership" over the domain of feeling but, instead of obfuscating the problem of religion, this very fact of the systematic architecture should allow for religion to achieve whatever "independence" it can and should without regard to the "direction of feeling" (ibid.). Religion is undeniably related to esthetics as much as to the domains of logic and ethics. But it must not be absorbed by any one of them nor attempt to replace them. 


\section{8.-20. Religion "beyond" Ethics. Wilhelm Herrmann's Challenge}

Not surprisingly, this is the place for Cohen to address the claim, programmatically formulated in EmkN and followed through in detail in ErW, that religion be resolved into ethics. In contrast to this claim, religion is now to be distinguished in its independence rather than in its absorbability into ethics. In the eschatological perspective of the Ethics "sinners are to be no more on earth" (yittamu hata'im min ha'arets). But, to be sure, such is an ideal and the Ethics is construed to make this ideal realizable. The eschaton determines the end and purpose of action and direction of the will; and religion does its own to contribute to the formation of these concepts of end and direction. In this sense religion is not only absorbable but, from the perspective of ethics, must contribute de facto towards making itself superfluous. For where there are no more sinners there is no more need for religion. But, in the meantime, before the messianic age, religion clearly continues to contribute to the realization of ethics, or at least it should do so. This is as far as the argument is carried in Ethics of Pure Will.

Here in BR, Cohen returns to the problem in light of the new problem, the systematic permanence and value of religion to the degree that it must not simply be resolved according to its ethical content but exert a function within the whole of the cultural consciousness that is as "eternal" as is the task of ethical perfection, the pursuit of truth, and the ideal of beauty. First of all, Cohen defends the right of his Ethics to argue, as it did, for a resolution of religion into ethics. In this context he prominently mentions Wilhelm Herrmann who had challenged him on the need for religion to go beyond ethics.

One could draw the conclusion (viz. from making feeling the exclusive domain of esthetics) that religion cannot be maintained as its own independent direction of consciousness in that feeling cannot be attributed to it and another direction of consciousness could not be identified for it. I myself could not escape this logical conclusion (Konsequenz) in the formulation contained in my Ethics of Pure Will. And Wilhelm Herrmann was the one who recognized that I merely drew the logical conclusion that Kant himself should have drawn from his determination of the foundation (Grundbestimmung) of religion according to its relation with ethics. I did not shy away from the methodical conclusion that religion is to resolve itself into ethics. Religion only appeared to be damaged thereby while in fact it adjudicated it a claim to fame and expressed the password to its innermost development. For how could one glorify religion better than by making resolution into ethics its own goal? This goal would truly not be its end but in it and in its formulation the guiding star would begin to shine brightly that, up till now, lit up its historical path only dimly. Perhaps this could 
even be the most important criterion for the truth content of religion: to what degree it is capable to resolve itself into ethics.

As Cohen reformulates the challenge and defends his earlier position in the process, the most striking element is the change of the subject of transformation. Conventionally, ethics seemed to guide the transformation; culture was the headmaster under whose tutelage religion was to shed its uncontrolled wildness and cultivate itself. From the perspective of the above formulation, and in keeping with the hermeneutic strategy that guided the references to religious traditions in ErW, however, religion itself is its own guide and source in the process of ethical self-transformation. As we observed in our chapter on the Ethics, the implementation and thus the meaning of the programmatic statement of a resolution of religion into ethics was hampered by the different quality of the religions Cohen referred to, Judaism (or, as he prefers to call it in order to emphasize its historical and philosophical priority: monotheism) as a source of ethical concepts, and Christianity as basic to Western culture and the primary target of the ethical critique of religion.

But even if Judaism were the only true religion, ${ }^{129}$ its cultural function beyond and aside from ethics seems to Cohen now insufficiently determined if the only knowledge we have of it is its readiness to infuse ethics with the ideals of God and humanity and not also breathe life into those ideals in a way that goes beyond the strength of esthetics. Furthermore, the very use of the term religion in the context of ethics makes clear that religion is more than the singular tradition of Judaism (which is not exactly a unified entity either) so that a general concept of religion must have been presupposed in the first place. Based on Cohen's overall attitude towards conceptual history, prophetic monotheism cannot function as a historical source of culture without also functioning systematically as an origin. Yet in the Ethics, the systematically originative aspect of religion was not considered because religion was meant to empty its whole content into ethics. On the other hand, among the virtues, such of a first order and such of a second order were distinguished, and this distinction pointed to a hierarchical order of allegiance: the natural love for one's community as regulated by the ethical virtue of love towards any fellow human being and loyalty to the universal ideal. The ethical perspective itself therefore could rely on religious sources but could not determine religion more than in a regulatory fashion, seeking to exclude fanaticism and disloyalty to the greater good. In positive terms, the universal solidarity that underlies the

${ }^{129}$ As explicitly claimed in "Ethik und Religionsphilosophie in ihrem Zusammenhange," Berlin, 1904 (= J2,108-125). 
legal framework and that acts as a limit to parochialism was itself seen as one of the outgrowths of religion rather than of Greek philosophy.

It is evident that in the Concept of Religion Cohen wants to carry the matter further. And he does so by bringing it closer, namely to realization and reality. By having religion "discover" yet another aspect in the correlation of God and the human being, one not absorbable into ethics, Cohen still follows the trajectory of his Ethics towards reality. But he also elevates the problem of concrete subjectivity, of the individual soi même, to the level of legitimate philosophical problem. ${ }^{130}$ In this respect, Cohen indeed meets the challenge of his Marburg colleagues. But are we saying now that it is necessary after all to distinguish between Ethics and a late philosophy of religion? And where does this leave our claim that the motif of a discovery of the individual in Ezekiel, and thus the idea of atonement, precedes the Ethics?

We must carefully distinguish between the project of a "Jewish philosophy of religion and ethics" that is realized in Religion of Reason From the Sources of Judaism on the one hand, and a systematic concept of religion as introduced in Begriff der Religion on the other. The first project, whose emergence and pursuit we traced above, is to a certain extent independent from the effort of systematic philosophy to determine the nature, character, meaning, and function of religion within the cultural consciousness. Religion "does its own thing," and the philosophy and ethics of a religion follows its own logic. In the case of Judaism, in Cohen's view at least, this own logic happens to be that of the idea of the unique God that tends to establish a truth concept within the Jewish tradition that strives for homogeneity with other truth concepts, especially with that rooted in Greek conceptual thought. Its logic is, in a sense, messianic in that it seeks union and universality of truth. The eschatological vision that drives the pursuit of truth in the tradition of the prophets is that of a God who is truth and who will at one time be worshipped by all.

Cohen found no contradiction between this vision of an internal truth and the ethics of idealism that was likewise infused by the logic of messianism in its determination of will, action, and self-consciousness. Culture as a whole could be construed so as to correspond to a religious heritage that followed the very same trajectory, only along different paths, in different languages, on different levels of empirical reality. The ethics of the ideal and the religion of monotheism were on a path towards convergence.

A separate concept of religion, one that elevated what happened within a concrete language community to the level of universality,

${ }^{130} \mathrm{Cf}$. Brelage (1965) pp. $126 \mathrm{ff}$. 
seemed unnecessary. The Ethics was to suffice as a guide in the right direction for particular communities to develop themselves. Now, pressed by the insistence of his interlocutors, Cohen is urged to take what he sees in Judaism and provide us with a concept of religion that is both authentically religious and able to serve the demand of universality. It is one thing to criticize the Christian tradition for an implicit pantheization of God or for being unduly enamored with the afterlife. But Christianity has undeniably provided a grand synthesis of religious and philosophical impulses which, if it is to be critiqued efficiently, surely should not leave us without a reflected concept of religion that teaches all religionists something about the nature of the beast. It seems as if Cohen thought to do just that. He had provided the ethical framework for religious self-development as well as planned, at least in the various dogmatic details, the grand work of exposition that was to become his great statement on the "world-historic" significance of Judaism that he had dreamed about since his youthful transition from rabbinical seminary to the academy. He also identified to his own content the core correlation between messianism and atonement that spans the gamut of religious thought from individuality to universality. Why then not take the last step and make this intimate truth of religion universal? Why not attempt to spell out the universal implications for the cultural whole of the truths of the Jewish religion?

Such universal significance (for example in the sense of an "eternal" configuration of liturgy) of the religious truths of Judaism seemed to Cohen himself not outrageous. He believed Judaism to be a truly "eternal" religion. Nor was his private resentment of Christianity, especially of Catholicism, much of a secret. 131 "No one has ever believed in it," he is supposed to have answered Rosenzweig when he spoke to him about his friends' conversion to Protestantism. The motivation of such an outbreak, however, was likely Cohen's sense that Judaism was not only "eternal" but embattled and endangered, engaged in a war aiming at its annihilation, in which dissidents and converts participated from within.

To go beyond ethics and formulate an aspect of the correlation of the human being and God that was based on the Jewish idea of atonement meant to make his whole system assailable. Systematic reason and the cultural consciousness had been pursued in the tradition of polite and tactful silence on the most intimate and most divisive questions: the religion of the individual, the personal standing before God within her own community of faith. The moral core of religion, in good Enlightenment manner, had been entered into the public sphere of state

${ }^{131}$ See, e.g., the letter to Kurt Eisner, here in the appendix. 
and law through ethics but the parochial side of religion had been kept beyond the famous "wall of separation." Note that this parochiality was seen as necessary both by the limitations of ethics as well as by the need of ethics for augmentation in the work of transforming selves, communities, and states. Religion was not a necessary evil. It was simply necessary. But how so? And if necessary then why should this necessity be beyond philosophical formulation?

Cohen must have been painfully aware of the contradiction that is involved when a despised provincial religion such as Judaism is made to bear the weight of religion for a whole cultural empire. He had to leave politeness and enter into the already vulnerable position of a Judah Halevi, a Saadiah, a Maimonides; yet by speaking in a universalizing manner (instead of intra muros, as his medieval predecessors had) he made himself even more vulnerable. For he had to best the majority religion from the perspective of a minority and best it on the territory of a universally agreed upon combination of criteria: it had to be both reasonable and authentic. Up until now Cohen tried to solve the problem by implication, polite silence, and a division of labor: philosophical ethics and polemic on religion for outside consumption, Jewish philosophy of religion and ethics for the Jews. Der Begriff der Religion ends this division of labor by accepting the responsibility to speak in public on what, until then, had been kept private, i.e., below the level of systematic grounding of the cultural consciousness.

Rosenzweig argues later that Cohen made an inadvertent transition. He broke through the "veil of idealism" even as he struggled to maintain it. What strikes me as true about this observation is that while Judaism is present in logic and ethics, it is disguised and hidden among the cultural sources. In the treatise on religion, however, it steps into the open. But reading Cohen's works in hindsight and as a whole, it becomes inevitably clear that the veil was not on Cohen himself but rather on the surface of his works. He himself sought a reconciliation of Judaism and the cultural consciousness all along and throughout his works, although this intention could not be stated too openly without appearing ludicrous or sectarian. Bringing Judaism out into the open as the historical condition of a systematic concept of religion, however, he ran the risk of generating new misunderstandings and distortions of the careful balance he was trying to maintain. And indeed, his late philosophy of religion, i.e., the universal legitimization of a concept that, until then, had been treated as local and only one-sidedly universalizable, gave rise to the ongoing debate on the character of this philosophy. It remains to be seen whether our close reading of the text is able to uncover the intentions of Cohen's philosophy of religion in greater clarity. To the very least, we should let Cohen's text reenter a 
discussion that often proceeds without it and thus foregoes the benefit of its potential contribution to the philosophical debate on religion. ${ }^{132}$

\section{9.-20. Defense of the Programmatic Unity of the System}

The defense of the programmatic formulation of a resolution of religion into ethics is based on the legitimate concern of systematic philosophy to clarify vague concepts that tend to generate a proliferation of arbitrary "philosophies of ..." For example, the concept of a philosophy of religion is ambivalent (schwankend) in that it stipulates a philosophical "independence" of religion whereas systematic philosophy insists on limiting "independence" to the primary directions of consciousness (thinking, willing, feeling). "Systematic" means in this context the task of philosophy to negotiate between and harmonize competing claims to validity by identifying the underlying grounds of truth claims. Theoretical culture, as envisaged here, then functions as the negotiating institution that establishes the formal commonalities of problems by reducing them to the principal source of legitimacy. To the degree, then, that religion can be reduced to ethical truths its resolution into ethics is legitimate.

\section{1.-23. Unresolved Problems in the Correlation of God and Human Being}

However, it is quite possible, and this is where the new inquiry begins, that not all aspects of religion can be resolved into ethics and thus a certain independence of religion is demanded by the negotiating agency of systematic philosophy. Religion is not entirely erledigt by ethics; the universality of the law has not absorbed all rational functions of religion. Systematicity then does not mean that the wide range of possible contributions to the whole of the cultural consciousness can be speculatively determined from within a complete set of known possibilities but rather functions as a regulative principle of philosophical discourse. The unity of the cultural consciousness is, in this sense, task rather than substance.

Concretely, the question is raised

whether it is in truth the case that ethics is in a position to deal with all problems that traditionally originate in religion and that their continued existence (Fortbestand) can be assumed to be legitimate and secure.

${ }^{132}$ The only contemporary introduction to the philosophy of religion that cherishes Cohen's contribution to this debate (or mentions it at all) that I know of, Richard Schaeffler's Religionsphilosophie [Handbuch Philosophie, ed. E.Ströher, W.Wieland] Freiburg/München: Alber, 1983, attributes to Cohen (with Rosenzweig) the perspective of a post-idealist whose late "turn to language" is evident in his hermeneutics of liturgy. 
In 1907, Cohen uses the same terminology when he speaks of the task of securing the future existence of Judaism. ${ }^{133}$ There the question of a continued existence has immediate political implications. The systematic justification of religion means to secure it as a political phenomenon within modern society. But the intention is to secure Jewish continuity in terms of a religion rather than in form of a political movement of self-determination. ${ }^{134}$ The success of this project, however, depends on a general legitimization of religion. It must receive its own "eternal" function beyond the temporal legitimacy ascribed to it in Ethics of Pure Will. Where the essay of 1907 was concerned with the internal conditions for a continued existence of Judaism, the treatise on religion addresses the principles of a framework that protects, preserves, and furthers the cultural conditions under which such internal development can be pursued. While in 1907 this framework seemed sufficiently determined by the Ethics, in 1915 religion is examined for its general contribution to the maintenance of the very framework that sustains it.

The aspect of religion that is not resolved into ethics and that demands attention is not merely of a practical nature but a conceptual aspect in the correlation of God and the human being that ethics itself cannot address. If such unique "combinations" in the correlation can be attributed to religion, its systematic position is secured and the concept of religion recognized as a legitimate philosophical problem.

It seems as if the correlation between God and the human being was to introduce a whole new attitude or content of consciousness after all. Yet Cohen does not admit this possibility. Religion is neither "independent" and hence "pure" content of consciousness nor does it compete with the major domains of theoretical culture. Thought, will, and feeling are originative or "pure" directions of consciousness. Religion, on the other hand, exerts its "peculiarity" (Eigenart) by generating a "new modification of that content whose origination (Erzeugung) is already secured through a pure kind of consciousness." What is sought after is therefore "modification" of a content of consciousness, namely in consciousness as determined by the correlation of God and human being.

133"Zwei Vorschläge zur Sicherung unseres Fortbestandes" in: Bericht der Großloge, Festausgabe, Nr.2, March 1907, 9-12; (J2,133-141).

${ }^{134}$ Hartwig Wiedebach (in: Die Bedeutung der Nationalität) correctly associates Cohen's philosophy of religion with his struggle against Zionism. However, even this concrete Sitz im Leben can be dated backwards to the 1890s. See e.g. the lecture "Das Judentum als Weltanschauung. Vortrag, gehalten im 'Politischen Volksverein' in Wien" in: Dr. Bloch's Österreichische Wochenschrift. Centralorgan für die gesammten Interessen des Judenthums, XV. Jg. 1898 (Vienna, April 4, 1898), 241 243. 


\section{4. -25. The "Sui Generis" of Religion: Correlating Unique God and Particular Individual}

Religion is thus denied independence or a content of consciousness all its own. But its peculiarity and unique contribution to the unity of the cultural consciousness is not damaged by its association with the primary domains. Religion is still different even though its difference is limited by the claim of a connection with the primary contents of consciousness. The very possibility of recognizing the peculiarity of religion depends on such connection without which its difference was to remain indeterminate.

Systematic dependence is thus turned into a "methodical advantage for the (...) gaining (Gewinnung) of [entrance of] religion to the general area of philosophy." Moreover, Cohen explicitly identifies the system with culture and asks rhetorically

wherein lies greater cultural content for religion: in its distinction as a kind of consciousness, if this were possible, or in its integration with both, the system of philosophy and the universalism of culture, namely under the precondition that its content demonstrate a peculiarity in contrast to all other contents of culture. (p. 45)

Having opted for Eigenart rather than Selbständigkeit as the proper modus of religion within culture, Cohen can now proceed by describing religion in relation to the primary "pure" directions of consciousness. The rest of the chapter can be divided into two general themes. Paragraphs 26 through 37 develop the peculiarity of religion in relation to logic, and paragraphs 38 through 102 deal with religion in relation to ethics. The relation to esthetics and psychology (neither of which will be dealt with here) provides the subject matter for two further chapters, in accordance with the overall structure of the treatise.

Briefly put, the concern of religion is with divine uniqueness and human individuality. The correlation of God and the human being concerns the relation between the quasi-logical religious idea of God as unique being and the quasi-ethical religious practice of atonement in which the particular individual becomes a true self. But the religious modification in the correlation of God and human being remains dogmatic or even mythological unless the elements of this correlation are contrasted with and distinguished from their pure correlates, the logical concept of being and the ethical concept of the self. ${ }^{135}$ The positive content of religion thus emerges out of its precise difference from the

${ }^{135}$ Although I avoid the term "meta-" the similarity to the relation between Book I and Book II of Rosenzweig's Star of Redemption is, of course, most obvious. 
negativity of the logical and ethical concepts of God and the human being.

This is not to say that the conceptual relation between pure consciousness and religious consciousness is such that logic and ethics postulate and precondition the religious concepts of God and human being, or that, conversely, logical and ethical terms are derived by means of analysis, generalization, and abstraction from the concrete religious experience. Rather the actuation of the religious correlation provides the cultural consciousness with a possibility of finding in it an augmentation of its other sources that are limited by their way of approaching the totality of problems of philosophy. Religion, while not enlarging the number of pure directions of consciousness, nevertheless augments culture by means of a modification that culture itself can only validate and accede to while being incapable of replicating it by means of critical thought, will, or feeling alone. The system, therefore, grows to be larger than the sum of its parts as the concept of religion is allowed to augment the reach of legitimate philosophical problems to include the correlation of unique God and particular human being. Systematic philosophy means, therefore, continuity of the project of reason through transformation and adjustment as philosophy is made to recognize its undue limitation and need for a more inclusive rationality than envisaged in classical Enlightenment and Kantian/neo-Kantian thought. 136

\section{PARAGRAPHS 26-37: LOGIC AND THE UNIQUENESS OF GOD}

\section{God and the Uniqueness of Being}

If religion is to be recognized in its philosophical strength and in its force as a wellspring of culture, and if this strength is to be exerted in the context of, or in correlation with, the already determined "pure" domains of consciousness, as we learned above, then religion is to be shown to shed its new light on those very domains and thus modify or expand the range of philosophy as a whole. Looking at the first domain, the logic of pure cognition, its central concept of being invites reflection on the relation between being as nature and the being of God in religion. What "God is to religion, Being is to philosophy." Moreover, what thought is to philosophy, "love of knowledge" (Liebe der Erkenntnis) is to religion. Finally, what oneness is to the being of nature, uniqueness is to the being of God.

${ }^{136}$ The possibility of anchoring even the seemingly post-Kantian thought of Cohen somewhere in Kant's texts should not be excluded offhandedly. Such examination, however, lies beyond the scope of this study. 
What good is such analogizing? In the first chapter, on the relation between religion and logic, Cohen merely established similarities without showing how the cognitive relation that is indigenous to religion may shed new light on the cognitive relation of thought and nature. How do we know nature differently when we take into account the uniqueness of God and the love of knowing Him/Her? Firstly, the logic of cognition has, strictly speaking, no judgment of uniqueness. The conceptualization of being in logic concerns the possibility to subsume the many under one law to which there must not be an exception. There are no unique propositions in the being of nature as it appears to the scientific perspective. From the religious perspective, on the other hand, God as the only being deserving of that name must not lead to the assumption that the being of nature is a mere shadow. Rather, since God is known to religion only in correlation with the human being, $\mathrm{S} / \mathrm{He}$ must enter into a necessary relation with the human being in he/r natural existence. For the sake of this correlation, then, religion postulates the actual being of nature.

\section{Existence of God}

Thus, however, religion enters into an unavoidable "dependence on logic" in that it replicates the logical distinction between being and being-there, or existence (Dasein). The main problem of logic is this distinction, for it concerns the pure being of laws of nature as the condition of the possibility of scientific experience, an experience which is not speculative but empirical and thus always in pursuit of the very point where sensual perception and "true" being "meet." The question of "reality" is thus immediately conjured up where the being of God and the being of nature are juxtaposed.

The question of the being of God is usually raised as the question of the existence of God. The logical caveat that existence is always associated with perception (Empfindung) usually leads to one of two responses, the mystical or the negative theological one. To the mystic the paradox of a perception of that which is beyond perception is no problem, and the negative theologian simply points to the fact that God is "incommensurable" to the human spirit and all the more so to perception.

\section{Docta Ignorantia}

Cohen points to Nicolas Cusa's fifteenth century treatise in defense of Docta ignorantia ${ }^{137}$ for an example of thinking of God in terms of negative

${ }^{137} \mathrm{Cf}$. Nicholas of Cusa's debate with John Wenck : a translation and an appraisal of De ignota litteratura and Apologia doctae ignorantiae, by Jasper Hopkins. Minneapolis: A.J. Banning, 1981. The treatise on "learned ignorance" was a favorite of Cohen's 
attributes. Maimonides, one of the sources for this Cardinal of the German Renaissance period, is among the most radical thinkers of this negativity in that he distinguishes between God and life and thus avoids even the appearance of an analogia entis. To Cohen, this denial of the attribute of life is raised in order to avoid the conclusion of pantheism which, in Cusa and elsewhere in the Christian world, is not quite so abhorred. But denying God's existence, as implied in Maimonides, does not lead to the consequence of atheism. For the function and purpose of this denial is entirely positive and originative.

Only being is the object of our knowledge of God; existence (Dasein) belongs among the negative attributes whose meaning incidentally demands a different formulation. We may only think: God has not [the attribute of] existence (hat nicht das Dasein). This means according to Maimonides: God is the origin of existence; without him there would be no existence. Here a spiritual communion with the basic thought of the logic of pure cognition is revealed. (p. 47 , emphasis in the original)

With Maimonides, Western religion has achieved its highest level of philosophical sophistication. By making the knowledge of God dependent on logic, religion transforms this dependence into independence by forming a new content, a correlation of Being and existence, that becomes a well-spring for new "treasures of logic." Cohen rarely admits more openly that not only his Ethics but already his Logic is deeply informed by the sources of classical Jewish philosophy. ${ }^{138}$

\section{Being and Time}

Correlation as a "treasure of logic" originates in the originative relation between God as telos and perfection of being and existence as conceived of in light of its transcendental condition. The relation of "purpose" or "end" as the ultimate "ground" of knowledge transforms knowledge of being from a contemplation of an eternal and unforethinkable past into the passionate pursuit of truth that is the common characteristic of scientific inquiry and religious love. Further, divine being as truth beyond mere existence generates the sense of time that is characteristic not only of religion but of the ethics of idealism.

because to him it indicated an intersection of Maimonidean thought with an incipient indigenous philosophical tradition in Germany. Cf. Deutschtum und Judentum. Mit grundlegenden Betrachtungen ïber Staat und Internationalismus, 2. Auflage, Durchgesehen, ergänzt und mit einem kritischen Nachwort als Vorwort, Gießen: Töpelmann, 1916 (59pp) [= Von dt. Zukunft, 1. Stück], reprinted in J2,237-301.

${ }^{138}$ Note, incidentally, that the allegiance to Maimonides may have been the very reason which prevented Cohen from giving philosophical rather than mere religious distinction to the notion of concrete subjectivity before $B R$. 


\section{Creation and Future}

In religion, God as the origin of existence is expressed in the doctrine of creation. But the relation of purpose is a stronger notion of a relation of God and world than creation seems to imply. Thus, in Jewish tradition, God is praised as the one who preserves and renews his creation. This ever-renewed relation of God that prevents the world from sinking back to nothing may be more central to the religious doctrine of creation than the problem of a creatio ex nihilo. ${ }^{139}$ Thus the correlation of God as being and nature as existence primarily unfolds in the notion of a purpose of the existence of the world and thus in the temporal dimension of its future rather than in its past.

\section{God and Teleology}

From the philosophical perspective, this inquiry into the relation between being of God and being of nature returns us to the question of the good sense, meaning, and purpose of the idea of God that, qua critique of traditional metaphysics, seems to have been lost in the modern philosophical discourse. The precondition for this question to make any sense within the context of philosophy is the philosophical transition, described before, from the formation of concepts to a formation of a comprehensive purpose of a cluster of concepts in the idea. The idea reveals (or is formulated to reveal) the purpose of the whole enterprise of concept formation. It executes the unification of concepts under a common purpose. This is the function of the idea in the context of biology, the science of organic life, and this is the sense in which the idea is used in the humanities (Geisteswissenschaften).

\section{God and the Purpose of Existence}

As an idea, the being of God transposes the being of nature into existence for the sake of a purpose. The correlativity between the ideas of nature and God means that God and nature appear as mutually constitutive purposes: the purpose of God's being for the existence of nature and, vice versa, the purpose of the existence of nature for the being of God. Without the idea, a purpose could not be conceived of; without a purpose, the human being would remain subject to the knowledge of nature. The whole content of ethics is presupposed before this question

${ }^{139}$ This aspect seems to be missing in Norbert Samuelson's otherwise excellent study of the Jewish doctrine of creation. Thus it also seems quite difficult to imagine how Professor Samuelson will proceed to realize the next step in his philosophical program, namely writing an ethics in accordance with his concept of a Jewish doctrine of creation. See his Judaism and the Doctrine of Creation (Cambridge, New York, Melbourne: Cambridge University Press, 1994), and cf. my review in Modern Judaism vol. 16 (1996), 291-316. 
can be meaningfully raised, for the question of purpose as the underlying question of the humanities in analogy to the teleological judgment that constitutes the whole of an organism is also the driving force at the limit between logic and ethics.

\section{3.-34. Cohen vs. Kant on Conditions for the Realization of Ethics}

But does this mean that the idea of God is ultimately to be considered part of the conceptual apparatus necessary in order to determine the ethical idea of a human being? But if religion is to be more or other than a practical appendix to ethics, how can this "beyond" be understood? The "absolute" of medieval metaphysics is evidently not an option, nor does Kant entirely solve the problem. For the latter not only fails to attribute any specific function to the religious idea of God (in his philosophy of religion) but he also vacillates between the transcendental idea of God as "the highest formal unity" in the sense of a "teleological unity of all things"140 and the existence of God as a postulate of practical reason on the other. ${ }^{141}$ The difference between Kant and Cohen in this respect is highly significant and it does not present itself clearly enough from Cohen's own scant remarks in this context. One must remember that Cohen began to present his own original thought, in whatever rudimentary form, in Kants Begründung der Ethik (first edition 1877). The struggle with Kant's idea of freedom dates as far back as this or even further. Once Cohen determined the distinction between noumena and phenomena as unhelpful and eliminated the need to refer to things in themselves as opposed to how they appear to us, the whole center of gravity of critical philosophy shifted from a critique of reason in its theoretical and practical uses to a logic of pure cognition that set the pace for the ethics of pure will and the rest of the system. ${ }^{142}$ In consequence, the regulative use of ideas as postulates of practical reason became obsolete as well. In order to save the erstwhile truths of metaphysics and natural theology (God, freedom, and immortality) Kant had limited pure reason to the condition of all possible experience and distinguished the ideas as possible assumptions of speculative reason as well as of "natural dialectics." In contrast, freedom became the necessary subjective presupposition that is the condition of the realization of a morality whose validity is beyond doubt. The possibility of freedom was demonstrated as non-contradictory with natural causality, and thus

${ }^{140}$ See "Von der Endabsicht der natürlichen Dialektik" in the appendix to Part I of Kritik der reinen Vernunft (Reclam ed. p. 710ff).

${ }^{141}$ Ibid. p. $696 \mathrm{ff}$ and in Kritik der praktischen Vernunft, Second Book: "Dialektik der praktischen Vernunft," Zweites Hauptstück, Ch. V "Das Dasein Gottes als Postulat" etc.

${ }^{142}$ Cf. Geert Edel, op.cit. 
freedom had achieved the primacy among the causes and functions even as a unifying principle of speculative and practical reason.

For Cohen, however, freedom as autonomy and in autonomy is the "basic law of ethics" (BR p. 50), of an ethics namely that is fundamentally limited to what Kant calls legality and excludes the very essence of Kantian morality: the assumption that the individual may constitute itself as moral agent by choosing to act according to the principle of universality. The possibility of this kind of realization of goodness was to Kant beyond doubt, for it was not only not impossible but demanded by the imperative itself: $d u$ kannst denn $d u$ sollst. Kantian ethics had been severely ridiculed by contemporaries, not least by Schiller, for its complete lack of realism. Cohen went further by construing ethical concepts in correlation with those of jurisprudence and so made ethics, among other functions, an inquiry into the condition of the possibility of legal and political progress. The realization of this ethics was envisaged in the context of chapters where freedom merely provided the background of the law, while the condition of realization involved the ideal, the idea of God, and the guideline of what one may call public virtues.

Further, in contrast to Kant, the idea of God was not correlated with the idea of immortality, as if in augmentation of the individual's motivation which otherwise remained too feebly grounded in the formality of freedom, but rather in the most abstract and remote condition of a transcendental unity of the conditions of ethical action: God as the warrant of a teleological dimension to the existence of a natural world as the precondition for the realization of ethics.

It is then quite evident why the concept of religion achieves significantly more and different attention here than in Kant. The latter believed that the human individual could fully realize the moral law by assuming the posture of a free agent. Where common experience belied this assumption and seemed to support the notion of primordial evil, religion helped out by acknowledging such evil but also by providing the means by which the imagination of the individual could be restored to such a degree that it fueled its ability to take upon itself the demand of freedom.

For Cohen, however, religion must do for philosophy what the postulates of practical reason did for Kant as well restore in realism what he lost by banishing the thing-in-itself. Morality itself, banished from Ethics, returns through the gate of religion. God as the condition of conditions receives the primary spot in the new constellation that includes the concept of religion while in Kant it was an expression of "natural dialectics." And immortality is banished except in the sense of "the idea as the soul of the human being" (p. 50). 
Ultimately, the difference between Cohen and Kant, as it emerges here, seems to me on the one hand to be grounded in a pessimistic streak in that Cohen trusts the natural ability and inclination of human beings to achieve goodness even less than Kant. On the other hand, Cohen's religion is rooted in a deeper empathy with the suffering of the weak. The sense of justice that is at work here is loath to blame the poor for their own suffering and seeks collective rather than individual means to abolish what we might call structurally caused pain. Finally, however, the question of the individual and of a God who corresponds to this setup of factors, collective and individual, demands a different constellation of answers than the one provided by Kant.

\section{5.-36. God as Space and Time of Existence}

In summary of the preceding considerations, Cohen reaffirms the function of the idea of God as that which associates logic and ethics, nature and moral agency, as a capstone of systematic connectivity. What is true and striking about this characterization is that the idea of God that is seen in this function is not a philosophical idea but the religious idea of God. Ethics is "enriched" by the notion that God "preserves" the world (p. 51). While God remains a theoretical term even in this context, it is nevertheless the theoretical aspect of the religious idea of God that has been "resolved" into ethics. At the same time, this God, who is Being, remains limited to the teleological function of indicating the final cause for the continued existence of the world. But this is an achievement that is not to be despised. It indicates primarily that from the perspective of logic alone the question why, i.e., to what end, the world exists, cannot be meaningfully answered. Conversely, the perspective of ethics has no inherent confidence that what ought to be can find a place wherein to realize itself. In keeping with rabbinic tradition, then, God is conceived of as "the space" (ha makom) for the world to exist, a space that involves a natural as well as a moral dimension. And God, in rabbinic diction, is also melekh ha-olam, usually translated as "King of the Universe," which, by virtue of the temporal connotation of olam, indicates the "Eternal." From Cohen's perspective one could say that God not only provides "space" or the origin of nature, but of nature as extended into the future by virtue of the "eternal" task of ethics. This, at least, seems to me the religious background to Cohen's otherwise incomprehensible confidence that the idea of God provides the ultimate link between nature and morality. He clearly speaks from a religious perspective rather than from "within the limits of reason alone." 


\section{The Flood}

This is confirmed from within the sources of Judaism by referring to the "yahwist redaction of the general myth of the flood" (p. 51) where the preservation (Erhaltung) of the natural world is tied to a vow by God not to destroy the world by flood in the future. According to this biblical story, nature testifies to this vow by the ever-renewed "sign" of the rainbow that indicates the flood will never return. This story anchors the future in God's Gesinnung, expressed in a promise made in his heart and in the subsequent covenant with Noah and his offspring, i.e., with humanity. Here the three elements are combined: God vows to preserve the natural world for the sake of the living beings.

\section{PARAGRAPHS 38-102: ETHICS AND THE HUMANIZATION OF THE CONCRETE INDIVIDUAL}

\section{The Lack in the Ethical Concept of the Human Being}

Turning to ethics, the fact that ethics was in need of a religious concept of God in order to complete itself is taken as an indication of a lack also in the ethical concept of the human being. With Plato, whose idea of the human being is depicted after the form of the ideal state, Cohen's idealist ethics constructed the individual solely in light of its correlation with the All of the state. This was necessary in order to provide the empirical human being in its grounding in relative communities (family, estate, ethnicity) with a universal direction from which the moral selfconsciousness is then derived. Ethics demands of the individual to "shed its isolation" and grow and elevate herself to the level of her civic calling.

\section{Ethics and Humanity: Elevation of the Individual}

While the individual is thus enriched by the perspective of the All, "worry" (Sorge) arises over the gap between the ethical ideal and empirical reality. "What is the human being and what is missing if the human being is merely humanity?" Before admitting this direction of the question, Cohen first reminds us of the tremendous heights to which the individual is lifted by detour of humanity and the fellow human being. Ethics is liberation from self-centredness and egotism, an impossible liberation were not the human Other, as individual and All, firmly imprinted on the Self, as we saw above.

\section{0.-41. The Danger of a Destruction of the Individual}

Yet this "firmly established moral ground" is not always available; the human being is a "living being visited upon by earthly afflictions and moral wants and maladies threaten his life and his fate" (p. 53). 
Especially the "plurality of nations" turns fateful for the individual, threatening it with annihilation.

Cohen remarks that, to some readers of his Ethics, the emphasis on the Other, the Many, and the All over the particular individual seemed to enhance "the destruction of the individual as its necessary consequence so that the ethics of humanity became identified with the doctrine of the annihilation of the self." This conclusion is emphatically rejected.

This conclusion must be erroneous; it rests on the misunderstanding par excellence of the idea. Every idea demands the correlate of its appearance. Thus humanity demands the human being in order for the human being to purify and elevate himself to the level of humanity in an eternal development of self.

\section{The Isolated Individual}

Even though self-transformation and self-origination rather than annihilation of self may be aimed at in the Ethics, the individual is nevertheless forced into a situation of "isolation" and "loneliness" (Vereinsamung). The standard of humanity causes this by shining its spotlight on the moral lack of the individual. This realization of insufficiency is not in and of itself beneficial unless it leads to improvement and thus turns into a source of consolation. Otherwise it would lead to despair.

\section{Self-Pity}

In one sense it is therefore even legitimate to feel self-pity. One thinks of the anecdote from Cohen's days as a private tutor when he gave some money to a beggar and his young charge asked whether the beggar was not merely going to spend it on alcohol to which Cohen replied by asking back, "And don't you nosh, too?" Generosity towards a minimal self-indulgence displaces the judgmental "high horse" of the socially more fortunate and extends humanity to the suffering, even the suffering self. The ethical demand must not mercilessly prevent a moment of relief and dignity contained in pity for the suffering self. Excessive self-pity must not lead to a lack in moral awareness, nor must it turn into a principle of pessimism, but a basic degree of acceptance of suffering is also an expression of the knowledge that a certain measure of pain can never be eradicated on earth.

\section{Lamentation as the Birthplace of Religion}

Self-pity however must not extend to one's moral failings as if it were acceptable not to struggle with one's moral insufficiency. The feeling of pain over one's own moral weakness should instead be felt to a degree that it absorbs the soul in the realization that we are fundamentally 
corrupt. "This self-realization of one's weaknesses is the birthplace of religion" (p. 54).

Cohen sees this "birthplace of religion" as an archetype (Urtypus) that precedes monotheism. Sacrificial practice indicates the dependence and weakness of the human being in a "feeling of misfortune." Cohen parses this feeling in terms of a phrase from the story of Cain preceding the murder of Abel: "sin lieth at the door." Here wickedness is located not in the heart and its thoughts but at the door, enticing, and its effect is the isolation of the individual that is unable to surmount this obstacle between herself and humanity. The lament of the individual is over its "remaining" rather than over its being obliterated.

\section{5.-46. The Useless Imperative}

From this perspective the effect of ethics and its universal demands is an effect "from afar." It seems unlikely for the individual to be able to turn away from the reality of her weakness and simply lift herself up towards the height of humanity. In a political aside, Cohen illustrates the uselessness of wanting to counter an allegedly ubiquitous individualism by demanding of individuals to integrate themselves into the All of the state. In contrast, the individual is to be preserved if the positive function of self-transformation is to be realized at all. Without the individual there is no realization of the task.

\section{The Insufficient Correlation of I and All}

The individual as the prerequisite of its idealization is thus not already determined by its idealizing relation with the All. The I does not fully originate in the Thou, as we thought when reading the Ethics. Or at least, certain aspects of the I are in need of further consideration before one can rest assured that the individual is not to vanish altogether. Individuality, in this sense, is thus indeed correlated to religion, and just as it is no longer satisfactory to consider religion only to the degree that it contributes to the formation of ethical concepts, so the individual is no longer a mere abstract correlate to ethical universality. Religion, and through it the individual, is to be preserved beyond and aside from all resolution into ethics. Ethics therefore determines the concept of the human being only incompletely. But, of course, already in the Ethics, it is clearly stated that the individual is discovered by the prophets of religion, by Jeremiah and Ezekiel, namely in the problem of sin. However, in the Ethics, this discovery was immediately correlated with the perspective of the All, with the transformation of the moral energy for which the individual was merely a waystation. Here in BR, this is acknowledged and criticized as insufficient. "A direct bridge," so Cohen here, "was spanned from sin to the All of the state. But now it matters to 
us to recognize that this bridge is hanging in the air, that it does not execute its tension in the development of the individual."

\section{8. (Legitimate Concern for the Human Person)}

Again it is Wilhelm Herrmann who is specifically mentioned in this context as the one who persistently raised his objection to this "state of the ethical question." And now his objections are being recognized, albeit "within certain limits." The individual indeed needs a sort of continuity and persistence beyond the task that recognizes the individual only in its value for the moment of self-transformation which itself has no duration. On the other hand, any substantive understanding of the human personality beyond its right to a "highest task" of self-formation is to be denied. Still, "the human person must not be completely resolved into humanity" (p. 57).

\section{Historical Concreteness of Relative Communities: ecclesia}

This line of argument is supported by the fact that, already in the Ethics of Pure Will, the individual was not just immediately stretched between solipsism and universality but the ethical self was mediated through relative communities that represent more than the mere biological interest of self-preservation of a kind, tribe, or species. Rather, the individual is first and foremost (here as in the Ethics) the member of a community which is not the All of humanity but, if guided by principles of morality, its mediator. Thus Cohen reintroduces the particular community, based on the judgment of Mehrheit (plurality, majority), as the necessary condition for a mediation between religion and ethics, individual and All. What this means, among other things, is that language and particular culture are historically individualizing agents without which individuality cannot be conceived. Again, and consistent with Cohen's method elsewhere, the concept of a particular individual is not given to sense experience but established in a cultural construction: the individual experiences the satisfaction of its need for redemption, atonement, and forgiveness from within a community (extra ecclesiam nulla salus).

Describing the function of religion vis à vis ethics is thus conceived as determining the community as the matrix for the ethical struggle that allows the individual to achieve both recognition of sinfulness (Sündenerkenntnis) and redemption, i.e. atonement (Versöhnung).

For sin first needs eradication, the consciousness of sin atonement with itself, if the all is to develop itself out of the many (Mehrheit). The individual wants not to be prematurely elevated beyond itself; it wants to endure in its state until saved and, in such salvation alone, eradicated. The neediness for this salvation (Rettung) is what distinguishes the state of sinfulness. 


\section{Law and Gospel}

The new concept of the human being thus emerges in continuation of rather than in opposition to the ethical concept. The "realization of a lack" is a direct result of the ethical concept of the human being. Here Cohen thinks in terms that are very close to the Christian idea of atonement, as proposed by Wilhelm Herrmann, to whom ethical thought, and thus (following Cohen) law, prepares the human being for the realization of a need of redemption. The difference lies in the notion that, to Cohen, the religious concept of the human being is a "further development of the thought of a lack to its satisfaction, from neediness to support, from sinfulness to redemption and atonement." The new concept thus arises in "homogeneous augmentation of the ethical concept of the human being: an augmentation as continuation."

\section{Law AND Gospel: Continuity of Ethics and Religion}

At "the conceptual origin of religion," then, Cohen emphasizes continuity with ethics rather than rupture and discontinuity. How are the ethical self and the religious self to be homogenized? The religious self is the sinning individual who insists on "remaining" - not in her sin but in her individuality. The ethical self, however, possesses itself in the task of autonomy that originates in relation to a specific human other (e.g., as in contractual relations). According to Cohen, this relational "autonomy" must be preserved in the formation of the religious concept of individuality if the demand of homogeneity is to be met.

Further, just as "the religious calling out" (der religiöse Aufschrei) is not to rank as an exception within the unity of consciousness, so religion as the context of this Aufschrei and as liberation from the guilty conscience must not violate the "basic force of ethics." The possibility of such a religion is not in contradiction with ethics which takes no exception to the facts of human frailty and guilt, especially if such frailty and need for redemption are already presupposed in the idea of autonomy. The content of the latter is an Aufschwung zur Allheit ("upwards swing" or "soaring" towards the All). Autonomy makes this Aufschwung the content of the task of the human being, and religion provides the setting for the realization of this Aufschwung in the atonement. ${ }^{143}$ The systematic concept of religion is thus recognized if and when its ability is demonstrated to bring to a solution and completion

${ }^{143}$ Max Scheler, in his 1921 work Vom Ewigen im Menschen, likewise determines the primary phenomenological religious experience as an Aufschwung. And cf. the chapters on Versöhnung and Day of Atonement in RV. 
the problem of the self, as guilty and forgiven, in homogeneity to the principle of autonomy. ${ }^{144}$

\section{The Ethical and Political Dimensions of Monotheism}

In another typical move, Cohen doubles back into the determining agency of the discipline that sets the stage for the new problem, here ethics, and insists that the transition in the concept of the human being from ethical self-transcendence to religious preservation and restoration of the individual happens nowhere else but in ethics itself.

It is essentially no transition that we have before us but this expansion of the problem and its solution happens within the ethics itself. Not that ethics transforms itself into religion but, by expanding its problems, by augmenting the concept of the human being and its moral self-consciousness and thus the applicability of the fundamental law of ethics, the circumference of ethics is expanded to include the contents of religion.

Since the religious concept of the human being is correlative to the idea of God, the new concept of the individual self will also influence the ethical notion of God, to include not only God as the guarantor of the being-there and existence of nature for the sake of the realization of the ethical task (God as creator or as the principle of preservation of the world) but also God as the redeemer from sin for the individual. In other words, the augmentation of ethics through religion allows to determine an ethical core not only in the belief in creation but also in the subjective experience of redemption (cf. paragraphs 55-67). This ethical direction of the experience of individual redemption is, according to Cohen, the core difference between Jewish and Christian religion (par. 68), a difference which is in the process of being mitigated through the ethical transformation of traditional doctrine in modern Protestantism (par. 69). Finally, the political dimensions of "monotheism" are explored, that is, Cohen returns to messianism as the consequence and trajectory of his ethically loaded concept of atonement (paragraphs 76-102).

In light of this turn in the argumentation it becomes evident that the treatise on the concept of religion allows Cohen to introduce into the context of the system such fundamental aspects of his Jewish thought (especially those relating to atonement and messianism) that in Ethics of Pure Will would have been out of place but which nevertheless were very much in evidence there, too. Bringing these doctrines into the open by justifying them in the context of logic, ethics, esthetics, and psychology is

${ }^{144}$ Note that here, as in the critique of Lazarus's Ethik des Judentums, Cohen insists that autonomy is not itself a religious concept. Only "homogeneity" with ethical autonomy in the discrete sense developed in the Ethics is demanded of religion. 
not a deviation in Cohen's philosophical convictions. On the other hand, Cohen embraces this opportunity because it provides him with a chance to spell out more openly and unapologetically the conviction that Judaism is a source of cultural values whose validity can be justified in philosophical terms. Here as before, the basic message is that biblical and post-biblical Judaism has a cultural voice to offer that can be articulated in a manner which enriches the ideal of a unified cultural consciousness. The will to overcome his hesitation to articulate the peculiarity of religion in general terms was generated by a number of factors such as challenges from within the Marburg school, the rise of political and cultural Zionism, and the foul Burgfrieden that barely concealed the pervasiveness of anti-Semitism during the war. ${ }^{145}$ But the content of religion that is articulated here is not new. And the joy of the philosophical author expresses itself in his renewed ability to articulate religion as homogeneous to the ethical enterprise which to him, as to the whole community of pious German Reform Jews, is the beacon of ethical monotheism.

\section{Autonomy and Moral Insufficiency}

Cohen maintains that the transition in the concept of the human being in which the peculiarity (Eigenart) of religion emerges is one that preserves the notion of autonomy. Autonomy stands for the ethical imperative of an Aufschwung towards the All. Religion stands for the realization that the demand alone does not generate its realization. "Du kannst, denn du sollst" is not enough. But du sollst is the precondition for the religious transformation and provides it with its inherently ethical direction. Religion steps in as the advocate of moral insufficiency, as an institution in which human weakness is amplified rather than ignored. In light of the "sinful" character of the human being, all "moral work must remain piecemeal." This is the basic insight religion expresses.

\section{Genesis 6:5}

The question is, what is to be done with this insight? The first answer is derived from a negative version of this question: What is not to be done with it? Here we recognize Cohen's ongoing struggle with pessimism that also informs his Ethics. Even Kant's notion of a "radical evil," Cohen says, should be interpreted "in accordance with its literal formulation" and limited to the meaning of "a switch of principles" (Verkehrung der Prinzipien). In contrast to the Augustinian doctrine of primordial sin, the human being must be regarded as fundamentally capable of acting

${ }^{145}$ For the biographical and historical setting of BR see Wiedebach, Die Bedeutung der Nationalität, 1. Teil: "Biographisches Profil einer Idee." 
according to the right principles. The verse at the bottom of this issue, Genesis 6:5, referred to above and elsewhere, is therefore taken to distinguish the evil inclinations manifest in one's daily pursuits from the "thoughts of the heart." The "consciousness of sinfulness is not equivalent to an essential wickedness." Rather, "being conscious of sin testifies against wickedness and for the guardianship of the Good."

Homogeneity prevails in the transition in the concept of the human being if both the autonomy of the moral task and the consciousness of insufficiency are preserved and neither cancels out the other. How can both be maintained at the same time? Or at different times without loss of continuity?

\section{Unity without Identity}

Again, Cohen reformulates the relation between religion and ethics, this time in keeping with the difference between identity and unification: the distinction (Unterscheidung) is to be retained while the "divorce" or "separation" (Scheidung) is to be overcome or canceled (aufgehoben). Echoing the general definition of thought in Logic and elsewhere (unification of separation and unification) as well as the notion of atonement and reconciliation (as opposed to a mystical or pantheistic unio), religion and ethics are to be maintained as different yet united.

The new concept of the human being entails a modification in the concept of God, one that "must not violate that of ethics," that rather expands and augments the latter. Even the concept of God that the Ethics justified as its capstone in the pursuit of a realizable Good was an innovation, as Cohen reasserts here. But the concept of the human being to which it was correlated in the Ethics was the concept of humanity: God and humanity. The harmony of ethics and religion depends on whether religion can reconcile its meta-ethical concept of the individual with the ethical concept of humanity. We know already that to Cohen this possibility is anchored in the messianic idea that links individualized morality of exilic prophecy with the universalism contained in the same literature.

\section{God of the Fathers}

The gap between ethical humanity (Allheit) and religious individual is bridged by a third category, familiar from before: the relative community or majority (Mehrheit). Communities such as the family and tribe "maintain the connection between the extreme members." Earlier in this treatise the "God of the Fathers" had already been considered as a precondition for God's revelation as Being. Relative communities and loyalty towards their inherent will to self-preservation had already been prominently thematized in the Ethics were Cohen distinguished between 
first-order and second-order virtues, trying to harmonize love towards one's nationality with loyalty towards one's state. This core question of the age of Jewish emancipation is here reintroduced from a different angle. What does it mean for the Mehrheit to mediate between God and the individual? What does the correlation mean when God is correlate of community rather than humanity or individual? For such a correlation is here envisaged. The religious concept of God, in contrast to the ethical correlation of God and humanity, is thus not merely a justification of individuality but of an individuality in historical context. Furthermore, religion gives individuality a historically concrete setting that is itself considered in its ethical dimension. The particular community or nationality is thus reichsunmittelbar, immediate before God, but only in its function of mediation. The national religious community, below the level of the state as the representative of humanity and above the level of mere individuality, is reflected in its moral potential by correlating it with the God of this nationality or community. The individual appears in this perspective not in singularity or uniqueness but as a member of the community.

\section{Individualization of $\operatorname{Sin}$}

The individual as member of a community is not yet the unique individual as correlate to the religious idea of the unique God (cf. par. 59). Rather the communal perspective on the problem of sin corresponds to the mythological idea of fate and collective guilt, i.e., of the very position the "discovery of the individual" steps in to overcome.

When the individual recognizes itself in its sinfulness, myth says: woe unto me, for I am of Tantalus' kin. This superstition-which has gained rather than lost in empirical force of proof-is countered by religion. Not because of the fathers do the sons suffer: each one dies for his own sin.

This position which elsewhere is identified with Jeremiah is the first but not the last step in the development in the religious concept of human individuality. It is the first in that it negates the collectivity of guilt and thus individualizes. It also discovers the concept of a soul as the movens of individual agency: "the soul that sinneth, it shall die." The soul is the subject of culpability, not yet the agent of change.

\section{8.-59. Uniqueness Contextualized}

The individualized soul as the bearer of culpability is helped neither by the God of humanity nor by the God of the community. Rather, the uniqueness of God unfolds its full meaning in correlation with the attempt to construe the individual as unique with respect to the subjective aspect of culpability. It is of course no longer surprising that 
the Ethics had located the discovery of the individual in this very same context. For in her culpability, the individual is no longer member of a "herd," representative of "a statistical majority," of a moral median, or simply an average person. "That all Cretans are liars" is of no help to the Cretan individual in her "moral work." "The human being, conscious of itself in its unity, i.e., as soul and spirit, knows itself only in its uniqueness."

The correlation of God and human being therefore includes the category of uniqueness and it is in this category that "the transition" from ethics to religion occurs (p. 61).

Uniqueness, however, wholly falls without the compass of ethics. Here the transition to religion must occur. The only God therefore executes the new meaning of his uniqueness: he is the only one for the human being insofar as this one has to be conceived of as the only one.

In formal logical terms the word einzig means "one of a kind," i.e., it refers to a singular proposition where the species has but one member. Yet for the logic of cognition, the unique or singular proposition is meaningless. It resides beyond the limit of conceptualization. ${ }^{146}$ The unique is the inconceivable par excellence. The very word "individual" is a negation, the Latin equivalent of the Greek a-tomos. Thus what is named here takes the form of an infinite judgment: in-divisible; it is inherently beyond description. Cohen speaks of "Einzigkeit" (uniqueness) to characterize the human individual in correlation with God. I am einzig, i.e., "the only one," but my uniqueness is contextual. The individual is "the only one" that counts in the situation of culpability; the unique God is "the only one" that counts for this individual in the moment of selfknowledge and acceptance of guilt. This situation, though common and liturgically formalized, is nevertheless unique for the individual as the self that acts at a time and in a space. To this self, its Self is not replaceable, namely as the origin of sin and as the person in need of forgiveness and transformation. No other causality is considered here but the self-generated recognition of a self-generated transgression.

The contextuality of this notion of uniqueness is quite radical and no less counter-intuitive than the notion that the self-consciousness of autonomy begins, originates, and operates only in the presence of a

${ }^{146}$ Medieval logicians in the Aristotelian tradition disagreed as to how to conceptualize singular propositions. Among the Jewish philosophers, Maimonides used singular propositions as the only proper mode of articulating knowledge of God without, however, elaborating on how to avoid contradictions between different singular propositions. Cf. Marvin Fox, Interpreting Maimonides. Studies in Methodology, Metaphysics, and Moral Philosophy (Chicago and London: University of Chicago Press, 1990), pp. 71-72. 
concrete other. Following Cohen's thought in this matter is, however, no longer difficult. The understanding we have of ourselves as unique or free agents, as souls and selves, is historically mediated and, from the perspective of philosophy, must be subjected to critique. Cohen does not deny the emotional manifestations of a sense of self but he denies that a unified sense of self can be had without a unifying agency. To have a notion of ourselves as responsible individuals who, despite the empirical certainty of moral frailty, conceive of ourselves as agents of goodness is not a natural given but a cultural achievement. ${ }^{147}$

The Jewish source Cohen refers to as a prooftext for the notion of a correlation between unique God and unique individual is not Maimonides but Judah Halevi. The reason for not quoting Maimonides is simple. In the works of the latter, singular propositions are used only with respect to God whereas providential knowledge of God extends to human individuals only to the degree that they overcome their individual consciousness. In other words, a correlativity that involves the human individual as unique cannot be sustained out of the works of Maimonides. The choice of the poetry of Halevi instead shifts from the neo-Aristotelian philosophical source to a composition of synagogal piety that is later to become central also in Franz Rosenzweig's writings. ${ }^{148}$ The key element at this point of the discussion is that the individual correlate to the unique God is seen as "primarily" referring to one's "ethical sufficiency" rather than to human insufficiency. The God of synagogal poetry is not the caricature of a wrathful God of the Christian Old Testament; the God of Jewish prayer and poetry is the enabler of human goodness.

\section{Particular Providence}

From the perspective of Cohen's philosophy it needs as yet to be spelled out how God can be more and other than the correlate of an eschatological humanity. The God of humanity exerts his effect on the human individual only "from afar" (cf. par. 45, p. 55). How is it possible to conceive of God's nearness in philosophical terms? Can God the

${ }^{147}$ The work of Michel Foucault and other more recent social philosophers likewise assume that our perceptions of self are culturally constructed. However, Foucault's characterization of the history of the interiorization of guilt and conscience as an achievement of modernity takes the opposite view of Cohen with respect to the value of this process. Cf. Michel Foucault, Histoire de la sexualité, Paris : Gallimard, 1976, vol. 1. "La volonté de savoir."

${ }^{148}$ For the sake of brevity I neglect the esthetic and psychological dimension of Cohen's writings which clearly deserve more attention. Myth itself, along with poetry, are important sources of the religious consciousness, and Cohen is preoccupied with their place in culture as elemental and eternal forms of self expression. 
redeemer, the most mythologically fraught concept of the divine, be retrieved for the sake of the individual in her need for forgiveness without such redemption either bursting away from its ethical direction or remaining bloodless? In Maimonidean philosophy divine knowledge of individuals is limited to the individual that "redeems" herself in the sense of attaining perfect knowledge of truth. Here God does not seem to know or care for the suffering individual. The Maimonidean God is akin to the God of Cohen's Ethics who seems unable to redeem the individual without also obliterating her individuality.

If therefore a new concept of the human being is produced in religion must not the God of ethics likewise be transformed in order to "care" for the sinning individual?

The question directs itself not towards particular stations in the life of a human being but towards the whole of a human life. If really this question be ethically defensible while the means of ethics fail to solve it, including the failure of the God of ethics: is it then necessary to postulate a new concept of God for the new concept of the human being, the sinning individual?

\section{1.-67. Liberation, Redemption, and Grace}

Sin and atonement are usually associated with sacrifice. So in Judaism and so in Christianity. Furthermore, propitiatory practices are not limited to these monotheistic traditions. Rather, they represent one of the most fundamental symbolic forms of relating to divine powers in the attempt to avert their wrath. In the search for a distinction of monotheism from polytheism, and thus of religion from myth, the sacrificial form used in both is unhelpful. "Sacrifice even atones not only the envious but also the merciful God" (p. 62). And as long as the intention of the religious practitioner is to influence the deity by means of her sacrifice (do ut des) the domain of religion, in Cohen's sense, has not yet been entered.

In contrast to favorable statements on the sacrificial cult prescribed in the Torah, ${ }^{149}$ Cohen speaks here in general and negative terms, comparable to the critique of sacrifices in the early written prophets (cf. Amos 5:21ff). The point he is making here concerns the attitude most often implied in sacrifices, an attitude that undercuts the moral purpose of religious self-purification before God.

Cohen introduces a distinction between two aspects of atonement: "liberation" (Befreiung) and "redemption" (Erlösung). Liberation has as its end the restoration of freedom. It is and must remain the act of the human being. Redemption, on the other hand, is not an "act" of God, for

${ }^{149} \mathrm{Cf}$. ErW 366 , Religion of Reason p. $174 \mathrm{f}$ and passim, and here Part I, Ch. 3.2 "The Development of Biblical Religion: Sacrifice and Atonement." 
an idea cannot be said to "act." Nevertheless it exerts an influence or, more precisely, fulfills a definable function. Sacrifice, on the other hand, is "ambiguous" in that it obfuscates the role of human agency and mythologically expects divine redemption to be received as an act of grace. It tends to obliterate the realization that God can only be "moved" towards redemption by means of the human struggle for self-liberation: Hilf dir selbst, dann hilft dir Gott. 150

The insistence on a distinction between liberation and redemption aims to obviate the common conclusion that a liberal and idealized concept of religion empties the concept of God of all significant content. Cohen denies the gospel of self-liberation by reminding "modern culture" that it commits a "grave error" when it identifies the struggle for self-liberation with divine redemption. Without the distinction between human effort and divine grace, the struggle for self-liberation inevitably, so Cohen, leads to pessimism and thus to self-destruction.

It is a grave error of modern culture that it regards the arguments of religion as dated and as historical material of mythology. The reaction to these prejudices soon shows itself even within the narrower confines of the philosophical business. Pessimism, this obstacle to true ethics, could not have spread and resulted in skepticism and obscurantism if religious speculation had been recognized within its ethical limits and according to its scientific meaning. (p. 65)

If enlightenment culture, as Ernst Cassirer similarly characterized it later, discards the myth of original sin without retaining the useful and necessary element in the concept of sin, it loses the "fermenting agent of morality" (ibid.).

Sin is a fermenting agent of morality, and the individual's state of sinfulness is an irreplaceable member in the chain of concepts of the moral human being. (ibid.)

Similarly, God as redeemer must retain a meaning and function for the cultured human being, one that transcends the meaning of the "distant God" of ethics.

Likewise the God of forgiveness, of redemption, and of atonement is not a myth but just as he represents an augmentation of the God of ethics he enables the liberating work of the individual which, without the goal of grace, would lose the meaning of its way. (ibid.)

The phrase Sinn des Weges ("meaning of its way") refers to the knifeedge or tightrope walk of the individual that the proper understanding

${ }^{150}$ This is not a quote from Cohen but it could be the motto of liberal Judaism and is the very core of its self-assured protest against Christianity. 
of sacrifice unveils. Monotheistic sacrifice and liturgy of atonement are not described in BR but nevertheless presupposed. Here in BR Cohen focuses instead on the conceptual implications of atonement describing in discursive language the purposes and ends of religious practice. The meaning of the religious correlation of God and the human being, as described here, is to link human self-transformation and the divine prerogative of forgiveness as means and end.

While the human being in this correlation, which is our present task, is conceived only as the active factor, God is conceived merely as the goal (Ziel, telos) towards which the moral work (Arbeit, avodah) as the human being's own property is directed. Thus the goal still belongs to the moral work; one could even call the goal a factor; but the goal is not to be identified with the factor. (p. 63)

In common with the autonomous self-consciousness of ethics, the religious individual is considered an agent in the process of selftransformation. Yet the "success of this moral work, conceived as an inward result that completes the concept of action, nevertheless does not exclusively depend on the human being and its work" (ibid.).

We recognize the terminology as that of the Ethics. The "new achievement" of God, the "redemption of the individual" (ibid.), thus rests on "seemingly mutually exclusive conditions:"

One is: the human being cannot redeem itself from the selfconsciousness of sin through all its moral work. The other one is: God alone cannot achieve this redemption either. The contradiction does not sublate itself into a general mediation between God and human being so that both concepts in cooperation lead to the result of redemption. Rather (...) the moral work of the human being remains the irremissible, perpetual precondition. (p. 63)

Instead of a general mediation of the problem of the sinful individual through a collusion of the concepts of God and the human being, a "gradual" (abgestuft) process leads to the reconciliation of this contradiction (ibid.).

The human being thus "stands alone" with respect to the realization of morality and God cannot replace her without violating her dignity ( $\mathrm{p}$. 64). The "business of regret and repentance" must remain the task of the human being. On the other hand,

(t)his has the presupposition that there is a God towards whom the correlation in this form of sin directs itself, and who brings the correlation to the new meaning that this liberation which the human being itself cannot accomplish is activated in this new correlation with God. The new meaning of God corresponds to the new concept of the sinning human being. (p. 64) 
The religious concept of God, in contrast to the God of ethics, is the one before whom

the human being spreads out the repleteness with sin of his heart because this perspective (Hinblick) provides him with the confidence that this moral work of repentance is not a lost labor of love but that its goal can be reached which, without God, would be unattainable. (p. 64)

God Himself does not participate in this labor; instead he remains the "token" (Wahrzeichen) of liberation from sin (ibid.).

The God of religion thus achieves for the individual what the God of ethics achieves for mankind (par. 65). In both cases, action is demanded of the human being but its realization is indicated in the correlative "beyond," God.

In ethics God glorifies humanity with the confidence of morality on earth; in religion (he glorifies) the individual with the confidence of its personal liberation from guilt and sin, its reconstitution for the task of moral freedom. (p. 65)

Finally, grace (par. 67) cannot and must not be perceived in contradiction to the notion of autonomy. Ethics is not to despise or reject the realization that the ultimate success of individual self-transformation is beyond the individual's reach. Further, the "work of repentance" would remain meaningless without confidence in a forgiving God. Ethics raises the general demand of self-transformation and individualizes it in the pursuit of virtue. Religion leads "into the labyrinth" of selfexamination, guided by ethical reasoning, but ethics must continue to hold on to the "thread of Ariadne" that leads back out of the labyrinth of repentance. Thus the religious framework that allows self-examination to end in restoration of moral energy and involves divine forgiveness must be approved by ethics. This aspect of the process of transformation cannot be generalized, yet ethics must not deny its validity. Conversely, the individual's repentance is a religious process that must be guided by the ethical direction that determines the goal or end of selftransformation. Ethics and religion are here contiguous (cf. p. 66).

\section{The Difference Between Ethical Monotheism and Classical Christianity}

As in the Ethics, Cohen determines his concept of religion in a constant juxtaposition of Jewish ethical monotheism with Christology. Here the difference is made fully explicit in that the Jewish concept of God, as a "God of grace and forgiving has only this meaning: to vouch for the goal, the success, the victory of the self(-generated) moral labor of the human being." God and human being remain separate, yet correlated. "The transcendence of God means sufficiency of the human being for its claim 
to humanity." The human being is complete in the ethical respect, a completeness that is "fulfilled rather than limited" by the fact that it stretches towards a goal that is not entirely within the range of human powers.

In contrast, "Christianity participates in the ambiguity of pantheism" by "letting the God in the human being participate in the ethical labor itself." The concepts "flow into each other" and both concepts lose in clarity and distinctness.

Not only the concept of God loses hereby its transcendence and unambiguousness but the ethical concept of the human being, too, turns inexact at this point of limit between ethics and religion in that the competence of its moral labor is impaired. (p. 66)

The ambiguity is increased by the fact that Christology credits the humanized God with the competence not only for the work of liberation but of redemption, whereas Cohen insists that the dignity of the human individual consists in remaining in a state of "suspense" on the "stairway of sin and liberation." The human being must not recognize herself as "empowered to overcome this state of suspense."

God is not to be conceived of as involved in the work of liberation, nor are divine forgiveness and redemption mere implications and the automatic result of human effort. While for God human repentance is "the necessary precondition," it is nevertheless not to be conceived of as exerting a quasi-theurgic or synergistic influence.

Human being and God remain separate, like striving and success, like battle and the prize of victory. Just as pure monotheism teaches true liberation, thus also true redemption. Religion combines both moments but it retains their difference. (p. 67)

\section{Convergence of Judaism and Christianity}

Cohen discerns a convergence of modern Protestantism and "this pure monotheism" where the "second person of the deity" is gradually "stripped of its pantheist ambiguity." With Martin Kähler ${ }^{151}$ Cohen distinguishes between the "human person of Christ" who is, rightly understood, an archetype for the idealized self, and the historical Jesus whose moral significance evaporates in the attempt to determine his empirical historicity. Cohen explicitly recognizes the moral value of the Christ of liberal Christianity who represents

${ }^{151}$ Martin Kähler, Der sogenannte historische Jesus und der gschichtliche, biblische Christus. Vortrag auf der Wupperthaler Pastoralkonferenz Leipzig: A. Deichert, 1892, 2nd. enlarged edition 1896. Published again by E. Wolf. München: C. Kaiser, 1953. 
the ideal of the human being, namely not of humanity in its historical universality but of the individual in the awareness of its isolation, its neediness, its frailty; at the same time, however, also in its worthiness for redemption. (p. 67)

The Christ of Kähler and Herrmann is thus recognized as the human being in correlation with God who is elevated beyond an otherwise inevitable despair and pessimism by "confidence in a redemption that shines towards him from beyond the limits of humanity."

This ideal image of the human individual is not the phantom of its despair but the heroic image of its struggle beyond its human limits, glorified by its confidence in a redemption that shines towards him from beyond the limits of humanity: the confidence in a God of grace and redemption, a God who is not a human being but who stretches out his hand towards the human being: entering into a correlation with the human individual. (Ibid.)

\section{The Question of the Origin of Sin}

After this excursion into the possibility of recognizing liberal Christianity in its purely monotheistic potential Cohen returns to the main thread of his exposition. The "labor of repentance" (Bußarbeit) first leads the individual to the realization of sin or transgression as her own "immoral action." Individuation and this realization of agency are mutually constitutive and beyond or aside from this realization individuality is not considered here. But the "moral character" of repentance is not yet exhausted. After having established oneself as the origin of an immoral action one needs to consider the reason why one acted immorally. "Grace" cannot alleviate one's burden as yet. In fact, the answer to this question may remain "incomprehensible." However, "radical evil" must not be claimed as the origin of one's immoral action, for such an answer would not only fail to "unveil this darkness" but eliminate the correlation. "For this would be the case if grace was distributed by God to someone unworthy rather than to someone worthy of God and his gift by force of human worthiness."

\section{Retribution as a Step in the "Labor of Repentance"}

Therefore, Cohen concludes, "guilt must not be proof for (someone's) falling away from God" and "heterogeneity" relative to God. "Sin must remain connected with forgiveness without therefore losing the acuity of its concept." In agreement with the Ethics, Cohen distinguishes punishment as retribution for sin (Vergeltung) as a necessary aspect of repentance. From the perspective of the individual, therefore, an absolute or substantive, empirical or intelligible, origin of $\sin$ is not claimed. The riddle of the origin remains unresolved and becomes merely the impetus for the individual's readiness to accept punishment as justified 
retribution and as a necessary step in the "labor of repentance" that leads to the transformation of a sinner into a righteous one, a soul whose moral life-force has been renewed.

\section{The Reality of Suffering}

The individual had no recourse to knowledge of why she had to consider herself the origin of immoral action but accepted onto herself punishment as justified retribution as a stage in the process that leads to an overcoming of sin and the restoration of moral energy. But the question of suffering in general is therefore not yet resolved. For not all suffering can be dismissed as the punishment we deserve for our moral insufficiency. Cohen reminds us of the fact that there is a gross discrepancy between the idealization of punishment and the empirical reality of suffering, just as there is generally a discrepancy between reality and idealization. Most "ethical abstractions" are simply "counterprojections" (Gegenbild) to reality. In this case, "reality is an image of the misery of divine punishments." The search for the origin of $\sin$ is therefore transformed into the question of the reason for suffering. This allows a broadening beyond the scope of individuation. Sin and punishment are transformed into the question of the purpose and telos of the concept of the sinning individual, and of $\sin$ in general, in relation to the human condition as one of suffering. The idea of repentance and individuation in which religion is actuated thus returns to the perspective of messianic politics, yet not before completing a number of intermediate steps.

\section{Suffering as the Necessary Condition of Liberation}

The ubiquitous reality of suffering, if conceived as punishment, allows us to recognize punishment, and thus sin, as a constant of the human condition. It has the purpose to allow the human being, qua sinner, to work towards liberation. The individual as a moral agent is thus not simply in existence but an ideal that is realized through the labor of repentance that entails the realization of self-agency, confidence in forgiveness, as well as acceptance of punishment/suffering as legitimate and necessary. Without suffering, there is no occasion for repentance, self-reflective recognition of agency, and transformation.

\section{4.-75. Correlation as Theodicy}

"Why does the righteous suffer while the wicked prosper?" This question cannot sting as long as it is understood that "suffering does not contradict the God of mercy." For if "the human being accepts suffering as punishment," suffering is a step in the elevation of the human being. No one "is" righteous, except one who is in the process of becoming 
righteous. The process of becoming righteous is inaugurated by the process of reflection on suffering that is the precondition of becoming a moral self. The story of Job is thus read against the grain of the assumption that Job suffered innocently. Without his suffering he would not be the righteous Job that he becomes only as the story unfolds. The prologue represents the timeless perspective of God for whom Job is always righteous; yet Job realizes what in our human perspective is a mere potential only as occasioned by suffering.

Keeping human agency in the process of liberation separate from divine care for the individual, suffering is made an integral part of the struggle of liberation which is really a struggle for the generation and becoming of the self as a moral agent. Yet the moral potential and the sufficiency to engage in this constant struggle is the human prerogative. God is therefore not involved in punishment. To conceive of suffering as punishment is part of the process of practicing the moral work of idealization, of transforming isolated individuals into human beings.

Suffering therefore poses no exception or challenge to the correlation of God as redeemer and human being as self-liberator. The forgiving God is exculpated from causing wanton destruction and pain as the human being learns to conceive of herself as the one who is legitimately, rightfully, deservingly punished for their own sin. The recognition of individual culpability therefore involves recognition of the fact that God must be blamed neither for the evil we wreak upon others nor for that others wreak upon us. By not distinguishing social evils in this context, Cohen implies that no suffering at all, not even that caused by "a higher force," should be attributed to God as its providential and particular author. But it is nevertheless to be regarded as punishment and thus as a challenge to take up the yoke of self-transformation. Just as in the Ethics, therefore, punishment is an aspect of the "ethical concept of the human being" (p. 70).

\section{The Suffering of Others}

The previous section deals only with the suffering individual. Now Cohen, however, returns to the fact that suffering is not only the characteristic of the self but also of others. The notion of retribution might exculpate God with respect to the individual, but to attribute the suffering of others to their sinfulness would be callous. The theodiceic function of the correlation therefore needs to be further developed.

In order to understand Cohen's argument at this point it is important to remember that the perception of suffering in the individual received a function in the process of repentance. By rejecting this function for the perception of the suffering others Cohen implies that the psychological perspective and thus the context of a perception within the psychological 
and cultural unity of consciousness is decisive for the value of the perception. The same perception can be useful in one context and detrimental in another. The notion of suffering as punishment is thus not a universal truth, as in classic dogmatics, but a relative or relational truth. The question which is raised in light of the fact of the suffering of others is that of a function of this suffering in the context of religion.

The question "what do sickness and death mean for the life of human beings" (p. 70) is therefore based on the realization that suffering is mediated as a cultural phenomenon rather than an immediate experience. Only to the degree that it can be reflected as to its "meaning for human life" does suffering become a problem for art, religion, and philosophy. ${ }^{152}$

\section{Three Historical Views on Suffering}

As a cultural value, the suffering of others has been conceptualized in different and sometimes contradictory ways, depending on a culture's moral notions, and there is no more of a necessary development in the notion of suffering than in any other concept.

Consider that the shift over time in religious as well as in moral notions, (as manifest) in the changes in leading personalities, does not unfold in a neat row according to a schema but what guides the process of thought in its natural and intricate development are often new motives that contradict the original ones.

This Herderian caveat prefaces the observation that one age is "captivated by the mystery of death" while another one thinks in the "sober" terms of the "historical view of social and political reality." It is quite characteristic for Cohen's method that modernity, referred to in the latter part of this observation, is here not in and of itself considered closer to the truth or a self-evidently superior cultural stage compared to the medieval metaphysical age. What the two cultural ages represent is, first and foremost, a different conceptualization of the phenomenon of the suffering of the many. ${ }^{153}$

Hebrew prophetic messianism presents yet another view on the suffering of the many, associating it with the language and symbolism of war. War is an eschatological symbol which appears in two ways. It represents the reality that is to vanish with the advent of the messianic age, just as medieval Christian mysticism longs for the vanishing of death. But war in all its misery, cruelty, and terror also provides the prophets and psalmists with the concrete imagery of suffering that accompanies the advent of the messianic future. In this sense war

${ }^{152} \mathrm{Cf}$. ErW 307, 365, and 555-558.

${ }^{153} \mathrm{Cf}$. ErW $305 \mathrm{ff}$. 
expresses the historical condition of humanity before the advent of messianism, a preliminary reality that is the more colorfully described as it is expected not to last forever. War is the characteristic of the old world that is coming to its end and the sign for the dawn of a new one, a world of peace.

\section{Local and Concrete Setting of Religious Literature}

This third view on suffering is situated in a historical culture whose literary imagination Cohen characterizes as primarily folkloristic, local, and immediately grounded in the self-interest of a national experience. Other nations appear only at the fringes of this world view, namely to the extent that the question of political treaties or the waging of war against them becomes relevant. Thus also "the style of the ancient Bible" is characterized by "political and juridical laws and statutes" rather than "merely" containing "messages, speeches, and epistles." The concern of Israelite literature, expressed in "prosaic detail and determination," is with "human business in society and state, family and the human attitude towards oneself." No "mother religion is polemicized against, nor even a new religion founded." Rather "it is narrated, reported, and reflected how religion arises and develops within ethnicity (innerhalb des Volkstums)" (p. 71). This culture grows from a "religion of the fathers" to the religion of the "Holy One of Israel" who "shall be called the Lord of all the earth."

This characterization of the development of the religion of Israel means to resolve a number of tensions. For one, Israelite literature must not be seen as having privileged access to revelation. It is a historical culture among others. Nevertheless, the Hebrew Bible reflects a religious development where, out of a common yet historically unique (in the weak sense of the word) experience, a religion grows that leads from the narrowly national to the universal. This development in the national perspective is expressed in the increasingly more profound understanding of God. The implications of this monotheism for the philosophical concept of religion, however, need to be distinguished from the continued historical and cultural setting from which this idea of God emerges and in which it functions. Israelite literature remains national literature even where its concept of God begins to take on universal features. Thus it should not be surprising that this literature remains primarily interested in the consequences of its concept of God for the national community and its well-being. Cohen clearly wishes to maintain both historical concreteness and universal implications of this religion. 


\section{Society and Redemption}

Just as the future of the other nations arises at the limits of the "foreign policy" of prophetic messianism, the "interior politics" of monotheism focus on the "narrow, small, and all-dominating circumstances of society and their economic conditions." The universal problem of suffering, as a challenge to the notion of a righteous God, is concretized in the "social criterion of poverty." What is the origin of this "social misery?"

Just as the mystic focuses on death and the world politician on war, so the social politician on poverty. This is the quintessence of the social misery of human beings; where does it come from? How can it be reconciled with the concept of God, with the concept of the human being? What would it help if sickness and death ended but not poverty; would this perpetuation not merely increase human misery?

Cohen reminds us of the absurdity of the notion that explains poverty from the lower moral quality of the poor. A religion that embraced such an explanation would rightfully fall under the verdict of all modern ethical and political critique of religion. To take the suffering of others as deserved is an attitude that makes it impossible for the one who harbors it to elevate herself to the self-idealizing correlation with the all, as concretized in state and law. "Equity and justice" can be pursued only if the poor are not morally disqualified because of their poverty.

\section{0.-81. Religious and Political Critique of Religion}

Spelling out the modern ethical and political critique of religion, Cohen returns to the style of exposition that we found in Ethics where Israelite monotheism appeared in a favorable light while Christianity was criticized as "religion." In light of the problems of social misery, poverty, and the universality of human suffering ethics severs its ties with a religion that focuses on death and the afterlife. Ethics is here the advocate of a this-worldly concern with the "topical life of worldhistory." This is the justification for the insistence of ethics on its independence from "religion."

Similarly, political thought attacks "religion" even further for being merely a tool in the hands of callous governments in the attempt to circumvent the establishment of universal equity and justice. In contrast to such Macchiavellianism, political thought calls upon the powers of society, as a second universal framework aside from the state, that allow us to generate a sense of the togetherness of people in economic and other relations from which change and an infusion of morality into the state can emerge. Without attention to society, states had no concept of social change and legal progress. 
Cohen reads this modern tension between society and state into the situation of ancient Israel, where "socialism complicated itself with the institutions of law and state." In other words, only in light of modern political and social thought are we able to discern fully the achievement of the Mosaic law and of prophecy where morality and political power are addressed in their concrete implications on social reality.

\section{2.-83. Sinless Suffering of the Poor}

The Hebrew prophets, operating within the concrete framework of a national culture, identified the suffering of the poor as a human problem that demanded unconventional answers. The conventional answer given in mythological terms, still present in Ancient Israel but perceived as increasingly problematic, recognized that people could suffer for reasons beyond their control and yet insisted on the justice of the fact that they were punished for the sins of their fathers. But even the individuation of guilt that disrupts the chain of generations is not a sufficient answer to the scourge of poverty. Aside from the political critique of injustice and abuse of power that is quite ancient and even precedes (and to a certain extend prefigures) the individuation of guilt, the dilemma of an unequal distribution of wealth arises as a challenge to divine governance.

Cohen sees modifications in Israelite theology arising from the theodiceic character of the correlation. God's justice is out of the question. Thus our perception of reality in light of causes, reasons, and purposes must be shifted until we can reconcile seeming contradictions that arise from carrying with us unreflected notions in need of correction. This theology is not merely guided by the interest of resolving cognitive dissonances but by maximizing the ethical veracity of its idea of God which, qua correlation, implies a humanization of our perception of the human condition.

Where the individual is forced to recognize herself as guilty by reflecting on her own suffering as deserved punishment, the suffering others, the poor, are declared innocent. They suffer without guilt.

Suffering is not punishment. Otherwise poverty was punishment and wealth virtue and its reward. Rather, poverty is the distinctive mark of piety.

\section{Poverty as Piety}

The virtue of the poor is indicated in the fact that they are not only the oppressed but they are also humble. Humility, according to the Jewish tradition, is the core virtue of piety. ${ }^{154}$ The humble, even the humiliated,

${ }^{154}$ This is especially emphasized in Maimonides where humility in opposition to pride is the only virtue that is not determined according to the Aristotelian doctrine of the mean. Nothing is too extreme in the pursuit of this virtue. 
are the pious par excellence. If the poor, however, are not to be blamed for their suffering, the question of the origin of suffering returns to God: "how can God account for the suffering of the pious ones?"

\section{Ethics as Theodicy}

Theodicy is thus the driving force, the "pivotal point," that propels the development of monotheism. Here as in Religion der Vernunft, the question of evil is seen as reaching from one end of the canon of scripture to the other. ${ }^{155}$ According to Cohen, si deus, unde malum is significant as a question alone, quite apart from the answers advanced at different stages. The position advanced in the Book of Job excludes the possibility of a theoretical answer to this question. Yet this agnosticism must not lead to an abandonment of the possibility of advancing a moral answer. Therefore, ethics itself becomes a form of theodicy.

\section{Divine Providence and the Suffering of the Pious Ones}

Cohen does not immediately describe the answer given by Israelite monotheism to the question of why God allows the pious ones to suffer. Other intermediate steps are to be taken first before this answer can make sense. Here Cohen only hints at the fact that the doctrine of poverty as piety also allows for a justification of God in light of the historical suffering of the Jewish people. ${ }^{156}$

More immediately relevant to the progression of the argument is the fact that the identification of poverty with piety is really a quite disturbing notion. The identity of poverty and piety is a theoretical notion that insults our "moral judgment." Can it really be part of God's providential plan to allow the pious ones to suffer? Are the poor to become the "historical tokens of morality?" What seems theoretically an acceptable resolution of a cognitive dissonance causes us to feel morally terrified.

\section{7.-88. From Theory to Love}

Hence the indifference of the theoretical attitude to actual time, actual space, and real human beings must be overcome. It is a morally insufficient attitude. The theoretical culture promoted by Greek philosophy fails to energize a sentiment that, due to the influence of Jewish and Christian preaching, is taken for granted as if it were an innate reflex. But love, the love of fellow-human being, is a religious notion rather than a natural impulse. In order to proceed from theoretical insight into the reason for the suffering of others to the engaged and engaging feeling of responsibility that is the affective ground also of

155 Op. cit. p. 283.

${ }^{156} \mathrm{Cf}$. Religion of Reason pp. $283 \mathrm{f}$. 
ethics, one must retrieve and enhance the prophetic awareness for the fact that "one human being to another is not an alien who could also be a slave but he belongs into my self-consciousness; and not merely theoretically but most of all practically" (p. 76).

This realization arose for Hebrew prophecy from the insight into the connectedness of human lives, a connectedness not in guilt but in mutual responsibility. In the prophetic tradition, the human being cannot be conceptualized without deriving it from the concept of the humanity of poverty or, more accurately, "from the concept of the human being of the poor" (ibid.). The poor rather than the wealthy determines who is to be regarded as a human being and for what reason.

But even this is still too theoretical. For the realization of humanity is accompanied by the "intense feeling of a relation, as theoretically from one I to another I, so practically from one's own feeling to the suffering of the poor." The affect of compassion returns here as the primary affective ground not of pure will but of religious love.

\section{Compassion}

"Even this love for the human being would remain an abstraction were it not for compassion which arouses it, challenges it, and brings it to life." This praise of compassion is explicitly defended against the suspicion against it in Spinoza and Schopenhauer (par. 88 et passim). If the poor is no longer a stranger but "as I" (kamokha), the difference between us, suggested by my theoretical view, "vanishes immediately." The notion of the piety of the other instigates me to look with compassion.

90. Mehrheit and Allheit

The modification in the concept of the human being has an immediate impact on the concept of God. But again the evident conclusion is not immediately drawn that compassion and love must be attributed to God as well. First it needs to be sorted out how religious love and compassion for the suffering pious one relates to the ethical relation between self and other.

"The God of ethics," Cohen begins this inquiry, "is the God of humanity." "In contrast, religion is first concerned with the individual which ethics uses but which religion discovers for ethics in sin." From this concept of the individual Cohen had proceeded to the social dimension of suffering. Is not this suffering universal? And if so, what remains of the distinction between majority (Mehrheit) and All (Allheit)?

\section{1.-92. Suffering Messiah and Destruction of the Wicked}

The prophetic tradition objects to an obliteration of the difference between many and All, between people and humanity. As Cohen 
describes this tension, one can feel his own autobiographical struggle pulsating beneath the surface of the text.

The prophets were not so thoughtless in their conclusions. They held fast to the All of humanity but they did not therefore lessen the overwhelming value of the majority that opened itself to their compassion. They clung to the unique God and were not shaken in their faith in him as the guarantor of the All by their social insight of the majority of the poor.

The ability of the prophets to act compassionately towards their people as well as remain truthful to the uniqueness of God is discernible in the transformation of messianism from a national or priestly concept to one in which the new concept of the human being is inscribed into the language of Jewish national expectation and hope. The suffering servant of the Lord of Isaiah testifies to the fact that the poor, the sufferer, has indeed become the "ideal human being" (p. 78).

Cohen even returns to the apocalyptic vision of a cataclysmic war preceding the advent of the messiah when he contends that the imagery of war merely plays out an emotional depth that is fueled by the desire for a complete obliteration of the enemies of God. A mere redemption would not be enough for the poor. Their "justification," which must be achieved in the destruction of the sinners, is needed. Thus the apocalyptic tone in the compassion for the poor in prophets and psalms.

\section{3.-97. Religious Love}

It seems as if the focus has shifted back to ethics or, at least, the God of the community of the poor is no longer too clearly distinguished from the God of All, the God of ethics. The "particularism" of the "social God" is rather "true universalism" (par. 93).

If the God of ethics is the advocate of the poor and thus, in a sense, present in historical reality what then distinguishes the God of religion? The difference is determined by swinging to the other side of the correlation. "Ethical human being, too, as an end to itself, defends the poor who is mostly a mere means and thus calls forth the institutions for such defense" (p. 79). What then is the difference between the ethical human being and the religious human being? Here, too, as in the case of guilt and repentance, individuation is the main issue.

Again the distinction between religion and ethics concerns perspective. In this case, it is the other who is brought from the generalizing perspective of virtue ethics to the proximity of religious compassion and love. Guided by the ethical virtue of "respect" (Achtung) "that refers merely to the moral dignity of every human being" no matter whether rich or poor, religious compassion energizes feeling for the suffering other. But where this feeling is not free from the danger of 
estheticization (à la andächtiges Schwärmen), the transference of this love to the correlative God of religion elevates the human other from all generalization and esthetic glorification. For the sufferings imposed by the God of religion on others are mere "chastisements of love." 157

The religious God may only impose sufferings of love. He must love the human beings, namely each individual as such. (p. 80)

God is seen as loving each human being as an individual in order for us to understand that we must love our poor neighbor (cf. ibid.). The God of such love, however, is not the God of ethics but of religion (p. 79). In contrast to religion, ethics "pursues a philosophy of history," not as an idle pursuit but as one indifferent to the fate of the particular individual. Politics considers mere generalities, poverty rather than my poor neighbor. But I must not be allowed to take such refuge. Thus the individualizing effect of religion concerns not just myself but the other as the suffering individual whom God loves and whom I must therefore love, too. The suffering of the other remains a member in the chain of social causes and effects but religious socialism involves me in this chain.

For when I recognize and love the human being in his social character I know at the same time that this social character is connected to a divine order of the world so that the poor is the pious one and that God loves both (viz. poor and rich). Thus love distinguishes God and human being in ethics and religion. (p. 80)

The religious correlation of God and human being is thus amplified. It individualizes not only self but also the other. But it does so under the guidance of ethics and for its sake. It could not be any other way if the maxim of religion is to propel ethics towards realization (par. 97).

According to the aforesaid, the core meaning of the religious correlation of God and human being is to enable us to love our fellow human being, the sufferer, the poor. Neither is the nature of this love clear, however, nor is it an original notion that God represents our love for our fellow human being. Ludwig Feuerbach already spelled out some of what, in Kant for example, was only a vaguely hinted-at possibility: that God's love is really a projection onto the screen of heaven of our own love for humankind. But to Cohen, this love is not a given. It is a cultural achievement that falls apart if its association with the God of religion is lost.

${ }^{157}$ Hebr. yissurey ahavah ("chastisements of love"). Cf. above Pt. I, Ch. 3.4 "T'shuvah as the Center of Gravity of Jewish Thought." 


\section{8.-100. To Love God}

Divine love for the other human being is my inspiration for a love that is both specific and moral. In this Cohen follows Maimonides' doctrine of active attributes. God is known only by attributes that teach us how to relate to others. Thus religious love is here radically ethicized. We have seen before, however, that Cohen deviates from Maimonides by individualizing the religious correlation. Yet he retains the ethical valence of individuation, as well as the uni-directionality of the vector of divine love. "While the pantheist takes issue with the notion of a loving God, the monotheist could take issue with love for God." The knowledge of God is an infinite task. This cognitive relation is what medieval nomenclature had distinguished as the true meaning of the command to love God. How is this equation of love and knowledge to be maintained, seeing that love functions as the "driving force of religious concepts?" ( $p$. 81) The combination of love and knowledge that gives the correlation a seemingly anthropomorphic character is retrieved in the relation between ethical knowledge and religious love.

To love God means in fact nothing else than to make oneself aware to the point of heartfelt tender affection (Innigkeit) of the connection (Verbindung) between ethics and religion in the concepts of God and the human being. (p. 81)

Cohen merges the language of mysticism (echoing, as it invariably does, a neo-Platonic ontology) and the meaning and content of a Kantian ethics, reconceived in light of the Maimonidean doctrine of attributes. From Kabbalah Cohen derives the notion of an internalizing and feelingevoking mental activity that has as its object the relation between God and the human being and as its objective the unitive "combination" of the two while maintaining their difference. From Kant he takes the ethical direction of the conceptual parsing and uniting. From Maimonides he receives the awareness that the affirmation of the infinity of theoretical love/knowledge and the practical concreteness of practical love/knowledge of God/Torah is true piety at the same time that it is true philosophy.

Cohen therefore reaches the necessary depth that is to be expected from someone who set himself the task of giving a general account of the character of monotheistic religion. He is able to explain what it means, on the background and basis of Judaism and its ethics, to conceive of religion as love, and of love as the demand to "think God" (cf. p. 81).

When I love God I do not pantheistically love the universe, not the animals, trees and herbs, as my fellow creatures but in God I onesidedly love the Father of the human beings. The religious term God the Father has now this higher meaning and social conciseness: he is 
not merely creator and originator but rather protector and support of the poor. (ibid.)

God teaches what a human being is by loving the poor, individually. The religious relation to God is therefore not love for the universe but love for my poor neighbor.

One of the central liturgical passages in Judaism which is also one of the core passages of the Pentateuch, Deuteronomy 6:5, commands Israel to "love the LORD thy God with all thine heart, and with all thy soul, and with all thy might" (KJV). Cohen suggests that instead of merely reading the triplet of heart, soul, and might as attributes of the love by which one is to love God one could see them as comprehensive qualifiers of the contents of this love:

I cannot love God without my whole heart in its living for fellow human beings, without my whole soul in its being turned in all directions of the spirit of my contemporaneous world, without using all my strength (...) for this God in his correlation with the human being. Therefore love for God ought to surpass all knowledge. It ought not, may not, and cannot unite with him but it ought to weave together (verkniipfen) all things and problems of the world with his concept. (p. 82)

This activity of weaving together the problems of the world with the concept of God is such an absorbing mental activity that it is "no longer mere thought but love." What may sound like an anthropomorphic exaggeration

is surpassed by the paradox that I ought to-love the human being. Worm that I am, devoured by passions, thrown as bait to egotism, I am nevertheless to love the human being. When and insofar as I can achieve this I can also love God. (ibid.)

\section{Worship: Reverence and Fear of God}

The activist mysticism of ethical knowledge and religious love is augmented by the fact that God is still also the distant Other, the fearful presence and object of reverential worship. The element of fear in the term Ehrfurcht (awe) suggests that just as philosophy begins with awe and wonder (Staunen) so the religious intent of associating the world with God must begin in mindfulness of the mysteries of existence. This sense of reverential fear imposes a limit and condition on the affect of love for God.

\section{Honor and Love}

The last paragraph of this chapter returns to the primary question of a relation between ethics and religion. Religion has been distinguished as the cultural setting of individuality, the organon of critical reason from 
which the individual emerges as the particular par excellence, in a sense that is distinguished from the logical and ethical meanings of the term. Religion thus achieves a "correction" by which abstract individuality is transformed into a concrete individual. The conceptual gain by which religion finds entry into the system of philosophy concerns not only the individual as I but also as Thou and We. The Other is my fellow human being; similarly the community that provides the setting for the formation of individuality is the historically concrete ethnos/ecclesia. But just as the human being is individualized, the individual is humanized. The correlation with God as unique being prevents the individual from becoming an absolute. God is the source and model of love; but he is the object of reverence (Ehrfurcht) which returns religious love to its place. As a virtue it takes second place to "honor" (Ehre). But the affects of love and honor are both religious sentiments and thus in the religious consciousness the demands of logic and ethics are no less satisfied than those of religion. Religion and ethics are reconciled and unified without their distinction being obliterated. 


\section{Postscript}

Hermann Cohen was to an equal measure philologist and philosopher. In this monograph I try to do justice to both sides of his scholarship and seek to determine the connections between them. In this I intend to contribute to a reappreciation not only of Cohen's contribution to the Wissenschaft des Judentums, but of this much maligned and misunderstood paradigm of Jewish learning itself which was developed by the European Jewish elite of the 19th century and which ought to be taken seriously as its cultural legacy to contemporary Jewish Studies.

Cohen is not just neo-Kantian and Jewish philosopher but, in an eminent sense, contemporary and alternative to the likes of Jacob Burckhardt and Friedrich Nietzsche. He hails from the same school as Burckhardt (trained by August Boeckh in Berlin), and shares with Nietzsche a struggle with pessimism that seeks to establish its philosophical foothold by way of a sweeping interpretation of the variegated sources of Western intellectual history. Both share the philologist's sense of the marked antagonisms inherent in these sources. Where Nietzsche sees dichotomic oppositions that force the lover of truth to make painful choices, Cohen reads the history of concepts by means of a hermeneutics of optimization and integration. For both, however, philosophy comes to life from the depths of its historical and philological sources. "The historian be philosopher!" Cohen demands from early on.

Providing a comprehensive illumination of the idea of atonement as it functions in Cohen's thought, the present work assigns equal attention to philology as well as to intellectual and political history as it does to the philosophical side of Cohen's enterprise. The first part traces Cohen's involvement in debates with Protestant Old Testament scholarship, whereas the second part shows him to be an innovative and creative social and political thinker. The combination of philology and philosophy in Cohen indicates his commitment to veracity and authenticity, a commitment also to the cultural heritages that shape the 
very fabric of his social interactions while urging him to carry the agenda of philosophy towards accounting for the principles by which a selftransformation can be achieved that contributes to a mindful and sustained struggle for social and political reform. Cohen's range and depth of learning and his attachment to Jewish tradition and community are moving characteristics of an extraordinary personality. It is not surprising that many of his contemporaries were impressed by his prophetic pathos; it is equally unsurprising that others, especially among the younger ones, were struck by the irreconcilable rift in his high-strung personality. I am convinced that Cohen felt the differences between the cultures his philosophy meant to reconcile no less than Nietzsche felt those between the Dyonisian and the Appolonian. While Cohen projected the task of reconciling mind and matter, of Athens and Jerusalem, of moral struggle and fulfillment, into the future, his emotional life was torn between the "worldhistoric significance of Judaism" and the ongoing "war aimed at its annihilation;" between the nation of Luther and Kant and the ubiquitous "anti-." Cohen, it must be said once and for all, was not a romantic or chauvinist idealizer of Germanism and Judaism. He looked into the abyss, and maintained that the answer must not be nihilistic.

Without distorting much, one could take Cohen's philosophy as an elaboration of a few basic lessons he learned from his father, the cantor and melamed Gerson Cohen. Just as his father was ready to suspend halakhic prohibition when he entered the Protestant church of Coswig on occasion of a public prayer service for the well-being of the nation, so Hermann Cohen entered Protestant culture: not to relinquish Judaism but mipney darkey shalom ("for the sake of the ways of peace").

With Rashi, whom he studied with his father, Cohen believed that the creation of humanity is ongoing. Human beings are responsible to continue the works of creation. Through this task, we shape ourselves into the image of God. This is the point of the concept of correlation. Cohen's Judaism is as humanistic as it is anti-metaphysical.

In this procedere towards the ideal, an ideal embodied in the Torah in its philosophical interpretation, religion and ethics are unified without ever being collapsed into one. Cohen shares this peculiar stance (wherein respect for the difference between religion and philosophical culture is combined with the conviction that religion possesses a deeply moral and political dimension) with his revered predecessor Maimuni/Rambam, and thus carries into the 20th century the possibility of continuing a project of ancient and medieval pedigree. Leo Strauss was one of the few 
members of the younger generation who grasped this characteristic of Cohen's thought. ${ }^{1}$

Beginning in 1880, Cohen's life and thought were flavored by the recognition of anti-Semitism as an ongoing threat to Jewish survival. The principal answer of the idealist philosopher and the Jew is to deny antiSemitism a decisive role in Jewish self-understanding and in the making of a contribution of Jews and Judaism to the transformation of state, culture, and society. Yet anti-Semitism made it urgent for Cohen to give account of the ongoing, "eternal," value of Judaism; the task of Jewish philosophy was to him a hora'at sha'ah, a timely counter-measure to the ongoing attrition of Jewish self-knowledge. To the erstwhile seminarian, this self-knowledge was "above parties" and reached beyond the questions of the day. Yet, in order to reacquire it and make it meaningful, it demanded the full force of an idealism recast to accommodate the Jewish idea of God. The love of the stranger that Cohen's moral thought inscribes into the annals of modern ethical theory is unthinkable without his confidence in a despised faith and his love for his fellow-Jews.

As in medieval conceptualizations of evil, Cohen construed hatred of the other as having no real ground. It represents mere opposition, negativity, and an empty anti-thesis to the very core of Judaism. Chauvinism and xenophobia are to be condemned. In contrast to Franz Rosenzweig who justified Christian contempt of the Jews as a necessary corollary of Christian doctrine, Cohen denies hatred the value of an "origin." Only love, not its absence or denial, can be the means by which to generate national cohesion and distinction. For Cohen, this love is that which turns toward one's own without eclipsing the other.

Cohen's concept of religion is deeply political. So is his critique of Christianity. At the same time, his concept of religion is not the standard fare of a liberalism that aims at overcoming, or at least at hedging in, religious difference. Atonement means transformation through action rather than obliteration of difference. Nevertheless, Cohen's political thought is heir to an Enlightenment theory of the relation between state and religion that limits religion to the status of a voluntary, non-coercive private social institution promoting the ideal aspects of the individual life in its communal relations. The model herefore is the emancipated and privatized Jewish reform congregation that begins with Mendelssohn's legal opinion to abstain from the exertion of religious power which geared the Jewish community towards integrating itself with a state based on tolerance. In the past century this "solution to the Jewish question" was hotly debated and Cohen himself was among those

${ }^{1}$ See the introduction in my forthcoming volume of translations of early Jewish writings of Leo Strauss (SUNY Press, Albany). 
who defended Jewish integration. His very theory of ethics and religion can be seen as an extended argument on the conditions for the possibility of religious diversity (limited by the demands of the religion of reason) within a society progressing towards unity (limited by ethno-religious difference). The most important problem in the history of emancipation was the suspicion of disloyalty. The question of loyalty can be parsed to concern two main aspects: love and responsibility. The problem of religious love ranks centrally among Cohen's ethico-religious themes and reappears among the secondary virtues: those associating the individual with her community.

Shunning the disdain in which virtue theory was commonly held in the idealist tradition, Cohen reintroduces virtues as guidelines in the pursuit of the ideal. In keeping with his collectivist construal of the agent of morality, virtues are primarily of a political nature and concern states and communities first, and only through education also the particular individual. In this, Cohen's Ethics speaks directly to the contemporary discourse on the necessity and character of mediating institutions (as in the ongoing debate on communitarianism).

One of the areas to which Cohen contributed is that of hermeneutics. Above, I describe his method as one of "optimization" or "elevation." Despite his thorough grounding in, and intimate familiarity with, the most postivistic methods of philology, Cohen legitimizes philosophical interest in the literature of the ancients and seeks to elevate their insights so we can learn from them. Instead of imposing modern methodological limits on ancient texts that emphasize their alienness and our own advancement, reading ancient texts becomes a tool in the critical assessment of our own responsibilities.

This hermeneutical strategy has a deeply moral core, one in which Cohen echoes Lessing, transforming the latter's call for a competition between religions into a practical rule. As an example for this strategy, we can take Cohen's effort to generate a Jewish path to the modern concept of the self. Following the initial recognition, articulated in his answers to Treitschke, of a Jewish debt to Christianity, Cohen realizes that, in order to argue forcefully for an "immediate" relation between Judaism and the modern state, Judaism must provide its own concept of self and subjectivity, its own moral thought; one which, if possible, does without the shortcomings of the Christian preoccupation with the afterlife. At the same time, Cohen wants to avoid the collapsing of religion into philosophy he sees at work in Lazarus' Ethik des Judentums; the rabbis are moralists, not ethicists in a transcendental vein. The question is, then, posed with great precision: what is it that corresponds in Jewish tradition and practice to the demands of the critical idealist defense of freedom and that can therefore serve as a core-theme in a 
philosophically contemporaneous exposition of Judaism that speaks to the need of establishing a deep congruence and union between the Jewish and the modern self? The answer to this question is found in the doctrine of atonement. And it is this doctrine that provides Cohen with the confidence that a reconciliation of Judaism and the cultural consciousness (critically conceived) can be achieved. 



\section{Abbreviations \& Bibliographies}

\section{ABBREVIATIONS}

$\mathrm{APh}$

Archiv für Philosophie, Stuttgart $1947 \mathrm{ff}$

ÄrG

Hermann Cohen, Ästhetik des reinen Gefühls, 1912 [=WW 8/9.]

ARPs

Archiv für Religionspsychologie, Tübingen: J.C.B.Mohr

AZdJ

Allgemeine Zeitung des Judentums

Brandt

Reinhardt Brandt/Franz Orlik (ed.), Philosophisches Denken-Politisches Wirken. Hermann-Cohen-Kolloquium Marburg 1992, Hildesheim, Zürich, New York: 1993

Brelage

Manfred Brelage, Studien zur Transzendentalphilosophie Berlin: Walter de Gruyter, 1965

Briefe

Hermann Cohen, Briefe, ed. Bertha and Bruno Strauß, Berlin: Schocken, 1939

BT

Franz Rosenzweig, Briefe und Tagebücher, ed. Rachel Rosenzweig und Edith Rosenzweig-Scheinmann, unter Mitwirkung von Bernhard Casper, (I. Band 1900-1918, II. Band 1918-1929), Haag: Martinus Nijhoff, 1979 [=Ranz Rosenzweig, Der Mensch und sein Werk. Gesammelte Schriften I, Briefe und Tagebücher]

Bulletin Bulletin des Leo Baeck Instituts

ChW

Die Christliche Welt. Evangelisches Gemeindeblatt für Gebildete aller Stände

DZPh Deutsche Zeitschrift für Philosophie 
EB (14)

EJ

EmkN

$\mathrm{EPh}$

ErW

FS (1922)

FS (1929)

FS Fox

GFWJ

Hoffmeister

Holzhey

Holzhey
The Encyclopædia Britannica (Fourteenth Edition, 1929/30)

Encyclopaedia Judaica, Editors in Chief, Cecil Roth, Geoffrey Wigoder, Corrected Edition (16 vols and suppl. vols), Jerusalem: Keter, 1966 ff

Hermann Cohen, "Einleitung mit kritischem Nachtrag" zu F. A. Lange, Geschichte des Materialismus, Leipzig: Brandstetter 1914 (3. edition) [=WW 5/II]

Edwards Paul E. (ed.), The Encyclopedia of Philosophy, New York/London, 1967

Hermann Cohen, Ethik des reinen Willens 5. ed., 1981 [=WW Bd. 7]

Festschrift zum 50 jährigen Bestehen der Hochschule für die Wissenschaft des Judentums in Berlin, Berlin: Philo Verlag, 1922

Festschrift zum 75 Jährigen Bestehen des Jüdisch Theologischen Seminars Fraenkelscher Stiftung, 2 vols., Breslau: Marcus, 1929

From Ancient Israel to Modern Judaism: Essays in Honor of Marvin Fox (ed.Neusner/Frerichs et.al.), 4 vol.s [Brown Judaic Series], Alabama: Scholars Press, 1989

Gesellschaft zur Förderung der Wissenschaft des Judentums

Johannes Hoffmeister, Wörterbuch der Philosophischen Begriffe, 2. Auflage, Hamburg: Meiner, 1955 [PhB 225]

1986/1 Helmut Holzhey, Cohen und Natorp, vol. 1 "Ursprung und Einheit. "Die Geschichte der "Marburger Schule" als Auseinandersetzung um die Logik des Denkens," Basel/Stuttgart: Schwabe \& Co, 1986

1986/2 C Cohen und Natorp, vol. 2 “Der Marburger Neukantianismus in Quellen. Zeugnisse kritischer Lektüre. Briefe der Marburger. Dokumente zur Philosophiepolitik der Schule", Basel/Stuttgart: Schwabe \& Co, 1986 
HS Bh 11 Stuttgarter Hegel-Tage 1970. Vorträge und Kolloquien des Internationalen Hegel-Jubiläumskongresses Hegel 1770-1970. Gesellschaft, Wissenschaft, Philosophie, ed. Hans-Georg Gadamer [=Hegel-Studien Beiheft 11], Bonn: Bouvier, 1974

HUCA Hebrew Union College Annual

$\mathrm{J}$

Hermann Cohens Jüdische Schriften (3 vols.), 1924

JJGL

Jahrbuch für jüdische Geschichte und Literatur, Berlin 18981938

$\mathrm{KBE}^{1,2}$ Hermann Cohen, Kants Begründung der Ethik (1. ed. 1877, 2. ed. 1910)

KTE 1,2,3 Kants Theorie der Erfahrung (1. ed. 1871, 2. ed. 1885, 3. ed. 1918) [=WW 1]

LrE $\quad$, Logik der reinen Erkenntnis, 4. ed. 1977 [=WW, Bd. 6]

Materialien H.-L. Ollig (ed.), Materialien zur NeukantianismusDiskussion [Wege der Forschung Band 637], Darmstadt: Wissenschaftliche Buchgesellschaft, 1987

MGWJ Monatsschrift für Geschichte und Wissenschaft des Judentums

NDB Neue Deutsche Biographie, Historische Kommission bei der Bayerischen Akademie der Wissenschaften (ed.) Berlin: Duncker \& Humblot,1953 ff

NJM Neue Jüdische Monatshefte, 1916-1919

NZZ Neue Zürcher Zeitung

Orlik Franz Orlik, Hermann Cohen (1842-1918). KantinterpretBegründer der "Marburger Schule"-Jüdischer Religionsphilosoph, Marburg: 1992 [Schriften der UB Marburg 63]

$\mathrm{PhJ} \quad$ Philosophisches Jahrbuch

PhR Philosophische Rundschau 
PIM

RV

RGG

$\mathrm{S}$

Schriften

ThLBl

ThLZ

$\mathrm{ThPh}$

Weltkongress Fischer Max/Schiele Friedrich Michael (eds.), Fünfter Weltkongress für freies Christentum und religiösen Fortschritt (Berlin 5.-10. August 1910), Berlin/Schöneberg: Verlag des Protestantischen Schriftenvertriebs, 1910

WW

Yearbook

Hermann Cohen, Das Prinzip der Infitesimal-Methode und seine Geschichte, intr. P. Schulthess [WW, Bd 5/I] 4. ed, 1984

- - Religion der Vernunft aus den Quellen des Judentums, reprint of the 2. ed., Wiesbaden: Fourier, 1978

Die Religion in Geschichte und Gegenwart. Handwörterbuch für Theologie und Religionswissenschaft, Dritte, völlig neu bearbeitete Auflage, in Gemeinschaft mit Hans Frhr. von Campenhausen, Erich Dinkler, Gerhard Gloege und Knut E. Løgstrup herausgegeben von Kurt Galling, (Ungekürzte Studienausgabe)[UTB für Wissenschaft, Grosse Reihe], 7 vols, Tübingen: J.C.B. Mohr (Paul Siebeck), 1986

Hermann Cohen, Schriften zur Philosophie und Zeitgeschichte, 2 vols (ed. Görland, A./Cassirer, E.), Berlin: Akademieverlag, 1928

Wilhelm Herrmann,Schriften zur Grundlegung der Theologie. Mit Einleitung und Anmerkungen, (ed. P.Fischer-Appelt), Two vols, München: Kaiser, 1966/1967

Theologisches Literaturblatt

Theologische Literaturzeitung

Theologie und Philosophie (Vierteljahresschrift), Freiburg: Herder

Hermann Cohen, Werke, Herausgegeben vom HermannCohen-Archiv am Philosophischen Seminar der Universität Zürich unter der Leitung von Helmut Holzhey, Hildesheim/Zürich/New York: Georg Olms Verlag, 1977ff

Leo-Baeck-Institute, New York (ed.), Yearbook 
Franz Rosenzweig, Zweistromland. Kleinere Schriften zu Glauben und Denken. [ =Der. Mensch und sein Werk. Gesammelte Schriften vol. III], ed. Reinhold M a y e $\mathrm{r}$ / A n n e m a r e M a y e r, Dordrecht/Boston/Lancaster: Martinus Nijhoff, 1984

ZPhF Zeitschrift für philosophische Forschung

ZThK Zeitschrift für Theologie und Kirche

ZVPs Zeitschrift für Völkerpsychologie und Sprachwissenschaft, ed. Moritz Lazarus/H. Steinthal

\section{BIBLIOGRAPHIES}

\section{Chronological Bibliography of Hermann Cohen's Writings}

1865 Philosophorum de antinomia necessitatis et contingentiæ doctrinæ. Particula I. Dissertatio inauguralis philosophica quam consensu et auctoritate amplissimi Philosophorum ordinis in Academia Fridericiana Halensis cum Vitebergensi consociata ad summos in philosophia honores rite capessendos $D$. XXVII. M. Octobris A. MDCCCLXV. hora X. una cum sententiis controversis publice defendet auctor Hermannus Cohen, Anhaltinus. Adversariorum partes suscipient: $\mathrm{H}$. Lewandowsky, R. Kautzleben. Halæ 1865 (36pp); (S1,1-29)

1866 "Die platonische Ideenlehre, psychologisch entwickelt" in: ZVPS 4/1866, 403-464; (S1,30-87)

1867 "Heine und das Judentum" anonymous in: Die Gegenwart. Berliner Wochenschrift für jüdische Angelegenheiten 1. Jg., 1867, Nr.1 p.4f, Nr.2 p.13f, Nr.3, p.21f, Nr.4, p.27-29, Nr.5 p.36-38, Nr.7 p.52-54, Nr.8 p.60f, Nr.9 p.69f, Nr.11 p.84f; (J 2,2-44)

1868 "Virchow und die Juden" anonymous in: Die Zukunft. Demokratische Zeitung, ed. Guido Weiß, 2.Jg. Nr.326, August 14,$1868 ;(J 2,457-462)$

1868/69 "Mythologische Vorstellungen von Gott und Seele, psychologisch entwickelt" in: ZVPS 5/1868, 396-434, and $6 / 1869,113-131 ;(S 1,88-140)$ 
1869 "Die dichterische Phantasie und der Mechanismus des Bewußtsein" in: ZVPs 6/1869, 173-263. Separate printing with new preface (March 1869): Berlin, F.Dümmlers Verlagsbuchhandlung (Harrwitz und Goßmann), 1869; (S1,141-228)

1869/1881 "Der Sabbath in seiner culturgeschichtlichen Bedeutung. Vortrag gehalten zu Berlin im Januar 1869 nebst einem Nachwort" in: Der Zeitgeist, ed. Adolf Moses (Milwaukee/Wisconsin, 1881); (J2,45-72);

1871 "Zur Controverse zwischen Trendelenburg und Kuno Fischer" in: ZVPs 7/1871, 249-296; (S1,229-275)

1871 Review of Jürgen Bona Meyer, Kant's Psychologie (1870) in: ZVPs 7/1871, 320-330

1871 Kants Theorie der Erfahrung, Berlin: Dümmler, 1871 (2. revised edition 1885, 3. ed. 1918, 4. ed. 1925, 5. ed. 1987)

1873 Die systematischen Begriffe in Kants vorkritischen Schriften nach ihrem Verhältnis zum kritischen Idealismus, Berlin: Dümmler, 1873 (58pp); (S1,276-335)

1876 "Friedrich Albert Lange" in: Preußische Jahrbücher 37/1876, 353-381; (S2,357-391)

1876 "Friedrich Albert Lange" in: Philosophische Monatshefte XII, 1876, p.46f

1877 Preface to Friedrich Albert Lange, Logische Studien. Ein Beitrag zur Neubegründung der formalen Logik und der Erkenntnisstheorie, ed. Hermann Cohen, (Iserlohn, 1877), p. vf

1877 Kants Begründung der Ethik, Berlin: Dümmler, 1877 (2., enlarged edition 1910)

1878/79 Platos Ideenlehre und die Mathematik, separate reprint from Rectoratsprogramm der Universität Marburg vom Jahre 1878, Marburg: Elwertsche Verlagsbuchhandlung, 1879 (31pp); (S1,336-366)

1880 "Zur Vertheidigung" in: Der Zeitgeist 1/Nr.16 (Aug. 5, 1880), 256-257; (J2,95-100) 
1880 Review of Ecker, A., Lorenz Ocken. Eine biographische Skizze (Stuttgart, 1880) in: Deutsche Litteraturzeitung I ed. Max Roediger), Berlin, 1880 Nr. 6, col.190; (S2,475)

1880 Ein Bekenntniß in der Judenfrage, Berlin: Dümmler, 1880; (J2,73-94)

1881 "Der Sabbath in seiner culturgeschichtlichen Bedeutung" in: Der Zeitgeist . Ein israelitisches Familienblatt, Organ für die Gesamtinteressen des Judentums, (bi-weekly, ed. Adolf Moses, E.G. Hirsch, Isaac S. Moses) Milwaukee/Wis.; (with "Nachwort" dated Marburg Dec. 24, 1880, pp. 15-19); (J2,6672)

1881 Review of W. Deisenberg, Theismus und Pantheismus (Wien, 1880) in: Deutsche Litteraturzeitung II, 1881 Nr.22, col.884f

1881 Review of Johannes Lepsius, Johann Heinrich Lambert. Eine Darstellung seiner kosmologischen und philosophischen Leistungen (München, 1881) in: Deutsche Litteraturzeitung II, 1881 Nr.43, col.1653f

1882 Review of P.J. Carbonelle S.J., Les Confins de la Science et de la Philosophie. 2e éd., tome I,II (Paris, 1881) in: Deutsche Litteraturzeitung III, $1882 \mathrm{Nr} .5$, col.163f

1882 Review of Christoph Sigwart, Kleine Schriften I, II. Reihe (Freiburg i.Br., 1881) in: Deutsche Litteraturzeitung III, 1882, Nr.25, col.891

1882 Review of Herbert Spencer, Die Principien der Psychologie (Stuttgart, 1882) in: Deutsche Litteraturzeitung III, 1882, Nr.43, col.1524f.

1883 Von Kants Einfluß auf die deutsche Kultur. Rede bei der Marburger Universitäts-Feier des Geburtstages Sr. Majestät des Kaisers und Königs am 17. März 1883; Berlin: Dümmler, 1883; (S1,367-396)

1883 Review of Ernst Laas, Kants Stellung in der Geschichte des Conflicts zwischen Glauben und Wissen (Berlin, 1882) in: Deutsche Litteraturzeitung IV, 1883, Nr.35, col.805f

1883 Review of Adolf Bolliger, Anti-Kant oder Elemente der Logik, der Physik und der Ethik, vol. 1 (Basel, 1882) in: Deutsche Litteraturzeitung IV, 1883, Nr.35, col.1218ff 
1883 Das Princip der Infinitesimal-Methode und seine Geschichte. Ein Kapitel zur Grundlegung der Erkenntnisskritik. Berlin: Dümmler, 1883 (162pp); (S2,1-170)

1884 Rezension über Gustav Theodor Fechner, Revision der Hauptpunkte der Philosophie (Leipzig, 1882) in: Deutsche Litteraturzeitung V, 1884, Nr.21, col.762f'; (S2,476f)

1885 Kants Theorie der Erfahrung, 2. revised ed, Berlin: Dümmler, 1885 (xxiv and 616 pp.)

"Biographisches Vorwort" zu F.A.Lange, Geschichte des Materialismus (4th ed)

Die Nächstenliebe im Talmud. Ein Gutachten dem Königl Landgerichte zu Marburg erstattet, Marburg: Elwert, 1888; (J1,145-174)

"Jubiläums-Betrachtungen" (Review of Philosophische Aufsätze. Eduard Zeller zu seinem fünfzigsten Doctor-Jubiläum gewidmet, Leipzig, 1887) in: Philosophische Monatshefte XXIV/1888, Heft 5/6, 257-291; (S1, 397-431)

Kants Begründung der Ästhetik, Berlin: Dümmler, 1889 (xii and 433pp.)

"Der Religionswechsel in der neuen Aera des Antisemitismus" in: $A Z d J$ 54/1890 (October 2), 489-490; (J2,342-345)

"Zur Orientierung in den losen Blättern aus Kants Nachlaß" in: Philos. Monatshefte XXVI, 1890, Heft 5/6, p.287-323; (S1,432-467)

1890 "Zur faktischen Berichtigung" in: Philos. Monatshefte XXVI, 1890, Heft 1/2, p.118; (S1,468)

1892 "Die Messiasidee" first published in 1924 (J1, 105-124)

1892 "Die Versöhnungsidee" first published in 1924 (J1,125-139)

1892 "Dem fünfzigjährigen Doctor medicinæ Herrn Sanitätsrath Dr. Salomon Neumann ein Festgruß" AZdJ 56/1892 (Sept. 16), 447-448 
Berlin: Dümmler, 1. Jg. Nr.18, April 29, 1893, 139f.; (S2,392395)

1894 "Zum Prioritätsstreit über das Gebot der Nächstenliebe" in: AZdJ 58. Jg., June 8, 1894, 268-270; (J1,175-181)

"Worte an der Bahre von Adolf Elsas" (S2,396f)

"Leopold Schmidt zum Gedächtnis" in: Neue Jahrbücher für Philologie und Pädagogik 66. Jg., 1896, 2. Abt., 42. Jg., 1896 [= 154. Band der Jahnschen Jahrbücher für Philologie und Pädagogik], 473-496; (S2,398-439)

1896 "Biographisches Vorwort und Einleitung mit kritischem Nachtrag" zu F. A. Lange, Geschichte des Materialismus, (1. Buch pp. v-xiii "Biographisches Vorwort des Herausgebers" and 2. Buch pp. xv-lxxvi "Einleitung des Herausgebers"), 5. wohlfeile und vollständige Auflage, Leipzig: Baedecker, 1896 (reprinted in 6. edition of Geschichte des Materialismus, 1898; second, enlarged ed. 1902 and 1908, 3. revised and enlarged ed. 1914 and 1921; reprinted in 1928 (S2,171-302); partly reprinted in 1970; critical edition WW 5/II)

1898 "Das Judentum als Weltanschauung. Vortrag, gehalten im 'Politischen Volksverein' in Wien" in: Dr. Bloch's Österreichische Wochenschrift. Centralorgan für die gesammten Interessen des Judenthums, XV. Jg. 1898 (Vienna, April 4, 1898), 241-243

1898 "Biographisches Vorwort und Einleitung mit kritischem Nachtrag" zu F. A. Lange, Geschichte des Materialismus, (1. Buch pp. v-xiii "Biographisches Vorwort des Herausgebers" and 2. Buch pp. xv-lxxvi "Einleitung des Herausgebers") 6. edition, 1898

1899 "Unsere Ehrenpflicht gegen Dreyfus" in: $A Z d J$ 63. Jg, June 9, $1899,268-270 ;$ (J2,346-351)

1899 "Das Problem der jüdischen Sittenlehre. Eine Kritik von Lazarus' Ethik des Judentums" in: MGWJ 43/1899, 385-400 and $433-449 ;(\mathrm{J} 3,1-35)$

1899 "Ein Buch über Kant" [=Review of Friedrich Paulsen, Immanuel Kant (Stuttgart, 1898)] in: Die Nation. Wochenschrift für Politik, Volkswirtschaft und Litteratur, ed. Th.Barth, 16. Jg., 1898/99, Nr.43/44, 609-613 and 623-626; (S2,478-500) 
1899 "Der 80. Geburtstag des Herrn Sanitätsrat Dr. Salomon Neumann" in: $A Z d J$ 63. Jg. Oct. 20, 1899, $496 \mathrm{f}$

1900 "Autonomie und Freiheit" in: Gedenkbuch zur Erinnerung an David Kaufmann, ed. M. Brann, Breslau, 1900, 675-682; separate printing Breslau: Schottländer, 1900 (8pp); (J3,36-42)

"Liebe und Gerechtigkeit in den Begriffen Gott und Mensch" in: JJGL vol. 3, Berlin: 1900, 75-132; (J3,43-97)

1901

1901

1902

1902

1902

1902

1904

1904

"Worte der Trauer um Hermann Lewandowsky, gesprochen am 8. Juni 1900"

"Der Stil der Propheten" (lecture, Vienna, March 31, 1901); (J1,262-283, 340f)

"Die Sprüche im Israelitischen Schüler-und Lehrlingsheim zu Marburg a.L." in: $A Z d J$ 65. Jg., May 31, 1901, 256f; separate printing Berlin: Mosse, 1901 (7pp); (J2,102-107)

System der Philosophie. Erster Teil: Logik der reinen Erkenntnis, Berlin: Bruno Cassirer, 1902 (xvii and 520 pp); second, improved ed. 1914, 3. ed. WW 6, 1977

“Über die literarische Behandlung unserer Gegner" in: AZdJ 66.Jg., July 29, 1902, 412-414; (J2,360-368)

"Biographisches Vorwort und Einleitung mit kritischem Nachtrag in zweiter, erweiterter Auflage" zu F.A.Lange, Geschichte des Materialismus (7. ed)

(with Leopold Lucas) "An unsere Glaubensgenossen!" pamphlet, 2pp, inviting to the founding convention of the Gesellschaft zur Förderung der Wissenschaft des Judentums

“Die Errichtung von Lehrstühlen für Ethik und Religionsphilosophie an den jüdisch-theologischen Lehranstalten" Vortrag gehalten 6. Januar 1904, in: MGWJ 48/1904, 2-21

Ethik und Religionsphilosophie in ihrem Zusammenhange [ = "Die Errichtung von Lehrstühlen für Ethik und Religionsphilosophie an den jüdisch-theologischen Lehranstalten"], enlarged by a preface, published by Gesellschaft zur Förderung der Wissenschaft des Judentums, Berlin, 1904, (24pp); (J2,108-125 under the original title) 
1904 "Ein Gruß der Pietät an das Breslauer Seminar" in: Ost und West 1904, 747-756; (J2,418-424)

1904 "Immanuel Kant. Zu seinem 100jährigen Todestage (12. Febr. 1904)" in: AZdJ Jg.68, Febr. 12, 1904, 76-77

1904 "Tapferkeit" in: Die Zukunft (ed. Maximilian Harden), Berlin, vol.49/1904, 46-53 (extracts from ErW 552-568)

1904

"Rede bei der Gedenkfeier der Universität Marburg zur hundertsten Wiederkehr des Todestages von Immanuel Kant gehalten am 14. Februar 1904" [= Marburger Akademische Reden 1904 Nr.10]; (S1,496-489)

1904 Review of J. Freudenthal, Spinoza. Sein Leben und seine Lehre, vol. 1 (Stuttgart, 1904) in: Literarisches Zentralblatt 36/1904, col.1189-1191; (S2,501-503)

1904 "Das allgemeine, gleiche und direkte Wahlrecht" in: Ethische Kultur. Halbmonatsschrift für ethisch-soziale Reformen, ed. R.Penzig, XII Jg., Nr 6, March 15, 1904, 42f; (S2,331-334)

1904 System der Philosophie. Zweiter Teil: Ethik des reinen Willens, Berlin: Bruno Cassirer, 1904 (xvii and 641pp); 2. revised ed. 1907, 3. ed. 1921, 4. ed. 1923, WW7 1981

1905 without title (on Schiller) in: Schiller im Urteil des 20. Jahrhunderts. Eingeführt von Eugen Wolff, Jena: Hermann Costenoble, 1905, pp.105f

1905/6 "Mozarts Operntexte. Zur 150. Wiederkehr seines Geburtstages, 21. Januar 1906" in: Frankfurter Zeitung 31.12.05, 3. and 4.1.06; (S1,490-519)

1906 "Der geschichtliche Sinn des Abschlusses der DreyfusAffäre" in: $A Z d J$ 70, 27. Juli 06, 352-355; (J2,352-359)

1906 "Gedanken über Jugendlektüre" in: Wegweiser für die Jugendliteratur, ed Großloge für Deutschland VIII U.O.B.B., Sept. 06, Nr. 13, 49-51; (J2, 126-132)

1906 (and Paul Natorp) "Zur Einführung" in: Philosophische Arbeiten, ed. Cohen u Natorp, vol. 1, Heft 1, pp i-iii, Gießen, Töpelmann

1907 System der Philosophie. Zweiter Teil: Ethik des reinen Willens, 2. revised edition Berlin: B. Cassirer, 1907 (xxiii and 679pp) 
1907 "Das Urteil des Herrn Professor Nöldeke über die Existenzberechtigung des Judentums" in: $A Z d J$ J1, 1.2.07 and in: Straßburger Post, 10.2.07 (Unterhaltungsblatt); (J2,369377)

1907 "Zwei Vorschläge zur Sicherung unseres Fortbestandes" in: Bericht der Großloge, Festausgabe, Nr.2, March 07, 9-12; (J2,133-141)

1907 "Religion und Sittlichkeit. Eine Betrachtung zur Grundlegung der Religionsphilosophie" first published in JJGL 10/1907, 98-171; enlarged separate edition Berlin: Poppelauer, 1907; (J2,98-168)

1907 "Religiöse Postulate. Rede gehalten am Frankfurter Verbandstage der deutschen Juden 1907" (13.10.07) Stenographischer Bericht der 2. Hauptversammlung des Verbandes, 11020. Also in $A Z d J$ 71, 13.12.07, 592-595; reprinted 1909; (J1,1-14)

1907 Kommentar zu Immanuel Kants Kritik der reinen Vernunft. Leipzig: Meiner, PhB 113; later editions in 1917, '20, '25, '89 (WW4)

1908

“Biographisches Vorwort und Einleitung mit kritischem Nachtrag in zweiter, erweiterter Auflage" zu F. A. Lange, Geschichte des Materialismus (8. ed), Leipzig: Brandstetter, 1908, pp. v-xiii, 435-535

1908 "Salomon Neumann. Rede bei der Gedächtnisfeier der Lehranstalt für die Wissenschaft des Judentums am 25. Oktober 1908" in: $A Z d J$ 72, 30.10.08, 519-524; separate ed., Berlin: Mosse (15pp); (J2,425-438)

1908 "Charakteristik der Ethik Maimunis" in: Moses ben Maimon. Sein Leben, seine Werke und sein Einfluß. Zur Erinnerung an den 700. Todestag des Maimonides, ed Gesellschaft zur Förderung der Wissenschaft des Judentums (W.Bacher, M.Brann, D.Simonsen with J.Guttmann) vol. I, Leipzig: Fock, 1908, 63134; separate printing Leipzig: Fock, 1908 (lxxii pp.); (J3,221289)

1908 "Auch ein Zeichen vom Geiste der Zeit" in: Der Zeitgeist. Beiblatt zum Berliner Tageblatt, 13.7.08; (S2,335-340) 
1909 "Religiöse Postulate. Rede gehalten am Frankfurter Verbandstage der deutschen Juden (1907) und durch einen Zusatz vermehrt" in: Ost und West IX, 09, 2, 70-82; (J1,14-17)

1910 "Innere Beziehung der Kantischen Philosophie zum Judentum. Vortrag, gehalten 3.1.10, Montagsvorlesungen der Lehranstalt für die Wissenschaft des Judentums" in: 28. Bericht der Lehranstalt für die Wissenschaft des Judentums, 1910, 41-61; (J1,284-305)

1910 “Die Einheit des Herzens bei Bachja" in: MGWJ 54/1910, 481-490; (J3,213-220)

1910 "August Stadler" in: Kantstudien XV, 1910/4, 403-20; (S2,440458)

1910 "Für Paul Heyse zu dessen 80. Geburtstag" (S2,459f)

1910 Kants Begründung der Ethik. 2. improved and enlarged edition, Berlin: Bruno Cassirer, 1910

1910/29 "Ein ungedruckter Vortrag Hermann Cohens über Spinozas Verhältnis zum Judentum" Eingeleitet von Franz Rosenzweig, in: Festgabe zum 10jährigen Bestehen der Akademie für die Wissenschaft des Judentums 1919-1929, Berlin: 1929, 4268

1910 "Gesinnung" in: Korrespondenz-Blatt des Verbandes der Deutschen Juden, Nr 7 (Apologetische Sondernummer) Juni 1910, 1-6; reprinted in: Vom Judentum, ed Verband der Deutschen Juden, Berlin, 1916 Heft 5/6, 1-13; (J1,196-210)

1910 "Die Bedeutung des Judentums für den religiösen Fortschritt der Menschheit. Vortrag, gehalten auf dem 5. Weltkongress für Freies Christentum und religiösen Fortschritt am 10. August 1910" in: Weltkongress; and as separate printing Berlin-Schöneberg: Protestantischer Schriftenvertrieb, 1910 (16pp); (J1,18-35)

1911 Le judaisme et le progres religieux de l'humanite. Paris, 1911 (25 pp.)

1911 "Die Liebe zur Religion" in: Gemeindeblatt der Jüdischen Gemeinde zu Berlin, 1. Jg., Nr.2, 10.2.11, col.1-4; (J2,142-148) 
"Über die Bedeutung einer philosophischen Jugendschrift Ludwig Philippsons" in: L. Philippson, Gesammelte Abhandlungen, Leipzig: Fock, 1911, vol.2, Anhang, 461-486; (partly in: J2, 439-445)

1911 "Äußerung zum Jubiläum unserer staatsbürgerlichen Gleichberechtigung" in: Gedenknummer zur Jahrhundertfeier der Emanzipation der Juden in Preußen der Mitteilungen des Verbandes der jüdischen Jugendvereine Deutschlands, Jg 2, Nr 4, 1.4.11, p.11

1912 "Emanzipation" in: Israelitisches Familienblatt, 14. Jg., Nr. 10, 7.3.12, 1-3; excerpts. in: Die christliche Welt 26, 1912, 483-485; $(\mathrm{J} 2,220-228)$

1912 "Rede anläßlich des am Donnerstag, 25. Juli 1912, dargebrachten Fackelzuges" in: Hessische Landeszeitung Marburg, Nr. 177, 31.7.12; (S2,471f)

1912 System der Philosophie. Dritter Teil: Ästhetik des reinen Gefühls, Berlin: B. Cassirer, 1912; 2. ed. 1923; WW 8/9, 1982

1912ff Immanuel Kants Werke. ed. Ernst Cassirer in Gemeinschaft mit Hermann Cohen et al. Berlin: Bruno Cassirer, 1912-1922

1913 "Zwei Rektoratsreden an der Berliner Universität" in: Israelitisches Familienblatt, Jg 15, Nr 35, 28.8.1913; (J2,404-409)

1913 "Die Eigenart der Alttestamentlichen Religion" in: $A Z d J 77$. Jg., Oct. 1, 1913, 472-474; (J2,410-415)

1913 "Die Geisteswissenschaften und die Philosophie" in: Die Geisteswissenschaften. Wochenschrift für das gesamte Gebiet der Philosophie, ed. O. Buek/P. Herre, vol. I, Leipzig: Veit, 1913/14, Heft 1, 2-4; (S1,520-526)

1913 "Das Gottesreich" in: Soziale Ethik im Judentum. Zur fünften Hauptversammlung in Hamburg 1913, ed. Verband der Deutschen Juden, Frankfurt: Kauffmann,1913; reprinted in: Ost und West, xiv. Jg, Febr 1914, Heft 2, Sp 105-112; 4. Aufl Frankf, 1918; (J3,169-175) 
1914 "Der Nächste. Bibelexegese und Literaturgeschichte" in: Abendausgabe des Berliner Tageblatts, 5.1.14; revised and enlarged in: Korrespondenz-Blatt des Verbandes der Deutschen Juden, Nr.14, June 1914, pp.1-6; also in: $A Z d J$ 78. Jg., July 24, 1914, 355-357; enlarged ed. 1916; (J1,182-195)

1914 "Professor Paul Natorp. Zu seinem 60. Geburtstag, 24.1.1914" in: Marburger Akadademische Rundschau, Nr 7, 22.1.14; (S2,466-470)

1914 "Die Bedeutung des Ordens Bnei Briss für die Harmonisierung der religiösen, sozialen und internationalen Gegensätze" Bericht der Großloge für Deutschland VIII UOBB, Jan 1914, 1, pp1-4; (J2,149-155)

1914 "Eduard Zeller: Zu seinem 100. Geburtstag am 22.2.14" in: Berliner Tageblatt, Nr 37, 21.1.14; (S2,460-465)

1914 "Antwort an Herrn Justizrat Fränkel" in: Israelitisches Familienblatt 16. Jg., Nr 9, 26.2.14; (J2,477-479)

1914 "Biographisches Vorwort und Einleitung mit kritischem Nachtrag" in dritter erweiterter Bearbeitung zur neunten Auflage von F.A.Lange, Geschichte des Materialismus, 9. ed. vol. 1, Leipzig: Brandstetter, 1914, p.III-XI and Anhang 1-125; $(\mathrm{S} 2,171-302)$

1914 "Die Lyrik der Psalmen" (J1, 237-261)

1914 "Das Gottesreich" in: Ost und West, xiv. Jg, Febr 1914, Heft 2, col. 105-112; also in: Soziale Ethik im Judentum, Herausgegeben vom Verband der Deutschen Juden, Zweite Auflage, Frankfurt am Main: J. Kauffmann, 1914, pp. 120$124 ;(J 3,169-175)$

1914 Die religiösen Bewegungen der Gegenwart, Leipzig: Fock, 1914 (31.p) [= Schriften herausgegeben von der Gesellschaft zur Förderung der Wissenschaft des Judentums]; (cf. J1,36-65)

1914 System der Philosophie. Erster Teil: Logik der reinen Erkenntnis. 2. enlarged ed., Berlin: B. Cassirer, 1914 (xxviii and 612pp)

1914 Über das Eigentümliche des deutschen Geistes, Berlin: Reuther \& Reichard, 1914 (45pp) [= Philosophische Vorträge der Kantgesellschaft, Nr. 8, 2. u 3. ed. 1915]; (S1,527-570) 
1914 "Vom ewigen Frieden" in: Deutsche Weihnacht, Kassel/Berlin: Furche, 1914 [ $=1$. Liebesgabe deutscher Hochschüler]; separate printing Cassel, 1914 (10pp); (S2,342346)

1914? "Über den ästhetischen Wert unserer religiösen Bildung" $(\mathrm{J} 1,211-236)$

1915 (title unknown) in: Kriegsmappe des Schutzverbandes deutscher Schriftsteller e.V. 80 autographische Blätter mit Abbildungen, Berlin: Verlag Deutscher Kurier, 1915 (quoted in R.A. Fritzsche, Hermann Cohen aus persönlicher Erinnerung, p.26)

1915 "Rede bei der Trauerfeier für Geh. Justizrat Hermann Veit Simon am 21. Febr 1915 in der Lehranstalt für die Wissenschaft des Judentums" in: 33. Bericht der Lehranstalt für die Wissenschaft des Judentums, 1915, 19-22; also as separate printing (4pp)

1915 "'Du sollst nicht einhergehen als ein Verläumder.' Ein Appell an die Juden Amerikas" in: New Yorker Staatszeitung; reprinted in: JüdischeVolkszeitung, Breslau, Jg 21, Nr 10; and in: Israelitisches Familienblatt 17. Jg, Nr 25, 24.6.1915, 9-10; (J2, 229-236)

1915 "Soziale Erbsünde" in: Hamburgischer Correspondent, 185. Jg., Nr 402, 9.8.1915, Abendausgabe, p.3

1915 "Spinoza über Staat und Religion, Judentum und Christentum" in: JJGL 18, 1915, 56-150; (J3,290-372)

1915 "Der heilige Geist" in: Festschrift zum 70. Geburtstag Jakob Guttmanns, ed. Vorstand der Gesellschaft zur Förderung der Wissenschaft des Judentums, Leipzig: Fock, 1915, 1-21 [= Schriften hg v d GFWJ]; (J3,176-196)

1915 Der Begriff der Religion im System der Philosophie, Gießen: Töpelmann, 1915 (164pp) [= Philosophische Arbeiten, ed. Hermann Cohen and Paul Natorp, $X / 1]$

1915 Deutschtum und Judentum. Mit grundlegenden Betrachtungen über Staat und Internationalismus, Gießen: Töpelmann, 1915, 45pp [= Von deutscher Zukunft, 1. Stück]; second ed. 1916

1915 "Der deutsche Idealismus und die Antike. Vortrag, gehalten in der Versammlung des 'Bundes der Freunde des 
humanistischen Gymnasiums in Frankfurt am Main und den Nachbarstädten' am 11.12.1915" in: Das humanistische Gymnasium (Organ d Gymnasialvereins) $27 \mathrm{Jg}$, Heidelberg 1916, Heft I/II, 17-31; (S2,303-327)

1915 Über das Eigentümliche des deutschen Geistes, 2. u 3. ed. 1915 [= Philosophische Vorträge der Kantgesellschaft, Nr. 8]; (S1,527-570)

1916 "Kantische Gedanken im deutschen Militarismus" in: Frankfurter Zeitung, Nr 8, 9.1.1916; (S2,347-354)

1916 Deutschtum und Judentum. Mit grundlegenden Betrachtungen über Staat und Internationalismus, 2. Auflage, Durchgesehen, ergänzt und mit einem kritischen Nachwort als Vorwort, Gießen: Töpelmann, 1916 (59pp) [= Von dt. Zukunft, 1. Stück]; (J2,237-301)

1916 "Deutschtum und Judentum" in: Vom inneren Frieden des deutschen Volkes. Ein Buch gegenseitigen Verstehens und Vertrauens. Hg Friedrich Thimme, Leipzig: Hirzel, 1916, 541$562 ;(\mathrm{J} 2,302-318)$

1916 Die dramatische Idee in Mozarts Operntexten. Berlin: B. Cassirer, 1916 (115 pp)

1916 "Don Juan" [= excerpts from Die dramatische Idee in Mozarts Operntexten (1916)] in: Die Schaubühne, 1916, 54-62

1916 "Der polnische Jude" in: Der Jude 1916, 149-156; (J2,162-171)

1916 "Gedenkrede auf Siegried Brünn, 18. Mai 1916" in: Mitteilungen des Verbandes der jüdischen Jugendvereine Deutschlands, Jg 6/7, Heft 1, 15.6.16, 17-19

"Zionismus und Religion" in: K.C. Blätter, Mai/Juni 1916, Heft 11, 643-646; separate printing with the title Religion und Zionismus. Ein Wort an meine Kommilitonen jüdischen Glaubens, Crefeld: Verlag der K.C.Blätter, 1916 (11pp); (J2,319-327)

1916 "Antwort auf das offene Schreiben des Herrn Dr. Martin Buber an Hermann Cohen" in: K.C.Blätter, Juli/Aug 1916, Heft 12, 683-688; separate ed.. Frankfurt/Main: Verlag der K.C. Blätter, 1916; (J2,328-340) 
1916 "Die Zugehörigkeit zur Gemeinde" in: Gemeindeblatt der jüdischen Gemeinde zu Berlin, 6.10.16, 115f; (J2,156-161)

1916 "Neujahr und Versöhnungstag" in: Neue Jüdische Monatshefte (abbr. NJM) I, 1916, Heft 1, 10.10.1916, 19-22 (Streiflichter über jüdische Religion und Wissenschaft 1.)

"Das soziale Ideal bei Platon und den Propheten" lecture given at the Soziologische Gesellschaft in Vienna, Oct. 19, 1916; repeated on January 7, 1918 as Cohen's last public speech (cf. J1,341); first published 1924 in: J1,306-330

"Grenzsperre" in: NJM I, 1916, Heft 2, 25.10.1916, 50-52 (Streiflichter, 2.); (J2,378-380)

1916

"Gottvertrauen" in: NJM I, 1916, Heft 3, 10.11.1916, 79-82 (Streiflichter, 3.); (J1,100-104)

"Monotheismus und Messianismus" in: NJM I, 1916, Heft 45, 25.11/10.12.1916, 106-111, 135-138 (Streiflichter, 4./5.)

"Die ethischen und historischen Motive der Religion" in: NJM I, 1916, Heft 6, 25.12.1916, 166-169 (Streiflichter, 6.); (J3,197-202)

"Gesinnung" in: Vom Judentum. Aufsätze und Vorträge, ed. Verband der Deutschen Juden, Berlin, 1916 Heft 5/6, 1-13 (enlarged edition of 1910); (J1,196-210)

"Der Nächste. Bibelexegese und Literaturgeschichte" in: Vom Judentum. Aufsätze und Vorträge, ed. Verband der Deutschen Juden, Berlin, 1916 Heft 5/6, 13-47; (J1,182-195)

"Ein abessinischer Rationalist im 17. Jahrhundert" in: NJM I, 1917, Heft 7, 10.1.1917, 198-201 (Streiflichter,7.)

"Betrachtungen über Schmollers Angriff" in: NJM I, 1917, Heft 8, 25.1.1917, 222-230 und Heft 9, 10.2. 1917, 256-260' (Streiflichter, 8./9.); (J2,381-397)

"Der Jude in der christlichen Kultur" in: NJM I, 1917, Heft 10, 25.2.1917, 291-294; Heft 11, 10.3.17, 322-325, Heft 13, 10.4.17, 387-389, Heft 17, 10.6.17, 509-514 (Streiflichter, 10-13); (J2,193-209) wissenschaftlichen Vereinigung zu Berlin am 9.6.17" in: 
Protestantenblatt. Wochenschrift für den deutschen Protestantismus, Beiblatt Nr 28, 14.7.17 und 19, 21.7.17, Sp. 441-445, 457-464; separate printing Berlin: Hutten Verl, 1917 (35pp); (J1,66-86)

1917 "Eine Pflicht der Selbstachtung" in: NJM I, 1917, Heft 18, 25.6.1917, 538-540 (Streiflichter, 14.); (J2,172-174)

"Eine Selbstanzeige" in: NJM I, 1917, Heft 20, 25.7.1917, 592594 (Streiflichter, 15.)

"Der ethische Monotheismus der Propheten und seine soziologische Würdigung" in: AZdJ 81. Jg, Nr 32, 10.8.1917, $373 f$

1917 "Der Prophetismus und die Soziologie" in: NJM I, 1917, Heft 22, 25.8.1917, 652-655 (Streiflichter,16.); (J2,398-401)

1917 "Der Tag der Versöhnung" in: NJM I, 1917, Heft 23/24, 10./25.9.1917, 699-702 (Streiflichter, 17.); (J1,140-144)

"Einheit oder Einzigkeit Gottes I." in: NJM II, 1917, Heft 1, 10.10.1917, 21-24 (Streiflichter, 18.); (J1,87-99 ; including parts II. \& III)

1917 "Zu Martin Luthers Gedächtnis" in: NJM II, 1917, Heft 2, 28.10.1917, 45-49 (Streiflichter 19.?)

"Zur Jahrhundertfeier unseres Grätz" in: NJM II, 1917, Heft $3 / 4,10 . / 25.11 .1917,51-57 ;(J 2,446-453)$

"Grätzens Philosophie der jüdischen Geschichte" in: MGWJ 61, 1917, 356-366; (J3,203-212)

"Mahnung des Alters an die Jugend" [Sondernummer der] Mitteilungen des Verbandes der jüdischen Jugendvereine Deutschlands, 8.Jg, Heft 6, 10.12.17, 162-175; (J2,175-192)

"Einheit oder Einzigkeit Gottes II. Die Schöpfung" in: NJM II, 1917, Heft 6, 25.12.1917, 140-143 (Streiflichter,20.); (J1,8799; incl I. \& III.)

Kommentar zu Immanuel Kants Kritik der reinen Vernunft, 2. ed, [= PhB 113], Leipzig, F. Meiner

1918 "Julius Wellhausen. Ein Abschiedsgruß" in: NJM II, 1918, Heft 8, 10./25.1.1918, 178-181; (J2,463-468) 

Judentums" in: NJM II, 1918, Heft 11, 10.3.1918, 254-259; also separate ed. and published in many Jewish weeklies in Germany; (J2,210-217)

"Einheit und (sic!) Einzigkeit Gottes III. Offenbarung" in: NJM II, 1918, Heft 12, 25.3.18, 281-284; (J1,87-99; incl I. \& II.)

Kants Theorie der Erfahrung (3. Aufl), 3. ed, Berlin: B. Cassirer

"Die Religion der Vernunft aus den Quellen des Judentums. Die Schöpfung" [= RV, Beginning of Ch. III] in: NJM II, 1918, Heft 15/16, 10./25.5.18, 339-346

Die Religion der Vernunft aus den Quellen des Judentums, Leipzig: Fock

Kommentar zu Immanuel Kants Kritik der reinen Vernunft (2. ed), 3. unveränderte ed, [= PhB 113], Leipzig, F. Meiner, 1920

"Biographisches Vorwort und Einleitung mit kritischem Nachtrag" in dritter erweiterter Bearbeitung zur zehnten Auflage von Langes Geschichte des Materialismus (S2,171-302); Leipzig: Brandstetter, 1921, p.III-XI und Anh. 1-125

System der Philosophie. Zweiter Teil: Ethik des reinen Willens (repr. of 2. rev ed), 3. ed. Berlin: B.Cassirer

"Briefe über Gottfried Keller. Veröffentlicht mit gütiger Erlaubnis der Frau Geheimrat Cohen" in: Gabe Herrn Rabbiner Dr. Nobel zum 50. Geburtstag darbegracht von Martin Buber, Rudolf Hallo u.a., Frankfurt a..M. 5682 (1921), 9-11

"Östjuden" [="Der polnische Jude"] in: M. Ehrenpreis, Israels Nutid och Framtid. Valda Essayer Av Samtida Judiska Tänkare. Med inledningar av M. Ehrenpreis, oversatta av Ernst Klein, Stockholm: P.A.Norstedt \& Söners Förlag, 1921, 74-83

Hebrew translation of Lange, Friedrich Albert, Toldot hamaterialismus $u$-vikoret erko bi-zemanenu (...) mavo (...) meet Herman Kohen.translated by Bar Tuvyah. New York/Warsaw: A.Y.Shtibl 1921 
1923 System der Philosophie. Dritter Teil: Ästhetik des reinen Gefühls. 2. ed, Berlin: B.Cassirer

1923 System der Philosophie. Zweiter Teil: Ethik des reinen Willens (repr. 2. rev ed), 4. ed. Berlin: B.Cassirer

1924 Hermann Cohens Jüdische Schriften. Mit einer Einleitung von Franz Rosenzweig herausgegeben von Bruno Strauß, Berlin: C.A.Schwetschke \& Sohn, 1924, Erster Band: "Ethische und religiöse Grundfragen", Zweiter Band: "Zur jüdischen Zeitgeschichte", Dritter Band: "Zur jüdischen Religionsphilosophie und ihrer Geschichte" [Veröffentlichungen der Akademie für die Wissenschaft des Judentums]

1925 Kommentar zu Immanuel Kants Kritik der reinen Vernunft, 4. ed, Leipzig, 1924 = I. Kant, Sämtliche Werke, ed. K.Vorländer, Bd X

1925 Kants Theorie der Erfahrung, 4. Aufl, Berlin: B.Cassirer, 1925 (573pp)

1928 Schriften zur Philosophie und Zeitgeschichte, ed. A. Görland/E. Cassirer, 2 vols, ed. A. Görland/E. Cassirer, Berlin: Akademieverlag, 1928 (570pp, 503pp) [Veröffentlichung der Hermann-Cohen-Stiftung bei der Akadademie für die Wissenschaft des Judentums]

1929 Ausgewählte Stellen aus unveröffentlichten Briefen. Ausgewählt und mit gütiger Erlaubnis von Frau Geh. Cohen herausgegeben von Dr. Bruno Strauß. Den Teilnehmern an der Jahresversammlung der Soncino-Gesellschaft der Freunde des jüdischen Buches am 17. Febr 1929 überreicht vom Akademie-Verlag (150 numbered copies)

1929 "Ein ungedruckter Vortrag Hermann Cohens über Spinozas Verhältnis zum Judentum. Eingeleitet von Franz Rosenzweig" in: Festgabe zum 10jährigen Bestehen der Akademie für die Wissenschaft des Judentums 1919-1929, Berlin: $1929,42-68$

1929 Religion der Vernunft aus den Quellen des Judentums. Nach dem Manuskript des Verfassers neu durchgearbeitet und mit einem Nachwort versehen von Bruno Strauß [=Grundriß der Gesamtwissenschaft des Judentums], Frankfurt: Kauffmann 
1934/35 Ketavim 'al ha-Yahadut (Hebrew transl. by Zvi Wisslavski), Jerusalem: Hebrew Univ. Press, 5695 (ed. Tortczyner) also transl. P (F?) Melzer; aided by A. (='aleph) Rosenzweig

1935 Der Nächste. Vier Abhandlungen über das Verhalten von Mensch $z u$ Mensch nach der Lehre des Judentums. Mit einer Vorbemerkung von Martin Buber, Berlin: Schocken, 1935 (excerpts)

1939 Briefe. Ausgewählt und herausgegeben von Bertha und Bruno Strauß, Berlin: Schocken, 1939 (83pp)

1946 Enrique Heine y el judaismo: El sabado: su significacion historicocultural. Traduccion directa del aleman por Herta Landshoff, Buenos Aires: Sociedad Hebraica Argentina, 1946

1955 El Judaismo y el progreso religioso de la humanidad. Montevideo: 1955

1959 Religion der Vernunft aus den Quellen des Judentums, reprint of 2. ed, Köln: Josef Melzer

1963 [texts] in: Contemporary Jewish Thought. A Reader. Ed. with introductory notes by Simon Noveck. B'nai B'rith Dept of Adult Jew. Ed., Clinton, Mass: 1963, paperback ed 1969, 129173

1964 The Purpose and Meaning of Jewish Existence. Abridged American translation of Religion der Vernunft by Mordecai Kaplan, Philadelphia, Jewish Publication Society of America, 1964

1965 "Ein Bekenntnis in der Judenfrage" in: Der Berliner Antisemitismusstreit, ed. Walter Boehlich, Frankfurt am Main: Insel, 1965, pp. 124-149 [=sammlung insel 6]

1967 "Die Versöhnungsidee" in: Wissenschaft des Judentums im deutschen Sprachbereich. Ein Querschnitt. mit einer Einführung herausgegeben von Kurt Wilhelm, 2 Bde, Tübingen: Mohr, 1967 [= Schriftenreihe wissenschaftliche Abhandlungen des Leo Baeck Instituts 16/I,II, pp. 771-782 (followed by a biobibliographical sketch)

1968 Das Prinzip der Infinitesimal-Methode und seine Geschichte. Ein Kapitel zur Grundlegung der Erkenntniskritik, intr. Werner Flach, Frankf a M: Suhrkamp, 1968 (299pp) = Theorie 1 
1968 [letters to F.A.Lange] in: F.A.Lange, über Politik und Philosophie. Briefe u Leitartikel, 1862-1875, ed G.Eckert, Duisburg: Walter Braun Verlg, 1968, 360-379 [=Duisburger Forschungen, 10. Beih.]

1968 "The Day of Atonement" in: Judaism 17, 1968, Nr. 3, 352-357 (translation of RV ch. XII)

1970 "Jubiläums-Betrachtungen" (excerpts) in: Philosophisches Lesebuch, ed. H.-G. Gadamer, Bd. 3, Frankfurt a.M.: Fischer, 1970, 205-219 = Fischer Bücherei 6019

1970 [Kant] from: "Einleitung mit kritischem Nachtrag" 5. Aufl. in: Marxismus und Ethik, ed. Rafael de La Vega/Hans Jörg Sandkühler, Frankf: Suhrkamp, 1970, 45-86; mit neuer Einleitung von H.J. Sandkühler ibid, 1974 [= stw 75]

1970 (1903) [Fakultätsgutachten von H.Cohen und P.Natorp zur Dissertation von Abraham Gideon] in: Norbert Hinske, Kants Weg zur Transzendentalphilosophie, Stuttgart (etc): Kohlhammer, 1970, 142f

1971 Reason and Hope. Selections from the Jewish Writings of Hermann Cohen, transl. by Eva Jospe, New York: W.W. Norton \& Comp, 1971 (237pp)

1971 Dat ha-tevunah mimeqorot ha-yahadut. Hebrew translation of Religion der Vernunft by Z. Wisslavski, ed. S.H. Bergmann/N. Rotenstreich. Introduction \& postscript by $S$. Ucko and J. Ben Shlomo, Jerusalem

1972 Religion of Reason out of the Sources of Judaism, American transl by Simon Kaplan, with an introduction by Leo Strauss, New York: Frederick Ungar, 1972 (489pp)

1977 'Iyyunim be-yahadut uve-ve'ayot ha-dor. P'raqim mitokh katavim yehudiim, transl. Z. Wisslavski, Jerusalem

1977 Hermann Cohen e la Fondazione Kantiana dell' Ethica, (Italian translation of Kants Begründing der Ethik) by Gianna Gigliotti: Firenze: G.C. Sansoni, 1977)

1977 WW, Bd. 6. Logik der reinen Erkenntnis, 4. Aufl., ed HermannCohen-Archiv (Leitung H. Holzhey), Hildesheim: Olms, $1977\left(\mathrm{xxv}^{*}\right.$, xxviii, $\left.772 \mathrm{pp}\right)$ 
1978 WW, Bd. 4. Kommentar zu Immanuel Kants Kritik der reinen Vernunft, 5. Aufl., introduction H.Holzhey, Hildesheim: Olms, 1977

1978 Religion der Vernunft aus den Quellen des Judentums. Wiesbaden: Fourier Verl., 1978, reprint of 2. ed.

"Kants Disposition des Begriffs Erkenntnis"/"Die transzendentale Methode" from: Kants Theorie der Erfahrung (3. Aufl, 1918) 79-110 in: Erkenntnistheorie und Logik im Neukantianismus, ed. W.Flach/H. Holzhey, Hildesheim: Gerstenberg, 63-137

1980 "Die Urteile der Denkgesetze" from: Logik der reinen Erkenntnis 4. Aufl (1977) in: Erkenntnistheorie und Logik im Neukantianismus, ed. W.Flach/H. Holzhey, Hildesheim: Gerstenberg, 63-137

1980 Hermann Cohens Jüdische Schriften. New York: Arno Press, 1980

1981 WW, Bd. 7. Ethik des reinen Willens. 5. ed., intr. by Steven S. Schwarzschild, Hildesheim: Olms

WW, Bd 8/9. Ästhetik des reinen Gefühls, intr. G. Wolandt, Hildesheim: Olms

"Das Verhältnis der Ethik zu Religion und Politik" from: EmkN zu F.A.Lange, Geschichte des Materialismus, 5. Aufl, Leipzig 1886 in: Neukantianismus. Texte der Marburger und der Südwestdeutschen Schule, ihrer Vorläufer und Kritiker, ed H.-L. Ollig, Stuttgart: Reclam. 1982, 73-96

1983 La fondazione kantiana dell'etica, a cura di Gianna Gigliotti, Lecce: Milella, 1983 (lx and 497pp)

1984 WW, Bd 5/I: Das Prinzip der Infitesimal-Methode und seine Geschichte, 4. ed, intr. P. Schulthess, Hildesheim: Olms, 1984

1984 WW, Bd. 5/II. "Einleitung mit kritischem Nachtrag" with an introduction by H.Holzhey, Hildesheim: Olms, 1984

1987 WW, Bd. 1.1 Kants Theorie der Erfahrung, intr. Geert Edel; Text der 3. Aufl. 1918 
WW, Bd. 1.3 Kants Theorie der Erfahrung, Text der 1. Aufl, 1871

$1988 \quad$ Religion der Vernunft aus den Quellen des Judentums; nach dem Manuskript des Verfassers neu durchgearbeitet und mit einem Vorwort versehen von Bruno Strauss. Wiesbaden : Fourier Verlag, 1988

1989 WW, Bd. 4 Kommentar zu Immanuel Kants Kritik der reinen Vernunft, 5. Aufl. (Einleitung von Helmut Holzhey)

1993 Jüdische Schriften. English. Selections [Reason and hope: selections from the Jewish writings of Hermann Cohen] translated by Eva Jospe. Cincinnati: Hebrew Union College Press, West Orange, NJ: Distributed by Behrman House, 1993

1994 Jüdische Schriften. French. Selections. [L'ethique du judaisme] presentation, traduction de l'allemand et annotation par Maurice-Ruben Hayoun. Paris : Editions du Cerf, 1994

$1994 \quad$ Religion de la raison tiree des sources du judaisme. Traduit de l'allemand par Marc B. de Launay et Anne Lagny. Paris: PUF, 1994

1994 Religione della ragione dalle fonti dell'ebraismo. Edizione italiana a cura di Andrea Poma. Traduzione e note di Pierfrancesco Fiorato. Cinisello Balsamo: San Paolo, 1994. [=Classici del pensiero. vol. 3]

1995 Religion of reason out of the sources of Judaism. Translated with an introduction by Simon Kaplan. Introductory essay by Leo Strauss. Introductory essays for the second edition by Steven S. Schwarzschild, Kenneth Seeskin. Atlanta, Ga.: Scholars Press, 1995

1996 Der Begriff der Religion im System der Philosophie. Einleitung von Andrea Poma. Hildesheim/New York: G. Olms, 1996 [= WW vol. 10]

Kleinere Schriften. Bearbeitet und eingeleitet von Hartwig Wiedebach. Hildesheim/New York: G. Olms [= WW vol. 16]

\section{Literature on Hermann Cohen}

Adelmann, Dieter, Einheit des Bewusstseins als Grundproblem der Philosophie Hermann Cohens, Heidelberg, 1968 
-, "H. Steinthal und Hermann Cohen" in Moses/Wiedebach [1997], pp. 1-33

Altmann, Alexander, "Hermann Cohens Begriff der Korrelation" in: Tramer Hans (ed.), Zwei Welten: Siegfried Moses zum Fünfundsiebzigsten Geburtstag, Tel Aviv, 1962, pp. 366-399

anonymus, review of "Logik der reinen Erkenntnis. Von Hermann Cohen, Professor an der Universität Marburg" in: The Monist. A Quarterly Magazine Devoted to the Philosophy of Science, vol.XIII (Chicago, 1903)

Baumotte, M., "Hermann Cohens 'Ethik des reinen Willens' als durchgeführte systematische Theologie" in: Neue Zeitschrift für Theologie und Religionsphilosophie 17/1975, 33-38

Ben-Shlomo, Yosef, "Pilosofiat ha-dat ve-tefisat ha-Yahadut shel Hermann Cohen" in: Dat ha-tevunah mi-mekorot ha-Yahadut (Religion der Vernunft aus den Quellen des Judentums, Hebrew by Zvi Wislavski and Hanokh Kalai), with notes by S.H.Bergmann and Nathan Rotenstreich, Introduction by Sinai Ucko and Postscript by Yosef Ben Shlomo, Jerusalem: Mossad Bialik, 1971

Bergmann, Samuel Hugo, s.v. "Cohen, Hermann" in EJ 5: 673-676

Faith and Reason: An Introduction to Modern Jewish Thought, New York: Schocken, 1961

- "Hermann Cohen" in: Between East and West: Essays Dedicated to the Memory of Bela Horowitz (ed. A.Altmann), London: East and West Lib., 1958, 22-47

Bertolini, L., “Apriori e telos. La Critica del Giudizio teleologico nel neokantianismo di Marburgo" in: il cannocchiale. rivista di studi filosofici, 1-2/1991, pp.117-130

Boehlich, Walter (ed.), Der Berliner Antisemitismusstreit, Frankfurt: Insel, 1965

Bornhausen, Karl, "Das Problem der Wirklichkeit Gottes. Zu Cohens Religionsphilosophie" in: ZThK 27 (1917) 55-75

Brandt, Reinhardt/Orlik, Franz,(ed.), Philosophisches Denken-Politisches Wirken. Hermann-Cohen-Kollo quium Marburg 1992, Hildesheim, Zürich, New York: 1993 (Abbr. "Brandt") 
Bruckstein, Almut Sh., Hermann Cohen's 'Charakteristik der Ethik Maimunis': A Reconstructive Reading of Maimonides' Ethics, Ph.D. Dissertation, Temple University (Philadelphia, Pennsylvania), Nov. 1992

Cassirer, Ernst, "Hermann Cohen. Gedenkrede von Ernst Cassirer" in S1, ix-xvi

—_ "Hermann Cohen. Vortrag" in: Korrespondenzblatt des Vereins zur Gründung und Erhaltung einer Akademie des Judentums, Frankfurt, 1920

- s.v. "Neo-Kantianism" in EB (14) vol.xvi, 215f

Cassirer, Toni, Mein Leben mit Ernst Cassirer, Hildesheim: Gerstenberg, 1981

Deegan Daniel L., "The Theology of Wilhelm Herrmann: A Reassessment" in: The Journal of Religion XLV/1965 \#2, 87-99

Dietrich, Wendell, Cohen and Troeltsch. Ethical Monotheistic Religion and Theory of Culture, Atlanta, Georgia: Scholar's Press, 1986 [= Brown Judaic Studies \#120]

-, "Preface: Classic Options in Interpreting Cohen's Influence on Rosenzweig" [unpublished paper, History of Judaism Section, History of Jewish Philosophy Subsection, American Academy of Religion Annual Meeting, Dallas, December 1983]

-, "The character and status of the concept of history in three twentieth century systems of Judaic thought: Cohen, Rosenzweig, Levinas" in: FS Marvin Fox, vol. 3, 197-211

Dreyer, Mechthild, Die Idee Gottes im Werk Hermann Cohens [Monographien zur philosophischen Forschung, Band 230] Königstein/Ts.: Hain, 1985

Ebbinghaus, Julius, "Cohen, Hermann" in: Edwards Paul E. (ed.), The Encyclopedia of Philosophy, New York/London, 1967 (vol.2)

— "Cohen, Hermann, Philosoph" in: NDB 3/1957, 310-313

- "Hermann Cohen als Philosoph und Publizist" in: APh 6 (1956) 109-122

- "Zur Berufung Cohens auf den Marburger Lehrstuhl" in: APh 9/1959, 90-92 
Edel, Geert, "Cohen und die analytische Philosophie der Gegenwart" in: Brandt, pp. 179-203

—_, "Kantianismus oder Platonismus? Hypothesis als Grundbegriff der Philosophie Cohens" in: il cannocchiale. rivista di studi filosofici, 1-2/1991, pp.59-87

— Von der Vernunftkritik zur Erkenntnislogik. Die Entwicklung der theoretischen Philosophie Hermann Cohens, Freiburg i.Br.: Alber, 1988

Elbogen, Ismar/Kellermann, Benzion/Mittwoch, Eugen (ed.), Judaica. Festschrift zu Hermann Cohens Siebzigstem Geburtstage, Berlin: Bruno Cassirer, 1912

Fackenheim, Emil L, "Hermann Cohen: After Fifty Years," in: Yearbook, 1969, pp.10ff

Ferrari, Massimo, Il giovane Cassirer e la scuola di Marburgo (Collana di filosofia ; 27) Milano: Angeli, 1988

Fiorato, Pierfrancesco, Geschichtliche Ewigkeit: Ursprung und Zeitlichkeit in der Philosophie Hermann Cohens. Würzburg: Königshausen und Neumann, 1993

-, "Storia e temporalità nel pensiero di Hermann Cohen. Per un approcio al problema" in: il cannocchiale. rivista di studi filosofici, 1-2/1991, pp.195-211

Fischer, Max/Schiele, Friedrich Michael (eds.), Fünfter Weltkongress für freies Christentum und religiösen Fortschritt (Berlin 5.-10. August 1910), Berlin/Schöneberg: Verlag des Protestantischen Schriftenvertriebs, 1910

Flach, Werner, "Eine Renaissance in der Philosophie? Zur Neuausgabe der Werke Hermann Cohens" in: NZZ Nr. 243, Sa/So 18./19. Okt. 1980 p.70

- "Einleitung" in Hermann Cohen, Das Prinzip der InfinitesimalMethode und seine Geschichte. Ein Kapitel zur Grundlegung der Erkenntniskritik, Frankfurt am Main: Suhrkamp, 1968

— / Holzhey, Helmut, Erkenntnistheorie und Logik im Neukantianismus [Seminar-Textbücher I, Fach: Philosophie], Hildesheim: Gerstenberg, 1980 
Frege, Gottlob, “Rezension von: H.Cohen, Das Prinzip der InfinitesimalMethode und seine Geschichte (1885)" in: Kleine Schriften (ed. Ignacio Angelelli), Hildesheim: Olms, 1967, 99-102

Fritzsche, Robert A, Hermann Cohen aus persönlicher Erinnerung, Berlin: Bruno Cassirer, 1922

Funkenstein, Amos, "On the Kantian and Neokantian Theories of Science" (Hebr.) in: Iyyun 31/1982, 235-261

Gerhardt, Gerd, Wider die unbelehrbaren Empiriker: Die Argumentation gegen empirische Versionen der Transzendentalphilosophie bei $H$. Cohen und A. Riehl (Epistemata/Reihe Philosophie; 11) Würzburg: Königshausen + Neumann, 1983

Giesecke, Peter, Kant und der Sozialismus : Studien zum Marburger Neukantianismus, philosophischen Kritizismus und kritischen Rationalismus. München, Univ., Diss., 1991: [s.n.], 1990

Gigliotti, Gianna, "Avventure e disavventure del transcendentale". Studio su Cohen e Natorp, Napoli: Guide editori, 1989

Goldstein, Walter, Hermann Cohen und die Zukunft Jisraels, (mit einer Einleitung von Martin Buber), Jerusalem: Rubin Mass, 1963

Gordon, Jacob, Der Ichbegriff bei Hegel, bei Cohen und in der Südwestdeutschen Schule hinsichtlich der Kategorienlehre untersucht. Erster Teil: Der Begrif des Denkens bei Hegel und Cohen, (Dissertation) Hamburg, 1926

Graupe, Heinz, Die Stellung der Religion im systematischen Denken der Marburger Schule. Inaug.-diss. Berlin: Druckerei für Dissertationen Thuringia-Druckerei, 1930

Günther, Henning, Philosophie des Fortschritts. Hermann Cohens Rechtfertigung der bürgerlichen Gesellschaft, München: Goldmann, 1972

Guttmann, Julius, Philosophies of Judaism. The History of Jewish Philosophy from Biblical Times to Franz Rosenzweig [transl. D.W.Silverman] New York: Schocken, 1964

Habermas, Jürgen, "Der deutsche Idealismus der jüdischen Philosophen" 1961 in: Philosophisch-politische Profile, Frankfurt: Suhrkamp, 1971 
Häußer, Hans-Dieter, Transzendentale Reflexion und Erkenntnisgegenstand. Zur transzendentalphilosophischen Erkenntnisbegründung unter besonderer Berücksichtigung objektivistischer Transformationen des Kritizismus. Ein Beitrag zur systematischen und historischen Genese des Neukantianismus, [ = Mainzer Philosophische Forschungen Nr. 35] Bonn: Bouvier, 1989

Heinzelmann, review of "Cohen, H.: Der Begriff der Religion im System der Philosophie", in: Theologischer Literaturbericht, J.Jordan (ed.), 41 Jg./Nr.4 (Wittenberg: April 1918) p.49-50

Herrmann, Johannes, review of "Cohen, Hermann, Die Religion der Vernunft aus den Quellen des Judentums" in: ThLBl 43/Nr.8 (Apr.14 ), Leipzig: Dörffling \& Franke, 1922, pp. 118-9

Herrmann, Wilhelm, "Die Lage und Aufgabe der evangelischen Dogmatik in der Gegenwart" in: ZThK 17/1907,1-33.172-201

- "Die Auffassung der Religion in Cohens und Natorps Ethik" in: Schriften II, 206-232 [=ZThK 19/1909 Heft 1, 57-69, Heft 2, 162175]

—_, "Der Begriff der Religion nach Hermann Cohen" (1916) in: Schriften II, 318-323 [ =ChW 44/1916, 839-842]

- "Herrmann Cohens Ethik" in: ChW 21.Jg. Nr.3, 51-59, Nr.10, 222228

Hessen, Johannes, Die Religionsphilosophie des Neukantianismus, 2nd enlarged ed., Freiburg: Herder, 1924

Holzhey, Helmut, Cohen und Natorp, vol.1 “Ursprung und Einheit. Die Geschichte der "Marburger Schule" als Auseinandersetzung um dieLogik des Denkens", vol. 2 "Der Marburger Neukantianismus in Quellen. Zeugnisse kritischer Lektüre. Briefe der Marburger. Dokumente zur Philosophiepolitik der Schule", Basel/Stuttgart: Schwabe \& Co, 1986

_- "Das Hermann-Cohen-Archiv in Zürich" in: ZPhF 31/1977, 443452

- "Hegel im Neu-Kantianismus. Maskerade und Diskurs" in: il cannocchiale. rivista di studi filosofici, 1-2/1991, pp.9-27

- (ed.), Hermann Cohen (Auslegungen ; 4), Frankfurt am Main u.a : Lang, 1994 
(ed.), "Zwei Briefe Hermann Cohens an Heinrich von Treitschke", Bulletin 46-47, 12.Jg. 1969 pp.183-203

Hommes, Ulrich, "Das Problem des Rechts und die Philosophie der Subjektivität" in: $P h J$ 72, $311 \mathrm{ff}$

Hubbert, Joachim, Transzendentale und empirische Subjektivität in der Erfahrung bei Kant, Cohen, Natorp und Cassirer. (Europäische Hochschulschriften/ 20 ; 388) Frankfurt am Main u.a: Lang, 1993

Jospe, Alfred, Die Unterscheidung von Mythos und Religion bei Hermann Cohen und Ernst Cassirer in ihrer Bedeutung für die jüdische Religionsphilosophie, Oppeln: Reuther und Reichard, 1932

Kajon, Irene, Ebraismo e sistema di filosofia in Hermann Cohen, Padova: CEDAM (Casa Editrice Dott. Antonio Milani), 1989

eadem, "I problemi della libertà e del male in Hermann Cohen e Paul Natorp" in: il cannocchiale. rivista di studi filosofici, 1-2/1991, pp.417-438

Kellermann, Benzion, "Die philosophische Begründung des Judentums" in: Judaica. Festschrift zu Hermann Cohens Siebzigstem Geburtstage, Berlin: Bruno Cassirer, 1912

Klatzkin, Jakob, Hermann Cohen, Berlin: Jüdischer Verlag, 1919 (Zweite, erweiterte Auflage, 1921)

, s.v. "Cohen, Hermann" in: Encyclodaedia Judaica. Das Judentum in Geschichte und Gegenwart, Vol. 5 Berlin: Eschkol, 1930, col. 603614

Klein, Joseph, Die Grundlegung der Ethik in der Philosophie Hermann Cohens und Paul Natorps-eine Kritik des Marburger Neukantianismus [Abhandlungen der Akademie der Wissenschaften in Göttingen, Philosophisch-historische Klasse, Dritte Folge Nr.100] Göttingen: Vandenhoeck \& Ruprecht, 1976

—, Art.: "Cohen, Hermann" in: RGG (3. edition) I:1846-7

Kluback, William, "Friendship Without Communication. Wilhelm Herrmann and Hermann Cohen" in: Year Book 31/1986, 317-338

- "Hermann Cohen and Kant: A Philosophy of History from Jewish Sources" in: Idealistic Studies 17/1987, 161-176 
- "Hermann Cohen und Martin Heidegger: Meinungsverschiedenheit oder Entstellung" in: ZPhF 40/1986, 283-287

-, "The Jewish Response to Hegel: Samuel Hirsch and Hermann Cohen" in: The Owl of Minerva 18/1986, 5-12

- The Legacy of Hermann Cohen [Brown Judaic Studies \#167] Atlanta, Georgia: Scholar's Press, 1989

Knittermeyer, Hinrich, review of "Hermann Cohens Religion der Vernunft" in: ChW 1922, 36. Jg, Nr. 42/43 col. 792-797 and Nr. $44 / 45$, Nov. 9 , col. 818-824

1830-1930, vol. 5, ed. Ingeborg Schnack, Marburg an der Lahn: N.G.Elwert, 1955, 13-32

Köhnke, Klaus Christian, Entstehung und Aufstieg des Neukantianismus. Die deutsche Universitätsphilosophie zwischen Idealismus und Positivismus, Frankfurt am Main: Suhrkamp, 1986 [English edition: The Rise of Neokantianism. German Academic Philosophy between Idealism and Positivism, (transl. by R.J. Hollingdale) Cambridge/New York: Cambridge University Press, 1991]

Kopper, Joachim, "Jenseits des analytischen und synthetischen Urteils. Reflexionen zu Hermann Cohens Logik der reinen Erkenntnis" in: Kantstudien 72/1981, 58-67

Korsch, Dietrich, Dialektische Theologie nach Karl Barth. Tübingen: Mohr, 1996

Lembeck, Karl-Heinz, "Cohens frühe Platon-Deutung und seine Quellen" in: il cannocchiale. rivista di studi filosofici, 1-2/1991, pp.89-116

- Platon in Marburg: Platon-Rezeption und Philosophiegeschichtsphilosophie bei Cohen und Natorp. (Studien und Materialien zum Neukantianismus ; 3) Würzburg: Königshausen \& Neumann, 1994

Lewkowitz, Albert, "Hermann Cohen" in: MGWJ Neue Folge 26. Jg. (1918), pp.1-4 
Liebeschütz, Hans, Von Georg Simmel zu Franz Rosenzweig. Studien zum jüdischen Denken im deutschen Kulturbereich, Tübingen: Mohr (Siebeck), 1970

Linden, Harry van der, "Cohen, Collective Responsibility, and Economic Democracy" in: il cannocchiale. rivista di studi filosofici, 1-2/1991, pp.345-360

- Kantian Ethics and Socialism, Indianapolis/Cambridge: Hackett Publ., 1988

Löwith, Karl, "Philosophie der Vernunft und Religion der Offenbarung in Hermann Cohens Religionsphilosophie" in: Aufsätze und Vorträge 1930-1970, Stuttgart: Kohlhammer, 1971,124-156 [also in: Materialien, 328-361; first published separately: Heidelberg: Winter, 1968]

Mackintosh, H.R., review of "Die Religion der Vernunft aus den Quellen des Judentums" in: Mind vol. 31/1922 (new series), Oxford: Basil Blackwell, 227-229

Marx, Wolfgang, "Idealität als dialektisch konstruierbare Totalität und als Hypothese der Fundierung wissenschaftlicher Geltung. Überlegungen zur Theorie des Begriffs bei Hegel und Cohen" in: HSBh 11, 515-535

, Transzendentale Logik als Wissenschaftstheorie. Systematisch-kritische Untersuchungen zur philosophischen Grundlegungsproblematik in Cohens 'Logik der reinen Erkenntnis' [Studien zur Phiosophie und Literatur des neunzehnten Jahrhunderts Band 32] Frankfurt/Main: Vittorio Klostermann, 1977

Melber, Jehuda, Hermann Cohen's Philosophy of Judaism, New York: Jonathan David Publishers, 1968

Meyer, Michael A., Response to Modernity. A History of the Reform Movement in Judaism, New York/Oxford: Oxford University Press, 1988

Meyer, Thomas, "Eine unzeitgemäße Intervention, die an der Zeit war,Hermann Cohens neukantianischer Sozialismus und die sozialdemokratische Ideologie im Kaiserreich" in Brandt pp. 257269

Mittleman, Alan L., "Christianity in the Mirror of Jewish Thought" in: First Things, (Aug/Sept 1992) pp. 16-17 
Moses, Stéphane/Wiedbach, Hartwig, Hermann Cohen's Philosophy of Religion. International Conference in Jerusalem 1996 [Publications of the Franz Rosenzweig Research Center for German-Jewish Literature and Cultural History], Hildesheim, Zürich, New York: Georg Olms, 1997 [= Philosophische Texte und Studien Band 44]

Natorp, Paul, Allgemeine Psychologie in Leitsätzen zu akademischen Vorlesungen. 2. ed., Marburg: N.G. Elwert, 1910

, Forschungen zur Geschichte des Erkenntnisproblems im Altertum: Protagoras, Demokrit, Epikur und die Skepsis. Berlin: W. Hertz, 1884

- Kant und die Marburger Schule (Vortrag, gehalten in der Sitzung der Kantgesellschaft zu Halle a.S. am 27. April 1912), Berlin: Reuther und Reichard, 1912

- Philosophie, ihr Problem und ihre Probleme. Einführung in den kritischen Idealismus. (Wege zur Philosophie. Ergänzungsreibe: Einführungen in die Philosophie der Gegenwart, nr. 1): Göttingen, Vandenhoeck \& Ruprecht, 1911

- Platos Ideenlehre: Eine Einführung in den Idealismus. Leipzig : Dürr, 1903, second edition: Meiner, 1961, third ed. Meiner, 1994

- Sozialpadagogik. Theorie der Willenserziehung auf der Grundlage der Gemeinschaft. 2. ed., F. Frommann (E. Hauff), 1904

Nauen, Franz, "Hermann Cohen's Perceptions of Spinoza: A Reappraisal" in: AJS Review 4/1979, 111-124

Navon, E., "Plato versus Aristotle: Hermann Cohen's Interpretation of Maimonides" in: il cannocchiale. rivista di studi filosofici, 1-2/1991, pp.29-43

Niebergall, F., "Religion und Sittlichkeit" in: ThLZ 20/1907, 562-564

Niewöhner, Friedrich W, "Ein schwieriges Maimonides-Zitat im 'Tractatus Theologico-Politicus' und Hermann Cohens Kritik an Spinoza" in: $Z P h F 31 / 1977,618-626$

Oelkers, Jürgen /Schulz Wolfgang K./Tenorth Heinz Elmar (ed.s), Neukantianismus: Kulturtheorie, Pädagogik und Philosophie, Weinheim: Deutscher Verlag, 1989 [= Beiträge zur Theorie und Geschichte der Erziehungswissenschaft vol. 4]

Ollig S.J., Hans-Ludwig, Der Neukantianismus , Stuttgart: Metzler, 1979 
- "Hermann Cohen und das Problem der Selbsterhaltung" in: ThPh 56. Jg., Heft 4, 1981, 507-534

- Religion und Freiheitsglaube. Zur Problematik von Hermann Cohens später Religionsphilosophie [Monographien zur philosophischen Forschung Band 179] Königstein/Ts.: Forum Academicum, 1979

Orlik, Franz, Hermann Cohen (1842-1918). Kantinterpret-Begründer der "Marburger Schule"-Jüdischer Religionsphilosoph, Marburg: Universitätsbibliothek, 1992 [Schriften der Universitätsbibliothek Marburg 63]

Orth, E.W., "Die anthropologische Wende im Neukantianismus. Ernst Cassirer und Richard Hönigswald" in: il cannocchiale. rivista di studi filosofici, 1-2/1991, pp.261-287

Ostertag, review of "Hermann Cohen, Der Begriff der Religion im System der Philosophie" in: ARPS 2-3/1921, 288

Pascher, Manfred, "Cohens Ethik im Spannungsfeld zwischen Kant und Hegel" in: Brandt pp. 95-109

- Hermann Cohens Ethik als Gegenentwurf zur Rechtsphilosophie Hegels. (Innsbrucker Beiträge zur Kulturwissenschaft/ Sonderheft 83) Innsbruck : Inst. für Sprachwiss, 1992

Pasternak, Boris, Safe Conduct. An Early Autobiography and Other Works, (transl. by Alec Brown), London: Elek Books, 1959

Philonenko, Alexis, L' Ecole de Marbourg: Cohen, Natorp, Cassirer. Paris: Vrin, 1989

Poma, Andrea, La Filosofia Critica di Hermann Cohen, Milano: Mursia, 1988 (English: The Critical Philosophy of Hermann Cohen (SUNY Press Albany, 1997)

Rauchenberger, Alois, review of "Der Begriff der Religion im System der Philosophie" in: Stimmen der Zeit, vol.91, Freiburg i. Breisgau: Herder, 1916, pp.457-9

Ritzel, Wolfgang, Studien zum Wandel der Kantauffassung. Die Kritik der reinen Vernunft nach Alois Riehl, Hermann Cohen, Max Wundt und Bruno Bauch [Monographien zur Philosophischen Forschung, ed. Georgi Schischkoff Band IX] Meisenheim/Glan: Westkulturverlag Anon Hain, 1952 
Rose, Gilian, "Hermann Cohen-Kant among the Prophets" in The Journal of Jewish Thought and Philosophy, Vol. 2/1993, pp. 185-199

Rosenzweig, Franz, "Einleitung in die Akademieausgabe der Jüdischen Schriften Hermann Cohens" in: J 1, XIII-LXIV

_ , "Über Hermann Cohens 'Religion der Vernunft'”, in: GS III, 225227

—, "Hermann Cohens Nachlaßwerk", in: GS III, 229-233

—_ "Vertauschte Fronten" in: Z 235-237

Rosmarin, Trude Weiss, Religion of Reason. Hermann Cohen's System of Religious Philosophy, New York: Bloch Publishing Company, 1936

Rotenstreich, Nathan, "From Consciousness of Culture to Symbolic Forms" in: il cannocchiale. rivista di studi filosofici, 1-2/1991, pp.247-259

- "From the Ethical Idea to the True Being" in: Jewish Philosophy in Modern Times: From Mendelssohn to Rosenzweig, New York/Chicago/San Francisco: Holt, Rinehart and Winston: 1968, 52-105

- "Judaism in the Context of German Philosophy" in: Reinharz J./Schatzberg W., The Jewish Response to German Culture. From the Enlightenment to the Second World War, Hanover/London: U. of New England Press, 1985, 51-63

_ , "Religion within Limits of Reason alone and Religion of Reason" in: Year-Book xvii, 1972, 179-187

Sacken, Helene, Zur Frage des Religionsbegriffs im System der Philosophie. (Inaugural-Dissertation) Marburg: Hamel, 1919

Saltzman, Judy Deane, Paul Natorp's Philosophy of Religion, Hildesheim/New York: Olms, 1981

Samuelson, Norbert Max, "Hermann Cohen" in: An Introduction to Modern Philosophy, Albany: SUNY Press, 1989, pp. 162-181

Sandkühler, Hans Jörg/Vega Rafael de la, Marxismus und Ethik. Texte zum neukantianischen Sozialismus [suhrkamp tb wissenschaft 75] Frankfurt: Suhrkamp, 2.ed 1974 
Schaeffler, Richard, Das Gebet und das Argument: Zwei Weisen des Sprechens von Gott. Eine Einführung in die Theorie der religiösen Sprache, Düsseldorf: Patmos, 1989

- "Die Vernunft und das Wort. Zum Religionsverständnis bei Hermann Cohen und Franz Rosenzweig" in: ZThK 78/1, 57-89

Scheler, Max, "Deutsche Philosophie der Gegenwart” in: Witkop P. (ed.), Deutsches Leben der Gegenwart, Berlin: Volksverband der Bücherfreunde Wegweiser=Verlag, 1922, 157-165

Schleiff, Thomas, Gottesgedanke, Freiheitsbewußtsein und Säkularisierung: Untersuchungen zu Richard Rothe, Hermann Cohen und Friedrich Gogarten. (Göttingen University Dissertation): [s.n.], 1980

Schmid, Peter A, Ethik als Hermeneutik: systematische Untersuchungen zu Hermann Cohens Rechts- und Tugendlehre. (Studien und Materialien zum Neukantianismus ; 5) Würzburg: Königshausen \& Neumann, 1995

Schmidt, Johann Michael, Die jüdische Apokalyptik. Die Geschichte ihrer Erforschung von den Anfängen bis zu den Textfunden von Qumran. 2. revised edition, Neukirchen/Vluyn: Neukirchener Verlag, 1976

Schmidt, Winrich de, Psychologie und Transzendentalphilosophie. Zur Psychologie-Rezeption bei Hermann Cohen und Paul Natorp [Abh. zur Philosophie, Psychologie und Pädagogik, Band 105] Bonn: Bouvier, 1976

Schoell, Jakob, review of "Cohen, Der Begriff der Religion im System der Philosophie" in: Monatschrift für Pastoraltheologie zur Vertiefung des gesamten pfarramtlichen Wirkens, XII Jg., Oct. 1915-Sept. 1916, Berlin: Reuther \& Reichard, 1916 p. 419

Scholem, Gershom, "In Memory of Hermann Cohen" in: Modern Judaism 5, (Febr. 1985), pp.1-2

Scholz, Heinrich, “Die Religion im Systembegriff der Kultur” in: ZThK 27 (1917) 230-249

Schuberth, Thomas, Der Begriff des Politischen im Marburger Neukantianismus: Hermann Cohen. [s.n.], 1986

Schulthess, Peter, "Einleitung" in: Hermann Cohen, Das Prinzip der Infinitesimal-Methode und seine Geschichte, (4. Auflage) [=WW 5], Hildesheim: Olms, 1984, $7^{*}-46^{*}$ 
55-75

Schwarzschild, Steven S, "Germanism and Judaism'-Hermann Cohen's Normative Paradigm of the German-Jewish Symbiosis" in: David Bronson (ed.), Jews and Germans from 1860 to 1933. The Problematic Symbiosis, Heidelberg: 1979, 129-172

_ "Introduction" in: WW 7, 1981, vii*-xxxv*

- "The Tenability of Herman (sic!) Cohen's Construction of the Self" in: Journal of the History of Philosophy 13/1975, 361-384

__ "To Recast Rationalism" in: Judaism 11/1962, 205-209

Seo, Djeong-Uk, Logik und Metaphysik der Erkenntnis: kritischer Vergleich von Hermann Cohens und Nicolai Hartmanns philosophischen Grundpositionen. Frankfurt am Main: Haag + Herchen, 1993

Sieg, Ulrich, Aufstieg und Niedergang des Marburger Neukantianismus. Die Geschichte einer philosophischen Schulgemeinschaft, Würzburg: Königshausen und Neumann, 1994

—_, "Der Wissenschaft und dem Leben tut dasselbe not: Ehrfurcht vor der Wahrheit.' Hermann Cohens Gutachten im Marburger Antisemitismusprozeß 1888" in: Brandt pp. 222-249

Simon, Akiva Ernst, "Zu Hermann Cohens Spinoza Auffassung" (1935), in: Brücken. Gesammelte Aufsätze, Heidelberg: Lambert Schneider, $1965,205-212$

Solowiejczyk, Josef, Das reine Denken und die Seinskonstituierung bei Hermann Cohen, Diss. Berlin, 1932

Srajek, Martin, In the Margins of Deconstruction: Jewish Conceptions of Ethics in Emmanuel Levinas and Jacques Derrida, Ph.D. Dissertation, Temple University (Philadelphia, PA), Jan. 1993

Steinthal, Salomon, "Aus Cohens Heimat" in: Jüdisches Gemeindeblatt für Anhalt und Umgegend 3. Jg, Nr. 4, 4. Nov. 1927

Stolzenberg, Jürgen, Ursprung und System: Probleme der Begründung systematischer Philosophie im Werk Hermann Cohens, Paul Natorps und beim frühen Martin Heidegger. (Neue Studien zur Philosophie ;9) Göttingen: Vandenhoeck \& Ruprecht, 1995 
Strauss, Leo, "Cohens Analyse der Bibel-Wissenschaft Spinozas." Der Jude 8 (1924): 295-314

—, "Introductory Essay" in: Hermann Cohen, Religion of Reason out of the Sources of Judaism, New York: F.Ungar, 1972, pp. xxiiixxxviii

Troeltsch, Ernst, "Cohen, Geh.Reg.-R. Prof.Dr.Herm.: Die religiösen Bewegungen der Gegenwart" in: ThLZ 1915 Nr.16/17, 383-395

-, "Cohen, Hermann: Der Begriff der Religion im System der Philosophie" in: ThLZ 1918 Nr.4/5, 57-62

_- "Grundprobleme der Ethik. Erörtert aus Anlass von Herrmanns Ethik" in: ZThK 1902, 44-94.125-178 [=Ges.Schriften II, 570-672]

Tucker, Bernard, Ereignis. Wege durch die politische Philosophie des Marburger Neukantianismus [European University Studies Series XX, Philosophy, vol. 140], Frankfurt/Bern/New York: Peter Lang, 1984

Ucko, Siegfried (Sinai), Der Gottesbegriff in der Philosophie Hermann Cohens, Berlin: Reuther \& Reichard, 1929

- "Mishnato ha-datit shel Hermann Cohen" in: Dat ha-tevunah mimekorot ha-Yahadut (Religion der Vernunft aus den Quellen des Judentums, Hebrew by Zvi Wisslavski and Hanokh Kalai), with notes by S.H.Bergmann and Nathan Rotenstreich, Introduction by Sinai Ucko and Postscript by Yosef Ben Shlomo, Jerusalem: Mossad Bialik, 1971, pp. 7-31

Ulbrich, Bernd, " $\mathrm{Zu}$ den philosophischen Grundpositionen von Hermann Cohen" in: DZPh 37/1989, 223-231

Weiss-Rosmarin, Trude, "Hermann Cohen. On the 50th Anniversary of His Death" in: Jewish Book Annual 26/1968-1969 (ed. Jewish Book Council of America), 88-93

eadem, Religion of Reason. Hermann Cohen's System of Religious Philosophy, New York: Bloch Publishing Co., 1936

Wiedebach, Hartwig, Die Bedeutung der Nationalität für Hermann Cohen (Europaea Memoria Reihe I: Studien, Band 6) Hildesheim/Zürich/New York: Georg Olms Verlag, 1997 
Willey, Thomas E., Back to Kant. The Revival of Kantianism in German Social and Historical Thought, 1860-1914, Detroit: Wayne State Univ. Press, 1978

Winter, Eggert, Ethik und Rechtswissenschaft. Eine historisch-systematische Untersuchung zur Ethik-Konzeption des Marburger Neukantianismus im Werke Hermann Cohens [Schriften zur Rechtstheorie Heft 9] Berlin: Duncker \& Humblot, 1980

Wolandt, Gerd, "Einleitung" in: $̈$ rG [WW 8], 1982, pp. vii*-xxii*

Xie, Yanan, Korrelation : der zentrale Begriff in Cohens Religionsphilosophie. Frankfurt am Main: Lang, 1996

Yaffe, Martin D, "Liturgy and Ethics: Hermann Cohen and Franz Rosenzweig on the Day of Atonement" in: Journal of Religious Ethics 7/2 (1979), 215-228

- "'One-Sided Platonism': Hermann Cohen on the 'Social Ideal' in Plato and the Prophets" in: il cannocchiale. rivista di studi filosofici, 1-2/1991, pp.45-58

- "On the Merit of Hermann Cohen's Critique of Spinoza: Franz Rosenzweig and Leo Strauss" [Paper for the American Academy of Religion Annual Meeting, Anaheim, Ca., Nov.19, 1989; typescript]

Zac, Sylvain, La Philosophie Religieuse de Hermann Cohen. Avant-propos de Paul Ricour, Paris: Librairie Philosophique J. Vrin, 1984

Zank, Michael, s.v. "Cohen, Hermann" in: Routledge Encyclopedia of Philosophy. ed. Edward Craig, London: Routledge, 1998

- _ "Hermann Cohen und die rabbinische Literatur," in: Hermann Cohen's Philosophy of Religion. International Conference in Jerusalem 1996 (= Publications of the Franz Rosenzweig Research Center for German-Jewish Literature and Cultural History), ed. Moses, S./Wiedebach, H., Hildesheim/Zürich/New York: Georg Olms, 1997 (= Philosophische Texte und Studien Band 44), pp. 263-291

—_, Reconciling Judaism and "Cultural Consciousness:" The Idea of Versöhnung in Hermann Cohen's Philosophy of Religion, Ph.D. Diss., Waltham/Mass.: Brandeis University, 1994 
, Review of Andrea Poma, The Critical Philosophy of Hermann Cohen (SUNY Press Albany, 1997), in: The Journal of Religion vol. 78 No. 3 (July 1998): 464-465

, Review of Ulrich Sieg, Aufstieg und Niedergang des Marburger Neukantianismus (Würzburg, 1994), in: Journal of Jewish Studies vol. xlvii, No. 1, Spring 1996, pp. 185-189

, "The Individual as I' in Hermann Cohen's Jewish Thought" in: The Journal of Jewish Thought and Philosophy, vol. 5, No. 2, 1996, pp. 281-296

-, "The God of Sinai, the God of Creation, and the God of Abraham: Three Recent Books in Jewish Philosophy " in: Modern Judaism 16 (1996): 291-316

Ziegenfuss, Werner, s.v. "Cohen, Hermann" in: Philosophen-Lexicon. Handwörterbuch der Philosophie nach Personen, Erster Band A-K, Berlin: W.de Gruyter, 1949, pp.194-196

\section{Other Consulted Literature}

\section{Editions}

Quotations from the Hebrew Bible are from the Massoretic text; quotations from the Mishnah are from the edition of Hanokh Albeck (Jerusalem: Mossad Bialik, 1973); quotations from the Talmud correspond to the standard editions. All translations of the above are my own unless noted otherwise. Other editions are listed below, along with further literature used.

Reference Works

Apel, Max/Ludz, Peter, Philosophisches Wörterbuch, Sechste Auflage, Berlin/New York: Walter deGruyter, 1976

Brugger, Walter (ed.), Philosophisches Wörterbuch, Freiburg/Basel/Wien: Herder, 1985

Die Religion in Geschichte und Gegenwart. Handwörterbuch für Theologie und Religionswissenschaft, Dritte, völlig neu bearbeitete Auflage, in Gemeinschaft mit Hans Frhr. von Campenhausen, Erich Dinkler, Gerhard Gloege und Knut E. Løgstrup herausgegeben von Kurt Galling, (Ungekürzte Studienausgabe)[UTB für Wissenschaft, Grosse Reihe], 7 vols, Tübingen: J.C.B. Mohr (Paul Siebeck), 1986 
Encyclopædia Britannica, Fourteenth Edition, 1929

Encyclopaedia Judaica, Jerusalem: Keter Publishing House (Corrected edition), seventeen volumes and supplements

Encyclopedia Biblica, ed. Inst. Bialik, Jerusalem, 1982

Even-Shoshan, Abraham, A New Concordance of the Bible. Thesaurus of the Language of the Bible, Jerusalem: "Kiryat Sepher", 1981

Gesenius, Wilhelm/Buhl, Frants, Hebräisches und Aramäisches Handwörterbuch über das Alte Testament, unveränderter Neudruck der 1915 erschienenen 17. Auflage, Berlin/Göttingen/ Heidelberg: Springer-Verlag, 1962

Ha-'Ensiklopedia Ha-'Ivrit. Klalit, Yehudit va-Arsyisraelit, Tel Aviv/Jerusalem: Hosa'at Ensiklopediot, 1981

Hastings, James A. (ed.), Encyclopaedia of Religion and Ethics, New York: Scribners Son's, 1928

Historisches Wörterbuch der Philosophie, ed. Ritter, Joachim/Gründer, Karlfried, Basel/Stuttgart: Schwabe, 1976

Hoffmeister, Johannes,W\%örterbuch der Philosophischen Begriffe, 2. Auflage, Hamburg: Meiner, 1955 [PhB 225]

Kosing, Alfred, Wörterbuch der Philosophie, Westberlin: verlag das europäische buch, 1985

Theologisches Wörterbuch zum Alten Testament, ed. G.Botterweck, H.Ringgren, H.-J.Fabry, Stuttgart: Kohlhammer, 1984

Pauly, A.F.v./ Wissowa, G. (eds.), Paulys Realencyclopädie der classischen Altertumswissenschaft, Neue Bearbeitung, Stuttgart: Metzlersche, 1896

Reallexikon für Antike und Christentum. Sachwörterbuch zur Auseinandersetzung des Christentums mit der antiken Welt, ed. Theodor Klause, Stuttgart: Hirsemann, 1966ff

Rosenkranz, Karl/Schubert, Friedrich Wilhelm, Immanuel Kant's Sämmtliche Werke. Leipzig: Voss, 1838

The Encyclopedia of Religion, ed. Eliade, Mircea, New York: Macmillan

The Jewish Encyclodedia, ed. Singer, Isidore, N.Y./London: Funk \& Wagnalls, 1902 
The New Oxford Annotated Bible. New York, 1991

Theologische Realenzyclopädie Berlin/New York: Walter de Gruyter, 19771988

Theologisches Begriffslexikon zum Neuen Testament, ed. Coenen, L./ Beyreuther, E./Bietenhard, H., 4th ed. (Studienausgabe), Wuppertal: Brockhaus, 1977

Theologisches Wörterbuch zum Neuen Testament, ed. Kittel, Gerhard, Stuttgart: Kohlhammer, 1950

Thormeyer, Paul, Philosophisches Wörterbuch, Dritte Auflage [Teubners kleine Fachwörterbücher 4l, Leipzig/Berlin: B.G.Teubner, 1922

Ziegenfuss, Werner (ed.), Philosophen-Lexicon. Handwörterbuch der Philosophie nach Personen, Berlin: Walter de Gruyter, 1949

Other Editions and Secondary Literature

Adler, Herbert M., Service of the Synagogue. New Year. New York: Hebrew Publishing Co., s.a.

Agus, Aharon (Ronald E.), The Binding of Isaac and Messiah. Law, Martyrdom and Deliverance in Early Rabbinic Religiosity, Albany: SUNY Press, 1988

Altmann, Alexander, Moses Mendelssohn, Alabama, 1973

Aristotle, The Complete Works of Aristotle. The Revised Oxford Translation, ed. Jonothan Barnes, two volumes [Bollingen Series LXXI.2], Princeton University Press, 1991

Assmann, Jan, Moses the Egyptian (Harvard University Press, 1997)

Aulèn, Gustaf, Christus Victor, New York: Macmillan, 1974

Baeck, Leo, Das Wesen des Judentums, third edition, Frankfurt a.M.: J.Kauffmann, 1923

—, "Romantische Religion" in: Festschrift (1922), 3-48

Bahr, Hermann, Antisemitsmus, ed. Hermann Greive, Königstein: Jüdischer Verlag, 1979

Bähr, Karl, Symbolik des mosaischen Cultus, 3 vols, Heidelberg, 1837-39 
Beck, Brian E., "Imitatio Christi and the Lucan Passion narrative" in: Horbury/McNeil (ed.) Suffering and Martyrdom in the NT (Cambridge, 1981), pp. 28-47

Belke, Ingrid, Moritz Lazarus und Heymann Steinthal. Die Begründer der Völkerpsychologie in ihren Briefen, Tübingen: Mohr, vol. I 1971, vol. II/1 1983, vol. II/2 1986

Benjamin, Walter, "Goethes Wahlverwandtschaften" in: Illuminationen. Ausgewählte Schriften, Frankfurt am Main: Suhrkamp, 1969

Boeckh, August, Encyklopädie und Methodologie der philologischen Wissenschaften, ed. Ernst Bratuscheck (2. ed. Rudolf Klussmann) Leipzig: Teubner, 1886

Böhl, F.M.Th. deLiagre, s.v. "Babylonien III" RGG 1:822f

Bousset, Wilhelm, Die Religion des Judentums im späthellenistischen Zeitalter, 1902

Brann, Marcus, Geschichte des jüdisch-theologischen Seminars (Fraenckel'sche Stiftung) in Breslau. Festschrift zum fünfzigjährigen Jubiläum der Anstalt, Breslau: Schatzky, 1904

Breitenstein, Urs, Beobachtungen zu Sprache, Stil und Gedankengut des Vierten Makkabäerbuchs Basel/Stuttgart: Schwabe, 1976

Brelage, Manfred, Studien zur Transzendentalphilosophie, Berlin: Walter de Gruyter, 1965

Breslauer, Bernhard, Die Zurücksetzung der Juden an den Universitäten Deutschlands. Denkschrift im Auftrage des Verbandes der Deutschen Juden, Berlin: Berthold Levy, 1911

Brichto, Herbert C., "On slaughter and sacrifice, blood and atonement" in HUCA vol.47, 1976, p.19-36

Brilling, Bernhard, s.v. "Breslau" in: EJ 4:1353-6

Brooks, R./Collins, J. (ed.), Hebrew Bible or Old Testament? , Notre Dame: University of Notre Dame Press, 1990

Buber, Martin, Between Man and Man (transl. R.G.Smith), New York: Macmillan, 1965 (ninth printing, 1975)

(et al.) ed., Gabe Herrn Rabbiner Dr. Nobel zum 50. Geburtstag dargebracht, Frankfurt: J. Kauffmann, 1921 
—, I and Thou (second edition, transl. R.G.Smith), New York: Charles Scribner's Sons, 1958

Büchler, A., Studies in Sin and Atonement in the rabbinic literature of the first century, (ed. Harry M. Orlinsky) New York: Ktav, 1967 (first published 1927)

Carlebach, Julius (ed.), Wissenschaft des Judentums. Hokhmat Yisrael. Anfänge der Judaistik in Europa, Darmstadt: Wissenschaftliche Buchgesellschaft, 1992

Cassirer, Ernst, Das Erkenntnisproblem in der Philosophie und Wissenschaft der neueren Zeit, Dritter Band: "Die Nachkantischen Systeme", Berlin: Bruno Cassirer, 1920

- The Problem of Knowledge. Philosophy, Science, and History since Hegel (transl. William H. Woglom and Charles W. Hendel), New Haven and London: Yale University Press, 1969

Cohen, Arthur A./Mendes-Flohr, Paul (ed.), Contemporary Jewish Religious Thought, New York: Free Press (Macmillan) 1988

Cohen, Philip, David Einhorn: Biblical Theology as Response and Reform. PhD Dissertation, Brandeis University, 1993

Cohen, Richard A., Elevations: the height of the good in Rosenzweig and Levinas. Chicago: University of Chicago Press, 1994

Cramer, Wolfgang, review of Hans Wagner, Philosophie und Reflexion, in: Philosophische Rundschau (11/1963) pp.68-90

Creuzer, Friedrich, Symbolik und Mythologie der alten Völker, besonders der Griechen, neue verbesserte Auflage, Leipzig/Darmstadt: C.W. Leske, 1842-43

Crown, A.D., The Samaritans. Tübingen, 1989

Dan, Yoseph, s.v. "Rossi, Azariah (Bonaiuto) Ben Moses Dei (c. 1511c.1578)" in EJ 14:315-8

Das jüdisch-theologische Seminar Fraenckelsche Stiftung zu Breslau. Am Tage seines fünfundzwanzigjährigen Bestehens, den 10. August 1879, herausgegeben im Auftrage des Curatoriums der Commerzienrath Fraenckelschen Stiftungen, Breslau: Grass, Barth \& Co., 1879 
Deegan, Daniel L., "The Theology of Wilhelm Herrmann: A Reassessment" in: The Journal of Religion vol.XLV, April 1965, Nr.2, p.87

Deutscher Bundestag (ed.), Fragen an die deutsche Geschichte. Ideen, Kräfte, Entscheidungen von 1800 bis zur Gegenwart, Bonn: Deutscher Bundestag, Presse- und Informationszentrum, 1984

Dober, Hans Martin, Die Zeit ernst nehmen. Studien zu Franz Rosenzweigs "Der Stern der Erlösung," Dissertation, Eberhard-KarlsUniversität Tübingen, s.a.

Duchrow, Ulrich, Weltwirtschaft heute. Ein Feld für Bekennende Kirche? München: Chr. Kaiser, 1986

Hyman, Arthur, s.v. "Philosophy, Jewish" in: EJ 13:456-9

Ebeling, Gerhard, Wort und Glaube, second ed. Tübingen: Mohr, 1962

Editorial Staff/Avenary, Hanoch, s.v. "Aleinu le-shabbe'ah" in EJ 2: 555559

Einhorn, David, Das Princip des Mosaismus und dessen Verhältnis zum Heidenthum und rabbinischen Judenthum. Leipzig: C.L.Fritzsche, 1854

Eisen, Arnold, "Divine Legislation as 'Ceremonial Script': Mendelssohn on the Commandments" in: AJS Review xv/2 (Fall 1990), 239-268

Elbogen, Ismar, "Die Hochschule, ihre Entstehung und Entwicklung" in: - / Höniger J., Lehranstalt für die Wissnschaft des Judentums. Festschrift zur Einweihung des eigenen Heims, Berlin am 22. Oktober 1907, Berlin: K.S. Hermann, 1907

—_Ein Jahrhundert Wissenschaft des Judentums" in: Festschrift zum 50 jährigen Bestehen der Hochschule für die Wissenschaft des Judentums in Berlin, Berlin: Philo Verlag, 1922, 103-144

—_ Der jüdische Gottesdienst in seiner geschichtlichen Entwicklung, Hildesheim: Olms:1967

Ettinger, Shmuel, s.v. "Graetz, Heinrich" in EJ 7:846

Feenstra, Ronald J./Plantinga Cornelius Jr. (eds.), Trinity, Incarnation and Atonement: Philosophical and Theological Essays, Univ. of Notre Dame Press, 1989 
Fichte, Johann Gottlieb, Addresses to the German nation, by Johann Gottlieb Fichte, translated by R. F. Jones and G. H. Turnbull. Chicago and London, The Open Court Publishing Company, 1922

Fisch, Menahem, Rational Rabbis. Indiana University Press, 1998

Fischer, Kuno, Kant's Leben und die Grundlagen seiner Lehre. Drei Vorträge. 2. unveränderte Aufl. Heidelberg, C. Winter, 1906

Fischer-Appelt Peter, "Einleitung" in: Wilhelm Herrmann, Schriften zur Grundlegung der Theologie, Munich: Kaiser, 1966 part I, xv-li

- Metaphysik im Horizont der Theologie Wilhelm Herrmanns. Mit einer Herrmann Bibliographie [=Forschungen zu Geschichte und Lehre des Protestantismus, ed. Ernst Wolf, 10.Reihe vol.22] Munich: Kaiser, 1965

Flusser, David, “Das jüdische Martyrium im Zeitalter des Zweiten Tempels und die Christologie" in Freiburger Rundbriefe 25/1973, 187-194

Fossum, Jarl, The Name of God and the Angel of the Lord. Samaritan concepts of Intermediation and the Origin of Gnosticism Tübingen, 1985

- "Sects and Movements" in A.D.Crown, The Samaritans Tübingen, 1989

Foucault, Michel, Histoire de la sexualité, Paris : Gallimard, 1976, vol. 1. "La volonté de savoir." [English: The History of Sexuality. An Introduction. vol. Transl. Robert Hurley, New York: Vintage Books, 1990]

Fox, Marvin (ed.), "Law and Ethics in Modern Jewish Philosophy: the Case of Moses Mendelssohn" in: American Academy for Jewish Research 13/1976,1-13

- Modern Jewish Ethics in Theory and Practice, Ohio State University Press, 1975

- "Philosophy and Religious Values in Modern Jewish Thought" in: Role of Religion in Modern Jewish History (ed. J.Katz), 1975, 6990

Frank, Manfred, Selbstbewußtseinstheorien von Fichte bis Sartre, Frankfurt: Suhrkamp, 1991 
Gadamer, Hans-Georg (ed.), Festschrift für Paul Natorp zum Siebzigsten Geburtstage von Schülern und Freunden gewidmet, Berlin/Leipzig: Walter de Gruyter, 1924

— s.v. "Geisteswissenschaften" in RGG 2:1304-1308

-_- Hermeneutik I. Wahrheit und Methode. Grundzüge einer philosophischen Hermeneutik, [Gesammelte Werke Band 1], Tübingen: J.C.B. Mohr (Paul Siebeck), 1986

, s.v. "Historismus" in RGG 3:369-371

- (ed.), Stuttgarter Hegel-Tage 1970. Vorträge und Kolloquien des Internationalen Hegel-Jubiläumskongresses Hegel 1770-1970. Gesellschaft, Wissenschaft, Philosophie, [=Hegel-Studien Beiheft 11], Bonn: Bouvier, 1974

Garnet, Paul, Salvation and Atonement in the Qumran Scrolls, Tübingen: J.C.B. Mohr (Paul Siebeck), 1977 [=Wissenschaftliche Untersuchungen zum Neuen Testament 2. Reihe, vol.3]

Gay, Peter, The Dilemma of Democratic Socialism; Eduard Bernstein's Challenge to Marx. New York: Collier Books, 1962

Gfrörer, Friedrich August, Das Jahrhundert des Heils, Zweite Abtheilung, vol. 2, Stuttgart: E. Schweizerbart's, 1838 [= Part 2 of Geschichte des Urchristenthums, five volumes, 1838]

- Kritische Geschichte des Urchristenthums 1. Theil. Philo und die jüdisch-alexandrinische Theosophie. II. Abtheilung Stuttgart: E. Schweizerbart's Verlagshandlung, 1831, Second edition 1835

Gibbs, Robert, Correlations in Rosenzweig and Levinas. Princeton, N.J.: Princeton University Press, 1992

Goodman, Lenn E., God of Abraham, New York/Oxford: Oxford University Press, 1996

Görlitz, Ana Maria Mariscotti de/Bredehorn, Uwe /Happel,Hans-Gerd, Martin Rade. Theologe-Publizist-Demokrat. 1857-1940, Marburg: 1990

eadem/Wagner, Walter, Martin Rade. Aspekte seines Wirkens, Marburg, 1990

Greenspan, Frederick E. (ed.),The Human Condition in the Jewish and Christian Traditions, Ktav Publ., 1986 
Grützmacher, Richard H. /Muras, Gerhard G., Textbuch zur deutschen systematischen Theologie und ihrer Geschichte vom 16. bis 20. Jahrhundert, vol.I, 4th ed. Gütersloh: Bertelsmann, 1955

Guttmann, Julius, "Religion und Wissenschaft im mittelalterlichen und im modernen Denken" in: FS (1922), 147-216

Händler-Lachmann, Barbara/Werther, Thomas, Vergessene Geschäfte, verlorene Geschichte. Jüdisches Wirtschaftsleben in Marburg und seine Vernichtung im Nationalsozialismus, Marburg: Hitzeroth, 1992

Hartmann, Frida/Heimsoeth, Renate (ed), Nicolai Hartmann und Heinz Heimsoeth im Briefwechsel Bonn: Bouvier Verlag, 1978

Hasler Ueli, Beherrschte Natur. Die Anpassung der Theologie an die bürgerliche Naturauffassung im 19.Jahrhundert (Schleiermacher, Ritschl, Herrmann) Bern/Frankfurt am Main: Peter Lang, 1982 [=Basler und Berner Studien zur historischen und systematischen Theologie Band 49]

Hegel, Georg Wilhelm Friedrich, The phenomenology of mind. Translated, with an introd. and notes, by J. B. Baillie. Introd. to the Torchbook ed. by George Lichtheim. New York: Harper \& Row, 1967

Heinz, Hanspeter/Kienzler, Klaus/Petuchowski, Jakob J. (eds.), Versöhnung in der jüdischen und christlichen Theologie [Quaestiones Disputatae, ed. H. Fries, R. Schnackenburg, No. 124], Freiburg, Basel, Wien: Herder, 1990

Hengel, Martin, The Atonement. The Origins of the Doctrine in the New Testament (transl. by John Bowden from an extended article, "Der stellvertretende Sühnetod Jesu: ein Beitrag zur Entstehung des urchristlichen Kerygmas," first published in German in: Internationale katholische Zeitschrift 9, 1980, 1-25, 135-47, with substantial additions by the author), Philadelphia: Fortress Press, 1981

Heller, Joseph Elijah, s.v. "Frankel, Zacharias (1801-1875)" in EJ 7:79-82

Henten, J. W. van (ed.), Die Entstehung der jüdischen Martyrologie [Studia Post-Biblica 38], Leiden: Brill, 1989

Herr, Moshe David, s.v. "Day of Atonement" in: EJ 5:1377 
Herrmann, Johannes, "Sühne und Sühneformen im AT" in:Theologisches Wörterbuch zum Neuen Testament, (ed. Gerhard Kittel), vol. 3, Stuttgart: Kohlhammer, 1950 pp.302-311

Herrmann, Wilhelm, Der Verkehr des Christen mit Gott im Anschluss an Luther dargestellt, Stuttgart/Berlin: J.C.Cottasche, 1886 ( 5. and 6., improved edition 1908. 7.ed. 1921)

- Die Wirklichkeit Gottes [= Die christliche Religion unserer Zeit, vol.1], Tübingen: Mohr (Siebeck), 1914

-_ Schriften zur Grundlegung der Theologie. Mit Einleitung und Anmerkungen, ed. Peter Fischer-Appelt, Munich: Kaiser, 1966 (vol.1) and 1967 (vol.2)

Hirsch, E., Hilfsbuch zum Studium der Dogmatik, 3.ed Berlin: de Gruyter, 1958

Hirsch, Samuel, Die Religionsphilosophie der Juden oder das Prinzip der jüdischen Religionsanschauung und sein Verhältniß zum heidenthum, Christenthum und zur absoluten Philosophie dargestellt und mit den erläuterten Beweisstellen aus der heiligen Schrift, den Talmudim und Midraschim versehen, Leipzig: Heinrich Hunger, 1842

Hoffmann, Christhard, Juden und Judentum im Werk deutscher Althistoriker des 19. und 20. Jahrhunderts, Leiden: Brill, 1988 [=Studies in Judaism in Modern Times, ed. J. Neusner vol. 9]

Horbury, W./McNeil (ed.), Suffering and Martyrdom in the NT (Cambridge, 1981)

martyrdom in the New Testament , 1981, 143-182

Huber, Wolfgang, Folgen christlicher Freiheit. Ethik und Theorie der Kirche im Horizont der Barmer Theologischen Erklärung, 2. Auflage, Neukirchen-Vluyn: Neukirchener Verlag, 1985

Idel, Moshe, Messianic Mystics. New Haven: Yale University Press, 1998

Ivry, Alfred (ed.), The Meaning of Jewish Existence (transl. by Edith Ehrlich and Leonard H. Ehrlich), Hanover and London: Brandeis University Press, 1991

Janowski, Bernd, Sühne als Heilsgeschehen. Studien zur Sühnetheologie der Priesterschrift und zur Wurzel KPR im Alten Orient und im Alten Testament, Neukirchen-Vluyn: Neukirchener Verlag, 1982 
[=Wissenschaftliche Monographien zum Alten und Neuen Testament; Vol. 55]

Jensen Ole, Theologie zwischen Illusion und Restriktion. Analyse und Kritik der existenz-kritizistischen Theologie bei dem jungen Wilhelm Herrmann und bei Rudolf Bultmann. Mit einer dänischen Zusammenfassung München: Christian Kaiser, 1975 [=Beiträge zur evangelischen Theologie Band 71]

Jodl, Friedrich, "German Philosophy in the Nineteenth Century" in: The Monist vol.1, January 1891, No.2, 263-277

Johnson, Sherman E. and Breck, John, "Preface to 4 Maccabees" in The New Oxford Annotated Bible. New York, 1991

Johnson, William Alexander, The Religious A Priori. A Critical Evaluation of the Philosophy of Religion of Anders Nygren, Ph.D. thesis, Columbia University, 1960

Kähler, Martin, Martin Kähler, Der sogenannte historische Jesus und der gschichtliche, biblische Christus. Vortrag auf der Wupperthaler Pastoralkonferenz Leipzig: A. Deichert, 1892, 2nd. enlarged edition 1896. Published again by E. Wolf. München: C. Kaiser, 1953 [English: The so-called historical Jesus and the historic, Biblical Christ. Translated, edited, and with an introd. by Carl E. Braaten. Foreword by Paul J. Tillich. Philadelphia: Fortress Press, 1964]

Kant, Immanuel, Religion innerhalb der bloßen Vernunft, ed. Malter, Stuttgart: Reclam, 1974

—, Sämmtliche Werke, herausgegeben von Karl Rosenkranz und Friedrich Wilhelm Schubert, Leipzig: Leopold Voss, 1838

Katz, Jacob , From Prejudice to Destruction. Anti-Semitism, 1700-1933, Cambridge/MA: Harvard University Press, 1980

- Out of the Ghetto. The Social Background of Jewish Emancipation, 1770-1870, New York: Schocken, 1978

Kettler, F.-H., s.v. "Versöhnung V. Dogmengeschichtlich" in: RGG 6:1376

Kieval, Herman, s.v. "Kol Nidrei" in: EJ 10:1167

Kisch, Guido (ed.), The Breslau Seminary. The Jewish Theological Seminary (Fraenckel Foundation) of Breslau 1854-1938, Memorial Volume, Tübingen: J.C.B.Mohr (Paul Siebeck), 1963 
Knohl, Israel, [Mikdash ha-demamah. English] The Sanctuary of Silence: The Priestly Torah and the Holiness School. Minneapolis : Fortress Press, 1995

Koch, G., s.v. "Herrmann, Johann Wilhelm (1846-1922)" in RGG 3, 275277

Kraft, Robert A. /Nickelsburg, George W.E. (ed.), Early Judaism and its Modern Interpreters, Philadelphia: Frotress, 1986

Krapf, Thomas M., Die Priesterschrift und die vorexilische Zeit. Yehezkel Kaufmanns vernachlässigter Beitrag zur Geschichte der biblischen Religion, Freiburg/Switzerland: Universitätsverlag; Göttingen: Vandenhoeck \& Ruprecht, 1992 [Orbis Biblicus et Orientalis 119]

Kraus, Hans-Joachim, Geschichte der historisch-kritischen Erforschung des Alten Testaments, 3. ed. Neukirchen/Vluyn: Verlag des Erziehungsvereins, 1982

Landmann, Michael, "Geleitwort" in: Brelage (1965), p.iii-viii

Lang, B., s.v. " כפippaer" in: Theologisches Wörterbuch zum Alten Testament, ed. G.Botterweck, H.Ringgren, H.-J.Fabry, vol. IV, Stuttgart: Kohlhammer, $1984 \mathrm{col}$. 303-318

Lange, Friedrich Albert, Geschichte des Materialismus., Wohlfeile Ausgabe, Iserlohn/Leipzig, 1887

Über Politik und Philosophie. Briefe und Leitartikel 1862 bis 1875. Ed. Georg Eckert. (Duisburger Forschungen, 10. Beiheft) Duisburg, W. Braun, 1968

Lannert, Berthold, Die Wiederentdeckung der neutestamentlichen Eschatologie durch Johannes Weiss (Tübingen, 1989)

Levine, Baruch, In the Presence of the Lord. A Study of Cult and Some Cultic Terms in Ancient Israel. [= Studies in Late Antiquity ed. J. Neusner, vol. Five], Leiden: Brill, 1974

Levinger, Jacob S., s.v. "Geiger, Abraham" in EJ 7:357ff

Levenson, Jon D., "Why Jews are not interested in Biblical Theology" in: The Hebrew Bible, the Old Testament, and Historical Criticism: Jews and Christians in Biblical Studies. Louisville, Ky.: Westminster/John Knox Press, 1993, pp. 33-61 
Lichtenstein, A., "Does Judaism Recognize an Ethic Outside of the Halakha?" in Marvin Fox (ed.), Modern Jewish Ethics in Theory and Practice, pp.155-168

Liebeschütz, Hans, Das Judentum im deutschen Geschichtsbild von Hegel bis Max Weber, [Schriftenreihe Wissenschaftlicher Abhandlungen des Leo-Baeck-Instituts Nr. 17], Tübingen: Mohr, 1967

Lohse, Eduard, Märtyrer und Gottesknecht. Untersuchungen zur urchristlichen Verkündigung vom Sühnetod Jesu Christi (2.ed. 1963)

Lucas, Leopold, Die Wisschenschaft des Judentums und die Wege zu ihrer Förderung, Berlin: Carl Flemming, 1906

Mahlmann Theodor, s.v. "Herrmann, Wilhelm (1846-1922)" in: Theologische Realenzyclopädie Berlin/New York: Walter de Gruyter, 1977-1988

- "Wilhelm Herrmann" in: Hans Jürgen Schulz, Tendenzen der Theologie im 20. Jahrhundert. Eine Geschichte in Porträts, Stuttgart/ Berlin: Kreuz Verlag; Olten und Freiburg/Breisgau: Walter Verlag, 1967 (2.ed, pp. 38-43)

Maimonides, The Guide of the Perplexed, transl. Shlomo Pines, 2 vols., University of Chicago Press, 1963

Marmorstein, A., The Doctrine of Merits in Old Rabbinic Literature and The Old Rabbinic Doctrine of God [Three Volumes in One], New York: Ktav, 1968

McGrath, William J., Dionysian Art and Populist Politics in Austria New Haven: Yale University Press, 1974

Mendelssohn, Moses, Jerusalem or on Religious Power and Judaism, transl. Allan Arkush, Introduction and commentary by Alexander Altmann, Hanover and London: University Press of New England, 1986

Mendes-Flohr, Paul R./Reinharz, Jehuda (ed.), The Jew in the Modern World. New York/Oxford: Oxford University Press, 1980 (First edition)

Meyer, Thomas, Bernsteins konstruktiver Sozialismus, Berlin/Bonn, 1977

Meyer, Michael A., Response to Modernity. A History of the Reform Movement in Judaism, New York: Oxford University Press, 1988 
Milgrom, J., s.v. "Day of Atonement as Annual Day of Purgation in Temple Times" in: EJ 5: 1384-1387

- s.v. "Repentance" in: EJ 14:73

Mitchell, Allan, Revolution in Bavaria, 1918-1919; the Eisner regime and the Soviet Republic. Princeton, N.J.: Princeton University Press, 1965

Momigliano, Arnaldo, "A Hundred Years After Ranke" in: Diogenes 7 (1054), 52-8, reprinted in: Studies in Historiography (London: Weidenfeld and Nicholson, 1966), pp. 105-111

-, "Friedrich Creuzer and Greek Historiography" in Studies on Modern Scholarship, ed. G.W. Bowersock and T.J. Cornell. Berkeley/Los Angeles/London: University of California Press, 1994, pp. 1-14

- "Jacob Bernays" in: Essyas on Ancient and Modern Judaism. (Ed. Silvia Berti) Chicago and London: University of Chicago Press, 1994, pp. 148-170

Munk, Elie, Die Welt der Gebete. Olam Hatefilot. Kommentar zu den Werktags-, Sabbat- u. Festtagsgebeten nebst Uebersetzung, 2 volumes, Basel: Victor Goldschmidt, 1975

Neue Jüdische Monatshefte (ed.), Das Deutsche Judentum. Seine Parteien und Organisationen. Eine Sammelschrift, Berlin/München: Verlag der Neuen Jüdischen Monatshefte, 1919

Neusner, Jacob, Ancient Judaism. Debates and Disputes, Second Series, Atlanta, Ga.: Scholar's Press, 1990

Niewöhner, Friedrich W., "Vorüberlegungen zu einem Stichwort: 'Philosophie, Jüdische'" in: Archiv für Begriffsgeschichte 24/1980, 195-220

Nilsson, Martin P., Geschichte der griechischen Religion vol. 1 [Handbuch der Altertumswissenschaft vol. 2.1]

O'Neill, J.C., "Did Jesus teach that his death would be vicarious as well as typical?" in: Horbury, William (ed.) Suffering and martyrdom in the New Testament , 1981, 9-27

Patzig, G., s.v. "Trendelenburg" in RGG vol. 6, 1011

Paul, Wolfgang, Rundgang. Bau- und Kunstdenkmale der Innenstadt Dessau, Dessau: IWG Dessau, s.a. 
Lothar Perlitt, Vatke und Wellhausen. Geschichtsphilosophische Voraussetzungen und historiographische Motive für die Darstellung der Religion und Geschichte Israels, Berlin: Töpelmann, 1965 [Beihefte zur ZAW 94]

Philippson, Ludwig, Die Israeltitische Religionslehre, Leipzig, 1861ff

Plato, The Collected Dialogues of Plato Including the Letters, ed. Edith Hamilton and Huntington Cairns [Bollingen Series LXXI] Princeton University Press, 1989

Rabinowitz, Louis Isaac, s.v. "Haftarah" in: EJ 16:1342ff

Rade, Martin, "Gedächtnisrede auf Wilhelm Herrmann" in: Herrmann, Wilhelm, Dogmatik, Gotha/Stuttgart: Perthes, 1925, pp.VIII-XXI

Rainey, Anson, s.v. "Sacrifice" in EJ xiv:599-607

Rat der Stadt Dessau (ed.), Dessau 775 Jahre 1213-1988, Dessau, 1988

Reinharz Jehuda/Reinharz Shulamit, "Leadership and Charisma: The Case of Theodor Herzl" in: Mystics, Philosophers, and Politicians. Essays in Jewish Intellectual History in Honor of Alexander Altmann. Edited by Jehuda Reinharz and Daniel Swetschinski, with the collaboration of Kalman P. Bland. Durham, N.C.: Duke University Press, 1982, pp. 275-314

Rendtorff, Rolf, Studien zur Geschichte des Opfers in Israel (1967)

- "The Image of Postexilic Israel in German Bible Scholarship from Wellhausen to von Rad" in: Sha'arei Talmon. Studies in the Bible, Qumran, and the Ancient Near East, ed. M. Fishbane/Emanuel Tov, Winona Lake: 1992, 165-173

- "Toward a Common Jewish-Christian Reading of the Hebrew Bible" in: R. Brooks, J. Collins (ed.), Hebrew Bible or Old Testament? (Notre Dame: University of Notre Dame Press, 1990), pp. 89ff

Richarz, Monika, Jüdisches Leben in Deutschland. Selbstzeugnisse zur Sozialgeschichte 1780-1871 New York: Leo-Baeck-Institute, 1976

Ritschl, Albrecht Benjamin, A Critical History of the Christian Doctrine of Justification and Reconciliation. Translated, with the author's sanction, by John S. Black. Vol. 1, Edinburgh: Edmonston and Douglas, 1872 
, Die christliche Lehre von der Rechtfertigung und Versöhnung. Second, improved edition, Bonn: Adolph Marcus, 1883 (3.ed., 1889; 4. Aufl. 1895-1903)

Robinson James M., Das Problem des Heiligen Geistes bei Wilhelm Herrmann. Inaugural-Dissertation zur Erlangung der Doktorwürde der Theologischen Fakultät der Universität Basel, Marburg: Universitäts Buchdruckerei, 1952

Jürgen Roloff, review of "Volker Hampel, Menschensohn und historischer Jesus" (1990) in: Biblische Zeitschrift (ed. J.Schreiner, H.J. Klauck) NF 1991 Jg 35 Heft 2, pp. 259-262

Rosenzweig, Franz, Briefe und Tagebücher, ed. Rachel Rosenzweig/Edith Rosenzweig-Scheinmann unter Mitwirkung von Bernhard Casper, 2 vols. [=Der Mensch und Sein Werk, Gesammelte Schriften I], The Hague: Martinus Nijhoff, 1979

$\longrightarrow$, Der Stern der Erlösung, ed. Reinhold Mayer (4th ed.) [=Der Mensch und sein Werk. Gesammelte Schriften II], The Hague: Martinus Nijhoff, 1976

—, Zweistromland. Kleinere Schriften zu Glauben und Denken, (ed.s Mayer R./Mayer A. [= Der Mensch und sein Werk. Gesammelte Schriften III], Dordrecht/Boston/Lancaster: Martinus Nijhoff, 1984

Samuelson, Norbert M., Judaism and the Doctrine of Creation. Cambridge, New York, Melbourne: Cambridge University Press, 1994

Schäfer, Peter, Hekhalot-Studien Tübingen, 1988

Schaeffler, Richard, Religionsphilosophie [Handbuch Philosophie, ed. E.Ströher, W.Wieland] Freiburg/München: Alber, 1983

Scheler, Max, Vom Ewigen im Menschen. Leipzig: Reinhold, 1921

Schilpp, Paul Arthur/Friedman, Maurice (ed.), The Philosophy of Martin Buber [= Library of Living Philosophers vol.xii], LaSalle, Ill.: Open Court, 1967

Schleiermacher, Friedrich, On religion: Speeches to its Cultured Despisers. Translated by John Oman. With an introd. by Rudolf Otto. New York, Harper, 1958

Schmied-Kowarzik Wolfdietrich (ed.), Der Philosoph Franz Rosenzweig (1886-1929). Internationaler Kongress-Kassel 1986 (vol.1: "Die 
Herausforderung jüdischen Lernens", vol.2: "Das neue Denken und seine Dimensionen"), Freiburg/Muenchen: Karl Alber, 1988

Schopenhauer, Arthur, On the Basis of Morality. Tanslated by E. F. J. Payne. With an introd. by Richard Taylor. Indianapolis: BobbsMerrill, 1965

___, Preisschrift über die Grundlage der Moral. (=Die beiden Grundprobleme der Ethik. vol. 2) Hamburg: Meiner, 1978

Schott, E., s.v. "Ritschl, I. Albrecht (1822-89)" in RGG 5:1114ff

Schrader, G.A., "Philosophy and Reflection: Beyond Phenomenology" in The Review of Metaphysics XV (1961) pp.81-107

Schweitzer, W., s.v. "Sozialethik" in: RGG 6:159-167

Sirat, Colette, A History of Jewish Philosophy in the Middle Ages, Cambridge: Cambridge University Press, and Paris: Editions de la Maison des Sciences de l'Homme, 1990

Smend, Rudolf, Die Entstehung des Alten Testaments, Stuttgart, Berlin, Köln, Mainz: Kohlhammer, 1978

Soloveitchik, Joseph B., On Repentance, ed. Pinchas Peli, New York/Ramsey: Paulist Press, 1984

Spiegel, Shalom, The Last Trial . New York: Pantheon, 1969

Spinoza, Baruch de, Tractatus Theologico-Politicus, ed. Carl Gebhardt, [Spinoza Opera, vol. III], Heidelberg: Carl Winter, 1925

Stadt Coswig, Elbe=Zeitung. Organ für die Stadt und das Amt Coswig

Steinthal, H. (Chajim), Über Juden und Judentum. Vorträge und Aufsätze (ed. Gustav Karpeles; third edition, ed. N.M.Nathan), Berlin: Poppelauer, 1925 [Schriften herausgegeben von der Gesellschaft zur Förderung der Wissenschaft des Judentums\}

Stendahl, Krister, The Scrolls and the New Testament, New York: Crossroad, 1992

Strack, Hermann, Einleitung in Talmud und Midrasch. (6th edition) Munich: Beck, 1976

Strauss, Leo, "Das Heilige" in Der Jude 7 (1923) 
- Die Religionskritik Spinozas als Grundlage seiner Bibelwissenschaft. Untersuchungen $z u$ Spinozas theologisch-politischem Traktat [Veröffentlichungen der Akademie für die Wissenschaft des Judentums, Philosophische Sektion/Zweiter Band], Berlin: Akademie-Verlag, 1930

- Philosophie und Gesetz. Beiträge zum Verständniz Maimunis und seiner Vorläufer, Berlin: Schocken, 1935

Sykes, S.W. (ed.), Sacrifice and Redemption. Durham Essays in Theology, Cambridge: Cambridge Univ. Press, 1991

Temkin, Sefton D., s.v. "Einhorn, David" in EJ vol. 6, col. 532

Tödt, Heinz Eduard, Perspektiven theologischer Ethik, München: Chr. Kaiser, 1988

Toury, Jacob, Die politischen Orientierungen der Juden in Deutschland. Von Jena bis Weimar, Tübingen: J.C.B. Mohr (Siebeck), 1966

Trendelenburg, Friedrich Adolf, Logische Untersuchungen, 1840 (3rd ed. 1870)

Urbach, Hazal. Pirqey Emunot uDe'ot Jerusalem: Magnes Press, 1986 [English: The Sages. Their Concepts and Beliefs, transl.of Hazal by Israel Abrahams, Jerusalem: Magnes Press, 1979]

Vermes, G., "Redemption and Genesis XXII-The Binding of Isaac and the Sacrifice of Jesus" in: Scriptures and Tradition in Judaism: Haggadic Studies (Leiden, 1961), 193-227

Wach, Joachim, Das Verstehen. Grundzüge einer Geschichte der hermeneutischen Theorie im 19. Jahrhundert, vol. I: Die großen Systeme (1925), reprint Hildesheim: Olms 1966

Wagner, Hans, Philosophie und Reflexion, München/Basel: Ernst Reinhardt Verlag, 1967 (2. unveränderte Auflage; erste Aufl. 1958)

Weber, Ferdinand, Die Lehren des Talmud quellenmäßig, systematische und gemeinverständlich dargestellt, Nach des Verfassers Tode herausgegeben von Franz Delitzsch und Georg Schnedermann, Leipzig: Dörffling \& Franke, 1886 [Schriften des Institutum Judaicum in Leipzig, II. Serie. Nr. 1] 
Weintraub, Karl Joachim, The Value of the Individual. Self and Circumstance in Autobiography, Chicago \& London: The University of Chicago Press, 1978

Wellhausen, Julius, Prolegomena zur Geschichte Israels , fifth edition, Berlin, 1899

Werner, Ernst, Geschichte der Stadt Coswig-Anhalt, 3. ed. Coswig: Mehnert, 1929

Wistrich, Robert S., Socialism and the Jews. The Dilemmas of Assimilation in Germany and Austria-Hungary, London/Toronto: Assoc. Univ. Presses, 1982

Wolandt, Gerd, "Überlegungen zu Kants Erfahrungsbegriff" in: Kantstudien 69/1978, 46-57 [also in: Materialien, 378-395]

Wolf, Abraham, s.v. "Category" in EB (14) 5:28f

Wolfson, H.A., Philo (2 vols), 1940

- The Philosophy of Spinoza, Two Volumes, Cambridge: Harvard University Press, 1934

Yerushalmi, Yosef Hayim, Zakhor. Jewish History and Jewish Memory, New York: Schocken, 1989

Zank, Michael, "The God of Sinai, the God of Creation, and the God of Abraham: Three Recent Books in Jewish Philosophy " in: Modern Judaism 16 (1996): 291-316

Zimmerli, Walter, Ezechiel, 1. Teilband Ezechiel 1-24, Neukirchen-Vluyn: Neukirchener Verlag des Erziehungsvereins 1969 [Biblischer Kommentar Altes Testament Band XIII/1]

Zimmermann, Moshe, Wilhelm Marr. The Patriarch of Anti-Semitism, New York: Oxford University Press, 1986

Zwickel, Wolfgang, Biblische Welten. Festschrift für Martin Metzger [Orbis Biblicus et Orientalis 123], Göttingen: Vandenhoeck \& Ruprecht, 1993 



\section{Appendix:}

\section{Manuscripts by Hermann Cohen}

\section{A. Letters from the National and University Library, Jerusalem}

The originals of the following letters can be found at the National and University Library, Givat Ram, Jerusalem. Numbers 1, 2, and 3 are part of the Abraham Schwadron Autographs Collection (Folder II). Number 4 (addressed to Philippson) is in the general archives (ARC. Ms. Var. $460 / 5)$. Page breaks in the originals are indicated in \{\}. Illegible passages are indicated by (...).

\section{Greeting Cards by Hermann and Gerson Cohen to Salomon Steinthal}

a) Written on occasion of the recipient's eleventh birthday (April 21, 1870). Salomon Steinthal later worked in Berlin as a physician (d. 1927). His daughter Eva Steinthal lived in Jerusalem, Reh. Alharizi 16. ${ }^{1}$

ברוך אחה בבואך וברוך אתה בצאתך

Wenn Du unter fremden Menschen lebst, dann denke recht oft an Alle, die Dich lieb haben; und suche Dir Freunde zu erwerben, indem Du Deine eigene Freude darein setzest, guten Menschen eine Freude zu machen. So wirst Du selbst gut und glücklich werden!

Von Deinem treuen Hermann

Cohen in Berlin, Coswig 23. April

1870

\footnotetext{
${ }^{1}$ One of the copies of vol. 1 of Cohen's Jüdische Schriften owned by the Brandeis University library that I used for my dissertation research showed the following autographed dedication by Salomon Steinthal to his friend Carl Loewenthal: "Seinem lieben Bruder Carl Loewenthal zur Erinnerung an die nun 25 Jahre bestehende, von Jahr zu Jahr inniger gestaltete Freundschaft! Im Juli 1927. Salomon Steinthal."
} 


\section{Translation}

(Hebrew:) May you be blessed in your coming and going.

When you live among strangers then think often of all those who love you; and seek to make friends for yourself by seeking your pleasure in bringing joy to good people. Thus you yourself will become good and happy!

By yours truly,

Hermann Cohen in Berlin

b) Greeting Card by Gerson Cohen, dated April 24, 1870; same paper and brown ink as the above. Presumably addressed to the same recipient and on the same occasion.

Wenn die guten Lehren, die Dir gegeben worden, frühzeitig auf Deinen Verstand wie auf Dein Gemüth der Art einwirken, daß sie noch Gesinnungen und ernstliche Handlungen ferner bringen, so ist Deine glückliche Zukunft-gesichert-!

Von Deinem Lehrer Gerson Cohen

\section{Translation}

When the good lessons that were given to you have the effect on your mind and sense from early on that they continue to bring forth attitudes and earnest deeds, then your future is 'secured!'

By your teacher Gerson Cohen

\section{Letter to Ludwig Philippson (December 1879)}

Material: Paper (brownish-beige), ink (dark brown).

The context of Cohen's letter to Ludwig Philippson is the Berlin debate on anti-Semitism triggered by Heinrich von Treitschke to which Cohen responded in an open letter to Treitschke ${ }^{2}$ which, when the latter declined to include it in his Preußische Jahrbücher, he published in enlarged form as Ein Bekenntnis in der Judenfrage (1880). The reference to Graetz refers to volume eleven (1750-1848) of his History of the Jews which Philippson's Institut zur Förderung der Israelitischen Literatur had refused to publish. ${ }^{3}$

${ }^{2}$ Cf. Helmut Holzhey, "Zwei Briefe Hermann Cohens an Heinrich von Treitschke" in Bulletin des Leo Baeck Instituts 12 (1969) vol.46-47, pp. 183-204.

${ }^{3}$ Cf. Michael A. Meyer, "Great Debate on Antisemitism. Jewish Reaction to New Hostility in Germany 1879-1881" in Yearbook XI (1966), p. 156. The Institut zur Förderung der Israelitischen Literatur, founded by Philippson in the middle of the 19th century was a predecessor to the Gesellschaft zur Förderung der Wissenschaft des Judentums, founded in 1902. Cf. Leopold Lucas, Die Wisschenschaft des Judentums und die Wege zu ihrer Förderung, Berlin: Carl Flemming, 1906, p. 9. Hermann Cohen was prominently involved in the Gesellschaft from its very inception. 
In the text Cohen refers to his father, Gerson, who had passed away July 25, 1879, at the age of 82 in Marburg. ${ }^{4}$ I acknowledge the help of Dr. Hartwig Wiedebach in deciphering this letter.

Marburg 23.12.79

Hochverehrter Herr,

ich danke Ihnen für Thre mir soeben zugegangene Zuschrift und für die in derselben ausgesprochene gütige Anerbietung: ich nehme dieselbe mit Dank an, und hatte schon daran gedacht, deßhalb an Sie zu schreiben. Mein Vater by-gestatten Sie mir von meinem מורי ורבי, dem ich meine religiöse Auffassung mit deutlichem Bewußtsein verdanke, dieser Abbreviatur mich zu bedienen-war der eifrige Leser und anhängliche Verehrer Ihrer Zeitung wie Ihres Wirkens überhaupt, und vorzüglich der Richtung derselben von Threm ersten Auftreten ab. Und ich, der ich durch die Breslauer Schule gelaufen bin, habe einsehen gelernt, wie sehr die jüdischen Dinge Ihrer Feder benöthigt bleiben: $:^{5}$ und ich beklage, daß von den Jüngeren nicht genug beherzigt $\mathrm{zu}$ werden scheint, wo [?] Sie Ihrem Meister nachzufolgen sich in allen Hauptsorgen bestrebt wußten. Mit Graetz haben wir nun die Misere, und Sie werden nun recht ohne Schonung Treitschke erwidern können, daß Sie und mit Ihnen die deutschen Juden zwar jenes undeutsche, in einer unguten Gesinnung überhaupt unangebrachte Gebahren dieses Romantikers aufs schärfste mißbilligen; u mit Triumph können Sie darauf hinweisen, daß Sie die glückliche Vorsicht getroffen haben, diesen Band nicht unter der Flagge des Lit. Kreises segeln zu lassen. $\underline{\operatorname{Im} \text { Vertrauen }} \underline{\underline{6}}$ will ich Ihnen mittheilen, daß ichsosehr ich in publizistischen \{p. 2\} Dingen mich scheue hervorzutreten-in diesem Falle jedoch für angemessen gehalten habe, meine Ansicht dem Collegen Tr. gegenüber in einem Privatschreiben zu bekennen, um dessen Abdruck ich ihn ersucht habe, zumal ich in den Pr. Jahrb. bereits einen Aufsatz veröffentlicht habe.

Wenn ich Sie recht verstanden, hat mein seeliger Vater stets postuum bezahlt: ich sende Ihnen jedoch schon von jetzt ab $9 \mathrm{M}$. 56., danke für die aufrecht erhaltene Vermittelung [?] und wünsche, daß Sie noch viele Jahre in deutschem Vertrauen und unentwegter programmmäßiger Bestimmtheitheit den Juden weit und breit sagen mögen, was uns Noth thut und was wir den Widersachern am Innern wie am Äußern gegenüber zu thun u zu lassen haben.

Mit verehrungsvoller Ergebenheit Hermann Cohen

\footnotetext{
${ }^{4}$ Cf. Elbe=Zeitung. Organ für die Stadt und das Amt Coswig Nr. 104, 3. Okt. 1876, 3. Jg., p. 4 and Nr. 86, 28. Juli 1879, 6. Jg., p.4. Gerson Cohen's Hebrew epitaph, written by his son, is translated in Fritzsche, op.cit., p. 42.

${ }^{5}$ Underlined with blue pencil, presumably by Philippson.

${ }^{6}$ Underlined by Cohen.
} 


\section{Translation}

\section{Dear Sir,}

I thank you for your letter which I received just now and for the kind offer you extend in it: I accept it with gratitude and had already thought of writing to you in this matter. My father, Sisr [= Hebrew abbreviation for "may the memory of the righteous be a blessing"] -allow me to use this abbreviation when referring to my [Hebr. "teacher and master"] to whom I clearly and consciously owe my religious perception-was a diligent reader and attached admirer of your newspaper ${ }^{7}$ as of your activities in general, and especially of its direction from your very first public appearance. And I myself, having gone through the school of Breslau, have learned to understand how much the Jewish matters remain in need of your pen: and I deplore that while [?] you strove to follow your master in all major concerns, this [example] seems no longer taken to heart by the younger ones. This wretched state of affairs has now become manifest with Graetz, and you are now able to respond to Treitschke without having to tread carefully that you, and with you the German Jews, sharply disapprove of the unGerman behavior of this romantic which in its unwholesome attitude is altogether inappropriate; and you can triumphantly point to the fact that in a fortuitous act of foresight you decided not to let this volume sail under the flag of the Literatur circle. ${ }^{8}$ I want to tell you in confidence that $I$, as much as I am reluctant to produce myself \{p. 2$\}$ in journalistic matters, have nevertheless deemed it appropriate to confess my views to colleague Treitschke in a private letter which I asked him to print, especially since I already published an essay in the Preußische Jahrbilcher. ${ }^{9}$

If I understood you correctly my deceased father always paid upon receipt. I rather send you already from now on M. 9.56, thank you for the sustained mediation [?] and express the wish that you may continue for many years to come to tell the Jews near and far in German confidence and steady programmatic determination what is necessary for us and what we ought to do in the face of our opponents within and without.

In admiring devotion, Hermann Cohen

\footnotetext{
${ }^{7}$ Allgemeine Zeitung des Judentums, founded by Ludwig Philippson in 1837 and edited by him until his death in 1889 .

${ }^{8} \mathrm{Viz}$. the Institut zur Förderung der Israelitischen Literatur. Cf. introduction to this letter and note above.

9"Friedrich Albert Lange" in: Preußische Jahrbiicher 37/1876, 353-381 (= S2, 357391).
} 


\section{Letters to Marcus Brann (1899-1900), Editor of Monatsschrift für die Geschichte und Wissenschaft des Judentums}

Source: National and University Library, Givat Ram, Jerusalem. ARC. Ms. Var 308/240.

The archive at the National and University Library in Jerusalem Ms. Var $308 / 240$ contains a number of letters and postcards from Hermann Cohen (mostly in Martha Cohen's handwriting) ${ }^{10}$ to Mordechai Marcus Brann (1849-1920). The earliest document is from 1899, the latest from 1917. There are also several machine copies of Brann's letters to Cohen. Marcus Brann succeeded the historian Heinrich Graetz as a lecturer at the Jewish Theological Seminary in Breslau as well as the editor of the scholarly journal associated with it, Monatsschrift für die Geschichte und Wissenschaft des Judentums, ${ }^{11}$ from 1904 on published as the organ of the Gesellschaft zur Förderung der Wissenschaft des Judentums which Cohen helped to inaugurate in 1902. MGWJ became the single most important place for Cohen to publish essays on Jewish theological matters until, in 1916, in addition to writing and lecturing, he co-founded a more popular non-partisan Jewish journal, the bi-weekly Neue Jüdische Monatshefte. Zeitschrift für Politik, Wissenschaft und Literatur in Ost und West, to which he contributed a regular column, the "Streiflichter über jüdische Religion und Wissenschaft," until his death in $1918 .{ }^{12}$ The other editors of the

\footnotetext{
${ }^{10}$ Martha Cohen, born June 20,1860, was the daughter of the composer and conductor Louis Lewandowski. H. Cohen was her private tutor when she was a girl living with her family in Berlin. They were married in 1878. Beginning in 1892, Hermann Cohen suffered from progressive retinal detachment and dictated most of his work to Martha. See the dedication to the second edition of Logik der reinen Erkenntnis, Berlin, 1914. The first time Martha had to write on his behalf was in December, 1892, when she wrote a letter to the university administration saying that due to the occurance of retinal detachment her husband would be unable to lecture the following semester (commencing in January, 1893). I owe this tidbit to Franz Orlik who prepared an exhibit and catalogue on occasion of a conference in honor of Hermann Cohen at Marburg University in 1992. Martha Cohen died twelve days after her deportation to Theresienstadt on September 1, 1942. Cf. Helmut Holzhey, 1986/1, p. viii.

${ }^{11}$ MGWJ had been founded by Zacharias Frankel (1801-1875), the first director of the Seminary in Breslau. It was continued by Heinrich Graetz and P. F. Frankl, then edited as a new series by David Kaufmann and Marcus Brann.

${ }^{12}$ The policy of the journal was to bring together all factions of German Jewry in an impartial forum. In 1919, for example, the surviving editors expressed their intentions as follows: "Die Neuen Jüdischen Monatshefte dürfen es sich zum Verdienst anrechnen, der jüdischen Gemeinschaft in einem Sinne gedient zu haben, der ihnen Dank und die gern gezollte Anerkennung aller Parteien erworben hat. In einer Zeit, in welcher der Kampf der Meinungen im deutschen Judentum so heiß war, wie vielleicht noch zu keiner anderen, sind die Neuen Jüdischen Monatshefte zu einer Tribüne geworden, von der herab die
} 
latter journal were Alexander Eliasberg, mainly known as a Tolstoy- and Dostoevsky-translator, the sociologist Franz Oppenheimer, Eugen Fuchs, then chairman of the Central-Verein and the Herzl-Zionist Adolf Friedemann.

Cohen's first publication in MGWJ was his review of Lazarus' Ethik des Judentums ("Das Problem der jüdischen Sittenlehre," 1899) (= J3,1-35). Cohen himself had offered such a review to Brann's co-editor David Kaufmann with the intent to refute what he called "this book of advertisement" (Verwahrung einlegen wollte gegen jenes "Reklamebuch"). Kaufmann seems to have shared Cohen's poor opinion. When Kaufmann died, however, before negotiations with Cohen were finalized, Brann renewed the committment to printing the review and also extended an invitation for Cohen to lecture in Breslau. Later Brann also published the Gedenkbuch zur Erinnerung an David Kaufmann (1900) to which Cohen contributed the essay "Autonomie und Freiheit " (= J3,36-42). The significance of both texts for Cohen's emergence as a Jewish philosopher is discussed in Part I, above. In the following I reproduce the text of the more substantive letters which highlight the history of the publication of both these essays. In addition the archives contain several postcards by Cohen urging Brann to send him the galleys of his essay on Lazarus' Ethik des Judentums.

a) Letter in Martha Cohen's handwriting (blue ink), to Marcus Brann after the death of David Kaufmann, Brann's fellow editor. Dated August 21,1899

\section{Hochgeehrter Herr Doktor!}

Sie sehen anbei, warum ich Ihren freundlichen Brief nicht sogleich beantwortet habe. Nach Schluß des Semesters bin ich sehr bald an die Arbeit gegangen, die ich dem sel. Kaufmann versprochen hatte. Sein Tod hat mich sehr erschüttert. Und ich war doch nur 1, allerdings vollen Tag mit ihm zusammengewesen. Wie tief muß Ihr Schmerz sein.-Ihm hatte ich sogleich bei meinem Anerbieten geschrieben, daß ich nach meiner schwachen Kraft

produktiven Geister in allen Lagern gern zur jüdischen Gesamtheit gesprochen haben, da sie wußten, daß die von dieser Stätte aus Gehör finden wïrden" (emphasis in the original; Das deutsche Judentum. Seine Parteien und Organisationen. Eine Sammelschrift, Berlin/München, 1919, p. 82). The subtitle of the journal was from its beginning: "Zeitschrift für Politik, Wirtschaft und Literatur in Ost und West" and its Motto was "Diese Zeitschrift ist ein offener Sprechsaal für Jedermann. Für die Inhalte der Artikel übernehmen die Autoren selbst die Verantwortung." The issue 15/16 (May 10./25., 1918) was a special issue commemorating Hermann Cohen. Contributors were Ernst Cassirer, Paul Natorp, Benzion Kellermann, Jacob Klatzkin, Karl Joël, Franz Rosenzweig, and Bruno Strauss. 
Verwahrung einlegen wollte gegen jenes "Reklamebuch." ${ }^{13}$ Und in diesem ausgesprochenen Sinne hat er mein\{p.2)Anerbieten angenommen $u$. gut gefunden. Ich hoffe, daß auch Sie es unparteiisch finden werden. Die Mäßigung, die ich mir auferlegt habe, besteht besonders darin, daß ich nur auf das Wichtigste mich beschränkt habe. Viele Einzelheiten dagegen ungerügt gelassen habe. Sie würden mich verbinden, wenn Sie nach Pontresina (Neue Post) gef. mir mitteilen wollten, wann der Druck beginnt, u. ich die Correktur erwarten darf.

Besten Dank endlich für Ihre freundliche Wiederaufnahme der Aufforderung zum Vortrag im dortigen Verein. Es soll mir Freude machen dort sprechen $\mathrm{zu}$ dürfen. Und ich würde in den Weihnachtsferien dazu bereit sein. Sagen Sie, bitte, Herrn Jacobsohn, daß ich dabei mich freuen würde, der ursprünglich von ihm ausgegangenen Anregung entsprechen zu können.

Mit besten Wünschen für die bevorstehende ernste Zeit ${ }^{14} u$. freundlichen Empfehlungen an Thre verehrte Frau Gemahlin u. liebe Tochter von uns beiden bin ich

\section{Ihr sehr ergebener}

HCohen

\section{Translation}

\section{Dear Herr Doktor,}

You will see from the attached why I did not immediately answer your kind letter. After the end of the semester I soon began the paper that I had promised the deceased Kaufmann. His death shook me very much even though I spend merely 1 day, albeit a full one, in his company. How deep must be your pain.-I had immediately written to him as I made my offer that I wanted to lodge protest, in accordance with my weak strength, against this "book of advertisement." And in this explicit sense he \{p.2\} accepted my offer and approved of it. I hope that you too will find it unbiased. The restraint that I imposed upon myself consists in particular in that $I$ have limited myself to what is necessary. Many details on the other hand I left unreproved. I would be obliged if you kindly were to notify me in Pontresina (at New Post Office) when you go to print and when I may expect the proofs.

Finally my sincerest thanks for your kind resumption of the invitation to lecture at the local chapter of the Verein. ${ }^{15}$ Could you please tell $\mathrm{Mr}$. Jacobsohn ${ }^{16}$ that on such an occasion I shall be pleased to correspond to the suggestion that he had originally issued.

\footnotetext{
${ }^{13}$ I.e., Lazarus' Ethik des Judentums.

${ }^{14}$ I.e., the Jewish High Holidays, the "days of awe."

${ }^{15}$ Not clear which association Cohen is referring to. In the same year Cohen was invited to Vienna to speak on "Judaism as a world-view." See Part I, above.

${ }^{16}$ Again, identity could not be ascertained. Presumably a personality in the Jewish community in Breslau.
} 
With best wishes for the coming solemn period and with kind regards to your dear wife and lovely daughter from both of us, I am Yours, very sincerely HCohen

b) Postcard (Kartenbrief, Deutsche Reichspost), written by Martha Cohen with addition by Hermann Cohen (pencil), to Marcus Brann, sent from Cassel, September 20, 1899.

The additions by Hermann Cohen are virtually illegible. As far as I could make them out, they deal with the proofs for the essay on Lazarus' Ethik des Judentums.

Hochgeehrter Herr Doktor!

Besten Dank für Thre Nachricht $\mathbf{u}$ insbesondere für die schönen Worte bei der Bestattung unseres Kaufmann.

Hoffentlich haben Sie die Korrektur ${ }^{17}$ noch nicht abgesandt:

ich bitte Sie nach Berlin W, Potsdamerstr. 88.

Wieviel Separatabzüge bekomme ich? Und darf ich noch [?] auf meine Kosten mehr bestellen?

Ich darf doch wohl hoffen das [sic] Sie die Sache als Abhandlung haben setzen lassen.

Mit besten Grüßen

Ihr ergebener

H. Cohen

\section{Translation}

Dear Herr Doctor,

Many thanks for your note and especially for the beautiful words during the wake for our Kaufmann.

I hope you have not yet sent off the galleys:

Please send them to Berlin W, Potsdamerstr. 88.

How many offprints do I receive? And can I order more at my expense?

I assume that you had the matter set up as an article.

With best regards

Yours, sincerely

$\mathrm{H}$. Cohen

c) Letter, Marburg, June 17, 1900 (Martha Cohen's handwriting)

Verehrter Herr Doktor!

Herzlichen Dank Ihnen u Ihrer sehr verehrten Frau, sowie Ihrer 1. Tochter für den herzlichen Ausdruck Ihrer Theilnahme an unserem großen Schmerze. ${ }^{18}$

${ }^{17}$ I.e., the galleys of "Das Problem der jüdischen Sittenlehre."

${ }^{18}$ Earlier the same month Hermann Lewandowsky, Hermann Cohen's oldest and most intimate friend, had passed away. On Hermann Lewandowsky and Cohen see Bertha and Bruno Strauss' 1939 edition of Cohen's letters, Briefe, passim. 
Wie lange schon wollte ich Ihnen schreiben, um Ihnen für die gemüthlichen Stunden zu danken, die wir in Ihrem Hause u Ihrer Nähe verleben durften, $u$ die uns so sehr wohl gethan haben. Auch an Guttmanns ${ }^{19}$ ist es versäumt worden. Jetzt fordert Ihr Brief sofortige Antwort. Es muß \{p.2\} ein Irrthum sein, daß ich einen Beitrag zu dem Gedenkbuch für unseren Kaufmann zugesagt hätte, denn ich kann mich schlechterdings nicht erinnern, daß Sie mich dazu aufgefordert haben. Und das kann ich nicht vergessen haben. Schreiben Sie mir, bitte, nun, in welcher Richtung ich noch dabei mitthun kann. Mit einer kleinen Betrachtung könnte ich ja wohl allenfalls noch mich einstellen, wenn auch nur um mit meiner Gesinnung dabei zu sein. ${ }^{20}$

$$
\begin{gathered}
\text { Mit herzlichen Grüßen, auch für Guttmann, } \\
\text { Rosenthal }{ }^{21} \text { u. Badt, } 22 \\
\text { auf gutes Wiedersehen } \\
\text { Ihr H. Cohen } \\
\text { Sehr erfreut hat mich Ihr Schlußwort über } \\
\text { Strack. }
\end{gathered}
$$

\section{Translation}

Dear Herr Doktor,

Thank you very much to you and your dear wife as well as to your lovely daughter for the cordial expression of your condolence for our great pain.

How long has it been since I wanted to write you to thank you for the comfortable hours that we were able to spend in your house

\footnotetext{
${ }^{19}$ Jakob Guttmann, father of the philosopher Julius Guttmann, was a friend of Cohen's from the days of their studies at the seminary in Breslau. Cohen, Guttmann, Brann, and other fellow seminarians were the founding circle of the Gesellschaft für die Wissenschaft des Judentums in 1902.

${ }^{20}$ See above. The essay Cohen eventually contributed is "Autonomie und Freiheit “(see J3,36-42).

${ }^{21}$ Ferdinand Rosenthal (1838-1921), orthodox rabbi in Breslau and historian of medieval Jewish philosophy of religion, editor (with Brann) of the Gedenkbuch zur Erinnerung an David Kaufmann. Breslau, Schles. Verlags Anstalt, 1900. He contributed also to the 1908 volume Moses Ben Maimon, published by the Gesellschaft für die Wissenschaft des Judentums as well as to Judaica. Festschrift zu Hermann Cohens Siebzigstem Geburtstage (ed. Ismar Elbogen, Benzion Kellermann, and Eugen Mittwoch), Berlin: Bruno Cassirer, 1912.

22Presumably Breslau classics scholar Benno Badt, an orthodox Jew whose son Hermann (1887-1946) was a friend of Franz Rosenzweig (see letters in BT) and rose to eminence as a Prussian Civil servant before emigrating to Palestine (1933). The younger Badt and Bertha Strauß were Rosenzweig's companions when the latter first met Martin Buber in 1914 (see BT II, p. 725).

${ }^{23}$ Hermann Strack (1848-1922), German orientalist and theologian, at the time the leading non-Jewish scholar of Bible, Talmud, and midrashic literature. His Einleitung in Talmud und Midrasch is still in print (6th edition, Munich: Beck, 1976) and his commentary, with Billerbeck, on the New Testament from rabbinic sources is still widely used.
} 
and near you, and that were such a pleasure to us. The Guttmann's, too, were neglected. Now your letter demands immediate attention. It must be \{p.2\} an error that I promised a contribution to the memorial volume for our Kaufmann since I cannot remember at all that you asked me for one. And that I cannot possibly have forgotten. Write me now, please, in what direction I can still participate. If nothing else I could certainly still join with a short essay even if only in order to have my intention represented.

With cordial regards, also for Guttmann, Rosenthal and Badt, until we meet again,

Your H. Cohen

I was very delighted about your final word about Strack.

d) Letter, June 28, 1900, Martha Cohen's handwriting.

It emerges from this and the last letter that Cohen wrote the essay

"Autonomie und Freiheit" in little over a week.

Verehrter Herr Doktor,

Um bei dem Gedenkbuch für unseren verewigten Kaufmann wenigstens mit meinem guten Willen ${ }^{24} \mathrm{zu}$ erscheinen, sende ich Ihnen anbei meinen Beitrag für den Sie hoffentlich noch Platz finden. Es ist ein kleiner Nachtrag zum "Problem der jüdischen Sittenlehre." Ich bitte dringend um Correktur.

Wenn Horowitz einsieht, daß die Anlage jenes ominösen ... \{p.2\} verfehlt ist, begreife ich nicht wie er ihm Loblieder singen kann. Und was macht er mit den Proben gröbster Unwissenheit? Traurig ist es, wie über "Liebe und Gerechtigkeit" 25 in allen Lagern geschwiegen wird. Und doch, wenn anders ich urtheilen darf, sollte man es bekannt machen.

Mit herzlichen Grüßen für Ihre verehrte Frau Gemahlin u Ihre 1. Kinder von uns

$$
\begin{aligned}
& \text { Beiden } \\
& \text { Ihr } \\
& \text { H. Cohen }
\end{aligned}
$$

\section{Translation}

Dear Herr Doktor,

In order to appear in the memorial volume for our deceased Kaufmann at least with my good will, I send you my contribution for which you will hopefully still find room. It is a small addition to "Problem of the Jewish Doctrine of Morality" (viz. Cohen's review of Lazarus' Ethik). I urgently request proofs.

If Horowitz recognizes that the disposition of this ominous ... $\{$ p. 2$\}$ is mistaken, I do not comprehend how he can sing his praises.

\footnotetext{
${ }^{24}$ This is a witticism; the essay is on autonomy and freedom, i.e., on the problem's of Kant's Grundlegung zur Metaphysik der Sitten, i.e., on the problem of a "good will."

25"Liebe und Gerechtigkeit in den Begriffen Gott und Mensch" in JJGL, vol. 3 (1900), pp. 75-132 (= J3,43-97).
} 
And what does he do with his proofs of the coarsest ignorance? It is deplorable how one is silent about "Love and Justice" in all camps. And still, as far as I can judge, it should be made public.

With cordial regards for your dear wife and your lovely children, from both of us,

Your

H. Cohen

\section{Letter by Hermann Cohen to Kurt Eisner, Silvaplana August 14, 1902}

Autograph and typed transcript (with several mistakes; by Bruno or Martha Strauß for the 1939 edition of Cohen's letters?) of a letter handwritten by Martha Cohen (based on Hermann Cohen's dictation), signed by $\mathrm{H}$. Cohen. Addressed to Kurt Eisner (1867-1919), written Silvaplana, August 14, 1902.26

The letter responds to a gift and greetings $H$.Cohen had received on the occasion of his sixtieth birthday. The file also contains a letter by Strauß to Schwadron saying that the political circumstances forbade the publication of this letter in the context of Strauß's collection of Cohen's letters. ${ }^{27}$ The letter testifies to Cohen's attempts to convince Eisner that religious committment to Judaism was not irreconcilable with a moral committment to socialism. It further contains remarks against the Catholic Zentrum, against Zionism, and against the academic establishment, a rather complete list of Cohen's dislikes at a time when he is inclined to take stock of his life. None of the letters Strauß decided to publish are nearly as emotional as this one. It gives us an inkling of the rather high-strung and passionate personality which censorship and loss of documentation have almost completely obliterated.

Mein lieber Herr Eisner!

Unter den vielen sinnigsten Zeichen eines herzlichen Gedenkens, die mir an meinem Geburtstage zu Theil geworden sind, wird mir Ihr Geschenk, das die Künstlerhand Ihrer 1. Frau geschaffen, stets obenan stehen. Obwohl ich Ihnen vielmehr vom Judenthum vorgeschwärmt habe, als Ihnen lieb war, haben Sie doch

\footnotetext{
${ }^{26} \mathrm{My}$ thanks go to Dr. Freya Eisner who kindly sent me a list of material by and on Eisner archived at the Marx-Engels-Institute in Moskow, as well as to Mieke Ijzermans from the Internationaal Instituut voor Sociale Geschiedenis in Amsterdam for searching the archives of the Instituut for me. The only letter by Eisner to Cohen that is known so far was written from Plötzensee in 1898 where Eisner was imprisoned as a socialist journalist. The letter describes life in prison and is a token of Eisner's deep appreciation for Cohen. The writing of letters was a severely restricted privilege (once a month, in exchange for the monthly permission of receiving a visitor).

${ }^{27} \mathrm{Cf}$. Briefe. Ausgewählt und herausgegeben von Bertha und Bruno Straus, Berlin: Schocken, 1939.
} 
die Liebe $\mathrm{zu}$ meiner deutschen Heimath, $\mathrm{zu}$ meiner kleinen Vaterstadt als eine lebendige Wurzel meines Wesens erkannt, u so hat dem Zionismus und anderem Antiismus [?] gegenüber Ihr Geschenk für mich die symbolische Bedeutung Ihrer sympathischen Anerkennung meines jüdisch-deutschen Menschheitsgefühls. Aber ich kann Ihnen nicht sagen, oder vielmehr ich freue mich darauf, Ihnen u Ihrer 1 Frau im Oktober es hoffentlich aussprechen zu können, wie sehr Ihre Güte und Liebenswürdigkeit, nach meinem lieben Coswig zu gehen, und von der schönen Elbe aus es aufzunehmen mich bewegt hat. Sie haben richtig vermuthet, daß ich in dem Oberstübchen die Theorie der Erfahrung geschrieben habe, stundenlang oft mit der Kritik in der Hand und vor dem Auge die Domgasse abschreitend, die Mittagsruhe auf der Elbwiese, die sie kaum gesehen haben werden, unter hohen Bäumen in Träumen und Sinnen haltend. Ich habe manchmal den Gedanken, als ob nur eine kleine Stadt eine Heimat sein könne, weil man nur da eine Volksschule besucht, mit den Kindern der mittleren und der niederen Stände aufwächst und die Landschaft mit der Stadt zusammenfließt. Doch ich weiß, daß auch Sie Ihren Berliner Lokalpatriotismus haben. Nehmen Sie zunächst schriftlich meinen herzlichen Dank für die große Freude, die Sie mir bereitet und befestigt haben.

Ich habe Ihnen für eine neue Freude zu danken, die mir hierher nachgesandt wurde. Es ist mir eine wirkliche Befriedigung $u$ ich knüpfe Hoffnungen daran, daß in der Beurtheilung des Centrums keine Differenz mehr zwischen uns besteht. Ich habe schon vor Jahren Singer ${ }^{28}$ gesagt, daß die Partei sich kein größeres Verdienst erwerben könnte als die Zerschlagung des Centrums wäre. Es ist meine tiefste Überzeugung, daß es kein größeres Hemmnis für die freie Sittengesetzlichkeit giebt als die Papstkirche, $u$ es ist schon von Übel, wenn man vor ihrer Organisation Respekt äußert. Doch genug davon. Es ist mir ferner eine wirkliche Freude, daß Sie über die Logik schreiben wollen. Was geht Sie, was geht uns die Zunft an, die natürlich noch lange schweigen wird, u wenn Sie [sic!] durch einen Unmündigen sich endlich wahrnehmen lassen wird, mir keine Enttäuschungen mehr bereiten kann. Wenn man aber außerhalb der Zunft Verständnis u Sympathie bezeugen wird, dann wird hoffentlich auch die Wissenschaft Vortheil davon haben. Ich will Ihnen noch berichten, daß meine Juden sich mit einer stilvollen Vornehmheit $\mathrm{u}$ Herzlichkeit zu meinem Eintritt in das Alter von ..... u ...... vereinigt haben. Wenn Sie können, lesen Sie den Leitartikel zum 4. Juli in der orthodoxen "jüdischen Presse." Aber auch die Studenten haben mir eine unseren Verhältnissen entsprechende Begrüßung bereitet, indem Herr Buch, bevor ich das Colleg begann, eine Ansprache hielt. Es wird sie interessieren, daß, wie ich indirekt höre, Gideon jetzt von Florenz aus nach Amerika gehen will. Ich schwelge hier wieder in der Engadiner Luft $u$ freue mich

${ }^{28}$ Paul Singer (1844-1911), German Jewish Social Democrat and Deputy to the Reichstag. Cf. Robert Wistrich, Socialism and the Jews, p. 81 and passim. 
noch tüchtig steigen zu können. Hoffentlich haben Sie auch eine kräftige Erholung (...).

\section{Translation}

My dear Herr Eisner!

Among the many most meaningful tokens of a cordial commemoration that I have received on occasion of my birthday, your present, created by the artful hand of your lovely wife, will always rank first. Although I was raving to you about Judaism more than you liked you still recognized the love of my German homeland, of my small hometown, as a living root of my being, and so, in the face of Zionism and other anti-ism [?] your present symbolizes to me your sympathetic recognition of my JewishGerman feeling of humanity. But I cannot express to you, or rather I am looking forward to the opportunity when, in October, I shall be able to express towards you and your lovely wife, how much your goodness and kindness moved me that you went to my beloved Coswig and took a picture as seen from the beautiful Elbe. You guessed correctly that I wrote Theory of Experience ${ }^{29}$ in the upper chamber, walking the Domgasse for hours with the Critique 30 in my hand and before my eye, taking a nap on the Elbwiese (which you probably did not see) day-dreaming under tall trees. Sometimes I think that only a small town can be home because only there does one visit a Volksschule, grows up with the children of the middle and lower classes, and the landscape merges with the town. But I know that you too have your Berlin local patriotism. In the meantime, please accept my written thanks for the great pleasure that you have given me and which you have reaffirmed.

I have to thank you for another pleasure that was sent on to me here. It really satisfies me and I associate with it the hope that there is no longer difference between us in the assessment of the Zentrum. Years ago I told Singer already that the party could accrue no greater merit to itself than the destruction of the Zentrum. It is my deepest conviction that there is no greater obstacle to the free moral law than the papal church, and it is harmful even to speak respectfully of this organization. But enough said. I am further pleased that you intend to write about the Logic. ${ }^{31}$ What do you, what do we care about the guild which will continue to be silent for a long time, and when it will finally let itself be noted through an outsider, 32 it [viz. the guild] will no longer be able to disappoint me.

\footnotetext{
${ }^{29}$ Kants Theorie der Erfahrung, Berlin: Dümmler, 1871.

${ }^{30}$ Immanuel Kant, Kritik der reinen Vernunft.

${ }^{31}$ Logik der reinen Erkenntnis, the first part of Cohen's philosophical system, had just been published.

${ }^{32}$ Literally "ein Unmündiger" means a "minor." Cohen alludes to Luther's translation of Psalm 8:3 as quoted in Matthew 21:16, the story of the purging of the temple; a telling remark about how Cohen felt about his situation within the German university system. Cf. Ulrich Sieg, Aufstieg und Niedergang des Marburger
} 
But if one shows comprehension and sympathy outside of the guild, then this will hopefully also be advantageous to the discipline. I want to report further that my Jews have united in stylish distinction and cordiality on occasion of my entering the age of ... and .... If you have the chance, read the editorial of July 4 th in the orthodox Jüdische Presse. ${ }^{33}$ But the students, too, gave me a reception in accordance with the circumstances, namely in that Herr Buch gave a speech before I began my lecture. It will be of interest to you that, as I hear indirectly, Gideon wants to go from Florence to America. I indulge here again in the air of the Engadin and am delighted that I can still climb vigorously. I hope you too are enjoying a thorough rest (...).

\section{B. Manuscripts on "Versöhnung"}

In the following I reproduce and translate 38 of 146 short notes and excerpts by Hermann Cohen, manuscripts found among the papers of Paul Natorp in "Nachlaß Natorp Ms. 831" at the Universitätsbibliothek Marburg. We owe a debt of gratitude to Dr. Franz Orlik who first alerted the scholarly community to the existence of this rare material.$^{34} \mathrm{I}$ also thank Dr. Uwe Bredehorn, keeper of the manuscripts, for allowing me not only to access the originals but also to make photostatic reproductions of the manuscripts that proved useful in the process of deciphering the texts. In his work on Cohen und Natorp (vol. 2), Helmut Holzhey reproduced some material from the same archive-not however the manuscripts on atonement. With one exception these texts are published here for the first time. ${ }^{35}$

The manuscripts are unique for the study of Hermann Cohen in that they represent a rare glance into his intellectual workshop. Most of Cohen's papers were lost when his widow Martha was deported to

Neukantianismus. Die Geschichte einer philosophischen Schulgemeinschaft, Würzburg: Königshausen und Neumann, 1994.

${ }^{33}$ Founded by Azriel Hildesheimer and later published by his son Hirsch, the Jüdische Presse was the organ of the so-called "communal Orthodoxy" which opposed secession (neo-Orthodoxy, founded by Samson Raphael Hirsch). Later the official paper of the German Mizrahi, in support of religious Zionism.

${ }^{34}$ See Franz Orlik, Hermann Cohen (1842-1918). Kantinterpret Begriinder der "Marburger Schule" Religionsphilosoph, Marburg: Universitätsbibliothek 1992. This fine catalogue accompanied an exhibit Dr. Orlik had mounted on occasion of a conference in Marburg, 1992, in memory of Hermann Cohen's 150th birthday. One of the papers was also exhibited at the Martin-Gropius-Bau in Berlin as part of the show Jüdische Lebenswelten, 1992.

${ }^{35}$ Only one of the manuscripts given below (Text 18 ) has been previously published by Franz Orlik. My deciphering deviates from his only slightly. A preliminary publication of these manuscripts was part of my PhD dissertation, Brandeis University, 1994. 
Theresienstadt in $1941 .^{36}$ They are particularly valuable to this study in that they deal with the idea of atonement. The word Versöhnung is, indeed, written on one of the envelopes in which the notes were originally preserved.

This envelope had originally been addressed to Cohen's address in Marburg (in Martha Cohen's handwriting?) and was mailed on November 25, 1907 (rubberstamped in Hamburg). It was found together with or inside another one on which someone had written the words "Natorp-Cohen, Philosophisches usw." Administrative archival notes indicate that the file as a whole consists of papers on Natorp's "Psychologie" (published by Holzhey 1986/2, pp.97ff), and "NatorpCohen Philosophisches usw." (which contained the envelope with the word Versöhnung). The same archival notes state that there is a total of 146 sheets and small leaves of paper. Hartwig Wiedebach is preparing a full edition of these notes in connection with the Werke edition of Cohen's works (ed. Helmut Holzhey). The selection below represents the result of a cooperative effort at deciphering Cohen's scribblings and I acknowledge Dr. Wiedebach's generosity in providing me with countless suggestions by which I was able to augment my readings.

All the notes below were written by Hermann Cohen in Sütterlin (Gothic script), Greek, and Hebrew (cursive script), using many characteristic abbreviations. I follow Dr. Wiedebach's suggestion when I represent the texts without the abbreviations which are merely distracting. Some orthographic idiosyncrasies have been retained as have the line breaks (as much as possible). The proliferation of emphases has been reproduced. This idiosyncrasy is typical for many of Cohen's published texts as well.

The manuscripts are relevant in a number of respects. They offer us a unique insight into Cohen's philosophy of religion "in progress." In connection with the argument I am making in this study, what emerges is the picture of a continuous work, commencing in the early 1890 s and leading to its completion in Religion der Vernunft. In my opinion, most of the notes were composed between 1890 and 1904. At least one paper, of unrelated content, was added to the pile at a later date. ${ }^{37}$ The excerpts

\footnotetext{
${ }^{36}$ Among the few remnants of Cohen's possessions that can still be viewed today are some of the volumes of Cohen's extended library that are stored in the basement of the National and University Library Jerusalem, Givat Ram, and that are in desparate need of restoration. Thanks to Hartwig Wiedebach who gave the participants in the Jerusalem conference on Hermann Cohen in 1996 the most touching introduction to this priceless yet neglected treasure.

${ }^{37} \mathrm{~A}$ manuscript added to the collection at a later date is the following (measuring 11.4 by $4.2-4.5 \mathrm{~cm}$ (unevenly torn), written with pencil): "Karpeles II 307 Sozinianer $u$ Unitarier in Polen für die Bildung auch auf die Juden Einflußs. 428
} 
allows us to establish their date ante quem non. Some excerpts, however, refer to works published much earlier than Cohen read them (e.g., Schlesinger's 1844 translation of Joseph Albo's Sefer Ha'ikkarim, or the editions of Einhorn and Gfrörer) making them irrelevant to the question of dating. In Part I, above, I show the connections between Cohen's published texts and the material presented here wherever there a meaningful parallel suggests itself.

Aside from attesting to the significance of the idea of Versöhnung in Hermann Cohen's Jewish thought, these manuscripts give us a sense of Cohen's command of Hebrew and of Jewish religious literature (e.g., Mishna, Talmud, Jewish liturgy, and Joseph Albo's Sefer Ha'ikkarim). Cohen occasionally represents terms he finds in German translation in the original Hebrew, using a well-honed rabbinic cursive script. We get a glimpse of his study of Wellhausen's Geschichte Israels as well of Ritschl's systematic theology, and we learn more about some of the literature he consulted in the attempt to construe a non-dialectic, linear history of the development of ancient Israelite religion (e.g., Gfrörer, Einhorn) in pursuit of a philologically sound Jewish philosophy of religion.

Most importantly, however, we can see in these notes and excerpts on atonement that Cohen constructed his philosophy of religion and his systematic ethics in tandem. In some of the passages problems are explored that are equally important to both and that show the connections and differences between them. As another theme we find Cohen also considering the relation between religion and art, especially of the notion of heroic individuality as it emerges from the Greek tragedians. The notes generally represent a stage of thought in Cohen's work that precedes the formulation of the Ethics of Pure Will and thus confirm my argument for the dating of Cohen's discovery of the idea of atonement in the mid-to late 1890's or, in any case, before 1904. These manuscripts are therefore a striking illustration of the otherwise quite puzzling programmatic directive, first pronounced in 1896, "to resolve religion into ethics." Religion-in particular the ideas of messianism and atonement-is first carefully ascertained as to its history, character, and ongoing relation to the major "directions of the cultural consciousness" and only then integrated into a philosophical argument that preserves the uniqueness and affirms the validity of the monotheistic tradition.

Wissenschaft des Judentums Auch" The remainder of the page is missing; on the right side of the sheet there are four more lines in a separate column, crossed out. The reference is to the second edition of Gustav Karpeles' Geschichte der jüdischen Literatur, vol. II, Berlin: M. Poppelauer, 1909, a work commissioned by the Gesellschaft zur Förderung der Wissenschaft des Judentums as part of its Grundriss der Gesamtwissenschaft des Judentums. Cf. above, Pt. I. The note seems unrelated to the rest of the papers. 
I have losely organized the 39 texts according to major themes. The first group consists of excerpts from various sources. The second batch contains meditations on the common root of the idea of atonement in the ancient cultures of Greece and Israel. The next section collects notes in which Cohen ascertained the development of the idea of atonement from within the sources of Judaism. Finally we find a series of texts exploring the moral and ethical implications of the concept of God in light of the idea of atonement. While the first three sections contain material that primarily feeds into Cohen's essay on the idea of atonement as well as into his fully developed philosophy of religion, the fourth group highlights the connection between the idea of atonement and Cohen's Ethics. The second category of texts fits both contexts in that it represents a few of the historical links that allow Cohen to make a case for a reconciliation of Greek thought and Hebrew religion. A more careful historical study of the relation between the notes and Cohen's published texts must await the complete deciphering of the material.

Sigla: () parenthesis in the original; <> insertion by Hermann Cohen; strikethreugh: correction in the original; [] editorial insertion $\mathrm{MZ}$; [?] deciphering uncertain; ... text illegible. To simplify navigation on the page the original manuscripts appear in a frame to distinguish it from translation and comments. The frame also invokes the original format of the small pieces of paper.

\section{Excerpts}

\section{Text 1 A Hebrew Excerpt}

11.5 by $9 \mathrm{~cm}$. Two lines of writing on the top of one side, ink.

Jes $56,7,66,21$

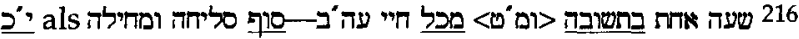

Translation

Isa $56: 7,66: 21$

Yom Kippur [the Day of Atonement] as sof s'likha um'khila [the end of pardon and forgiveness]-sha'ah ahat bit'shuvah <uma'asim tovim> mikkol hayyey olam haba [one hour of repentence <and good deeds> is better than all the life of the world to come] 216

\section{Notes/Comments}

Isa 56:7-cf. J 1, 115

sha'ah ahat etc.-cf. Mishna Avot 4:17 and Qohelet Rabba 4:10

The exact source of this excerpt could not be determined. But cf. below, Text 11, an excerpt from Gfrörer, Das Jahrhundert des Heils, Zweite Abtheilung, vol. 2, Stuttgart: E. Schweizerbart's, 1838 where, on p. 152 Avot 4:17 is also quoted. 
On the expression ' $t$ 'shuvah and ma'asim tovim 'cf. below, Text 21.

\section{Text 2 Joseph Albo, Sefer $\mathrm{Ha}^{\prime}$ ikkarim}

10.8 by $3 \mathrm{~cm}$, writing on one side, ink.

Albo, Ikkarim, ed. Schlesinger Frankfurt 1844

635 Über חסידי אה

Translation

Albo, Ikkarim, ed. Schlesinger Frankfurt 1844

635 On hassidey umot ha-olam [on the righteous gentiles]

\section{Notes/Comments}

This and the following papers contain excerpts from Joseph Albo, Buch Ikkarim, Grund= und Glaubenslehren der Mosaischen Religion. Translated by W. and Ludwig Schlesinger, Frankfurt/Main: $1844 .^{38}$

Sefer Ha'ikkarim is of great interest to Cohen not least because it was written by a late medieval philosopher who, like him, formulated his thought in debates with Christianity. ${ }^{39}$ The purpose of "The Book of Principles" is to determine the fundamental characteristics of a divine law.

\section{Text 3 Albo: Divine Likeness}

11.3 by $8.6 \mathrm{~cm}$, writing on one side, ink.

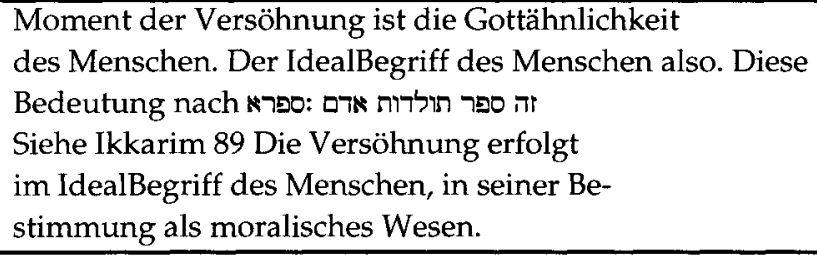

\section{Translation}

A moment in the atonement is the divine likeness

of the human being. In other words, the ideal concept of the human being. This meaning according to Sifra: Zeh sepher toldot adam.

${ }^{38}$ Joseph Albo, "the last of the Jewish Philosophers" (I. Husik), active in Christian Spain during the first half of the 15th century (died presumably 1444), was a student of Hasdai Crescas (d. 1412). Cf. Alexander Altmann, s.v. "Albo, Joseph" in EJ 2:535ff, Julius Guttmann, Philosophies of Judaism (New York: Schocken, 1973) 281-286, Colette Sirat, A History of Jewish Philosophy in the Middle Ages, Cambridge: Cambridge University Press, Paris: Editions de la Maison des Sciences de l'Homme, 1990, 374-381.

${ }^{39}$ Albo participated in the disputations at Tortosa and San Mateo (1413-14). Sefer ha-Ikkarim ("The Book of Principles") was written in 1425. 
See Ikkarim 89 Atonement comes to pass

in the ideal concept of the human being, in his

determination as a moral being.

\section{Notes/Comments}

This is another excerpt from, cum meditation based on, Joseph Albo, Sefer Ha'ikkarim. The passage on p. 89 of the edition Cohen uses is at the end of part I, chapter 24, where Albo quotes a passage from Sifra, a tannaitic midrash on Leviticus, as a prooftext for the character of a divine law which is to comprise both moral laws and directives towards the achievement of human perfection.

"Liebe deinen Nächsten wie dich selbst (3. B. M. 19,18)-R. Akiva sagt, dieser Vers ist ein wesentliches Moment für die Lehre. Ben Azai sagt: Dies ist das Buch der Geschlechtsfolge Adams (1. B. M. 5.1)-ist ein wesentliches Moment für die Lehre." (Saphro Kap. 14.) Sie geben dadurch zu erkennen, daß das göttliche Gesetz diese beiden Punkte umfassen müsse, Unrecht und Gewaltthat von den Staatsbewohnern fern zu halten, worauf durch das Gebot der Nächstenliebe hingedeutet wird, und die Menschen auf die menschliche Vollkommenheit aufmerksam zu machen, was sich in dem Verse "Dies ist das Buch der Geschlechtsfolge Adams" ausspricht, in welchem es weiter heißt: "am Tage, da Gott den Menschen erschaffen, hatte er in Aehnlichkeit Gottes ihn gemacht" dem Menschen also eine Gottähnlichkeit zuerkannt wird, die er deßhalb weder an sich noch an seinem Nächsten geringschätzen darf, und für deren Erhaltung und Anschließung an höhere Wesen, an dem Orte ihres Ursprunges, er Sorge tragen muß. (Albo, Ikkarim, ed. Schlesinger, loc.cit.)

['Love Thy Neighbor as Thyself (Lev. 19:18)-R. Akiva says, this verse is an essential moment of doctrine. Ben Azzai says: This is the book of the generations of Adam (Gen. 5:1)--is an essential moment of doctrine" (Sifra Ch. 14). In this fashion it is brought to light that the divine law must contain both these points, to keep away injustice and violence from the inhabitants of the state (this is hinted at in the commandment of Love Thy Neighbor) and to draw people's attention to human perfection. The latter is expressed in the verse "These are the generations of Adam" where it goes on to say "on the day when God created the human being he created him in the likeness of God." Thus the human being is recognized in his likeness of God which he must therefore neglect neither in himself nor in his neighbor but rather concern himself with its preservation and attachment to higher beings, at the place of its origin. (Albo, Ikkarim, ed. Schlesinger, loc. cit.)]

It is noteworthy that Cohen summarizes the gist of Albo's passage by subordinating the rationalistic moralizing interpretation of the latter to the general concept of atonement. This method corresponds to what we find in the essay "Die Versöhnungsidee" (see above, $\mathrm{Pt}$. I)where atonement is made the key-principle whose 
development guides the history of Jewish doctrine and practice. In the late philosophy of religion (Begriff der Religion, 1915), the idea of atonement is subordinated to the concept of a correlation between the idea of God and the human being.

The notion of Gottähnlichkeit (divine likeness) occurs also in Text 17 (homoiōsis theō).

\section{Text 4 Albo: Eschatological Unity of the Nations as "Israel"}

This is one of the pages from a small notepad, $6.7 \mathrm{by} 4.3 \mathrm{~cm}$, pencil.

Wie man aus עpר sieht, gilt als

Israel auch die Gesamtheit der

Nationen nach der messianischen

Bedeutung. K. 42. S. 593

Translation

As one can see from Ikkarim,

the totality of the nations can also count as

Israel in accordance with its messianic

meaning. Ch. 42 . p. 593

\section{Notes/Comments}

The reference is to $I k$ karim, part IV, chapter 42 , same edition as above, p. 593:

Solche, die sich zum jüdischen Gesetze bekehren, heißen Israeliten oder Juden, wenn sie auch zu andern Nationen gehören. So heißen denn auch die Römer Edomiten; alle Völker, die sich zum Islam bekehrten, Ismaeliten, nach dem ersten Volke, das diese Religion bekannte, und das von Ismael abstammte.

[Those who convert to the Jewish law are called Israelites or Jews even if they belong to other nations. Thus the Romans are also called Edomites; all people who converted to Islam, Ishmaelites, according to the first people who confessed this faith, which descended from Ishmael.]

The context of Albo's passage is the problem of messianism. According to Albo's system of principles, the belief in the coming of a messiah is a dogma branching off from the principle of reward and punishment (Ikkarim I:23). In part IV, chapter 42, the same status of the belief in the coming of a messiah is affirmed, as laid out in the first part. This is one of the basic dogmas, yet if its truth were denied, the divine law would not become incoherent or futile. Messianism is not mentioned in the Torah and its authority is only based on the prophets. In other words, as long as the principle of reward and punishment is affirmed, 
one cannot speak of heresy but only of a case of disobedience to the command to believe in the words of the prophets.

In a situation of forced religious disputes, as Albo experienced them, it was important to emphasize what the commentator Ibn Ezra (10891164) had stressed before, namely that many of the prophecies towards the coming of a messiah had already been fulfilled before Jesus and that other prophecies have never been fulfilled, implying therefore that messiah was still to come.

Albo affirms that among all the nations populating the medieval European landscape it was only Israel which had retained continuity with regard to both name and progeny. Yet he contradicts a merely tribalistic justification of this superiority when he links the names of nations with the respective principles that first came into being with them. "Israelite" thus refers to a believer rather than to the member of a tribe. It is this assertion from which Cohen derives the sense that his own universalizing reading was in agreement with the intention of the medieval Jewish philosopher.

\section{Text 5 Albo: On the Activity of Peace}

One of the pages from a small notepad, 6.7 by $4.3 \mathrm{~cm}$, ink.

Wer Ruhe durch Ruhe sucht,

verliert die Ruhe und findet Mühe

עקרים Schluß (614)

Translation

One who seeks rest by rest

loses rest and finds toil.

Ikkarim end (614)

Notes/Comments

Literal quote from the final chapter of Albo, Sefer Ha'ikkarim, which deals with "peace." Cf. the final chapter (!) of Religion der Vernunft, on peace as a religious virtue. Also cf. Text 8 , below. 


\section{Text 6 Leo Baeck on Levy ben Abraham: God As a Living Being}

11 by $14.3 \mathrm{~cm}$, ink.

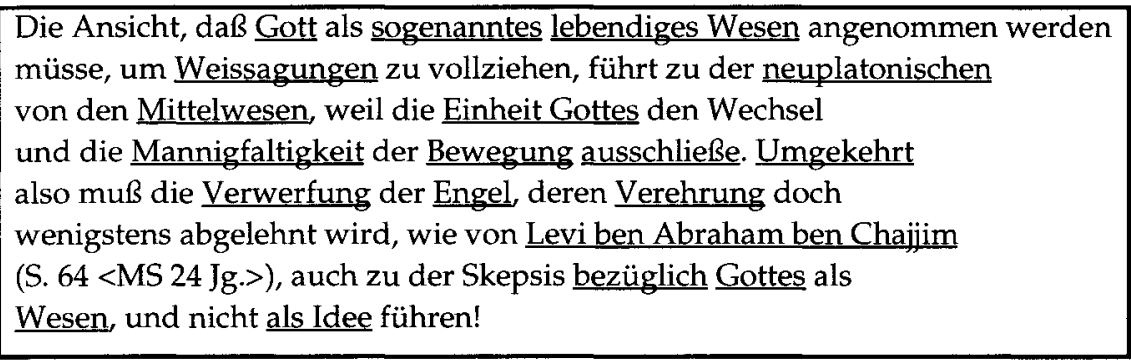

Translation

The view that God must be assumed as a so-called living being, in order to execute prophecies, leads to the neoplatonic one of intermediaries, because the unity of God excludes change and the manifold of movement. Conversely therefore the rejection of angels, whose worship is at least rejected, as by Levi ben Abraham ben Chajim (p.74<MS $24 \mathrm{Jg} .>$ ), must lead to skepticism with regard to God as being rather than as idea!

\section{Notes/Comments}

"Levi ben Abraham ben Chajiim" referred to here is Levi ben Abraham ben Hayyim (c. 1245-1315) also called Levi ben Abraham of Villefranchede-Conflent, philosophic rationalist. Said to have been the grandfather of the eminent Levi ben Gershom (RaLBaG; 1288-1344). Levi ben Abraham is the author of two encyclopedic works, Batey ha-Nefesh ve-ha-Lehashim (ten chapters on philosophy and science, composed in Montpellier, 1276, in rhymed prose) and Livyat Hen (six parts, on various scientific topics and the mysteries of faith). Levi ben Abraham was an Aristotelian and Averroist, and his allegorical exegesis of the Bible was not more radical than that of Maimonides, yet he became the focus of an intense antiphilosophical debate. Cf. EJ 11:91f, 14:353, 3:446, 4:898.

Julius Guttmann writes in Philosophies of Judaism (New York: Schocken, 1973) p.212: "The opponents of philosophy imputed to the philosophic rationalists the hidden intention of destroying the belief in a supernatural divine activity, and of subordinating the whole of reality to the necessary operations of the laws of nature. The objects of these attacks indignantly reflected such imputations, and, in fact, the writings of one of the most maligned of contemporary philosophers, Levi $b$. 
Abraham of Villefranche, show that he was very far from any such extremism-indeed, he never went beyond the position of Maimonides."

More recently, Colette Sirat claimed that the attacks levelled against Levi ben Abraham were due to this author's carrying the allegorical exegesis to such extremes that Torah and aggadah become the indistinguishable raw material for the exposition of hackneyed philosophical notions. Cf. A History of Jewish Philosophy in the Middle Ages, Cambridge: Cambridge University Press, and Paris: Editions de la Maison des Sciences de l'Homme, 1990, pp, 243-247, 436f (lit.).

In this manuscript, Cohen refers to Leo Baeck's article "Zur Charakteristik des Levi ben Abraham ben Chajjim" in: MGWJ, 44 (1900), 24-41, 59-71, 156-67, 337-44, 417-23, specifically to page 64 where Baeck discusses Rabbi Levi's chapter on intermediary beings. Baeck describes the problem in medieval Jewish philosophy that assumed the existence of intermediary beings between God and creation while prohibiting their worship. According to Baeck, R. Levi's text may imply an anti-Christian polemic. The keywords "Einheit Gottes," "Mannigfaltigkeit," and "Wechsel" are at the end of page 64f: "Die philosophischen Gründe, die für die Annahme von Mittelwesen angeführt werden, sind die alten aristotelischen, durch den Neuplatonismus weiter ausgebildeten, denen Abraham Ibn Daud zuerst entschieden Eingang in die jüdische Religionsphilosophie verschaffte: Aus der absoluten Einheit Gottes kann nur eine einzige Bewegung emanieren; die Mannigfaltigkeit (p.65) und der Wechsel des Naturgeschehens kann aus Gott nicht abgeleitet werden."

\section{Text 7 Ritschl: Luther and Political Reason}

13.4 by $5.7 \mathrm{~cm}$ (unevenly torn), written with ink.

Luther denkt den Glauben im sittlichen Gegensatz

gegen die [...], politische ratio.

Ritschl III, 159

Translation

Luther thinks faith in moral opposition against the (...), political reason.

\section{Notes/Comments}

This note refers to Albrecht Ritschl, Die christliche Lehre von der Rechtfertigung und Versöhnung. Volume III: "Die positive Entwicklung der Lehre", second, improved edition, Bonn: Adolph Marcus, 1883. This is Ritschl's only three volume work, and the 1883 edition is the only one where the content of p. 159 deals with the Lutheran concept of faith. Cf. 
"Liebe und Gerechtigkeit" (1900) J 3, p. 85 (references to Wellhausen, Israelitische und Jüdische Geschichte, and Gfrörer as a student of Samson Raphael Hirsch) and p. 65 (Schleiermacher, Ritschl). Cohen's copy of Ritschl's work is preserved at the National and University Library at Givat Ram; in it one can find heavy underlinings and notes on the margins.

\section{Text 8 Ritschl: "Peace as Esthetic Judgment"}

11.5 by $4 \mathrm{~cm}$ (on the longer side, 3.5 on the shorter side; unevenly torn), ink.

Der Friede im Schicksal des MenschenGeschlechts sei ein

ästhetisches Urteil! Urtheil Ritschls u Stahls.

III, $529 \mathrm{f}$.

Translation

Peace in the fate of humankind is supposed to be an esthetic judgment! Ritschl's judgment and Stahl's. ${ }^{40}$

\section{Notes/Comments}

This note refers to Albrecht Ritschl, Die christliche Lehre von der Rechtfertigung und Versöhnung. Volume III: "Die positive Entwicklung der Lehre", second, improved edition, Bonn: Adolph Marcus, 1883 pp. $529 f$. On 'peace' cf. Text 5, above.

\section{Text 9 Excerpts From Wellhausen: On the History of Sacrifice}

\section{5 by $11 \mathrm{~cm}$, ink.}

\begin{tabular}{|c|c|}
\hline \multicolumn{2}{|c|}{ Wellhausen } \\
\hline & 59 Hosea, Jesaia und Micha schließen sich Amos an in \\
\hline 60 & Meines Volkes Sünde essen sie (Hos 8,8$)^{42}$ \\
\hline & Die Altäre sind ihm da, zu sündigen $8,11 .{ }^{43}$ \\
\hline 73 & $\begin{array}{l}\text { שלמים Bundesgemeinschaft zwischen Jahve und den Gästen und diesen } \\
\text { untereinander, }\end{array}$ \\
\hline & "für die Opferidee wesentlich" (Exod. 18,12; 24,11) 44 \\
\hline 75 & 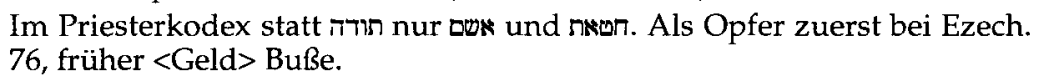 \\
\hline
\end{tabular}

\footnotetext{
${ }^{40}$ Friedrich Julius Stahl (1802-1861), Jewish born, later Lutheran philosopher of law, influenced by Schelling, proponent of strict confessionalism as the basis for the Christian state.

${ }^{41} \mathrm{Cf}$. Wellhausen, Prolegomena (5th edition, 1899), p. 58f.

${ }^{42}$ Ibid p. 58: "Hosea führt 4.6 ss. bittere Klage darüber, dass die Priester statt der Thora die Opfer kultivieren. 'Mein Volk geht unter aus Mangel der Erkenntnis,
} 
76 Das 7.te Jahrhundert für das Blutvergießens sehr empfänglich ${ }^{45}$

Mysterium der Sühne und des

78 'Das Opfer Jah' war ein Mahl der Menschen, bezeichnend für das Fehlen des Gegensatzes von geistlichem Ernst und weltlicher Fröhlichkeit." "Es sind irdische Beziehungen, denen <dadurch> die Weihe gegeben wird." Es "verbindet

Angehörige der Familie" usw. 4679 beim Kriegszug keine Eingeweideschau, sondern Verbündung. ${ }^{47} 81 \mathrm{Im}$ Priesterkodex entsteht die Gemeinde. ${ }^{48}$

83 Im Priesterkodex Beziehung zwischen Opfer und Sünde die früher nicht war, vielmehr <das Opfer> fröhlicher Natur. ${ }^{49}$

91 In der alten Zeit kein menschliches Erstgeburtsopfer, erst kurz vor dem Exil. ${ }^{50}$

110 Fürst und Volk bei Ezechiel Vorstufe der Gemeinde der Stiftshütte und des zweiten Tempels. ${ }^{51}$

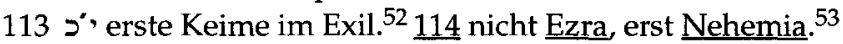

so will auch ich euch verachten, dass ihr mir nicht Priester sein sollt; ihr habt die Thora eures Gottes vergessen, so will ich auch euer vergessen. So viel sie sind, so sündigen sie gegen mich, ihre Ehre vertauschen sie gegen die Schande. Meines Volkes Sünde essen sie und nach seiner Verschuldung tragen sie Verlangen.'“ Here and in the following notes, emphasis is added to indicate passages copied by Cohen literally or slightly modified.

${ }^{43}$ This refers to the continuation in Wellhausen's text (1899, p. 58): "Auch [viz. Hosea] 8,11ss. setzt er die Thora dem Kultus entgegen. 'Ephraim hat sich viele Altäre gebaut, zu sündigen, die Altäre sind ihm da, zu sündigen.' .... ; die Opfer sind also nicht Gegenstand der Weisungen."

${ }^{44}$ Ibid. p. 71: "Durch das Mahl bei Jahve wird eine Bundesgemeinschaft einerseits zwischen ihm und den Gästen, andereseits zwischen den Gästen unter einander gestiftet, welche für die Opferidee wesentlich ist und von der die Schelamim ihren Namen haben.Vgl. Exod. 18,12. 24,11."

${ }^{45}$ Ibid. p. 74: "Die heiligen Strafen, Ascham und Chattath, als Opfer finden sich zuerst bei Ezechiel und scheinen an die Stelle der gleichnamigen Geldbussen (2. Reg. $12,17)$ getreten zu sein; wol im siebenten Jahrhundert, welches für das Mysterium der Sïhne und des Blutvergiessens sehr empfänglich und in der Einführung neuer Kultusgebräuche recht fruchtbar gewesen zu sein scheint." $\mathrm{Cf}$. also pp. $72 \mathrm{f}$.

${ }^{46}$ Beginning of summary of Wellhausen's paragraph on sacrifices, p. 76: "Das Opfer Jahves war ein Mahl der Menschen, bezeichnend fïr das Fehlen des Gegensatzes von geistlichem Ernst und weltlicher Fröhlichkeit. Ein Mahl bedingt einen abgeschlossenen Kreis von Gästen: so verband das Opfer die Angehörigen der Familie, die Glieder der Korporation, die Genossen des Heeres und jedweder dauernden oder vorübergehenden Vereinigung. Es sind irdische Beziehungen, denen dadurch die Weihe gegeben wird".

${ }^{47} \mathrm{Cf}$. ibid.: "Kein Kriegszug, der nicht auf diese Weise eingeleitet, keine Verabredung, die nicht dadurch perfekt wurde, kein irgend wichtiges Unternehmen ohne Opfer". "Verbündung" cf. previous note.

${ }^{48}$ Cf. ibid. p. 78: "Jetzt verlieren sich die kleinen Sakralgemeinschaften, die bunten Kreise des Lebens verschwinden in dem Schatten der universalen Gemeinde". Cf. Cohen, J 1, 130: "Das Volk sollte verjüngt werden. Entstanden aber 
ist die Gemeinde. Die Gemeinde ist nicht nur der Sonderbund der Gläubigen. Sie ist im prophetischen Begriffe die Vereinigung der Menschen über Stände und Völker zur Einheit des Gewissens, zur Einheit der sittlichen Menschheit."

${ }^{49}$ Cf. ibid. p. 80: "Der zweite Punkt betrifft folgendes. In dem Maasse wie die speziellen Ânlässe und Zwecke der Opfer wegfallen, tritt ein gleicher allgemeiner Anlass hervor die Sünde, und ein gleicher allgemeiner Zweck, die Sühne. Im Priesterkodex ist bei allen Tieropfern das eigentliche Mysterium die Sühne durch das Blut; am reinsten ausgebildet scheint dieselbe bei den Sünd- und Schuldopfern, welche ebensowol für den Einzelnen, als für die Gemeinde und ihr Haupt dargebracht werden. In dem grossen Versöhnungstage gipfelt in gewisser Hinsicht der ganze Gottes- und Opferdienst, dem bei aller Verschiedenheit der Riten eine durchgehende Beziehung auf die Sïnde gemeinsam ist. Hievon lassen nun die alten Opfer wenig merken. Wol suchte man ehedem durch reiche Gaben auf die zweifelhafte oder drohende Stimmung der Gottheit einzuwirken und ihr Angesicht zu glätten, aber die Gabe hatte dann naturgemäss den Charakter des tastenden Versuchs (Mich. 6,6). Der Gedanke lag fern, dass eine bestimmte Schuld durch ein vorgeschriebenes Opfer gesühnt werden müsse und könne. Wenn im Gesetz zwischen solchen Sünden, die durch ein Opfer gedeckt werden, und solchen, die unnachsichtlich den Zorn nach sich ziehen, unterschieden wird, so ist diese Unterscheidung durchaus nicht antik; für das hebräische Altertum war der Zorn Gottes etwas völlig Unberechenbares, man kannte nie seine Ursachen, geschweige dass man im voraus die Sünden hätte angeben können, die ihn erregen und nicht erregen." [Note 1: "Wenn sich der Zorn nach den Regeln "des Bundes" richtet, so ist der ursprüngliche Begriff vollständig alteriert: der spottet der Abmachung. Gerade dass man sich auf keine Weise davor in Acht nehmen und nichts dagegen machen konnte, gab der Sache ihr unheimliches Grauen.-Unter dem Druck des Zornes Jahves unterliess man nicht nur das Opfern, sondern vermied es sogar seinen Namen zu nennen, um seine Aufmerksamkeit nicht auf sich zu lenken. Os. 3,4.9,4. Amos 6,10.] Im allgemeinen fand eine obligate Beziehung der Opfer zur Sünde durchaus nicht statt. Sie waren durchweg fröhlicher Natur, ein sich Freuen vor Jahve, bei Sang und Klang, unter Pauken Flöten und Saitenspiel (Os. 9,1ss. Amos 5,23. 8,3. Isa 30,32). Kein grösserer Gegensatz hiezu, als der monotone Ernst des sogenannten mosaischen Kultus."

${ }^{50}$ Cf. Ibid. p. 88: "Eine regelmässige und geforderte Abgabe ist in der alten Zeit das menschliche Erstgeburtsopfer auf keinen Fall gewesen (...). Erst kurz vor dem Exil kam mit vielen Neuerungen das Kinderverbrennen im grossen Stil auf (...).

${ }^{51}$ Cf. ibid. p. 105: "Ezechiel ist der Vorläufer des priesterlichen Gesetzgebers im Pentateuch, sein Fürst und Volk [emphasis in the original] die noch eingermassen von der vergangenen Königszeit gefärbte Vorstufe der Gemeinde [emphasis in the original] der Stiftshütte und des zweiten Tempels."

${ }^{52}$ Cf. ibid. p. 108: “Trotz seiner überragenden Wichtigkeit ist der Versöhnungstag weder im jehovistisch-deuteronomischen Teile des Pentateuchs (...) noch in den historischen und prophetischen Büchern bekannt. Seine ersten embryonischen Keime zeigen sich im Exil."

${ }^{53}$ Cf. ibid. p. 109: "Ezra beginnt die Vorlesung des Gesetzes am Anfang des 7. Monats, darnach wird am 15. Laubhütten begangen: von einer Sühnfeier am 10. des Monats wird in der genauen und gerade für Liturgisches interessirten Erzählung nichts berichtet, sie wird dagegen am 24. nachgeholt (Nehem. 8.9). Dies 
Translation

59 Hosea, Isaiah, and Micah follow Amos in his polemics against sacrifices ${ }^{13}$

60 They eat the sin of my people (Hosea $8: 8)^{14}$

The altars are there for him to $\underline{\sin }(8: 11)^{15}$

73 sh'lamim covenantal communion between Yahweh and the guests and among those themselves, "essential for the idea of sacrifice" (Ex. 18:12, 24:11) ${ }^{16}$

75 In the Priestly Code instead of todah only asham and hatat. As sacrifice only in Ezekiel. 76, earlier <money> fine.

76 The 7 th century susceptible for mystery of sin and shedding of blood. ${ }^{17}$

78 "The sacrifice of Yah' was a human meal, characteristic for the lack of an opposition between spiritual solemnity and secular blitheness." "It is the earthly relations which <thereby> received their dignity." It "connects between members of the family" etc. ${ }^{18} 79$ during a military campaign no augury but covenanting. ${ }^{19} 81$ In the Priestly Code the community comes into being. ${ }^{20}$

83 In the Priestly Code relation between sacrifice and sin which did not exist earlier, rather < sacrifice> of a cheerful nature. ${ }^{21}$

91 In ancient times no human sacrifice of firstborns, only shortly before the exile. $^{22}$

110 Prince and people in Ezekiel preliminary stage of the community of the tabernacle and of the second temple. ${ }^{23}$

113 Yom Kippur first seeds in exile. ${ }^{24} \underline{114}$ not Ezra, only Nehemiah. ${ }^{25}$

\section{Notes/Comments}

This page contains exerpts from Julius Wellhausen, Geschichte Israels, first edition (1878). ${ }^{54}$ Wellhausen's eloquent critical historical reconstruction of the history of Israel based on the relative dating of the sources of the Pentateuch that builds on the work of Reuss, Graf, and Kuenen became an instant classic. It established assumptions about the historical sequence of the sources of the Pentateuch that are still widely shared. As stated in the book's preface, the main question Wellhausen addresses is whether the Mosaic law is the origin (and product) of Israel (i.e., that of the Hebrew tribes and their subsequent kingdoms before the Babylonian exile) or that of Judaism (i.e., that of the religious community emerging from the catastrophic destructions of 722 and 586).

Wellhausen's work is usually seen as the final point in a development which had begun in the 18th century with the first modern

testimonium e silentio ist vollgiltig-bis dahin bestand der grosse Tag des Priesterkodex nicht, der erst jetzt eingeführt wurde."

${ }^{54}$ The later editions were published under the title Prolegomena zur Geschichte Israels. Cohen's excerpts can only refer to the first edition. I thank Hartwig Wiedebach for ascertaining the exact edition. 
attempts of historical criticism. ${ }^{55}$ The critical method and the assumption of the Pentateuch's composition out of various documents is uncontested among scholars. However, the late dating of the Mosaic law has been challenged by the studies of Y. Kaufmann and his students and is still debated among Christian and Jewish students of the Hebrew Bible. ${ }^{56}$

Hermann Cohen's personal relationship with Wellhausen is documented in the last text Cohen published himself, an eulogy on his former Marburg colleague. ${ }^{57}$

The central issue in the excerpts is the position of the sacrifices in the development of the religion of Israel, a topic Cohen continuously tackled over the years. In the essay "Die Versöhnungsidee," ${ }^{58}$ Cohen presents a view of the original character of Israelite sacrifice which corresponds to the view held by Wellhausen in his Geschichte Israels. Both assume that the sacrificial cult underwent certain changes. Wellhausen sketches the development of sacrifices from their earliest forms as festive meals of the family or community in the presence and under the participation of their deity, a joyous feast, ${ }^{59}$ to the later stages described in the Priestly Code in highly technical priestly language, emphasizing guilt- and sin-offering. Out of the dating of biblical material and based on axioms about natural as opposed to institutionalized religion a tendency emerges which leads from the natural expression of gratitude towards the deity (pre-exilic Israelite religon) towards an highly elaborate and abstract clerical institution of sacrificial practice (exilic and post-exilic Judaism). While Cohen extracts the basic historical facts from Wellhausen's study he comes to an independent conclusion which runs counter to the Christian scholar's evaluation.

${ }^{55} \mathrm{Cf}$. Rudolf Smend, Die Entstehung des Alten Testaments, Stuttgart, Berlin, Köln, Mainz: Kohlhammer, 1978, p. 34.

${ }^{56}$ See, most recently, the monograph of Thomas M. Krapf, Die Priesterschrift und die vorexilische Zeit. Yehezkel Kaufmanns vernachlässigter Beitrag zur Geschichte der biblischen Religion, Freiburg/Switzerland: Universitätsverlag; Göttingen: Vandenhoeck \& Ruprecht, 1992, which gives a good introduction to the relevant literature and the implications of Wellhausen's position.

57 "Julius Wellhausen. Ein Abschiedsgruß” in: Neue Jïdische Monatshefte 1918, Jan. 25, Nr. 8, pp. 178-181. Also in J 2, 463-468. For an impression on Wellhausen's attitude towards Cohen see a letter by Wellhausen of July 19, 1906 where he writes: "Mein Naturell ist anders als Cohens, und ich pfeife auf die humanistische Philosophie, die gewöhnlich doch nur nachdenkt, was von anderen intuitiv vorgedacht oder von ganzen Völkern und Gemeinschaften erlebt ist." Quoted in Lothar Perlitt, Vatke und Wellhausen. Berlin: Töpelmann, 1965, p. 240.

${ }^{58}$ For the date of composition of the essay "Die Versöhnungsidee" see the editor's comment in $\mathrm{J} \mathrm{1,} \mathrm{p.} 338$.

${ }^{59} \mathrm{Cf}$. Wellhausen (1899), pp. 62 and 71. 
In the second half of the 20th century, Wellhausen's construction of history has also attracted much criticism among Christian theologians. Lothar Perlitt showed that Wellhausen's history was guided by historicophilosophical axioms that are no longer acceptable and Rolf Rendtorff has been fighting against the blinding effect Wellhausen's construction of the religious history of Israel had on German Old Testament scholarship in particular. ${ }^{60}$ However, the Wirkungsgeschichte must not be confused with the historical origins and it may be that Wellhausen is unjustly blamed for the thoughtlessness or viciousness of those who perpetuated the man's weaknesses without acquiring any of his strengths.

Wellhausen was primarily a philologist. When he found historical phenomena which contradicted an all too neat construction of history, he needed at least to mention these in a footnote. This can be seen on page 81 (5th edition, 1899) where Wellhausen mentions that contrary to his characterization of the development of the Israelite sacrifice from a joyous occasion to a solemn cult of atonement the rejoicing of old was continuously cultivated in Israel in the poetry and music of the Jewish service. In this note, Wellhausen attributes this to the recovery of Israel which grew from a "pitiful sect to people again." This illustrates two aspects of Wellhausen's intentions. Firstly, he was not interested in antiSemitic propaganda when he wrote about the historical development from the heights of folk-religion to the low point of clerical petrification. Secondly, this passage illustrates the accuracy of what Cohen wrote in 1918 about the bond between Wellhausen and himself. Their friendship, according to Cohen, rested on their common love of music. Quite obviously, this love of music was seen not just as a matter of taste but as the expression of the religion of the heart.

Cohen chose to disregard Wellhausen's historical and philosophical views as immaterial for the evaluation of his philological merits. In the genteel style expected in an academic obituary Cohen (1918) simply puts Wellhausen in his place when he says that he had no sense whatsoever for "the Jewish religion in its continued existence in world history" (J 2, 466), a most severe criticism considering the sweeping allegations Wellhausen makes about the tendency of Jewish religious history. ${ }^{61}$

${ }^{60}$ Perlitt: see note above; Rolf Rendtorff on many locations, most recently in "The Image of Postexilic Israel in German Bible Scholarship from Wellhausen to von Rad" in: Sha'arei Talmon. Studies in the Bible, Qumran, and the Ancient Near East, (ed. M. Fishbane/Emanuel Tov, Winona Lake: 1992, 165-173. Cf. Thomas M. Krapf, op. cit. p.20f and passim on the debate between Smend and Rendtorff over this issue.

${ }^{61} \mathrm{Krapf}$ (op.cit.) presents Rendtorff's analysis of the final paragraph of the Prolegomena, where Wellhausen calls St. Paul the "great pathologist of Judaism" which implies the death of Judaism. Another passage is also very revealing of 
This, of course, is an extremely relevant point for Cohen himself. He obviously tried to integrate the best available scholarship with the intention to construct a history of Judaism as a living faith. His intention was partly to counter the image of a deadly legalistic and historically and culturally obsolete ghost of a religion projected by Christian scholars who may have had no worse intention than-in a bad Enlighenment tradition (with Voltaire and others) - to destroy the church by eroding its Jewish base. The other challenge Cohen faced was that despite the tremendous achievements in Jewish scholarship made during the 19th century, those Jews who had no formal training in Jewish studies and who did not read Hebrew received much of their knowledge about the history of Judaism from Christian authors (Weber, Herford, Bousset, Gressmann, et. al.). ${ }^{62}$ In many publications and public initiatives Cohen pursued the improvement of Jewish learning from basic education through the academic level. ${ }^{63}$

In the essay "Die Versöhnungsidee," Cohen characterizes the earliest stages of the sacrifices as unrelated to the problems of guilt and atonement.

\begin{abstract}
Just as the Greeks of that primeval time relished desire and rejoicing in the presence of their gods, the Israelites in the beginnings of their cult rejoiced not so much before their God as with him. These beginnings are the first stage of the sacrificial cult. (J 1, 125)
\end{abstract}

Wellhausen's views, namely the final passage of the chapter from which Cohen takes most of his excerpts (1899, p.81): "In dieser Weise zeigt sich im Priesterkodex die mit der Centralisierung gleichlaufende Vergeistlichung des Gottesdienstes. Er erhält so zu sagen einen abstrakt gottesdienstlichen Charakter, er scheidet sich zunächst vom Leben und absorbirt es sodann, indem er das eigentliche Geschäft desselben wird. Das ist für die Zukunft von folgenschwerer bedeutung geworden. Die mosaische Gemeinde ist die Mutter der christlichen Kirche ; die Juden sind es, die den Begriff geschaffen haben." Here it becomes clear that if Wellhausen attacks Judaism he attacks the church as well. Hence Cohen may be correct in simply ignoring this aspect since it is mainly the expression of an enthusiastic but generic anticlericalism, very much in the spirit of the Kulturkampf and similar to the views held by the majority of liberal Protestants at the time. This does not mean that Cohen agrees with Wellhausen in this negative view of community.

${ }^{62} \mathrm{Cf}$. the introduction to the "Study of the Beliefs and Concepts of the Sages" by Urbach, Sages, vol. I, pp. 1 ff.

${ }^{63}$ See, e.g., the essays "Die Errichtung von Lehrstühlen für Ethik und Religionsphilosophie an den jüdisch-theologischen Lehranstalten" (1904; the same year, Cohen began to teach at the Lehranstalt für die Wissenschaft des Judentums in Berlin), "Gedanken über Jugenslektüre" (1906), "Zwei Vorschläge zur Sicherung unseres Fortbestandes" (1907), "Die Liebe zur Religion" (1911), etc. (all in J). 
In Part I, I compare this and other statements with the excerpts from Wellhausen and evaluate Cohen's use of Protestant Old Testament scholarship. There is no doubt that the essay on the idea of Versöhnung responds to Wellhausen's study. ${ }^{64}$

\section{Text 10 Gfrörer: Hellenism and a Linear Concept of the History of Judaism}

The manuscript measures 10.4 by $15.5 \mathrm{~cm}$ and is a sheet from a note pad.

Gfrörer, Philo II

196 Im IV. Buch der Makkabäer ruft Eleasar: Laß<Empfange> mein Blut als

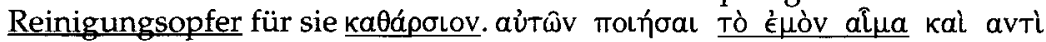

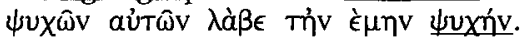

249 der Gerechte ein Sohn Gottes. "Er prahlt mit seinem Vater."

251 (Auch Buch der Weisheit) "unser Volk ein Sohn Gottes"

292 Philo, der einzige Autor, der über die Therapeuten berichtet $=$ Sie sind der Ursprung der <Essäer $>345$.

345 Asarja in Meor Enajim über Ursprung der Essäer aus den Therapeuten ([...] izezia)

401 Bei Philo $\lambda o$ yos $=$ Messias

351 Maimonid (ad <tr.> Sota) וזה שהם קורים חכמת יונית הם הרמזים שהם

II, 2 Allegorie

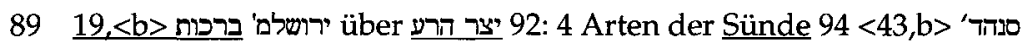
חזובח את יצרו

96 31,b 102 Durch Adam den Tod, nicht die Sünde vererbt. Dagegen 102.

113 Schicksal und Freiheit Mischna Rosch haschana I, 2 und 'רושלמ dazu besonders $\underline{115}$

136 Nächstenliebe, Talmud Stellen 142 Gebet: 17, a 'ברכ' ירושל

145 מלכות שמים

152 Buße[triple underlined in the original] 154 -Glauben 159-165

שכת als Versöhnungsmittel 179, $180 \mathrm{f}$ sind Sprüche betreffend Versöhnung angeführt, welche vielmehr die Correctur der Vorstellung vom זכוח אבות zu beweisen scheinen Sündenbekenntnis [?]

183 Berach. 10, b Eigene u fremde Verdienste

${ }^{64}$ Note that Cohen continues to read and discuss not only Wellhausen but also some of the other authors represented among those which are documented in these manuscripts; cf. "Liebe und Gerechtigkeit" (1900) J 3, 85 (references to Wellhausen, Israelitische und Jüdische Geschichte, and Gfrörer as a student of Samson Raphael Hirsch) and p. 65 (Schleiermacher, Ritschl). 
Translation

Gfrörer, Philo [vol.] II

196 In the IV.th Book of the Maccabees Eleazar calls: Let <Receive > my blood as a sacrifice of purification for them katharsion auton poiesai to emon haima kai anti psuchon auton labe ten emen psuchen.

249 the righteous as a son of God. "He boasts of his father."

251 (From the Book of Wisdom) "our people a son of God"

292 Philo the only author reporting on the Therapeutes = They are the origin of the $<$ Essene $>345$.

345 Azariah in Me'or Enayim on the origin of the Essenes from the Therapeutes ([...] baytussim)

401 In Philo logos = messiah

351 Maimonides (on <tractate> Sota) ve-zeh shehem korim hokhmat yevanit hem haremazim shehem b'leshonot shenotim miderekh hayesharah Allegory

II, 2

89 Yerushalmi Berakhot $19<\mathrm{b}>$ on yetser ha-ra' $92: 4$ kinds of sin 94 Sanhedrin $<43 \mathrm{~b}>[:]$ ha-zoveah et yitsro

96 Berakhot 31b [:] asher hir'ati 102 Through Adam inherited death, not sin. [See] However 102.

113 Fate and freedom Mishnah Rosh Hashanah I:2 and Talmud Yerushalmi on this in particular 115

136 Love Thy Neighbor, talmudic passages 142 Prayer: Yerushalmi Berakhot 17a

145 malkhut shamayim

152 repentance [triple underlined in the original] 154-faith 159-165 shabbat as a means of atonement $179,180 \mathrm{f}$ are verses concerning atonement that rather seem to prove the correction to the notion of a zekhut avot confession of sin [?]

183 Berakhot $10 \mathrm{~b}$ merits, one's own and those of others

\section{Notes/Comments}

This and the following manuscript contain excerpts from two works by the historian August Friedrich Gfrörer (1803-61) a friend of the eminent Göttingen New Testament scholar and historian Friedrich Lücke (17911855) whose hermeneutics was inspired by Schleiermacher and Herder. ${ }^{65}$ Gfrörer is known as the founder of the modern study of apocalypticism.

Gfrörer's works on Philo of Alexandria and on the Jewish background of the theologies of the New Testament are memorable from

${ }^{65}$ Lücke co-founded and drafted the principles of the scholarly journal Theologische Studien und Kritiken. Cf. RGG (3. ed.), 4:470. On Gfrörer see ibid. 2:1565. For an assessment of Lücke's contribution to hermeneutics and the study of apocalypticism see Johann Michael Schmidt, Die jüdische Apokalyptik. Die Geschichte ihrer Erforschung von den Anfängen bis zu den Textfunden von Qumran. 2. revised edition, Neukirchen/Vluyn: Neukirchener Verlag, 1976, 98-100. And cf. Hermann Cohen "Liebe und Gerechtigkeit" (1900) J 3, 85 (references to Gfrörer as a student of Samson Raphael Hirsch). 
a scholarly as well as from an ethical and political point of view. Gfrörer resisted the dialectical scheme of history presented by Hegel and his followers. Rather, he was interested in the organic development of ideas. ${ }^{66}$ Hence he was able to demonstrate the lines within the Jewish tradition which were taken up in the early Christian church. In order to do this convincingly and based on documents he studied with various rabbinic scholars (especially with the young Samson Raphael Hirsch) and read the publications of the first generation of scholars associated with the movement of the Wissenschaft des Judentums (especially Abraham Geiger). Gfrörer was not the only one in the early 19th century to see the development from biblical to post-biblical Judaism as a linear and ascending one. Given the influence of academic anti-Semitism in the later 19th century, however, it took until the 1920's before the study of Jewish apocalypticism and the role of Jewish eschatological speculations in the formation of early Christianity was revived in the works of Johannes Weiß ${ }^{67}$ and Albert Schweitzer. W. Bousset valued Gfrörer as the predecessor of Gunkel in his discovery of the principle of the correspondence between Urzeit and Endzeit in Jewish apocalypticism. ${ }^{68}$ With respect to Gfrörer's attitude towards Judaism, it is significant that he expected that the objective study of Jewish history would result in an improvement in Christian-Jewish relations. ${ }^{69}$

The first ten lines of Cohen's excerpts refer to Gfrörer's study on Philo of Alexandria (Kritische Geschichte des Urchristenthums 1. Theil. Philo und die jüdisch-alexandrinische Theosophie. II. Abtheilung Stuttgart: E. Schweizerbart's Verlagshandlung, 1831, Second edition 1835). ${ }^{70}$ The remainder of the notes refer to Das Jahrhundert des Heils, Zweite

${ }^{66}$ See Schmidt's summary, op.cit., pp. $152 \mathrm{ff}$.

${ }^{67}$ Cf. J.M. Schmidt (1976), pp. 12-15 and, on Weiß' rediscovery of eschatology, Berthold Lannert, Die Wiederentdeckung der neutestamentlichen Eschatologie durch Johannes Weiss (Tübingen, 1989). Weiß was A. B. Ritschl's son in law and, ironically, deprived the Ritschlians of one of their central ideological pillars, Ritschl's ethical interpretation of the theologumenon of the kingdom of God. Cohen viewed Ritschl's interpretation of the gospel as a sign of a potential convergence between Christianity and Judaism. See above, Pt. II., on BR.

${ }^{68}$ Ibid. 15 and $221 \mathrm{ff}$.

${ }^{69} \mathrm{Cf}$. ibid. pp. $24 \mathrm{f}$ note 75 and H. Liebeschütz, Das Judentum im deutschen Geschichtsbild von Hegel bis Max Weber (1967), 101-110. My former teacher G. Maron fails to mention any of these facts in his article on Gfrörer in RGG (3. ed). What he finds most memorable about his subject is his conversion from Protestantism to Catholicism in 1853 in the wake of his yearning for the restoration of the Christian European Empire under German leadership, contradicting the kleindeutsche Lösung championed by the Protestant kingdom of Prussia.

${ }^{70}$ H.A. Wolfson (Philo, 2 vols, 1940) recognizes his predecessor in ample annotation. 
Abtheilung, vol. 2, Stuttgart: E. Schweizerbart's, 1838, which is the second part of Gfrörer's Geschichte des Urchristenthums (five volumes, 1838).

Comments on the excerpts from Philo und die jüdisch-alexandrinische Theosophie, II

ad p. 196: Cohen's underlining emphasizes the equation of blood and soul as a means of purification (= atonement) based on Lev. 17:11, i.e., he recognizes that 4. Macc 6:29 expresses its peculiar theology of the atoning power of martyrdom in language evoking and utilizing one of the most important verses on atonement in the Torah and, perhaps, the most abstractly formulated one. ${ }^{71}$ The editors characterize 4 . Maccabees as influential mainly in the Eastern Churches and as one of the

classic example(s) of the interpretation of Judaism in terms of Greek philosophy. (...) The author's theology, with its emphasis on the absolute sovereignty of the Law, is genuinely Jewish but with two special characteristics. The martyrdoms are a substitutionary atonement that expiates the nation's sin and purifies the land (1.11; $17.21 ; 18.4)$. The martyrs are immediately immortal, received by the patriarchs and living in God $(7.19 ; 16.25)$.

The book was composed some time between 63 B.C.E. and 70 C.E., either in Alexandria or, more likely, in Antioch. Gfrörer presupposes Alexandrinian provenance.

Gfrörer highlights the connection between virtues and self-sacrifice (martyrdom) as means to achieve divine grace ("noch ein großes, dem Offenbarungsglauben angehöriges, Gnadenmittel, nämlich die Opfer'). Gfrörer's purpose is to explain the development of New Testament ideas from their immediate historical Jewish predecessors. He finds that "no other Alexandrian writing is as suitable as this one to shed light on the teaching of the New Testament in this respect," i.e., with respect to the atoning power of the death of the righteous. ${ }^{72}$ The closest New

\footnotetext{
${ }^{71}$ Cf. Sherman E. Johnson and John Breck, "Preface to 4 Maccabees" in The New Oxford Annotated Bible (New York, 1991).

${ }^{72}$ There are other Jewish texts from the Hellenistic period which testify to the wide currency of martyrological meditations. See 2. Macc 7; Test. Jos. 19:11, Test. ben. 3:1.6-8, Frag. Targum and Neofiti ad Gen 22, 1QS 8:6.10, 9:4; CD 14:19; Apoc. Elijah 3:33, Josephus, Bell Jud V. 9:4 (419). See also Sifra ad Lev 10:3 representing a reinterpretion of the death of Aaron's sons as the atoning death of righteous ones (cf. Judith 8:10f, Lev. 10:3LXX and 1QM XVI,3-XVII). Martyrology in other rabbinic traditions: bGittin 57b, bSanh $96 \mathrm{~b}$, jTaanit 69a. Jewish martyrologies are further produced throughout the Middle Ages in liturgical poetry; cf. Shalom Spiegel, The Last Trial (New York: Pantheon, 1969). On the important martyrological motif of the "binding of Isaac" see further Aharon (Ronald E.) Agus, The Binding of Isaac and Messiah. Law, Martyrdom and Deliverance in Early Rabbinic Religiosity, Albany: SUNY Press, 1988 and G. Vermes, "Redemption and
} 


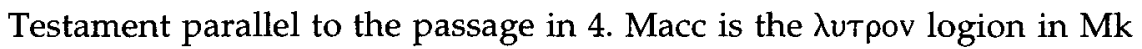
$10: 45 b .^{73}$

Within the early Christian tradition the death of Jesus was regarded by many as the death of a martyr. ${ }^{74}$ Moreover, the suffering of the members of the body of Christ (i.e., the Christians) was seen as the continuation or even "fulfillment" of Christ's suffering (cf. Col.1:24) ${ }^{75}$ Eventually, however, other trends prevailed which saw the essential difference between Christ and other Jewish and Hellenistic pious martyrs in the idea that the atoning death of Jesus supersedes its predecessors and contemporaries "once and for all" (ephapax).

In Religion der Vernunft aus den Quellen des Judentums (1919), Cohen does not connect martyrdom with atonement but interprets it as an expression of the virtue of courage which, in Cohen's understanding of Judaism, is connected to the virtue of righteousness (cf. RV chapters 19 and 20). Cohen follows Gfrörer in seeking a continuity between the revelation-based belief in the meaning and efficacy of sacrifice and the virtue theory put forth in the interpretatio Graeca. ${ }^{76}$

Genesis XXII-The Binding of Isaac and the Sacrifice of Jesus" in: Scriptures and Tradition in Judaism: Haggadic Studies (Leiden, 1961), 193-227.

${ }^{73} \mathrm{Cf}$. Jürgen Roloff, review of "Volker Hampel, Menschensohn und historischer Jesus" (1990) in: Biblische Zeitschrift (ed. J.Schreiner, H.J. Klauck) NF 1991 Jg 35 Heft 2, pp. 259-262. Note that the Greek $\lambda v \tau$ To

${ }^{74} \mathrm{Cf}$. Brian E. Beck, "Imitatio Christi and the Lucan Passion narrative" in: Horbury/McNeil (ed.) Suffering and Martyrdom in the NT (Cambridge, 1981), 2847, David Flusser, "Das jüdische Martyrium im Zeitalter des Zweiten Tempels und die Christologie" in Freiburger Rundbriefe 25/1973, 187-194, Paul Garnet, Salvation and Atonement in the Qumran Scrolls, Tübingen: J.C.B. Mohr (Paul Siebeck), 1977, J. W. van Henten (ed.), Die Entstehung der juidischen Martyrologie, Leiden: Brill, 1989 William Horbury, "Suffering and messianism in Yose ben Yose" in: Suffering and martyrdom in the New Testament, 1981, p143-182, Eduard Lohse, Märtyrer und Gottesknecht. Untersuchungen zur urchristlichen Verkündigung vom Siihnetod Jesu Christi (2.ed. 1963), and J.C. O'Neill, “Did Jesus teach that his death would be vicarious as well as typical?" in: Horbury, William (ed.) Suffering and martyrdom, pp. 9-27. The third Gospel seems to promulgate this view in particular. Cf. Brian E. Beck, op. cit., pp. 28-47 and see C.F.D. Moule's introduction, ibid., p. 3. The whole discussion on how to interpret Mark 10:45b belongs into this context. Cf. Volker Hampel Menschensohn und historischer Jesus (1990) reviewed by J. Roloff in Biblische Zeitschrift, NF 1991, Jg.35/2, pp. 259-262.

75 See the articles by Hooker and Flemington in the collection edited by Horbury/McNeil (see previous note).

${ }^{76}$ The Stoic character of 4 . Maccabees is also emphasized in the recent study by Urs Breitenstein, Beobachtungen zu Sprache, Stil und Gedankengut des Vierten Makkabäerbuchs (Basel/Stuttgart: Schwabe, 1976). According to Breitenstein, 4. Maccabees sees martyrdom as an illustration of the principle of the domination of the human passions (pagh) by reason. 
ad p. 249: Quote from the apocryphal book Wisdom of Solomon 3:18a and $16 \mathrm{~b}$, passages from a speech mocking the righteous.

We are considered by him (viz. the righteous) as something base, and he avoids our ways as unclean; he calls the last end of the righteous (dikaios) happy, and boasts that God is his father. Let us see if his words are true, and let us test what will happen at the end of his life; for if the righteous man is God's child (uios theou), he will help him, and will deliver him from the hand of his adversaries. Sapientia Salomonis.3:16-18 (NRSV)

In his commentary Gfrörer identifies the dikaios with the people of Israel as a whole, parallel to the suffering "servant of Jehovah" of Isa. 53.

The larger context of Gfrörer's passage is also significant for Cohen's understanding of sin and atonement in Judaism. While Wisdom 2 is quoted by Gfrörer as an example of the negation of the equation of (collective) sin and (collective) suffering as a punishment, chapters 3 and 4 see reward for the righteous and punishment of the wicked as extended across generations. This is in deviation from the individuation of guilt inaugurated by Ezekiel, as Cohen emphasizes elsewhere. ${ }^{77}$

ad p. 251: Gfrörer observes an ambiguity on the part of pseudo-Solomon with regard not only to the question of individual or collective guilt, but also with regard to the subject of righteousness. Like Philo, Gfrörer says, the author of Wisdom solves the "same contradiction (...) by making the Jews a holy people." His prooftexts are 10:15, 18:13, 3:9, 4:15 (xapıs кal $\epsilon \lambda \epsilon O \varsigma$, cf. 1. Tim 1:2, 2. Tim 1:2, 2. Joh 3). Cohen's note refers to the passage 18:13 in Gfrörer's translation: "Da die Aegypter vorher wegen der Zaubereien (ihrer Weisen) nicht glauben wollten, mußten sie jetzt bei dem Tode der Erstgeburt anerkennen, daß unser Volk ein Sohn Gottes sey."

ad p. 292: Gfrörer describes Philo's exposition of the teachings of the therapeutx (literally: "healers"), a Jewish sect which is otherwise unknown. They are surmised to be an Egyptian Jewish parallel group to the Essenes. The latter sect is also described by Josephus, and it is generally assumed that they are identical with the sectarians from Qumran. On page 345, after describing the teachings of the therapeutes (according to Philo) in detail and juxtaposing them with Josephus' account of the Essenes, Gfrörer draws the conclusion that the Essene sect

${ }^{77}$ Cf. "Die Versöhnungsidee," J 1 p. 128: “Die Erfassung dieses Gedankens ist der fundamentalste Fortschrittt der ganzen Versöhnungslehre", but also see Ethik des reinen Willens, fifth edition, 1981, $298 \mathrm{f}$ and 365, as well as in Begriff der Religion, 1915 , p. 56 and 125, RV, chapters $x$ and $x i$. 
was imported from Egypt and that it was an offshoot of the Alexandrian therapeutes.

\begin{abstract}
Also die Lehre und die Anstalt der Essäer ist aus einem anderen Lande nach Judäa eingeführt worden. Folglich stammt sie aus Aegypten, und der Orden der Therapeuten ist die Muttergesellschaft. Diese Wahrheit ist so einleuchtend, daß sie sich Jedem bei dem ersten Anblicke empfehlen muß. Denn unter den Juden Aegyptens fanden sich, wie aus dieser unserer Schrift klarr hervorgeht, seit 200 Jahren alle Bedingungen beisammen, welche das Institut der Therapeuten hervorbringen mußten. Ihre Mystik ist die herrschende Lehre der meisten Hellenisten. (Gfrörer, op.cit., p. 345)
\end{abstract}

Gfrörer supports the plausibility of the theory that Jewish mystical sectarian ideas were exported from Egypt to Palestine not only by pointing to the facts of geographic proximity, economic ties, and regular pilgrimages to Jerusalem. He also adds a psychological observation which he finds verified in his contemporary Jewish culture.

Die Verpflanzung aus Aegypten nach Palästina ist höchst begreiflich wegen der Nähe beider Länder, wegen des häufigen Verkehrs durch Handel und die gesetzlichen Festreisen, endlich wegen der jedem Juden so natürlichen Sehnsucht, seinen Glauben und seine Ansicht von der väterlichen Religion, auch in dem Lande der Verheißung, in dem Erbtheile der Väter, ausgebreitet zu sehen. Aus eben diesem Grunde finden sich noch bis auf diese Stunde alle verschiedenen Ansichten, welche das heutige Judenthum kennt, in und um Jerusalem vereinigt.

This is a remarkable statement because it provides an insight into the fact that even in the late 1820's Jerusalem was known as a place where all sects and movements of Judaism were represented by people who perpetuated the ancient desire to have their understanding of the tradition represented at this sacred center.

ad p. 345: Gfrörer credits Azariah de Rossi ("since Maimonides the wisest among the rabbis") with having been the first to recognize the historical relation between Essenes and Therapeutes (in Me'or Enayim, Mantua, 1573).$^{78}$ The Hebrew word Cohen adds in parentheses is misspelled. Gfrörer quotes de Rossi's derivaton of the talmudic name for the sect of the ביתוסים (baytusim) which de Rossi claims is a corruption of בית אוסים (bayt ussim) and refers to the Essenes. ${ }^{79}$ If Cohen heard the text (perhaps read aloud by Martha?) rather than read it himself and was

${ }^{78}$ On Azariah see Yoseph Dan, s.v. “Rossi, Azariah (Bonaiuto) Ben Moses Dei (c. 1511-c.1578)" in EJ 14:315-8

${ }^{79}$ The idea that there is a connection between or even identity of Essenes and Boethusians has not found any adherents. Cf. EJ 4:1169 s.v. "Boethusians". 
unfamiliar with the term he may have simply jotted it down in accordance with the phonetics of the Ashkenazi pronunciation which would indeed allow the word baytusim to be spelled the way he did.

ad p. 401: In his argument for an Alexandrian origin to the mystical speculations prevailing in Palestine at the time and in the culture from which Christianity emerged, Gfrörer emphasizes the similarities between Alexandrian theosophy and the teachings surrounding the 1st century sectarians Simon (the Samaritan "magician" of Acts 8:4-13) and Elchasai (literally "the hidden power"). ${ }^{80}$ Samaritan orthodox and heretic speculations on God and His manifestations grew out of the same ambiguities in the biblical texts from which Philo and others received their exegetical and ideological challenges. ${ }^{81}$ In the light of recent scholarship and especially with the publication of the Dead Sea scrolls and of the Nag Hammadi library, the 19th-century position of Gfrörer is definitely too simple and reckons with ideological influences without the necessary textual finetuning. ${ }^{82}$

Philo is seen as having prepared the ground for the idea of a physical manifestation of the divine logos by "closely connecting both Jewish ideals, logos and messiah, if not merging them." This connection of ideals "almost necessarily" led to the "embodiment of the former because the Jews were in need of a visible and active messiah." It should be noted that Cohen reduces Gfrörer's relatively tentative statement to a straightforward equation.

ad p. 351: After a compilation of talmudic sources testifying to the study of Greek philosophy during the Hasmonean rule, a commentary of Maimonides on Sotah 49 is quoted which identifies the allegorical method of exegesis as that which the talmudic sages found upsetting in the study of sapientia ionica. Gfrörer quotes Maimonides in Latin ("quod dicunt sapientiam graecanicam, sunt $a \lambda \lambda \eta \gamma$ otat in lingua, quae declinant a via recta"), and also gives the Hebrew. Cohen copies the Hebrew silently correcting the typographic error in the word yo'unnit.

\footnotetext{
${ }^{80} \mathrm{On}$ the Samaritan heresiarch Simon and the problems of the origins of gnosticism see Jarl Fossum, The Name of God and the Angel of the Lord. Samaritan concepts of Intermediation and the Origin of Gnosticism (Tübingen, 1985).

${ }^{81} \mathrm{Cf}$. Fossum "Sects and Movements" in A.D. Crown, The Samaritans (Tübingen, 1989) p.367 (with note 298).

${ }^{82}$ Cf. Peter Schäfer, Hekhalot-Studien (Tübingen, 1988), p. 2.
} 
Comments on the excerpts from Das Jahrhundert des Heils, Zweite Abtheilung, vol. 2

All quotes are from chapters seven ("Die Lehre vom Menschen, der Seele, Unsterblichkeit, Freiheit und Schicksal, Sünde und Fall") and eight ("Die Lehre von den Mitteln und Wegen, durch welche der Mensch die Gnade Gottes erwirbt und seinen Zorn abwendet"). The whole volume is built on the pattern of classical Christian dogmatics, beginning with the creation of the world (cosmology, theology), proceeding to the special creation of the human being, his perfection and his sin (anthropology), and, finally, the restoration of the human being to his original state (soteriology) and the restoration of the world (messianology, eschatology). Liebeschüt ${ }^{83}$ notes that this work more than the previous one on Philo-which remained, after all, the unfinished attempt to derive the early Christian teachings from Alexandrian theosophical speculations-reflects Gfrörer's increasing concern with the Christian truths (title of this volume is The Century of Salvation). Yet, on the whole it is still primarily and essentially an attempt to reconstruct the development of Christianity as organically evolving from its historical origins as opposed to the dialectic conceptual idealizations and deductions of religion still en vogue at this time. ${ }^{84}$

ad 89: Gfrörer translates several passages from rabbinic literature on the problem of the 'evil inclination' (yetser ha-ra'). Literally translated it means the 'inclination towards evil' or (since inclination is not literally correct either) the 'formation' or 'shape' of evil. All these clumsy formulations only indicate that the concept is complex and needs careful parsing. In Religion der Vernunft Hermann Cohen translates-or, rather, leaves untranslated-Gen. 8:21 as "Jezer des Herzens" (chapter XI, paragraph 9) to circumvent the notion of original sin. Here, in his excerpt from Gfrörer, Cohen refers to the expression in Hebrew only, i.e., he does not follow Gfrörer's traditional Christian translation of the expression as "böser Trieb."

Gfrörer adduces a well known interpretation that explains the pleonasm of Dtn 6:5 ("with all your heart") as implying both the good as well as the evil inclination (in Aramaic: bitre yitsre livkhon) as well as the derivation of this rabbinic teaching from the two doubling of the letter 'yud' in the word vay-yitser in Gen 2:7. He then continues by citing Mishnah Berakhot 4:5, Talmud Bavli bBer 61a, Targum Onqelos on Exod

${ }^{83}$ Liebeschütz (1967), p. $104 \mathrm{f}$

${ }^{84}$ The main thrust of Gfrörer's critique is directed against the radical left-Hegelian criticism of David Friedrich Strauß (1808-74). Cf. Liebeschütz (1967) ibid. 
32:22 and Talmud Yerushalmi Ber 19b. The last passage is the one most noteworthy to Cohen.

Rabbi Tanchuma betete: Laß Dir wohlgefallen, o Herr, zu zerbrechen und abzuthun das Joch des bösen Triebes aus unseren Herzen, denn du hast uns erschaffen, deinen Willen zu thun, wir sind schuldig, demselben nachzuleben, thäten es auch gerne. Allein, was hindert uns? Der Sauerteig in dem Teige! Vor Dir ist kund und offenbar, daß keine Kraft in uns ist, demselben zu widerstehen. Deshalb laß Dir wohlgefallen, o Herr, daß in unserm Loose wohne Liebe und Brüderschaft, Friede und Freundschaft, und beglücke unser Ende mit Hoffnung. (pBer 19b, as transl. by Gfrörer)

ad 92: The yetser ha-ra' implies intent and thus becomes a way of further differentiating the biblical distinction between sins committed "inadvertently" and those committed "high handedly" (cf. Num 15:2731). The way Gfrörer interprets it, sin in its full sense is only what is committed with intent and, in that sense, "high handedly." He then proceeds to quote several lists of four cardinal sins (e.g. Tos. Peah 1:1 counts idolatry, fornication, bloodshed, and an evil tongue among those evils for which one is punished in this world and in the world to come).

ad 94: Emphasizing the reference to bSanh 43b, Cohen notes that the sages saw it as the highest task of piety to "sacrifice the evil inclination", i.e., to overcome it in the pursuit of the good embodied in the fulfillment of God's commandments.

ad 96: While God can himself be declared the creator of the evil inclination (so in the passage Cohen marks, i.e., bBer 31b), Gfrörer also notes that God is the origin of sin only insofar as the inclination or the possibility for it was part of our nature from the beginning: "und es mußte auch so seyn, weil das Gute ohne das gegenüberstehende Böse nicht gut wäre; die Gegensätze sind nothwendig" (p. 98).

ad 102 (cf. 101) Death rather than sin is distinguished as the legacy of Adamic humanity. Sinlessness is thus, at least theoretically, within the realm of the humanly achievable.

Den bisher entwickelten Beweisstellen liegt die Ansicht zu Grunde, daß nur der Tod, nicht auch die Sündhaftigkeit Adams sich auf seine Nachkommen erstreckt habe, und daß es folglich Menschen geben könne, die trotz des anerschaffenen bösen Triebs keine wirkliche Sünde begehen.

On p. 102, however, Gfrörer lists passages that supporting the opposite opinion, namely that there is no one without $\sin$.

ad 112-115: Gfrörer discusses what Cohen paraphrases as "Fate and Freedom," a topic he discussed also in his work on Philo (vol. II, p.319ff). 
Gfrörer compares the teachings of the Essenes, the Sadducees, and the Pharisees on the problem of the freedom of the will (p. 112). Cohen is interested in the teachings of the Pharisees only. This is fortunate because Gfrörer's sources for the Essenes and the Sadducees are rather doubtful (the teachings of the latter group he wants to extract from the pseudepigraphic mystical work, Sefer ha-Zohar). As a source of pharisaic doctrine he naively takes rabbinic literature in general and as a whole. Cohen uses Gfrörer's book as a florilegium of rabbinic teachings on the problem of predestination. The passages Gfrörer adduces (Mishnah Rosh Hashana 1:2 and Yerushalmi ad loc) contribute to the overall impression of a "middle position" (cf. 114) between predestination and freedom. While God's decrees are firm, repentance is always seen as a way for the sinner to redeem herself, to generate the fear of God (bBer. 33b) necessary to "acquire eternal life" (p.115; the language of Gfrörer's interpretations is Christian).

ad 136: "Love Thy Neighbor" is a topic Cohen dealt for the first time in 1888 when he defended the Talmud in court (see above Pt. I; and cf. "Die Nächstenliebe im Talmud. Ein Gutachten dem Königlichen Landgerichte zu Marburg erstattet " J1,145-174) and again in 1894 ("Zum Prioritätsstreit über das Gebot der Nächstenliebe" J1,175-181). In this excerpt Cohen notes the page number where Gfrörer lists talmudic passages on this topic.

ad 142: Gfrörer calls prayer a "hohes Mittel, die Gnade Gottes und die Seeligkeit zu erringen." One of the prooftexts is pBer 17a which Gfrörer translates: "Aus der Stelle Deuter. XI, 15 geht hervor, daß es auch einen Dienst Gottes im Herzen gebe. Dieser innerliche Gottesdienst ist das Gebet...." Prayer is the 'service (avodah) of the heart' and thus a precise substition for the sacrifices.

ad 145: According to Gfrörer "the rabbis determined certain rules for the content of prayers" which had to be adhered to if prayer was to be efficacious. One of these rule is to mention the kingdom of the heavens (malkhut shamayim; Cohen writes in Hebrew what Gfrörer mentions in German). Prooftexts: bSanh 28b, bBer 40b, etc. Again, Cohen "milks" this work for passages which conform to his interest while he ignores all of Gfrörer's asides. Here on p. 145, for example, Gfrörer somewhat petulantly criticizes ancient Pharisees and modern ministers for not adhering to their own reasonable rules such as keeping prayers short (cf. Matth 6:7).

ad 152-154: Cohen stresses the word Buße (repentance, triply underlined). On p. $152 \mathrm{ff}$ Gfrörer continues his discussion on Gnadenmittel (means of achieving divine merc) with a section on repentance. 
Prooftexts: Avot 4:17.18, Midrash Tehilim 37:3, bYoma (Yom Hakkipurim), and pMakkoth (Perek Hen Haggolin), and others. In Gfrörer's translation of the latter passage from the tractate Makkoth Cohen finds practically all the material he needs for his own exegesis of Ezekiel 18. This may be the very source that provided him with the necessary ammunition for his essay on the Versöhnungsidee, if it did not inspire the idea itself.

ad 159-165: Another Gnadenmittel is 'faith' (der Glaube). Prooftexts: Targ. Yerushalmi ad Gen. 40:14. ad Num 11:32, Mekhilta ad Ex.14:30, etc.

ad 'shabbat:' Another Gnadenmittel (sacrament; Cohen: Versöhnungsmittel) is the 'celebration of the Sabbath.' Prooftexts: bShab. $119 \mathrm{~b}$ et al. (Gfrörer pp. 165-167). 167ff Gfrörer summarizes: "Wer nun die bisher beschriebenen Pflichten erfüllt, der besitzt gute Werke, hat durch sie Verdienst erworben, und darf deßhalb des Lohnes gewärtig seyn" (p.167). For Cohen, the focus is on Versöhnung instead of Gnade. Again he ignores the classical anti-Jewish stereotype Gfrörer falls back on to illustrate the doctrine of merits: "Eine Art kaufmännischer Abrechnung liegt diesen Ansichten zu Grunde" (p.174).

It is noteworthy that here and elsewhere in these papers Cohen makes atonement the central tool for the conceptualization of the Jewish religion as a whole. Thus, for example, here the erstwhile symbol of social justice, the Sabbath, is converted into a "means of atonement."

ad 179-183f: This is a passage on 'merit' (zekhut) accrued by the biblical patriarchs and regarded as meritorious for the people as a whole. The merit of the Fathers exert an atoning or expiating effect (versühnen; p.181). This implies that the majority of people are regarded as morally insufficient. Were it not for the perfection of the patriarchs none of Israel would deserve the world to come. This motif developed in prayers of penitence, referred to on $\mathrm{p}$. 183f. The reference is to bBer. 10b (Gfrörer transl.): "R. Jochanan sagt: Wer sich im Gebete auf eigenes Verdienst beruft, den verweist Gott auf fremdes; wer sich aber auf die Verdienste Anderer beruft, bei dem siehet Gott seine eigenen Verdienste gnädig an" etc.

\section{Text 11 Gfrörer: On Prayer}

$8.5 \mathrm{~cm}$ wide on top and 8.3 on the bottom, the length is $5 \mathrm{~cm}$ on the right and 4.4 on the left, ink.

Gfrörer II, b

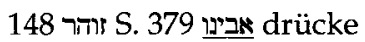

die Inbrunst des Betenden am stärksten aus

תשובה 152 


\section{Translation}

\section{Gfrörer II, $b$}

148 zohar p. 379 ovinu ["Our Father"] expresses

the ardor of the prayer most strongly.

152 'shuvah [repentance]

\section{Notes/Comments}

This excerpt refers to Das Jahrhundert des Heils, Zweite Abtheilung, vol. 2, Stuttgart: E. Schweizerbart's, 1838, which is the second part of Gfrörer's Geschichte des Urchristenthums (five volumes, 1838).

ad page 148f: "Endlich lehrt noch der Sohar, [Note: "Zu Numeri S. 379"] $\mathrm{da} ß$ Nichts die Inbrunst des Betenden stärker ausdrücke, als die Worte: Unser Vater." The passage is part of a study on possible Jewish sources of the Lord's Prayer especially through a comparison with the Amida (Eighteen Benedictions). See, for example, p.149:

Ich habe, wie man sieht, aus den Büchern der Juden die Grundsätze entwickelt, nach welchen das Vater Unser zusammengesezt ist. Nicht nur sein Charakter ist jüdisch, sondern auch die einzelnen Sätze, die in verschiedenen jüdischen Gebeten wiederkehren.

Gfrörer's explanation of the Amida emphasizes the spiritual attitude (Andacht) of the person who speaks the prayer. See, e.g., p. 144: "Andacht der Beter ist die unerläßliche Bedingung, daß das Gebet erhört werde." The prooftext for this assertion is Berakhot 4:4, the saying by $R$. Eliezer which he translates, "R. Elieser sagt: Wer sein Gebet zu einem alltäglichen Handwerk macht, dessen Gebet ist kein Gebet." Although Gfrörer's translation is oblivious to the fact that tahanunim in the second part of the saying implies that God will hear the prayer (cf. Avot 2:13 and Albeck's notes on Ber. 4:4) the tendency is represented correctly by emphasizing what was later called kavvanah (Andacht), i.e., the attention and focus of intention of the one who prays as a condition for the efficacy of prayer.

ad page 152: Here Gfrörer begins to list rabbinic passages on repentance as a 'means of achieving mercy:' "Neben dem Gebet wird die Buße als Gnadenmittel hochgepriesen." Prooftexts are Avot 4:17: "An hour in repentance and good deeds in this world is more beautiful than all the life of the world to come." Gfrörer adds the traditional explanation (also quoted by Albeck, ad loc) that this is so because in the world to come repentance and merciful deeds are no longer possible. Other prooftexts are Avot 5:18, Midrash Tehillim ad Psalm 37:3 (Siman 9, quoting Hos 14:3), bYoma 86 a,b (quoting Hos. 14:2), pMakk Ch. 2, Hal. 6, fol. 8a (quoting Psalm 25:8), and Midrash Shir HaShirim 6:1 (ad Cant. 5:16). 
involved in practical attempts to reform Jewish worship (his prayer book Olat Tamid-'perpetual whole-offering'-eventually became the model for the Union Prayer Book, instituted by his son-in-law, Kaufmann Kohler), Einhorn believed in the perfectibility of Judaism as a religion based on a fundamental notion. As this notion he identified the messianic belief in a universal truth uniting all human beings. ${ }^{86}$

Although he had planned to write a comprehensive theological work, only the first volume was ever completed and published. The chapters deal with creation ("God and World," "God and Human Being," "Body and Spirit"), the problem of evil ("Essence and Origin of the moral evil and its relation to the natural evil"), and "Sin and Atonement."

Cohen's excerpts refer to the chapter on sin and atonement, especially to the extensive notes and sources Einhorn adds to the main body of his relatively short treatise ( 90 pages of notes on a text of 148 pages).

ad p. 197, Note 48: "Im Pentateuch wird Gott niemals als Sündensühner bezeichnet" (cf. main text, p. 79). Einhorn determines as basic tenets of the "Mosaic" atonement that God or fellow-human being against whom one may have sinned are never referred to as the direct object of atonement, nor is God the subject of atonement, except "in a few postMosaic passages." The note refers to this final assertion and discusses the apparent exceptions. Einhorn claims that "the Pentateuch has not a single reference where the forgiving God (soleah) appears as the atoning one (mekhapper); rather, atonement originates either from the priest or from the blood of the sacrifice." Cf. below, Texts 25 and 26 .

This exegetical observation leads to the thesis that

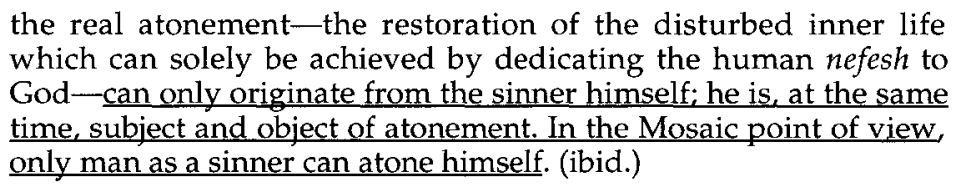

Note that the verb "atone" is intransitive, as is the German sühnen and the way Einhorn uses it is highly idiosyncratic and its meaning somewhat unclear.

ad p. 90: Einhorn claims that, with the exception of Yom Hakkippurim which expiates all manner of transgressions, sin offering (hattat) and guilt offering (asham) are efficacious only with respect to involuntary transgressions (hatta bish'gagah). Despite the absence of intent, the transgressor is considered guilty and needs to make atonement. Einhorn

${ }^{86}$ Cf. Sefton D. Temkin, s.v. "Einhorn, David" in EJ vol. 6, col. 532 
denies that this has anything to do with a troubled conscience, a concept introduced only by the later sages. Einhorn refers to the commentary of Nahmanides on Leviticus 4:2 to support the observation that sh'gagah implies some objective element of guilt which causes damage to the nefesh (the soul or divine part of the human being). Nahmanides writes (according to Einhorn's translation)

the benefit $\left(t^{\prime} a m\right)^{87}$ of the sacrifices (korbanot) with respect to the nefesh hashogeget ("the soul that sins involuntarily") rests on the fact that all transgressions (avonot) cause disgrace (gnay) in the soul and they are a deficiency so that it can no longer be a likeness of its creator ${ }^{88}$ unless it is pure from all sin.

In the essay on the idea of atonement $(J 1,131)$ as well as later, the notion of erroneous $\sin$ is central to Cohen. He takes from Einhorn the possiblity of arguing for a gradual development from sacrificial practices to psychologizing interpretations: "From this ceremony (viz. of priestly functions in the sacrificial cult of post-exilic Judaism) develops a fundamental concept of the moral consciousness: the concept of sh'gagah, of sin without knowledge."

ad p. 97: Einhorn developed his "Mosaism" in contrast to, but also in dependence on, studies on "biblical archeology" (cf. RGG, 3.ed, vol. I,582f) by the romantic historians Georg Friedrich Creuzer and Karl Bähr (Symbolik des mosaischen Cultus, Heidelberg: 3 vols, 1837-39). Against Bähr's assertion that sin offerings were meant to atone only for "theocratic sins" Einhorn claims that even someone who was not "within the theocratic sphere" (as, for instance, the ger) was required to participate in such sacrifices (Num. 15:22ff).

Einhorn's argument is not particularly forceful since it leaves theocracy undefined. Yet, the ger is indeed a favorite instrument to demonstrate the universal character of the Torah. Whatever its original meaning (cf. Jacob Milgrom regards it as a technical term that originally refers to an "encroacher" onto a sacred precinct to which s/he should not have access), the term has come to serve as a textual basis for the extension of the applicability and authority of the commandments to a universal scope.

ad p. 127: Cohen summarizes Einhorn's elaborate analysis of biblical sacrifices unrelated to the terminology of sin, namely "peace-offering" (sh'lamim ), "whole-offering" ('olah), and meal sacrifices. Of interest is hereby the character of the sacrificial altar which is called mizbeah ha'olah.

\footnotetext{
${ }^{87}$ Literally: purpose, meaning, significance.

${ }^{88}$ Einhorn's translation is tendentious. Literally the sentance says lehagbil p'ney yotsrah.
} 
Since 'olah and sh'lamim are not essentially connected with sin but with gratitude (cf. Einhorn 116-127), the altar, too, is not primarily and not in its essential character associated with guilt. It can be taken as an instrument of gratitude rather than of expiation. Referring to Ex. 20:21 as a prooftext, Einhorn concludes that according to the Mosaic perception of the nature of $\sin$,

the expiation of sin should and could not be indicated as the original purpose of the altar because man's destiny is not to sin. Scripture wants to highlight the absolute unconditional purpose of the altar which can only be an absolutely necessary objective. Such an aspect is found solely and exclusively in the moment of thanks to God and in the worship of God not, however, in the sin against God requiring expiation.

In other words, sin and atonement are historically and systematically secondary and serve as means to restore the ability to pursue the overall human purpose of gratitude, celebration and worship of God. This is further confirmed by Einhorn, and noted by Cohen, in the fact that sin offerings are absent on the Sabbath. On p. $224 \mathrm{f}$ (note 72 referring to text p. 126) Einhorn writes:

Highly significant ... is that there are no sin offerings on the Sabbath. This day is to be wholly dedicated to the idea of divine goodness and wisdom and to the divine likeness of the human being; because and by means of this distinction the human being as a sinner should not appear at all and vanish from the public cult entirely. Interesting and meaningful are the words of Nahmanides in this respect: In the additional offerings on the Sabbath there is no [mention of] sin-offering [hattat] ... because the assembly of Israel is His partner and everything is peace. Accordingly, even rabbinic Judaism knows no confession of guilt on the Sabbath, no prayer of repentance but only songs of gratitude and triumph, admiration of the divine power of creation, praise of God and Israel!

ad p. 144: Cohen finds two things noteworthy in Einhorn's passage on the additional meal offerings on the occasion of Sabbaths, New Moons and festivals. One is the fact that the blowing of the shofar is not permitted if the New Year falls on a Sabbath. Cf. bRosh Hashana 29b "lest he carry it (viz. the shofar) from one domain to another (in violation of the Sabbath)." The Mishnah rules, however, that the blowing of the shofar was required even on the Sabbath, namely in the Temple as long as it existed. In Einhorn's characterization the shofar is a symbol of national self-defense used to arouse the warrior-citizens in a time of national emergency. It is, therefore, used in festivals which have primarily national-historical contents, commemorating the experience of salvation and expressing the hope for future preservation of Israel. According to Einhorn's reinterpretation in the spirit of classical liberalism this 
affirmation of the necessity for Israel to engage in the "holy battle" for its self-preservation is superseded by the Sabbath not-as in the Mishnahbecause it may violate the law against carrying but: "Der Tag der Weltvollendung verdrängt das nationale Element." The perfection celebrated on the Sabbath is that of the creation of the human being in God's image. The halakhic ordinance is interpreted as establishing a hierarchy of values in which human perfection, individual and universal, supersedes the otherwise fully valid and enthusiastically championed preservation of national existence.

The second aspect noted by Cohen is mentioned in a footnote on $p$. 144. According to a rabbinic opinion (bSukkah 55b) the seventy wholeofferings on the festival of Sukkoth were an atonement for the seventy peoples of the earth (i.e., for humankind). How this view fits into Einhorn's argument is not clear. For Cohen, however, this passage may have been of interest because it proves that the sages were concerned with the universal aspects of Torah even with respect to cult and sacrifice. Thus we find in the essay on atonement, that

(a)ccording to the Talmud, 70 festival-whole-offerings are commanded for the 70 peoples. Thus, the particularism of national unity which was to be strengthened by the centralization of the cult was simultaneously shaken by the mutual influence of messianism and sacrificial legislation. (J 1 p. 130)

ad p. 233 (note on main text p. 143): Einhorn interprets the rabbinic symbolism of Sabbath and festive family meals. With respect to the Sabbath, he states that it celebrates universal rather than Israelite holiness. The benediction of the day illustrates that not Israel but the Sabbath itself is blessed (birkat ha-yom: mekaddesh hashabbat). The reason given in bBezah $17 \mathrm{a}$ is that the holiness of Sabbath springs from creation and, hence, does not depend on the election of Israel. Einhorn does not withhold the contrasting rabbinic view either but it is clear that he regards it as a degeneration and aberration.-The second agreement between Einhorn's Mosaism and rabbinic thought concerns the festive family meal with its customs and prayers which is seen as a (temporary?) replacement of the sacrifice. Since the essence of atonement is symbolic it can be transferred from one means to another. As a prooftext, Einhorn quotes the dictum by R. Yohanan and Resh Laqish (bBer.: R. Eliezer) that while the Temple existed the altar made atonement for a person; now, however, a person's table makes atonement for them (bHagiga 27a; cf. bBerakhot 55a). Similarly we find in Cohen:

We have no priest. 'The table in everyone's house makes atonement.' The table of family discipline and family custom which, at the same time, is the table of charity, it has become the Jewish altar. (J 1, 139) 
In bBerakhot, the equation of table and altar is midrashically derived from Ezekiel 41:22. Cohen adds the idea of charity to the aspects mentioned by Einhorn which indicates that he had the version according to bBerakhot in mind (cf. also Mishnah Avot 3:3).

In the essay "Die Versöhnungsidee" (J 1,125ff) Cohen reconciles Einhorn's determination of the biblical concept of atonement with Wellhausen's chronology of the sources of the Pentateuch (Hexateuch). Einhorn's 'Mosaism' was based on the assumption of two sources (Elohist and Jahvist) both of which were taken to precede the prophets and other biblical books. Cohen accepts the exegetical details of Einhorn's analysis and tries to adjust them to the chronology of the newer documentary hypothesis. Einhorn's 'Mosaic' teaching of the atonement is essentially preserved and maintained by Cohen, yet it is reconsidered in the light of a more complex historical development. With the help of Einhorn's exegesis, Cohen is able to counter the general assumption of Wellhausen and other Christian scholars, namely that law and cult were essentially regressive institutions introduced in the wake of the experience of destruction and exile.

\section{Atonement in the History of Religion and Art}

\section{Text 13 Atonement in Art (Greek Tragic Heroism) and Religion}

13.7 by $10.7 \mathrm{~cm}$, ink. On the left upper corner Cohen wrote the ordinal number 1 . Other texts in the archive not given here bear the ordinals 2 and 3.

1) Versöhnung ist GrundBegriff der Religion, zugleich aber auch der Kunst, insbesondere der dramatischen Poesie, also derjenigen, welche das Verhältnis von Mensch und Schicksal , also von Mensch und Gott darstellt. Hierin zeigt sich der Zusammenhang von Kunst und Religion: Beide stellen je eine Art

Vereinigung von Natur und Sittlichkeit dar. Und so ist es begreiflich daß sie Beide die VersöhnungsIdee brauchen und behandeln.

Aber der Unterschied ist instructiv: Was die Kunst

Versöhnung nennt und als solche herstellt, wird von der Religion nicht als solche anerkannt, gesucht. In der Kunst ist Versöhnung Untergang des Individuums in seiner Verklärung zum Helden; bei der Religion: Erhaltung des Individuums, aber auf Kosten des Heroismus? 


\section{Translation}

1) Atonement is the basic concept of religion, simultaneously however also of art, especially of dramatic poetry, therefore

of that [form of art] which represents the relation of human being and fate that is of human being and God. In this the connection

of art and religion shows itself: Both represent each one kind

of unification of nature and morality. And thus it can be understood

why both need and deal with the Idea of A tonement.

But the difference is instructive: What art

calls atonement and produces as such

religion does not recognize or seek as such. In

art atonement is the destruction of the individual in its glorification

as a hero; in religion: the preservation of the individual, but at the expense

of heroism?

\section{Notes/Comments}

This note corresponds very closely to a passage in Ethics of Pure Will, where Cohen deals with the discovery of the individual in both Hebrew religion and the Greek tragedians. The difference between the passage in ErW and this note is that in the former he has followed through with a notion that here is still doubtful, namely that the religious individual must forgo the characteristic of heroism. Cf. above, $\mathrm{Pt} \mathrm{II,} \mathrm{3.2.8.3} \mathrm{and} \mathrm{cf.}$ ErW pp. 365f.

\section{Text $14 S^{\prime}$ 'gagah and Anagnorisis}

\section{5 by $18 \mathrm{~cm}$, pencil.}

Die Sünde als Unwissenheit בי לכל העםבשגי statt $\supseteq$ vielleicht $\underline{\text { ? }}$ ? Verlegung aus dem Willen in den Intellekt und Demüthigung desselben als des höchsten Vorzugs des Menschen als Geist.

Die Idee der Erlösung und Versöhnung ist das

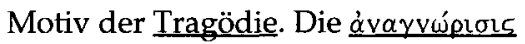
ein wichtiges Moment daher. Zusammenhang der

Religion und Kunst in diesem Grundmotiv erkennbar.

Die Versöhnung der Religion bedeutet die Aussöhnung mit dem Menschenschicksal und Ergebung in dasselbe, zum Zwecke der Anerkennung des Gottesreiches.

Translation

Sin as ignorance $k i$ l'khol ha-'am bish'gagah instead of $\underline{b^{\prime}}$ perhaps $\underline{k^{\prime}}$ ? Relocation from the will to the intellect and humiliation of the same 
as highest quality of the human being as spirit.

The idea of redemption and atonement is the

motif of tragedy. The anagnorisis

therefore as an important moment. Connection of

religion and art recognizable in this fundamental motif.

The atonement of religion means the reconciliation with

the human fate and resignation to it,

for the purpose of the recognition of the kingdom of God.

\section{Notes/Comments}

The Hebrew quotation is from Numbers 15:26: "since the entire people has sinned through inadvertence." Cf. Religion der Vernunft p. 250 and "Die Versöhnungsidee," passim, where Cohen leaves the word sh'gaga untranslated. Particle $b^{\prime}$ (the letter bet) differs only slightly from particle $k^{\prime}$ (the letter khaf). The former indicates an instrumentalis, the latter the preposition "as." The verse from Numbers refers to inadvertent sin as opposed to sins committed with intent. In its rabbinic liturgical setting the verse prefaces the kol nidre ceremony which opens the Day of Atonement. Cohen interprets this setting as pointing to a transformation of all sin into inadvertent sins which are therefore subject to atonement. The Day of Atonement thus means to enable a reconstitution of the self as the origin of moral agency.

Anagnorisis is Greek for "recognition" (cf. Plato, Theætetus 193c) or "discovery" (cf. Aristoteles, Poetica 1452a, 1.29 and 36, 1454b, 1.19). In the essay "Die Versöhnungsidee" and elsewhere, Cohen explores the relation between art and religion which he regards as originally related and differentiated only over the course of cultural history.

\section{Text 15 Prometheus and Job: Theodicy}

7.4 by $10.2 \mathrm{~cm}$, ink.

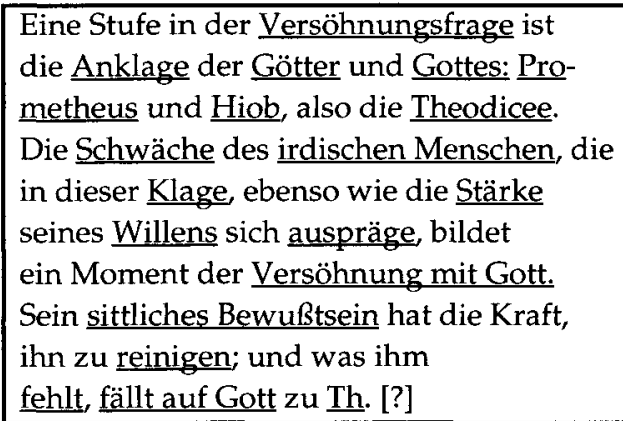




\section{Translation}

A stage in the question of atonement is

the accusation of gods and God: Pro-

metheus and Iob, that is, theodicy.

The weakness of the earthbound human being, that

coins itself in lament, forms

a moment in the atonement with God.

His moral consciousness has the power

to purify him; and what he

lacks falls to God (...).

\section{Notes/Comments}

On theodicy cf. Der Begriff der Religion im System der Philosophie (1915), pp. $69 \mathrm{f}$ and cf. above,

Pt. II, 3.3.3 (on paragraphs 74.-75.).

\section{Text 16 (Stoic) Suffering and the Divinity of Christ}

\section{5 by $14.4 \mathrm{~cm}$, ink.}

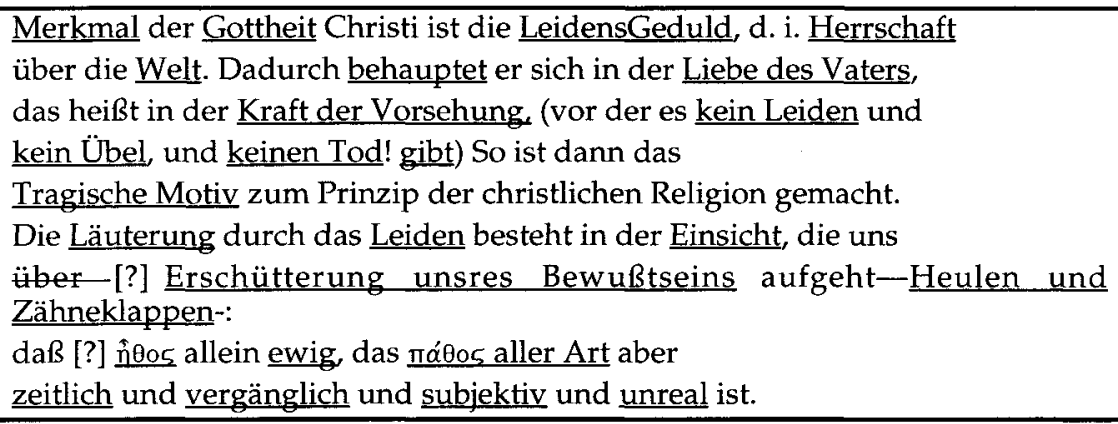

\section{Translation}

The characteristic of the divinity of Christ is the patience of suffering, i.e., the domination

over the world. Herein he prevails in the love of the Father,

that is in the power of providence, (before which there is no suffering, and no evil, and no death!) In this way the

tragic motif is made the principle of the Christian religion.

The purification through suffering consists in the recognition, that arises ever [?] the trembling of our consciousness--weeping and gnashing of teeth-: that [?] ethos alone is eternal, all manner of pathos however temporal and transient and subjective and unreal. 


\section{Notes/Comments}

ethos (Gr.)-morals, customs, morality

pathos (Gr.)-passion, suffering

The divinity of Christ is interpreted in Stoic terms as freedom from suffering (apatheia). The realization of condemnation which is here expressed in the terms of Matthew 8:12 and similar passages according to Luther's translation ("Heulen und Zähneklappen") is reminiscent of Kierkegaard's Fear and Trembling only in appearance. Cohen's interest is here in the possibility of providing the Christian idea of a suffering son of God with a rational interpretation that aims at moralization. Hence, the "trembling of consciousness" leads here to the quasi-Stoic realization of a transience of suffering and the eternity of morality.

\section{Text 17 Likeness and Unlikeness of God}

Page from small notepad, 6.7 by $4.3 \mathrm{~cm}$, pencil.

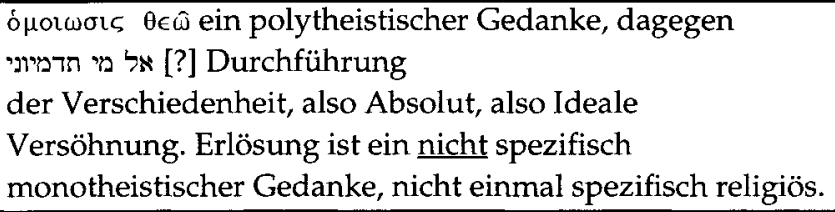

\section{Translation}

homoiosis theo [divine likeness] a polytheistic notion, in contrast

el mi tedamyuni therefore here [?] execution

of difference, therefore absolute, therefore ideal

atonement. Redemption is not specifically

monotheistic notion, not even specifically religious.

\section{Notes/Comments}

homoiosis theo [Gr., divine likeness]: Cf. Text 3, above and Gen. 1:26 LXX (homoiosis) for Hebr. d'mut (but see Gen. 5:1LXX et al. where d'mut elohim (divine likeness) is rendered as eikon.) Cf. James 3:9, 1.Clemens 33:5, Barnabas 5:5 and 6:12.

el mi tedamyuni ["To whom will you liken me?"]: Isaiah 40:25. LXX renders tedamyuni as homoiosate, parallel to its translation of Gen. 1:26.

The distinction made in Text 17 between atonement and redemption is also found in Begriff der Religion (1915). There, however, redemption functions as a religious concept augmenting atonement. Cf. above, Pt. II, 3.3.3., on BR, Ch. III, par. 52 and par. 61.-67., where "liberation" and "redemption" are seen as equally important aspects of the idea of atonement. 


\section{The Liturgical Practice of Atonement}

\section{Text 18 The Origin of Prayer (Concentration of the Mind)}

14.5 by $11.5 \mathrm{~cm}$, ink. ${ }^{89}$

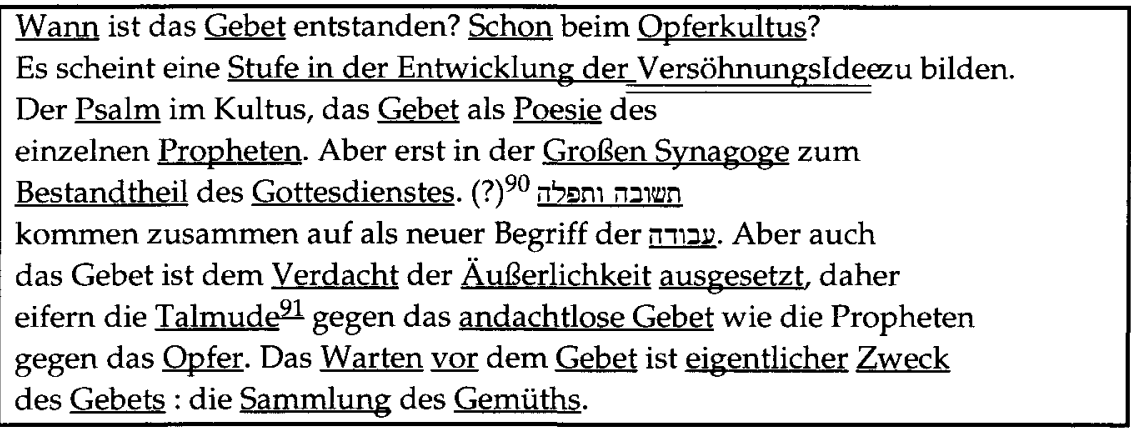

Translation

When did prayer come into bein[g]? Already in connection with the sacrificial cult?

It seems to be stage in the development of the Idea of Atonement

The psalm in cultic ceremony, the prayer as poetry of the individual prophet. Yet only in the Great Assembly as

part of the service (?) t'shuvah u-t'filah

arise together as new concept of avodah. But

prayer, too, is exposed to the suspicion of being a superficiality

hence the Talmuds ${ }^{11}$ agitate against prayer without intention as

the prophets did against sacrifice. Waiting before prayer is the actual purpose of prayer: the concentration of the mind.

\section{Notes/Comments}

t'shuvah-repentance (literally: "returning")

$t^{\prime} f i l a h$-prayer, reflection

The waiting period before commencing prayer is a medieval kabbalistic institution with the intention to focus the mind (kavvanah).

${ }^{89}$ Published previously by Franz Orlik in: Hermann Cohen (1842-1918). Kantinterpret Begrïnder der "Marburger Schule" Religionsphilosoph, Marburg: Universitätsbibliothek 1992, p. 163 (text) and p. 165 (photographic reproduction of the original).

${ }^{90}$ Question mark and parenthesis in the original.

${ }^{91}$ In the original: Talmud (sg.). Orlik reads "Talmud[isten??]." Although this sounds awkward the word "Talmudisten" for the amoraim is in fact used, e.g., by Philippson, Die israelitische Religionslehre (Leipzig, 1861), p.viii, and also by Gfrörer, Das Jahrhundert des Heils, Zweite Abtheilung, vol. 2, p.183 (see below ad Text 53). The word could also be abbreviated from "Talmude," i.e., referring to both the Palestinian and the Babylonian Talmud. 
The "Great Assembly" Cohen refers to is, according to rabbinic historiography, the source of authoritative decisions sometime between the period of Ezra the Scribe (mid-5th century BCE) and before the rule of the Hasmoneans (mid-2nd century BCE).

\section{Text 19 Repentance and Faith}

11.1 by $14.6 \mathrm{~cm}$, writing on one side (ink).

Unter dem Gesichtspunkt, daß die תשובה den Glauben vertritt, wird es verständlich, daß im Judenthum der Glaube nicht besonders zur Pflicht gemacht wird, außer in der Abstraction von Axiomen wie bei Maimuni, aber auch da nicht abstrakt, sondern in Rücksicht auf die Dogmen selbst.

Die השבוב hat den Glauben an Gott zur Voraussetzung und richtet sich daher allein an die Arbeit des Menschen an sich selbst. Die Existenz Gottes wird nirgend

in Zweifel gezogen und mit der Existenz ist die Qualität gegeben. Anders im Christenhum,

wo eine neue Form der Existenz gelehrt werden soll, oder für den <Inhalt des> Glaubens außer dem Einen

Gott noch ein Mittler gefordert wird. Dieser aber ist nur erdacht für die Erlösung: also kann die Buße nicht allein dem Menschen gelingen.

Translation

Under the aspect that t'shuvah substitutes faith

it becomes clear why in Judaism faith is not distinguished as a particular obligation,

except in the abstraction of axioms as in Maimuni,

but even there not abstractly but in reference to the dogmas themselves.

T'shuvah has faith in God as its presupposition and therefore turns

exclusively to the work of the human being on himself. The existence of God is nowhere

doubted and with existence quality is given. Different in Christianity

where a new form of existence is supposed to be taught, or for the <content of > $\underline{\text { faith }}$

a mediator is postulated in addition to the One God. This [mediator], however, is invented for [the sake of] redemption: thus the human being cannot accomplish repentance by himself.

Notes/Comments

Maimuni-Moses Maimonides (d. 1204), born in Spain, later lived in Morocco and finally, as court physician, in Fostat (ancient Cairo). By all standards the most eminent medieval Jewish philosopher. Formulated "thirteen principles" of faith that were adopted, often in poetic form (yigdal), into Jewish prayer world wide. This is exceptional for, as Cohen 
rightly asserts, dogmatic formulations generally do not have the same rank in Judaism as in Christianity.

Redemption-cf. Texts 14, 17, 21, 26, and 29.

\section{Text 20 From God of Wrath to God of Love}

11.1 by $13.8 \mathrm{~cm}$, ink.

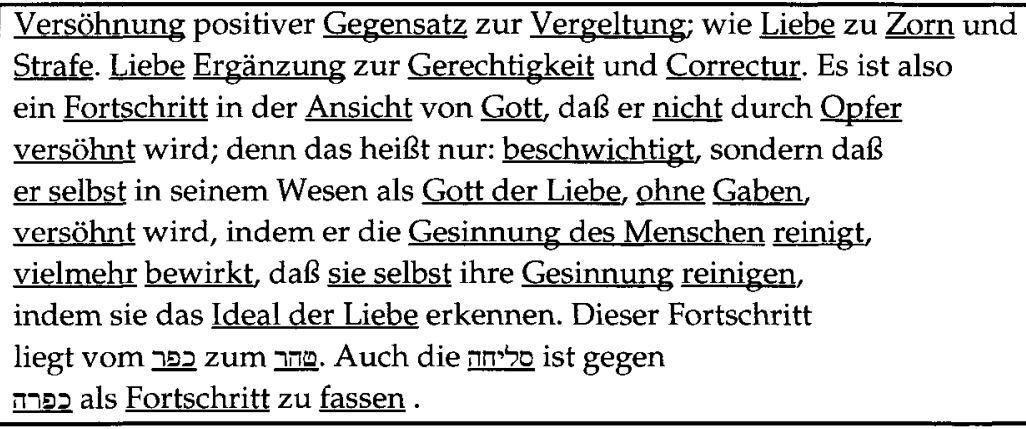

Translation

Atonement positive opposite to retribution; as love to wrath and punishment. Love [is] augmentation and correction to justice. It is thus a progress in the view of God that he is not reconciled through sacrifice; for this merely means: appeased, but that he himself in his being as God of love is reconciled without offerings, or rather causes that they themselves purify their attitude by recognizing the ideal of love. This progress

is [found in the progression] from kipper to taher. S'liha, too, compared to kappara is to be conceived as progress.

\section{Notes/Comments}

kipper (Hebr.) - to atone, make atonement (see below).

taher (Hebr.) - to purify

s'liha (Hebr.)-forgiveness

kapparah (Hebr.)-atonement

\section{Text 21 Meaning and Connotations of $\boldsymbol{t}^{\prime}$ shuvah}

\section{5 by $9.2 \mathrm{~cm}$, ink.}

תשובה ומעשים טשי gehören zusammen nach P. Abot 3.

תשבבה scheint Einkehr überhaupt zu bedeuten, nicht

nur Buße, sodaß es dem christlichen Glauben nahe-

kommt. Vielleicht wird dadurch Paulus verständlicher:

Werke ohne Buße sind allerdings ganz wertlos. 


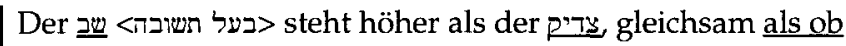

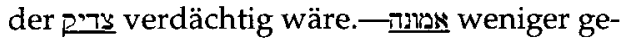

bräuchlich in der Zeit des $<$ Talmud $>$ : Daher Verbindung von

נגול mit משולה micht

von פריון?

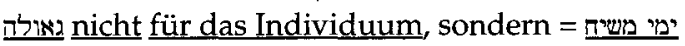

Translation

t'shuvah and ma'asim tovim belong together according to P. Abot 3 .

t'shuvah seems to mean self-communion in general, not

just repentance so that it approaches the Christian [concept of] faith.

Perhaps Paul becomes more plausible thereby:

Works without repentance are indeed totally worthless.

The shav $<b a^{\prime} a l$ t'shuvah $>$ ranks higher than the tsaddik, as if

the tsaddik was suspicious. - emunah less

common in the period of the $<$ Talmud $>$ : Therefore connection of

t'shuvah with kapparah and g'ulah, not

of emunah with both. pidyon?

g'ulah not for the individual, but = y'mey hamashiah

\section{Notes/Comments}

ma'asim tovim - good deeds, acts of loving-kindness

Although the exact reference is inaccurate, Mishnah Avot refers to "repentance and good deeds," for example, 4:11: "Rabbi Eliezer ben Ya'akob says: (....) Repentance and good deeds are like a shield against calamity," protecting against mishaps that can be construed as punishment. Repentance and good deeds undo guilt and thus avert evil. The dictum is presumably an ironic play on superstitous fear. Also cf. 4:7 and bShab 32a. The pair of terms also occurs in bBer 17a ("The end of wisdom is repentance and good deeds") et. al.

t'shuvah as Einkehr-The German word Einkehr may also be translated as "meditation." It is literally "introversion," i.e., turning one's attention inward. Cohen plays with the literal meaning of the Hebrew t'shuvah which is Umkehr in German. By choosing Einkehr instead, Cohen shifts the emphasis from an external process, i.e., a change of external direction as in the literal sense of the word, to an internal action similar to a phenomenological reduction, a psychological cum transcendental move of reflection. This is what Cohen means by the term $t^{\prime}$ shuvah.

shav-participle of shuv, the root of $t^{\prime}$ shuvah. Referring to the penitent Cohen first writes shav ("the returning one"), and later amends using the more common ba'al t'shuvah (penitent).

tsaddik-"the righteous one." 
emunah-biblical Hebrew, "firmness, security, faithfulness" (cf. Ex. 17:12, Isa 33:3, Jer 5:1, Hos 2:22, Ps 37:3, etc). The word occurs in context with tsaddik in Hab 2:4 which is quoted as a prooftext by St. Paul in Rom 1:17, Gal 3:11, and also in Heb 10:38. While St. Paul attaches theological significance to the term, in rabbinic literature it is indeed of secondary significance, as Cohen points out correctly. See, e.g., bShab 31a. In the Middle Ages the term is used similarly to the Christian "belief" or "faith," e.g., in the Hebrew translations of the Rambam's "Thirteen Principles."

gemara (Aramaic)-literally "saying, teaching," is the traditional name for the Babylonian Talmud. Cohen strikes it out and replaces it by the perhaps more generally used term "Talmud" which he writes in his usual Gothic script.

kapparah-Mishnaic Hebrew noun based on the Biblical kipper. Cf. Jacob Milgrom, s.v. "Kipper" in: EJ X:1039: "The customary rendering of kipper is 'to atone for,' or 'to expiate' but in most cases this is incorrect." Depending on the etymological theory and the theological context the basic meaning of the root is taken to mean either "to wipe away," "to cover" or "to purge." In the context of the Yom Kippur ritual (Lev. 16) the act of kapparah performed by God on behalf of the people means a removing, covering up, or transferring the source of impurity (sin) and so to purge or sanctify the people.

When God is the subject of kipper the word can also be rendered as "to forgive," especially when God is the subject of the action. Kapparah is usually rendered as "atonement." Cf. Sanh. 6:2, bYoma 5a, bZeb 6a. The connection between $t^{\prime}$ shuvah and kapparah has its roots in the polemics of the biblical prophets against a purely ritualistic understanding of atonement through sacrifice (see, e.g., Micah 6:6-8). T'shuvah and confession (viddui) must accompany the sacrifices as a prerequisite of forgiveness (cf. Maimonides, Hilkhot T'shuvah 1:1). The most important rabbinic discussions of the efficacy of $t^{\prime}$ shuvah as a means to achieve kapparah are found in Mishna Yoma 8:8-9 and bYoma 85b-88a. The idea of substituting one for the other presumably arises only sometime after the Bar Kochba revolt (135 CE).

pidyon-"redemption, delivery" cf. Lev. 25:24, Ruth 4:6, Jer 32:7. Biblical Hebrew from the root $p d h / i$ "to redeem by paying a price." The noun pidyon occurs in Ex. 21:30 and Psalm 49:8-9 parallel to kopher ("ransom," related to kipper) and means the "price of redemption" in a legal context. The Greek translation (LXX) renders pidyon as lutron, a term which becomes especially significant in the NT (cf. Mt 20:28, Mk 10:45, Lk 1:68, 2:38, 24:21, Act 7:35, Tit 2:14, 1. Pt 1:18, Heb 9:2). 
$g^{\prime} u l a h-$ redemption

$y^{\prime}$ mey ha-mashiah — days of Messiah, the messianic age.

\section{Text $22 t$ 'shuvah Is Not Penance}

One of the pages from a small notepad, 6.7 by $4.3 \mathrm{~cm}$, pencil.

תשבה ist nicht Buße. Diese ist aus dem

römischen Recht in den GlaubensBegriff übergegangen.

Buße war die תטח vor dem PriesterKodex.

תשובה ist Rückblick und Einkehr, תפלה

Vorblick שגנגד ${ }^{92}$ Bedeutung daher (?) für $=$

Translation

t'shuvah is not penance. This has been transferred from

Roman law to the concept of faith.

Penance was hattat before the Priestly Code.

$t$ 'shuvah is review and self-communion, tefilah

preview-sh'gagahmeaning therefore (?) for hattat<and asham>

\section{Notes/Comments}

Cf. "Die Versöhnungsidee" (J 1, 132)

(...) die Buße. Unser deutsches Wort ist irreführend. Es ist juristischen Ursprungs und entspricht dem, was Chattath früher war, bevor es zum Sündopfer wurde, nämlich Lösegeld. Das hebräische Wort für Buße, Teschuba, bedeutet Umkehr, Abkehr, Rückkehr zum Guten, Einkehr in sich selbst. Der Urheber des Opferkultus ist der Verkündiger der Lehre von der Buße, als der entscheidenden Tat alles Gottes-Dienstes und aller Sittlichkeit.

(...) penance. Our German word (viz. Buße) is misleading. It is of judicial origin and corresponds to what Hattat used to be before it became sin offering, namely ransom. The Hebrew word for penance, $t$ 'shuvah, means turning around, turning away, return to the Good, self-communion. The inaugurator of the sacrificial cult is the preacher of the doctrine of repentance as the decisive deed of all service of God and all morality.

Normally Cohen refers to Buße in the loaded sense of $t^{\prime}$ shuvah, in which case I translate it as repentance. Here, however, the first two passages refer to the same limited and original meaning as the English "penance." Hence I translate the same word differently, depending on how it is used. So in Text 20, for example, it would make no sense to translate $B u \beta e$ as penance while here in 21 this is clearly what Cohen means (also cf. Texts 9, 10, and 19).

${ }^{92}$ In the original emphasized by a frame drawn around it. 
There is rarely such a close correspondence between manuscripts and published text as in this case. The essay on atonement is clearly based on this and some of the other excerpts and meditations in this batch.

\section{Text 23 t'shuvah and kapparah}

12.1 by $2.5 \mathrm{~cm}$ (unevenly torn), ink.

כפרה תמשרה vertritt $u[$ nd] ersetzt ? die

Translation

T'shuvah represents a(nd) replaces ? kapparah.

\section{Notes/Comments}

The question mark is in the original. Here and in the following notes we can trace Cohen's gradual approach to the understanding that $t^{\prime}$ shuvah really displaces all earlier forms of atonement and thus becomes the indicator of a process of spiritualization and interiorization of repentance, compared to the operations of the sacrificial cult. It is all the more important however that the exterior forms of worship, the "service of the limbs," continue to function as means "to achieve and deepen repentance" (Text 24).

\section{Text $24 \boldsymbol{t}^{\prime}$ shuvah as the Means of Atonement}

Sheet from small notepad, 6.7 by $4.3 \mathrm{~cm}$, pencil.

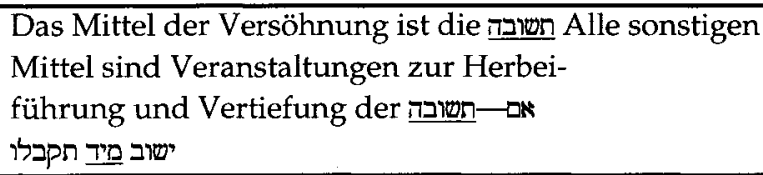

Translation

The means of atonement is t'shuvah. All other means are arrangements for the

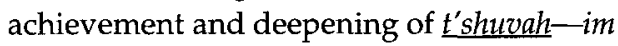
yashuv miyyad tekab'lo

\section{Notes/Comments}

Cohen's confidence in the centrality of repentance to the idea of atonement is here grounded in a quote from unetaneh togef ("We Will Celebrate the Mighty Holiness of This Day"), which is part of the additional prayer (musaf) on the Day of Atonement. ${ }^{93}$ In the context of the phrase im yashuv

\footnotetext{
${ }^{93} \mathrm{Cf}$. Adler, Synagogue Service, pp. $149 \mathrm{ff}$ and cf. bYevamot $47 \mathrm{a}$ as a possible source for the formulation.
} 
miyyad tekab'lo ("if he repents, instantaneously [miyyad] you accept him"), the verse Ezekiel 18:23 is cited in poetic variation: "for thou desirest not the death of the sinner, but that he turn from his way and live."

\section{Text 25 The kohen (Priest) as "Expiator"}

\section{5 by $9 \mathrm{~cm}$, ink.}

Der כist mehr der Vertreter des Richters und so der

Gegenpartei als Gottes. Gott ist nur durch לפני

bezeichnet [?]. Jede Satisfaction ausgeschlossen, als $\underline{\mathrm{ihm}}$ zu

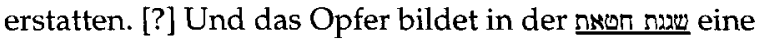

Ergänzung zum Civil ${ }^{94}$-Gericht, ähnlich wie כרות

zur Todesstrafe- So bereitet der בחן als-Opfrer

Sühner den Gedanken vor, daß nur zwischen Mensch und

Mensch, und vor Gott, die Versöhnung zu vollziehen sei.

\section{Translation}

The kohen is representative of the judge and thus of the oppositional party rather than of God. God is indicated [?] only through liphney. All satisfaction is excluded as something to be repaid [?] to him.

And in the sh'gagat hatat the sacrifice forms an augmentation to civil justice, similar to [the relation between] karet and death penalty.-In this way the kohen as sacrificer expiator prepares the way for the notion that the atonement is to be brought about only from human being to human being and before God .

\section{Notes/Comments}

kohen-priest. Hermann Cohen himself, whose name in the birth register of Coswig is spelled 'Cohn,' hails from the priestly caste of Israel.

liphney_-"before," e.g., "before God shalt thou be purified," Lev 16:30.

sh'gagat hatat-Not a biblical expression. However, hatat is the sin offering due for an inadvertent transgression. Cf. Leviticus 4-5. karet-punishment of extirpation.

\footnotetext{
${ }^{94}$ Cohen began to write the word Gericht and crossed it out again.
} 


\section{Text 26 "And Before Whom Do You Purify Yourselves?"}

Sheet from small notepad, 6.7 by $4.3 \mathrm{~cm}$, pencil.

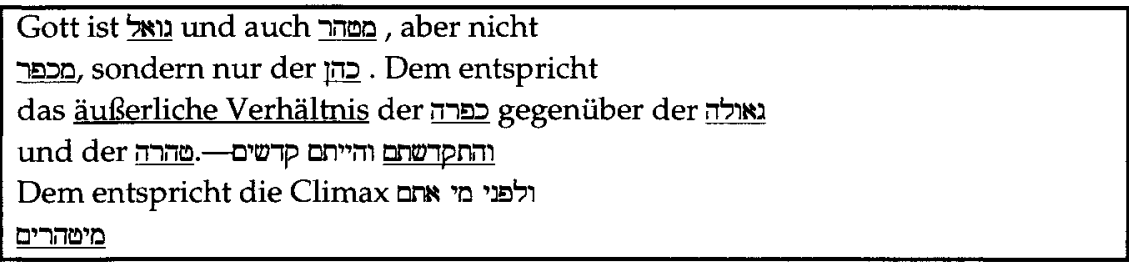

Translation

God is go'el and also metaher, not however mekhapper, only the kohen. To this corresponds

the external relation of kapparah with respect to ge'ulah

and taharah.-vehitkadashtem v'hayitem $k^{\prime}$ 'doshim.

To this corresponds the climax uliphney mi atem mittaharim

\section{Notes/Comments}

go'el-redeemer.

metaher-one who purifies.

mekhapper-one who atones.

kohen-priest.

kapparah-atonement.

ge'ulah-redemption.

taharah-purification.

vehitkadashtem v'hayitem $k^{\prime}$ doshim-"and you shall sanctify yourselves so that you shall be holy," cf. Leviticus 11:44, 20:7

uliphney mi atem mittaharim-"and before whom do you purify yourselves," cf. Mishnah Yoma 8:9

Here and in the following we find expression of some of the thought that went into what may be a conscious switch in the sequence of the clauses of the famous motto of Religion der Vernunft, which is also quoted in the essay on atonement, a passage from Mishnah Yoma 8:9, where R. Akiva praises Israel:

\footnotetext{
אשריכם ישראל! לבני מי אתם מיטהרין? ומי מסהר אתכם? אביכם שבשמים. -"Blessed are you, Israel! Who purifies you? And before whom do you purify yourselves? It is your Father in Heaven." (J 1, 137-8)
}

\footnotetext{
${ }^{95}$ "Heil euch, Israel, wer reinigt euch und vor wem reinigt ihr selbst euch? Es ist euer Vater im Himmel." The editors of Cohen's Jewish writings of 1924 were worried about Cohen's idiosyncratic quotations and it is thanks to Franz Rosenzweig's intervention that quotations were not silently corrected. See letter to Bruno Strauß (August 24, 1923), BT II, p. 919.
} 
The emphasis rests on self-purification. The human being is not passive recipient of atonement, although the notion of redemption indicates that the ultimate completion of moralization is beyond human power and a matter of confidence in God.

\section{Text 27 Yom Kippur and New Year}

One of the pages from a small notepad, 6.7 by $4.3 \mathrm{~cm}$, pencil.

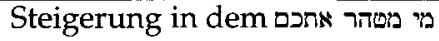

zu dem ולפני מי אחם מטהרים

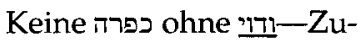

sammenhang des 2 כ" mit dem messianischen

\section{Translation}

Climax in the mi metaher etkhem

to the uliphney mi atem mittaharim

No kapparah without viddui-Con-

nection between Yom Kippur and the messianic rosh hashanah (neilat shearim)

\section{Notes/Comments}

mi metaher etkhem - "who purifies you," cf. Mishnah Yoma 8:9

uliphney mi atem mittaharim-"and before whom do you purify yourselves," ibid.

kapparah-atonement

viddui-confession

Yom Kippur-Day of Atonement

rosh hashanah-the New Year Festival

neilat shearim-the "closing of the gates," concluding liturgy on the Day of Atonement

Aside from returning to the climactic relation between the clauses of Mishnah Yoma 8:9 (based on the characteristic reversal of the sentences), this text points to the reason why Cohen sees the idea of messiah and the idea of atonement as related and as augmenting each other. The connection between them is first and foremost a liturgical and symbolic one. The New Year's Festival that initiates the Days of Awe culminating in the Day of Atonement has a primarily messianic message. The kingship of God that is proclaimed on this occasion harks back to the creation of the world and stretches forward to the day of messianic redemption. The connection between these occasions is seen by Cohen as deeply intentional and meaningful. 
Text 28 Sequence of the Atonement Liturgy

11.6 by $7 \mathrm{~cm}$, ink.

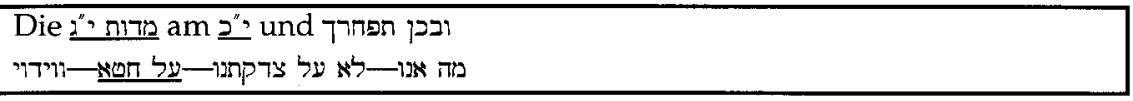

Translation

The yud"gimel middot on y(om) k(ippur) and uv'khen ten pakhdekha viddui-al khet—lo al tsidkateynu-ma anu

\section{Notes/Comments}

yud"gimel middot-"thirteen attributes" of divine mercy

$y$ (om) k(ippur)—Day of Atonement

$u v^{\prime} k h e n$ ten pakhdekha-"and thus give thy fear"

viddui-confession of sin

al khet_-"over the sin"

lo al tsidkateynu-"not on the merit of our justice" ma anu-"what are we"

A sequence of liturgical passages referred to by their first words as titles. The first line refers to the "thirteen attributes" of divine grace and forgiveness, based on Exodus 34:6-7. Rabbinic tradition converts the figura etymologica in verse 7 (venakeh loyenakeh) into an element of forgiveness rather than retribution and thus counts 13 rather than twelve attributes of mercy, against the literal meaning of the text. Coming after the episode of the golden calf, the passage of self-revelation is thus a most powerful expression of divine love and mercy and an appropriate element of the liturgy of the Day of Atonement.

The liturgical passages Cohen lists represent the progression from the confession of sin to the confidence of forgiveness and thus establish the psychological process of the experience of atonement.

\section{Text 29 Day of Atonement and Messianic History}

12.5 by $14.2 \mathrm{~cm}$, ink.

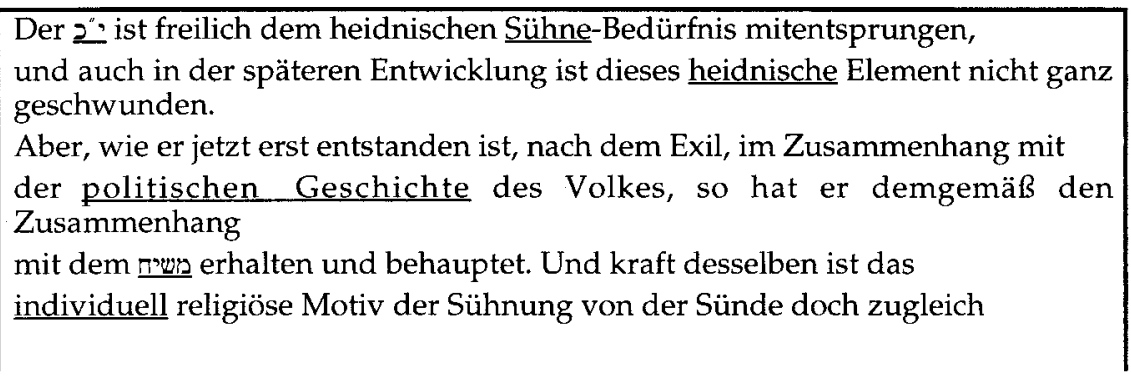


in die allgemeine religiöse Sphäre der Erhebung und Erhöhung des Menschengeschlechts

gerückt worden. In dieser Verbindung aber vorzugsweise vollzieht sich die echte

Versöhnung und Erlösung. Versöhnung mit Gott muß bedeuten die

Versëhnung Erlösung des Menschenbegriffes, der MenschenIdee und die

Versöhnung des Individuums mit dieser $\underline{\text { Idee }}$ die sein $\underline{\text { Ideal ist. }}$

Translation

Yom Kippur, to be sure, also arose out of the pagan need for expiation, and also in the later development this pagen element did not entirely disappear.

But seeing that it developed only now, after the exile, in connection with the political history of the people, it has accordingly retained and reaffirmed its connection with mashiah. And by its virtue the individual motif of expiation of sin was relocated to the universal religious sphere of elevation and uplift of humankind. It is in this connection that true atonement and redemption preferably realizes itself. Atonement with God must mean the atonement and redemption of the concept of the human being, the Idea of the human being and the atonement of the individual with this idea, which is his ideal.

Notes/Comments

Yom Kippur-the Day of Atonement

Mashiah-Messiah

\section{Idea of God and Moral Ideal}

Text 30 Atonement and the Moral Purpose of the Human Being

One of the pages from a small notepad, 6.7 by $4.3 \mathrm{~cm}$, pencil.

Im Problem der Versöhnung handelt es

sich um den Begriff des Menschen, und nicht

in erster Linie um das sittliche Mittel

die Versöhnung herbeizuführen, um den Zweck

und Werth desselben; die Reinheit (vor Gott)

Translation

What is at stake in the problem of atonement

is the concept of the human being, not

primarily the moral means

by which to achieve atonement, the purpose

and value of it; purity (before God). 


\section{Notes/Comments}

In this and the following papers we see how Cohen turns his exetical, philological, and historical observations into philosophical coinage. We also note that purity which above is used in the liturgical context is stripped of its particular context and generalized as a moral principle contained in the concept of the human being. Religion is "resolved" into ethics.

\section{Text 31 Covenant and the Idea of God}

8 by $11.5 \mathrm{~cm}$, ink.

Frage wie das Verhältnis des Bundes zwischen Gott

und Israel in Bezug auf die Bedeutung der GottesIdee.

Mythologisches Verhältnis, bei den Propheten zur Poesie

der Liebe, der Brautschaft und Ehe versittlicht.

Aber auch hierbei den Begriff Gottes noch nicht zu seiner

sittlichen Höhe gebracht: erst im Problem der Versöhnung.

\section{Translation}

Question how the covenantal relation between God

and Israel with reference to the meaning of the Idea of God. ${ }^{96}$

Mythological relation, in the prophets moralized into poetry

of love, of engagement and marriage.

But thereby the concept of God not yet brought to its

moral climax: only with the problem of the atonement.

\section{Notes/Comments}

The question Cohen raises correlates the idea of God as the guiding principle with the theme of a covenant between Israel and God. Modifications in the idea of God lead to a new conceptualization of the covenant. The progression Cohen sees at work here and elsewhere (cf. esp. Pt. I, above, on "Die Versöhnungsidee") leads from a mythological origin of the idea of the covenant (and inherently of the idea of God), to a poetization (in the pre-exilic prophetic imagery of love, adultery, and marriage), to a transformation into a purely moral concern in the concept of atonement.

\footnotetext{
${ }^{96}$ Here and elsewhere Cohen writes "GottesIdee", as a composite word with the first letter of the second component ("Idee") capitalized. Where this is the case, I use capital ' $I$ ' in 'Idea.'
} 


\section{Text 32 God as the "Ideal Termination" of Atonement}

\section{5 by $14.7 \mathrm{~cm}$, ink.}

Die Hauptsache bei dem Problem der Versöhnung ist: daß sie

nur gesucht werde in der Läuterung der Gesinnung von

Individuum zu Individuum, nicht aber in der Isolirung eines Verhältnisses zwischen Mensch und Gott.Versöhnung in

Gott erfolgt durch die Versöhnung von Mensch und Mensch,

und zwar auch in Bezug auf die tieferen, inneren

Schwächen des Individuums, die sogenannte Sündhaftigkeit der Creatur.

Auch so ist Gott nur die ideale Terminatio, nicht ein

Bundes-Partner.

Translation

The main thing in the problem of atonement is: that it is to be sought only in the purification of the attitude from individual to individual, not, however, in the isolation of a relation between human being and GodAtonement in God results through the atonement of human being with human being, namely also with regard to the deeper, inner weaknesses of the individual, the socalled sinfulness of the creature.

Thus too God is merely the ideal termination, not a covenantal partner.

\section{Text 33 God and the Being of the Ought}

9 by $13.8 \mathrm{~cm}$, ink.

Die Sittengesetze beziehen sich auf das $\underline{\text { Sollen als }}$

Sein. Die Idee Gottes aber auf das Sein

der Zukunft, welches das Sollen der Freiheit

gewährleistet, als stetiges ermöglicht.

Dieses Sein der Zukunft, als Wirklichkeit zu gewährleisten , ist die Aufgabe der Gottes-

Idee. Die Empfindung der Wirklichkeit liegt

(...) Begriff des Seins der Zukunft.

Bleibt dieses Sein Sein der Zukunft?

Verstand! Und doch fällt der Schein

der Zukunft auch als Verwirklichung

auf alle Wirklichkeit. 


\section{Translation}

The $\mathrm{m}$ [oral laws are related to the ought as

being. The idea of God, however, to the being

of the future which guarantees the ought of freedom,

making it possible as continuous.

Warranting this being of the future as reality

is the task of the Idea of God. The perception of reality lies

(...) concept of the being of the future.

Does this being remain being of future?

Reason! Yet the appearance of

future as realization also falls

upon all reality.

\section{Notes/Comments}

Despite a few illegible words, the gist of this note shows a strong proximity with passages in the Ethics where Cohen discusses the "being of the ought" and where the idea of God is ascribed the very function given it here, namely to "warrant the being of the future as reality." Whether this note and others not directly related to the topics of atonement or messianism slipped into the envelope by accident is impossible to say. It is my contention, however, that Cohen worked on both themes contemporaneously and that his Jewish philosophy of religion and his systematic philosophy are mutually constitutive. This explains why jottings on either project end up might have ended up in the same file.

\section{Text 34 Religion as the "Pre-Language" of Morality}

10.8 by $9.3 \mathrm{~cm}$, ink.

Allgemeine Schwierigkeit, Problem des Conflicts
zwischen Religion und Sittlichkeit ist die Frage: der Mensch
kann sich nur mit der Idee seiner selbst versöhnen.
Ebenso wie er nur im Glauben an diese $\underline{\text { Idee, }}$
welche seine Aufgabe ist, $\underline{\text { Seligkeit }}$ das heißt Freiheit
gewinnen kann. Also wie kann die Versöhnung mit Gott
sittlich wirken? Antwort: Gott bedeutet dasselbe
in der Sprache der Religion, d.i. der Vor-Sprache der Sittlichkeit
<welche als das geschichtliche Mittel zu achten ist für die Erzeugung des
sittlichen Begriffs.>

$97<>$ Continued as insert on top of page. 


\section{Translation}

General difficulty, problem of conflict

between religion and morality is the question: the human being can reconcile himself only with the idea of himself.

Just as he can only gain salvation, that is freedom, through faith in this idea, which is his task. Therefore how can atonement with God

exert a moral effect? Answer: God means the same

in the language of religion, which is the pre-language of morality

$<$ which is to be respected as the historical means for the generation of the moral concept. $>^{97}$

\section{Notes/Comments}

In this rather demythologizing passage Cohen conceives of religion as a preliminary expression of morality whose concepts can be translated into the culturally more advanced language of ethical terminology. To avoid conflict between religion and morality, "atonement with God" can then be articulated as reconciliation with the moral idea of oneself as a human being. In order not to over or misinterpret this text one should keep in mind, however, that Cohen speaks here of atonement in Christian terms as if the Jewish concept were not the issue here. Hence the emphasis on "faith in this idea." In the Ethics, when religion is cast in potential conflict with morality, the term usually refers to Christian doctrine.

\section{Text 35 In Religion: Human Being Not a Sensory Being}

\section{5 by $9 \mathrm{~cm}$, ink.}

Die Unschädlichkeit und der Nutzen der Religion ist bedingt

durch ihr Anschmiegen an die Idee und ihre Entfernung

von der sinnlichen Ausmalung. So im Begriffe Gott.

So in Allem, was das Verhältnis zwischen Gott und Mensch

betrifft, ... [?] die Vermittlung besonders. Sie selbst liegt

in dem Begriff Gottes als Idee. Das ist die Menschlichkeit

Gottes und die Göttlichkeit des Menschen-Auch der Mensch soll

nicht als Sinneswesen in der Religion gedacht werden, sondern nach seinem Antheil am Ewigen.

Translation

The harmlessness and utility of religion is conditioned

by its clinging to the idea and its distance

from sensory embellishment. So in the concept God.

So in everything that concerns the relation between God and human being,

(...) especially the mediation. This itself lies

in the concept of God as idea. This is the humanity 
of God and the divinity of the human being-The human being should not be thought of as a sensory being either in religion but according to his share in the eternal.

\section{Text 36 Atonement as Idealization of the Human Being}

One of the pages from a small notepad measuring $6.7 \mathrm{by} 4.3 \mathrm{~cm}$, pencil.

\begin{tabular}{|l|}
\hline Die Versöhnung mit Gott bedeutet die Idealisierung \\
des Menschen, seine Befreiung von dem Selbstvorwurf \\
der Mangelhaftigkeit und Sündhaftigkeit, mithin Erhebung \\
zu seiner Aufgabe als Mensch, also Versöhnung \\
mit dem Ideal der Menschheit.
\end{tabular}

Translation

Atonement with God means the idealization of the human being, his liberation from the charge against himself of insufficiency and sinfulness, thus elevation to his task as a human being, that is atonement with the ideal of humanity.

\section{Text 37 Atonement and the Unity of Consciousness}

\section{4 by $9.1 \mathrm{~cm}$, ink.}

Die Gefahr, welche in der Person Gottes liegt, wird besonders schwierig bei dem Problem der Versöhnung: als ob diese mit der Person Gottes erfolgen müßte, während die Idee der Versöhnung nur eine Seite in der Idee Gottes darstellt. Die Versöhnung muß stattfinden zwischen Mensch und Mensch und vor Allem

zwischen den Richtungen und Bestrebungen des Bewußtseins, daher in dem Individuum selbst. Und indem sie stattfindet vollzieht sich die Kraft der GottesIdee. Aber sobald die Idee Gottes mythologisch gedacht wird, wird auch die Versöhnung zum Opfer für ${ }^{98}$

\section{Translation}

The danger which lies in the person of God is particularly aggravated in the problem of atonement: as if this was to be accomplished with the person of God

while the idea of atonement represents only one side in the idea of God.

Atonement needs to take place between human being and human being and first of all

between the directions and aspirations of consciousness, therefore in the individual itself. And by taking place the power of the

${ }^{98}$ Writing breaks off in the middle of the sentence. The last third of the page is empty. 
Idea of God comes about. ${ }^{99}$ But as soon as the idea of God is thought mythologically

the atonement also becomes a sacrifice for ${ }^{98}$

\section{Notes/Comments}

This text is interesting in at least two respects. It shows that Cohen underlined while writing rather than when using the notes for another purpose such as lecturing. The excessive markings are thus a means of concentration for Cohen as he thinks about what he formulates. This is born out by the fact that Cohen broke off writing the formulation in midsentence but there is still some underlining present, although not as much as usual in these texts.

Secondly, Cohen notes here that the idea of atonement indeed functions as a form of thought that is parallel to the psychological task of the system as a whole: "Atonement needs to take place (...) first of all between the directions and aspirations of consciousness, therefore in the individual itself." If to Cohen the idea of atonement is not only a religious term but one which denotes the psychological process of achieving a unity of the cultural consciousness within the individual it is no longer surprising that these notes were found together with a number of longer passages related to "psychology."

\section{Text 38 Atonement and Faith in the Possibility of a Realization of the Good}

11.2 by $6.1 \mathrm{~cm}$ (irregular cut), ink.

Die Hilfe, welche Gott dem Individuum leistet, besteht nicht in der

Stütze seiner Moral, sondern in dem Trost für den Glauben

an die Versittlichung der Gesamtheit, daher vielmehr an die Möglichkeit einer

Realisierung des Guten in der Welt. Also die Messianische

Idee bleibt auch für die Versöhnungsfrage die Hauptsache.

Glaube ist Gewißheit der Zukunft. Sünde ist Zweifel an

der Zukunft. Die Versöhnung mit Gott, in Gott ist die Aufrichtung

zu diesem Glauben

Translation

The help which God provides to the individual consists not in a support of his morality, but in the solace for faith in the moralization of the whole, thus rather in the possibility of a realization of the Good in the world. Therefore the Messianic

${ }^{99}$ The reflexive of "vollzieht sich" in this and similar clauses cannot be properly rendered in English. I translate literally but it makes the sentence awkward in English which it is not in German. 
Idea remains the main issue also for the question of atonement.

Faith is confidence in the future. Sin is doubt in

the future. The atonement with God, in God is the encouragement

to this faith

\section{Notes/Comments}

The frequently noted connection between messianism and atonement is here again fully expressed. In addition we find here the connection of both with the problem of the realization of the Good, a problem Cohen addresses in the second part of his Ethics of Pure Will. Here the role of the core religious doctrines of messianism and atonement, as well as faith and confidence, are distinguished more clearly and unapologetically than in Ethics as conditions for the realization of morality. 


\section{Contents in Detail}

Acknowledgments ...........................................................................................

Preface by Wendell Dietrich ................................................................... xi

Introduction: Between Judaism and Philosophy...................................... 1

1. Hermann Cohen and Marburg Neo-Kantianism.................................. 1

2. Hermann Cohen and the Philosophy of Judaism ................................ 8

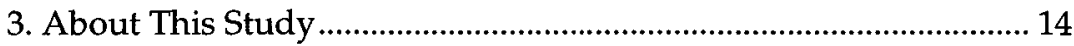

4. The Idea of Versöhnung (Atonement).................................................. 19

5. Identifying the Proper Narrative.............................................................. 33

Part I: Atonement in Hermann Cohen's Project of

Renewing Jewish Philosophy of Religion and Ethics ................. 45

1. Biographical Background ............................................................... 47

1.1 Childhood in Anhalt: Coswig and Dessau (1842-1856)......... 47

1.2 Rabbinical Studies: Breslau (1857-1861)................................. 54

1.3 From Filial Piety to Reaffirmation: Berlin and Marburg

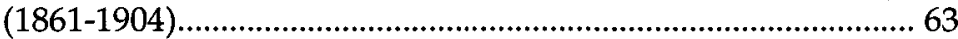

2. Early Writings on the Religion of Israel and Modern Culture ...... 69

2.1 "Monotheistic Pantheism" and Social Justice .......................... 69

2.2 Defending Judaism (1880 and 1888) ....................................... 77

2.2.1 "Ein Bekenntnis in der Judenfrage" (1880)..................... 77

2.2.1.1 Political and Social Background ............................. 77

2.2.1.2 The Berlin Antisemitismusstreit ........................... 79

2.2.1.3 Cohen's "Confession" .............................................. 80

2.2.1.4 Culturally Speaking, We are all

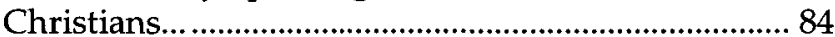

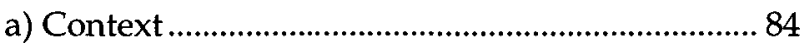

b) Idealization of Judaism and Christianity........... 89

2.2.2 Defending the Ethics of the Talmud (1888).................... 97

2.3 "The Messianic Idea" (1892):

Ideal of World-History and "Touchstone of Religion" ........ 101 


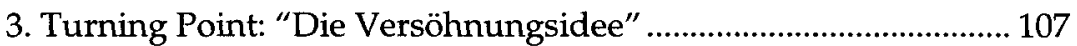

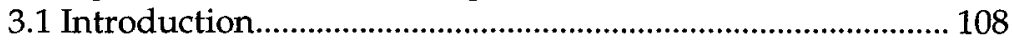

3.2 The Development of Biblical Religion: Sacrifice and Atonement................................................................................. 113

3.3 Guilt and Individuality in Ezekiel 18 ………........................ 118

3.4 T'shuvah as the Center of Gravity of Jewish Thought.......... 134

4. Renewing Jewish Philosophy of Religion ......................................... 151

4.1 Jewish Philosophy of Religion and Ethics ............................. 151

4.2 Institutional Framework:

Die Gesellschaft zur Förderung der Wissenschaft des Judentums

4.3 Realization of the Program

Religion of Reason Out of the Sources of Judaism 165

4.3.1 "Late" Philosophy of Religion or Maturation?........... 165

4.3.2 Religion of Reason Out of the Sources of Judaism..... 177

4.3.2.1 The Table of Contents ........................................... 178

4.3.2.2 The Introduction: Reason, Religion, and the Sources of Judaism ........................................ 183

a) "Reason" .................................................................. 183

b) "Religion" ..................................................................... 188

c) "The Sources of Judaism"................................... 194

4.3.2.3 Versöhnung in Religion der Vernunft..................... 196

a) The Unfolding of the Correlation of God and Human Being in the Chapters of RV ....... 196

b) Concrete Subjectivity as the Completion of the Correlative Anthropology:

"The Individual as I" (Ch. X)

c) Versöhnung as the "Pivot of Monotheism" (Ch. XI-XII) 204

\section{Part II: No Self Without Other.} Substance, Self-Consciousness, and Concrete Subjectivity in Cohen's Logic, Ethics, and Philosophy of Religion

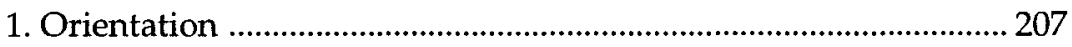

1.1 Philosophy and Religion ....................................................... 207

1.2 Religion and Critique............................................................... 209

1.3 Philosophy as Problems in Motion.......................................... 212

1.4 From Psychological to Transcendental Method .................... 215

1.5 Unity of the Cultural Consciousness...................................... 217 
2. Early Writings on Religion:

Cohen and the Berlin School of Hermeneutics ............................. 218

3. Substance, Self-Consciousness, and the Realization of the Good in Cohen's Logic, Ethics, and Philosophy of Religion ...... 230

3.1 From Substance to Function: Logical Provisions for the

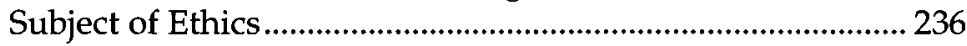

3.1.1 The Human Being as an Analogue to Nature............. 236

3.1.2 Substance and Subject ................................................. 249

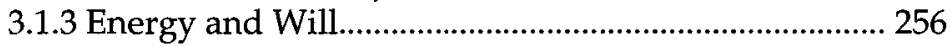

3.2 The Correlative Self-Consciousness of Ethics ........................ 260

3.2.1 Introductory Questions ................................................... 264

3.2.2 "Resolving" Religion into Ethics ................................. 267

3.2.3 The Law of Truth ........................................................... 272

3.2.4 Will and Action................................................................. 275

3.2.5 The Self-Consciousness of Pure Will ........................... 279

3.2.6 The Law of Self-Consciousness...................................... 284

3.2.7 Freedom of the Will ......................................................... 287

3.2.8 Autonomy of Self-Consciousness .................................. 293

1. Self-legislation (Selbstgesetzgebung) ............................ 293

2. Self-determination (Selbstbestimmung) ......................... 295

3. Responsibility (Selbstverantwortung) ............................ 297

4. Self-Preservation (Selbsterhaltung) ................................300

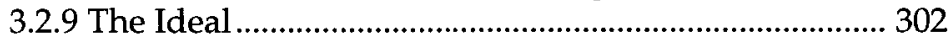

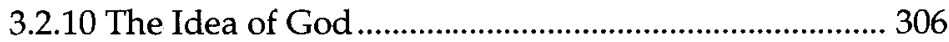

3.2.11 Virtues and the Realization of the Moral Self ........... 310

3.3 The Concept of Religion in the System of Philosophy......... 314

3.3.1 The Problem of the Concept of Religion ...................... 322

3.3.2 The Relation of Religion to Logic................................... 329

3.3.3 The Relation of Religion to Ethics.................................. 333

Paragraphs 1 - 25: The Correlation of God and the

Human Being.............................................................. 334

1. Correlation................................................................... 334

2. Beyond Fear of the Gods ......................................... 337

3. Correlation and the Good. Micah 6:8 ..................... 338

4. The Time of Correlation: Messianism and

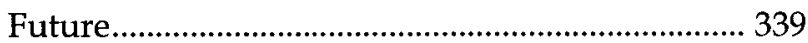

5.-6. T'shuvah and Paideia........................................... 340

7.-10. epekeina tes ousias.................................................. 341

11. Teleology and Theology ........................................ 342

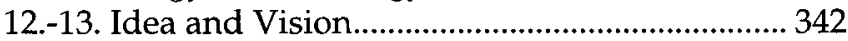

14. Esthetics and Religion ................................................ 343

15. Esthetics and Religion in Cultic Ceremony......... 344 
16. The Religious Apriori .............................................. 344

17. The Difference of Religion......................................... 344

18.-20. Religion "beyond" Ethics. Wilhelm

Herrmann's Challenge .............................................. 345

19. - 20. Defense of the Programmatic Unity of the System ...................................................................... 350

21. - 23. Unresolved Problems in the Correlation of God and Human Being......................................... 350

24. -25. The "Sui Generis" of Religion:

Correlating Unique God and Particular Individual

Paragraphs 26 - 37: Logic and the Uniqueness of God

26. God and the Uniqueness of Being ........................ 353

27. Existence of God ........................................................... 354

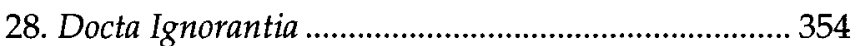

29. Being and Time ...................................................... 355

30. Creation and Future ............................................... 356

31. God and Teleology ................................................... 356

32. God and the Purpose of Existence ......................... 356

33. - 34. Cohen vs. Kant on Conditions for the Realization of Ethics ............................................... 357

35. - 36. God as Space and Time of Existence ............ 359

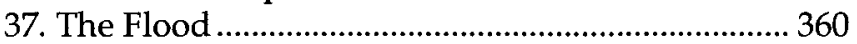

Paragraphs 38 - 102: Ethics and the Humanization of the Concrete Individual.......................................... 360

38. The Lack in the Ethical Concept of the Human Being ............................................................ 360

39. Ethics and Humanity: Elevation of the Individual

40. - 41. The Danger of a Destruction of the

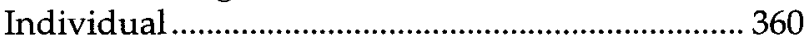

42. The Isolated Individual .......................................... 361

43. Self-Pity .......................................................................... 361

44. Lamentation as the Birthplace of Religion............ 361

45. - 46. The Useless Imperative ................................... 362

47. The Insufficient Correlation of I and All .............. 362

48. (Legitimate Concern for the Human Person)...... 363

49. Historical Concreteness of Relative

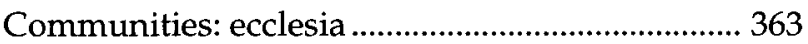

50. Law and Gospel....................................................... 364

51. Law AND Gospel: Continuity of Ethics and Religion. 
52. The Ethical and Political Dimensions of Monotheism

53. Autonomy and Moral Insufficiency ................... 366

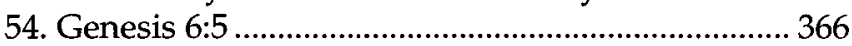

55. Unity without Identity ........................................ 367

56. God of the Fathers ................................................ 367

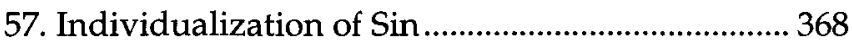

58. - 59. Uniqueness Contextualized.......................... 368

60. Particular Providence.......................................... 370

61. - 67. Liberation, Redemption, and Grace ............. 371

68. The Difference Between Ethical Monotheism and Classical Christianity .................................. 374

69. Convergence of Judaism and Christianity .......... 375

70. The Question of the Origin of $\operatorname{Sin}$........................ 376

71. Retribution as a Step in the "Labor of Repentance"

72. The Reality of Suffering .................................... 377

73. Suffering as the Necessary Condition of Liberation

74. - 75. Correlation as Theodicy ........................... 377

76. The Suffering of Others ...................................... 378

77. Three Historical Views on Suffering ................... 379

78. Local and Concrete Setting of Religious

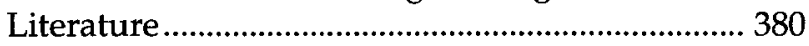

79. Society and Redemption ......................................... 381

80. - 81. Religious and Political Critique of

Religion

82. - 83. Sinless Suffering of the Poor....................... 382

84. Poverty as Piety ................................................. 382

85. Ethics as Theodicy ............................................... 383

86. Divine Providence and the Suffering of the Pious Ones.................................................................. 383

87. - 88. From Theory to Love .................................. 383

89. Compassion ........................................................ 384

90. Mehrheit and Allheit ........................................... 384

91. - 92. Suffering Messiah and Destruction of the Wicked .............................................................. 384

93. - 97. Religious Love............................................... 385

98. - 100. To Love God ............................................... 387

101. Worship: Reverence and Fear of God ............... 388

102. Honor and Love................................................. 388 


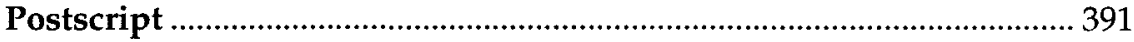

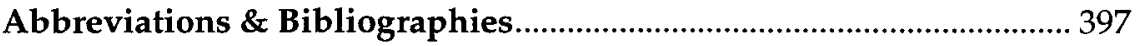

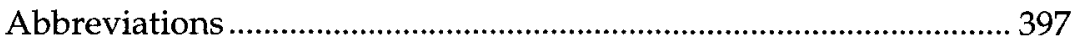

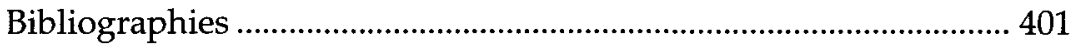

1. Chronological Bibliography of Hermann Cohen's

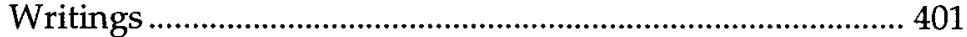

2. Literature on Hermann Cohen ................................................. 422

3. Other Consulted Literature........................................................ 438

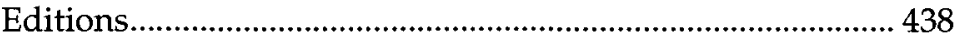

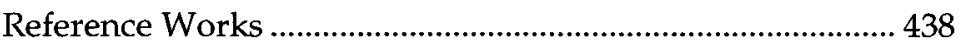

Other Editions and Secondary Literature ................................ 440

Appendix: Manuscripts by Hermann Cohen .......................................... 457

A. Letters from the National and University Library, Jerusalem.

1. Greeting Cards by Hermann and Gerson Cohen to Salomon Steinthal

2. Letter to Ludwig Philippson (December 1879) 458

3. Letters to Marcus Brann (1899-1900), Editor of Monatsschrift für die Geschichte und Wissenschaft des Judentums

4. Letter by Hermann Cohen to Kurt Eisner, Silvaplana

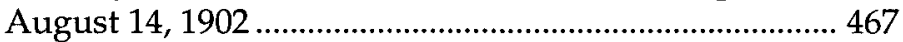

B. Manuscripts on "Versöhnung" ................................................. 470

1. Excerpts.............................................................................. 473

Text 1 A Hebrew Excerpt...................................................... 473

Text 2 Joseph Albo, Sefer Ha'ikkarim ................................. 474

Text 3 Albo: Divine Likeness............................................. 474

Text 4 Albo: Eschatological Unity of the Nations as

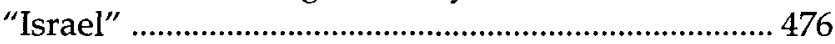

Text 5 Albo: On the Activity of Peace ............................. 477

Text 6 Leo Baeck on Levy ben Abraham: God As a

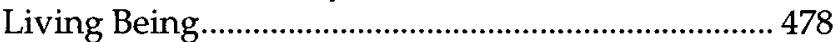

Text 7 Ritschl: Luther and Political Reason.................... 479

Text 8 Ritschl: "Peace as Esthetic Judgment"................ 480

Text 9 Excerpts From Wellhausen: On the History

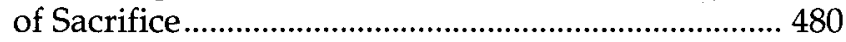

Text 10 Gfrörer: Hellenism and a Linear Concept of the History of Judaism. 
Text 11 Gfrörer: On Prayer ................................................ 498

Text 12 Einhorn: On Sacrifice ...........................................500

2. Atonement in the History of Religion and Art ................. 505

Text 13 Atonement in Art (Greek Tragic Heroism)

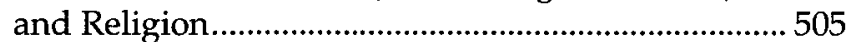

Text $14 S^{\prime}$ 'gagah and Anagnorisis..................................... 506

Text 15 Prometheus and Job: Theodicy............................ 508

Text 16 (Stoic) Suffering and the Divinity of Christ..... 508

Text 17 Likeness and Unlikeness of God........................ 509

3. The Liturgical Practice of Atonement ............................... 510

Text 18 The Origin of Prayer (Concentration of the

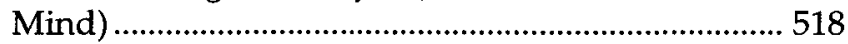

Text 19 Repentance and Faith ......................................... 511

Text 20 From God of Wrath to God of Love ................. 512

Text 21 Meaning and Connotations of $t^{\prime}$ shuvah ............ 513

Text $22 t$ 'shuvah Is Not Penance .......................................515

Text $23 t^{\prime}$ shuvah and kapparah........................................ 516

Text $24 t^{\prime}$ shuvah as the Means of Atonement................. 516

Text 25 The kohen (Priest) as "Expiator" .......................... 517

Text 26 "And Before Whom Do You Purify

Yourselves?" ................................................................ 518

Text 27 Yom Kippur and New Year................................ 519

Text 28 Sequence of the Atonement Liturgy ................. 520

Text 29 Day of Atonement and Messianic History ...... 520

4. Idea of God and Moral Ideal ............................................. 521

Text 30 Atonement and the Moral Purpose of the

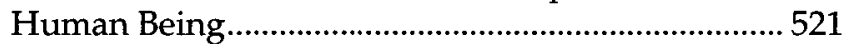

Text 31 Covenant and the Idea of God ........................... 522

Text 32 God as the "Ideal Termination" of

Atonement ...................................................................... 523

Text 33 God and the Being of the Ought........................ 523

Text 34 Religion as the "Pre-Language" of

Morality ........................................................................ 524

Text 35 In Religion: Human Being Not a Sensory

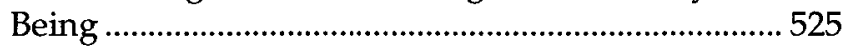

Text 36 Atonement as Idealization of the Human

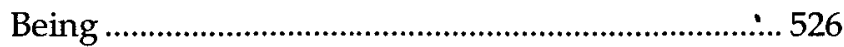

Text 37 Atonement and the Unity of

Consciousness ...............................................................526

Text 38 Atonement and Faith in the Possibility of a

Realization of the Good 

140001 Approaches to Ancient Judaism I

140002 The Traditions of Eleazar Ben Azariah

140003 Persons and Institutions in Early Rabbinic Judaism

$140004 \quad$ Claude Goldsmid Montefiore on the Ancient Rabbis

140005 The Ecumenical Perspective and the Modernization of Jewish Religion

140006 The Sabbath-Law of Rabbi Meir

140007 Rabbi Tarfon

140008 Rabban Gamaliel II

140009 Approaches to Ancient Judaism II

140010 Method and Meaning in Ancient Judaism I

140011 Approaches to Ancient Judaism III

140012 Turning Point: Zionism and Reform Judaism

140013 Buber on God and the Perfect Man

140014 Scholastic Rabbinism

140015 Method and Meaning in Ancient Judaism II

140016 Method and Meaning in Ancient Judaism III

140017 Post Mishnaic Judaism in Transition

140018 A History of the Mishnaic Law of Agriculture:

Tractate Maaser Sheni

140019 Mishnah's Theology of Tithing

140020 The Priestly Gift in Mishnah: A Study of Tractate Terumot

140021 History of Judaism: The Next Ten Years

140022 Ancient Synagogues

$140023 \quad$ Warrant for Genocide

140024 The Creation of the World According to Gersonides

140025 Two Treatises of Philo of Alexandria: A Commentary on De Gigantibus and Quod Deus Sit Immutabilis

140026 A History of the Mishnaic Law of Agriculture: Kilayim

140027 Approaches to Ancient Judaism IV

140028 Judaism in the American Humanities I

140029 Handbook of Synagogue Architecture

140030 The Book of Mirrors

140031 Ideas in Fiction: The Works of Hayim Hazaz

140032 Approaches to Ancient Judaism V

140033 Sectarian Law in the Dead Sea Scrolls: Courts, Testimiony and the Penal Code

140034 A History of the Linited Jewish Appeal: 1939-1982

140035 The Academic Study of Judaism

140036 Woman Leaders in the Ancient Synagogue

140037 Formative Judaism I: Religious, Historical, and Literary Studies

140038 Ben Sira's View of Women: A Literary Analysis

140039 Barukh Kurzweil and Modern Hebrew Literature

140040 Israeli Childhood Stories of the Sixties: Yizhar, Aloni, Shahar, Kahana-Carmon

140041 Formative Judaism II: Religious, Historical, and Literary Studies

140042 Judaism in the American Humanities II: Jewish Learning and the New Humanities
William S. Green

Tzvee Zahavy

William S. Green

Joshua B. Stein

S. Daniel Breslauer

Robert Goldenberg Joel Gereboff Shamai Kanter

William S. Green Jacob Neusner

William S. Green

Howard R. Greenstein

Pamela Vermes

Anthony J. Saldarini Jacob Neusner Jacob Neusner

Baruch M. Bokser

Peter J. Haas

Martin S. Jaffee

Alan. J. Peck

Baruch M. Bokser

Joseph Gutmann

Norman Cohn

Jacob J. Staub

Winston/Dillon

Irving Mandelbaum

William S. Green

Jacob Neusner

Marilyn Chiat

Daniel C. Matt

Warren Bargad

William S. Green

Lawrence H. Schiffman

Marc L. Raphael

Jacob Neusner

Bernadette Brooten

Jacob Neusner

Warren C. Trenchard

James S. Diamond

Gideon Telpaz

Jacob Neusner

Jacob Neusner 
140043 Support for the Poor in the Mishnaic Law of Agriculture:

Tractate Peah

Roger Brooks

140044 The Sanctity of the Seventh Year: A Study of Mishnah

Tractate Shebiit

140045 Character and Context: Studies in the Fiction of Abramovitsh, Brenner, and Agnon

Louis E. Newman

Jeffrey Fleck

140046 Formative Judaism III: Religious, Historical, and Literary Studies

140047 Pharaoh's Counsellors: Job, Jethro, and Balaam in Rabbinic and Patristic Tradition

140048 The Scrolls and Christian Origins: Studies in the Jewish Background of the New Testament

140049 Approaches to Modern Judaism I

$140050 \quad$ Mysterious Encounters at Mamre and Jabbok

140051 The Mishnah Before 70

140052 Sparda by the Bitter Sea: Imperial Interaction in Western Anatolia

140053 Hermann Cohen: The Challenge of a Religion of Reason

140054 Approaches to Judaism in Medieval Times I

140055 In the Margins of the Yerushalmi: Glosses on the English Translation

140056 Approaches to Modern Judaism II

140057 Approaches to Judaism in Medieval Times II

$140058 \quad$ Midrash as Literature: The Primacy of Documentary Discourse

140059 The Commerce of the Sacred: Mediation of the Divine Among Jews in the Graeco-Roman Diaspora

140060 Major Trends in Formative Judaism I: Society and Symbol in Political Crisis

140061 Major Trends in Formative Judaism II: Texts, Contents, and Contexts

140062 A History of the Jews in Babylonia I: The Parthian Period

140063 The Talmud of Babylonia: An American Translation XXXII: Tractate Arakhin

140064 Ancient Judaism: Debates and Disputes

140065 Prayers Alleged to Be Jezvish: An Examination of the Constitutiones Apostolorum

140066 The Legal Methodology of Hai Gaon

140067 From Mishnah to Scripture: The Problem of the Unattributed Saying

140068 Halakhah in a Theological Dimension

140069 From Philo to Origen: Middle Platonism in Transition

140070 In Search of Talmudic Biography: The Problem of the Attributed Saying

140071 The Death of the Old and the Birth of the New: The Framework of the Book of Numbers and the Pentateuch

Jacob Neusner

Judith Baskin

Matthew Black

Marc Lee Raphael William T. Miller Jacob Neusner

Jack Martin Balcer William Kluback David R. Blumenthal

Jacob Neusner Marc Lee Raphael David R. Blumenthal Jacob Neusner

Jack N. Lightstone

Jacob Neusner

Jacob Neusner Jacob Neusner

Jacob Neusner Jacob Neusner

David Fiensy Tsvi Groner

Jacob Neusner

David Novak

Robert M. Berchman

Jacob Neusner

Dennis T. Olson

Jacob Neusner XVII: Tractate Sotah

140073 Understanding Seeking Faith: Essays on the Case of Judaism II: Literature, Religion and the Social Study of Judiasm

140074 The Talmud of Babylonia: An American Translation VI: Tractate Sukkah

140075 Fear Not Warrior: A Study of 'al tira' Pericopes in the Hebrew Scriptures

Jacob Neusner

Jacob Neusner

Edgar W. Conrad 
140076 Formative Judaism IV: Religious, Historical, and Literary Studies

140077 Biblical Patterns in Modern Literature

140078 The Talmud of Babylonia: An American Translation

I: Tractate Berakhot

Jacob Neusner

Hirsch/Aschkenasy

Jacob Neusner

140079 Mishnah's Division of Agriculture: A History and Theology of Seder Zeraim

$140080 \quad$ From Tradition to Imitation: The Plan and Program of Pesiqta Rabbati and Pesiqta deRab Kahana

Alan J. Avery-Peck

Jacob Neusner

140081 The Talmud of Babylonia: An American Translation XXIII.A: Tractate Sanhedrin, Chapters 1-3

140082 Jewish Presence in T. S. Eliot and Franz Kafka

140083 School, Court, Public Administration: Judaism and its Institutions in Talmudic Babylonia

140084 The Talmud of Babylonia: An American Translation XXIII.B: Tractate Sanhedrin, Chapters 4-8

140085 The Bavli and Its Sources: The Question of Tradition in the Case of Tractate Sukkah

140086 From Description to Conviction: Essays on the History and Theology of Judaism

140087 The Talmud of Babylonia: An American Translation XXIII.C: Tractate Sanhedrin, Chapters 9-11

$140088 \quad$ Mishnaic Law of Blessings and Prayers: Tractate Berakhot

140089 The Peripatetic Saying: The Problem of the Thrice-Told Tale in Talmudic Literature

140090 The Talmud of Babylonia: An American Translation XXVI: Tractate Horayot

Jacob Neusner Melvin Wilk

Jacob Neusner

Jacob Neusner

Jacob Neusner

Jacob Neusner

Jacob Neusner

Tzvee Zahavy

Jacob Neusner

Martin S. Jaffee

140091 Formative Judaism V: Religious, Historical, and Literary Studies

140092 Essays on Biblical Method and Translation

140093 The Integrity of Leviticus Rabbah

Jacob Neusner

Edward Greenstein

Jacob Neusner

140094 Behind the Essenes: History and Ideology

of the Dead Sea Scrolls

140095 Approaches to Judaism in Medieval Times III

140096 The Memorized Torah: The Mnemonic System of the Mishnah

140097

Knowledge and Illumination

Philip R. Davies

David R. Blumenthal

Jacob Neusner

Hossein Ziai

140098 Sifre to Deuteronomy: An Analytical Translation I:

Pisqaot 1-143. Debarim, Waethanan, Eqeb

140099 Major Trends in Formative Judaism III: The Three Stages

in the Formation of Judaism

Jacob Neusner

140101 Sifre to Deuteronomy: An Analytical Translation II:

Jacob Neusner

Pisqaot 144-357. Shofetim, Ki Tese, Ki Tabo, Nesabim,

Ha'azinu, Zot Habberakhah

140102 Sifra: The Rabbinic Commentary on Leviticus

140103 The Human Will in Judaism

140104 Genesis Rabbah I: Genesis 1:1 to 8:14

140105 Genesis Rabbah II: Genesis 8:15 to 28:9

140106 Genesis Rabbah III: Genesis 28:10 to 50:26

$140107 \quad$ First Principles of Systemic Analysis

140108 Genesis and Judaism

140109 The Talmud of Babylonia: An American Translation

XXXV: Tractates Meilah and Tamid

Jacob Neusner

Neusner/Brooks

Howard Eilberg-Schwartz

Jacob Neusner

Jacob Neusner

Jacob Neusner

Jacob Neusner

Jacob Neusner

$140110 \quad$ Studies in Islamic and Judaic Traditions I

Peter J. Haas

Brinner/Ricks 
140111 Comparative Midrash: The Plan and Program of Genesis

Rabbah and Leviticus Rabbah

140112 The Tosefta: Its Structure and its Sources

140113 Reading and Believing

140114 The Fathers According to Rabbi Nathan

140115 Etymology in Early Jewish Interpretation: The Hebrew Names in Philo

140116 Understanding Seeking Faith: Essays on the Case of Judaism I: Debates on Method, Reports of Results

140117 The Talmud of Babylonia: An American Translation VII: Tractate Besah

140118 Sifre to Numbers: An American Translation and Explanation I: Sifre to Numbers 1-58

140119 Sifre to Numbers: An American Translation and Explanation II: Sifre to Numbers 59-115

140120 Cohen and Troeltsch: Ethical Monotheistic Religion and Theory of Culture.

140121 Goodenough on the History of Religion and on Judaism

140122 Pesiqta deRab Kahana I: Pisqaot 1-14

140123 Pesigta deRab Kahana II: Pisqaot 15-28 and Introduction to Pesiqta deRab Kahana

140124 Sifre to Deuteronomy: Introduction

140126 A Conceptual Commentary on Midrash Leviticus Rabbah: Value Concepts in Jewish Thought

140127 The Other Judaisms of Late Antiquity

140128 Josephus as a Historical Source in Patristic Literature through Eusebius

140129 Judaism: The Evidence of the Mishnah

140131 Philo, John and Paul: New Perspectives on Judaism and Early Christianity

140132 Babylonian Witchcraft Literature

140133 The Making of the Mind of Judaism: The Formative Age

140135 Why No Gospels in Talmudic Judaism?

140136 Torah: From Scroll to Symbol Part III: Doctrine

140137 The Systemic Analysis of Judaism

140138 Sifra: An Analytical Translation I

140139 Sifra: An Analytical Translation II

140140 Sifra: An Analytical Translation III

140141 Midrash in Context: Exegesis in Formative Judaism

140142 Sifra: An Analytical Translation IV

140143 Oxen, Women or Citizens? Slaves in the System of Mishnah

140144 The Book of the Pomegranate

140145 Wrong Ways and Right Ways in the Study of Formative Judaism

140146 Sifra in Perspective: The Documentary Comparison of the Midrashim of Ancient Judaism

140147 Uniting the Dual Torah: Sifra and the Problem of the Mishnah

140148 Mekhilta According to Rabbi Ishmael: An Analytical Translation I

140149 The Doctrine of the Divine Name: An Introduction to Classical Kabbalistic Theology

140150 Water into Wine and the Beheading of John the Baptist

140151 The Formation of the Jewish Intellect

140152 Mekhilta According to Rabbi Ishmael: An Introduction to Judaism's First Scriptural Encyclopaedia

Jacob Neusner Jacob Neusner Jacob Neusner Jacob Neusner

Lester L. Grabbe

Jacob Neusner

Alan J. Avery-Peck

Jacob Neusner

Jacob Neusner

Wendell S. Dietrich

Neusner/Frerichs

Jacob Neusner

Jacob Neusner

Jacob Neusner

Max Kadushin Alan F. Segal

Michael Hardwick

Jacob Neusner

Peder Borgen

Tzvi Abusch

Jacob Neusner Jacob Neusner Jacob Neusner Jacob Neusner Jacob Neusner Jacob Neusner Jacob Neusner Jacob Neusner Jacob Neusner Paul V. Flesher Elliot R. Wolfson Jacob Neusner

Jacob Neusner Jacob Neusner

Jacob Neusner

Stephen G. Wald Roger Aus Jacob Neusner Jacob Neusner 
140153 Understanding Seeking Faith: Essays on the Case of Judaism III: Society, History, and Political and Philosophical Uses of Judaism

140154 Mekhilta According to Rabbi Ishmael: An Analytical

Translation II

140155 Goyim: Gentiles and Israelites in Mishnah-Tosefta

140156 A Religion of Pots and Pans?

140157 Claude Montefiore and Christianity

140158 The Philosophical Mishnah HI: The Tractates' Agenda:

From Nazir to Zebahim

Jacob Neusner

From Ancient Israel to Modern Judaism I: Intellect

in Quest of Understanding

140160 The Social Study of Judaism I

140161 Philo's Jewish Identity

140162 The Social Study of Judaism II

140163 The Philosophical Mishnah I: The Initial Probe

140164 The Philosophical Mishnah II: The Tractates' Agenda:

From Abodah Zarah Through Moed Qatan

140166

140167

140168

140169

140171

Women's Earliest Records

The Legacy of Hermann Cohen

Method and Meaning in Ancient Judaism

Jacob Neusner

Gary P. Porton

Jacob Neusner

Maurice Gerald Bowler

Jacob Neusner

Neusner/Frerichs/Sarna

Jacob Neusner

Alan Mendelson

Jacob Neusner

Jacob Neusner

Jacob Neusner

Barbara S. Lesko

William Kluback

Jacob Neusner

The Role of the Messenger and Message in the Ancient

Near East

140172 The Philosophical Mishnah IV: The Repertoire

140173 From Ancient Israel to Modern Judaism II: Intellect

in Quest of Linderstanding

140174 From Ancient Israel to Modern Judaism III: Intellect

in Quest of Understanding

140175 From Ancient Israel to Modern Judaism IV: Intellect

in Quest of Understanding

John T. Greene

Lawerence Perlman

Jacob Neusner

Neusner/Frerichs/Sarna

Neusner/Frerichs/Sarna

140176 Translating the Classics of Judaism: In Theory and In Practice

Neusner $\%$ Frerichs/Sarna

140177 Profiles of a Rabbi: Synoptic Opportunities

in Reading About Jesus

140178 Studies in Islamic and Judaic Traditions II

140179 Medium and Message in Judaism: First Series

Jacob Neusner

140180

140181

140182

Making the Classics of Judaism: The Three Stages

of Literary Formation

140183

The Law of Jealousy: Anthropology of Sotah

Esther Rabbah I: An Analytical Translation

140184

140185

Ruth Rabbah: An Analytical Translation

Formative Judaism: Religious, Historical and Literary Studies

The Studia Philonica Annual 1989

140186

140187

140188

140189

140190

The Setting of the Sermon on the Mount

The Midrash Compilations of the Sixth and Seventh Centuries I

The Midrash Compilations of the Sixth and Seventh Centuries II

140191

The Midrash Compilations of the Sixth and Seventh Centuries III

The Midrash Compilations of the Sixth and Seventh Centuries IV

140192

The Religious World of Contemporary Judaism: Observations and Convictions

Approaches to Ancient Judaism VI

Bruce Chilton

Brinner / Ricks

Jacob Neusner

Jacob Neusner

Adriana Destro

Jacob Neusner

Jacob Neusner

Jacob Neusner

David T. Runia

W.D. Davies

Jacob Neusner

Jacob Neusner

Jacob Neusner

Jacob Neusner

Jacob Neusner

Neusner/Frerichs

Jacob Neusner

Robert S. MacLennan

Judson R. Shaver 
140204 Judaism, Christianity, and Zoroastrianism in Talmudic Babylonia

140205 Tzedakah: Can Jewish Philanthropy Bty Jewish Survival?

Jacob Neusner

140206 New Perspectives on Ancient Judaism I

Neusner/Borgen/Frerichs/Horsley Scriptures of the Oral Torah

Christian Faith and the Bible of Judaism

Jacob Neusner

Philo's Perception of Women

Case Citation in the Babylonian Talmud: The Evidence

Tractate Neziqin

140211 The Biblical Herem: A Window on Israel's Religious Experience

140212 Goodenough on the Beginnings of Christianity acob Neusner Dorothy Sly

140213 The Talmud of Babylonia: An American Translation XXI.A: Tractate Bava Mesia Chapters 1-2

Eliezer Segal Philip D. Stern

A.T. Kraabel

140214 The Talmud of Babylonia: An American Translation XXI.B: Tractate Bava Mesia Chapters 3-4

Jacob Neusner

Jacob Neusner

140215 The Talmud of Babylonia: An American Translation XXI.C: Tractate Bava Mesia Chapters 5-6

Jacob Neusner

140216 The Talmud of Babylonia: An American Translation XXI.D: Tractate Bava Mesia Chapters 7-10

Jacob Neusner

140217 Semites, Iranians, Greeks and Romans: Studies in their Interactions

140218 The Talmud of Babylonia: An American Translation XXXIII: Temurah

Jonathan A. Goldstein

140219 The Talmud of Babylonia: An American Translation XXXI.A: Tractate Bekhorot Chapters 1-4

140220 The Talmud of Babylonia: An American Translation XXXI.B: Tractate Bekhorot Chapters 5-9

Jacob Neusner

Jacob Neusner

Jacob Neusner

140221 The Talmud of Babylonia: An American Translation XXXVI.A: Tractate Niddah Chapters 1-3

Jacob Neusner

140222 The Talmud of Babylonia: An American Translation XXXVI.B: Tractate Niddah Chapters 4-10

Jacob Neusner

140223 The Talmud of Babylonia: An American Translation XXXIV: Tractate Keritot

140224 Paul, the Temple, and the Presence of God

140225 The Book of the People

140226 The Studia Philonica Annual 1990

Jacob Neusner

David A. Renwick William W. Hallo David Runia

140227 The Talmud of Babylonia: An American Translation XXV.A: Tractate Abodah Zarah Chapters 1-2

Jacob Neusner

140228 The Talmuld of Babylonia: An American Translation XXV.B: Tractate Abodah Zarah Chapters 3-5

140230 The Studia Philonica Annual 1991

140231 The Talmud of Babylonia: An American Translation XXVIII.A: Tractate Zebahim Chapters 1-3

Jacob Neusner David Runia

Jacob Neusner

140232 Both Literal and Allegorical: Studies in Philo of Alexandria's Questions and Answers on Genesis and Exodus

David M. Hay

140233 The Talmud of Babylonia: An American Translation XXVIII.B: Tractate Zebahim Chapters 4-8 
140234 The Talmud of Babylonia: An American Translation XXVIII.C: Tractate Zebahim Chapters 9-14

Jacob Neusner

140235 The Talmud of Babylonia: An American Translation XXIX.A: Tractate Menahot Chapters 1-3

140236 The Talmud of Babylonia: An American Translation XXIX.B: Tractate Menahot Chapters 4-7

140237 The Talmud of Babylonia: An American Translation XXIX.C: Tractate Menahot Chapters 8-13

140238 The Talmud of Babylonia: An American Translation XXIX: Tractate Makkot

140239 The Talmud of Babylonia: An American Translation XXII.A: Tractate Baba Batra Chapters 1 and 2

140240 The Talmud of Babylonia: An American Translation XXII.B: Tractate Baba Batra Chapter 3

140241 The Talmud of Babylonia: An American Translation XXII.C: Tractate Baba Batra Chapters 4-6

140242 The Talmud of Babylonia: An American Translation XXVII.A: Tractate Shebuot Chapters 1-3

140243 The Talmud of Babylonia: An American Translation XXVII.B: Tractate Shebuot Chapters 4-8

140244 Balaam and His Interpreters: A Hermeneutical History of the Balaam Traditions

140245 Courageous Universality: The Work of Schmuel Hugo Bergman

140246 The Mechanics of Change: Essays in the Social History of German Jewry

140247 The Talmud of Babylonia: An American Translation XX.A: Tractate Baba Qamma Chapters 1-3

Jacob Neusner

Jacob Neusner

Jacob Neusner

Jacob Neusner

Jacob Neusner

Jacob Neusner

Jacob Neusner

Jacob Neusner

Jacob Neusner

John T. Greene

William Kluback

Steven M. Lowenstein

Jacob Neusner

140248 The Talmud of Babylonia: An American Translation XX.B: Tractate Baba Qamma Chapters 4-7

Jacob Neusner

140249 The Talmud of Babylonia: An American Translation XX.C: Tractate Baba Qamma Chapters 8-10

Jacob Neusner

140250 The Talmud of Babylonia: An American Translation XIII.A: Tractate Yebamot Chapters 1-3

Jacob Neusner

140251 The Talmud of Babylonia: An American Translation XIII.B: Tractate Yebamot Chapters 4-6

Jacob Neusner

Jacob Neusner XI: Tractate Moed Qatan

140253 The Talmud of Babylonia: An American Translation XXX.A: Tractate Hullin Chapters 1 and 2

140254 The Talmud of Babylonia: An American Translation XXX.B: Tractate Hullin Chapters 3-6

140255 The Talmud of Babylonia: An American Translation XXX.C: Tractate Hullin Chapters 7-12

140256 The Talmud of Babylonia: An American Translation XIII.C: Tractate Yebamot Chapters 7-9

Tzvee Zahavy

Tzvee Zahavy

Tzvee Zahavy

Jacob Neusner

140257 The Talmud of Babylonia: An American Translation XIV.A: Tractate Ketubot Chapters 1-3

140258 The Talmud of Babylonia: An American Translation XIV.B: Tractate Ketubot Chapters 4-7

140259 Jewish Thought Adrift: Max Wiener (1882-1950)

140260 The Talmud of Babylonia: An American Translation XIV.C: Tractate Ketubot Chapters 8-13

Jacob Neusner

Jacob Neusner

Robert S. Schine

Jacob Neusner 
140261 The Talmud of Babylonia: An American Translation XIII.D: Tractate Yebamot Chapters 10-16

Jacob Neusner

140262 The Talmud of Babylonia: An American Translation XV. A: Tractate Nedarim Chapters 1-4

Jacob Neusner

140263 The Talmud of Babylonia: An American Translation XV.B: Tractate Nedarim Chapters 5-11

140264 Studia Philonica Annual 1992

140265 The Talmud of Babylonia: An American Translation XVIII.A: Tractate Gittin Chapters 1-3

140266 The Talmud of Babylonia: An American Translation XVIII.B: Tractate Gittin Chapters 4 and 5

Jacob Neusner David T. Runia

Jacob Neusner

Jacob Neusner

140267 The Talmud of Babylonia: An American Translation XIX.A: Tractate Qiddushin Chapter 1

Jacob Neusner

140268 The Talmud of Babylonia: An American Translation XIX.B: Tractate Qiddushin Chapters 2-4

140269 The Talmud of Babylonia: An American Translation XVIII.C: Tractate Gittin Chapters 6-9

140270 The Talmud of Babylonia: An American Translation II. A: Tractate Shabbat Chapters 1 and 2

140271 The Theology of Nahmanides Systematically Presented

140272 The Talmud of Babylonin: An American Translation II.B: Tractate Shabbat Chapters 3-6

140273 The Talmud of Babylonia: An American Translation II.C: Tractate Shabbat Chapters 7-10

140274 The Talmud of Babylonia: An American Translation II.D: Tractate Shabbat Chapters 11-17

140275 The Talmud of Babylonia: An American Translation II.E: Tractate Shabbat Chapters 18-24

Jacob Neusner

Jacob Neusner

Jacob Neusner David Novak

Jacob Neusner

Jacob Neusner

Jacob Neusner

Jacob Neusner

140276 The Talmud of Babylonia: An American Translation III.A: Tractate Erubin Chapters 1 and 2

140277 The Talmud of Babylonin: An American Translation III.B: Tractate Erubin Chapters 3 and 4

140278 The Talmud of Babylonia: An American Translation III.C: Tractate Erubin Chapters 5 and 6

140279 The Talmud of Babylonia: An American Translation III.D: Tractate Erubin Chapters 7-10

Jacob Neusner

Jacob Neusner

Jacob Neusner

Jacob Neusner

140280 The Talmud of Babylonia: An American Translation XII: Tractate Hagigah

140281 The Talmud of Babylonia: An American Translation IV.A: Tractate Pesahim Chapter I

140282 The Talmud of Babylonia: An American Translation IV.B: Tractate Pesahim Chapters 2 and 3

140283 The Talmud of Babylonia: An American Translation IV.C: Tractate Pesahim Chapters 4-6

Jacob Neusner

Jacob Neusner

Jacob Neusner

Jacob Neusner

140284 The Talmud of Babylonia: An American Translation IV.D: Tractate Pesahim Chapters 7 and 8

140285 The Talmud of Babylonia: An American Translation IV.E: Tractate Pesahim Chapters 9 and 10

140286 From Christianity to Gnosis and From Gnosis to Christianity Studia Philonica Annual 1993

140288 Diasporas in Antiquity

140289 The Jewish Family in Antiquity

140290 The Place of Judaism in Philo's Thought

Shaye J D. Cohen, Ernest S. Frerichs

Neusner Jean Magne David T. Runia Ernest S. Frerichs Shaye J. D. Cohen Ellen Birnbaum 
140291

140292

140293

140294

140295

140296

140297

140298

140299

140300

140301

140302

140303

140304

140305

140306

140307

140308

140309

140310

140311

140312

140313

140314

140315

140316

140317

140318

140319

140320

140321

140322

140323

140324
The Babylonian Esther Midrash, Vol. 1

The Babylonian Esther Midrash, Vol. 2

The Babylonian Esther Midrash, Vol. 3

The Talmud of Babylonia: An American Translation

V. A: Tractate Yoma Chapters 1 and 2

The Talmud of Babylonia: An American Translation

V. B: Tractate Yoma Chapters 3-5

The Talmud of Babylonia: An American Translation

V. C: Tractate Yoma Chapters 6-8

The Talmud of Babylonia: An American Translation XXII.D: Tractate Baba Batra Chapters Seven and Eight

The Talmud of Babylonia: An American Translation XXII.E: Tractate Baba Batra Chapters Nine and Ten

The Studia Philonica Annual, 1994

Sages, Stories, Authors, and Editors in Rabbinic Judaism

From Balaam to Jonah: Anti-prophetic Satire in the

Hebrew Bible.

The History of Sukkot in the Second Temple and Rabbinic Periods

Tasting the Dish: Rabbinic Rhetorics of Sexuality

The School of Moses: Studies in Philo and Hellenistic Religion

The Studia Philonica Annual, 1995

The Talmud of Babylonia, An American Translation

IX, Tractate Rosh Hashanah

Eliezer Segal

Eliezer Segal

Eliezer Segal

Jacob Neusner

Jacob Neusner

Jacob Neusner

Jacob Neusner

Jacob Neusner

David T. Runia

Richard Kalmin

David Marcus

Jeffrey L. Rubenstein

Michael L. Satlow

John Peter Kenney

David T. Runia

Alan J. Avery-Peck

Early Rabbinic Civil Law and the Social History of Roman Galilee: Hayim Lapin A Study of Mishnah Tractate Baba Mesia

The Libes Briv of Isanc Wetzlar

The Studia Philonica Annual, 1996

Morris M. Faierstein

David T. Runia

Rashbam's C ommentary on Exodus: An Annotated

Translation

The Elijah Legends and Jehu's Coup

The Studia Philonica Annual, 1997; Wisdom and Logos:

Studies in Jewish Thought in Honor of David Winston

The Echoes of Many Texts: Reflections on Jewish and Christian

Traditions, Essays in Honor of Lou H. Silberman

William G. Dever and

J. Edward Wright

Marc Bregman

The Sign of the Serpent

Kol Nidre: Studies in the Development of Rabbinic

Votive Institutions

Ben Sira's Teaching on Friendship

Some Jewish Women in Antiquity

Rereading Talmud: Gender, Law and the Poetics of Sugyot

The Studia Philonica Annual., 1998

Hesed ve-emet: Studies in Honor of Ernest S. Frerichs

Women and Womanhood in the Talmud

Rhetorical Argumentation in Philo of Alexandria

The Studia Philonica Annual, 1999

The Idea of Atonement in the Philosophy of Hermann Cohen

David T. Runia and

Gregory E. Sterling

Martin I. Lockshin

Marsha C. White

Moshe Benovitz Jeremy Corley Meir Bar-Ilan Aryeh Cohen

David T. Runia

Jodi Magness and

Seymour Gitin

Shulamit Valler

Manuel Alexandre, Jr.

David T. Runia

Gregory E. Sterling

Michael Zank 


\section{Brown Studies on Jews and Their Societies}

145001 American Jewish Fertility

145002 The Impact of Religious Schooling: The Effects of Jewish

Calvin Goldscheider Education Upon Religious Involvement

145003 The American Jewish Community

145004 The Naturalized Jews of the Grand Duchy of Posen in 1834 and 1835

145005 Suburban Communities: The Jewishness of American Reform Jews

145007 Ethnic Survival in America

145008 American Jews in the 21st Century: A Leadership Challenge

Harold S. Himmelfarb Calvin Goldscheider

Edward David Luft

Gerald L. Showstack David Schoem Earl Raab

\section{Brown Studies in Religion}

$147001 \quad$ Religious Writings and Religious Systems I

147002 Religious Writings and Religious Systems II

147003 Religion and the Social Sciences
Jacob Neusner, et al Jacob Neusner, et al Robert Segal 